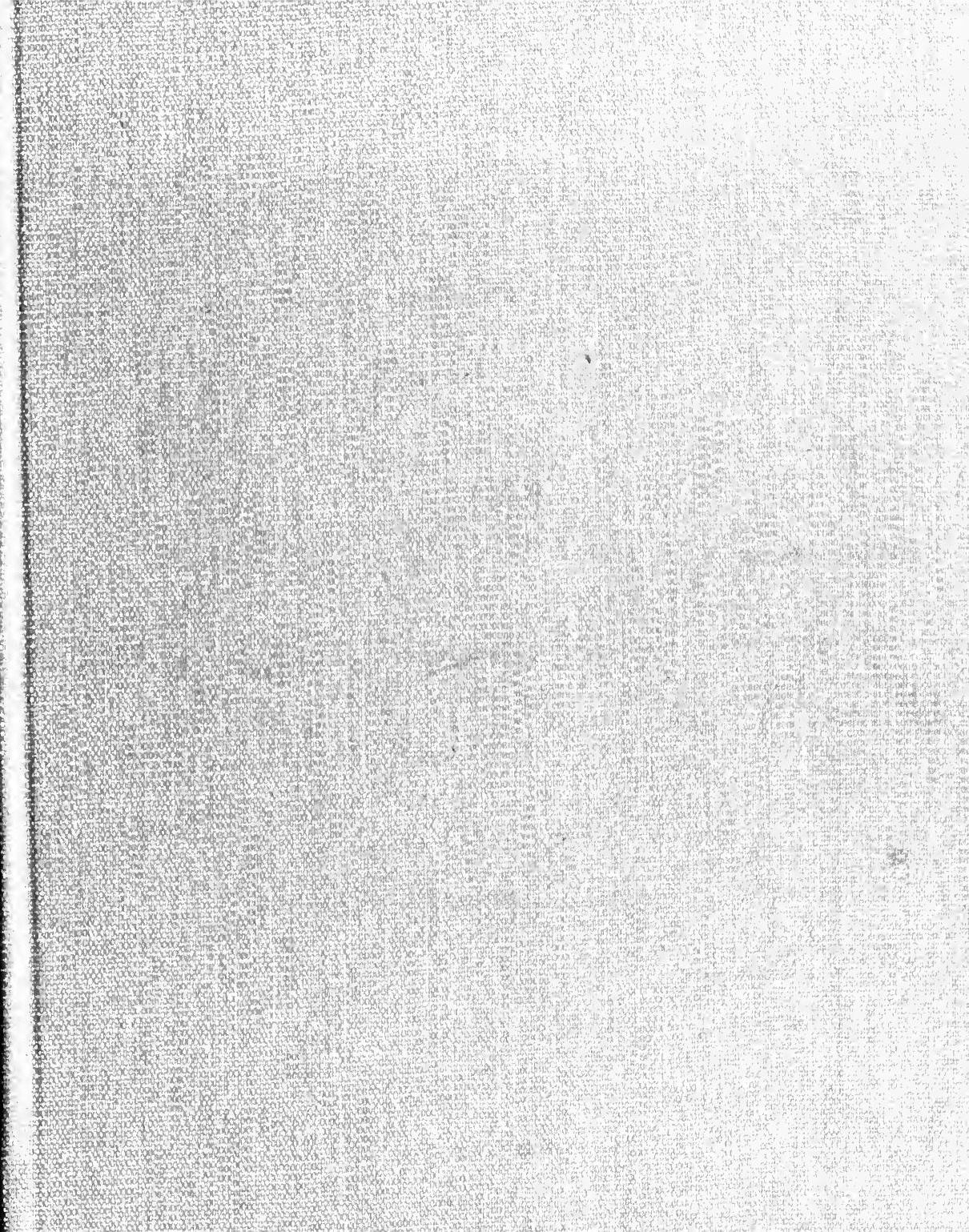


REYNOLDS HISTORICAL GENEALOGY COLLEETION 


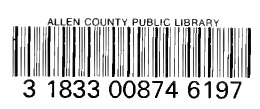






\section{HISTORY OF \\ SASKATCHEWAN \\ and}

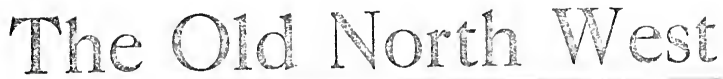

BY

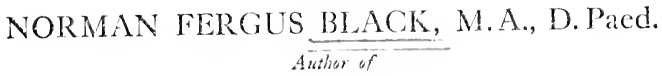

English for the Non-English

etc.

NORTH WEST HISTORICAL COMPANY

PUBLISHERS

REGINA, SASL. 


\section{3}

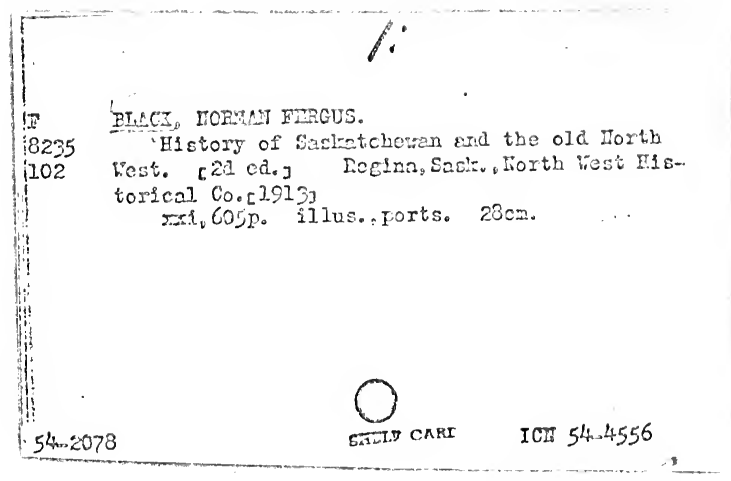


. 


\section{PREFACE}

The outstanding fact impresed upen the author at every turn, in connection with the monmmental task of collecting information for the following work, is that of the crying need in Saskatchewan of the services of a Provincial archivist. Meck by week (Old Tlimers are passing away, and with them is being lost information of incalculable histurical value which no future expenditure, no matter how lavish, can possibly make good. Nut only is there no provision yet made to reluce to permanent form the unwritten reminiscences of those whose courage, enterprise and cndurance laid the foundation of Saskatchewan's greatness; no systematic effort is being made even to collect and preserve the actual documents now available. Many such papers have already been mislaid or destroyed through accilents or through ignorance of their value. For example, an account of the rehellion of 1885 , written by an Indian in Crec syllabic cliatracters, has passed from hand to hand, apparently to become a children's plaything, at last, and but a short time ago, to be destroyed. Other valuabie Riel papers were burned by someone cngaged in "tidling up" an old desk. Three or four thousand dollars per annum woulcl suffice to make an invaluable beginning in the creation of a Dejartment of Archives, and it is not to be belicved that public opinion would not heartily endorse the necessary expenditure. The activity of some of the Western American States should arouse healthy emulation in this connection.

The author is conscious that in this, the first History of Saskatchewan, many matters have been given a relative prominence that some realers will think undue, and that other topics have been ignored or given but passing notice, which perhaps should have been treated of at length. The problem of selecton is one of the most perplexing that has conf ronted the writer, and in so far as his decision is faulty, he can offer lut the poor extenuation of mingled good intentions and inexperience.

The work has grown on the author's hands to a bulk far excceding that originally projected, and it has proved necessary to eliminate whole chapters for which materials had been gatliered, and serionsly to curtail many others. This elimination hats ocasioned the anthor the greater regret in that scores of obliging helpers lave aided in collecting the materials he has at length felt compelled to reject. He hopes that these kind friends will accept his apologies, and not interpret the nnission of their contributions as a failure to appreciate their value. 

To his hundreds of correspondents and other helpers, the writer desires to express his deep gratitude. He hojes that they may feel rewarded for their cooperation by a sense of valuable public service ungrulgingly performed. Special mention mu-t le made of liclp rendered by ex-LicutenantGovernors Laird, Dewelney, Mackintosh and Forget, and with their names must be compled that of His Ilonor, Lieutenant-Governor Brown. The most generous assistance has also been afforded by many other distinguished public men, prominent among them being Chief Jutice Ilaulain, Commissioner Perry, Colonel Stecle, Lientenant-Governor Bulyea, Bishop Pinklian, Bishop Matthicu, Hon. Jillyard Mitchell and Rer. Dr. John MacLean.

Most intimately associated with the task of lameling the present History have been the members of what may be called an informal Advisory Board, including Hon. James II. kuss, Arch. I. Mclonald, M.I..... Hon. Thos. Mckay, John.A. Reicl. Eisq. IVilliam Trant, Isif., Sherilf L. B. Murphy, J. H. C. Willoughlyy, Esq., and I)t. I. M. Shaw. The importance of the aid rendered by several of these gentemen it would be hard to exaggerate.

Acknowledgment is gratefully made of many services received at the hands of Mr. John tlawkes, of the Saskatchewan legislative l.ibrary, and Assistant Librarian MInro, who have spent many toilsome hours in unearthing historical data: and at the Parlianentary Library. Ottawa, the Ontario Legislative Library, the I'ublic Reference Library, Toronto, the Manitoba I.egislative Library, the Regina Public Library, and in other kindred inctitutions every aid and facility was placel at the author's disposal.

Space forbids any detailed list of the many others whose aid has rendered the writer's task a possible one; and it does not scem necessary to load these pages with the mames of the hundreds of hooks to which he is more or less indebted. Many of the most important of these will be named when material bortowed therefrom is used. To one writer in particular, however, it has not always been practicable to express the author's indebtedness; this is Dr. Castell Hopkins, whose Annual Reico has provided the ground-work of more than one chapter.

Acknowledgments are made to those authors and publisicers by whose permission use has been made of a considerable number of the most valuable illustrations to be found in the succeeding pages. Such thanks are due to Mr. Lawrence Burpee, author of Search for the II cstern Sca, and to his publishers, the Alston Rivers Company, for permission to tuse portraits of Harmon and llenry, and pictures of Fort Saskatchewan and an Indian Encampment; to Dr. Bryce, author of The Rimarkable History of the Hudson's Bay Company, for permission to reproduce portraits of D'Iberville, Simpson and Selkirk; to Mr. Peekles 17 illson and Messrs. Copp, Clark \& Co. for permission to borrow from his The Great Company the portraits of Prince Rupert and Radisten and a picture of a trader in an Indian camp; to Mr. 

Belden fur permission to borrow from the beantiful pages of Picturesque Canada pictures of Trappers on the March. A Prairie Caravan, Scene at a Portage, and Rapids Near the Mottle of the Saskatchewan; and to Mr. R. G. Maclieth and Messrs. Lirggs and Company for the use of pictures of the Northwest Assembly of 1886 and the Interior of Fort F'itt, and of portraits of Archibald, Morris, Otter, Strange, Midhlleton, Williams and Crowfoot. Some other pictures have been user that have affeared elsewhere before, but which have been reproduced here from the same originats; others again either did not scem to be coyyrighterl or for the cupyright of them the author was unable to fund the owners. No onc's rights have been consciously violated, and if any person find lis rightful anthority in this connection ignored the writer lupes that his profonmel apolugic's will be accepted.

A word as to accuracy: To secure it no labor or expense hat been avoided. However, it has been said with truth that the only way to avoid misstatenent is to maintain silence, and, unfortunately, this policy is not availalile to the historian. Consegnently it camnet but be flat errors will be found in the succeeding pagres. These the anthor hopes will lec reported to him to be rectified in prosilble futne colitions.

As Appendices to this Ilistory of Salkatchewan a latge munler of interesting and valuahle bingraplical sketeles have been prepared. In the prepatration of these, however, the atuther of the Ilistory itscli has hatd no share, and for this portion of the work he therefore disclaims buth responsibility and credit. He knows, however, that the pullishers have left no stone unturned to render these sketches trustworthy.

The writer has habitually endcarored to eliminate any undue personal element from his work, even to the extent, he fears, of rendering his account of the political history of the first decade of the present century a mere colorless chronicle. At all times he has earnestly endeavored to be fair. If his personal point of view, in cases in which he has revealed it, prove obnoxious to bigets and extremists of every party and sect, he will fecl that he has succeeded; for the approval he covets is that of those who in religion and politics dey the ancient injunction to respect and study moderation in all things.

Normax Fregt's Br.ick.

April 30, 1913, Regina, Sask. 



\section{PREFACE TO SIECND EDITION}

The original subserintion erfition of the author: 1 lintory of Saskatchewan and the (Md North-lled was necesarily somenhat expensive: otherwive it could never hate lecen publisherl. Whith a view to reelucing the expense of the second edition, the appendies, consiting of lisegraphical slictehe: of prominent citizens of sitskateliewan of the present and prot. have been omitticl and ecrtain changes have luen introduced in connection with the linding. The main bonly of this popalar edition is however. ifentical with that of the history as it first appearea, being printed from the anne plates.

In one comection the atuthor owes whoth the reader and him-elf a word of explanation and gond-humered expostulation. The printers and puld. lishers have upon the whole performed their duties most creditalbly, and it wotd be unreasonalie to look for complete immunity from lypografphical blunders in the first plates of a bonk (f over 250,000 words. Such slip)= wouht have heen frwer, howerer, hat not circumstances prechded the anthu: from personal superintendence of the progres of his manu-criph through its. final stages in the hand of copyist and printer. In a few cases a word $j$ inexplicably omitted or intruded. and in other passages, famitiat but irrelevant words have been substituted for thos intended by the author: as, "fired" for "prayed" (p. 365.1.12), "tribute" for "tribune" (p. 3(6, 1. 2.3), "Duck Latie" for "lireg Lake" (1).340, 1.12). In most or all canen the charity and ingentity of the reater irmli lad him to recongize how the passage was intended to stant. Except in two instances probably mo error ocsurs that conld really prote mislealing ats to important matters of fact: om 1. 245 "the rising of 1860 and $18-5$ " shonled of conre, real "the rising of 1860 and $18,0 "$; and in transeribing the manuscrint for p. 2 (s the copeist has read 300 as $3 \mathrm{C}$. in the passige treating of the number of lialibreets and lndians present at Duck lake. Further crata ct corrigenda seen uncalled for, as doubtiess such lingses on the part of printer or copyist are nuere exasperating to the author than perplexing to the realer. If genume historical errors the author himself has dutthess leen guilty, and he will welcome their being brought to his attention: 1.ut if he be held accountable for manifest nonsense. and sy ntactical or orthegraphical bhunders he will reply with a disclanner framed upon that adtresed ly . Wacheth to the accusing ghost of bimentul

N. F. B.

Regina, zory Retallitek St..

Novemler 1, 14)13. 



\section{CONTENTS}

PAGE

Prentce $\ldots \ldots \ldots \ldots \ldots \ldots \ldots \ldots \ldots \ldots \ldots \ldots \ldots \ldots \ldots \ldots \ldots \ldots \ldots \ldots$

\section{CHAPTER I}

Purpose and Plan of the following Work................ I

\section{CHAITER II}

The Founding of liritish Interests in North Western America...... 5

CHAPTER III

Early Explorations and International Rivaly For Control of the West. 15

CIIAPTER IV

The Rival Fur Companies and larther Explorations in the West-

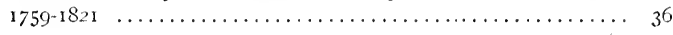

CHAPTER Y

Life and Customs of Prairie Traders and llunters............ 52

\section{CHAPTER II}

Saskatchewan Indians: Origin. Tribes and Modes of Life........ 68

CHAPTER VII

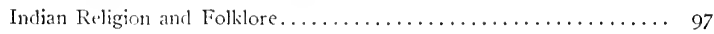

\section{CHAPTER VIII}

The First Settlement Colnyy in the Canadian West........... II

\section{CHAPTER IN}

The Forgotten Commonwealth of "Mlanitoba," and Other Provisional Goveruments ............................. 124 

The Surrender of the Noril Nest Territorien ly the Hudsonts liay

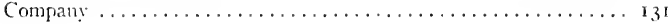

\section{CHAPTER NI}

A Lesson Lost: The Troubles of 1870 .

\section{CIIAPTER XH}

The First Settemonts in Saskatelewan; Preliminary Ontline of the

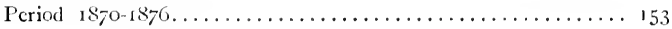

\section{CIIAPTER XIII}

Political IIistory of the Territories, I870-1876............ I70

\section{CHAPTER XIV}

Unrest of Canalian Indians and Incursion of the Sioux.......... Iso

\section{CIIAPTER XV}

Laird's Adouini-tration and Councils, $1876.1881 \ldots \ldots \ldots \ldots \ldots \ldots$ I9

\section{CHAPTER XVI}

The Surrender of Saskatchewan by the Indians............... 204

\section{CHAPTER XVII}

The Building of the Canalian Pacific Railway............. 2I9

CHAPTER XVIII

Dewdney's Administration and Councils, I8RI-1888. 226

\section{CHAPTER XIX}

Discontent in the IVest and Premonitions of Rebellion.

\section{CHAPTER XX}

The Outbreak of the Rebellion: Pattle of Inck Lake. 265

\section{CHAPTER XXI}



CONTENTS
CHAPTER XXII PAGE

Middleton's Plans: the Advance to the Seat of Insurrection......... 29I

CHAPTER XXIII

The Batle of Fish Creek.................... 300

CHAPTER XXIV

The Battle of Cut Knife Creek.................... 3 os

CH.APTER XXY

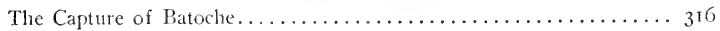

\section{CHAPTER XXII}

Middleton's Advance atia Prince Albert to Battleford, and the Surrender

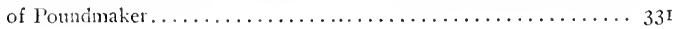

\section{CHAPTER XXVII}

The Work of the Alberta Field Force, and the Close of the Campaign. . $33^{5}$

\section{CHAPTER XXVIII}

Racial Aspects of the Rebellion of $1885 \ldots \ldots \ldots \ldots \ldots \ldots \ldots \ldots \ldots$

\section{CHIPTER XXIX}

Religions Aspects of the Rebellion of $1885 \ldots \ldots \ldots \ldots \ldots \ldots \ldots \ldots \ldots . \ldots \ldots 7$

\section{CHAPTER XXX}

Life, Character and Fate of Riel. . . . . . . . . . $\ldots \ldots \ldots$

\section{CHAPTER XXXI}

Miscellaneous Rebellion Aneclotes................... $3^{81}$

\section{CHAPTER XXXII}

Royal's Administration: Political History, 18SS-1893 . . . . . . . . . 391 

Royal's Adninistration: Social and Industrial Development....... 415

CHAPTER XXXIV

Mackintosh's Administration: Political History, I893-1898......... 420 CHAPTER XXXV

Mackintosli's Administration: Social and Industrial Development.... 432

CHAPTER XXXVI

Cameron's Administration

\section{CHAPTER XXXVII}

Forget's Administration: Political History, ISg8-I905..........4.2 CHAPTER XXXVIII

Forget's Administration: Social and Industrial Progress.......... 449

\section{CHAPTER XXXIX}

The Agitation for Provincial Status

$$
\text { CHAPTER XL }
$$

The New Provincial Constitution...................... 46 I

\section{CHAPTER XLI}

Forget's Administration: Political History, I905-1910.......... 480

\section{CHAPTER XLII}

Forget's Administration: Social and Industrial Development....... 490

\section{CHAPTER XLIII}

Colonization Companies and Analogous Enterprises: Anglo-Saxon Im-

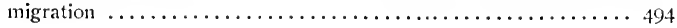

\section{CHAPTER XLIV}

Continental Immigration: North Western Europe............ 504 

CHAPTER XLV PAGE

Inmigration from South Eastern Europe................ 509

CHAPTER XLVI

The Catholic Church in Saskatchewan............... 521

CHAPTER XLVII

The Methodist Clurch in Saskatchewan............... 532

CHAPTER XLVIII

The English Church in Saskatcliewan................. 544

CIIAPTER XLIX

The Presbyterian Church in Saskatchewan.............. 554

CHIAPTER L

The Educational System of Saskatchewan............... 561

CHAPTER II

The Royal North West Mounted Police................ 57 I

CHAPTER LII

Fraternal Societies in Saskatchewan. . . . . . . . . . . . . 599 



\section{GENERAL INDEX}

Adam, Captain G. Mereer--

Comments on Cut Kuife Battle, 314

Albertal Field Forec, $336 \mathrm{ff}$.

Alberta, Old District of, 227 .

Almighty Voice, 588 .

Ancient Order of Hibernians, 605 .

Anderson, Bishop, 545.

André, Rev. Tather-

llalf breed gricrances, 256 .

Invitation to Riel, 259 .

Annexation to the Inited States-

Petitioned for, 133 .

Bill introduced in Congress, 36.

Archibald, Lieut mant Governor-

Fenian Raicl. 15I.

Marle I.icutenint Governor of Territories, 170 .

Uncertainty of Inctructions, IzI.

Indian Treaty. 208 .

Assinibnia, District of, 227.

Astley-

Heroism at Batoche, 321.

Athabasca, District of, 22-.

Athabasca, Fort, Founded, fo.

Austro-H Iungarian lmmigration, 506.

Autonomy Bill, 694, 691, 472. .

Baftin, Win. See Explorers.

Baker, Didrey, 38 I.

Barr Colony, 502 .

Batoche, Battle of-

Capture of. Chap. XXV.

Heroism at, 386 .

Battleford-

Survey of, 22\%.

Conditions When Relieved by Otter, 298.

Beardy. Chief-

Demands in 1879, 200.

Bell Farm, fy).

Better Financial Terms for Northwest, 4II ff, 430,463 .

Betts, J. F., $400,423$.
Big Bear-

Attitude Towards Treaty, 218.

Conduct at Duck Lake, 28 ;

Character and Trial. 348 .

Black, Rev: Joln, 555.

Blackfect. See Indians and Indian Treaties.

Visited ly Hendry, 35 .

Bole, J. F., 4 \&2.

Bompas, Bishop, 546 .

Borden, Kt. Hon. R. L.-

On Antonomy Fill, 454, 470 .

Poulton, Major-

Account of Fisll Creek liattle, 302.

Comments on Cut kinife Battle, 312.

Breland, Pascat--

Investigates Indian Situation, 182.

Nember of Northweet Council. Ig6.

Brett, Dr. R. G., 30S if, $400,4+2$.

Brown, James-

First Secretary Board of Education. $f^{19}$

General Services to Eilucation, 563 .

A Founder of Provincial Nusical Association, 560 .

Bryce, Rev; George, 556.

Buchan, David. See Explorers.

Buffaloes, Disapmearance of, 62, 199.

Bulyea, G, H. S.-

Expedition to Youkon, $436,4.3 \%, 458,460$,

Burn, Bishop, $55 \mathrm{I}$.

Fintler, Captain W. F., $155,156 \mathrm{ff}, 573$.

Button, Sir Thomas. Sce Explorers.

Bylot, Rolert. See Explorers.

Cabots, The, John and Sebastian. See Explorers.

Calder, $110 \mathrm{n}$. James, $48 \mathrm{i}, \mathrm{ft} 5$.

Cameron, X. C.-

Discusses Northwest Gricvanees, 2,37.

II is Administration, Clap. XXXVI.

Cantulian Mounted Rifles, 591 . 


\section{.}


Canadian Pacilic Railway-

Building of, Chap. AVII.

Pacific Scandal, 220.

Tuper's Policy, 222, 223

Blake's Criticism, 223.

Canoes, 62.

Carlton, Fort, Evacuaterl and Purned, 279.

Carmichacl, kev. J. A. 550.

Carteret, Sir George. See Iudson's Bay Company, Founding of.

Catholic Church, Chapter XLi'J.

Cayley, IJugh St. Q., 3us, 405.

Chamberlain on North American Indians, Quoted, 94.

Charles, Fort, Founded, i2.

Charles 11. See Hudion's Bay Company, Founding of.

Cheadle, 6I, 86.

Also see Mlilion and Clicarlle.

Chippeweyan, Fort, Established, 4I.

Christie, W. J.-

Nember of Northwest Council, 172.

Services in Treaty Making, 211, 214.

Clarke, Dr. C. K.-

Opinion on Ricl's Sanity, 501 .

Clarke, Dr. Daniel_-

Opinion of Ricl's Sanity, 360 .

Clark, Lawrence-

First Elected Member of Council, 202, 228.

On Half-Breed Claims, 250.

Interview with Disturbed Half-Breeds, 267.

Conduct in Duck Lake Affair, 280.

Letter of 11 arning to Government, 282.

Clinkskill, James, 398, 405.

Clut, Rev. Father, 527 .

C. MI. B. A., 605.

Colonization Companies, $494 \mathrm{ft}$.

Conradi, Constable, 586 .

Coureurs du Bois, 56 .

Also see Traders and Hunters.

Crozier, Major-

Adventure on Lucky Man's Reserve, 252.

Telegrams Prior to Rebellion, 264, 269

Portrait of, 273 .

Advances on Duck Lake, 274 .

Commands First Shot, $2 ; 6$.
Explanation of Conduct at Duck Lake, 280.

Despateh from Prince Albert, 295.

Cut Knife Creek, Chap. XXIV.

Cypress Hills Massacre, 167,573 .

Davin, Nicholas Flood. See also "Regina Leader."

Founded "Leader," 232.

Indian Industrial Schools, 249.

Deadlock of $1892,407 \mathrm{ft}$.

Delaney, Mrs, and Mr., $286 \mathrm{ft}$.

Demnis, Captain, 293.

Denny, 200.

Dewdney, IJon. Edgar-

Becomes Indian Superintendent, 202.

Becomes Lieutenant Givernor, 226.

Address to First Comeil, 230.

Criticism of His Administration, 24.4.

On Half-Breed Clains, 25I.

Why He Did Not Foresee Rebellion, 282,524 .

Correspondence with Otter Prior to Battle of Cut Knife Creek, 328 .

Communication with Indians, 33\%.

Opinion of Poundmiker, 355.

Diaries of Volunters, 294. 297, 208, 310. 384.

D'Jberville, Le Moyne, $21 \mathrm{ff}$.

Dobbs, 23.

Dog Trains, 6r.

Donaldson, S. J. $4_{42}$.

Douglas, Fort, 5 I.

Doukhobormog ff.

Draper, \& , Justice, I34.

Duck Lakí-

Battle of, 265 ff.

Consequences of Disaster, 286.

Dumont, Gabriel-

Provisional Govermment of 1875,130 , 157.

Account of Duck Lake Battle, 279.

Plans at Fish Creck, 300.

Account of Fish Creek Bittle. 305.

Escape After Fall of Batocle, 320.

Dunmore, Earl of, 122.

Educational Association. 567 .

Educational System of Saskatchewan, Cliap. L. 
Emmanuel College, $5+7$.

English Church in Saskatchewan,

Chap. XLVIII.

Evans, Rev. James, 445, 532.

Explorers-

The Cabots, John and Scbastian, 5.

Hobisher, Captain Nartin, 6.

IIudson, Henry, $6 \mathrm{ff}$.

Button, Sir Thomas, 8 .

Jones, Captain, 8.

Gibbons, Captain, 8.

Bylot, Robt., 8.

Baffin, Wm., 8.

Hawbridge, Captain, 8 .

Fox, Captain Luke, 8 .

Radisson, Pierre Fsprit, $8 \mathrm{ff}, 17 \mathrm{ff}$.

Groscilliers, Médart Chouart de, $8 \mathrm{ff}$, I7 ff.

Munck, Jens, $15 \mathrm{ff}$.

Gillam, Captain, 12, 18.

Saint Picrre, 33.

Kellsey, Henry, 24 ff, 34.

Vérendryc, La, $29 \mathrm{ff}$.

IIendry, Anthony, 34.

Finlay, James, 36,38 .

Henry, Alexander (Sr.), 36 ff.

Larocque, 48.

Hearne, Samuel, 50.

Buchan, David, 5o.

Franklin, Sir Joln, 50.

Parry, Edward, 50.

Palliser, Captain, 122.

Farand, Bishop, 527.

Farmer's Union, 260 .

Fenians--

Attempted Invasion, 149.

Privy Council Report, 163 ff.

Ficld, Corporal, 587.

Finlay, James. See Explorers.

Fish Creck, Chap. XXIII.

Lepine's Report of, 363 .

Fitzgerald, Inspector, 592.

Forget, IJon. A. E.-

Tribute to Mr. Laird, 192.

Clerk to Northwest Council, 193.

Commissioner for Consolidation of Ordinances, 393.

Forts, General Character of, $52 \mathrm{ff}$.
Fox. Sce Explorers.

Frank, Landslide at, 451 .

Franklin, Sir John. Sce Explorers.

Fraternal Socicties, Cliap. LII.

French, Commissioner, 293, 573, 576.

French Language-

Discontinued in Official Documents, 394 .

Frenchman's Butte, Thattle of, 339 .

Frolisher. See Explorers. Sce Northwest Company.

Frog Lake Massacre, $285 \mathrm{ff}, 529$.

Furs, Chicf Varicties Exported, 62.

Gibbons. See Explorers.

Goggin, Dr., 564 .

Gordon, Rev. Charles W., 558.

Government Elevators, 492.

Grain Blockade, 45I.

Grand Trunk Pacific, 452.

Grandin, Bishop, 526.

Grant, Rev. A. S., 559.

Grant, Dr. G. M., I69.

Grisdalc, Bishop, 55 I.

Groscilliers. See Explorers.

Half-Breed Claims--

Petitions, $247 \mathrm{ff}$.

A Commission, 295.

Half-Breed Fetitions, $247 \mathrm{ff}$.

Harding, Bishop MICAdam, $55 \mathrm{I}$.

Harmon, Danicl. See Northwest Company, $76,82,88$.

Haultain, J. W. G.-

First Elected, 242.

Regarding Estimates of $1889,396$.

Nember of Territorial Executive Committec, 405, 423 .

Regarding Liquor Permits, 437 ff, 442.

Regarding Separate School Bill, 447.

Visited Ottawa, 453.

Regarding Sir Wilfred's Letter to, 456.

Visit to Ottawa 1905,460 .

Letter Regarding Autonomy, 464.

Regarding Financial Natters, 482 .

Political History of Administration, 1898-1905, Chap. XXXVII; 1905-1910, Chap. XLI.

Social and Industrial History of Administration, 18g8-1905, Chap. XXXVIII; I905-1910, Chap. XLIJ. 
Regarding Telenlune System. 485 .

Hawbridge. Sec Explorers.

Hearne, Stmuel. See Evplorers.

Hebrew Jumigration, 507 .

Hendry: Sce Lxpluters.

Henry, Alcaunder (Jr.). Sec Northwest Company:

Henry, Alexander ( $\mathrm{Sr}$ ). Sec Explorers. Sec Northwest Company.

Henry, Willian, ros

Henty, G. A. Jr.-

Description of Capture of Batoche, 322.

Herchmer, Commis-ioner, 590.

Hind-

Quoted, gS.

Comments on Indian Lurest, ISO.

History-

What It Is, Chap. I.

Purpose and Plan of This. Chap. I.

Hogg, Corporill, 5\&).

Ilougliton, Coloncl-

Comments on Cipture of Bituche, 321.

Hudson's bay Company-

Founding of, in.

Chater, $12 \mathrm{ff}$.

Sharcholder's Oath, 1 1.

D'lberville's Raids, 2l ff.

Dobb's Controversy, 23.

Trading I'osts. 24. 132 .

Explorations by, 24 .

Recetion of Iendry" Report, 35.

See Governors Simpson, Sempler.

Rivalry witl Northwest Company, 51, II4 $\mathrm{ff}$.

Fusing with Northwet Company, 51.

River Boats, 62.

Sce Selkirk.

Loss of Monopoly, 12I.

Surrender of Northwest Territory, Cliap. X.

Retired Servanti, 142, I44, $150,482$.

Hugomard, Father, 528.

Hudson. See Explores.

Icelandic Immigration, 506 .

Immigration, $417,419,435,451,462,494 \mathrm{ft}$. 50I, 504 fi.

Teutonic Immigration, 506 .

Memonites, $5(x)$.

Anglo-llumgitian, 506.
Helrew, 506 ,

From Southastern Europe, 509 if. lcelandic, 506 .

Ruthenian, 519.

Indians. See Indian Treatics and Racial Aspects of kebellium of 1885 .

Indian Trentics, $204 \mathrm{ft}$.

Outline of, 206.

Attitude of the Clices, $20 \%+49$

Last Great Surrender. 493.

Irvine, Major-

Inflience with Indians, 184.581.

Telegrams Prior to Relycllion, 264.

Report Regarding Relicllion, 269.

March from Regina, 272.

Defense of Prince Alliert, 332.

Attempt to Co-cuprate with Micddeton, 332.

Demolished Fort Walsh, 58,3 .

Jemneraye. See Verendrye.

John Lester Kaye Farms, 500 .

Jones. Sec Explorers.

Kanc, $8_{3}$.

Kellsey: Sec Explorers.

Kildonan, 554 .

Lacombe, Fatlies, 155

Report of Smallpox Epifemic, I6o ff.

Peacemtier in $1885,337,527$.

La France, Josepl. Sce Explorers.

Le Garé-

Negotiations with Sitling Bull, 189.

Praise from Irvine, $190,386,582$.

Laird, David--

Superintendent Gencral of Indian Af. fairs, $1 ; 1$.

Appointed Licutenant Governor, 191.

Treaty witl, Blachecet, 106.

Budget of $18 ; \div-18,8,196$.

Treaty of Qu'Appeilc, $210 \mathrm{ff}$.

Half-litecd Question, 249. +49.

Laird, H. W.., + \&2.

Laird's Council, 191, 193.

Lamont, Judge, $4 \AA_{4}, 486$.

Lind Girants, $49 \%$.

Land Regulations, $41 \%, 40,494$.

Langevin, Pishop. 5,30.

Langley, 1 lon. George, 495. 

Larocrue. Sec Explorers.

Lost Mountain-

Visited l,y Itarmon, if ff.

Laurier, Sir Wilfrid-

On Nortlwest Autonomy, $456 \mathrm{ff}$.

Lawson, Rev. Thomas, 451 ff, 5,36 .

Legends, ro5-111.

Legislation, Disallowanee of. $f \circ 9$.

Lestanc, Fitther, 528 .

Lett, Scrgeant, syo.

Liquor Iraffic-

Permit System, 236.

Failure of Permit Law, 243.

Debates on, 394, 420, +23. 4.3.

Lloyd, Arcludeacon, $5.48,549$.

Local Improvement J istrict, 450.

Loon Jakke, Skirmish it, 4 \%.

Loyal Orange Association, ( $k+f \mathrm{ff}$.

Mactonc1l, Miles, I14 ft.

Macdougal, Rev. Goo, fith, 470, 534, 535

Maclean, Rev. Dr. John, 457, 459, 541, $5+2$.

Nachray, Bishop, 546.

Mackay, Ircluketeon, 5ti

Mackiı, Ilon. James-

Indian Treaties, 182, 217.

Mackiny, Joseph, Sr., 38,3.

Mackay, Thomas-

On Half-Lreed Claims, 250.

Acts as l'eacemaker, 270 .

Nember of Advisory Council, to

Nclean, W. J-

Opinion of Big Fear, 35I.

Mackenzic, IIon. Mlexanter-

Comments on Disorder in Northwest. $17+$.

Introduces Northuest Territorics Act, 178 .

Attitude Towards Canadian Pacific Kailway, 220 .

Mackenzic, Alexander and Roderick, $f 1$. 117.

Sec Northwest Company:

Mackintosh, Charles Herbert-

Political llistory of Administration. XXXIV.

Social and Political Development of Administration, XXXY.

Nacleot, Archibald Norman. Sce Northwest Company.
Macleod, Jutice, f2u.

MicGillivary, William. Sec Northwest Company:

IIcDougall, Rev. George, 215.

MeDottyall, Rev. John, I55.

Indians and the Lnion Jack, 181 .

Peacemaker in 1885,337 .

McDougall, Jlom. William, l.t. fi.

Attitule of Loyaliats. 566 .

Melaren, Rev. i. D., 559.

Icl.ean, Bishop-

Opinions on IJalf-Jireed Question, 249

Services to Saskatchesan, 547,566 .

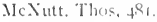

NeTavish, Simon. Sce Northwest Company.

Mnguire, Chief Ju-tice, I. 11.-

On Provincial Antonomy, $f(x)$.

Mair. Charles, 450.

Manitola, Forgotten Commonwealth of, Chap. 1.

Nanitolia Act, 1.49

Masonic Oreler, $559 \mathrm{ft}$.

Matthieu, Rishup, 5.31.

Melgumil (Lord Jinto) -

At Fish Creck, 305.

Departure from liatuche, 3 I8.

Ilemorials to Federal Government, 232. $240,393.399,411,419,428,432.440$.

Mennonites, 50 r.

Methodist Church in Saskatchewan. Cliap. Xll1.

Middletun, General-

Notified of Rising, $29 \mathrm{I}$.

Flan of Campaign, 24 r.

Employment of Cavalry, 203.

Forces at Disposal of, $29,3$.

Suppression of Intoxicants, 206.

Change in l'lan of Campaign, 206.

Description of Fish Creek Battle, 30.3.

Erroneous Reprot of Relul Jumes, 305.

Capture of Fitnclie, Chap. X.V.

Message to Riel, 320.

Letter to Poundmaker, 333.

. Irrest of Poumlmaker, 334 .

Pursuit of Bigr Bear. $34 \mathrm{I}$.

Takes Farewell of Northwest Field Force, 34.

Nition and Cheadle, 75, 122, 16n.

Also see Cheadle. 

xviii

Ninnesota Massacres, i8r.

Mitchell, Hon. Hillyard-

Acts as Peacemaker, 2(x).

Stores Seized, 272.

Member of Advisory Council, 396.

Morris-

Licutenant Governor of Territorics, 170.

Address to Northwest Council, i72.

Speech to Last Council at Fort Garry, 175.

Danger of Indian War, I82.

Also see Indian Treaties.

Motherwell, Hon., 48I.

Mounted Police, Chap. LI, 415.

Munck. See Explorers.

Neff, James Ryerson-

Member of Royal's Advisory Council, 398.

Member of Territorial Executive Committee, 405.

Newton, Rev. Canon-

Comments on Western Discontent, 260.

Nisbet, Rev. James, 155, 556 .

North Atlantic Trading Company, 504.

Northwest Conpany-

Founded by Pond and Associates, 40.

Henry, Alexander (Sr.), 40.

Frobishers, Joseph and Thomas, 40.

The Mackenzies, Alexander and Roderick, $4 \mathrm{I}$.

McGillivary, William, 4I, I34.

McTavish, Simon, $4 \mathrm{I}$.

Thompson, David, $4 \mathrm{I}$.

Macleod, A., 4I.

Ross, John, 41.

Pangman, Peter, 4I.

Henry, Alexander (Jr.), 43 ff.

Harmon, Daniel, $43 \mathrm{ff}, 53 \mathrm{ff}$.

Relations with X. Y. Company, 43 .

Rivalry with Hudson's Bay Company, $51,114 \mathrm{ff}$.

Fused with Hudson's Bay Company, 5I.

Organization of, 172 .

Legislation by, 173 .

Protest Against Federal Inaction, 174.

Comments on Indian Situation, 174.

Nembers, 193.

Records, 193 .

Northwest Territories Act-
Passed 1875,178 .

Educational J'rovisions, 179, 394.

Amended, 404.

Amendments of $\mathrm{s} 8 \mathrm{gI}, 437$.

Odd Fellows, 603 ff.

Oliver, Frank-

Introduces School Bill, 236, 238.

Ballot Papers, 420, 447, 4.58.

Otter, Colonel-

Original Orders, 291.

Relicves Battleford, 297.

Cut Knife Crcek, 308 .

Palliser. Sce Explorers.

Pangman, Peter. See Northwest Company.

Parry, Edward. Sec Explorers.

Pascal, Bishop, 529.

Panl, John, 382.

Pcdley, Constable, 586.

Pekan, Chicf, 455, 538 .

Pelleticr, L. A., 592.

Perley, Senator, 418

Perritt, T. E., 565.

Perry Commissioner, $336,5^{8} 4$.

Pi-a-pot, $58_{3}$.

Pinkham, Bishop, 548 .

Pitt, Fort, Threatened, $2 \& 9$.

Pond, Peter-

See Northwest Company.

Extract from Journals, 59 ff.

Poundmaker, $30 \mathrm{ff}$.

Letter to Middleton, 333.

Surrender, $334 \mathrm{ff}$.

Trial of, $353 \mathrm{fi}$.

Capture of Otter's Supply Train, $3 \$ 6$.

Presbyterian Church-

History of, Chap. XLIX.

Prince Albert-

Siege of, 33 .

Pritchard, John, $287 \mathrm{ff}$.

Provencher, Bishop, 524.

Provincial Autonony, Chap. XXXIX.

Provincial Constitution, Chap. XL.

Analysis of Saskatchewan Act, 472.

Unwritten Elements, 474.

Provincial Educational Association-

Establislment of, 492.

Provisional Governments- 
See Manitoba, Forgotten Commonwealth. John Bruce's Government at Fort Garry, 145.

Louis Ricl's Goverument at Fort Garry, 147 .

Gabricl Dumont's Govermment at $\mathrm{Ba}$ toche, 167.

Louis Riel's Government at Batoche, 268 .

Qu'Appelle-

Visited by Harmon, 47 .

Radisson. See Explorers.

Railway Development, 4I7, 481, 490 .

Railway Xlissions, 552.

Rebellion Anecdotes, Clap XXX1.

Rebellion Casualties-

At Duck Jake, 278.

At Fish Creck, 305 .

At Cut Knife Creek, 313 .

At Batoche, 327.

Rebeltion of IS8-

Premonitions, 24.5 ff.

Racial Aspects of, 347.

Religious Aspects of, XXIX.

Regina-

Chosen Capital of Territories, 228.

As Provincial Capital, $48 \mathrm{I}$.

Regina Leader-

Founded, 232.

Comments on Dewdney's First Council, 232.

Comments on Deadlock of 1892,407 .

Comments on Mackintosh's Veto of School Bill, 644 .

Responsible Government, 394, 399, 402, 403, $405.428,46 \mathrm{Iff}$.

Richardson, Judge Hugh-

Nember of Northwest Council, I93.

On Half-Breed Clains, 250 .

Address to Riel, 375 .

Member of Royal's Advisory Council, 400.

Administrator During Lientenant Governor Cameron's Illness, 436 .

Richardson, Sergeant A. H., 59I.

"Riders of the Plain," a Ballad, 579.

Riel, Louis, 167 .

Seizes Fort Garry, 145.
Relations to Fenians, 147 .

Bill of Rights, 147, 259.

Interview with Donald A. Smith, I. 18.

Treatment of Union Jack. I 49.

Fenian Raid, 15I.

Herald's Comments on Arrival, 258.

Begins Dangerous Agitation, 266.

Organizes Provisional Government, 268.

Number of His Followers, 268.

Letter to Crozier, 27o.

Attitude at Battle of Duck Lake, 280.

Not at Fish Creek, 306 .

Message to Middleton, 320.

Methods of Obtaining Indian Support, 355.

His Commonplace Books, 358 .

Hampered Ilis Military Licutenant, 36,3 .

Life, Character and Fate, Chap. XXX.

Services in $1871,367$.

Invitation Received from Northwest Half-Breeds, 368 .

Conments on His Own Supernatural Power, 360 .

Alleged Insanity, 370 .

Alleged Merecnary Motives, 373.

Acceptance of Half-Breed Invitations, 373.

Trial, $374 \mathrm{ff}$.

Letter to Judge Richardson, 376, 377.

Conduct Prior to Execution, 379.

Ritchot, Father, 52\%.

Robertson, Rev. James, $556 \mathrm{ff}$.

Robinson, Christopher-

On Constitutional Aspects of the Autonomy Bill, 470 .

Ross, Hon. James H.-

Chosen as Speaker, 405.

Resignation of Speakership, 407.

Nember of Executive 1895, 423, 442.

Colonization Roads, 4.49.

Visited Ottawa, 453.

Ross, John. See Northwest Company.

Rouleau, C. B.-

Appointed to Council, 234.

Royal's Administration-

Administration, Political History, Chap. XXXII.

Social and Industrial Development, Chap, XXXIII. 
Rupert, Frince. Sec Ifudson's Pay Company, Founding of.

Ruthenian Immigration, 5ry.

Saint Pierre. See Fixplarer.

Saskatchewan Board of Health 163 .

"Saskatchewan Heralr"-

Comments on Sionx Incursion, 184.

Comments on Printil Systent, 227.

Saskatchewan Murieal A-socitition, 5iu.

Saskatefewan, P'ruviaional pistrict of, 227.

Saskatoon, Inounded, 451, 536.

Seloolcraft, Quoted, 9.3.

Schools-

Grant of $1879-80$. Ir. 8 .

Oliver's Selonet Pill, 234,235

Abolition of Poard of Edncation, fIS.

Statistice, 418 .

Separate School Quention. tzr.

Ordinance of $18,5,347,4.30,4.5$.

Founding of in Red River, 561 .

Attitude of Nortinwest Council Toward, 562.

Establishment of Northwest System. 562.

Normal Schools, 594.

Characteristic Features of Saskatchewan System, 5ijo.

Scott, Ilon. Walter, t4i, 4 S.

Visited Ottawal 1906, $4 \&_{4}$.

Secord, $400, .158$.

Selkirk, Earl of, I $12 \mathrm{ft}$.

Deatl, 117.

Selkirk Settlement-

Chap. VIH.

Founded, 114.

Hardihips, 117 ff.

Troubles of $18 \% 0,143 \mathrm{ff}$.

Semple Murdered, 51, II6.

Separate Scliooli-.

Separate Schond Question, $308,458 \mathrm{ff}$, $46 \mathrm{I}, f^{6} 3$.

Provisions of Pritish North American Act Relating to, t7s. 5600 .

Settement of the IIest-

Chap. VHII.

See also Inmigration.

Seven Oaks, Massacre of, si.

Siftum, Clifford, 454.

Simpson. Sir George-

Notable Journeys, 50; 120,132
Sinchir, James, 121, 1.2.

Sionx Incursion. Chnp. XIV.

Sitting Pinll's Band, 5,8 .

Sitting Bull-

Battle of Little Big Horn, 183.

Negotiations for Return, $18_{5}$

Reply to Commissioner, 186.

Mesinge to Ilis Imople, 188

Return to Enited States, roo.

S1112tlpox. I58.

Papanckis 1Expeulition. 534.

Smith, Colonet Oborne--

Importance of Services. 344.

Smith. Domald . A.-.

Conmissioner to Red River, It $\mathrm{ff}$.

Opinion of Loyalist Rising. ItS.

Interview with Rive, I 4 S.

Inquiries in Parliament, $17 \mathrm{I}$.

Services to Canddian Pacific Railway, 224.573.

Society for the Advancement of Art, Litcrature and Science, 560 .

Southesk, Earl of, I 6 ).

Spence. Thomas-

See Manitoba, Forgotsen Commonwealth

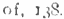

St. Clad's Hostel, 551.

Stecte, Coloncl-

Negotiations witl Sitting Bu!l, I 8 .

Pursuit of Big Pear, $3,3 \mathrm{Sff}$.

Engagement at Loon Lake, 340.

Importance of Services, 34t. 574.

Steinlienr, Rev: Henry, $447,533$.

Stephen, Sir George, 224.

Stewart. Alexander-

Account of Battle of Duck Lake, 278 .

Strange. General-

Original Orders, 292.

Advance of Columu, 3,36 .

Report re French Camalian Voluntects, $5^{12}$.

Importance of Services. 34t.

Strathona Horse, 591 .

Supplenentary Revenue Act, fis.

Supreme Court of Sakatchewan, 486.

Sttherland, Rev: Dr. A., 6,0, 535.

Tache, Archbishop-

Tronbles of I8;o, 151.

Jfalf-Breed Question, 24l?. 
Relations with Ricl, $3(6)$

Memorial on Schoul System, 42t.

First Reacherl Red River, 524.

MacBeth's Tribute to Taché, 520.

Taylor, James WI., 122, 135.

Telephones, $71 \mathrm{I}$.

Territorial Exhibition of $1807,433 \mathrm{ff}$.

Tentonic Immigration, 506 .

Thompson, David. See Nurthwest Company.

"Toronto Mail"-

Comments on Ifalf-Breed Grievances, 263.

Denies Likeliliond of Releflion, 246.

Description of battle of Batoche, 322.

Traders and Hunters. Sce Explorers, Northwest Company, Hudson's Bay Company, X. Y. Company.

Trant. Police Magistrate-

Regarding Society of Art, Litcrature and Science, $5 \%$.

Troubles of 1870,528 .

Turgeon, W. F. A., 486 .

Turriff, J. G.-

Elected to Conncil, 23-1. 447.

Tweed, Thomas, $308,405,456,482$.
Universily of Saskatchewan, 419, 492, 566.

Van Horne, Sir William C. 224. 582.

Vérendrye La. Sce Explurers.

Verigin, Peter, 510 ff.

Vetcrans of the Fur Trade Association, II $3, \mathrm{I}_{2} \mathrm{O}, \mathrm{IL} 2 \mathrm{2}$.

Walker, Colsnel James, 44.3, 575, 578 .

Withh, lnspector-

Relations with Sitting Lull, 186, 189; $574,579$.

West, Rev. John, footnute, 84. $5+4$.

Whitccap, Chief, $4513,5.39$

Wilderness Mlurder, The, 587.

Williams, Colonel-

At Batoche, 32I.

Wolselcy, Coloncl, iso.

X. Y. Company, 4.3 .

Young, Edgerton Ryerson, 181, 4fs, 534.

Yukon District-

Cut off from Northwest, 4,39

Services of Mounted Police, 590. 


\section{LIST OF ILLUSTRATIONS}

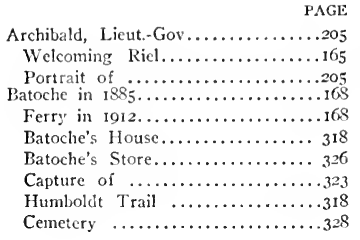

Battleford

Brown, G. IV., Lientenant Governor...483 Buffalo-

Herd $\ldots \ldots \ldots \ldots \ldots \ldots \ldots \ldots \ldots \ldots \ldots$

Pile of Bones..................

Cameron, C. M. ...............477

Canora .........................

Coat of Arms, Hudson's Bay Company $\ldots \ldots \ldots \ldots \ldots \ldots \ldots \ldots, 9$

Crow foot, Chief ................205

Crozier, Major ..................273

Cut Knife Creek, Battle of ..........

Dewdney, Edgar ...............4 47

D'Iberville ..................... 20

Dixon, John ...................487

Duck Lake Battlefield.............275

Dumont, Gabricl ...............275

Estevan $\ldots \ldots \ldots \ldots \ldots \ldots \ldots \ldots \ldots, \ldots 57$

Fish Creek, Battle of ............. 30r

Fitzgerald, Inspector .............594

Memorial Tablet ..............597

Forget, A. E..................477

Fort Edmonton in $1867 \ldots \ldots \ldots \ldots . \ldots 154$

Fort NIacleod .................. 176

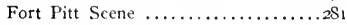

Fort Saskatchewan ............. 76
PAGE

Fort Walsh $\ldots \ldots \ldots \ldots \ldots \ldots \ldots \ldots 176$

Fort Whoop-up ...............577

French, Captain (of French's Scouts).3r

French, Sir George A., Commissioner

R. X. W. M. F........... 572

Grading on Canadian Pacific Railway, 221 Great Indian Comeil .............28

Hamon, D. W................ 20

Haultain, Hon. F. W. G............48

Henry, Alex., Sr............... 20

Herehmer, Commissioner R. N. IV.

II. P. $\ldots \ldots \ldots \ldots \ldots \ldots \ldots \ldots, \ldots \ldots \ldots+2$

Indian Encampment ............ 46

lrvine, Commissioner R. N. W. M. P..572

Lacombe, Rev. Father...............159

Laird, David ................... 477

Mackintosh, Lieutenant Governor.....477 Macleod, Commissioner R. N. W. M.

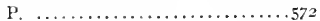

MeDonald, Arch ............... $8_{3}$

McDougall, Rev. Geotge ..........205

MeKay, Hon. Thomas ............487

NeLean, Bishop, Original Palace.....235

Maple Creek ....................468

Marion, Louis ....................328

Nasons, Grand Masters ...........602

Melfort ........................ 540

Middleton, General ...............292

Mitchell, Hilliard, kesidence in $1886 \ldots 273$

Morris, Hon. Alex................205

Noose Jaw........385, 395, 406, 422, 429

Murphy, G. B..................487

"No Complaints" .................594

North Battleford .................35t

Northwest Council. Picture of Men-

bers in $1886 \ldots \ldots \ldots \ldots \ldots \ldots \ldots \ldots \ldots 235$ 
PAGI:

Old-Time Prairie Cur a.t. ........66

Otter, Lientonant Colonel..........292

Panorama of Life on the Platins..... . 70

Perry, Commisioner R, . . M. M. P...5\%

Poundunker. Surreneler of ........334

Prince Allyett ............406, 511, 522

Grotip of Pinneer ............530

Prince Rupert ................ 9

Qu'Appelle .................

Radisson ................... 9

Rapids Near Nlouth of Saskatchewan River .....................20

Regina $\ldots \ldots \ldots \ldots \ldots .30,42,49.80$, 90

Riel's Councillors in $1885 \ldots \ldots \ldots \ldots \ldots 27$

Riel, Lotris ................. 275

Letter to Richardson, Fac-imile.376, 377

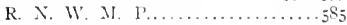

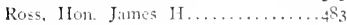

Royal, Lieutuant Governor.........47

Saskatoon.........194, 212, 229, 246, 254 Scene at a Portgae............. 46 Scenes in the Bufialo Hanters' Camp. . 62
PAGE

Scott, 1lurt. Wilter...............487

Setkirk ....................113

Seven Oaks Monument ..........45

Simpion ..................113

Stcele, Colonel .................273

With Inetachment ............

Strantze, Najor Gentral. . . . . . . . 292

Stratliconit ITur-e, Otileers of.......445

Montment to..................445

Stratlicona, Lord...............13

Driving last Spike on Canadian Pácific Railway ............221

Trader in an Indian Camp ......... 58

Trant, 11 m.................48;

Trappers on the March .......... 58

Types of Sa-katchewan Indians........

Typical Cattle Round LP............

Walker, Lientenant Colonel . . . . . . 577

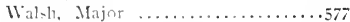

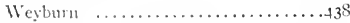

White, Licutenant Colonei.........5\%

Williams, Lientemant Colond........292

Willoughlyy, Dt. J. H. C..........

Wolseley ................. 4 . 


\title{
History of the
}

\section{Province of Saskatchewan}

\author{
CHAl'TER I
}

\section{PURPOSE AND I'LAN OF TIIE FOLLOWING WORK}

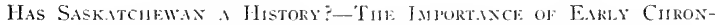

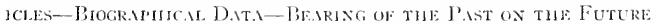

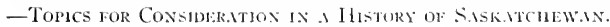

Lpon learning of the anthor's intention of writing a history of his province, varions thonght ful persons hale olijected with the question, "lint has Saskatelewan any histery ". The answer to this query will depend on one's conception of history. If the rise and fall of dymaties, the intrignes of brilliant courts and the clash of mighty armies are the essential subjectmatter of history, then, in truth and fortunately, Saskitchewan las none.

The historian of to-day, however. does not loxk upon the land of which he writes merely as a stage upon which the great ones of the earth play their several roles or upon $11 \mathrm{~s}$ common people as mere supernumeraries appearing in the background of the scene from time to time. On the contrary, it is his duty to tell the people's own story, to show whence they come and how and why, to trace the rise and transfornation of their local institutions and the relations existing between these and the social conditions of the hour.

The primary function of the historian is that of the chronicler. In the pages that follow will be gathered a mass of information that will become more and more interesting and vahable as years pass by. Whech of it will be collected from sumecs not available to the general public. Men of action are rarely facile writers, and the old pioneers are rapidly passing away. It will be the anthor's privilege, to the extent of his ability to perpetuate their story, communicated to him by word of mouth, by ofd diaries. through the pages of faded scrap books and by a multitude of letters. Already the struggles of the pioneers are all but unknown to the mass of 

our citizens and if the present work could do no more than inform the rising gencration of the doings of generations passed and passing, it seems to the author that his task would he well worth while.

History, however, is more than a mere catalogue of facts. It is a nation's assembled biographies. It is important not only that the humble work of comtless nameless men should be rememhered. but also that names themselves should be preserved from oblivion. In the pages that follow will, therefore, appear biographical records of many men who served this country well even thongh at present their names may be unfamiliar to the popular ear.

"Hlistery is philosophy teaching by examples." since the white man first appeared in the great Vorth llest more than two hundred years ago, many deeds of wistom and folly have been performed which have a very dired bearing upen the present and future. It wili be our task to trace not only the records, but the reasons of success and tailure, the causes producing cach of which, if repeated, will produce similar results in times to come. Incleed. true history is the most reliable kind of prophecy, for the future is the child of the l'ast. What ean and should he done in this great new Provine depend in large measure upen what has already been performed: and of what this is, the general public and even our active politicians know all too littic.

Saskatchewan as a prevince cane into existence but a very few years ago. Prior to that the records of the country are those of the North West Territories, or, earlier still, of Rupert's Land. We will commence our story, therefore, with the first appearance of the white man $m$ North Western America. I very considerabe portion will he such as might with efual but munestionable propriety he included in the instory of any of the prairie provinces.

We will call to mind the founding of British interests in North Western America, the story of its exploration and of the international rivalry for its control. This will involve a study of the doings of the great fur companics. and in comection therewith we will endeavor so to project ourselves into the past as to understand the life and customs of pioncer tracks and hunter. The scene of their romantic adventures was peopled by mumeroun and diverse Indian tribes, whose origin, subdivisions, mamer of life, religion and folk lore also offer topics of superlative intere-t.

We will record the beginning of real settlement. trace the rise and fall of all but forgotten provisional govermments, recall how and why this rast domain passed under the aegis of Canada and will briefly relate the troublous events comected witl its transfer.

The separate political history of the North llest Territories dates from 18;0, when they were given the institutions of Crown Colony Govermment. 

the adminintration being onducted from lont Garry. The intensely interesting political history of the territories from 1870 to 1856 we will derive chiefly from unpublished official record . It will be the author's pleasant duty to cmplatize the debt of gratitude that the people of Canata in general and of Saskatchewan in particular owe to a group of faithful, conragcous and far-secing men who, when this country was trembling on the verge of ruinous catastrophe in the form of Indian wars, saved it from such bloody tragedy and rendered possible the promel luest that wo racial conflict of this familiar type is to be recorded in Canadian history.

In 18,5 the territories were given a govermment entirely distinct from that of Manitoba. The Crown Colony system was retained in essence, but provision was nade for transition to representative institutions. Ender the North 17 est Territories Let of 18,5 , provision was made for elected representatives of the people gradually to take their place in the LientenantGovernor's Council, side by side with its appointed members. The amount of important legislation enacted ly the North 11 est Council is now-a-days realized by only a few, and all those interested in the political superstructure now being raised upon the fommlations laid a generation ago will find much wortly of note in the records of the councils from isfit to 1 ses.

The outstanding event of this period is the reinellim of $1 \times 85$. To the best of the writer's know ledge and helief no story of that sad and meaning episode has hitherto heen written which is at once acourate amel comprehensive. He will, therefore, examine with care the cames of discontent and will trace in considerable detail the events of the sanguinary drama. The writer will endeavor to make more intelligible to the public the character and jodeals of the unfortmate relel leader, and will emphasize certain important racial and religious aspects of the rebelion which have hitherto received little or no attention at the hands of writer of history.

The history of the Xorth IVent is of exceptional value to the student of political institutions, from the fact that within a period of less than half a century it presents the maximum of variety. lolitical evolution such as elsewhere has extended through centuries has herc been reproduced within the limits of a generation. Thus in ses the terribories achieved representative institutions. but the transition to true responsible govermment was attended loy events essentially similatr to those through which it has been attained in all other solf-governing portions of the empire. The political battles of Royal's regime will be found excedlingly signifieant in this regard and many remarkable episodes leading up to the eatahlishment of cabinet govermment will be brought to the reader's attention.

It will be our business very careiully to inquire into the rise of provincial institutions and to make clearer than at present they are to many of our cituens the essential protsions and practical workings of our present 
constitution. The political history of the Prosince will be ontlined to the year 1910.

Saskatchewan differs from most other provinces and states in that the vast majority of its citizens wee born without its borders. The history of inmigration will, therefore, be given a prominence not wsually accorded it in similar works.

Side ly side with political and industrial institutions, those learing upon the religione interents of the people of Saskatchewan will be given due proninence. Whaterer be une's religions creed or affiliation, it is essential that the forces naking for the due emphatis of things unseen and eternal should not be ignored. Special attention will also be devoted to the erolution of our educational system and of the varied institntions in which it finds embociment.

In many respect the most interesting portion of our work will deat with the romatic story of the Royal Vorth llest Mounted l'olice, of which the citizens of the Province are justly prond, and yet know too little.

Such in ontline is the purpese and plan of the author as he alproaches the task of writing the llistory of Saskatchewan. With so varied and alluring a fiekd one well may hope to present matter of interest and value to every type of reader. 


\section{CHAPTER JI}

\section{THE FOUNDING OF BRITISH INTERESTS IN NORTI WLSTERN AMERIC.}

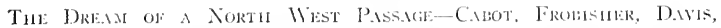

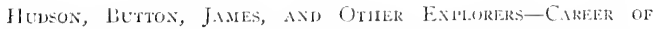

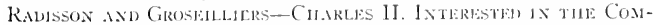

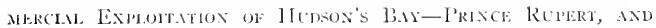

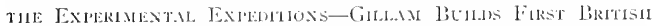

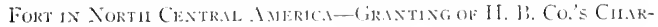

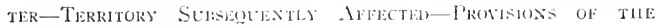
Charter-Sil.keholdek's O.tif.

The foumding of british interests in that portion of Imerica in which Saskatche wan lies was the practical outcome of an impractical dream. Fver since 11 had hecu realized that Columbur was in error in supposing that he bad reached the castern limits of India, the most adventureus spirits of Europe iarl fostered the hepe of discovering a watervaty to Asia through or around the American continent. Englishnen devoted themselves chielly to the cudcator to find such a passige by way of the Irctic Suas and the atast archipelago of the Nortli.

It will be rememlered that in the reign of Ilenry VII., John and Sehastian Cabot, nominally in the employ of the English King. reached the American mainland. The letters patent under which they served indicate the valuable nature of the encouragement at first offered by Princes to those who were to double their empires for them. The document informs us that Ifenry V1I. granted to his "lieloved John Cabot, citizen of Venice, to Lewis, Selsastian and Santius, sones of the said John, full and free authority, leave and power upon their own proper costs and charges to seck ont, discover and finde, whatever isles, countries, regions or provinces of the heathen and infidels, which before this time have leen unknown to all Christians." Incidentally, onc-fifth of Cabot's net gains was to go to his royal patron. However, as Cahot took possession of Cape Iireton Island in the name of Fingland, he received from King Henry a special reward of $\dot{f}$ o. In a second voyage John Cabot mitule the first serious attempt to find a northern passage to isia. For conturies thereafter the enterprise was pur- 
sued with extratorlinary persistency and at chormons financial foss to its various pronoters.

Almost sixty years after Cabot's preliminary royagc. Captain Martin Frobisher continued the scarch for the passinge to (athay and luclia. sailing west and north with thirty-five men, distribnted anong a ten-ton pinnance and two other ton ships of about twenty or twenty-five tons each. This sturdy old mariner, mder the encouragement of (Ducen Elizabetls, twice renewed his attempt $(15 \%-15-8)$. Seven years later the great task was in the hands of John Davis, who also mide three attempts, and narrowly missed the dincovery of Hudsons Ray.

This important fent. however, was rescred for llenry lludson, His famous voyges fall within the period of tho; and 161 I. Jn the first of these expeditions he piered the northern sats ats far ats $60^{\circ}$ north latitude and discovered the polat drift, subseruenty ntilized by Vansen. His crew consisted of ten men and his own litle boy. and their adventures were terrific in the extreme.

When he made his second voyage, iros. only three members of the old crew re-enlisted. This time he attempted to find the desired waterway by skirting the coasts of forway and following the current. As ustal, the outward voyge entinted mitil the incvitable muting oceurred, whereupon Iludson returned home.

The Dutch East India Company, however, immediately inviter lludson to make another voyage and under their anspiecs. For obvious reasons it was possible to secure but few except the must desperate characters to serve on these expeditims. IJudson's crew consisted of halscats. buccaneers, Asiatics, two Englishmen of his old crew and his own son. The unfortunate commander was som atl hut helpless in the hands of this motley crowd. He was forced to change his route, to abandon the search for the northern passage and sail southward along the lunerican coast. It was as a result of this muting that lludsen leceame the discoverer of New Jork harbor and Hudson's river. (on his return lludson and his tellow Englishunen were commanded by the fesernment not to go on such an expestition again, but to stay at home and serve their country!

Nevertheless, in 1610 lludson set ont on his fourth and last voyage. The fuancial expense was borne largely by private members of the Muscovy Company, which had sent lludson forth in loof and toos. After spending a month in the straits since then known hy his name, he nlimately entered and was the firs definitely to explore that vast inland sea, which was to form a waterway. if thot to China, to a region probably of more immediate importance to the reader. ()f course. the men mitinied, lat Iludson wintered in the hay. Ignes Latut thinks it was at the motth of the Moose River, though it is more generally supposed to be off the Xekon. When 

spring returned half his crew were ill with scury and the mutineers seized the ship, marooning lludsom, his on and eight sick nen in an open beat. Such was the price that this ireroic explorer paid for his fanc and for the addition be marle to the world's store of knowledge.

Coldly in splencior desends

The Aretic evening. The waste

()f resolate waters. thy seat,

Washes its desolite shore:

And on its far reaches, a sail,

Loncly, ontcast and forlorn; -

like solitary bird with wing

Wounded atud broken, and spent,

Secking in vain its nest

On some dim, oceanward crag:-

Glimmers a space, and is gone.

Pint thou wert not outcast.

Great soul of the seafaring blood,

Thow pioneer pilot of dreans.

Thon finder of uceans remote

In the ultinate linpires of man.

lendrick lJ tudson, tis here

That thou hast graven thy name,

To be a word of great need

In the thoughts of men for all time,

Not in thy miglity stream,

Splendid and vast, of the south,

Where twivt its motntainward walls.

It surges beneficent tides

Trimmphant and glad, to the main.

But here in thy northern wastes

Of the short red summers of joy

And the long dark winters of dream,

Is the gulf of thy world-fame to be:

Great Englishman! Outfaring soul!

Immortal, with that high band.

Bold Raleigh and Franklin and Drake.

Thy brother pilots: where surges

Heave on the crimson edge

Of ocean's ultimate rim

Oer horizons of vastness and morn.

1 From Wilfed Camplell's Ode, "To the Spirit of Hendrick Fiudson." By the way, the spelling. "Ifenclrick," though popular, toes not secm justitied by the old documents. 
Jere, where thon cried'st, Sail on!

Sail on! satil on! till we come

To the long lost passage : that path

From Europe to furthermost Ind:-

That road once open: when man.

In that rare, golden age of the past.

Did compass all earth in a span

Of Godlike effort and drean.

'This road, which thine innormost soul

Knew well carth's sceker mot find:-

As find it, he slall, some day:

And prove that high courage, that faith

Which led thee onward, great soul,

Out on thy last drear voyage :-

But left thee forsalien, forlorn,

Betrayed and lost. but not quelled,

Only thy trust in Gorl left,

On those drifts of thy desolate main.

When word reached Fingland of Hulson's fate, Sir Thomas Button was sent to endeavor to find and bring him lack home, if, perchance, he and his companions had escaped to land, but no tidings were erer received of the cleserted men. lintton male careful explorations, lut, unfortunately, his diary was never made public. I Iowever, from the point of view of our present narrative his cxpedition was of great importance: he discovered the important Nelson liver, which is, in point of fact, merely that portion of the Saskatchewan lying letween Lake Wimipeg and the Great lay.

Into an accotant of the explorations in lludson's bay conducted by Captain Gibhons, Rohert lyylut. Wiliam laaffin, Captain IJawbridge, Captain Jones, Calptain Luke Fox and Captain Jannes, we camnot enter. James explored the bay which consectuently bears his name, though it had been entered prerionsly by Itudson himself. James entered upon Carleton Island where he built a house. However, his cxperience was so disheartening that for a generation no English expedition re-entesed the bay.

Indecd, when at last British interests were to becomc definitely established upon the shores of Junlson's Jay, it was through the initiative of two Frenchmen, Védart Chonart de Groscilliers ant his brother-in-law, Pierre Esprit Radisson.

Radisson had come over from France to Canada in his early youth and indeed still was but a lad when he was eaptured and adopted by the Mohawks. After his escape from these undesirable companions, he went overland to the upper Mlississippi, with the combined purposes of pursuing explorations and carying on the fur trade. In these adventurous undertakings Groseilliers was his partner. They visited the Crees and sioux and heard from the Indians of the Great Bay of the North. Whether they actually visited 


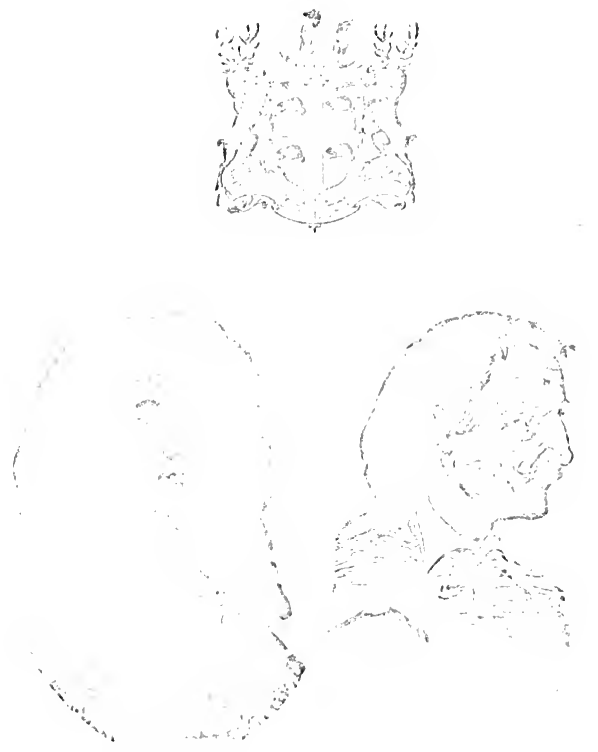

Prince Rupert, the organizer and first Ralisson, the French alventurer, upon (iovernor. whose initiative the Comprany was organized.

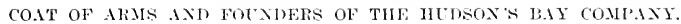



it has been a subject of di-pute. Among the numerons writers wh have discussed the question l'rofessor George bryec and Agnes latut may be taken as typical. The former convicler- the clam of the two Frenclunen invalid. whereas the latter is quite convinced that it is somel. It may be added that other students of the uriginal documents think that it is by a misunderstandling of Rarlinsons work that he in credited with ever claiming to have reached the lnland seat, in person, on this oceasion.

At all events, the season in which this northern excursion is sairl to have occurred was emineitly - neecsint from a commercial standpoint. and the adventurers returnel to Quehee with a very large cargo of furs. Ilaving escaped with their spoils from the savages. the minfortmate partners now encountered the more serious peril imblvet in depentence upon the respectable banditti of civilized society: The liovernor of Cinada fund sufficient pretext for confiscating the rewarks of their toils and dangers and the young Frenchmen either flect or were expelled to Cape breton. and thence to Port Royal in Acarlia, sifit. They appealed to the Court of France for redress and for aid in conducting an expedition by water to the Inland sea they are alleged to have visted; and the French cont. in accordance with precedent, promined freely but did nothing. The explorers then went to Boston. where they enrleavored to interest merclants and marners. Captain Zachariah Gillam, indced, offered his ship, hut when he and his French colleagues reached the terrifing Huchon straits. he chose discretion as the better part of valor and returned home. The disappointerl Frenchunen then chartered two ships on their own account. but this enterprise involved them in more disaster and litigation, and, according to Agnes Latt, one of their ships was wreckerl, so their proposed northern journey was again prevented.

Radisson and froseillier were nuw at their wits ent, when. to the great good fortume of linglankl, they met Sir George Carteret. Vice Chamberlain to the King and Treasurer of the Royal Nary, who was visiting America on his Majesty business. He was profoundly interested in their proposal to open up trate with the natives ato the lnland Sea, and advised them to return with him and lay their project before King Charles II of England. On their way acros they were captured by Dutch privateers and put ashore in Spain. At las aiter many further atventures, they reacherl England, where, thrungh Carteret's influence, they were able to present their scheme to King Charles in person. Oetoler 25. 1666). The undertaking appealed strongly to the "Merry Monarch." who was keenly interested in commerce. and though immediate action was stayed by the plagne and London fire, the King instructed lames. Duke of York, the Commander of His Nary, to place a ressel at the disposal of the Frenchmen, with a 
view to undertaking further expleration and the entablisment of trate in the Bay.?

The King's conciu, Prince Rupert, Duke of Cumberland and Count Palatine of the Rhine, hat heavy clatms upon King Charles for services both to him and his father, and hat, as yet, been umrewarded. He was accordingly given a slare in this cnterprise and. together with a groty of friends, mulertook the expenses of wages and victmalling. Dutch spies learning of the proposed mulertaking endeavored to bribe Radisson and his kinsman into deserting the service of England for that of Ifolland. Failing in this they pletterl the ruin of the prestige of the young Frenchmen, by cansing them to be prosectuted on a trumper-np cluage of connterfeiting. Ratisson and Groseilliers were exonerated and H. M. S. "Eaglet," and the "Vonsuch" under Captain Gillam. to whom we have already referred, were chartered for the initial voyage. (iroseilliers sailed on: the "Nonsuch" and Radision on the "Eaglet," leaving England in June. I6rs. The following passages are selected from the sailing orders given to the Captains :

"You are to salile with the first wind that presents, keeping company. with each other to vour place of rendezvous." Vou are to saile to suclu place as $\mathrm{Mr}$. Gooseberry and $\mathrm{Mr}$. Ratisson , hall direct to trade with the Inclian therc, detivering the goods you carry in small parcels of no more than fity pounds worth at a time ont of each ship, the furs in exchange to stowe in each ship before delivering ont any more goods, according to the particular advice of $\mathrm{Mr}$. Gooseberry and Mr. Radisson

"You are to take notice that the Nampunpeage which you carry with you is part of our joynt cargoes. wee having bought it for money for Mr. Gooseberry and Mr. Kadison to be delivered by small puantities with like caution as the other goods

"You are to have in your thought the discosery of the passage into the South Sea and to attempt it with the advice and direction of $\mathrm{Mr}$. (uosselsery and Mr. Radisson, they having told $u$ s that it is only seren daies parlding or sailing from the River where they intend to trade into the Stinking Lake and not ahove seven daies more to the straight which leads juto that sea they call the South sea, and from thence hut forty or fifty leagues into the Sea itself . . .

"Lastly, we advise and require you to use the said Mr. Gooseberry and Mr. Radisson with all manner of civility and courtesy and to take care that

2 Agnes Laut clains to be the firt to show that the initiation of this supremely: important enterprise is due to Charles himself and not to Prince Rupert. Conquest of the Great North West. Vol. I. 1" ro4.

${ }^{3}$ Presumably the old mark atleged to have been set up by Radisson when he went overland to the bay:

t Groseilliers. 

all your company lear a particulat respect wnto them, they being the persons upon whose credit we have undertaken this expeclition.

"Which we beseech Aluighty God to prosper.

$$
\begin{aligned}
& \text { (sgd) "RLगJRT ALH:RM.MLE. } \\
& \text { "Crines G. Contere"tr. } \\
& \text { "J. HAYES P. COHLENON." }
\end{aligned}
$$

The expedition encomtered fierce storms and the vessels were driven apart. Indeed, the Eaylet, with Radisson on board, was so seriously dismantled that its commancler wats obliged to return to lingland. The Admiralty then granted Radisson another vessel, the Haicro, in which he set sail in March, 1869. Again the northern tempest checkmated his plans and he was forced to return.

Meantime Captain Gillam and Groseillicr lad been more fortunate. They entered the bay, tork possession of the sonthern coasts and gave the name of Prince Rupert to a large river emptying into the south cast corner of James Bay, where they also built the first british fort in North Central America, calling it lort Charles. The Nonsuch left the bay in June, I $6(n)$. and was anchored in the 'Thames when Radison returned in the I'arero. A secret application was now made by the promoters of the trading enterprise for the formal issue of a kogal Charter, which was granted in the following May. 16;0.

Thus was established one of the most extraordinary commercial organizations of moklern tines. "To the I Ionorable, the Governer and Company of Adventurers of England, trading in Iludson's Bay," was entrusted the exploitation and control of the greater part of the American continent. The real extent of the stupendous territory through which they were ultimately to operate was, of course, as yet unknown. Is time passed by, however. their trading posts spread throughout the present Canadian North West. through a vast region south of the Columbia River, extencling to California, through Nevada. Utah, Iy yoming and Iclaho, and even into far away Hawaii."

In the preamble to the Charter, Charles declared that his "dear and entirely beloved cothin, Prince Ripert." and other gentlenen whose names are recited, "have at their own great cost and charges unclertaken an experlition for IIudson's Ray in the North West part of America for the discovery. of a new passage into the South Sea and for finding some trade in fur. minerals, and other considerable commodities, and by such their undertaking lave already made such discoveries as to encourage them to proceed further in purstance of their said clesign by means whereof there may probably arise very great advantage to us and our Kingdom. Accordingly,

${ }^{5}$ Agnes Latit's Conquest of the Great North II'cst, Foreword. 

being desirous to promote all endeavors tending to the public good of our people, to the end that the said Governor and Company of Adventurers of England may be encouraged to undertake and effectually to prosecute the said design . . We have given . . and by these presents for us our heirs and successors do give, grant and confirm tum the said Governor and Conpany and their sncessors the sole trade and commerce of all those seas, straits, bays, rivers, lakes, creeks, somts in whatsoever latitude they shall be, that lie within the entrance of the strats, commonly called Hudson's Straits, together with all the land and territoric upon the comntries, coasts and confines of the seas, hays, lakes, rivers. creeks and sounds aforesaid, that are not already actually possessed by or granted to any of our subjects, of possessed by the subjects of any other Christian Prince or State, with the fishing of all sorts of fish, whales, sturgeons and all other royal fishes in the seas, bays, inlets and rivers within the premises and the fish therein taken, together to the royalty of the sea upon the coasts within the limits aforesaid, and all mines royal, as well discovered as not discovered . . . to be found . . Within the territories - . aforesaid; and that the said land be from henceforth reckoned and reputed as one of our plantations and colonies in America, called 'Rupert's I and'; and, further, we do . . . make, create and constitute the said Governor and Company . . and their successors the trute and absolute lords and proprictors of the same territory, limits and place aforesaid . . . yielding and paying yearly to us, our heirs and successors for the same, two elks and two black beavers wlienoever and so often as we, our heirs and successors shall happen to enter into the said countries; and . . . it shall be lawfinl to and for them . . . to make, ordain and constitute such and so many reasonable laws. . . as to them - . shall seen necessary and convenient . . and at their pleasure to revolie and alter the same. . . as the occasion shall require; - . And, furthermore, of our ample and abundant grace, certain knowledge and mere motion, we . . our heirs and succensors to grant unto the said Governor and Company and their successors . . . that they and their successors . . . shall forever hereafter have. use and enjoy not only the whole entire and only trate and traffic . . . to and from the territory, linits and places aforesaid, but also the sole and entire trade and traffic to and from all livens, bays, rivers, lakes and seas into which they shall find entrance or passage by water or land out of the territories, limits or places aforesaid, and to and with all the natives inluabiting or which shall inhahit within the territories. . . and to and with all ofler nations inhahiting any of the coasts aljacent to the said territories: - . and we rlo grant that neither the atid territories. . . nor any part thereof . . . shall he visited, irequented or hatuted by any of 


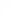


the subjects of us, our heirs or suceestors. . . unlens it be by the license of the saicl formor and Company. . . upon pain that every such person or persons. . . shall incur our indignation and the forfeit and loss of the goods. . . brought into this realn of England or any of the dominions of the same. . . and moreover we do give and grant moto the aid Governor and (Company, free liberty to make peace or war with any prince or penple that are not Christian in any place where the said company shall have any plantatiens, forts or factories, or adjacent thereto; . . . And we do herely strictly charge and command all and singular, our admirals, vice-arlnimals, justices, mayors. sheriffs, constables. bailiffs and all and singular our officers, minimers, licgemen and subjects whatsoever to be aicling, favoring. helping and ascisting to the said Gorernor and Company and their successor. . . and every of them . . when any of you shall theremuto be required; any statue, act, ordinance, proviso or restraint . . . or any other matter, canse or thing whatsoever to the contrary, in any wise, notwithstanding."

Truly, when Charles undertook to give, he did it royally!

This account of the founding of liritish interests in North llestern America, and of the entrusting of them to the lJudson's Bay Company. may very well close with the quoting of the ath taken by the shareholders and their successurs:

"I doe sweare to bee True and faitliful to ye Govern'r and Comp'y of Adventurers of England Trading into Hudsons S lay and to my power will support and naintain the said comp y and the privileges of ye same: all bre laws and orders not repeated which have becn or shall be made by ye Govern'r and Comp'y I wil to my best knowledge truly olserve and keepe: ye secrets of ye said company, which shall be given me in charge to conccale, J will not disclose: and during the joint stock of ye said compy I will not directly or indirectly. trarle to ye limitts of ye said comp's charter without leave of the Covern'r, the Ijeputy Govern
God." 6

In the following chajter we shall recount in part the success and failure of this great experiment in empire-building by means of private commercial enterprise, and sce to what extent English sovereignty in the North Western America has been disputed or endangered.

-Agnes Laut's Comquest of the Great North II'ist. p. 136 . 
EARLY EXPLOR.ATIONS AND INTERI.ITIONIL RIVALRY FOR THE CONTROL ()I: TIIF WEST

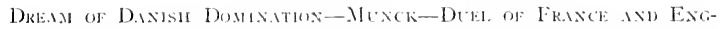

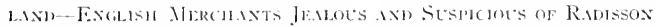

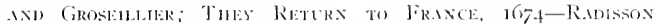

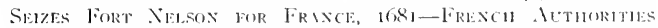

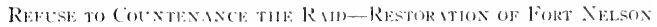

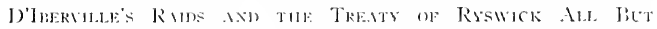

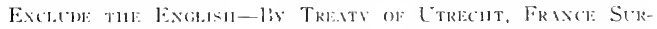

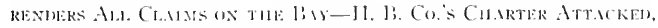

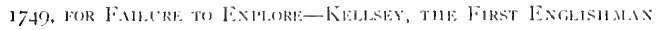

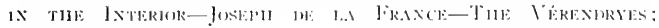

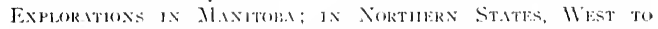

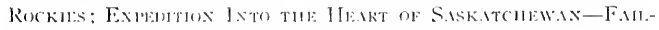

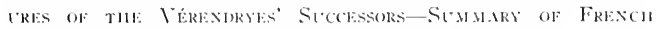

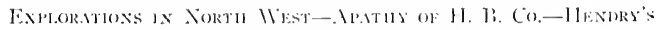

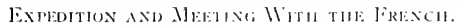

No reader need be iniomed that Fingland was far from having undisphed juriscliction in the vast territories described in the charter of the great company or otherwise subsequently damed by that gigantic corporation.

As carly as 1fo5 the Danes had sought to obtain a foothold in the regions bordering the bay. Their carly expeditions, the Danish government entrusted to English mariners, but in 1618 the bay was visited by Jens Munck, one of the most picturesque of all the famous rovers of his era. Ile was a Danish nobleman who, being left an orphan in childhood, had early entered upon a career of powery and adventure. In the year alove mentioned Munck discovered the mouth of the Churchill River, the best port on the bay. There he took up his winter guarters. Is he and his men were miserably equipped and ignorant of how to cope with scurv and the terrible cold, the hardships of that fearful winter reduced his company from sixtyfive to three. This was ruin. indeed, but no calamity could shatter the fortitude and piety of this magnificent old mariner. Even after his return to Denmark he was still eager to bring back colonists, but other duties forhade, as he was summoned to service in the navy. llad his plans carried, 
the iater history of North Imerica, and of Sinkatchewan as a part thereof, might have been written in rery diffetent terms. To julge the spirit of the man and the conseguent importance of his frustrated colonizing enterprises one nced but reat such portions of his journal as are quoted below:

"Oct. 15--Last night, ice drift lifted the ship ont of the dock. At next low water 1 had the space filled with clay and sand.

"Oct. 30.-Ice everywhere covers the river. There is stach a heary" fall of snow it is impossible for the men to go into the open country without siowshoes.

"Dec. 12.-One of my surgeons died and his corpse had to remain unburied for two days liecause the frost was so terrible no one ciared go on shore.

"Bec. 24. \& 25-Christmas Eve. I gave the men wine and beer, which they had to boil for it was frozen to the bottom. All very jolly but no one offended by so much as a word. Iloly Christumas Day we all celebrated as a Christian's duty is. We had a sermon and after the sermon we gave the priest an offertory according to ancient custom. There was not much money among the men but they gave what they had,--come white fox skins for the priest to line his coat.

"Jan. I.-New Jear's Day. Tremendous frost. I ordered a couple of pints of wine to the how of every man to keep up the spirits.

"Jan. Io.-The priest and the other surgeon took to leet. A violent sickness rages among the men. Ny hearl cook died.

"Jan. 2r.-Thirteen of us down with sickness. I asked the surgeon, who was lying mortally ill, whether any remedy might be found in his chest. IJe answered he had issd as numy remedies its lie knew and if God would not help, there was no remedy.

"Jan. 23-- This day died my mate, Ilans IBrock, who had been in bed five months. The priest sat uij in his berth to preach the sermon, which was the last he ever gave on this earth.

"Jan. 25--1 Iad the small minute gums discharged in honor of my mate's burial, but so exceedingly britle had the jron become from frost that the cannon explodecl.

"Feb. 5.-. More deaths. I again sent to the surgeon for Codl's sake to do something to allay sickness, hut he only answered as hefore, if God did not help there was no hope.

"Fel. 16.- Fothing but sickness and death. Only seven persons now in health to do the necessary work. On this day died a seaman, who was as filthy in his halpits ans an untrained least.

"Feb. 17.-Twenty persons hate died.

"Feb. 20.-In the evening. died the priest. Ilave had to mind cabin myself, for my servant is also ill.

"March 3o.-. Sharp frost. Now begins my great misery. I am like the ionely bird, rumning to and tro wating on the sick.

"April 1,-1)ied my nephew, Fric Munck, and was huried in the same grave as my second mite. Sit cone of us is well enough to fetch water and fuel. It is with great difficulty I can get coffins made. 

"April I4-Only form besides myelf able to sit tup and listen to the scrmon for Good liriday, which 1 real.

"Nay 6.-Died John Meston, ny English mate. The bodies of the dead lie uneovered because none of us his the strength to bury them. . . ."

Early in the summer, the brave hearted Dane made in his journal the following dramatic entry, which he supposed wottl he the last:

"As I have now no more hope of life in this worlel, I repuest for the sake of God, if any Christians should happen to conne here, they will hury my poor body, together with the others fumd, and this, my journal, forward to the King. . . . Herewitl, good night to all the world, and my sonl to God.

Jens Minnck."

When Xlunck wrote these words he was alone upon the ship and hat lain for four rays without food. Some of his men had previonsly gone ashore. int they had been given up for lost. Two, however, returned to him alive and helped him to the land. There the three survivors kindled a fire of drifuroud, party to protect themselves from tice hungry wolves, and beside it they lay ipon the ground, sucking the juice of every root and sprout that they could reach-weeds, sea nettles, hemlock vines, sorel grass. Strange as such diet mat seem, it restored their strength, and in the course of time they recovered from seurvy. ()n June is they were able to walk out to the ship at elb tide and about a month later, says Munck, "In the name of Jesus, after prayer and supplication to God, we set to work to rig the Lamprey." Mnnck and his two companions lightened the stoop by throwing overboard the many corpses and all hallast and cargo, till the ship floated from the winter doek. Hlis other wessel, the L micorn, he scuttled where he thought he could recover it on another voyge. "On luly 16 , Sunday, in the afternoon. We set sail from there in the name of Gol." It is a relief to know that the datuntless three actually steceeded in navigating their craft in safety back to Denmark.

The dream of a Danish empire in the iar North VIest had come and gone before the creation of the Hudson's Jay Company, to which was devoted the preceding chapter. Is we have seen, the founding of liritish interests in Rupert's land was, in a large measure, due to the indomitable perseverance of two French adventurers: and these same Frenchmen played an important pert in inaugurating a mighty national duel for the control of North Vestern .merica that culminated in the capture of Oucbee, 1759. and has not been unrelated to many erents of recent history-such, for example, as the rehellion of 1885 .

A month after the granting of the charter, Radisson and Groseillicrs sailed from England for the bay with ahout forty men. The company, in

1 Agnes Laut's Conquest of the Grcat Nerth I'cst. 
this expedition used three ressels, all loaned by the liritish Armiraltr. These were the II aicro, the Prince Rupert and the Shajtshurg. The last two vessels passed the summer at Fort Charles, where, at the head of James Bay and the mouth of the Rupert River, it will be remembered that the first britisl tratding fort hat been built by Groseillicrs and calptain Gillam. Radisson, in the ITatero, explored the southern coast. In the autumn he and Captain Gillan returned to England in the Prince Kupert. leaving Grosellliers to winter in the bay. Within the next couple of years several trips were made by the English adventurers and their French assistants to and from the bay, lut, owing to French interierence, the pronts did not prove as great as had been anticipater. Hesently an English Jesuit arrived at Fort Charles from Xew France, with a pasport from firontenac, and with letters to Ritlison and firoseilliers. This aroused distrust in the hearts of the English traders and was the souree of violent quarrels. Accordingly, Radisson returned to England to lay his case before the Governor and Conncil of the IIndson's liat Lompany: With charming consistency they: acquited Radisson of all disloyalty and amounced to him his permanent exclusion from partnership in the company. It would probably have leen more ceononical for them to have promised him a handwome share of the profits for years to conce. Radisson immediately withdrew from the service of the comntry and returned to France, 1674, where for a time he drops out of history:

In 1682 John liridgar, Governor of the Nelson district, sailed to his post witl Captain fillam, Fort Xelson, as the reader will remember, is on the west side of lludson's liay and at the mouth of the Satsatchewan- Velson River. Cpon reaching the harbor the landing party was startled hy a sharp challenge. "Vle are Tludson's Pay Company men," explaned Covernor bridgar. "lsut I an Kadison," replicel their interlocutor, "and [ hol, possession of this reginn for France." The consternation of the English traders may be imagined when they saw themselves thus falling into the hands of the adventurer to whom the company owed so much and whom it had so harsbly driven from its services eight years before.

The consternation. however, would not have been so great had they known the facts as Radision knew them. I short distance up the river there was, as lie knew, another English trading party, commancled by Captain Gillan's nephew. They were poachers, to be sure, but they were Britishers as well, and woukl not have objected seriously to the purchase of immunity irom prosecution at the hands of the company by assisting in the expulsion of intruding Frenchmen. Audacity, however, carried the day for Radisson. The Prince Rupert itself was presently sunk in a storm, whereupon Radisson succored and then made prisoners of all members of the expedition. Ite also attacked and captured the poachers' fort and 
before the season was over he had fat more prisoncts than he conld conveniently look after. Accordingly, he was obliged to send some of them off to the British establishments at the foot of the bay.

Chouart Groseiliers, the son of Radisson's partner, together with seven other Frenchmen, Rarlisson left to hold Fort Nelson and he himself, in the Bachclor's Delight, the poaching vessel bronght thither by Gillam, Ir., set ont for Quebce by sea.

Lpon his arrival at the capital of New France, Radisson fomd, to his chagrin, that the sturdy and none too scrupulous Frontenac, a man much after his own heart, had been replaced by De la Barre. That official refused to give comntenance to Radiscon's filibustering raid upon the English. Radisson and Groseilliers determined to appeal to the home govermment, and went over to France, where they received the public reprimand and private thanks of Louis XiV. The French govermment instructed Radison to set sail for the bay again, but be was beconing wiser by experience. If refused to go withont a written commission, the guarantee of a definite share in prospective profits from his traling enterprises and the payment of an indenunity for the furs confiscated by the Governor of New France so many years before. The French anthorities kept him hug in stuspense while they haggled orer his terms; and at this juncture Lomis Xil determined that it would he good policy to placate the English. Accordingly Radisson and Groseilliers were commanded to proceed to England and formally restore Fort Nelson to the British Company. They landed in London in sost and in disgust at their treatment by the French government they took the oath of allegiance to the britisin crown. The following quotation from the records of the great company indicates the terms of the settlement agreed upon:

"In order to put an end to the differences which exist between the two nations of the French and Finglish touching the Factory or Settlement made by Messs. Groseilliers and Radisson on lludson lity, and to avoid the effusion of blood that may happen between the two saicl nations, for the preservation of that place: the expedient weh. appeared most reasomable and advantageons for the Company is that the said Messrs, de Groseilliers and ladisson return to the sd. Factory or habitation. fumished with the passport of the English Company, inporting that they shall withdraw the French wh. are in garrison there with all the effects belonging to them in the space of eighteen months, to be accounted from the day of their departure by reason they cammot goe and come from the place in one year. . . The said gentlemen shall restore to the English Company the liactory or Habitation by them settled in the sl. comnty to be thenceforward enjoyed by the Englich company 11 ithon molestation. As to the indemnity pretended by the English for effects seized and brotght to Quelsec . . . that may be accommodated in bringing back the said inventory and restoring the same effects or their value to the English proprietors." 


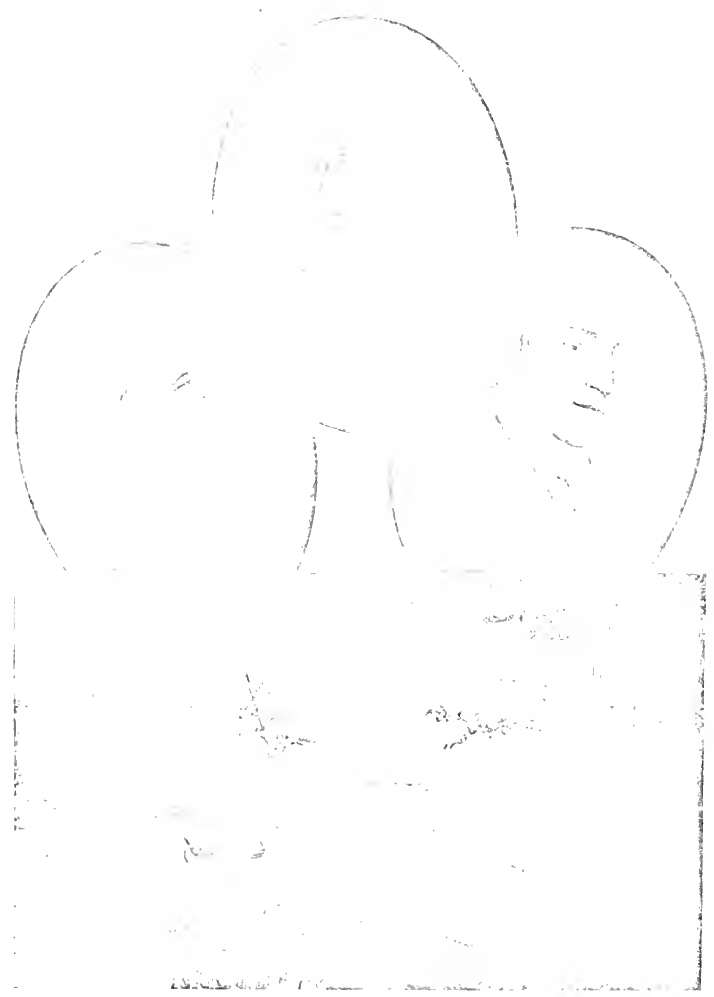

Alexamer llenry, the elder. D'lherville, the French filibuster.

] taulial W. Harmon, Nor' West trater.

Rapids near the mouth of the Saskatchewan. 
from the foregeing record it is evident that the IIdson's lay Company reccired Radisson back with open arms and, as a matter of fact, he was promised liberal reward. Into the details of his suberpment history we cannot enter, but they do mot reflect credit on the great company. Having used him to their great advantage they discarded him like a broken tool and the uniortmate adventurer died in England in extrene puserty. Return to his own country had been rendered impossible by his transfer of citizenship, which had resulted in the lirench fovernment placing at price on his head.

In the next act of the trama which we are studying. the leading characters are the D'lberville brothers, Le Inome and liemville, and their associate. 1)e Troyes.

Certain French adventurers had come down the Ilbany River to Fort Allany on James liay, where they were seized as pies and shipped to England. When this was noised almoad. three lumelred french raiclers, under the command of te Morne D'therville and hin companions above named. came overlanel from Montreal, mominally w releatse the sples, really to capture the forts. Ifter a journey through six hundred miles of swamp and forest 1)'Therville's filihusters surprised Fort Mlece at the sonth west angle of James bay and captured it in a midnight raicl. flurrying on to Fort Charles fknown to the French, who for a time bat liekl it, as Fort

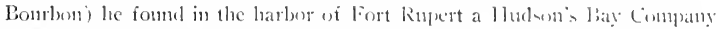
vessel with (oorernor Bridgat. 1)'llerville hoarded the ressel in the blackness of the night and by shere autlacity captured hoth the vessel and the

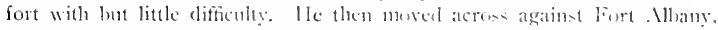
but by this time the British at that place hat heard of his operations and a surprise was imposible. The lrenclman demanded the surtender of the alleged spies, but the company's ship had already leit with them for lingland. There followed a ciege of two days, after which the English surrendered the fort with the homose of war and were placed upen Carlon lsland to awat the arrival of linglish bats. Is a matter of fact. 1)'lberville's sitution at this time was all bu desperate. lle was r.,300 miles from aicl. and practically withont fond or ammunition. The English, huwever, were in equal straits, and evislently did not realize those of their enemy.

For ten long years the bay was the scene of such ratids as these, and many barharities were intlicted upon each other by the Jirench and Englin. Meantime, I)'Tberville himself hat gone off to New foundland on a filibustering cuterprie, but he was ultimately recalled to leat the firench in a limal and decisive struggle for the lordship of the lay. No lover of stirring tales of adventure should fail to real Ignes Laut's Conguest of the Great North II ist, and I do not think that 1 can do bether than to gunte from its pages her vivid deseription of D'Lberville's extraordinary exploit of 1 (x) 
"On the 3rd of September. Herville anchored before Fort Nelson. Anxiously, for two days, he scanned the sea for the rest of his fleet. On the moruing of the fifth the peaked sails of three vessels rose above the ofting. Kaising anchor, lberville hatstened un to meet them, and signaled a welcome. Co resuonse was signaled hack. The horrified watch at the masthead called down some warning. Then the full extent of the terrible mistake dawned on lherville. Thesc were not his consort ships at all. They were English men-of-war, the Hampshire, Captain Fletcher, fifty-two guns and sixty men: the Dorint, Cajptain Grinmington, thirty gums and sixty men; the Iludson's Bay. Edgciombe and Smithsend, thirtw-two guns and fifty-five men-hemming him in a fatal circle between the English fort on the land and their own cannon at seat.

"One can gues the wild whoup of jubilation that went up from the Engrlishmen to see their encmy of ten vears' merciless raids, now hopelessly. trapperl hetween their fleet and the fort. "The English vestels hat the wind in their favour and raced over the waves, all sails set, like a war troop keen for prey. Herville didn't wait. Ihe had weighed anchor to sail out when he thought the ressels were his own, and now he kept unswervingly on his course. Of his original crew; forly were imvalided. Some twenty-five had been sent ashore tr reconnciter the fort. Counting the Canadians and Indians taken at Xiewfommland, he could muster only one hundred and fify fighting men. Ouiclily, ropes were stretched to give the matriners hand-hold over the frost-slipery decks. Stuppers were ripped from the tifty cammon, and the batterymen lelow, under la Salle and firandville, lat stripped naked in preparation for the hell of thane and heat that was to he their portion in the impending hattle. Licnville. 1lwrville's brother, swung the infantrymen in line abowe decks, swords and pistols prepared for the hand-to-hand grapple. 1)e la Fotiserie got the (anadian to the forecaste. knives and war hatelets out, bedies strifped, all ready to board when the ships knocked heels. Herville knew it wa to be like those old time raidsa Spartan conflict - a figh to the death: death or victory: and he swept right up to the llampshire, leteher's frigate, the strongest of the foc, where every shot would tell. The llampshime shifted broadside to the french, and at nine in the morning the battle began.

"The llampshive let Ay two ruaring cammonades that ploughed up the decks of the Peliom and siripued the Firench bate of masts to the hutl. At the same instant Frimmington's Dering and Smitlsend's Mudson's Bay circled to the left oi the lirench and poured a stream of muketry fire acrosis the Pelican's stern. At one blast. forty French were mowed down; but the batterymen below never ceased their crash of bombs straight into the Hampshiri's lull.

"Hberville shonted for the iniantrymen to fire into the Doring's furecastle. to pick oft Grimmington if they could: and for the Canadian sharphlooters to rake the decks of the Hudson's Bay.

"For four hours the" three-cornered battle raged. The ships were so close, shout and counter shout could he heard across the decks. Faces were singed with the closeness of the musketry fire. Ninety French had been wounded. The Peliean's deck swam in blood that froze to ice, slippery as glass, and trickled down the clinker bourds in reddening splashes. Girape shot and gremale had set the fallen sails on fire. Sails and mastpoles and splintered davits were a mas of roaring flame that would presently extend 

to the powrler magazine and blow all to eternity. Railings had gome over decks; and when the ship rolled. only the tangle of burning debris kept those on deck from washing into the sea. The bridge was crmmbling. A shot had tom the high prow away: and still the batterymen below poured their storm of fire and bomb into the linglich hull. The fighters were so close, one old record says, and the holes torn by the bomls so large in the hull of each ship, that the gunners on the Pelican were looking into the eyes of the smoke-grimmed men below the decks of the Hampshire.

"For three hours the English hat ticked to board the Pelican, and for three butrs the mastless splintered Pelican had fouglit like a demon to cripple her enemy's aptroach. The blood-grimmed. half naked men of both declis had rushed on masse for the last leap, the hand-tu-hand fight, when a frantic shout went up.

"Then silence and feariul confusion, and a mal panic hack from the tilting edges of the two vessels with cries from the wombled above the shrick of the sca.

"The batteries of the IIampshirc had suddenly silenced. The great ship refused to answer to the wheel. That persistent, undeviating fire bursting from the sides of the l'clican had done its work. The llampshire gave a quick lurch. Fefore the amazed Frenchmen could believe their senses, amid a roar of flames and crashing lillows and hiss of fires extinguished in an angry sea, the Hampshire, all sails set, settled and samk like a stone anicl the engulfing billows. Not a soul of her two hundred and fifts menone bundred and nincty mariners and servants. with sixty soldicrs-escaped.

"The screams of the strugeling seanen had not died on the watucs before Iberville had turned the batteries of his shattered slip full force on Smithsend's Hudson's Bay. l'romptly, the Hudson's Bay struck colors, but while lberville was engaged boatding his captive and taking over ninety prisoners, firmmington on the Dering showed swift heel and ganed refuge in Tort Xelson."

Then followed a terrific storm in which the Pelican was driven ashore. The survivors were only rescued by the arrival of the two French vessels which D'lberville had been expecting but which hat failed to connect with him before the battle. Fort Nelson (York Factory) and indecd the whole territory through which the Indson's Lay Company harl operated, now fell into French hands. The great company was staggering to ruin under the burden of a war loss of f,200,000 when peace was signed at Ryswick, 1697, leaving them no foothold in the Fay cxcept Fort . Ibany.

For many years to come Britisly interests in North IVestern America rested upon a footing very insecure indeed. For the Hudion's Bay Company, dividends became a far away dream of the past. When at last, however, the power of Lonis XIV was humbled and the Treaty of Utreclit was signed, the French withdrew all claims upon the Bay, and the prosperity of the great company was restored.

A quarter of a century later the company found itself endangered, not by its foreign foes, lut by domestic cnemies. The leader of these was 
Arthur Doblss, a vigorous writer and company promoter. For a dozen years be conducted a campaign agatinet the monopoly exercised by the Hudson's hay Company. Throngh his inflnence screral exploratory expeditions were sent on a vain search for the northern waterway, and in $17+9$ the Hudson's liay Company had to fight for its life-which it dicl most successfully-before a committec of the British House of Commons. Dobbe himself was in possession of a most exceptional func of knowledge regarding North West America and secms to have been shrewd chongl to recognize that in the interior was to lxe ionglu ont to its still doubtinl conclusion the great duel between the representatives of France and those of England.

In $17+9$ the company had still but at few trading posts on the shores of the bay and knew searcely any thing of the great interior whence came the Indian bands who tratled with them. True it is that half a century earlier they had produced at least one notalle explorer. This was Henry Kellser. a London strect aral, still but a lad when in the acrvice of the I Indson: Bay Company he was sent to Jort Nelion. There his pranlis and nngovernable disposition canned the slcepy traters much disturbance. One iniers from the records that the officers heaved a sigh of relicf when the young madeap undertook (1) go off with the Indians and conduct explorationin the interior with a view to the enconragement of comnerce and the possible establishment of trading posts. While the story of Kellsey's adventures rests almost entirely upen his unsupported work, and while the whole narrative has by some been treatecl as a iabrication, present day historical critics are pretty well convinecl of his good faith. The ronte he followed is certainly doubtful. Bryce thinks it would talie him into Manitoba, but this conclusion is more than questionable. It is generally agreed, however, that kellsey penetrated the prairies and northern wilds of what is now the Province of Saskatchewan, and that he was the first white man to see them. In vicw of these facts all reaters of the History of Saskatchewan will be interested in cxamining the young adventurer's diary. It very baklness, monotony and crudity are internal evidence of its authenticity as a picture of the first exploratory journey into Saskatchewan. It is reproducel from the Parliamentary Report of 1749 regarding Indson's Bay Company affairs.

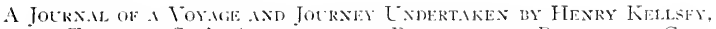

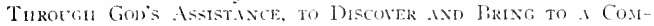

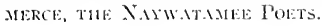

Iuly 15 th, $1(x) 2$. Now having receivel those things in full which the Governor sent me, takes me Darture from Deering s Point for the Stone Indians, which were gone Ten Days before; We, having no Provision, paddied ahont is miles, and came to. 
Ioth. To-daty set forward again, and paddled in Pond within land Dist. 25 Mliles, and cante to.

iztl. Now getting inte the River, the Stream running very strong; and we having no Sustenance whereby to follow our Chace, conciuded to take our Conrse into the 11 oods on the Morrow having got To-day about 20 miles.

I8th. Today about Joun we pitched by a little Creek, and set our Nets, and made onr Sterehomses. and laid up our Canoes, \& rested the remaining J'art of the Daly, having catched Three l'ike in onr Nets. Dist. about 8 miles.

Igth. This Morning set forward into the woods, and having travelled abont Ten Wiles, came to, and went a hunting. all returning in the Fvening, having killed nothing lnt Two llood Partridges, and ( nne Siquirrel.

20th. So setting forward again, had not gone above Nine Mliles but came on the "race of Indians which had passed lion bavs before, having seen their old tents: they having killed two Mnse, I thouglut they might have Victuals, so sent an Indian with my l'ipe, and some Tobaceo, desiring relief of them. and to stay for me: To day we travelled abont is Miles.

2ist. Setting forward again, alont blev'n a clock, mecting with my Post, telling me he had seen no Indians. I presently caused another lndian to set forward, leing heavy loaded myseli, and conld not gro, having travelled about 16 . 11 iles.

22nd. This Morning having nuch Rain, but J Junger forcing tore to leave my (ompany, set forward with wwo fudians, to scek for those which were gone hefore, hoping to get relief of them; Travelled 25 .likes, and came to.

23rd. To-day about Xoon, one Indian turning back, fearing the women wonld starve, which were hehind, sw proceeded forward myself, having travelled about 30 Miles. Jlaving wothing to eat lut one IVood l'artrislge, came to.

24th. Setting forward again, alsont Soon canle up with their Tents they had left To-diy, hut having increased from two to seven: and about Six in the Jivening came up with them, they having nothing to eat but Grass and lierries. Part of which they gave to me: so in the livening their People returned from Ilunting: one had killed Two Swans, and another a Buck Muse. I'art of which they gave to me, we having travelled to-day about 20 Mliles.

25th. This Morning I desired them not to pitch very far, but to stay for them which were hehind; which accordingly they did; Xbout Ten Miles, came to.

2úth. To-day I bid them lie still, and go a IInnting: accordingly they did; So they which were behind came up with us in the Evening: on Hunters likewise having killed Five Beasts.

27th. To-day we pitched, and about Ten cane to where one Beast lay to suffice on Ilunger: Ibout Two this afternoon came five Indians, Strangers, to our Tents: J)ist. about seven miles.

28th. This instance the Indian having told us their News, which was, that they desired of ts to meet then at an appointed Place: so we told them we would: and in the Evening they returned to their Tents. 
2gth. To-day we fritched, having no want of victuals: Dist. r2 Miles, and came to.

3oth. Now we pitched again, about ten miles, and came to.

3ist. This Morning it rained very hard; but in the Afternoon it cleared up; so we pitched about Nine Miles and came to.

August I, 1602. To-day we pitched again, and got to the Place where they appointed as; hut they were gone hefore lificen Mliles, by estimation, To-day.

2nd. Now we followed their Track, and in the Evening came up with them, they being in nmmber ahout 26 Tents, we having travelled near is Miles to-day:

3d. This morning we pitched abont 15 Mliles, and came to.

4th. To-day we lay still, having Strangers come to our Tents from some Stone Indians, which were to the Sumthwat of us, loringing News, that the Naywatamee l'oets hat killed Three of the flome Indian 11 omen the last spring: and withal appointed where they would meet 11 : but as for the Naywatamce Pocts, they were fled so far, that I should not sec them.

5th. Now we pitched again, the Strangers likewise returning to their Tents, l telling them. if by any Means they conld come to a speech of those Indians aforesaid, to telf them to come to me, not fearing anyone shonld do them any harm: so, giving them some Fohacco, parted: Our Dist. To-day being near Twelve Wliles.

8th. Now lying still, I sent two Indians to seek for the Motnutain Poets, and tell them 1 would meet them at a place to Miles before us.

9th. This Day we pitched alout i6 Miles, and come to.

1oth. We pitched again, the Indians having killerl leasts in Abundance Yesterday; and where they lay, we came to: Dist. 8 Miles.

Ith. To-day we lay still for the Nomen to fetch the Neat home and dress it.

12th. This Daty we pitched again, and about Noon the fromnd begins for to grow healthy and barren in Fields of about halt a Mile wide; So we came to: Dist. Ten Miles.

I $3^{\text {th. }}$. Now is raining very hard caused us to lie still To-day.

14tl. To-day we pitched, the ground continning as before: lut no Fir growing, the llood leing, for the nost part Poplo and Firch, Jlaving travelled by Estimation Twelve Miles, came to.

15th. This instant one Indian lying a dying, and withal. a Nurnuring which was amongst the Indians, because I wottli not agree for them to go to wars; so I made a feast of Tolbicco, telling them it was none of the way to have the ${ }^{-}$se of English guns and other Things; nor should go near the Governor, for he would not lonk upon them, if they did not cease from warring: so lay still.

16th. Now, not knowing which would conquer, Life or Death, lay still; To-day our People went a hunting, hut had small strcess.

I th. Last Night Death scized on Him: and this Morning was hurnt in a Fire, according to their 11 ay, they making a great Feast for him that died; so after the Flesh was burned, his bones were gathered up and hurried, 

with Logs set up, romnd it: So we pitched to abont It Miles, and came to, they holding it not good for to stay hy the Dead.

i8th. This Day I sent two Indians to seek for those which were so long gone. fearing they might have come to some Misfortune; So we pitched To-day Light Miles, and came to.

19th. Now setting forward again, the Ground being more barren than formerly, the Indians having seen some Buffalo, but killing none; Dist. Estimation I2 Miles.

2oth. To-day we pitched to the ontermost Edge of the Woods, the Plain affording nothing hut shott round sticky grass, and liuffalo, not like those to the Northward, their Ilorns growing like an English Ox, but Ilack and short; Dist. about Six Miles.

21st. This day we lay still, expecting a P'ost, but none came.

22nd. Now we pitched into the barren Gromel; it is very dry frotund, and no Water; nor conld not see the Woods on the other Side; Dist. Sixteen Miles.

24th. This Day we lay still, waiting for a Post, which came in the Afternoon from the Stone Indian Captain named VIaska, who desired to to meet him when we pitched again.

25th. So we pitched to-day, and came to allogether: so we were in all Eighty Tents; We travelled by Estimation Twelle Miles: yet not reach the woods.

26th. Now we are all together, they made a Feast, desiring Iccalve of me for them to go to Nars; but I told them I would not grant them their Request; for the Governor would not allow me to do so.

2yth. To-day we pitched, and got to the Woods on the other Side, this Plain being ahout Forty-Six miles over, and rums througl great Part of the Country; We had travelled six Miles To-day, when we came to.

28th. This day we lay still for the Indians to lunt linffalo: for there is none of those lieasts in the Woods; so I fitted Six Intians out for to go to seck for some Naywatamee Poets.

3Ist. This Day the Indians made a Feast, desiring of me for to be their Post to a Parcel of Indians which was to the Northward of 11s, and to desire then to stay for us, they telling me an Indian would not be believed, although he went.

Sept. 1st. To-day I set forward with Eight Indians, one of which was my Interpreter; and laving travelled about Thirty . Mlikes, came to.

2nc. So setting forward again, it being very bad Vieather, we lost the Track: so I filled Two Pipes according to their IV ay, and gave them to Two Young Men, telling then to go seck for the Track, which accordingly. they dicl: so we made a tire: but a great Parcel of Buffalo appearing in Sight. we gave them (hace, and he the llay found the Track, and in the Evening came up with them; We travelled To-day by Estimation Twenty. Five Miles.

3rd. This Morning they made a Tent, and provided a Feast, to hear what I had to say; so I tolit them my Message: which was for them to for those which I came from: and withal that they must not go to Wars, for it 
will not he liked on by the fiovernor: and that he will not trade with them. if they did not coase from Marring.

4th. To-day I sent Two Indans back in tell our Peryple to make haste hither. I tarrying there myelf to hear what News some young Men brought, which were gone Three Days before I came, to seck for heir Fnemien.

5th. About Ton this morning the lonng Men appearing in sight, and crying out just like a Cranc: which gave a Sigu, that they had discovered their Enemies: and as som as they came near to the Tent they sat down all in a Kow inon the Cirass, saving not one lliond; so the old llen filled their l'ipes, and served them romel. and eried for loy they had discovered their linemies, the young.$/$ m having brought some old Arrows to verify what they had been abont.

6th. This instant 1 unclosed the Pife which the fixcruor sent me telling them that they must employ their Time in catching of lieaver: for that will be better liked on when they come to the fatory, than the killing of their Enemies.

8th. To-day we pitched again, and by the Way met with those Strangers I had left formerly: and in the Ifternom came liour Indian Post from those which are called the Naywatamee l'octs, the which I kindly intreated, and made very much of, inquiring for their (aptain: who gatve me an Account that he was Two Days Journey hehind ours; Not extending light dliles To-1)ay.

oth. This Morning I went to the Captain of the Stone Indians "Tent with a Piece of Tobacen, telling him to make a speech to all and tell them not to meddle nor disturl) the Xalyatamee Poets: for I wat going bate to iavite and encourage them to a l'eace: which they all ireely consented to; so I took my IVay back along with those which came yesterdat; . Ind. having travelled near Eigluten Nliles, came to.

Ioth. This Morning setting out agatin, my Strangers left me, becatse they conld make better 11 aly to their Tents than I could: Sor we travelled till Night, and canne to. 1)ist. 20 .likes.

I2th. This Morning having not wherewithal to invite the Captain to. filled my lipe. Which the fovernor sent ne: and then sent for him who was their Captain: so told him be should not mind what had palsed formerly, as concerning their being killed by the Xaybaytbayss and Stone Indians: and as for the iuture, we English would seek to prevent it from going any further: and withal gave him my Present, loal. Cap, and sash, and one of my Guns, with Kinives, Iwls, and Tobaceo, with small Duantity of Poweler and Shot, and part of all ach Thing as the Governor sent me: so he scemed to be very well contented. and told me he had forgot what had passed, although they had killed most l'art of his kindred: lout told me, he was sorry he had ind wherewithal for to make me. Inends for what I had given him: but he would neet me the next Spring at Deering's Point. and go with me to the Factory. But it happencel in the 11 inter after I parted with them. that the Nasbavibawas Indian came up with Two Tents of them, and killed them: which struck a new Fear into them, and they would not venture down. fearing that the Naybaybayways would not let them up into their nwn (ountry again: so when I was at I) eering's Point in the Spring which is the llace of Restoration. when they are coming down to 
trade, I had News came, that the Captain aforesaid had seme me a I'ipe and Stem of his own making; and withal that if I would send him a l'iece of Tobacco from the lactor!, he would ecrtainly come down the nest tear: but if not the fieaver which is in their Conntry are in-mumerable, and will certainly be brotght down every year.

So having not to enlarge, I rist,

Ilonourable Masters.

Your Mlost Obedient, and

Faithful Servant,

At Command,

HeNRY KELLES:

British records contain 110 further explicis acconnts of travels in the interior nutil the publication by Dobbs in $I 7+3$ of the story of Joseph lat France. This interesting character was a French halfhreed, born at Nichilimackinac, and from him lobbs had obtained a verbal narrative of his adventures. Until the age of twenty-seven or twenty-eight he was engaged as a fur trader and hunter, generally in the vicinity of his birthplace. It will be remembered that, during the french regine, such a business conth be conducted only under government license. On a certain occasion he was the victim of robbery and oppression at the hands of the Governor at Quelec, when endeavoring to ohtain a license, and to escape further persecution he took flight, travefled westward to Jake II imnipeg aib the Grame Portage and thence to the head of the hay by the Ifayes River ronte, to join the English. He reached lork liactory June $29.17+2$, thee years and a half after leaving Sanlt Ste. Marie. However, the pathway indicated by the courage of this Netis was not turned to advantage ly the liritis Company.

Meantime, in Eastern Canada there had arisen a heroic explorer of whom Canadians today of whatever racial origin are unanimously pront. This was Pierre Gaulthier de Varennes de la Vérendrye. He was born in I686, his baptismal name being Pierre Gatulticr. Before he was ont of his 'teens he had scen campaigns in New England and Newfomndind, after which, in the military service of France, he went to Europe, and at the Battle of Malplayut in 1, wo he was seriously wounded. A few years later he returned to Canada. where in 5728 we find him commandant of a trading post at Nipegon and becoming profoundly interested in the search for the Wistern Sea. In I7.30 he visited Montreal to discnss with Beatt-

2 His father was Riné Ganltiet, Sieur de Varennes, and Governor for Ilis Majesty at Three Rivers. In the parish register of $1,02,1704$ and 1707 Pierre describes himselif as Sienr de Bommois. There is in the parish of Tarennes a fief bearing the name De la Verendrye. Dr, de Sulte, the distiuguished Canadian historian, who did much to reseue the name of De la Verendrye from oblivion, believes that Pierre adopted it after the death of his older brother, Lotis, who had hele the Verendrye fief. The name is found under fourteen different spellings. 
harnois, the Governor, the plans he had in mind for western exploration, and he spent the following winter in preparatione. The govermment conlel not, or would not, supply funds for exploratory work, thongh I a lérendrye was granted the momopoly of the fur trale in the comntry he would explore. It was conseruently nocessiry for him to malie provision for the expenses of his undertaking. This conld he effected only by the pro-ecution of the fur trade conjointly with the work of cxploration. In the nature of thing these two enterprises could not procced satistactorily under a single management. The rest of La V'erenlrye's life was continually cmluttered by the accusations and intrigues of those wlo alleged, some that he was neglecting the fur trade for exploration, others that he was neglecting exploration for the fur trade. The first charge involved him in wretcherl litigation with Canadian mercliants who were thancing his entcrprise; the second weakened his precarions hold npon the good will of the government.

In June, 1731, he set out from Montreal, and on Sugust 26 we find him at Grand Portage, fifteen leagues beyond Kaministiquia. Ile was acconpanied by his nephew, Christopher Dujrost, sieur de lat Jemeraye, a tried and competent frontiersman, who wats his chief lieutenant; ly tlurce of his four horoic sons, Tean, P'ierre and Francois, aged, respectively. cighteen. seventecn and siviren years; a missionary or chaplain, Father . Iesaiger: and about fory-live voygers. At Grand Portage, however, he found himself clecked by a mutiny. In quelling it the influence of his chaplatin and of La fenneraye was invaluable, and a compromise was effected. I small number of the voygers, with ha lienenelryes neplew and eldest son, were to advance to Rainy Lake and establish a post. Neanwhile La Vérendryee himself, with the rest of the party, would go into winter guarters at Kaministiquia.

In the following year La Temmeraye returned from Ratiny Iake, where he had built a good post, which, in honor of his uncle, he called Fort Saint Pierre. In Jume La Vérendrye and his company went thither. From that point La Vérendrye, escorted ly fifty canoes of lndians, advanced to the lake of the Woods, Where he built Fort St. Chartes, which for the time being he made his headquarters. His clest son proceeded during the winter to the mouth of the 11 immipeg River, where he established Fort Maurepas. Abbé Dugas is among the authorities who helieve that a traveller by the name of De Noyon had already penetrated this comtry, but Lawrence Burpee and most recent students are convinced that Jean Paptiste Vérendrye was the first white man to reach lake Winnipeg. This fort was built in 1734. It stood on the north side of the River Minnipeg, near the present Alexander, and was not long in use. Meanwhile. La Jemmeraye, accompanied by the missionary, had returned to IIontreal for further financial 
assistance, which, however, he failed to obtain. Aceordingly La Verendrye. who was now at the very end of his resources, was obliged to return, but his optimism and enthusiasm olutained for him from his Nontreal partners a measure of the assistance he required. A short time after his return to the fort at the Lake of the Woods, his eldest son came from Matrepas with the news of the sudden death of La Jemmerayc. This heary blow was followed almost immediately by a still more crushing calanity. Jean de la Verendrye, Father Aulneau, the new chaplain, and a party comprising the crew of three canoes. were massacred by the Sioux on June 8, 1736. The unfortunate father was almost heart-broken and his letters and journals referring to this event are pathetic in the extrome. Nevertheless, his purpose renained unshaken, and ifter another visit to Montreal he advanced to the site of the city of Wimipeg. He ascended the Issiniboine to Portage la Prairie, where he built fiort la Reine, from which point he pressed west by south to the upper waters of the Missurit, the home of the Mandans. ${ }^{3}$ Hc left two men with these lndians to learn their linguage and fit themselves to act as guides for further explorations, and returned to Fort la Reine, reaching it only after terrible hardships. The Indians with whom he was endeavoring to establish trade insisted upon the building of a post on Latie Nanitoba (Lac des Prairien). Vérendrye, accordingly sent Pierre to make the necessary explorations. Ile visited the mouth of the Saskatchewan River, which appears in the journal as Paskoyac, and Fort Dauphin was established about fifty miles south east from the site of Fort Cumberland.

De la Verendrye wats compelled to make two more visits to the list. From Montreal in 17fo he wrote directing his sons, with the Frenchmen who had remained with the Mandans, to proceed westward in their search for the sea. In their first attempt they faited to secure the Indian guides they desired and therefore returned to Jort la Reine. It was at this time that Fort Dauphin was luilt on the site previously selected and Fort liourlon on the Saskatchewan. In the spring of 1842 the two sons, Pierre and François, together with the Frenchumen who had wintered with the Mandans. revisited the upper Mi-sissippi Valley. They then proceded westward, travelling throngh what are now the northern states of the American Linion and carning inmortal fame by reaching the Rocky Mountains in January. 1743. They were compelled to turn back on account of the refusal of their Indian guides to go farther for fear of massacre. The return journey to Fort la Reine was by another ronte and they were weleomed back ly their father after an absence of fourteen months. De la Vérendrye at once reported the exploit to fovernor Peatharnois, but owing to the intrigues of

3 A translation of the jonrmal deceriptive of this expedition may be found in the report of the Canadian Archivist for 184.

+ According to Agnes Lant. 

his encnies at the French court, neither he nor his sons received any reward, though they were specially recommended for it by the fovemor.

After again visiting Fort l'askoyac on the Saskatchewan River, young Pierre was recalled in 1745 by beanharnois and given a position in the army. In the following year the father was obliged to return to Montreal to iace inis calummiators and 1)e Noyelles was placed in charge of his forts. The effect was disastrous to liench interests in the west. The Indian wars. which De la Vérendrye had restrained, broke ont afresl and the Indians ceased to freguent the French trading stations, gradually elrifting back to those of the English at the bay.

Young Pierre De la Verendrye, after distinguishing himself in the military service, obtained permission to return to the 11 est in 1747 . and, under his father's instructons, he proceeded up the saskatchewan River to The Forks, which he reached in the autumn of 1749 .

Meantime, Beatharnois had been replaced by. Galissomicre, whose letters on the explorer's behalf produced better results. His sons were given military promotion, and De la Verendrye fire was decorated with the (ross of St. Louis and commissioned to return to his explorations. It was too late, however, and on December 6, 1749, the famous explorer suddenly died at Montreal, at the age of sixty-three. The sons were recallerl, and in spite of their earnest and dignificd protests they wore precluded from continuing the work which they and their father had so heroically begun.

The successor of the Vérendryes was Captain Jacques Repentigny Legardeur de Saint l'ierre. He went to liort la Reine in I75I and sent his lieutenant, Niverville, on ahead, but through ill health that officer was obliged to halt at Fort Paskoyac. Hlowever. Niverville despatehed ten of his men into the far IVest, who built Fort La Jonquière at the foot of the Rockies, probably on the south branch of the Saskatchewan River.

The end of France's effort to establisl control of Western America wats at hand. Saint Pierre himself was brave, but unscrupulous and high handed, and he and his agents did not suceced in maintaining friendly relations with the Indians. He resigned in 1763 and his successor, De la Corne, had no hetter fortune. Not by such men as these was the work of the Vérendrye's to come to fruition and North Western America to be held for France.

Nevertheless, much had been done in the lliest by the French before the final catastrople of the Plains of Abraham. They had discovered and explored the water ronte to the hed River, that river itself, the Assiniboine, the Missouri Valley to the foothills of the Rockies, Lake Manitoba, Lake Dauphin, Lake Wimipegosis, and the Saskatchewan River, and had followed at least one of its branches to its upper waters. If the Government of France had known how to appreciate and support such heroes as the Vérendryes, the Frencli power might have been represented in trading posts 

all over the territories claimerl and ultmately helel in the name of England by the Hudson 's liay Company.

Except for Kellsey serplexing journey of adventure westward from the bay, probably into urthern Sakkitchewan, the great company and its servants had as yet done practicaily nothing in the way of exploration. Indeed, the great duel between france and Eugland would have heen at very onesided affair in. Incrica latd it not leen that in the approaching crisis Fingiand recognized the man for loer tatk in IVillian I'itt, and te the man for his tasks in General Wolfe.

The only recorded intercourse of firench and linglish alventurers in the Far llest, prior to the fall of (melsec, wats of a very friendly chatracter. In I 554 and 1755 . Anthony. I Iendry, a young Jinglishman, bold and enterprising. who had gotten inte treulle for smuggling, voluntected to his superiors at

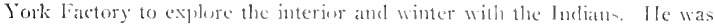
absent nearly a year. Ile leit Jork lactory on June 26, 155t, travelling sonth west via the llatyes River. Ilis ronte hat been the olject of much dispute, apparently beatse the waterway he followed is in considerabie part ummarked on any ordinary map, and, inded, has lren redicenered only within recent years. (In July 21 his canoe was on the mighty Sakatehewan, his being the first lingling yes to see the nolle stream from which the central praticie provine derises its name. I laving journeyed at siont diatance up stream, he came to a lirench trading fort established in the preceding year by De la Come. There he was courteonsly entertaned, theugh some attempt was makle. or threatened, to intinidate him from pursung his explorations further. This was the first meeting on record of cmissaries of liritain and liance in the North West. Judeed. Ilendry's intercourse with the french during this expedition of $175+-1755$ created a precerlent never to be followed in the remaining fitteen years during which France was to dispute with Fingland the lordship of Imerica.

The French post, at which lemelry first met the Jienchunan, was situated at the l'as, and near its deserted ruins the IJukinin's liaty Company subsecutently built one of their most impertint establi-hunents. This is the only one of the mumerons bench trading posts that hats rematined at commercial centre from the daly of the French regime until the present.

Continuing his journey. Ilendry presently left the salkatchewan kiver. crosed to Carmot River atul on July 27 took to the prairies.

As he advanced into what is mow the province of Siskatchewan. he wrote in his journal, "I am now entering a most pleasant and flentiful comutry of hills and dales and little wouds." Proceding sonth west l lendry and his Indian companions crosed the Sonth Saskitchewan in bull boats somewhere near Clarke's crossing. not far from the old telegraph line." Three days later he reacherl the Voth Saskatchewan "letween the mouth of Eagle

"Searih for the Hiatern siol, page te.5. 


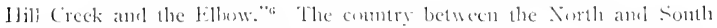
Saskatchewan he was the first white lian to explore, and to him we owe the furst detailerd deseription of the somb Satkatchewan and the lied Deer Rivers with the adjacent prairie. Jle was moreover, the first English trater to meet the blackfect, by whom he was kindly received. The following is copieri from his journal:

\section{3}

"The leader"s tent was bage cnough to contain fifty perconn. Ile

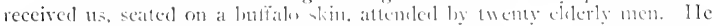
made signs for me to sit down on his riglut hand. which l dirl. i) ne leaders

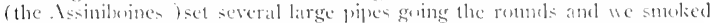
according to their custom. Sot one nored was spoken. Sumbing over.

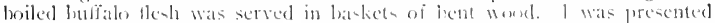
with ten bulfalde tongues. Mly gubles infomed the leater l wise sent by the grand leater who lives on the cireat llaters to mule his yomg men down with their furs. Thes would receive in return. perveler. Shot gans. and cloth. He made little ansuer: said it wat fat off ambl his people could

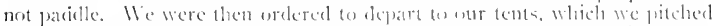
a quarter of a mile outricle their tents. The chice told me his tribe never wanted ford at they followerl the buftaler, but he was informed the matives who irefuented the settements often starved on their jombrey, which was excedingly true."

From a commercial stamelpont Ifendry expedition wat net remarkably succesital. The French hat alrealy established what might well have luen a permanent hold upen the lndian trate. To ixe sure, the young Finglishman on his return journey started with a great cargen of furs. lunt the wiles of the french traters, pate whose establishments he jumbered. were too much for his Indians to resist, and int hew of his peftries were left when he arrived back at lork Factory.

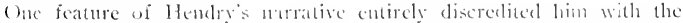
English traters: He told them of the Plackifeet Indians, a race uf nomats

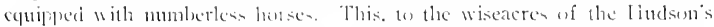

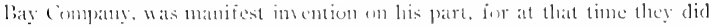
not even know there were such tribe of horsemen anywhere in the interior. Hendry was aceordingly treated as a romancer and batgered ont of the sericie of the company.

This pratically ended the liritish explorations of the Verth lles prior

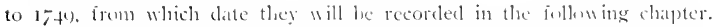
The Iluthon's lial Compans, in its corpurate capacity. gave but litte

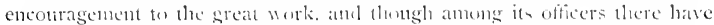
been many men who rank high as explorers, they athiered hat diandindion usually in spite of the company" apathy, rather than hy its encouragentent. otiin. 


\section{CHAPTER IV}

THE RIVAI. JLR COMPANIES AND FLRTHER EAPLOR.ATIONS IN THE IVEST-1759-182I

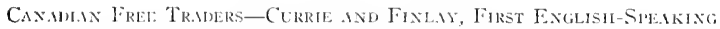

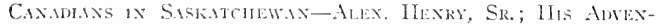

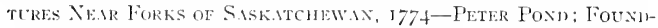

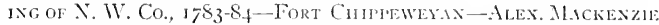

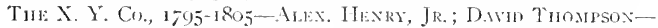

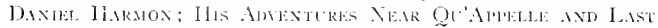
Motxtan, $1804-$ L.irocote-Fxplorers Sext Out by H. B. Co.

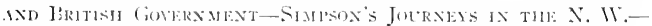

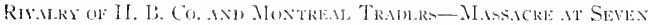

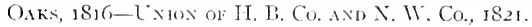

As we have seen in previous cinaters, the clams of the Iludsun's bily Company to exclusive control of western trade were strenuously disputed by the Irench, whose intrepid adventurers had penetrated far into the interior before the fall of Onebee in 1759 . With the surrender of Canadat. the activities of French governmental officials, in connection with westcrn trade and exploration, of course, ceased; but with the new regime came the rapid development of independent trading organizations, some of which even rivalled in the mannitude of their interests and operations the I Iudson $\mathrm{s}$ Bay Company itself. Many years later the ancient firitish company regained its old monopoly, but only by virtne of amalgamation with its rivals. To picturesque aspects of this long commercial strife and of the important explorations consequent upon the activities of the rival fur traters, especially as regards directly the present province of Satkatchewan, the present chapter is to be devoted.

Thomas Curric was the first Britisher from old Canada to penetrate the regions of Saskatchewan. Ile was followed very closely by James Finlay, and the sucecs of their ventures rendered them the forerunners of numerous other traders operating from Montreal.

One of the first and most important of these was Alexander Ifenry, Sr., whose fascinating Jomrnal has been edited by Dr. Jannes Pain muder the title of "Traiels and Adacntures in Canada and the Indian Territorics Bcticen the Jears 1800 and 18 ; $0 . "$ 

With the conquest of Canada the fur trade was soon made free from all govermment interference. Henry had served in the war of the conquest, but on its completion he promptly gave up military pursuits and proceeded westward to take a share in what he foresaw would develop into a rery lucrative trade. His initial attempts proved premature, however, as he remarks in his preface, and his furst rewards were almost entirely contined to adventures. It was not until 1775 that he penetrated the North Viest proper. His deseription of the journey westward, sia the (irand Portage 1)u liat (or Rat Portage, the River IVinnipegon. IVinnipic (or IVinnipeg), and westward ria the River du Bourbon, Pasquayah or Saskatchiwaine, to (umberland House, which had heen established in 1774, constitutes an entrancing tale. From it we obtain some of our earliest geographical data regarding what is now the province of Saskatchewan. The hardships expericnced by early explorers and the nature of the comntry as it then was are well pictured in the following extract:

"From Cumberland House I pursucel a westerly course on the ice, following the southern bank of Sturgeon Like, till I crosed the neck of land by which alone it is separated from the great River Pasquayah, or Saskatchiwaine. In the evening I encamped on the north side of this river at a distance of ten leagues from Cumberland IJouse.

"The depth of snow and the intenseness of the cold rendered my progress so much slower than I had reckoned upon, that 1 soon began to fear the want of provisions. The sum did not rise until half past nine in the morning, and it set at half past two in the afternom; it is, however, at no tine wholly dark in these climates; the northern lights and the retlection of the snow affording always sufficient light for the traveller. Add to this that the river, the course of which I was ascending. was a guide with the aid of which 1 could not lose mo way. Fvery day's journey was commenced at three o'clock in the morning.

"I was not far advanced before the country betrayed some approaches to the characteristic nakedness of the plains. The wood dwindled away, both in size and quantity, so that it was with difficulty that we could collect sufficient for making a fire; and without fire we could not drink: for melted snow was our only resource, the ice on the river being too thick to be penetrated with the axe.

"On the evening of the sixth, the weather" continuing severely cold, I made my two men slep on the same skin as myself, one on each side: and though this arrangement was particularly beneficial to nyself, it increased the comfort of all. At the usual hour in the morning we attempted to rise. but found that a foot of snow had fallen on our hed, as wcll as extinguished and covered our fire. In this situation we remained till day-break, when, with much exertion. we collected fresh fucl. Proceeding on our journey; we 

found that the use of our sledges had become impracticable through the quantity of newly fallen snow, and we were now constrained to carry our provisions on our hacks. Lnfortunately, they were a diminishing burden.

"The two day's succeding, the depth of the snow and the violence of the winds greatly retarded our journey; but fom the ninth to the twelfth the elements were less hostile and we travelled rapilly: No trace of anything human presented itself un our roari, except that we satw the old wintering ground of $\mathrm{M} / \mathrm{r}$. Jinlay, who hatl ieft it some years lefore, and was now stationed at fort des l'rairies. This fort was the stage we had to make before we condd enter the prairies or platins; and, on our examining our provisions, we fomm only sufficient for five days, while, even at the swiftest rate we had travelled, a journey of twelve days was before us. Ny men began to fear being starverl, sceing no prospect of relief; but I endeavored to maintain their courage by representing that I should certainly kill red deer or elk, of which the tracks were visible along the banks of the river and on the sides of the hills. ITat I hoped for in this respect, it was not easy to accomplish: for the animals kept within the shelter of the wooks: and the snow was too deep to let me seek them there.

"On the fifteenth our situation was rendered still more alarming by the commencement of a fresh fall of snow, which adked nearly two feet to the depth of that which was alreacly on the ground. At the same time we were scarcely able to collect enongh wood for making a fire to melt the now. The only trees around us were starveling willows, and the hills which discovered themselven at a short distance were hare of every vegetable production such as coulcl rear itscli above the snow. Their appearance was rather that of lofty snow banks than of hills. We were now on the borders of the plains.

"On the twentieth the last remains of unr provisions were expended; but I had taken the precaution to conceal a calie of chocolate in rescrve for an occasion like that which harl now arrived. Towards evening. my men. after walking the whole day, began to lose their strength, but we nevertheless kept our feet till it was late: and when we encamped 1 informed them of the treasure that was still in store. I slesired them to fill the kettle with snow, and argued with them the while that the chocolate wonld keep us alive for five days at least, an interval in which we should strely mect with some Indian in the chase. Their spirits revived at the suggestion; and. the kettle being fillecl with two gallons of water. I put into it one square of the chocolate. The quantity was scarcely sufficicnt to alter the color of the water; but each of us trank albout half a gallon of the warm liquor, by" which we were much refreshed, and in its cnjoyment felt no more of the fatigues of the day: In the morning we allowed omrelves a similar repast. after finishing which we marched vigorously for six lours. But now the 

spirits of my conntrymen again deserted them, and they declated that they neither would, nor could, proceed any further. For myseli, they arlvised me to leave them and accomplish the journey as $I$ could ; but for themselves. they said, they must soon dic. and might as well tie where they were as anywhere else.

"While things were in this melancholy posture I filled the kettle and boiled another square of chocolate. When prepared, I prevaled upon my desponding companions to return to their warm beverage. On taking it. they recovered inconceivably; and, after smoking a pipe, consented to go forward. While their stomachs were comforted by the warm water they walked well; but as the evening approached, fatigue overtook them, and they relapsed into their former condition: and, the chocolate being now almost consuned, l began to fear that 1 nutst really abanclon them: for I was able to endure more hardship than they, and, had it not been for keeping company with them. I contel have advancel donble the distance within the time which had becu spent. To my great joy, however, the ustal quantity of warm water revived them.

"For breakfast the next morning, I put the last remaining square of chocolate in the kettle, and our meal finished, we began our match, but in very intifferent spirits. We were surromeled hy large herels of wolves, which sometimes came close 11 on $11 \mathrm{~s}$, and who knew. as we were prone to think, the extremity in which we were, and markerl us for their prey; but I carried a gun, and this was our protection. I fired several times; but unfortunately missed at each; for a morsel of wolf's fesh would liave afforcled us a banquet.

"Onr misery, however, was still nearer the end than we inagined: and the event lats to give one of the innumerable proofs that despair is not made for man. Before sunset, we discovered on the ice some remains of the bones of an elk left there by the wolves. IIaving instantly gathered them we encamped and. filling our kettle, prepared ourselves a meal of strong and excellent soup. The greater part of the night was spent in boiling and regaling on on booty; and early in the morning, we felt ourselves strong enongli to proceed.

"This day, the twenty-fifth, we found the borders of the plains reaching to the very banks of the river. which were two humbel feet above the level of the ice. Water marks presented themselves twenty feet above the actual level.

"Want laad lost his dominion over us. At noon we saw the horns of a red cleer standing in the snow on the river. On examination we foum that the whole carcass was with them, the animal having broken througl: the ice in the heginning of the winter in attenyting to cross the river toc early in season: while his horns, fastening themselves in the ice, had pre. 
vented him from sinking. By cutting away the ice, we were cnabled to lay bare a part of the back and shonllers, and thus procure a stock of food amply sufficient for the rest of the journey. We accordingly encamped. and employed our kettle to gond purpose, forgot all our misiortunes and prepared to walk with cheerfulness the twenty leagues, which, as we reckoned, lay between ourselves and Fort des Prairies.

"Thongh the deer must have been in this situation ever since the month of November, yet its flesl was perfectly good. Its horns alone were five feet high or more, and it will therefore not appear extraordinary that they should be seen above the snow.

"On the twenty-seventh, in the morning, we discovered the print of snow shoes, demonstrating that several persons had passed that way the day before. These were the first marks of other hman fect than our own which we had seen since our leaving Cumberland Honse; and it was much to feel that we had fellow creatures in the wild waste surrounding us! In the evening we reached the fort."

Meantime, among the oflier traklers and explorers from the far East operating in Saskatchewan and adjacent territories, the student of history meets with the notorious American, P'eter Ponl. This picturespue adventurer came from Comnecticut to Cantata in the latter sixtics, and spent his first winter in the North West in 1760 . Indeed, he purchatecl more peltries than he could carry away, and a creditalle light is thrown on the character of the Indians by the fact that a large quantity of furs left by him, unprotected in his hut in the wilderness, was found undisturbet when he returned from Nontreal the following year. Though prolits were great, the competition in the trade led Pond to form a combine. In it were inchuded llenry Cadotte, a Canadian who had been associated with Alexamler Itenry, Senios. and the Frobishers. Joseph and Thomas. From this symlicate, the North West company subsequently developed. In 1728 Peter I'ond carried on extensive explorations in the district later known as Athabasca. The details of his journey are ill known as he did not publish his journal, only a fragment of which has been preserved for students of torlay. Some interesting extracts from it will be found elsewhere in the present work. The Athabasca district. as it was then called, was the greatest fur comtry. in the Forth West. and in it Pond pursued his commercial enterprises with great energy and suceess. He built a trading post on the Churchill River and shortly after crosised the height of land ria Lake Lache Portage, being the first white man so to do. Ile also built Athabasca on the Biche River. Through his efforts trade was established in the North beyond the regions controlled by the Ifudson's liay Company. Ilis competition with the British and other rival concerns led to many quarrels and culminated in a duel in which Pond killed a trader of the name of Ross. On a previous occasion 
he had been accused of killing another trader in the same district. Maddin by name. On his return to Montreal. Iond was charged with murder, and though the trial ended in hin release, the more respectable. llontreal traders ostracized him, and he returned in disgust to Poston in 1790.

Though I'ond achieved relatively hittle as an explorer if he be compared with such men as Mackenzie, he did amply sufficient to entitle him to a place in the history of western exploration, anct the part he played as the forerumner of the famous North llest liur Trust makes his a very important name to the student of Saskatcliewan history:

In I7\%9, through his inlluence, nine distinct commercial interests had become parties to an agrement valid for a single year by virtue of which their entire trade was rendered common property. The agleement was renewed on substantially the same terms the following year, and again for a period of three ycars longer. Internal jealonsics, however, luroke up the trust before this time expired.

In 1783 , according to nust authorities (but in 1784. according to the important treatise on The ()rigin and Progress of the North IV ent Company. published anonymously in 181 I by Nathanicl Atcheson), the trust wat revived, assuming as its name "The North 11 est Company." The compact was renewed from time to time until 1802 , and in 1803 : 13 agreement Was consummated, to be valid for wenty years.

Resides the partners already mentioned in comnection with these initial combines, J'eter l'angman, John Ross, Alexander Mackenzie, his cousin, Roderick Mackenzie, William McGillivray, Simon McTavish, David Thompson. Archibald Norman Macleod, John Gregory, Thomas and Joseph Frobisher, and others played prominent roles. Fort Chippeweyan was established by Roderick Mackenzic in 1788 , and soon became the most important trading rendezvons and distributing post in the north country. thongl it was alundoned thirly-two years later. It was situated in west longitude $111^{\circ}, 18^{\prime}, 32^{\prime \prime}$ and north latitude $58^{\circ}, 40^{\prime \prime}$. The Slave River and its tributaries to the north, the I'eace River to the west, Athaluasca to the south, and the Churchill, with its chain of lakes, to the east, constituted natural highways to this centre.

This fort was for several years the headquarters of the great fur trader and explorer, Alexander Mackenzic, and from it he conducted his exploring expeditions down the Slave River, up the Peace River, down the Mackenzie River to the Arctic Seas in 178 ), and over the Rocky Mountains to the Pacific in 1793. In recognition of his notable achievements as an explorer, Mackenzic was knighted in 1802, his entrancing journals having been published in the preceding year.

* Prof. Bryce speaks of Pond as "the marplot who had divided the company," Makers of Canada, Vol. VIHI, p. 6 . 



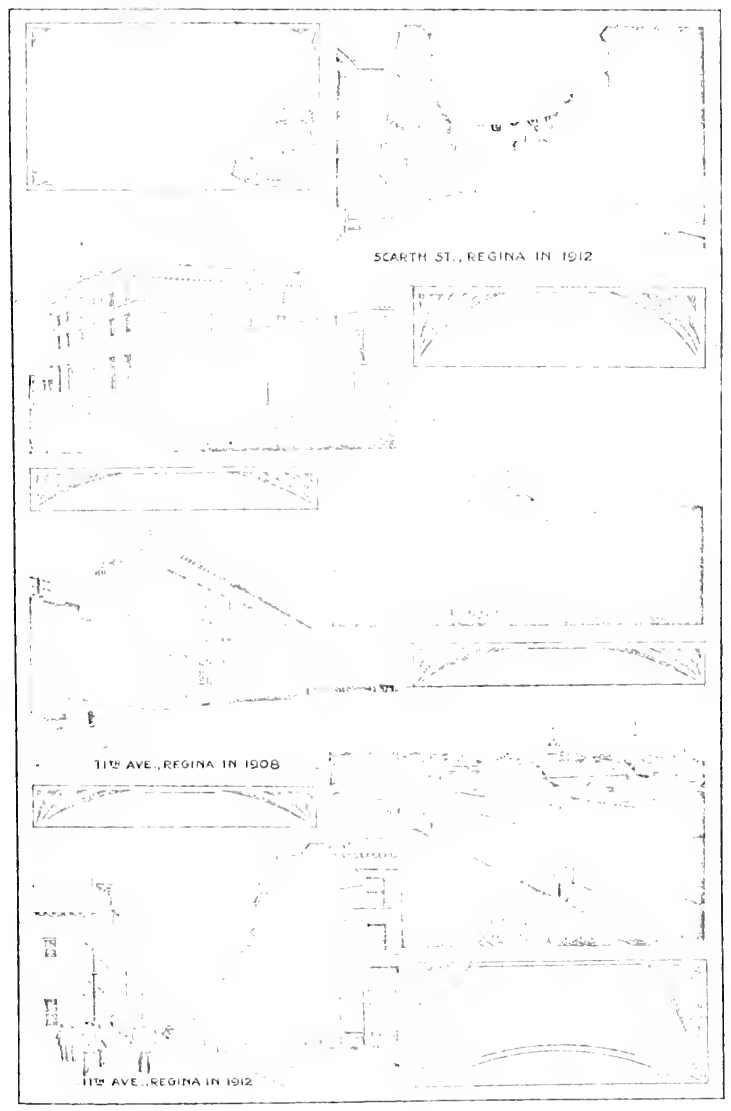


in 5795 , or, as some authorities state, in $17 y 8$, a new trading organization. known as The X. Y. Company, came into existence as an offishoot of the Norti llest Company. Apparently the mysterions letters involved in its name were not initials or contractions. The bales of the North West Company were marked with the letters $\mathcal{X}$. II., and the new company simply employed the next wo letters of the alphillet. The concern is sometimes called the little North West (ompany, or Lat I etite Compagnic. From this its members and employees got the name of Les Petits, which degenerated into The I'otties. This company uw ed its origin to the bitter rivalry hetween Alexander Mackenzic and Simon .leTavish with their respective adherents. and consisted of partisans of the former, thongh Roderick Mackenzie remained with the North West Company. The two concerns again united in 1805 .

Among the most interesting of all the cary tales of exploration and adventure is that embodied in the voluminous journals of . lexander Henry, the Younger, which remained all but mknown for nearly at century, until edited by Elliot Cones. This Ilenry was the nephew of the Alexander Henry to whom we have previously referred. Ilis joumals cover the period from 1790 to 181. . The years 1808 to 1811 were spent in the Saskatchewan district and regions further west.

In all llemry's journeyings he was, as (ones remarks, shadowed or foreshadowed by Thompson. This latter explorer was an astronomer and surveyor in the employ, first of the lludsolis lay Company and afterwards of the North West Company. Among his discoveries were the Athabasca and Saskatcheran passes. The nost important of his numerous expeditions was probably that made in 1708 . The record of his adventures is included by Cones with that of llenry"s under the title of "New Light on the Early. Ilistory of the Greater North West."

In the year t800 Daniel W. Jlarmon left Montreal for the West, "there to remain," as he says in his journal, "if my life should be spared. for seven years at least. For this space of time I an under engagement to seric as a Clerk to the North West Company, otherwise denominated McTavish, Frobisher and Company." Is a matter of fact, he remained in the interior for nineteen years, and it would le hard for anyone interested in the West to fund more fascinating reading than that contained in his journal, of which several celitions are extint.

In 1804 we find him in the vicinity of Qu'Appelle and hast Mountain. The following record of his adventures in that locality is of such interest as to justify quoting at length.

"Wednesday. February 22nd. 1804. Lac la Pèche, or Fishing Lake This lies about two days march inte the large plains, west from Mexandria. which prace l left on the 1 sti thtimo, accompanied hy twehe of our people. 
I have come here to pass the winter, by the side si the X. Y. I'eople. For some time after our arrival we existed on rose buds, a lind of food neither very palatable nor mourishing. Which we gathered in the fields. They were better than nothing, since they would just support life. When we should procure anything better 1 knew not, as the bufifalos at that time, in consequence of the mild weather, were at a great distance, out in the large plains. and ny hunters could find neither moose nor deer. I hoped, however, that a merciful (jod would not suffer us to starve, and that hope has not been disappointed. for we now have provisions in abundance, for which we cindeavor to be thankful.

"On the eleventh instant, 1 coks one of my interpreters and ten laboring men with me, and procected several days' march into the wildernes, where we found a camp of upward of thirty lodges of Crees and Assiniboins, of whom we made a goox purelase of furs and provisions. They were encamped on the smmunit of a litl, whence we hat an extensive view of the surrounding country, which was low and level. lot a tree could he seen as far as the eve could extend, and thumand of buffaloes were to be seen grazing in different parts of the plain. In order to kill them, the natives, in large bands. mownt their horses, rum them down, and shoot with their hows and arrows what number they pleatse, or drive them into parks and libll them at their leisure. In fact, these Indians who resite in the large platins or prairies, are the most indepenient, and appeat to be the most contented and happy people on the face of the earth. They sulsist on the Hesh of the bufialo and of the skins of that animal they make the greater fart of their clothing, which is both warmi and comenient. Their tents and beds are also made of the skins of the same animal.

"Thursday, March 1 st. 1804 . Es-qui-1n-a-wich-a, or the Iast Mountain, or rather Hill: for there are no momitains in this part of the comtry. Here 1 arrived this evening, having left Lac La Pèche on the 28 th ultimo. in company-with my interpreter and seven men. The men I ordered to eneamp at a short distance from this, and to join me early tomorrow morning; as it is more convenient and safe, especially when we are not in our forts, to give the Indians spirits to drink in the day time than at night. On our arrival we were invited to several of the tents of the principal Indians, to eat and smoke our pipes.-Indians slow great hospitality to strangers, before they have been long acquainted with civilized people, after which they adopt many of their customs: but they are by no means always gainers by the excliange.

"Tuesday, Narch 6. I804. North side of the Great Devil's Lake, or. as the natives call it, Much-e-nnan-e-to Sa-ky-e-gun. As I had nothing of importance to attend to, while our people would be absent in their trip to and from the fort, and was desirous of seeing my friend Henry, who, I 

tunderstood, was about half a day's march from where I was the last night, J therefore set off this monning, acemmanied by an Indian lad who serves as a guicle, with the intention of visiting this place. After walking all day, without finding either food or water, and but a few inches of snow, just as the sum was desending below the horizon, we thought we deseribed a small grove at a comsiderable distance, directly before us. So long, therefore, as the light remained, we directed our course to that object; but, as soon as the daylight failed, we had nothing by which to guide ourselves excepting the stars, which, however, answered very well until even their faint twinkling was obscured by clouts and we were enveloped in total darkness. In this forlom condition, we thought it hest to continue our march as well as we cottld; for we were unwilling to lie town, with little or mothing with which to cover us and keep ourselies from freezing. There was no wood with which we conld make a fire, or buffalo dung, which often serves as fuel when travelling about these plains. Neither could we find water to drink, and withent fire, we cotnd not melt the snow for this purpose. IVe stuffered much from the want of water, as we had nothing to eat but very dry provisions which greatly excited thirst. To be deprived of drink for one day is more distressing than to be destitute for food for two. It wonld not have been safe for to to camp without a fire, for we should have been continually exposed to be trodken by the large herds of buffaloes that are perpettally roving about the plains, or to be devotured by the wolves which ever follow the buflalo. We therefore continned travelling, uncertain whither we were going, mutil at length the dogs that drew my sledge suldenly passed by us, as if they saw some uncommon object directly before us. We did not attempt to impede their motion. but followed them as fast as we conkl, until they bronght us to the place where we now are. It is almost incredible that my dogs should have smelt this camp at such a distance, for we walked vigorously for four hours after they passed us before we arrived.

"We are happy in finding fifteen tents of Crees and Assiniboins, who want for none of the danties of this comtry ; and I met. as usual, with a very hospitable reception. The mistress of the tent where I tunharnessed the dogs put my sledge, etc., in a safe place. She was then proceeding to give food to my dogs, which labor I offered to do myself: but she told me to remain quict and smoke my pipe, for she added "they shall he taken good care of, and will be as safe in my hands as they would be were they. in your own," Notwithstanding it was near midnight when I arrived, yet. at that late hour, the most oi the Indians rose, and many of them invited me to their tents to eat a few monthituls, and to smoke the sociable pipe.

"Friday, March 9, I So4. North side of Devil's Lake. In the morning I left the Canadians" camp, and this afternoon reached this place, where 



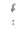

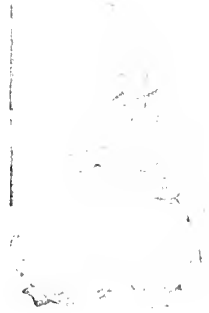

SCENE AT A PORTAGE.
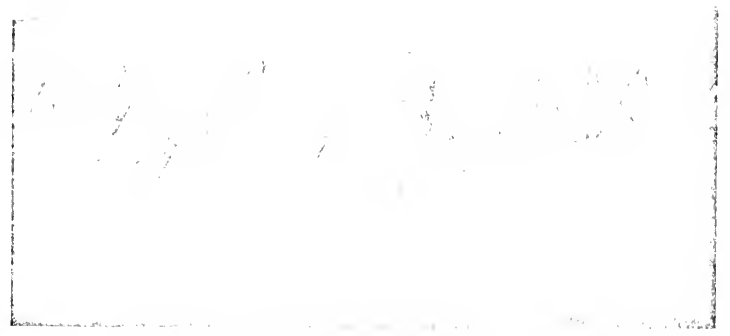

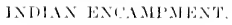


I found my young guide waiting my return. Ite is the son of at chict among the Crees and Assiniboins. Ilin grandfather was Mfom-ieur Florineaux, a Frenchman, who passed a number of years in the hurlian comutry. When he went to Canata he touk his son, the father of my young guile, along with him as far as Onelee, intenling to and him to France. lint the lad, who was then twelve or thirteen years old dicl not like w leave his mative country. Siter remaining in Canarlat some time therefoge. he deserterl. and returned to thi part of the world, where he in time became a famens warrior, and at length a chief. He is much respected and helored he his relatives, and is revered hy his own family. Is a husband he is affectimate, and as a father. he in kind. It wa- perlatps fortmatte for him that he disl not go to France; for I am persuafed he comlel not have livel more batpily and at ease in any part of the world than in this independent commery wich is abundantly supplied with all the necesaries and many of the luxures of life.

"Saturday, Narch 10, IRof. In the midelle of an extensive plain. Farly in the morning. accompanied ly my young gride. I left our lat thight" lodging to go wh the place where I expect to bind our people. which is alont two days march farther inte the great plain than where l separated with my interpreter on the foth inct. Ifter walking all da! withont lineling either fook or water, at eight o'dock at night we have concluderl to laty ourselves down, in order, if possible, to get a little rest. In the daytime the snow melted a little, but in the evening it has frozen hart, and our feet and legs, as high as on knees, are so mucle cosered with ice that we canmot take ofi our sloes, and having moling witl which to malic a lire in oriler to thaw them, we must pass the night with them on. I more serioms evil is the risk we must run of being killed ly wild lueasts.

"Sunday, Mareh II, 1So4. Ca-ta-buy-e-pu, or The River that Calls. This stream is so named by the superstitions natives, who imbgine that a spirit is constantly going ap and down it and they say that they often hear its voice distincty, which resembles the ery of a imman leing. The lant night was so umpleasant to ne that I conld not even sleep. arising in part from the constant fear I was in of tecing torn to pieces before the morning by wild leasts. Despomelency to a degree tonk possession of ny spirite. Thut the light of the morning dissipated my fears, and restored to my mind its ustal cheerfulness. Is soon at the light of day appeared we left the place where we had lain, not a litte pleased that the wild heasts had wod fallen on us. It las snowed and rained all dity. Jlere l fund wy interpreter and eighty tents, or nearly two hundred men with their families. - Vlong the hanks of this rivulet there is a little timber, ensisting chictly of the inferior species of the maple: but nowhere else is there cren a shrub to be seen. The surrouthding comntry is a barren plan, where nothing grom-exepting grass, 
which rises from six to eight inches in height, and furnishes food for the buffalo.

"Wednesday, March 1 the, sof. Last evening my people returned froin the fort; and as I now had spirits for the natives, they, of course, drank during the whole night. feing so numerous, they mate a terrible noise. They stole a small keg of spirịts from us and one of timem attempted to stals me. The knife went through my clothes and just grazed the skin of my body. Today 1 spoke to the lnolian who made this attempt, and he cried like a child and said that he had nearly killed his father, meaning me, and asked why I did not tie him when he had lost the use of his reason.-.ly people inform me that there is little or no snow for three days march from this; but after that, there is an abmelance all the way to the fort.

"Friday March I6th, ISof. About twelve o'clock we left the Indians" camp; but, leing ieavily loaded considering that there is no snow and that our property is drawn by dogs on sledges, we mate slow progress. After we had cncamped we sent our dogs, which are twenty-two in number, after the buffalo: and that soon stoppet one of them, when one of our party went and killed him with ai axe, for we have not got a gun with us. It is, however, imprudent for us to venture thus far without fire-arms; for every white man, when in this savge country, onght at all times to be well armer. Then he need be under little apprehension oi an attack; for Indians, when sober, are not inclined to hazard their lives, and, when they apprehend danger from quarrelling, will remain quiet and peaceable.

“Tinursday, March 22nd, I8o4. Lac la Péche. Here we have arrived, and I am happy in reaching a place where I can take a little repose after so long and fatigning a jaunt. Yet it has been, in matu respets, both pleasant and profitable. The country which I have travelled over was beautifully situated, and overspread with buffaloes and other kinds of anmals, as well as many other delightful objects. which in suecession presented themselves to our view. These things nade the days glide away almost impereptibly. But there were times when my situation was far from being agreable; lhey, however, soon passed away, and we bave all abundant reason to render thanks to a kind Irovidence, for Ilis protection and for a saie return to our homes and families."

Another early jomrnal of 17 estern adrenture and exploration is that of Larocque, of which an important portion is published in a report of the Canadian Archivist for 1910. Jarocene was a contemporary and acquaintance of Harmon. The special interest of his journal lies in the fact that it describes the first visit of white men th the country of the (row Indians, and provides the earliest authoritative account of that tribe, if we except the narrative of La Verendrye's expedition of $17+2$ and $I T+3$. 


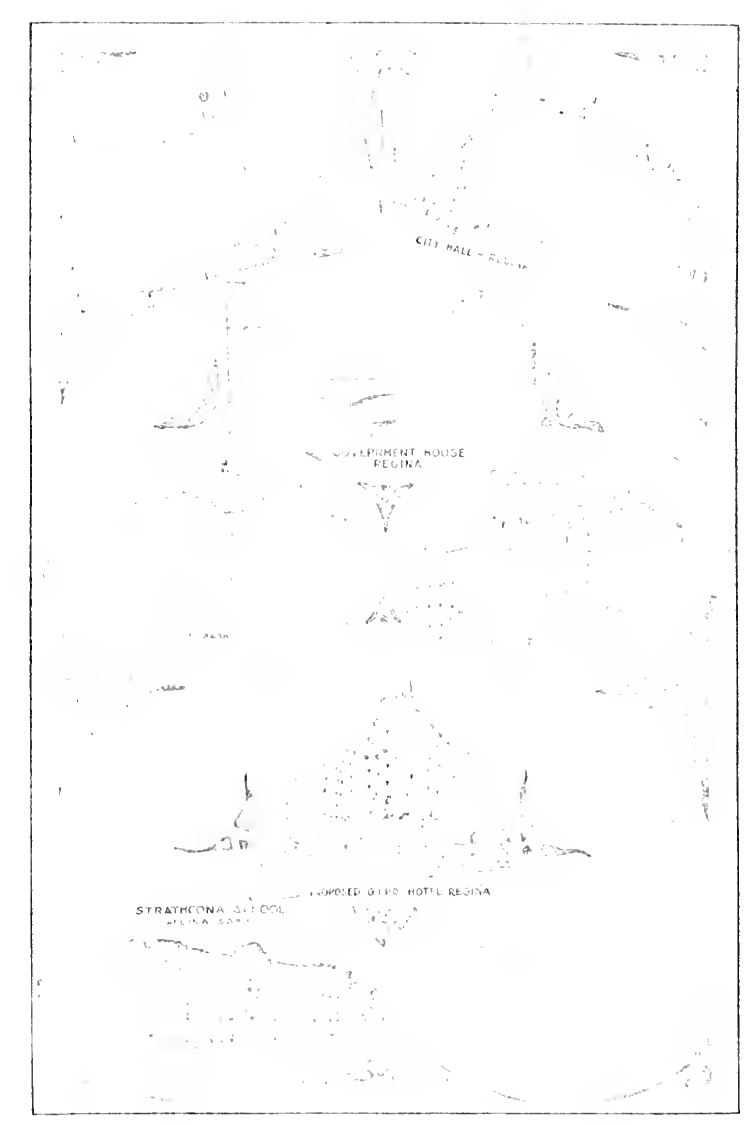


During the long period of which we have been treating, the Vorth West Company showed astonishing energy in exploring the llest and eppening it up to trade, and the lfudson's lay Company, of which we hatre satd litte. had been far from idle in this regard. A long period of relative inaction hat been terminated by the agitation of 17.49 for the cancellation of the company's charter. It that time it forts were all on the coast and numbered only four or five. In 1551 Ciljtain Coats conducted an expluratory expedition up Wagner Inlet. In Fovemler, 1- $(x)$, the company sent Samuel Hearne on at rain attempt to explore the Northern Seas, which, aiter a second failure, he reached sia the coppermine River two pears later. It will he remembered that the great Alexinder Mackenzic was also in the employ of the Hudson's liay Company during the sarly jart of his carees as an expiorer, as aloo was David Thompion.

In 1816 an experlition was sent mo he the liritish (iovernment te search for the long-decired North 11 est pasage. and after its fallure a rewarel of twenty thousand pounds was promised to any one who shonkl thow the existence of a water route nerth of the Inerican continent. ()wing to this encouragenent, two motable expeditions followed. The first was moler the leadership of David buchan and Sir John Franklin. The second was under that of (aptain Jolun koss and (aptain Edwarel Parry. Gaptan Parry continued for several years his unsucessul efforts to discurer the northern passage. Franktion was also sent overland in 1810 to explore the comutry west of the Coppermine River. While these and varius other expeditions failed of their primeny purpoce, they gave to the worla much valuable geogratphical knowledge, though they adderl lout little, if anthing. to what was known of that portion of the North llest to which this treatie is levoted.

In 1821, however, Sir (icorge Simpson, linernor of the lludemis liay Company, made the first of his notable journevs across the ontincnt. ()

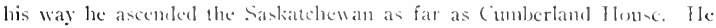
atso visited lake . Mhahasca. Sir George was a most intere-ting character, and the reports of his jonneys did much to make the country hetter known. He was famous for the extratorlinary speed at which he travelled. When journeying by water, he did not even allow his men to stop for meals. Two of his little batkis would be tied side ly side, and half the crew would thus be released from the parldle for a lasty repast, after which they would take the places of the voygeurs who in the meanwhile had continued their lahours. () one of his journeys Sir George wrote as follows:

"Here (that is, at Colville) terminated a jong and laborions jonrney of nearly two thonsand miles on horseback, across plains, momntains, rivers and forests. For six weeks and five dats we have been constantly riding. 
or at least, as constantly as the strength of our horses would alluw, from early dawn to sunset. and we have, on the average, heen in the saddie eleven and a half hours a day."

In the main the relations of the rival companies in the pursuit of the tur trade were at first reastmably free from acrimong, thongh the llations lay company always looked on its competitors as pouchers. Througlunt the region of the interion in which the Hudsun's lat Company enulueted active operations, the rival concens systematically established their trading posts side by sirle with those of the liritish company. As the competition becante kecner, mutnal recrininations became more and more general, and culminated erentuly in numerous deeds of violence. These lawless proceeding; at last feveloped into real wartare. The Red River settlement

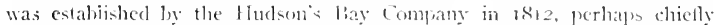
to check the ingress and hamper the operations of the North Vlest Comprans: This region thus lecame the srene of binody feurls, of which we wili have more to say in the chapter devoted to the Scikirk settement. The murcler of Governor Semple of the Jndson's Jay Company, with twenty of his

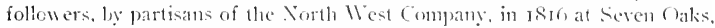
together with the forcible seizure of Fort bonglas ly the Nurth Vienters and its recapture 1, sedkirk in the following year, Ists, rouscol public sentiment in Great firitain and Canada. and in the councils of the companies themselves. to the necessity of putting a stop to this disgraceful atrife. Accordingly, in 1821 , mutual concesions were made, and the North West Company was absorbed by its ancient rival. 
LIFE AND CLSTUMS OF I'RAIRIE TRADEKS ANT HIXTERS

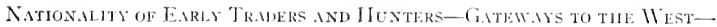

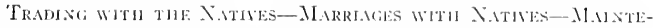

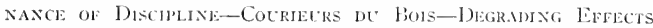

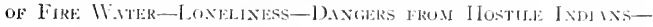

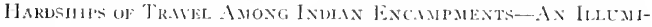
NATING QLOTATION FOM POND'S JOLRXAL-TR.NSPORTITION:

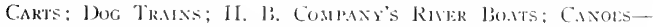

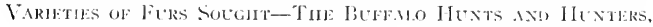

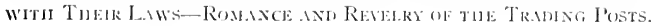

Few topies in connection with the early history of the llest and of Saskatchewan in particular are of greater interest than that presented to the student who undertakes to form an intelligent mental picture of the life and halits of the hardy traders who constitnted the advance guard of white civilization. As indicated in preceding chapters, the majority of these adventurers were ascociated with the Iludson's liay Company; or some of its important rivals. A very large proportion were Scots from the Orkneys. Many others were French-Canadians, thongh even the Montreai traders included a large proportion of Scotchmen. Americans were present, however, in not inconsiderable numbers, and a dozen other mationalities were represented.

Access was obtained to the country, by the Ifudson's Bay Company and their dependents, by means of Ifudson's Ijay. The traders from Old Canada came up aia the Great Lakes, the Grand Portage west of Fort William, and the series of lakes and rivers which from that point form the natural highways into the interior. In later times J'embina, just south of the Manitoba boundary, and St. Taul were the headfuarters for most of the American trallers. [ntil times within the menory of many yet living. it was quite possible for a newcomer without a guide to follow the well-beaten trails leading between Northern Saskatehewan and St. Paul or Fort Garry.

In the iuterior most of the traders were connected with some or other of the numerous permanent trading posts, or "forts." These were commonly 
built in a commanding situation at the head of some beatutiul river, or at the junction of 1 wo great streams. They were usually in the form of parallelograms from ten to twenty-four rods in widils, and from eighteen to thirty in length. The walls consisted of a stockade of pickets often fifteen to twenty-five feet in height, and made of the tupright trtulis of trees placed in a trench and fastened along the top by horizontal heans. At each corner of the fort, if of any pretensions, there wotld be a strong bastion, built of squared logs, and provided with loopholes for gruns sweeping every side of the fort. There were also other loopholes for musketry all along the side walls. Over the gateway there commonly was still another bastion commanding the entrance. Along the inside of the stockade was a gallery high enough to permit those occupying it to fire over the top of the pickets. Within the palisales would be gardens. an open spuare, and the dwellings, shops and siore hotses of the traders. These were often plastered within and without and washed over with white earth in the place of lime. By night sentinels would pace the gallery crying the hours, watch by watch. ${ }^{1}$ It was a very ustal thing for the competing companies to establish such forts as we have described, side by side.

Within the forts the dull rotutine of daty life was varied by the tumultuous celeluation of numerous national festivals. The following deseription of such an event is from IIarmon:

"Sunday, November 30, 1800 . This being St. Andrew"s dity, which is a fete among the Scotch, and our burgeois, Mr. Macleod, leclonging to that nation, the people of the fort, agrecally to the custont of the comutry. carly in the morning presented him with a cross, etc., and at the same time a number of others who were at his door discharged a volley or two of muskets. Soon after they were invited into the hall, where they received a reasonable dram, after which Mr. Alacleod made them a present of a sufficiency of spirits to keep them mery during the remainder of the day, which they drank at their own louses. In the evening they wore invited to dance in the hall; and during it they received several flagons of spirits. They behaved with considerable propriety mul alout cleven oclock, when their heads had become heated by the great quantity of spiritous liquor they had drunk during the course of the day and he evening. Some of them becane quarrelsome, as the Canadians generally are when intoxicated, and to high words blows soon succeeded: and finally two battles were fought, which put an end to this truly gentecl Sorth Western ball."

Connected with the fort there would generally be a disproportionate army of employees and dependents of all sorts. The fort at Alexander was

IIarmon deacribes stel forts in his diary of Oetoher $23 \mathrm{rd}$ and June $13 \mathrm{th}$, roon.

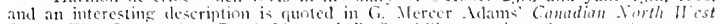

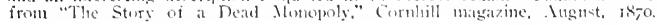


a relatively small one. but we find there, with IJamon in charge, one elerk, two interpeters, ive lalsouring men and many women and children belonging either to the traters or to Indians aldeent on war expeditions or engaged in hunting. Harmon had aloun a hundred monthe to fill from the company's stores for the greater part of the smmmer.

The trafle with the Indians wain, of course, entirely a system of harter, the beaver skin being the standard of trate. When an Indian wond arrive with his burden of furs. llieg would le semarated, classified and valued iy the trader, who would deliver to the hunter a mumber of wooden cumbers. each representing the value of a beaver skin, and equivalent altugether to the price placed upon the furs. When this had been settled, the Indian would proced to the store rom and lay out his counters or "beaver skins" upon the table, dividung them into little groups, cach representing the amont ine felt disposed or alle to invest in the difierent articles of value to be found on the traters shelves and selected for purchase. So many beaver skins would be for tomahaisk of liminglam mannfacture, so many for scalping knives, so many for powder lorns and ammunition, so many for flints, axes, blankets, guns. ete. l'robalsly he would find at first that his pile of beaver skins at asicle for the purchase of fincry and luxuries was disproportionate with that devoted to some absitute necessity, and the litte motunds of counters would have to he redivided. All this was a show process, and before the hunter finally gave his order, it would probably he discussed by him with his family. When at last the heaver skins were subdivided to his satisfaction, the Indian wonld step back and the trader would proceed to fill his order. Such methods still prevail in the remoter parts of the Far North.

In the daytime the Judians usually came and went freely alsut the fort, and freguently indulged in native dances within the enclosure. In comnection with these festivities, the traders-especially, perhats, those of the Nor" West Company-wouk present the Indians with a not inennsiderable supply of well-diluted lipuors.

Most of the white men took from among their Indian neighlours a wite or concubine. The ceremonics tending such an erent were simple. The trader made to the parents of the girl of his choice a present of such articles as he supposed would be most acceptable, usually including an alundance of rum, and if the parents acepted the present, the girl assumed the garls of civilization, or something approalhing it, and took up her residence permanently within the fort. The traders were usully under contract for a period of seven years. and at the end of that time. if they left the comntry, their families lecante the wards of the company. The young Indian women themselves seemed as a rule well pleased to take up life with the white men. even on these muromising terms. Such matches were encomraged by the 
2 
companies, as they increased the influence exercised by the traders themsclves, and renclered it easier to retain them in the service.

As a general rule, those in charge of trarling stations maintaned their authority ix moral suacion and foree of characer alone, but sonetimes more viguroms methods were neeessary. J larmon relates an anmsing anecdote in this connection :

"Monday, (xotoher $7.181 \mathrm{I}$. The next day after I had chastised the Indian as above described, he sent one of his wives to request me either to cone and see him or to send him some medicine. I, therefore. sent him some salve with which to diess the womnd on his head. A few days after he became so well ats to be able to lount: and he killed and bronght home a number of beavers, with which he yesterday made a feast: and I concluded that it would be necesary for me to go, or he might think that I was afraid of him. I accordingiy put a brace of pistols in my pocket and hung a sword by my side, and directed my interpreter to arm liniseli in a similar manner and to accompany me. Ne procecled to the house of the chicf, where we found nearly an hundred Indians assemhled. Is soon as we arrived he refuested us to lic seated. The then rose and sterol in the centre of the circle formed hy the guests, and with a distinct and clevated voice make a long harangue, in which he did not furget to matie mention of the beating which he lat lately reveived from me. Ile satil that if it had been given to him ly any other person hut the ligg knife the name which they gave to me), he would cither have lost his own life or taken that of the person attacking him. lint nom: he said, he considered himseli as my aife; for that was the way, he said, that he treated his women (of whom he has four) When they hehave ill. He said that he thanked me for what I had done, that it had given him sense. To this I replied that in a remote country I had left my friends and relations, who wanted for none of the good things of this world. and had come a great distance with such articles as the ludians needed, and which I would exchange for their furs, with which I conld purchase more: and in this way I conld always supply their necessities: that I considered the Indians as my children, and that I must chastise them when they behaved ill, as it was for their good. 'Tou all know;' said I, 'that I treat good ludians well, and that I strive to live in peace with you.' 'Yes, replied the father-in-law to the chici. 'Big Knife speaks the truth. My son had no sense and vexed him, and therefore has deserved the beating which he has reccived. Onits then told the Indians that if ever he heard of any of them langhing at him for the beating he had receired he would make them repent of their mirth."

The moral influcnce of the traders upon their Indian associates was usualy far from good. Harmon himself, a man of noble character, remarks in one place in his jomrual: "I have passed the day in reading the Bible 
and in meditating ujon my present way of living, and I must confess that it too much resembles that of a satvage." When he remonstrated with his companions on their godless behaviour, their reply was that in this country there was neither Gorl nor devil. Many of the white men who had been in the comntry for any considerable time laid aside the greater part of the restraints of Christian and civlized life and degenerated morally to a level little, if any, superior to that of the sarages." Nevertheless, there always were anong the adventurers men of honour and discretion. The influence exercised by the wilderness depented in every case upen the original character of the individnal white man himself. The most serions degentration occurred not in the forts, lut among the wandering winte hunters and traders. These couricurs du bois hall, however, their characteristic virtuescourage, endurance, enterprise, good humor and perseverance.

Often as it has been denied, practically all the traders dehauched the Indians with ligutur whenever it suiter their purposes. When the Indians once acquired a taste for the intoxicants, it indeed became amost impossible to do business with them withent the use of fire water. When the Indians first saw it effects, however, they were frequently filled with consternation. The naive criticism quoted in the following extract might well provicle a text for reformers even today:

"Tuesday, Jamuary 1, 181 . This being the first day of another year, our people have passerl it, according to the custom of the Canadians, in drinking and figlting. Some of the principal lndians of this place desired us to allow them to remain at the fort that they might see our people drink. As soon as they began to be a little intoxicated and to quartel anong themselves, the natives began to be apprehensive that something might befall them also. They therefore hicl themselves under the beds and elsewhere, saying that they thought the white people had gone mat, for they appeared not to know what they were abont. They pereeived that those who were the most heastly the early part of the day became the most quiet the latter part, in view of which they exclamed, "The senses of the white people have returned to them again,' and they appeared not a little surprised at the change: for it was the first time they had seen a person intoxicated."

To men of refined and social instinets, perhaps the cruelest of the deprivations endured by the traders was the isolation from congenial companionship. In the smaller forts, except among the couricurs du bois and labonrers, the only language spoken would be that of the Indians. The traders, of course, in time lecame masters of several languages, but it would frecuently happen that young men fresh from homes of refinement in the far East would in the wilderness be plunged into such an enviromment

2Harmon: journal, November j6h, 1800. 

that for montho together they might never hear their own language spolien, or be able to take any intelligent patt in any conversation not confined severely to the routine of trade. The sitnation was further complicated by the diversity existing anong the Indian trongues themselves. Thus J hamon's duties bronght him into familial contatet with fifteen tribes, no two of whom spoke precisely the same language. Indeed, nine of these languages Harmon deseribes as radically different the one from the other.

Intercourse with the ontsile world was possible only at rare intervals. The companies mantained a crude postal system, but the letters were slowly accumulated and forwarded from point to point throughout the enormons interior, and might consmme a welvemonth in ultimately arriving from or reaching the Fatst.

Of course the more intelligent clerks and traters found relief in reading and reflection, but book were few, and the difficultics in the way of stuly many.

At all tines the handful of white men seattered through the plains and forests were subject to more or less dauger from hostile Indians. The traders comnected with the lludson's Jay Company suffered less in this regard than did the others, as none of the rival conecrns sueceeded equally well in inpresing the native with its atuthority, dignity and nentrality as regards Indian feuds. In the old records freguent references occur to periods of anxiety during which the forts were subject to actual or theatcned altaclis. In the open platins the traders werc of course in still greater danger from Indian attack, and it was often necessary to forhear lighting fires at their encampments for fear of inviting robbery and massacre.

Generally speaking, the lutians brought their wares directly the fort. but, especially as competition became keener, it was frequently necessary for the companies to send ont representatives on trading excursions. The company's delegate, with a small retinue of servants and guides. would set off to visit scattererl cncampments. Ile would take with him a small assortment of goods for immediate use, and would make it his insines: to securc future permanent custom and to induce the Indians to frefuent his fort. These little caravass were frepuenty overtaken by blizzards and severe cold. By day the party would advance as rapidly as possible and by night would encimp aronnd a great fire, if fucl conld be obtainel. which was not always the case. Lnexpeeted had weather would, of course. disorganize more or less the party's plans, and frepuently on these expeditions they would be obliged to go for days without food. On such accasions one can imagine with what glee the killing of a stray buffalo would he greeted. The two iollowing entries in the journals of one of the old traters indicate the hardships to whicin such adventurers were accustomed: 

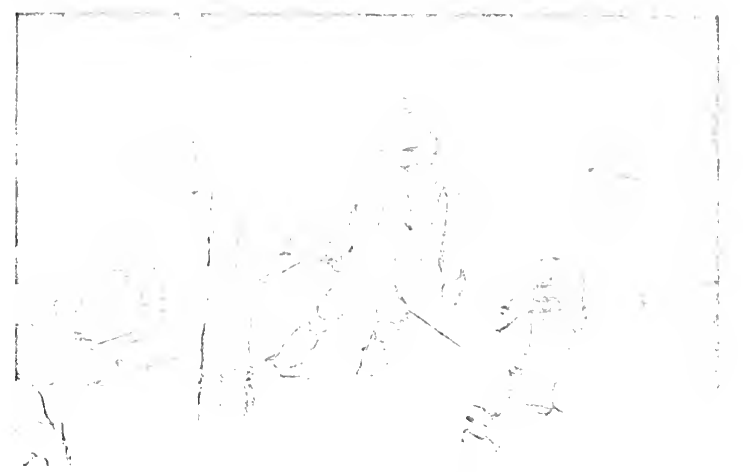

TRAPPER UN THE MARTI.
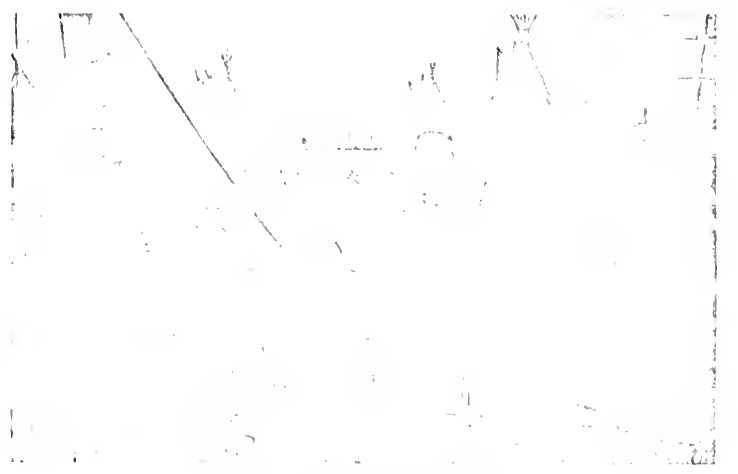

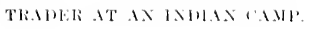


$\cdot$ 
"I For six daty after I had sent the people to fish in the alwere mentioned lake (Devil's lake) we sulsisted at the furt on parchnent skins, dogs, herbs, and a few small fish that we turk out of the river opposite to the fort.

"I)tring the last three days we have subsisted on tallow and dried cherries. This evening my men returned from . Nexambria with sleelges loaded with buffalo meat and the sight of it was truly reviving. Ilacl this favour been witheld from us a few datys louger, we mist hate all miserably perislied by famine."

As a gencral rule the strangers would receive a hearty welenme in the Indian villages, but these were often a surprising di-tance apart. Indeed. as Ifamon and others have remarled, such visiturs were treated by the Indians with nore real politenes than is commonly shown to strangers in the civilized parts of the worlel.

The reater will readily forgive me for here introducing a somewhat lengthy extract from the delight ful journal of the couragcon and unecrupulous Peter Pond. I le came to Canarla from Comnecticut between I 55 and

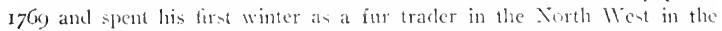
latter year. Of his relations with the Sorth West Company we have spoken elsewhere. It may be rematked that only a fragment of l'ond's journal has survived. This previons relic was saver from de truction unt many years sine when a worthy Vew England house-cleaner was ensigning to the flames a mass of old papers that had lain in the garret for a centi1y or more:

"I then embarkt. The Thirteenth 1)ay I arrived and put my Goods into the Same IIouse 1 Had wintered in ye year hefore. I heard by Sume Indians there was a large liand of the Natives Ineampt on the Panks of the River about Two Hundred Miles above. Which Wanted to sea a trader. I conkluded ameatley to Put a Small asortment of Goods into a Cannoc and go up to Then-a thing that never was attempted before liy the (bilest of the traders on . lecomt of the Rukleness of those leople who were Nottawaseas liy Jation lint the liand Was (ald Yantonoes-the Cheafe of the Fand Allwase Jead them on the l'lanes. Is I was about to imbark the Cheafe arrived to Give me an Invatation to Cum up and trade with them. I agreet and we seat off toliather-1 liy water and he by land. I was nine dass filting up to thare (amp). The Cheafe arrived liefour me-his Ront was Shorter than Mine By Cuting across the Planes. When I arived within three Niles of ye camp it lieaing Neat 11 eather and Cold 1 incampt and turned up my Canoe which Marle us a grand shelter. At Night it liegan to snow and frease and lilow: I lard. Ne ware then on a Larg Sand flat By the River Side. Earley in the Morning the wind took the Canew up in the Ar-Ieat hir fall on the frozen that and liroke hir in Pecis. I 
was then in a Sarl Sitnation. Nhout Noon I Perseated a Number of the Xatives on ye Opaset Sid of the River Aproaching ne-Sum on horseback -Others on foot. When thay Came Near, finding the Situation we ware in, thay forded the Kiver and offered me thare asistans to talie my Goods up to thare (any). I was glatd and Execpted thare offer. We Narcht on with our Joded tlorses and Cuming Near the Camp. Nade a Stop and Seat Down on the Ground. I Perseaved hive Parsons from the Camp. Iproching, four was imployd in Caring a [icaver lianket finely. Panted-the other lield in his Jand a Callemeat or Pipe of l'ece, Verey funely. Inest with Differant feathers with Panted Hairs. They all Seat Sy me Except the one who Held the l'ipe. Thay ordered the Pipse Lit II ith a Gate dele of Sarremoney. After Smokeing a fue Whifs the Stem was pinted Last and West--then North and South-then upward toward the Skies-then to ye Earth after which we all smoked in turn and Ipeard lerey frendige. I conld not understand one word they said lut from thare actions ] Supposed it to be all friendship. Ifter smokeing thay tuock of my shoes and Put on me a pair of fine Nockitsans or I cather shoes of thare One make, Ranglit in a Cureas Manner-then thay Late me down on the Blanket-Une Ifold of Each Corner and Cared me to the Camp in a Lodg among a Verey Vemarabel Asembley of Ole men. I was l'latsed at the Pottom or Pack Fart which is Asteamed the IIighist l'lase. After Smokeing an Ord man Ros uj, on his fect with as much Greavealy as Can be Conseaved of; lie Came to neLaid his Ilands on my Ilead and Girond out-I-I-I three times-lhen drawed his Rite lland Down on my Armes fancing a Sort of a Crey as if he Shead tears-then it lown-the lloke follode the Sane Exampel which was twelve in Number. Thare Wats in the Nidel of the Lodg a Ralsed Pece of Gromed about five Inchis in Ilight five feet long two and a half Brod on which was a fire \& Over that llung lhree Prass Kettels fild with Neete loiling for a feast. While we ware Imployd in the Sarremony thare was wateing at the Dore four meri to take ne up and Care me to another ieast. At lengh an Old nan loreck up some of the Vittels out of one of ye Kittles which apeared to be a Sort of Sompe thick and with lounded Corn Mele. He fead me with lhrce Sponfuls first and then Gave me the Dish which was Bark \& the Sporon Made ont of a Iniffeloes J Jorn to fead myselt. As I had got a good apatite from the fateages of the Day I eat Hartey. As Sm as I had got threw vith my part of ye feast I was desired to Steap ont the Dore which I Did. The People in Wateing then toock me and I a aid me on Another Skin and Carred me to another Lodg where I went threw the same Sarremony. There was not a Woman Anong Them-then to a third after which I was taken to a Large Prepaird for me in which they had put my. People and Coods with a Jarge I'ile of wood and six of thare Men with Spears to Gard it from the Crond. It four oclock I Cummenced 

a trade with them liut ye Crourl was so Grate that the Chefe was Obligerl to Dubel this Gard and I went on with my trade in Safety. Seventy-five Loges, at least ten Parsons in Each, will Make Seren Ilundred and fifty. My People ware Bystamlers-Note a worl-Not a Word to Say or Acte. The Chefe who Cane Down the River to Envite me up trade with them Gave me (1) understand that my trade was to begin at Sundown Pun he was abscnt when thay Compeld me to liegin liefoar the time-he Like wise tokl me if I was to Contend with them thay Mite take all that I had. I was in a Bad Situation but at Sundown the Clefe arived and seeing the Crowrl Grate he put to the Gard six Men more and took the Clarge on himself. He was as Well Obade $\&$ Kept $u$ as Smart Disapline as 1 kver Saw. One of ye hand was more than Commonly Dairing-ine ( )relered one of the Gard io throw his 1 ans threw hm $\ln$ (ase he persisted in his lmperfensthe fellow Came again-the Sentanal threw his lans \& it went threw his close and Drew a leattel lilod liut he never atempted agane. I Continuet my trade till Near Morning. Ly that time thare furs ware Gon. Thay Prepard to March of As thay had la on the Spot Sum time liefour my arival, they had got out of I'rovivhon I was not in a Situation to Asist than Beaing Destatute Myself. By Day Lite I Could not Sea One But the Chefe who Cept Close liy me to the last to l'revent aney Insult which mite arise as thay ware Going of. The reson of the Behaver of these Jeople is thay Never Saw a trader Before on thare One Ground or at Least Saw a Bale of Goods Opend. Sum traders Long licfore sent thate Goods into the Planes with thare men to trade with these people-they often would have them Cheaper than the French men Could sell them. These People would fall on them and take the Goods from them at thair One I'rice til thas Could Not Git Eney. I was the first that atempted to go thare With a Bale of Goods. These People are in thare Sentaments Verey Averishas But in this Instans thay made not the Least Demand for all thar Sarvis. I ate in the Morneing the Chefe Left me. I went to work Bundling or Packing my furs which 1 Got from them."

Like the Judians, the white traders used dogs, boats, and canoen as their chief means of transportation in early days. To these were added in late. times the famous Red River cart,-curious, creaking, lumbering velucles usually drawn by oxen, and containing no metal in their structure.

Each pair of dogs could draw a load from two hundred to two hundred and fifty pounds, besides perhaps abut fifty pounds of provisions for themselves and their driver. Indeed, the loads were frequently very much heavier. Cheadle reports a journey of upwards of one humberl and forty miles made by dog sleds in less thatn forty-eight hours, the last serenty milebeing corered without a halt for rest or food. Dog lriving. however, was an art calling for much experience, not to mention an unlimited vocabulary 
of expletives. The dogs themselves harl communly a wolf strain in their veins, and were almost as fierce as their murlonesticated consins. In camp, it was necessary to place out of their reach not only the provi-ions. but everything else of anmal origin. They would invarialbly devonr any snowshoes, larness, or other leather goods, if given an (opportunity.

The Hudson"s Bay Company"s traders nsed tw mount the Sakkatchewan and other northern rivers, - as indeed they frequenty do even yet,-in large clumsy boats with a tree or rail attached an a ruckler. Nlong each sicle wats a row of oarsmen who stood to their oars when the currents were strong. These boats bad also a mast and sails ant were equipped with ropes by which part of the crew working on the shore would pull them up against the rapicls.

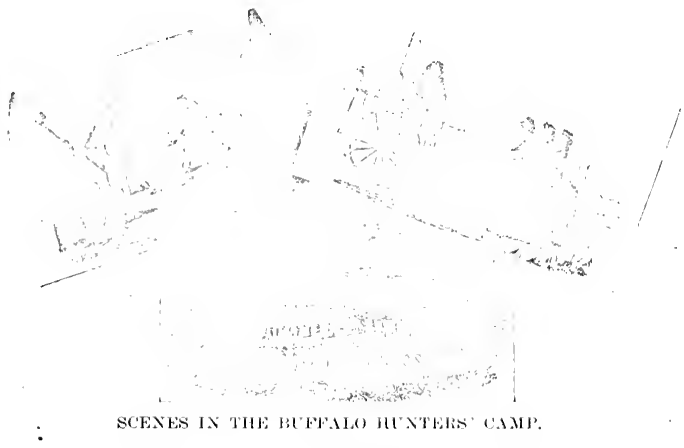

The Montrealers, however, made almost exclusive use of light canoe; carrying a burden of from two to four tons and manned by from six to nine voyagenrs. The freight was made up into packs of about ninety pounds each. On portages two or three of these great bumlles would constitute the load for each man. It was frequently necessary to portage the canoes also. The furs in which the traders dealt inclucled beaver, otter, muskrat, martin. bear, fox, linx, fisher, nink, wolf and buffalo. On the plains the last named animal was the chief object of chase.

Even within the menory of many now living. the prairies of Saskatclewan and other western provinces teemed with comtless migratory herds of buffalo, and in carly days they were, at ecrtain seasons, alnost inconceiv- 
ably numerous. In the early part of the summer during the mating seatson they were exceclingly ferocious, but in the latter part of the smmmer it would not be at all dangerous to go right among them. A well ileveloped male in gool condition would weigh from one thousanl to one thonsand five hundicel pounds, and a female from eight hundred to one thousand pounds. Their flesh, while less of a delicacy than that of the moose, was excellent food, but the improvident hunters slew them by thousands in mere wanton sport, taking only their skins and tongues. As time advanced, and the fur market called for crer increasing quantitics of buffalo skins, this slatughter became more ant more reckless, until at last the plains were denucled of the cinief resontce of the Indians, and the native tribes were consegnently reduced to hopeless dependence on the niggardly bounty of the white man's Government.

For the traders operating from the Red River settlements, the great events of the year were the spring and fall huffato hunts. In 1820 the number of ox carts assembled for the smmmer hunt reached five hundred, and thirty years after they would total three times that nimber, with two thonsand men, women and children in the caravan. The men were paid three pounds, the women two pounds one shilling and the children a pound for their services in the three months' exenrsion.

The first expedition started abont the miklle of June. In early times they operated as a single band, but latterly one party, known as the Red River hunters, used to proceed to the 11 issomi Coteatu, while the other party, known as the White IIare Plain hunters, usually operated west of the Souris liver and hetween the branches of the Saskatchewan.

On their return to the settlements after the summer hunt, a brief interval would be spent in trading and perfurming some of the sorely neglected duties of husbandry. Before the end of August, the antumm hunt would commence, lasting till the cul of October or the early part of November. The place of rendezvous varied from year to year according to the variations in the movements of the migrating butfalo. HLowever, during the later years of the buffalo trade the hunters usually gathered for the atumn expedition at Pembina Monntain.

As they gratually collected, scenes picturesque in the extreme were to be observed in or about the great camp. Ilere and there the horse dealers would he vigoreusly plying their calling, describing with vocifernus enthusiasm the merits of their beasts, and about them would be talkative and gesticulating groups speaking in many languages. The numberless dogs with their continuous chorus of barking. the hundreds of horses neighing to their companions, the herds of eattle lowing on the plains, and the noisy welcome that greeted the continuous stream of new arrivals made the disorclerly camp re-echo all day long. 
. 
The dress and general alpearance of the hunters wouk have scemed strange indeed in eastern centers of civilization. The reader should picture to himscli a concourse of vigorous pioneers whose bold and graceful abat1don, noble stature, bronzed features, varying in shade from the dusky hue of the Indian to the ruddy color of the Celi, and long foating hair, sonetimes straight and black, and sometimes fair and waving. woukl remind one that in them was incarnated the mystery of the mingling of a civilized with a barbarots race. These men were the bois brulis, the children usually of French and Scottish sires and Indian mothers. Their coarse dark blue coats glittered with at barlsarous profusion of great brass buttons; their long, waving sashes were of the briglutest red; their trousers perhaps of corduroy, perhaps of elk or buffalo leather. Upon their feet would he the moceasius of the Indian wilds.

During the afternoon, the concourse of hunters, decked in their most brilliant finery, would move to a short distance from the encampment to engage in sports. A straight course, half a mile long, would be marked off upon the prairic, and well known leatlers would be stationed at each end to superintend the races. On such occasions betting ran high, the stakes including horses, carts, oxen, articles of dress and many other kinds of valtables. Di-putes were quickly settled by the umpires. The contestant: usually wagered their own steeds, and after the race the losers wonld strip off saddle and bridle from their coursers and hasten to find consolation in strong liquors, which were consumed in great quantities.

H. M. Robinson, in his Great Fur Land, gives a spirited picture of the hunters' camp at niglutfall :

"Towards night the huge camp becomes again resonant witl a more intense babel of sounds. The lucky wimer of the race course parades his gains, and depicts in graphic pantomime his share in the sports, while the loser bewails his losses in matlin tones or arranges the terms of a new race on the morrow. The hetling of the afternoon is steceeded by the deeper gambling of the evening: and the sounds of shuthing cards, the clinking of the buttons and bullets of the moceasin gane, and the exclamation of trimmph and despair of wimer and loser, are evervwhere lieard. Rum flows frecly: for each hunter hrings a supply to ticle lim over the grand encampment and start him fairly on his journey. Is the night advances the camp becomes more and more boisterous, the confusion worse confounded. The wonen disappear from the camp fires, and hetake thenselves to tents ont of harm: way. Drumken nen reel ahout the thaming fires; wild yells fill the still air: quarrels are engendered: fierce invectives in many tongues roll from angry lips, and the satmmaliat becomes general. The caimp fires, lighting up the strange secne with a lurid glare--tent, cart and awning,-cast fantivlic shadows over all. The orgy continnes late inte the night, and when the fires thicker and die out, their last fechle ginw 

reveals shadowy forms stretched promiscuonsly ahont, sleeping the sleep of drunkenness."

When at last the main body of hunters had assembled, the caravan would start for the plains. After an interval allowed for stragglers to overtake the party, a president was clected, and a corps of captains was appointed. Each of these chose eight or ten assistants to perform police duties and to enforce the laws of the camp, which had been determined at the rendezvons before the expedition set out. These raried but slighty irom year to year. The laws of the buftalo hunt, as drawn up at Pembina in the year isfo, included the following provisions:

(1) No buffalo to be rum on the Sabbath day.

(2) No party to fork off. lag behind or go before withont permission.

(3) No person to rum buffalo before the general order.

(4) Every captain with his men, to patrol the camp and keep guard in turn.

(5) For the first trespass against these laws the offender to have his saddle and bridle cut up.

(6) For the second offence, the cont to he taken oft the back of the offender and cut up.

(7) For the third offence, the offender to be flogged.

(S) Any person convicted of theft, even to the value of a sinew to be bronglit to the middle of the camp, and the crier to call ont his or her name three times, adding the word "thief" at each time."

At night the carts were arranged in a great circle with the shafts projecting outwards. Within this barrier the tents were pitched at one end, and the horses and oxen were tethered at the other. All night long sentinels patrolled the camp, and a watchful guard was even maintained against the stealthy attack of treacherous and hostile Indians.

When his scouts had reported to the commander of the hunt the number and position of the huffalo herd, the camp was formed again, and the hunters prepared for the onslatught. Hotmed on their flect and highly trained horses, and cantiously taking adrantage of all possible cover, they adranced regularly under their leader's command until near enough to charge the buffalo herd. At the word of command, they then swept down at a gallop upon the startled huffaloes, and poured a deadly volley into their slaggy sides. The bewildered animals, maddened with terror and pain, would scatter over the prairie, tearing up the sward, roaring in rage or agony, and making the earth tremble with their trampling. The hunters followed the

"The foregoing laws are quoted from a capital article on "The Penple of the Red River," containcd in Harper's New Monthly Magazine, January, 1859. 

herd at a gallop, hathing and firing their weapons while at full speed. I charge of powder wotld he scttled in place by striking the gum against the sadklle, the bullet heing iropperl from the huntsman's mouth down the barrel without any wads. It is not surpriting that their crucle, old-fashioned weapons frequently expluded, maiming their reckless users. The wake of the flying herd was marked lyy piles of dead butfalo, and the prairie was deluged with bloorl like a field of battle. The carts followed up, and removed the carcases to the camp. Nuch of the meat was spoiled by the heat, but the hides and tongues were removed and great quantities of pemmican were marle, the meat for this purpose heing shredded and boiled with

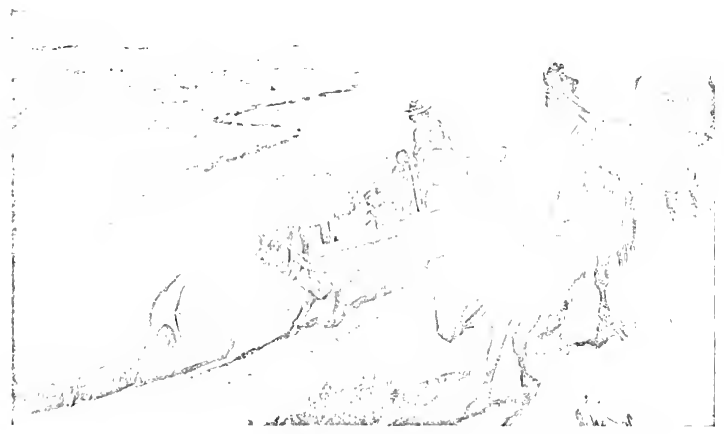

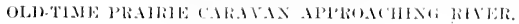

the tallow. This staple articke of food was poured, while in a fluid state into sacks mate of raw skins. The tongues were cured and the robes dressed. After the autumn hunt, however. the meat was taken back to the settlements frozen.

Such are some of the brief outlines of life among the hunters and traders who first established contact between the western provinces and the civilized world. It was a life full of adventure, glamonr ant romance, well fitted to call forth the sterner virtues, and characterized by a botish conmingling of frolic and toil. In their isolated posts the commanders or clerks surromiled themselves with the barbaric dignity of feurlal barons 



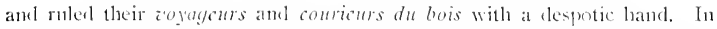
the seasons of rest between their laborions thties of gathering peltries and transporting their supplies, the lumtsmen gathered at the forts and held high revel. Marvelou tales of adventure were exchanged, the ancient songs of French Canada and the old lands rang out mon the atir, and to the stirring notes of the bag-pijes or vinfin the hunters and traters danced with the Indian girls. As the season advanced the hunters wothld gradually settle to preparation for fortheoning exenrsions. Carts or sleigls, cames or snow shoes, would he marle or repaired by the men who were to nse them. Harnesses would be mannfactured ont of rawhide strips and buifals skins would be sewn into tents. till at last the periof of comparative rest was over, and that of travel, toil and adventure returnet. 


\section{CHAPTIR VI}

\section{SASKATCIIEWAN INDIANS: ORIGIN, TRIBES AND MODES OF LIFE}

Origix of Term Indax and of the Ixdian Race--Pimsicil. Cimarictekistics-Dinersity of Linguistic Stocks-Folk Cinel S.IS-

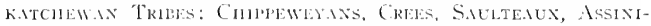

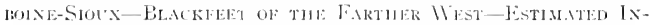

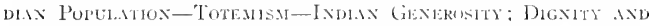

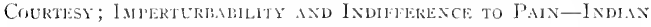
Cretetr; Impronhince; Love of Disphay- Mones of Dress-

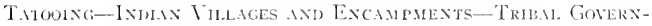

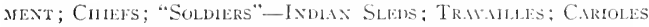

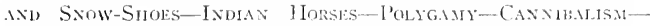

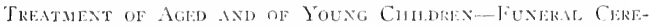

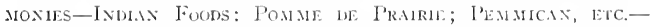

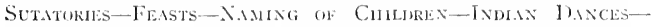

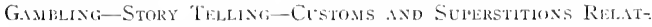

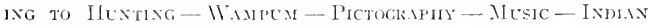

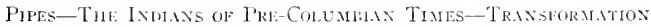

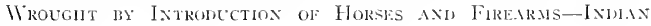
WARF,IRE,

Christopher Columbus, in a letter written in 1493. referred to the aborigines of the new lands which he had discovered as Indios. From this misnomer we have inherited the word Indiuns: and from the suggestion which it implies ill injormed ethnologists lave been led to adopt divers far-fetched or preposterous theories as to the origin of the Nortls American Indians. It is of course out of the fuestion to enter upon any extencled study of exploded ethnohgical theories. but it may lo interesting to note that hooks have been published undertaling to trace the Indians to a primeval lome located according to taste in almost any corner of the old world,-Egypt, Carthage, Phoenecia, Canaan, Asia Minor and the Cancasus, Assyria, BabyIonia, Persia and India, Central Isia, Siberia, the East Indies, Polynesia. Greece and ancient Celtic Europe, eren medieval Ireland and Wales. ${ }^{2}$

1 Alexander Francis Chamberlain. A. M., Ph.D., in article on the Forth American Indians. Enc. Brit. Edition XI. 

In general the North American Indians are brown skinned, thongl various shades of complexion occur from reddish brown to chocolate color. and sometimes almost black. The hair is miformly hlack. The eyes vary in color from hazel brown to dark brown. Indians are ustally tall, though some tribes of low stature exist. While most ethnolugists ject justified in gromping the aboriginal inhahitants of America morth of Nexico as a single race, it must not be forgutten that it includes very widely dificring types. It was long ago observed that a very close relationship exists hetween the natives of North Eastern Asia and the Indians of North America, but whether our Indians are immigrants from Asia, or whether their Asiatic cousins are emigrants from America is a question still under debate. Some authorities believe that in relatively recent times, races quite distinct from the North American Indians have dwelt in what is now Canada and the United States. The Nandans, or white bearded Sionx, a race now practically extinct, are described by La Vérandrye and their other first visitors as sonctimes white, and as possessing a grade of culture that secms to mark them off from the other North American Indians as we know them.

In like manner the so-called Nomnd Builders and the Eskimos have, by many, been considered as non-Indian races.

These views, however, do not seem to find fatror with the most widely accepted authorities of the present time. "The exaggerated ideas entertained by some authorities concerning the 'Mound Builders' of the Ohio and Nississippi valleys have led them to assume, without arlequate proofs, long continued relations of the tribes inhabiting this part of the country in the past with the ancient people of Yukatan and Mexico, or even an origin of their culture from beyond the Gulf," says Dr. Chamberlain: "but since these mounds were in alt probability wholly the work of modern Indians of this area or their immediate ancestors, and the greater part, if not all, of the art and industry represented therein lies easily within the capacity of the aborigines of North America, the 'Mlexican' theory in this form appears unnecessary to explain the facts."

Whether or not the North American Indian belong to a single race, they inclule an astonishing mumber of different linguistic stocks. Indeed, a study of the many diverse languages spread over America would seem to indicate that the tribes speaking them could not have originated at a common center, unless, indecd, at a period anterior to the formation of organized language. Nore than fifty of these distinct linguistic branches have been definitely recognized by philologists. It is to be understood that a single one of these linguistic families may include several different but related languages: on the other land, the most painstaking scholarship has failed to trace any common element in the root words of any two of the linguistic stocks of families themselves. The language of the Cree, for example, is as 



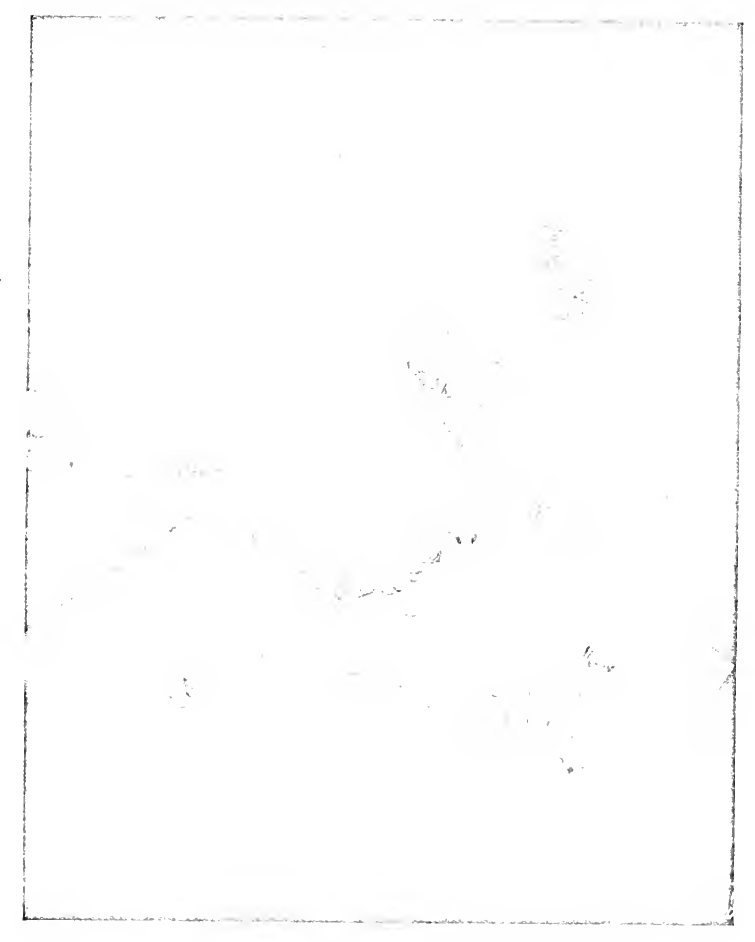

PANURAM OF LIFE AN THE ILAN 

diverse from that of the neiglboring Sionx as the English language is from that of the Japanese."

The Indian tribes with which we have to do in the study of Saskatchewan history are chiefly four,-the Chippewayans, Crees, Sanltcaux and Stonies, -thongh others will be mentioned.

The Clippewayans, including a number of semi-distinct tribes and representing the Atlabasean linguistic stock, have long dwelt in the forests of the northern half of Saskatchewan and adjacent territories. They have never been very numerous, enterpriving or blood-thirsty, and consecunently the role they have played has been inconspicuous. The general trend of Athabascan migration secms to have been from somewhere in the interior of North West Canada, though the family is now widely distributer from the interior of Mlaska to Mexico and Texas.

The Crees have dwelt cliclly in the South Western fart of the l'rovince. They are commonly stublivided as the Pain Crees, the 11 ood Crees and the Swanpies, according to their habitat. The Swampies, however, have resided cliefly in Keewatin and Manitoba. The Crees belong to the Algonquin stock. They are frequently called Kinistinoes, or Kristinoes by early writers. Varions other forms of this name also occur.

The Ojibways, or Chippeways, frequently called the Saultean, were also Algonquins. They were the chief ludian dwellers in South Eastern Saskatchewan and the adjacent parts of Manitoha. The Satileaux were immigrants from the Eastern provinees, and cane to their present home but little more than a century ago.

When Candian writers speak of the Siowx they nsually mean the Decotas. The Assiniboins, however, who have always been looked upon as Canadian Indians are really of Sionan stock. These Assiniloins, or Stonies, were at one time very numerous in Pritisl Territory, hut from the earliest period of white settlement in the West, their numbers have been small.

Along the southern border dwelt the Sionx or Dacotas. These are really American Indians, and have from the earliest times been looked upon as interlopers, but they lave penetrated Pritish domains so frequently and so persistently, whether in peace or war, that they must be given a place in ont listory. Indeed, a considerable number of them are now permanent dwellers in Canada. They came cliefly as reftgees after the Mimesota massacres of I862 and 1863 , and after the so-called Custer massacre of 1876 .

A few Iroqtiois found their way to the western plains in early times, but even half a century ago they were already nearly extinct or absorbed.

The Plackfeet occupied the western prairics and mountain slopes, and

${ }^{2} I^{\circ} i d e^{2}$ Chamberlain on N. A. Indians, Enc. Brit. Fdition XI.

${ }^{3}$ Perhaps it would he more proper to say the Denes, of whom the Chippewayans are a branch. 
therefore belonged to Alberta, rather than Saskatchewan. This nation consisted of four tribes: the Blackfoot proper, the Bloods, the Piegans and the Gros Ventres. They, like the Saulteaux and Crees, are of Algoncuin origin. The Algonquins are now generally believed to have originated somewhere between the Great Lakes and Iudson Bay, but they are at present the most widely scattered race in British America, and the languages spoken by the tribes have becone so diverse as often not to be intelligible to other tribes of the same race.

Various authoritie have attempled to compute the Indian population at various times. The more recent students of the subject believe that the figures earlier accepted were usually much too large.

Colonel H. I.efroy, in a treatise on the probable number of the native Indian population in British America places the aggregate of the tribes inhabiting the British plains in 1843 at not more than twenty-three thousand four hundred. Attempts were made to estimate the Indians on the hasis of the number visiting the IItdson Bay Co.'s establishments, but these estimates are very unreliable. During the first half of the Seventeenth Century, the Indians were probably four times as numerous as in the mildle of the Eighteenth. Donbtless the clief inftuence at work in producing the wholesale reduction of the Indian population have heen epidentes and the destruction of the bufialo and other gane wron which the Inulian subsisted.

Among numerous Indian tribes, descent usually followed the female line. This is notably the case among the Iroquois, whose social system was more definitely organized, or, at all events, has been more successfully studied than that of most other Indian nations. Each of the five tribes which constituted the original confederacy consisted of eight clans, or perhaps it would be more accurate to say that each of the eight clans was sub-clivicled among the five tribes. Members of the same clan dwelt together in comnunal lodges. The clans were distinguished by the names of certain animals,-the Wolf, Bear, Beaver, Turte, Deer, Snipe, Heron, and Hawk. Between the members of any of these eight clans the could be no intermarriage, as they were lonked upon in all cases as near kinsmen, though one night hail from the Rocky Monntains and the other from Lake Champlain. Thus in every family two clans were represented. The children belonged to the mother's clan. It is manifest that such a system of cross relationship bomd the tribes indissolubly together, and so constituted a permanent factor making for peace within the conferleracy. It would be impossible for any of the tribes to make war on any other tribes. without violating, in the case of erery warrior, the principle that war between kinsman and kinsman is sacriligions and unnatural.

Totemism-as such a system of kinship and descent is called-was once thought to have been miversal among the Indians, but later authorities hold 

a contrary view. The belicfs and institutions in this connection were not jelentical even within the same nation or stock. For example, female descent prevailed among the Algonguins of the South Eastern but not among those of the North Vestern l'rovinces of Canada.

The faults and virtues of the Indians are alike prominent, from the point of view of the white man. Perhaps their most admirable trait is their generosity. Doubtless this characteristic is closely connected with their undevcloped notion of private property, and with the conception of the good of the individual as being entirely stubordinate to the good of the tribe. The Indian lunter would rarely return successful from the chase withont sending portions of his spoils to some of his neighbors, or inviting his friends to a feast.

Dignity and its allied virtue, courtesy, are in a special scusc characteristic Indian traits. I)r. Milton relates that in one season of dire scarcity, he was visited when alone by a friendly native. Ile sat down and talked for an hour or two, stating that he was out trapping, and that his fanily was about five miles distant. In due time Milton produced some pemmican for supper, when the fellow justified the sobriquet of Maluagegun, or The Wolf, eating most voracionsly. He then mentioned that he had not tasted food for two days. He had visited the white nan's tent the day before in his absence and had lit a fire, melted some snow in the pot, and waited for a long time in the hope that some one might cone in. At last he had gone away withont touching the pemmican which lay on the table right to his hand. "The story was doubtless perfectly true, according with all the signs previously obscrved and the fact that the pemmican was untonched. With the pangs of hunger gnawing at lis stomach, and cyeing no donbt with longing eyes the food around, he had yet, according to Indian etiquette, refrained from clamonring at once for food; he sat and smoked for a long time withont nuking the sliglitest allusion to his starving condition."

The same author records another instance of a similar character in which a considerable number of starving Indians were involved. "As the miserable company came, they were invited to sit down by the fire. Their cheerfulness belied their looks, and they smoked and chatted gaily without appearing to covet the meat that lay around, or making any request for food." When, however, a supply was cooked and offered to them they ate in silence and dignity, being too well bred to show any signs of grecdiness, though they proved equal to the consumption of any quantity that was put before them.

In his intercourse with strangers, and on all formal occasions, the typical Indian was dignificd to a degree, punctilious in the observation of his accustomed marks of respect to his associates and superiors, and never in haste. Of his customs in these connections we shall have occasion to speak elsewhere. 

Growing ont of his sene of hic own diguity was the Indian's impertmoability and ostentations contempt for his own physical pain. Instances are recorded in which an Indian stubniting to torture at the hands of his enemies has snecred at their alleged minamiliarity with the refmements of their art, and has himself given instruction and assistance to rencler more excruciating the agonies inflicted upon him and brone without a sign.

The characterisic Inclian fatults are the faults of childhood. It must not be forgotten that three centuries ago the Indians were just emerging from the stone age in their cultural development. Mentally and morally they were a race of children. Like children their inagination was vivid, but so limited as to render impossible that projection of oneself into the experience of another. mon which all broad and intelligent sympathies depend. Consequently the Inclian was cruel, as julged by our stamclardi.

Again, after the manner of chilfrent, he lived only for the prenent. As a rule he was ntterly improvident in all his labits; feasting to exess while abtndance lasted, and making no aderpate provision for the wants of the future. While capable of cherfully enduring enormons physical fatigue in pursuits appealing to his barbarous instincts, he held ordinary labor in profound disdain, and was incapalble of prolonged and systematic toil the fruit of which was not immediately to be obtained.

As I'owell points unt, however, the Indian "does not lack indthtry so mucls as wirdom."

Like a child, the Indian had an absurd and indiscriminating love of display and showy adomment. The Cree danty would array himself in scarlet garments; paint a halo of bright vermilion about his eyes, a patch of the same color on each cheek and perhaps a circle alout his month, arrange his hair in a fantastic manner, and then luxuriate in the admiration of his friends.

The dress of an Indian consisted chicty of a tight pair of leggings:each made of a single piece and sewed with a single seam ruming up the outside.-and a leather breech cloth abont a foot wide and five times as long passing between the legs and over a belt, the ends hanging flown. The body was also covered with a shirt, belted, and reaching to the thighs, over which the Indian wouk] wrap a blanket of dressed buflalo skin, frequently highly ornamented. Caps were made of a single piece of fur. Their leather garments the Indians generally painted or ornanented with porenpine quills. fringes or tassels, often in a very tasty manner. They also used moccasins and mittens; and horns, claws, feathers and strings of teeth constitnted additional ornaments. Many of the Indians rubbed their hair with grease or colored clay to give it a glosay appearance.

The dress of the women was made of the same material as that of the men, but somewhat difierently arranged. The shirt was cut of fringed 

roumd the bottom of the skirt and fancifully painted. The arms werc covered with detachable sleves, connected by a cord cxtending from one to the other across the shoulders. Their hair the women parted at the top of the head and tied lehind, or fastened with great knots over the cars and covered with ornaments.

Both nen and women frequently tattuoed their skins. With the women this form of ornament u-mally concisted of a line from the middle of the upper lip to the centre of the chin and others down the sides of the chin. The men indulged in tattouing to a much greater extent and frequently corered their bodies with all kinds of fanciful patterns.

"They would often pinch up a fold of the skin and flesh an inch broad, in which they pass the iron barb of an arrow; they raise stripe in this manner from the back of the hand to the shoulder, and thence to the breats, there joining three or four separate circles of incisions made in the same manner on the lower part of the breast. Some content themselves by raising stripes of different lengths tuom their arms and thighs, and forming concentric cuts on the breast in a very regular manner, one within another; some with the horns upward, others downward, according to fancy."

"When on the warpath, the figure of a hame is often painterl over the montl. The Ojibways are particularly fund of vermilion, the l'lain Crees being partial to white, green and bluc. They paint the diest and arms, as well as the face. It was customary to gats the arms, side, chest and legs as a tohen of grief, and some of the Indians were drealfully diefigured by the resulting scars. Among the Jlain Crees, the arms and breat were often ormamented with figures of animals and various symbols. Such tattooing is performed with a bone or other shatp instrument, the colour being rubbed in." These ormancuts represented the brave's persomal or tribal totems and were commonly tattooed mpon him at pulserty.

Many of the tribes shaved or plucked all the hair cxcept a spot on the crown about the size of a silver dollat. Here the hair grew long and was made the object of the greatest care, being frequently covered with a picce of skin.

The 1 ood Crees Milton describes as a race of solitary trappers as compared with the Crees of the plains, who are horsemen and very gregarions in their habits. The llood Crees are very peaceable, and Clucadle considered them remarkably honest,-in this respect liffering much from their kinsmen of the prairies. The oljects of their chase were moose and fur bearing animals, and occasionally such bufiflo as entered the bounts of the woods. They were better clothed and fuartered than the lndians of the plains, but often suffered severely from starvation. which, in Cleadle's time, rarely overtook the Plain Crees.
'Cones, p. 365.
${ }^{5}$ Hind. 

The Assiniboins, or Osinpoiles, as Alexander Ifenry, Sr., calls them, had had in his time no acquaintance with any foreign nation sufficient to affect their pristine habits. "Iike the other Indians, they were crucl to their enemies, but, as far as the expericnce of myself and other Europeans authorises me to speak, they were a harmless people, with a large share of simplicity of manners and plain dealing. They lived in fear of the Cristineanx, by whom they were not only frcquently inposed upon, but pillaged when the latter met their bands in smaller numbers than their nwn."

"They are generally of moderate stature, rather slender and very active; there are, however, many tall and well-proportioned men among them. Their complexion is of lighter copper colour than that of the Crees, and their features are more regular. Their dress, tents, customs and manners are nearly the sane as those of the Crees, but they observe more decormm in camp, and are more cleanly and hospitable. Their robes and other garments are kept clean, but daubed with clay. They are excellent riders and notorious horse thieves, even among themselves, perpetually embroiled on account of horses and women; instant murder is irequently the consequence, and inteed to those two causes may be attributed all the quarrels and disturbance anong the meatow tribes." ;

The Crees and the Stone Indiaus were numerous tribes, and IIanmon tells ws that they frequently intermarried. The Plain Crees and the Assiniboins were both well supplied with horses, but the Assiniboius were much more skilful in their use, and wonld never go any distance on foot.

The tents of all the tribes of the plains were made of dressed leather and erected upon poles, ustrally seventeen in number. Two of these were tied together about three fect from the top. These were set apart at the base, and the others were placed in a slanting position against them, so as to form a circle. The tent would consist of ten or fifteen dressed hides and be abont twenty feet in diameter. The fire was always made in the centre, generally within a ring of stones. When new the Indian tents were white, and they were frequently decorated with fantastic devices suggested by dreams, or bygone adventures. Even those who have not seen an Indian village or encampment will realise that a large camp of such tents, pitched regularly on the level prairie, would present a very pleasing appearance, to which the gaily dressed natives and the horses grazing in the vicinity wonld lend additional interest and colour.

The wigwans of the Wood Indians were generally made of thin, flexible rods, fixed in the gromd in a circle and then bent over, tied at tops and covered with strips of white birch bark. These strips were fitted at the bottom with a rim of cedar, around which they were rolled when the lodge was taken down. The most expert soldiers could not pitch or strike 

their tents more expeditionsly than could the Indian braves, or rather, the Indian women, set up these bark lodges or roll them up to be placed in the canoes.

While certain fanilies enjoyed a hereditary prestige anong their people, the office of chief was not a mere matter of inheritance. Lsually the community constituted a kind of rude democracy, and its cluicf rose to power over his people by virtue of his proven skill ant conrage in lunting and warfare and his exceptional force of character and oratorical ability. As he had no highly dereloped civil machinery for the enforcement of his will, he could lead his followers only when they chose to follow and were convinced of the wistom of his plans.

The chicf associated with himself ten or a dozen selected braves, whom the old writers designated lyy the rather ill-chosen name of "soldiers." The commanding officer of this group of police was called the "conductor." These young men regulated the hunting expeditions, and superintended the pitching or raising of the encampments. They kept the members of the tribe together when on the march or setting ont upon a tribal hunt, and frequently enforced their anthority even to the extent of the breaking of limbs and the destruction of tents. Every young man enjoyed, in his turn, the dignity of leing a "soldier." lut "the conductor" retained his post as long as he was pleased to keep it. "The conductor," says Larocque, "never does anything of consequence withont consulting the other chiefs. and it is in consegnence of the resolution taken in council that he luarangnes and acts. His tent is thrown the first when they raise the canp, he goes forcmost ali the way (except a few young men who go far hefore as scouts) and pitches his tent the first, all the others encamp about him. Previous to their flitting he goes about the camp and tells them to throw down their tents, that they are going to such a place, and for such and such a reason. Some of the soldiers go far ahead, and olhers remain to watch and see if there be no enemies. When buffaloes are seen on the road and they wish to hunit, they cause the peojle to stop and the old man harangues from one end to the other. When all are ready, the huntsmen set off and the body of the people follow slowiy.

"When a quarrel happens between two persons tiney interfere and try to reconcile them by fair means (that is, when they push their quarrels too far), but I do not know that they cmployed an anthoritative one. Generally: a present of a lorse or gun is made to the oftended person, as the means of reconciliation, but there bappen few quarrels, and they are generally occasioned by their wives and jealousy."

The only animals donesticated by the Indians are the horse and dog. and the use of the former animals was confined to the Indians of the plains. The dogs were used as beasts of burden, and could carry upon their shoul- 

ders a joad of sixty or seventy pounds over a di-tance of twenty-five or thirty miles a day. The only vehicles for transportation were sleds and travailles. The travaille is a contrivance consisting of two poles fastened together at an acute angle, with crossbars between them. The point of the angle rests on the back of the horse or dog, and the baggage is secured to the crossbars. The sleds or carioles consisted of thin strips of wood ahout one and a half feet wide and bound un at the front. The sides were made of green buffalo hide, dried and seraped free from hair. At the back there was a straight board. Over the upper and front part of the sled there was a leather covering. Each cariole accommodated but one person. To the back of the sled were attached cords which were held by a man ruming behind to reduce the danger of the little craft capsizing. The dogs constituting the teams were gatudily decorated. One or two men usually ran in front to beat a track and lead the way.

Indians' snowshoes differed considerably from those nuw used by the whites. The shoe came to a point in front and was turned up. The side pieces were from eighteen inches to two fect apart and the shoc was frequently five or seven feet in length, double that of the snow hoes nowadays nsed by white men. The imer side was nearly straight, the outside arching. and the extremities came together behind at a point. The space between was covered with a network of thongs. The Indians farthest north used the simplest style of snowshee. The matives were trained to their use from early childhool and could walk farther with them in a day through the snow than they could go on the bare ground without them.

By the time the first white man came into the West the Indians of the plains were in the possession of some cxecllent lorses. In this connection Harmon stpplies as witl some interesting information:

"They sometimes go seventy miles in twelve hours; but forty or fortyfive miles is a common day's ride. They do not of ten use bridles, hut guide their horses with hafters. made of ropes winch are manufactured from the hair of the buffalo, which are very strong and duralle. On the back of the horse they put a dressed bufiato skin. on top of which they place a pad, from which are suspended stirrups made of wood and covered with the skin of the testicles of the butialo.

"Some of these Indians have forty or fifty horses; and they attach great value to those that are distinguished for their speed. Whenever an Assiniboin sells a racer, he separates from him in a most alfectionate manner. Immediately before delivering him to the purchaser he steps up to the favourite animal and whispers in his ear, telling him not to be cast down or angry with his master for disposing of him to another, for, he adds. 'Tou shall not remain long where you are: I sold you to obtain certain articles that I have stood in great need of: but iefore many nights have 

passed I will come and steal you away.' And unless greal vigilance on the part of the purchaser prevent, he generally fultills his promise; for they are the greatest horse thicies, perlaps, on the face of the earth." "

When travelling by water the forest Indians uned, as a rule, birch-batk canoes, constructed and propelled with great skill. The ludians of the woodless plains, lwwever, had no watercraft except their chums coralcs or bull-boats. These were constructed of leather stretched over at crude framework of light, hent rods. linll-hoats were ased chielly in emergencies when the plain dwellers had oecasion to cross a river.

The status of the women varied considerably in different tribes. They performed all the drudgery of the eamp, and European critics have usually considered the subdivision of labour very unfair to them. This opinion, however, is not shared by those whose familiarity with Indian life best fits them to form a judgment.

Schooleraft. like others, emphasises the fact that in the domestic circle the wife was distinctly mistress. "The lodge itself with all its arrangements is the precinct of the governuent and rule of the wife. She assigns to each member his or her ordinary place to sleep and to put their effects. These places are permanent and only clanged at her will, as when there is a guest by day or might. The hushand has no voice in this watter, and I have never heard of an instance in which he would so far deviate from his position as to interfere in these minor particulars. . The duties and labours of Judian life I believe to be equaliy and unt unergually divided between the male and the female. This division is also a most natural onc. and such as munt necessarily resule from the condition of man as a mere humter. It is the duty of the maie to provide ford, and the female to prepare it. . . . To the man belongs not only the business of hinnting. for this is an employment, not at pastine, lut the care of the territory and the kecping off of intruters and enenies, and the preparation of canoes for travelling, and of arms and instruments of war. The duty of dressing the meats and fowl, on the other hand, is the share of the hunter's wiic, with the care and control of the lodge, with the construction and lieeping it in order, with all its utensils and appurtenanses.

"The whole amount of the transferable materials of the lodge is often coinprehended in some hali dozen good rolls of bark and as many of rusl mats, which the merest girl conld casily lift. The mats, which are the sulpstitute for floor cloths, and also the under stratum of the sleeping conch. are made out of the common bulrusl, or the flag. gatthered at the proper season, and woven in a warp of fine hemp, sucl as is furnished by traders. The pattem of this soft vegetable woof is dyed and woven in various colours. Before we can affirm that the labour of preparing these larks and 



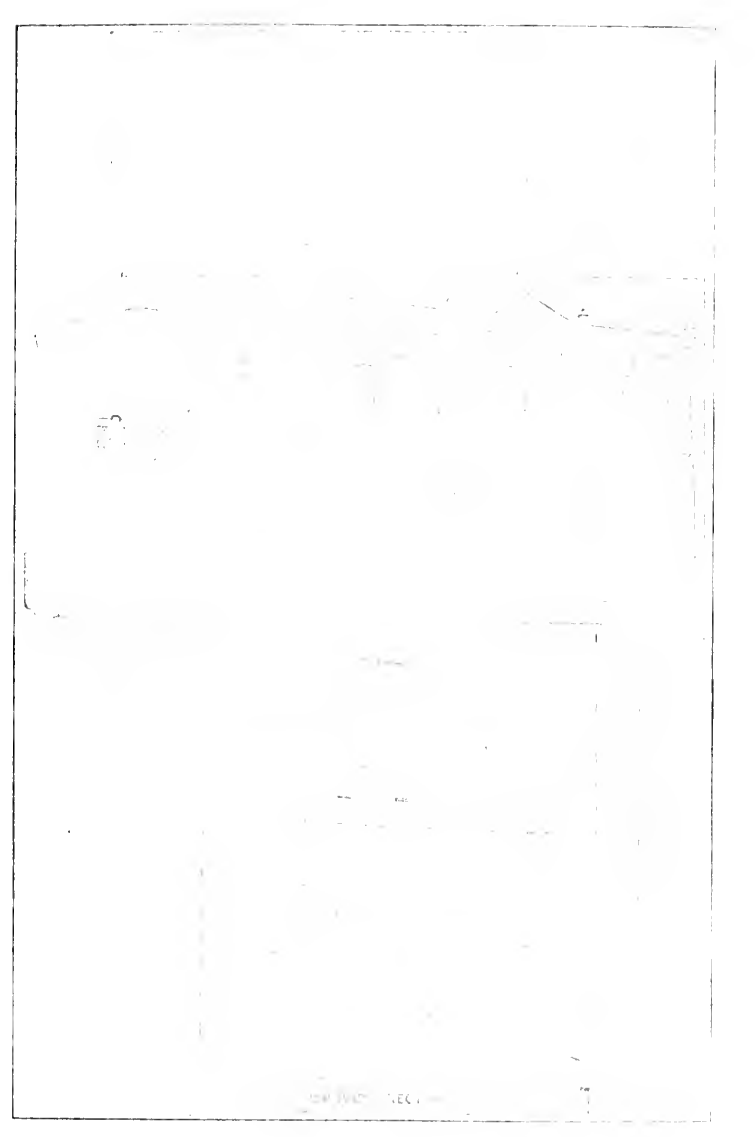



mats, and sctting up and taking down the lodge is disproportionately great or heavy on the females, it will be necessary to inquire into other particulars, both on the side of the male and female.

"Nuch of the time of the Indian female is passerl in idleness. She has not, like the farmer's wife, her cows to milk, her butter and cheese to make and flax to spin. She has not to wash and comb and prepare her cliblren every morning for school. She las no extensive or fine wardrobe to take care of. She has no books to read. She scts lithe value on time. which is characteristic of the race. What she does is either very platin sewing or some very painstaking ornanental thing. When the sheathing and flooring of the lodges are once made, they are permanent pieces of property, and do not require frequent renewal. When a skin his been dressed and the garment made, it is worn till it is worn out. The articles which enter into the mysteries of the laundry add but little to the cares of the forest housekecper. There is much mocenpied time when her huband is compelled by their necessities to traverse large tracts and endure great fatigues in all weathers in the quesi of food.

"It is also p:art of her cluty at all scisons to provide fuel for the lodge fire. She tales a hateliet of one or two pounds weight, and after collecting dry limbs in the forest. she breaks them into lengths of abunt eighteen inches and ties them in hundles or faggots and carries them at her leisure to her lodge. Small as these sticks are in length and diameter, hut few are required to boil her pot. The lodge being of small circumference, but litte heat is required to warm the place, and by suspending the pot by a string from above over a small blaze, she boils the contents withunt that expenditure of heat which to the amusement of the Indians claracterises the inmigrant's roaring fire of logs.

"The few fields which the Indians have cleared and prepared for cornficlds in northern latitudes are generally to be traced to sone adventitious opening, and have been enlarged very slowly. Cunld the whole of this physical efiort, therefore, be traced to female hands, which is very doubtful, for the old men and boys will often do something, it would not be a very severe imposition.

"There is at least a good deal in this riew of the domestic condition of the women to mitigate the severity of the judgment with which the prond and labour-hating hunter has sometimes been visited. He has, in our view, the most important part of the relative duties of Indian life to do. In the lodge he is a mild and considerate man of the non-interfering and nonscolding species. He may indeed be looked upon rather as the guest of his wife than what he is often represented to be, her tyrant. and he is often known only as the lord of the lodge by the attention and respect which she shows to hin. He is a man of few words; if her temper is 

rufficd he smiles: if he is dicpleased, he walks away. It is a province in which his actions acknowledge her right to rule; and it is one in which his pride and manliness have exalted him albove the folly of altercation." (Schoolcraft.)

In the time of famine Cheatle observed that the children and women were much better supplied than the men. "Nlthough the Indian sumaws and children are kept in subjection, and the work falls principally unen then, it is erroneons to suplose that they are ill treated, or that the women labour harder or endure greater hardship, than the men. The Indian is constantly engaged in hunting to supply his family with food, and when that is scarce he will set out without any provisions himself, and often travel from morning to night before he finds the game he seeks: then, loaded with meat, he at last toils home again, and while it lasts considers hinuself entitled to complete rest after his exertions." Nany examples of this selfdenial and wonderful cndnrance of lunger are given by Cheadle.

My readers will doultless be interested in the Indian methods of conducting a courtship. Lpon this delicate topic I will again make use of the observations and records left us by first-hand observers.

"The young men", says Laroçue, "seldom hum until they are married. their whole time previous to that epoch being dedicated to dress and paracke. A young man rises late in the morning: aluont midday he begins to dress and he is not finished until late in the evening. He then momnts on his horse. on which he has spread two fais, red and blue, and then in company with his associates he rides about the camp, with the wing of a bustard or hawk before his face in lieu of a fan to keep him from the burning sun.

"At night he dismounts, courts the women or goes to the place of rendezrous and at daylight comes in to sleep. The married man dresses fine only when they raise the camp and on certain special occasions. To please the females and to attract their attention is the motive of the young men's attention to dress. They in their turn dress as clean and fine as they can to please the young men. I have seen courtship carried on in much the same mamer as we do, whether it is their tustal custom of wooing the girls before marriage or not I do not know, as I could not get the proper information: but some attention and deference scem to be paid to the young female."

According to Harmon, however, courtslip and marriage differed ratlser widely from the customs usually followed nowatays in polite society:

"A young man who is desirous of taking a wife, looks around among the young women of his acquaintance to find one that suits his fancy. Having thus singled out one, to her he makes known his intentions; and if his addresses are favourably received, he visits her in the night season by crawling softly into the tent where she lodges and where she is expect- 

ing him after the other inhalitants of the lodge are asleep. Here they: pass the night by conversing in a whisper lest they should be heard by the rest of the fanily, who ali occupy the same aparment. As the morning approaches he withdraws in the same silent manner in which he came.

The girl then proposes the subject to her mother, and she converses with the father with regard to the intenrled match. If he give his consent, and the mother agree with hin in opinion, she will rirect her danghter to invite her suitor to come and live with them. It is now only that they colnabst; and whatever the young man kills, he brings it home and presents it to the father of his wife. In this way he lives during a year or more, without any property he can call his own. After his wife has a child she calls her husband by no other name than the father of her son or daughter. And now he is at liberty to leave the tent of his wife's father, if he pleases. All the Indians on the cast side of the Rocky Mountains think it very indecent for a father or mother-in-law to speak to or look in the face of a son or daughter-in-law, and they never do either unless they are very much intoxicaled.

"When two young persons of different sexes have an affection for each other and wish to be connected in marriage to winich the father of the girl will not comsent, they frequently leave the tents of the parents and go and join sone distant band of Indians. They are, however, often pursued by the father of the young woman, and should he overtake them, he will bring his dangliter back and keep a strict watch over her conduct. All neighbouring tribes often intermarry."

Alexander Henry tells us that the Cristineawx or Crees usually had two wives each and often thrce. According to Schoolcraft, however, polygany occurred chiefly among bands that were favorably located and had the best means of subsistence. Even here it was often considered disreputable. There were always some who disapproved of the practice, even though it miglit increase the brave's general influence among his tribe.

Among many of the Indians it was custonary to devour the heart of a courageous enemy with a view to acquiring his bravery, but real cannibalism was regarded universally with horror and superstitious dread. Says Kane: "I do not think that any Indian. at least none that J have ever seen, would eat his fellow creature except under the influence of stariation; nor do I think that there is any tribe of Tudians on the North American continent to whom the word cannilual can properly be applied." Anyone known to have been guilty of having used human flesh as food was called by the Algonquin Indians "Meendigo." These wretches were feared and simumed as dangerous madnen, but were, as a rule, not subjected to active molestation. On the other hand, they were rather piticd for the misery which alone could have reduced them to such straits. 

Harmon and other obscrvers agree that the aged of both sexes were generaliy treated kindly and not allowed to want for anything which it was in the power of their relatives to procure for them. When diseased or decrepit, however, and unable to follow their nomadic kinsmen or endure the hardships of savage life, they might, with their own consent, be slain as a release from their misery. This was lokked upon as an act of filial piety. Kane relates that one of his Indian fricnds told linin of having liiled his own mother. Oppressed by age and infirmity, she had asked him in pity to end her misery, and he had accordingly shot her. When kine inquired whereabouts he had directeri his bullet, his answer was, "Do you think I would shoot her in a barl place? I hit her there"-pointing his finger to the region of the heart. If not thus slain, it would, in many cases, he the sad fate of the sick and decrepit to be left belind as the nomatic bands moved away to new hunting groumcls.

The Indians were exccedingly deveted to their little dhildren, among whom corporal punishment for juvenile misclemeanours was practically unheard of. Infanticirle from motives of prulence was, however, not uncommon among some of the Indians of the North West. With mothers dying in childbirth, their infants were buried. Howerer, infanticide was rare among the Crees; and the liackfoot Indians believed that women guilty of this unnatural act wond nerer reach the llappy Mlountain after death.

The private property of an Indian consisted of lis horses, dogs, tents. weapons and household utensils. Some of these things he would bequeath to his friends, bnt all his clothing and weapons were huried with him. Nothing of which the deceased had made special and personal use was allowed to remain about the encanjment, and it was even considered a kind of sacrilege to mention his name or speak of him as deatl. East of the Rocky Mountains it was almost universally the custom to bury the dead. The corpse was dressed as gaily as possible and wrapped in a blanket. This garment, Harmon tells us, was never sewn or bound together, however. lest the deceased should be mable to shake it off upon his arrival in the land of the hereafter. Beside the corpse the Indians placed in the grave a pipe and some tobacco, dishes and materials for repairing the snowshoes of the deceased, together with sufficient provisions to support him during his few days' journey to the other world.

Frequently, however, the body, instead of being buried, was elevated on a scaffolding or stage of sticks, some ten feet in the air, and sometimes the

1 "Upon inquiry I found that it was a common custom among the Chippewayans, to leave the aged, the intirm, and the sick, when supposed incapable of recovery, to perish for want, and that one-half of the aged probably die in this miserable condition." Journal of John West. M. A., late Chiplain to the Hon. the Hudson's Bay Co, $18 \geq 0-18_{23}$. 

body was incinerated. Ilarmon relates an incident illustrative of this form of funeral ceremony:

"The corpse was placed on a pile of dried wood with the face upward, which was painted and bate. The body was evered with a robe made of beaver skins and shoes were on the fect. In short. the deceased was clothed in the same mamer as when alive, only a little more gaily. His gum and powcler horii, together with every trinket $w$ hich he had possessed, were placed by his side. Is they were alont to set fire to the wood on which the deccased lay, one of his hrothers asked him if he would ever come anong-t then again: for they suppose that the soul of a person, after the death of the body, can revisit the earth in another body. They must, therefore belice in the immortality, thongh they connect with th the trasuigration of the soul.

"The decased had two wives, who were placed the one at the foot and the other at the hearl of the corpse: and there they lay until the hair oi their heads was almost consumed by the fiames and they were almost stiffocated by the smolie. When almost senseless they rolfed to the ground to a litte distance from the fire. Is noon as they harl recovered a little strength they stood up and legan to strike the inming corpes with both the ir hands alternately, and this di-gusting, savage ecremony was contimed mutil the lody was nearly consumed. This operation was intertupted by their frequent turns of fainting. arising from the intensity of the heat. If they dicl not soun recover from these turns and commence the operation of striking the corpse, the men would seize them by the little remaining hair on their heads, and push them into the llames in order to compel them to do it. This vinlence was specially used towards one of the wives of the deceased, who had frefuently rum away from him while he was living.

"When the body was nearly burned to ashes, the wives of the decensed gathered up the ashes and the remaining pieces of lones, which they put into bags. These they will be compelled to carry upon their back and to iay by their sides when they lie down, for about two years. The relations of the deceased will then make a feast and enclose these bones and ashes in a bux and dejosit them in a shed erected for that purpose in the centre of the village. Lntil this tine the widows are kept in a state of slavery, and are rectured to claub their faces over with some black substance and to ajpear clothed in rags and sometimes to go without any clothing except round their waists. Bnt from the time of this feast they are set at liberty from these disagrceable restraints."

In some of the tribes it was customary, especially for women, to cut off a joint from one of their fingers when they lost a near relation. In consepuence of this horrid usage, it was not infreyuent to see agel women 

who lacked the first joint of each finger on both hands. The men on such occasions usually satisfied the propricties by cutting their hair and by scratching and cutting the faces and arms, frequently in a shocking manner.

During a burial the friends of the deceased would sing a weird chant, and weep and cry aloud in a despairing manner. Suicide from grief at the loss of a member of the family was not uncommon. Harmon is our anthority for stating that the strength of conjugal attachment was the frequent cause of suicide in every part of the Indian country.

An important article of food among the lndians of Saskatchewan was the pomme de prairic. ${ }^{9}$ This plant has a root nearly a foot long and two or three inches in circumference. It is shaped like a carrot and tastes something like a turnip. The Crees used it in many ways-mncooked, boiled, roasted, dried or crushed into a powder for making sonp. Hind remarks that in the Qu'Appelle country especially many bushels of this plant were collected by the squaws and children and large quantities were stored in buffalo bags for the winter. The roots were cut into slureds and dried in the sun.

Animal food, however, supplied the chief sustenance of the Indians. The meat of the buffalo, moose, deer, antelope, bear, etc., was prepared by boiling or roasting. liefore the advent of the whites the kettles used were frequenty made of bark. The water was heated by throwing into them hot stones. The meat was roasted on a spit stuck in the ground and inclining towards the fire. As the Indians were ignorant of the use of salt for the preservation of their meat, the lean parts of what was not immediately consumed they used to cure by drying in the smoke. and the fat was melted down. Boiled marrow fat was considered a special delicacy.

A staple article of Indian food was pemmican. This consisted of lean meat, dried and pounded fine, and then mixed with melted fat. Sometimes a flavoring of wild berries was added. This mixture was put into leather bags and when cold it became solid. If kept dry, it woukl remain good for years. This penmican was very healthy and nourishing food.

Cheadle reports that the Crees regarded the moose as a sacred animal. Certain portions of the meat, including the breast, liver, kidneys and tongue, must be eaten at once. All scraps were burnt, never given to the dogs.

No regular meal hours were observed. The Indians would eat a little lalf a dozen times a day if they had food to hand. and sometimes, particularly at formal feasts, they would gorge incredibly. Generally speaking, however, they were not great eaters, and sometimes existed for a very long time upon very little food.

In eating, the Indians made nse very commoniy of birch-bark dishes.

o Botanical name. psorales esculenta. 

They would take a pice of meat in their fingers and dip it in the soit marrow contained in their dish. The pottery of the Algonquin and Iroquoian tribes was generally crude and undeveloped.

One of the most interesting institutions to be found in connection with every indian encampment was the sutatory, or sweating-house. Such lodges were commonly made of plaited willows. If for one or two persons oniy, they were three or four ieet in height, and about five feet in diameter. Over the willows were laid the skins of buffaloes, and in the centre of the hut heated stones were placed. The Indian would enter the lorlge perfectly naked, carrying with him a dish of water which he would sprinkie over the hot stones. The steam and the heat of the stones would soon put him in a profuse perspiration, and in this condition he would remain for perhaps an hour, though a person unaccustoned to such heat conld not bear it for half that time. The Indians helicred that by this sweating they rendered their limbs supple. Noreover, they considered sweating a sovereign remedy for most disorders. On leaving the sweating lodge, they would often plunge into a stream or rub thenselves with snow. The sutatory was also an important factor in very many of the religions cercmonies observed ly the lndians.

Whenever food was plentiful, feasts of a social or réigions character were very common. Whan a dief proposed to make o feast, he sent to lis friends little tokens of his intended hospitality, either consisting of small pices of wood or quills. Every guest brought with him a dish and knife. The host received his guests either standing or sitting in his wigwam, and they were appointed scats according to their age and social status, the most honourable place being next to the chief giving the feast. When the food had been divided up among the guests, the host would light his pipe, draw a few whiffs himself and present the stem towards the sun, the earth and the fire. Having thus done honor to his gods and deceased relatives, he presented the pipe successively to each person present. A small quantity of food was then sacrificed by being cast on the fire, and the feast began. It was considered an evidence of appreciation and good breeding to devour one's portion with the utmost rapidity. While the company were eating, it was customary for the chicf to sing, beating time to his song upon a tambourine or drum.

Interesting ceremonies were associated with the birth of children. As soon as the child was born, it was washed in water previonsly prepared by boiling in it a sweet-scented root. The mother would then order a feast for the neighbouring women who had gathered to assist her. The oldest of the women would cast a small portion of the food into the fire and then divide the rest among the company. Thereupon she wotld offer up a prayer to the Master of Life on behalf of the newborn infant, asking that its life 

might be spared and that it might grow up in beaty. The meat of the first animals killed by a male child was carefully prescrved by the parents until sufficient was collected to make a feast. Upon this auspicious occasion the most respected warrior present would place some of the food in the fire, and beseech the Great Spirit to he kind to the lad, allowing him to grow up a skifful hunter and a brave and successfinl warrior.

Names were usually bestowed by some aged member of the lodge or camp, and the choice was usually considered to be guided by some particular spirit. Frequently the names were suggested by mysterious seenes occurring in dreams. Names bestowed $i_{11}$ childhood with solemn ceremony were considered sacred, and were seldom used. An Indian would rarely give his own name, though he would freely indicate those of other persons.

"Among the natives," says Ilarmon, "those persons who are in any way deformed or have any blemish about then, receive their names from this circumstance, while the others are often named after some beast or bircl. No Indian will inform another, even if requested. what his own name is, though he will, if asked, give the names of other Indians. Of the reason of this reserve I am ignorant."

Feasts of a certain character were habitually observed in silence and darkness. After dividing up the food, the master of the lodge wonld perliaps for half an hour address himself to the spirits of deceased relatives and friends, praying them to be with him to share the food and to assist him in his hunting enterprises. The food would then be eaten in silence, after which the host made still another speech. Thereafter a new fire was kindled and the pipes lit. The whole fanily would then dance and sing, continuing these exercises for a greater part of the night.

Among the many Indian dances were four of special importance, according to Schoolcraft's classification. These were the war dance, the medicine dance, the wabeno dance, and the dance of honour. Each of these had its own special movements and was performed to special music with associated words.

The dance was a common resonrce, as Schoolcraft remarks, winenever the mass of the Indian mind was to be acted upon, and it may thus be riewed as related in nature to the school, the plation and the press in civilized society. Harmon gives the following description of a native dance as witnessed by himself :

"While I was at a camp of the natives. I was invited to attend and see them dance. The dancers were about dhirty in number, and were all clothed with the skins of the antclope-dresses which were nearly as white as snow: and upon their heads they sprinkled a white earth, which gave them a very gented appearance. Their dance was conducied in the follow- 

ing manner: A man nearly forty years of auge arose with a tomabawk in his hand, and made with a very distinct voice, a long harangue. Ile recounted all the noble exploits which he had achieved, with the several war parties with which he had engaged his enemies; and he made mention of two persons in particular whom he first killed and then took off their scalps; and for each of these he gave a blow with his tomaluawk against a post, which was set up expressly for that purpose near the centre of the tent. And now the music began, which consisted of tambonrines and the shaking of bells, accompanied by singing. Soon after, the man who had made the harangue began the dance with great majesty, then another rose and joined him; then anothes, and so on mutil there were twelve or fiften up, and all danced round a small fire that was in the middle of the tent. While dancing, they made many sarage gestures and shieks, stch as they are in the habit of making when they encounter their enemies. In this course they continued for nearly an hour, when they took their seats, and another party got np and went through with the same ceremonies."

All Indians were inordinately addicted to gambling. Refore commencing a game of chance, cach piayer collected whatever he intended to stake, and the relative value was mutually agred upon. The players commonly sat side by side with a blanket over their knees. One favourite game consisted in one player holding in his hands certain small objects, and the other participants being required to guess what he had in each hand. The holder would kep his hands continnally in motion, now under the blanket, now behind his back. At each change of position the hands are held ont to invite a guess, hut usually considerable time elaped lefore a stake was risked. Meantime the onlookers drmmmed and sang, and the players lodies bent rlythmically backwards and forwards. Such a gane might last half a day or more, or until one of the players had won alt the stakes.

Story telling was a favourite form of entertamment in the Indian camp, and in this art the aborigines greatly excelled. The scene described was acted out in so far as was possible. hy very free use of gesture and pantomime. Sometimes the stories were simply tales of adventure. Very often they were deliberately adapted to the inculcation of Indian virtues in the breasts of the children and young folk who were permitted to hear them. Others of their tales embodied the religious belicts of the tribe, or the traditionary history of its mighty men of old. Willan Ifenry tells us that by the tone of voice, the Indian story teller would clearly indicate whether he was relating incidents communicated to him by others, or whether he was describing his own experience or expressing his own personal sentiments. Some examples of Indian folk lore will be given in a future chapter.

Some of the most important Indian customs were, of course, those relating to the chase. The favorite method of hunting the buffalo was by the 


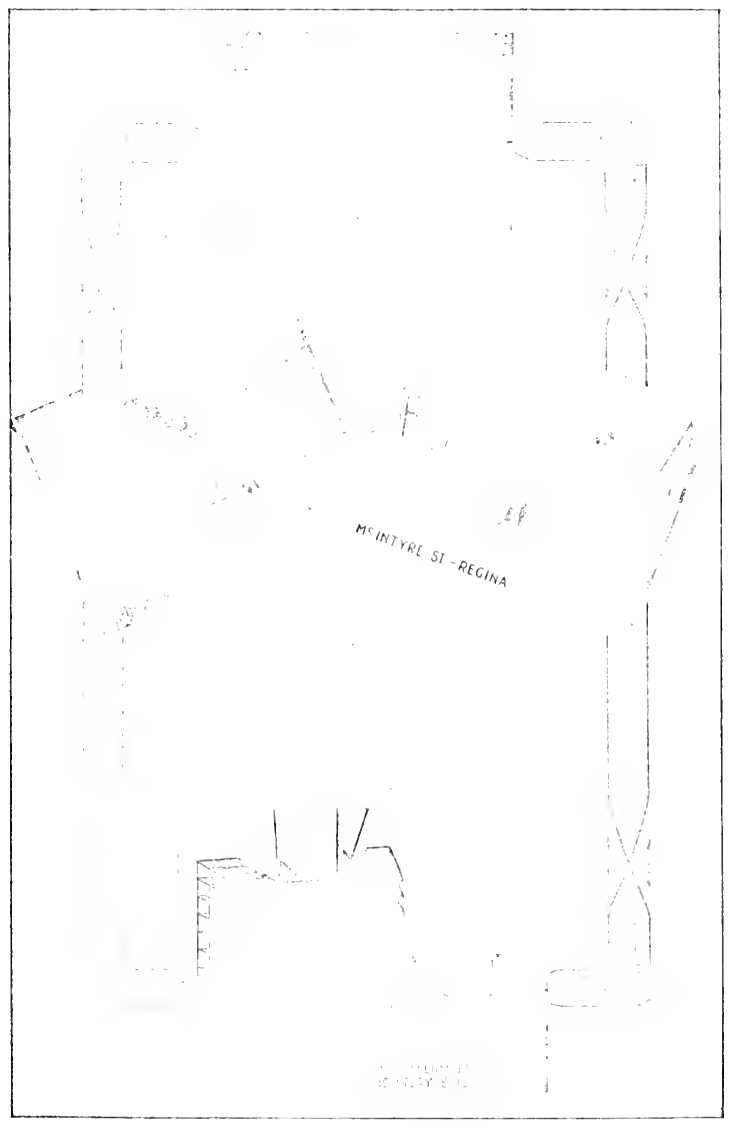


. 
use of what is called the buffalo pound. This was an enclusure formed with straight sticks about four feet high, wattled with smaller branches. If possiblc, the enclosure was lower than the surrounding pratiric. From each side of the opening there extended two ranges of sticks at a wicle angle. This lane would reach perhaps two miles into the plain. When a herd of buffialo wandered near or had been cautionsly rounded up in the vicinity, some of the most experienced hunters would go forth to decoy the animals into the pound. They would cover their faces and array thenselves in buffialo skins, and take positions betwcen the herd and the pound, bellowing from time to time in initation of the wild battle. Their actions wonld so closely rescmble those of the buffalo thenselves that the authors of some of our old jonrnals confess that had they not heen in the secret they wonld have heen as much deceiverl as the unthinking cattle. When the herd was got in motion and approached the pound, the dogs were muzzled and all the members of the band would surround the enclosure. Sometimes horsemen pressed upon the herd from behind, and as they approached they were gradually raised to a high pitch of excitement, and would rush forward, tumbling wildly into the pit inside the gateway of the pound. When the buffaloes were secured within the enclostre, the Indians smoked their ceremonial pipes. and then went into the yard killing the bufialo with their bows and arrows. When the animals were all slangliterel, their tongnes were taken to the tent of the chief; part of then were used for a feast and the remainder were generally given back as presents. The meat and skins were then distributed among the people. Shonld any of the party be displeased with their share, they were too dignificd to complain, but would quietly decamp and join another band.

As the Indians belicved that animals were possessed of souls similar to their own, they frequently addressed long harangues to the animals they had taken. Sometimes these speeches wonld be delivered before the slaughter and sometimes afterwards. The bear was held in special honor. When one was slain the Indians would kiss and stroke its head, apologizing profusely for laving taken its life, and sxplaining at length the dire necessity which had fored such an act upon them. At the lodge the bear's head would be adorned with trinkets such as wristbands and belts of wampum and laid upon a scaffold. Near its rose the Indians wonld place a lingo quantity of tobacco. Pipes wonld be lit, and the master of the lodge would blow smoke into the bear's nostrils to appease its anger at being lilled. After all this formality the chief would make a speech in which he wonk specially deplore the necessity umder which men labored of thus destroying their friends. Then the whole party would devote themselves to a hearty feast of bear's flesh. Even the head, after remaining a few days on the scaffold, would find its way into the kettle. 

The superstition of the Indians sometimes seriously interfered with their hunting operations. An unpropitious dream would be sufficient to prerent an attempt being made to capture any animals of the chase eren if they were numerous in the vicinity.

Various simple arts had their place in Indian life. [hasketry was highly developed among many Indian tribes, and woven goods made of buffialo hair were prodnced by the Indians of the plains. Wampum ormanents vere mannfactured especially by many of the Algonumins and lroquis tribe.

Wampum might he called the shell money of the North American Indians. It consisted of heads made from shells, and required considerable skill in its manufacture. The beads were cylindrical in form, purple or white in color, and about a quarter of an inch in length. The term "wanpum" was applied to the beads only when strung or woven tegether. Wampum lelts served as symbols of anthority, and were surrendered on deicat in battle. They were also used to commemorate feats of personal or tribal history. Belts passing from one nation to another on the occarion of any important inter-tribal transaction were very carefully preserved ats public trea-ures and memorials. The patterns on the belts served as mnemonic symbols, particular facts being associated with a particular string or figure to aid the menory.

No real hieroglyphics were used by the aborigines of America north of Mexico, but picture writing was widely practiset. This mode of communication was of great service. When a band of lndians separated they would fix in the gromel where they had encamper a number of sticks leaning towards the direction in which they were travelling. If they had been successful in the chase, the Indians painted or drew, on pieces of bark, pictures indicating the number and kinds of animals which they had killed, and then hung the piece of bark upon a stick. Other Indians. unsuccessiul in the chase, finding these notices, might derive important advantages from them, and be guided to a place where they would probably obtain a supply of food. But for such devices, the Indians would have been in much greater danger of perishing by stamation than they already were. Lpon the piece of bark there would also be symbols representing the phatse of the moon indicative of the time of the month. So accurate was this mode of conveying intelligence that a person accustomed to it would generally ascertain the designated time to within twenty-four hours.

The Indians alio used pictograply upon their leather tents, and even upon their garments. In some tribes a warrior's robe might contain a pictorial history of his wars and hunting expeditions, and show the number of scalps he hat taken.

"The pictographic delineation of ideas is found to exist chiefly anong the Shamans, hunters and travellets of the ()jihwa, and there does not appear 
to be a recognized system by which the work of any one person is fully intelligille to another. . . . The figures are more than simply mnemonic; they are irleographic." 10

Agriculture was engaged in but little by the Indians of the North West. The Satteaux, however, and some others, planted Indian corn and potatoes. Other tribes also cultivated tobacco, pumpkins, beans, etc. Sugar was made from the sap of the maple tree in regions where it grew.

Indian music constituted an excedingly important factor in tribal life. It was the medium through which nan communicated wih his own soul, with the unseen world, and in a special manner with his companions. The music of each Indian ceremony had its peculiar rhythm. Fasting. prayer. hunting, courtship, games, and the facing or defying of death, all had their special and peculiar songs associated with them.

The only wind instrmment known of by Schoolerait as existing among Indians was a kind of flute, made generally of some eylindrical pieces of cedar, united with fish glne, and having a snake slin clrawn in a wet state tightly over it to prevent its cracking. In this instrument eight holes are perforated by burning. It had a montl piece, and was blown like a flageelet. This was called a "pibbegwon." The "taywategun" was a drum or tambotriue, made by stretching a skin wer the end of a section of hollow tree. The "sheshegwon" was a rattle, made sometimes of the wild gourd, sometimes of a bladder, and sometimes by attaching the dried hoofs of a deer to a stick.

"In the hot summer evenings," says Schoolcraft, "the children of the Chippeway Algonquins, along the shores of the upper lakes and in the northern latitudes, frequently assemble before their parents lodges, and amuse themselves by chants of various kinds, with shouts and wild dancing. Attracted by such shouts of merriment and gambols, I walked out one evening to a green lawn skirting the edge of the St. Mary"s river, with the fall in full view, to get hold of the meaning of some of these chants. The air and the plain were literally sparkling with the phosphorescent light of the fire fly." The following is Schoolcraft's translation of the fire-fly song as he then heard it: "Flitting-white-fire-insect! Waving-white-fire-bug! give me light before I go to bed! Come, little dancing white-fire-bug! Come little flitting white-fire-beast! Light me with your bright white-flame-instrument-your little candle."

"Netre there was none," he say's, "at least of a regular character; they were the wild improvisations of childhood in a merry mood."

Indian smoking pipes were usually made of a kind of stone harder than gypsum and softer than carbonate of lime, now known to science as catlinite, 

in honor of the well known traveller Catlin. Tle was the first white man to visit the famons pipestone quarry on the Missouri Coteau, $183^{\text {fr. This }}$ quarry was the centre of Indian poetry and ronance. Ifere was to be found what was apparently the only deposit of red pipe stone, though grey pipe stone occurred elsewhere. For ages the red pipe stone quarry was the most sacred shrine of the red man. It was netural grouml, and upon entering it the Indians buried their weapons of war, and met as frjends.

Different tribes of Jndians show a preference for different shapes and ornament in making their pipes. While the stone pipes of the Indians were the result of long and patient labor, they could on emergency mannfacture a pipe at very short notice. They would join together some reeds, and attach to the end a piece of firm clay, which they would mould with their fingers. ${ }^{11}$

Chamberlain, one of our most distinguished authoritics on Indian affairs, believes, with many others, that the amount and extent of tribal wars north of Mexico in pre-Colmullian tines was not nearly so great as is generally: supposed. Such wars wenally involved unly a portion of the tribes concerned, there often being permanent peace trihes.

Even within historic times, the hunting gromels of the varions triles were definitely distinguished the one from the other, and, upon the whole. it was very unusual for any nation to eneroach upon the territory of the others.

The Indian birth rate was low, and owing to their mole of life and barbarous practices in connection with the treatment of lisease, the leath rate was high. From these and other canses the popnlation was practically stationary. The small bancls or tribes scattered thronghout an enormons contincnt abounding in game were generally able to maintain themselves in comparative plenty withont moving far from their natal hunting gromuls. When discovered by the Europeans. Fowcll tells us that the Indians of the East were found living in fixed habitations from which their wanderings were but oceasional excursions. The extrandinary dissimilarity of most of their languages, shows that in prinitive times the different nations had practically nothing to do with each other. The gradual introduction of fire arms and the acquisition of the horse, which was of course introduced into America by the white men, are responsible for great changes in aboriginal habits. The horse mate nomats of many tribes which there is abundance of evidence to show were formerly almost sedentary in character.

Morcover, as the white settlers displaced the native tribes the latter retreated westward, and, strengthened by the weapons obtained from the Europeans, they in turn displaced adjacent tribes. Thus, long before the first white man had crossed the continent, the malign influence of white ${ }^{11}$ llind. 

suttlement had producel an alnost miversal state of war all through the interior, as tribes driven from their ancestral lomes retreated to lands previously oceupied by other peoples. Nomadic habits and, in consequence, Judian wars, were further encouraged when a commercial value was given to skins and furs. It thus appears that in pre-Colunbian times, the normal condition of the trihes was one of peace, and the original moral responsibility for its disturbance rests with ourselves.

Personal vengeance lay at the root of much Indian strife. A savage whose near relation had been lilled was never content until he had avenged the death, if possible by killing the murderer, or some person nearly related to him; at all events, by killing somebody. Fven a natural death would often be avenged by indiscriminate homicide. This barbarous custom was strengthened by the belicf that death from natural catuses was attributable to some one's hostile magic. The following entry from an old joumal is of special interest in this comnection:

"Yesterday five Sicannies came here, from Macleod's Lake, who form a snall war party. Their Jeader, or war chicf, desired me to allow them to go where they might think proper; upon which 1 inqtired of them whither they wished to direct their course, and what their intention was. The speaker replied that when they left their lands their intention was to go and try to take a scalp or two from the Indians of Jraser's Lake, 'who,' he added. 'have done us no injury; but we have lost a relation, and we must tty and avenge his death on some one.' This is a custon common to a greater or less extent to all the tribes."

Through varions parts of the West there existed special paths of travel througl which hunting was disallowed. They constituted established war roads for the Ojibways and Crees in their periodical experlitions against the Sionx. One of these extended from near the elbow of the south branch of the Saskatchewan to the flank of the Grand Cotean. IVar parties would frequenty travel four humdred or five lumbled miles before they would reach the territories of their encmies.

The Wood Crees and Chippewcyans, and the forest tribes generally, were less given to warfare than the Indians of the plains. The stmmer was the only season employed for military operations, but with its retnrn the Plain Indians usually engaged in war, offensive or defensive, every ycar. The war pipe was then lighted, and those wishing to join in the approachins campaign smoked it together. No one, lowever, was compelled to enlist.

Pitched batles were unknown. Warfare consisted in stealthy and nuexpected attacks. In these onslatiglits the attacking party generally had greatly the advantage and usually wrought terrible havoc anong the men of their enenies' tribes. The women and children were taken alive, if possible. and carried home as slaves. They were sometimes even adopted into the 

families of their encmies, in the place of children lost, and were then treated with all the tenderness and affection that would be exercised in the case of near relations. These captives were rarely tortured, though warriors who fell into the hands of their enemies might expect to die a terrible death.

The Indians were usually very skilful archers. From childhood to maturity their youth passed almost half their time shooting arrows at a mark. To render this sport the more interesting, the participants had almost always something at stake. In times of war, the stone arrow heads were sometimes dipped in poisonons juices.

When an Indian settlement expected an immediate attack which it wonkl be unable to resist, the whole camp would flee, leaving their lodges standing. Under such circumstances, however, it was not umusual for the old and fecble warriors to remain. They wonld dress themselves in their gayest garments, paint their faces, light their pipes and sing their war-songs until the enemy arrived and dispatched them.

As a general rule, Indian ralids were not associated with any very great loss of life. If a victorious party returned with a score of hideous trophies after their summer's war excursion, the warriors were well satisfied with their snccess.

The practice of scalping. which most people associate solely with Indian warfare, las been common in Asia, and Africa, and even in Europe. It is described by Herolotus as a Seythian practice, aud it existed among the Franks and Anglo-Saxons as late as the nintl century. Its motive lay in the desire of the wartior to precerve sone indisputable token of his prowess. The Indian braves wore scalping tufts as an implied clallenge. Captured scalps were dricd, mounted and consecrated by solemn dances, and were sometimes worn as articles of personal adornment. 



\section{CIIAPTER VII}

\section{INDIAN REIIGION AND FOLK LORE}

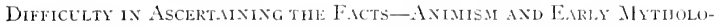

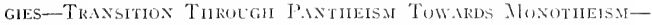

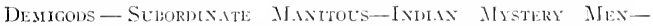

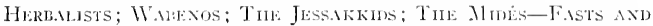

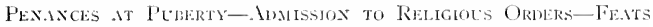

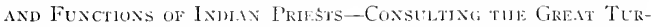

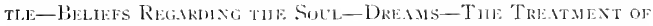

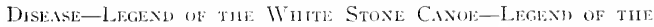

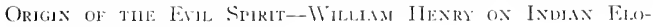
QUEXCE-AX IRogLOIS LligEXI).

Regatding the religion of the Aborigines, much has been written, but unfortumately much of the information has been erroneous or misteating. The Indian's almost ineradicable reticence, especially with regard to topies upon which he has reason to smspeet that the white man will leok with ridicule, has made the facts hatrl to discover; and our own religious and philosophic standpoint is so far remosed from that of the race of children of whom we are speaking that the whites have the intensest difficulty in grasping Indian religions conceptions and icleas, consequently we tend to read into Indian lore notions really attributalle to our own religions inheritance and quite foreign to that of the Red Man. Moreover, ever since the advent of the whites, the institutions of the . Jborigines have been sinking into decay, and have been subject to insidions transformation resulting from intercourse with the pale-faces.

Every intelligent observer of childhood will have noticed that at a ecrtain stage of development little children tend to treat all things in their enviromment as if possessed of life and intelligence. Here we have a clue to animism underlying Indian religion conceptions in their least develoged forms. Upon Animism proper followed the development of mythologies in which it is notewortly that most of the characters are considered as mythic animals rather thim mythic men. Some of these are the first ancestors of the aninals of todiay ; others are the spirits of momtains, winds and other natural phenomena: while yet others of these deities include fire 

and the heavenly bodies, notably the sum. That great luminary came to be regarded as the symbol of a divine intelligence and in Indian pieture writing. the figure of the sun denoted the Great Spirit. Largely owing to the influence of the White Men, the ancient animal mytholog! has gradually degenerated into mere fairy tales and folk stories, told for the amusement of children and their elters.

Among some of the Indian tribes, notably the Irognoian, we may trace a gradual growth toward Monotheism by way of Pantleism. Among numerous 1 gontuin tribes, also, we sce distinet approaches to the conception of a single supreme being, but it is impossible to define to what extent the mythology of even these pagan tribes has been moulded by Christian infuences.

All over America, native races have held in veneration varions religions heroes or demigods, who reformed the institutions of mankind, and then retired temporarily or permanently from intercourse with the mations. The great Ojibway hero is Nana-bo-zho; among the Crees it is 11 is-a-ket-chak. The Siotx demigod was Ic-tin-i-ke. The Blackfeet hero was Na-piw: and that of the Irofluois rejoiced in the alarming name of Te-hor-on-hi-awak-hon.

The Algonguin mythology manifests a frm belief in a cosmic mystery or a manitum present thronghout all nature. ${ }^{1}$ Nana-bo-zho is the creator of the world and of everything it contains, and the anthor of the institutions and religions ceremonies of Agonfuin society. He is also the central figure in a great deluge legend, common in one form or other in very many races. Numerous other manitous of varying degrees of importance also re ceived the homage of the Indians.

In the valley of the Qu'Apelle River, Mr. Ilind mentions that he frequently saw offerings to manitons or fairies suspended to branches of trees. They consisted of bits of cloth, strings of beads, shrets of painted buffalo hide, bear's teeth and claws, and the like. This custon was general in the Valley of Lake Winnipeg, and along parts of the Red River. Such offerings were never molested by other Indians or hali-breeds.

The Indian Priests are generally known by the misleading title of Medicine-Men. Mystery Men would be a better name; and in reading books about the Indians one will gain a more intelligent grasp of Indian notions if one mentally substitutes the word "magic" for the word "merlicine" wherever it occurs.

There was indeed an important class of persons commonly denoted as medicine-men who were herbalists. These were simply persons really or supposedly versed in the mysterionts properties of varions plants.

Among the Ojibway Indians there were three distinct classes of my-terymen proper, the Mide, the Jessakkid and the Vabeno. The Wahenos, mnlike the other mystery-men, did not constitute an organized sucicty. They relied

1 Enc. Brit. 
1 
chiefly for their prompting upon dreams superinduced by long fasting. Their magic was supposed to promote the success of hunting expeditions, love affairs and the like. The grateful beneficiaries commonly repaid them by feasts given in their honor. These were always celebrated at night and associated with singing and dancing. In the course of the programme the Wabeno would entertain the company by further exhibitions of his magic. By the use of mysterious herbs he was enabled, apparently, to handle with impunity red-lot stones and bathe his hands in boiling water or syrup.

The Jessakkid was much superior in dignity to the Wabeno. IIe was a seer or proplset described by the Indian as a revealer of hidden truths. The mysterious powers of the Jessaklicl were supposed to be received direct from the Thunder God at the time of the Sacred Fasts observed upon entering manhood.

The highest class of the mystery-men was that of the Mide. While the power of the Jessakkid consisted in bringing calamities upon one's enemics, that of the Midé lay in the averting of evil.

"The lodge used by this class of men consists of four poles stuck in the ground, forming a sfuare of three or four feet, and upward in diameter, around which are wrapjed birch bark, robes, or canvals, in such a way as to form an upriglut cylincler. Communion is ledel with the Turtle, who is the most powerful Min'ido of the Jessakide, and through him, with numerous other malevolent llanidos, especially the Animiki, or thunderbird. The fact is that there is not the slightest connection between the practice of the Jessakkid, and that of the Nlickwiwin, and it is seldom, if at all, that a Midé becones a Jessakkid, although the latter sometimes gains admission into the Mide'wiwin, clictly with the intention of strengthening his power with the tribe."'

The chief divinity of the Ojibway is called Kit-chi-man-i-do, or the Great Spirit, and the second in rank is Dzhe-Man'ido, who is the guardian of the Midé Society, and the author of their sacred rites. The name Kit-chi-man$\mathrm{i}$-do is always spoken with reverence. Indeed, its use is avoided except in connection with the rites of the Mide wiwin or a sacred feast or the offering up of tobacco.

An event of extreme importance in the life of an Ojibway youtl was his first religious fast, mudertaken at pulberty. Long abstinence from food produced at last the desired vision of some object-perhaps an animal, perhaps some exceedingly commonplace object-which was accepted as cmbodying or representing the guardian spirit of the individual, and was never mentioned by him without a preliminary sacrifice. A small effigy oi this manitou was thenceforward carried suspended by a string about the

2 Powell. 
Indian's neck or in his "medicine lag." Almost every male lndian had such a bag. It was usualy made of leather, and was about two feet long and one fout load. It contaned the inage representing the lird, lewst of other being which was considere: the peculiar residence of the individual's tutelary spirit. With it were kepe a variety of other trinket, fooked upon by the Indians as satered.

When a youth applicel for athission inte the secret society of the Mlide priests, if his admission was approved, he was assigned at spectal instruetor. and sometimes spent several years in preparation for the first of the four separate and distinct degrees of the dlide wiwin.

"It has always been the custom of the Nide priests fo preserve birchbark records bearing delicate incised lines to reperesent pictorially the gromel plan of the numier of degrees to which the owner is entited. Such records or charts are sacred and are never exposed to pullic view."

These sacred clats are now exceedingly rare and valuabie. Powell gives a very minute description of une representing a "pictorial resume of the traditional history of the origin of the Mide wiwin. This curious lirehbark document was more than seven feet hong and eighteen inches in width."

When a candidate is being initiated, he aakes font ceremonial vajen baths in the sutatory or sweating homse. During the last of these the camp would resomel with the beating of drums and the cries of many dancers, white the offeiating priest was propitiating and involing the presence of Kit-chiman-i-do. Late in the niglit the canclidate wonld retire to his own wignan. and the next day his initiation would occur anid inpressive ecremonies.

The Mlicle priests were experts in many mitifying feats. (Ine of the most astonishing of then consisted in making a medicinc l:ang move on the ground as if it were alive-probably lye temporary retention within the bag of some smal! animal. Wany of the performances of these sorcerers were so inexplicable to the minitiated that the belici lats been contidently helf eren hy many white men that the ludian priest were really in league with evil spirits. The lishop of Montreal in $3 \delta_{4}$, writing 1 pon these topics, ${ }^{4}$ reframs from denying the posilbility of demoniacal as-istance, lun relates an incident which throws a sidelight upon the real nature of the apparent miracles performed:

"That in many instances the performances of the soreerers are mere juggling cheats, is matter leyond dinpute, and a remarkable example of this nature was related to me ly a gentleman to whom I have atrearly owned myself inclebted for much information. lle was present when one of these fellows pretended to conjure lack and produce to view lullets which he had

" Powell.

4 Journal of the lishup of Montreal, during a visit to the Church Minsionary Soctetics X. W. Americ:an Mlission. 



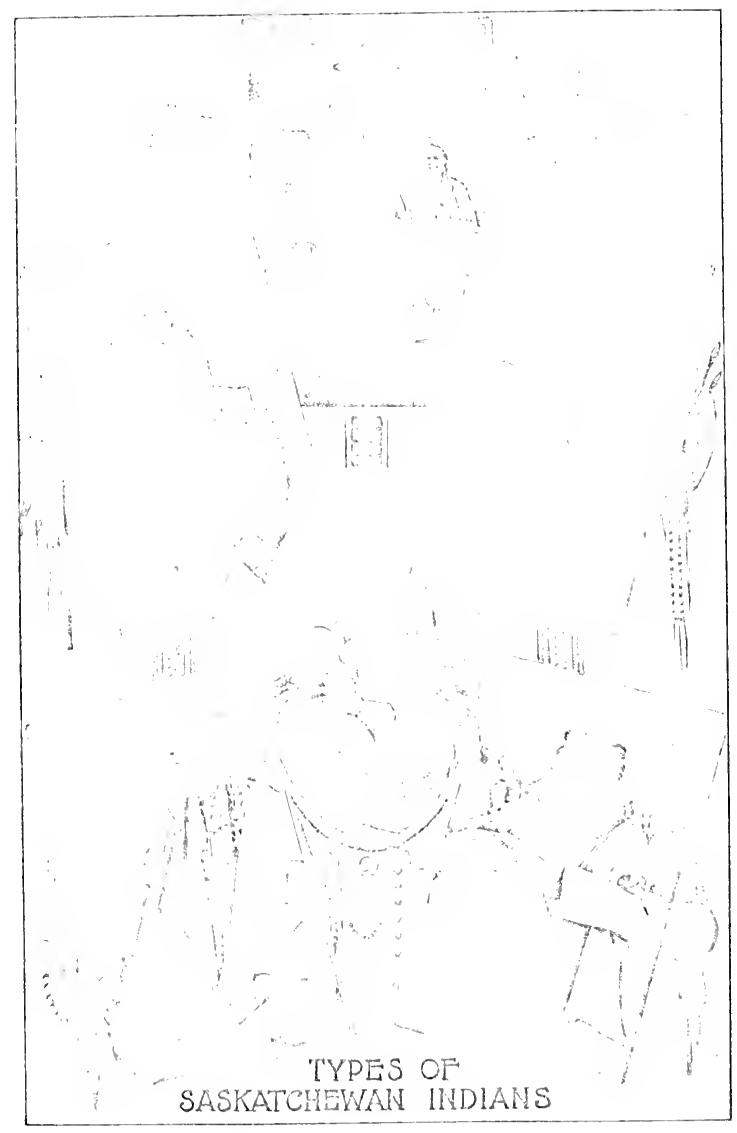



told some of the Indians to throw with all their might into the river. Hc was either naked or stripped for the purpose, and his very hair was searched in order to ascertain that he had no bullets in it. The factor, observed, however, that in executing his varions movencnts and gesticulations to operate the cham, he prased his hands orer his face, and was convinced that by a piece of well concealed dexterity, he took the bullets from his mouth, and the factor privately chesired me of the other Indians when the exhibition was alrout to be repeated, to make a little notch in his loullet by which it might be recognised. The bullet produced by the conjuror was, of course, without the mark and the cheat was detected."

One of the most important functions of the Mide Was that of constlting on behali of his people the Gireat Turtle or Guardian Spirit of the Ojitways. Alexander Henry, writing ahout $\mathrm{J} f \mathrm{f}$, hats given us one of the most circumstantial accomts of such a ceremony. From it the following extrect is taken:

"For invoking and consulting the Great Turtle, the first thing to be done was the butlding of a large honse of wigwam, within which was placed a species of tent, for the use of the priests anel reception of the spirit. The tent was formed of mouse-skin, hung over a frame of wood-work. Five poles or rather pillars, of five different species of timber, about ten feet in height and eight incles in diameter were set in a circle of abont four feet in diancter. The holes made to receive them were ahont two feet deep, and the piliars being set, the holes were filled un again with the earth which had been dug out. At top, the pillars were bound together by a circular hoop or girder. Over the whole of this edifice were sprear the moose-skins covering it at the top and around the sides, and made fast with thongs of the same; except that on one side a part was left unfastened to armit of the entrance of the priest.

"The ceremonics did not commence but with the approach of night. To give light within the house, several fires were kindled aromnd the tent. Nearly the whole of the villigre assembled in the louse, and my-elf anong the rest. It was not long before the priest appeared, almost in a state of nakedness. As he approathed the tent, the skins were lifted up as much as was necessary to allow of his creeping under them on his hands and knces. His head was scarcely inside, when the edifice, massy as it has been described, hegan to shake; and the skins were no sooner let fall, than the sounds of numerous voices were heard beneath them. some yelling. some barking as Jogs, some howling like wolves: and in this horrible concert were mingled sereams and sobs, as of despair, anguish and sharpest pain. Articulate speech was also uttered, as if from human lips: but in a tongue unknown to any of the audience.

"After some time, these confused and frightful noises were succeeded by a perfect silence: and now a voice, not heard beiore, seemed to manifest 


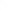


the arrival of a new character in the tent. This was a low and feeble voice, resembling the cry of a young puppy. The sound was no sooner distinguished, than all the Indians clapped their hands for joy, exclaiming that this was the Chief Spirit, the Turtle, the Spirit that never lied. Other voices which they had discrininated from time to time they had previously hissed, as recognising them to belong to evil and lying spirits which deceive mankind.

"New sounds came from the tent. During the space of half an hour, a succession of songs were heard, in which a diversity of voices met the ear. From his first entrance till these songs were finished, we heard nothing in the proper voice of the priest; hut now he adciressed the multitude, cieclaring the presence of the Great Turtle, and the Spirit's readincss to answer such questions as should be proposed.

"The questions were to come from the chief of the village, who was silent, however, till after he had put a large quantity of tobacco into the tent, introducing it at the aperture.

"The questions of public interest being resolved, individuals were now permitted to seize the opportunity of infuiring into the condition of their absent friends, and the fate of such as were sick. I observed that the answers given to these questions allowed of much latitude of interpretation. . . . The Great Turtle continted to be consutcal till near midnight, when the crowd diepersed to their respective lodges. I was on the watch through the scene I have described to detect the particular contrivances by which the fraud was carried on; but such was the skill displayed in the performance, or such my deficiency of penctration, that I made no discoveries, but came away as I went, with no more than those general sumises which will naturally be entertained by the reader."

Schoolcraft declares that the Algonquins believed that every person had two souls, one of which had the power of leaving the body in dreams, while the other remained in it until after the burial. Provision was made for the egress of this second soul, the lid or cover of the receptacle of the body being merely tied down, and never nailed, and the rope or string being left loose. Over the grave was placed a cover of cedar bark to shelter it from the rain, and in this an aperture was also left to allow the soul to escape.

Dreams were esteemed as highly important by all Indians, and were encouraged by long fasting. A young Indian's initial fast, marking the end of childhood and the attainment of maturity, was viewed with special solemnity. Schoolcraft says, indeed, that it was as important anong Indians as is baptism among Christians. It was looked upon as a free-will rite, in which the individual dedicated himseli to the religious duties of manhood.

It is impossible to separate the rites and ceremonies supposedly comnected with the healing of disease by magic means from the other religions and 

semi-religions usages observed among the Indian peoples. The customary incantations and the barbarous treatment to which the sufferers were sulhjected must very seriously lave augmented the death role. - Mexander Ilenry may again be quoted for an interesting description of the means used in the hope of recovering the sick:

"I was once present at a performance of this kind, in which the pationt was a female clild of about twelve years of age. Several of the elcler chic is were invited to the scene, and the same compliment was paid myself on account of the medical skill for which they were pleased to give me credit.

"The physician (so to call him), seated himseli on the ground and placed before him on a blanket was a basin of water. in which were three bones, the larger ones, as it appeared to me of a swan's wing. In his hand he had his shishiquoi, or rattle, with which he beat time to his medicine song. The sick child lay on a blanket near to the physician. She appeared to have much fever and a severe oppression of the lungs, breathing with difficulty ancl betraying the last stages of consumption.

"After singing for some time, the plyysician took one of the bones out of the basin: the bone was hollow, and one end being applied to the breast of the patient, he put the other into his mouth in order to remove the disorder by suction. Having persevered in this as long as he thonght proper, he suddenly seemed to force the bone into his month and swallow it. He now acted the part of one suffering severe pain, but, presently finding relicf, he made a long speech, and after this returned to singing to the accompaniment of his rattle. With the latter during his song he struck his head, breast, sides and back; at the same time straining as if to vomit forth the bone.

"Relinquishing this attempt, he put himself to suction a second tine, and with the second of the three bones. This also he secmed to swallow.

" $\mathrm{U}$ pon its disalppearance he began to distort himself in the most fright ful manner, using every gesture which could convey the idea of pain; at length he succeded, or pretended to succeed, in throwing up one of the bones. This was handed about to the spectators, and strictly examined; but nothing remarkable could be discovered. Upon this he went back to his song and rattle. and after some time threw up the second of the two bones. In the gronve of this, the plysician upon examination, found and displayed to all present a small white substance, the piece of a quill of a feather. It was passed round the company from one to the other, and declared by the physician to be the thing cansing the disorder of the patient.

"The multitude believe that these physicians, whom the French call jongleurs, or jugglers, can inflict as well as remove disorders. They believe that by drawing the figure of any persen in the sand or ashes or clay, or by considering any object as the figure of a person, and then pricking it with a stick or other substance, or foing in any other manner that which done to a 

living body would canse pain or injury, the indivichal represented, or supposed to be represented, will stiffer accordingly. On the other hand the mischicf being fone, another physician of equal pretentions, can hy suction remove it. Unfortunately, however, the operations which I lave described were not sucessful in the instance referred to; for on the day atter which they bad taken place, the girl died."

Space will not permit us to reproduce Indian tales in any number. Very many of them. indeed, are of little interest except to the serious student engaged in tracing the development of a barbarous race. The tates are commonly so grotesque as to make little appeal to the white rearler. On the other hand many of them are singularly heatuiful, and of such a couple of examples may be quoted. The following story was taken down by Schoolcraft.

\section{THE WIITE STONE C.INOE.}

"There was once a very beautiftul young girl who died on the day she was to have been married to a handsome young warrior. He was also lirave, but his heart was not proof against this loss. From the hour when she was buried there was no more joy or peace for him. He went often to visit the spot where the women had buried her, and sat musing there, when it was thought by some of his friends he would do better to try and anuse himself in the chase, or by diverling his thoughts on the war-path. Fut war and hunting had both lost their clarm for him. Ifis heart was alrealy ilead within him. He pushed aside both his war club and his bow and arrows.

"Ile had heard the old people say that there was a path that led to the land of the souls, and he letermined to follow it. He accordingly set out one morning, after having completed his preparations for the joumey. At first he did not know which way to go. Ile was only guided by the tridition that he must go sonth. For a while he conld see no change in the face of the comntry. Forests and hills and valleys and streams lad the same looks which they wore in his native place. There was snow on the ground when he set ont, and it was sonetimes seen to be piled and matted on the trees and bushes. At length it legan to diminish and finally disappeared. The forest assumed a more cheerful appearance. The leaves put forth their buds. and before he was aware of the completeness of the change, he found himself surrounded by spring. He had left hehind hin the land of snow and ice. The air became mild; the dark clouds of winter had rolled away from the sky; a pure field of blue was above him, and as he went he saw the flowers beside his path and heard the song of the bircls. By these signs he knew he was going the right way, for they agreed with the traditions of his tribe. At length he espied a path. It led him througl a grove and up a long and elevated ridge. on the top of which he came to a lodge. At the door stoorl an 
old man with white hair, whose eyes, though decply sunk, had a ficry brilliancy. He had a long robe of skins thrown loosely round his shoulders, and a staff in his hand.

"The young Chippewayan began to tell his story, but the chicf arrested him before he had proceerled ten words. 'I have expected you,' he replied, 'and have just risen to hid you welcome to my abode. She whom you seek passed here but a few days since, and being fatigued with her journey, rested herself here. Enter my lodge and be seated, and 1 will then satisfy your inquiries, and give you dircetions for your journey from this point.' Having done this, they both issued forth from the lodge door. 'You see yonder gulf,' said he, 'and the wide strctching blue plains beyond? It is the land of souls. You stand upon its border, and my lodge is the gate of its entrance. But you cannot take your body along. Leave it here with your bow and arrows, your bundle and your dog. Iou will find them safe on your return.' So saying, he re-entered the lodge, and the freed traveller bonnded forward as if his feet had suddenly become endowed with the power of wings. But all things retained their natural color and shapes. The woods and leaves, the streams and lakes were only more conely than he had ever witnessed. Animals bounded across his path with a freedom and confidence which seemed to tell him that there was no blood shed here. Birds of beautiful plumage inhabited the groves and sported on the waters. There was but one thing in which he saw a very musual effect. He noticed that his passage was not stopped hy trees or other objects. He appeared to walk directly through them. They were, in fact, but the souls and shadows of material things. Ile became sensible that he was in a land of shadows. When he had travelled half a day's journey through a country which was continually. beconing now more attractive, he came to the banks of a broad lake, in the centre of which was a large and beautiful island. Ife found a canoe of shining white stone tied to the shore. He was now sure he had cone the right path, for the aged man had told him of this. There were also shining partdles. He immediately entered the canoe and took the paddles in his hand, when to his joy and surprise, turning round, he beheld the olject of his search, in another canoe exactly its comterpart in everything. She had exactly imitated his motions, and they were side ly side. They at once pushed out from shore and began to cross the lake. Its waves seemed to be rising and at a distance looked ready to swallow them up, but just as they entered the whitened edge of them, they semed to melt away as if they were but the images of wares. But no sooner was one wrcath of foam passed, than another still morc threatening rose up. Thus they were in perpetual fear, and what added to it was the clearncss of the water through which they could see heaps of heings who had perished before, and whose bones lay strewn at the bottom of the lake. The Master of Life. however, had decreed to let then pass, for 

the actions of neither of them had been harl. Put they saw many others struggling and sinking in the waves. Old men and young men, males and females were there; some passed and some sank. It was only the little children whose canoes secmed to meet no waves. At length every difficulty was gone as if in a moment, and they loth leaped out on The IIappy lstand. They felt that the very air was food. It strengthened and nourished them. They wandered together orer the blissful ficlds where everything was formed to please the eye and the ear. There wcre no tempests-there was no ice or chilly winds-no one shivered for the want of warm clothes: no one suffered from hunger; no one mourned for the dead. They saw no graves; they licard of no wars. There was no hunting of animals, for the air itself was their fool. Gladly would the young warrior have remained there for ever, but he had to go back for his body. Ife did not see the Master of Life, but he heard his voice in a soft breeze; 'Go back,' said the voice, "to the land from which you came. Your time has not yet come. The duties for which I made you and which you are to perform, are not yet finished. Return to your people and perform the duties of a good man. You will be the ruler of your tribe for many days. The rules yon must observe will he told you by my messenger who keeps the gate. When he surrenders back your body, he will tell you what to do. Listen to him, and you shall afterwards return to the Spirit which you must now leave lechincl. She is accepted, and will be for ever here, as young and as happy as she was when I first called her from the land of the snows.' When this voice ceased, the narrator awoke. It was the fancy of a dream, and he was still in the bitter land of snow, and hunger and tears." . . .

Many of the myths conflict with each other to a greater or less extent. and stories prevalent among some tribes are treated as unworthy of credence by others. Schoolcraft reproduces a legend of the origin of Machimanito, or the Great Evil Spirit. In the days of creation the Mlaster of Life made creature after creature and sometimes experimentally, as partially completed products, withont definitely endowing them with life. On a certain occasion he made a creature on the model of many beasts of the ficld, but with hands like a god-like himself and with uplifted head. In this creature he had left some germs of life which he had forgotten to take away when he disearded his creation, casting it into an old care amongst the remains of other works that had been thrown thither without life. Long afterwards, however, the germ of vitality worked in the image, and it came forth from the cave with a great noise and terrible to behold. Thus originated the Spirit of Evil.

As Schoolcraft remarks. "The coolness with which the fact is assumed that the origin of evii was incidental in the process of developing a perfect humanity would, at an earlier date, have heen quite appalling to the schoolmen." 

Though but few Iroguois made their way to the Western plains, the following tale reported by 11 illiam Ilenry in I tof interest that it is well worlh reproducing as an example of one of the best Indian stories extant. This William Ilenry was the mele of Alexanfler llenry. Having iecn taken urisoner by lroquois, he owed his life to his adoption into his captors tribe. He was possessed of a faculty for languages and took patius to acquire that of his captors, so that he isecame much respected by old Cambassateg, a warior, comeillor and chicf man of the village. Je took much pains to instruct the white man in the principles of Indian eloquence. "This," says Henry, "is an art (it may scem strange to say it, but it is strictly true) carried much higher among these sarages than it is now in any part of Europe, as it is their only polite art, and they practise it from their infancy, as everything of consepuence is transacted in councils, and all the fore of their gorernument consists in persuasion."

On one occasion the Indian had heen making infuiries of Henry regarding the history, customs and religions opinions of the white people.

"When he had sat silent a few minutes ine said, "White man, listen to me: hear me, Coseagon. Sou say that there is but one great gond Mannitta. lou know of no more. If there were but one, how mhappy must he be without friends, withont compations, without that efuality in conversation ly which pleasure is mutually giren and received. I tell you that there are more than a hundred of them. Shey live in the sun and in the monn; they love one another as bretinen: they visit and converse with eath other, and they sometimes visit, though they do not often converse with us. Every combly has its great good Maninita who hirst peoples that conntry. 1 am now going to tell you how my comntry wat first made and peopled."

"Then raising his voice and entering into the conncil style and nanter of speaking witl that modulation which l nught call the quoting tone, being what they use in repeating mestages, treaties or anything that has been said by othcrs in former tines, other places or preceding conncils; a tone so particular. that if you come into council in the micklle of a speech, you can tell whether the person is delivering his own sentiments or reciting those of another, this tonc having the same effect in their speeches. and answering the same end with our marginal inverted commas in writing, to distinguish borrowed passages quoted as authorities; only that the Indians have three differences itl the quoting tones, none of which we have in writing. viz. : the approving accent, the disapproving accent and the uncertain or doulting, and that there is something measured or musical in all these tones. I say, Camnatego. in the quoting or instorical tone, with the approving accent, and with an air

"Account of the Captivity of Willian Menry in 1755. and of Jlis Renidence

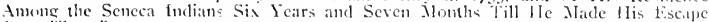
from "Then." 

of great anthority and dignity, went on with his account of the manner in which his country was made and peopled.

"When our great, gond Nannitta raised Akanishionegy." out of the great waters he said to his brethren, "I low fine a comntry is this! I will make the Red Men the best of men to enjoy it." Then with five handfuls of red seed like the eggs of thies did he strew the fertile fields of ( mondagra. Little worms came out of the seeds and penctrated the earth, where the spirits who had never yet seen the light entered into and united with them. Nannitla watered the earth with his rain; the sun warmed it; the woms with the spirits in them grew, putting forth arms and legs and moved the light earth that covered then. After nine moons they came forth perfect hoys and giris. Namitta covered them with his mante of warm purple cloud and nourished them with milk from his finger ends. Nine summers did he nurse them, and nine summers more did he instruct them how to live. In the meantime he had made for their use trees, plants and anmals of varions kinds. Akanishionegy was then covered with woods and filled with creatures. Then he assombled his children tegether and said," Ye are five nations for ye sprang each from a different handful of the seed 1 sowed; but ye are all brethren and I am your father, for I made you all: I have nursed and brought you up: Mlohods, I have mate you bold and valiant, and see I give you corn for your food. () neidas, I have made you patient of pain and of hunger, the nuts and the fruits of the trees are yours. Semueliers. I have made you industrious and active; beans do I give you for nourishment. Cayugas, I have made you strong, friendly and gencrous: ground uuts and every root shall refresh you. Onondogas, I have made you wise, just and eioquent; squashes and grapes have I given you to eat and tolaceo to smoke in the council. The heasts, bircls and fishes have I given to you all in common. Is I have loved and taken care of you all, so do you love and take care of one another. Communicate freely to each other the goon things that I have given you, and learn to imitate each other's virtues. I have made you the best people in the world, and I have given you the best country. You will defend it from the invasions of the other nations. from the children of other Mannitas and keep possession of it for yutrselves while the sum and monn give light and the waters rum in the rivers. This you shall do if you observe my words. Spirits, 1 an now about to leave you. The bodies that I have given you will in time grow old and wear out, so that you will be weary of then, or from various accilents they wiil become unfit for your habutation, and you will leave them. I cannot remain here always to give you new ones.

". I have great affairs to mind in distant places, and I cannot attend so long to the nursing of children. J have enabled you there fore among your-

The Land of the Irogunis 

selves to produce new bodies; to supply the place of the old ones, that every one of you when he parts with lis old habitation may in due time find a new one, and never wander longer than he chooses under the earth, deprived of the light of the sum.

"Nourish and instruct your children as I have nourished and instructed you. Be just to all men and lind to strangers that come among you. So shall you be happy and belored by all, and I myself will sometimes visit and assist you." Saying this he wrapped himselt in a bright cloud and went like a swift arrow to the sun, where his brethren rejoiced at his return. From thence the often looked with pleasure to his brothers, the country he had formed and the nation he had produced to inhabit it.

"'Here the five nations lived long and happily, conmunicating frecly' to cach other as their wants required, all the good things that had been given them, and generations had succeeded generations when the great evil Mannitta came among them and put evil thoughts in their hearts. Then the Nohocks said, "We abound in corn which our brothers have not; let us oblige them to give us a great deal of fruits, beans, roots, squashes and tobacco for a very little corn, so shall we live in idleness and plenty while they labour and live hardly." And in the same mamer spoke the other nations. IIcnce arose discord and animosity and hatred, insomuch that they were on the point of lifting the hatchet against each other, and miring the ground with brothers' blood. Their father saw this from the sum, and was angry with his children. A thick blue and red cloud covered all the land, and he spoke to them in thunder. "Wretches!" said he, "Did I not freely give to each of you different kinds of good things, and those in plenty, that each might have something in his power to contribute to his brothers' happiness, and so increase the happiness and strengthen the union of the whole, and to you now abuse those gifts to oppress each other; and would onc brother, to make himself, in imagination, more happy, make four brethren, in reality, more miserable? Ye have become unworthy of the goodness I have shown you, and shall no longer enjoy my favors."-Then the sun of Akanishiongy gave forth darkness instead of light, the rivers ran backwards to the mountains, and, with all their fish, reentered the fountains from which they sprang, forsaking their ancient beds, and leaving dry the banks they used to water.

"'The clouds withheld their rain, and carried it away to other regions. The surface of the earth became dust: whirlwinds filled the air with it, and every breathing creature was ahmost stifled with it; everything green withered; the birds flew away; the beasts ran out of the country, and last of all, the afflicted people, famished nearly to death, their dry eyes not having even a tear left, departed sorrowing, begging every where for food from those who despised them for their late wickedness to one another.

" 'Nine summers passed away, and their distresses continued. Then the 

evil spirit left then, for they no longer livtened to his councels; they legan mutually to fecl and pity one another's mi-fortunes; they began to love and to help each other. The nation anong whom they were scattered now began to esteem them, and ofiered to adopt and incorporate them annong themselves. But they sairl, "No, we are still a people; we cluose to continte a people; perhaps our great Mannitta will restore ns to our country, and we will then remember this your offered lindness." The Great Mannitta, seeing their hearts changed, looked on then with compassion. He spoke, and the sun again gave light; the rivers came again forth from the fountains and ran rejoicing throngh the delighted valleys; the trees and plants renewed their verdure, the birds and beasts returned to the forests, and the five nations, with glad and thankful hearts, went back to repossess their ancient seats. From that time down to the present day it has been an inviolable rnle and custom among the nations, that every brother is welcome to what a brother can spare of the good things which the spirit has caused to spring for him out of the earth.'" 
THE FIRST SETTLEMENT COLONY IN THE CANADIAN WEST

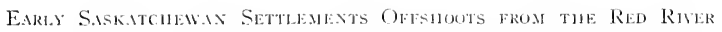

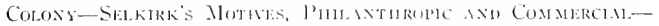

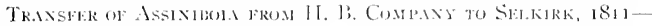

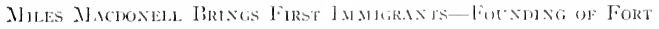

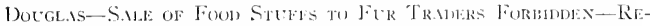

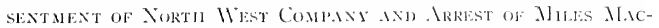

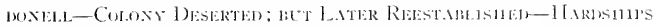

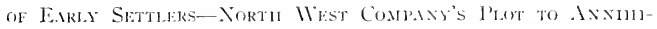

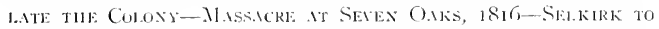

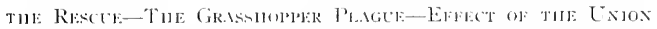

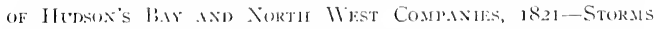

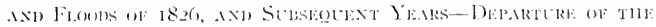

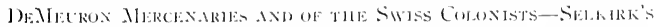

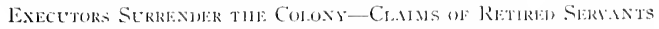

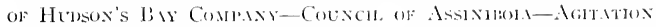

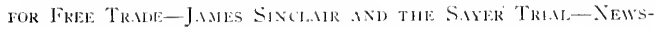

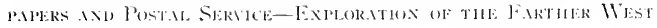

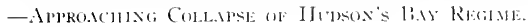

The first settlements in the present l'rovince of Saskatchewan were primarily off shoots from the Red River Colony, established log Thomas. fifth Earl of Selkirk, in the year 1812 . Nready this remarkable phitanthropist and adventurer lad heen engaged in colony building, having established settements in Prince Edward Jsland and in West Central Ontario. Strange to relate, it was through Sir Alexankler Mackenzie's reports of the far West that Selkirk was led to loring thither the first serions tillers of the soil to appear on the British prairies-an enterprie resisted by Sir Alexander Machenzic and his Montreal colleagues with unrelenting severity.

The motives of Lord Selkirk have frequently been severely questioned. Since he was only human, they were probably mixet. but the researches of each succeding decade tend to corroborate the views now held by most historians that the vicionary Earl was genuinely concerned for the betterment of the peasantry of the british Isles, and was chiefly intent upon denonstrating that on the untilled fields of british America numberless multitude 

miglu find refuge from the hopeless prospect confronting them in the old lands.

At the same time there is no dombt that the Earl's colonizing scleme was intended to hring advantages to the Iludion's bity Company in its struggle with Canadian rivals. The bitter competition of recent years had seriously shaken the ancient Company. Its shares, which at one time had been rated at double their par value had fallen in 180 g to fifty for contum.

In order to gain control of the Company pulicy. Selkirk purchased forty fer ecutum of the Companys shares. and a cunsilerable portion of

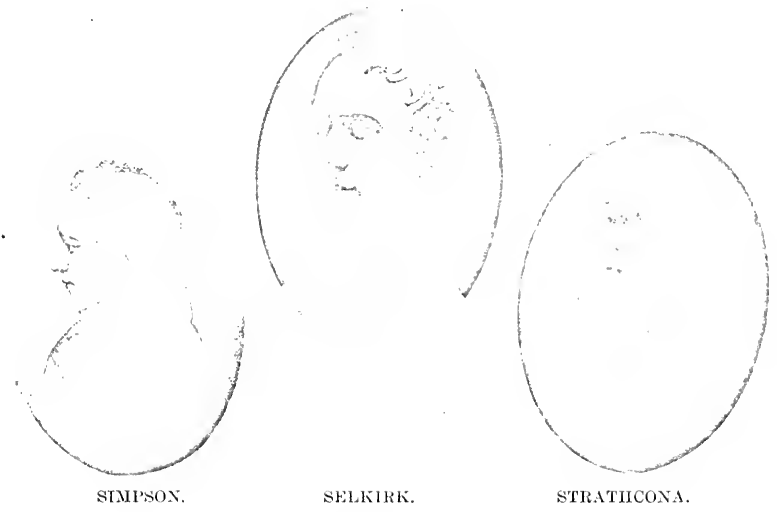

the remainder he controlled througl friend. On Jay I1, 181 I, he secured from the Company the transfer to him of $16,49,3$ square miles. including the southern portion of the present I'rovince of Manitoba and a large part of south eastern Saskatchewan. ${ }^{2}$ His enemies maintain that the Earl's real motive was his desire to plant in the comntry a large group of dependents

${ }^{1}$. Iccording to Rev. James Taylor, in an article publishert ly the Veterans of the Fur Trade Asseciation. in toos. thic western homblary of this valt tract, as defined on the map accompanying this deed, ran through fort Carlon. Yr. Taylor now agrees with the present writer that the decel would place the western hothdary in Saskitchewan, indecd, hut much itrther east. The territory thus acequiresl hy Selkirk

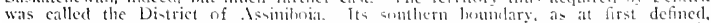
proved to be in Anerican territory. Lltimately, for mmicipal purposes. Assiniboia became, in $1 \$_{35}$, a circular district of tifty miles radius, having Fort Garry as center. 
who would be virtually game-kicepers to the IIudson's Bay Company, employed to cut off the communications of the Montreal merchants trading in the interior. It is undeniable that the scheme was grossly mismanaged if indeed the Earl's purpose was to establish a prosperous agricultural colony. On the other hand, if the undertaking had for its object active resistance to the North West Company, a fatal blunder was committed in so locating the settlement that no line of communication could in actual practice be kept open between it and the Company's base on the shores of Hudson's Bay.

Our chief present interest is with events rather than motives. Selkirk scattered broarleast a glowing prospectus for the encomagement of prospective emigrants, and a considerable number assemlled at Stornoway, where they were taken in charge by Captain Miles Macdonell, acting under Selkirk's instructions. Long delays occurred through the open opposition or secret intrigues of representatives of the Mlontreal traders, but on Jinly 26, I8I1. the first party at length set sail, arriving at York Factory two months later. Captain Macdonell had with him ninety laborers and fifteen other emigrants. including the Reverend Mr. Pourke, who, however, never went into the interior. In November, Nacdonell moved his protógis fifty miles up the Nelson River to winter. Severe hardships were experienced and Macdonell's difficulties were complicated ly considerable insulvorlination among his followers. Ilowever, gloomy as was the truth regarding this memoralle winter, there is good reason to believe that the facts were not as bad as they have commonly been represented. Nuch of the information bearing on the matter has come to the modern historian througl the distorting medium of accounts written by the North West Company's employees and partisans.

In July, Macdonell and his party set out for the Red River, which they reached in August. It was an ill omen that they were there met by employees of the North West Company disguised as Indians, who warned them not to attempt a permanent settlement. However, by 1813 a consilerable number of buildings had been erected, including a post named Fort Douglas. This same year bronght a party of irish immigrants and numerous evicted tenants of the Duchess of Sutherland.

Early in January, ist4, Miles Macdonell, the Governor of the Colony, issued a proclamation that was fraught with serious conseguences:

"Whereas the Rigltt Honourable Thomis, Earl of Selkirk, is anxious to provide for the families at present forming settlements on his lands at Red River, with those on the way to it, passing the winter at York and Churchill Forts, in Hudson Pay. as also those who are expected to arrive next antumn, this render's it a necessary and indispensable part of my duty to provide for their smpport. In the yet uncultivated state of the country, the ordinary resources derived from the buffalo and other wild 

animals hunter within the territory, are not deemed more than adefuate for the requisite supply. Wherefore it is hereby ordered that no person trading furs or provisions within the territory for the Honomable Hudson's Bay Company, or the North Vest Company, or any individual, or unconnected traders or persons whatever, shall take any provisions, either of thesh, fish, grain or vegetables, procured or raised within the said territory, ly water or land carriage, for one twelve-month from the date hereof; save and except what may be judged necessary for the trading parties at this present time within the territory. to carry them to their respective destinations; and who may, on due application to me, ohtain a license for the sanc.

"The provisions procurer and raised as above shall he taken for the use of the colony; and that no loss may atcerue to the partics concerned, they will be paid for by liritish bills at the customary rates. And be it hereby further known, that whosoever slall he detected in attempting to conver ont, or shall aid and assist in carrying ont, any provisions prohibited as above, either ly water or land, shall be taken into custody, and prosceuted, as the laws in stch cases direct, and the provisions so taken, as well as any goods and chattels, of whatsoever nature, which may be taken along with them, and also the craft, carriages, and cattle, instrumental in conveying away the same to any part but to the settlement on Red River, shall be forfeited."

While it may be that the precarious condition of the colony at this time rendered some such nuature necessary, and while, in the proclanation. Macdonell makes no distinction between the traders of the IIudson's hay Company and those operating from Montreal, it is, of course, evident that the regulations would press most severely ujon the North Viest Company; and that great organization defiantly resolved to wp-root the colony. A party was sent by it to effect Macdoncll's arrest. A mêlé occurred in which one man was killed and, to prevent further bloodshed, the Governor surrendered and was taken to Montreal. There he was kept for a couple of years, though he was never brought to trial.

When Captain Miles . Macdonell left, the infant colony passed uncler the charge of James Sutherland, who was forced to sign an agreement with the halfbreeds controlled by the North IVest Company in accordance with which the settlement was to be vacated.

About this same time another party, ignorant of the disasters that had befallen their predecessors, left Scotland to join Selkirk's pioneers. They embarked in June and reached the banks of the Red River in November. finding the colony descrted. Their own supplies were practically exhausted and, there being no others to be had, the unfortunate inmigrants were compelled to undertake an additional march of seventy miles through the snow to Pembina, whither most of their predecessors had retreated. Even there famine still faced them, and most of their numbers were obliged to join the Indians and Metis buffalo hunters on the prairie, and to remain with them 
through the winter. In the folloning year, however, the settlers returned to the Red kiver and mate a good start. Colin Robertson assumed charge of Fort Donglas and, on Narch 17, he seized and destroyed Fort Gibraltar. belonging to the North West Company, and captured Duncan Cameron, who had effected the arrest of Miles Macdonell. Selkirk secured the assistance of a considerable number of French (amalians and his agents were sufficiently strengthened to carry out the wholesale conliscation of property beionging to the Porth Ilest Company, which was equally violent and unscrupulous in its own policy.

A definite plet was now hatched by the Canadian traters to raise such a force of halfbrects and Indians in the interior as would annihilate the Red liver Colony. This scheme was entrusted largely to the representative of the North We Company at Fort (Qu'. Iprelle, Nexander Macdonetl.

In a letter dated March 13, 1836, which (olin Rolertson intercepted, Alexander Macdonell wrote that "a storm was brewing in the North" and "ready to burst on the heads of the niverable people." What the Nortl IVest Company had done last year woukl be in comparien, he said, "mere child's play." He also spoke of "glorious news from - Athalbasca," to-wit: the death by startation of eighteen employees of the lhulson's lay. Company. Robertson realized the dangers of the situation, but he was unalhe to convince the newly appointed Governor-in-Chief of the Indson's liay Company, Rolert Semple. Accordingly, Rohertson washed his hands of the whole matter, and retired to Jork lactory, leaving Scmple in charge at fort Douglas.

On June 19. 1816, Governor Semple saw upon the prairic a party of seventy horsmen. The partisans of the North llest Company hate persistently cndeavored to prose that the intentions of this cavalcade were entirely peaceable and that they were simply mang a detont around Fort Donglas to join a party of their friends whe were arriving from the Eatst. There is probably some truth in this, but an examination of the available evidence makes it very evident that they intenderl when the junction was effectcel, assaulting Fort Douglas in force. Governor Semple, with foolhardy rashness, went ont with twenty men to meet them. In altercation ensued, whereupon he and his adherents were massacred, only one escaping. This occurred at a spot known as Seven Oaks. The North Westers then advanced upon the colony and under the threats of assassination compelled the hapless inmigrants again to desert the settiement. Nany were taken East, to Canada. Others retired to Jack River at the north end of Lake W'imipeg.

The story of Selkirk's operations in the following year we cannot here review in detail. Ite organized a military force, consisting chicfly of French soldiers-of-fortune, captured Fort William, the heidquarters of the Canatian traders, and recovered Fort Douglas. Imperial Commissioners now inter- 
fered in the interests of peace, and the seche of wartare was transferred to the batw courts, where the representatives of the two empanies became engaged in an intrieate series of interminable law suits.

A considerable number of the settless had returned to the Red River, but in the winter of 1817 inpending famine fored them to retire once more to P'ombina. They must hate berm mate of heroic stutf, for in 1818 , they returned to enltivate their deserted farms. New disaters anaited them. On July 18, 1818, a stupendouts chend of grasshoppers settled tum the colomy. The invaluable gardens wore tobaliy destruyed and once again the sculers found a winter reinge in l'embina. The struggle with the grasshoppers lasted three years."

Meantine, in 1Szo. loted Selkirk and Sir . Nexander Mackenzie both died, and in the following year the lluklson's bay Company and the Forth llest Company were fused. This last event, while immensely benefieial in many respects, was not withom its disatrantage to the colony. The mom naturally rendered more comomical the alminictration uf the fur trate: this meant that a considerable number of halflureeds formerly employed ly one or the other of the companies were left withont any atlecpuate means of suplort. For a long time muln members of this class lived in great porefty.

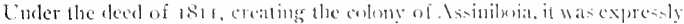
slated that one-tenth of the vast atea included in the sedkirk grant. Was to be reserved for redired servants of the llutson's lial ("ompans, and "for no olher use, intent or purpose whatsocver." The size of the estates to be granted these retired servants was dependent npon rank. The matster of a trading post was entitled on 1.000 acres, and even an welinary taborer who ind served the company only three years was entitled on 200 acres. These provisions were not faithiully olserved, howcver. Many retired servants were not given deeds to any land. and many that did receive land grants had to be content with farms much smaller than those to which they felt themselves in law and right entitled.

2 The following pasage is from . Whe 1)ugats' Cunadian $\mathrm{H}^{\circ}$ ist, p. 203:

"At the end of two or three weeks the insects went off to die chenhere, lut hefore

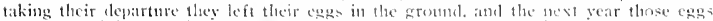
prodnced milloms of fresh arawhopers that ate all the segetation mintil the end of July. When they had then wings these rose in clouds so thick that they completely hid the rays of the sum--so mach w that those who watched their depatture coukl hosk at the orli of day without winking an eyclid.

"That year liere was no harvest of auy kind. In the sprime of 1820 each one hastened to sow whaterer quantity of grain he had in reserve for they alwas were careful to put a little ande eatel year. The scasom wats favorable, ererylhing grew splendidly, hope for the inture eatused the miseries of the pate to he forgoten, when. on the zoth of July another cloud of prasehopuets came duwn. This time the poof settlers became entirely disomraged: ererything was ats ompletely alestroyed as if fire had swept the entire conntry. but still more dieconraging were the qututitic of eggs

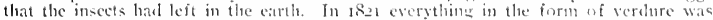
eaten, and the soil of the fields and of the prairice wats let as black as the dust on the highway. The grasohupers penetrated everywhere and ate everything-chothes, leather,

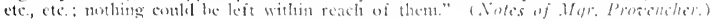


However, npon the whole, the Red River seftlenent prospered until the winter and spring of ${ }_{1} 826$. An unexpected snow fall of umprecedented depth occurred in this year, for which the numerots hunters upon the plains were quite unprepared. In spite of retief parties sent ont from the colony, many. of the hunters perished from cold or exhatistion. Most of their horses were lost and the bufialo lierd was driven heyond reach. The cold of this winter was terrific, and it is said that the icc on the river measured nearly six feet in thickness. At all cvents, whon the enormons mass of snow melted in the spring. the river was still impeded wilh ice, and a disastrons flood occurred. The river rose some fifteen fect above its usual level and practically the whole setllement was under water. After eighteen days the flood bogatn to recede, but it was the mildle of June, almost four weeks later, before the settlers were alle to return to where their homes had stood. Similar floods had been recorded in 1776 . 1790 and 1 Sog. Others oecurred in 1852,3 I 86 I and later, but the disaster of 1826 prolualily caused nore distress than did any of the others, though only one life was lost.

"Notes of the Fllood at the Red Riter, 1853, by the hishon of Rupert's Iand.

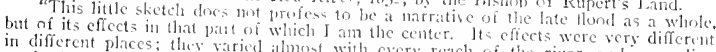

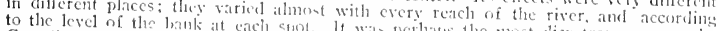

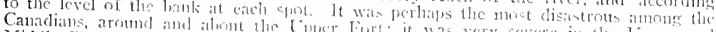

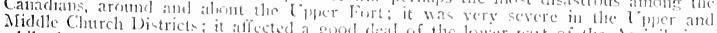

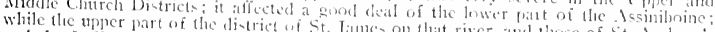

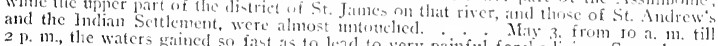

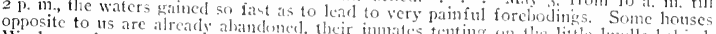

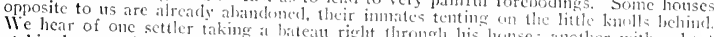

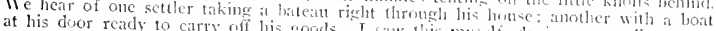
at his door ready to carry off his sonds. I saw dhis my iclf, during my walk, at one house on a low point near use lirim the furt we hear that more thath fifty deserted

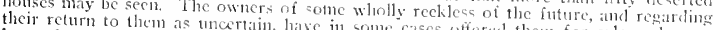

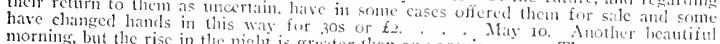
mothing, but the rise in the niglti is greater than any previons one. The water was mow the icc-celler, endenvoring to rescue some thanding in the witer, which hrad got into deferred doing on Saturday night cecded in doing this, thought the cridt was ine energy of those around me we sucimvaluable to us, as it constituted cold was intence. The store of provisions was warm weather. The loss of the ice dlownth in stock and main denendence during the

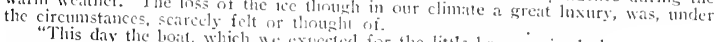

with Xr. Black, the oflicer ill we expected for the little lows, arrived alout it a. m.

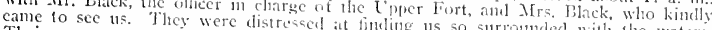

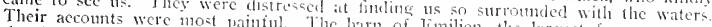
the Canadians had floated away, The harn of Limilien, the largest farmer among

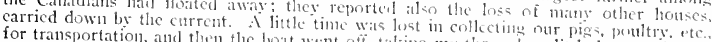
invaluable nutses to their spot of refuec on, the ling my three dear litule boys and their

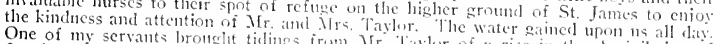
five inches and a halt during the niglat. Ir. Thoorlor of at rise in the Assiniboine of

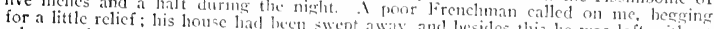
a batcan: he was homelese and stwen swept awaty, and hesides this he was le fit without added, "Cest le bon Dicu qui anilige"-it lessnit of patience to all," 
$$
\text { . }
$$ 


The philusomhic Scotehmen of Red Riser found it possible to discover redeeming features even in this disister. It resulted in the emigration of the disbandeci soldiery that Sclkirk had brought to the colony-a class of men with whom the typical Selkirker could have litte in common. Vore mfortunately the Swins artisin setters, the lirst of whom had arrived in $182 \mathrm{i}$, also departed with them, settling in Minnesota, where St. P'al now stands. A process of natural selection was at work which was to result in the permanent settlement of the shores of the Red River by metn who conld not be dismayed, and therefore cotnll not fail.

As years passed by, Lord Sclkirl's excentors hecame more and more weary of their duties in connection with the guardianship of his colony: Accordingly, in 1834 , it was transferred to the Hutson's bay ('ompany under a secret arrangement. Thongh Selkirk is alleged to have spent alout t200,000 upon the settlenent, his executors were content to acept 1118,85

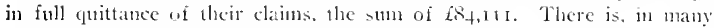
quarters, a strong conviction that the terns of the agrement were contrary to the spirit of Sellirk's will and distinctly to the disadvantage of the immigrants and halibrects.

As so many of these affected in this matter are now prominent citizens in the province of sakitchewatn. it seems necessary to explain their oft-repeated protests against this surtencler and the conseduences it cntailed. By such well informed atutherities as Rer. Jannes Taylor, sonnetime I'rincipal of Emmannel College. Who for a gencration has battled unweariedly for the rights of the retired trakers and servants, it is even questimed whether any bona fide surrender of the Sellkirk estate ever occurred. Howerer, even if the district of Assiniboia as originally confined lat been reconvered to the Ifudson's liay Company, it is argued that such reconveyance manifestly could not effect the previously established rights and interests of retired servants. Selkirk's will could involve only nine-tenths of the district originally surrendered by the Iludsm s lay Company. That meant that a vast area of land remained the property of, or was held in trust for the servants of the company and their descendants. Mr. Taylor declares that Sir George Simpson for the last thirty-seven years of his life was simply the atturney for the executors. In course of time important doctiments were mislatid or conceaied and the legal rights of the retired servants becane more and more obscure. Accorlingly, the feeling spread that the great company was deliberatcly intent wpon robljing its retired scrvants and their descendants of their law ful rights. To this topic it will be necessary to recur in future pages of our history.

The Governors of Issiniboia-appointed by Selkirk, his executors or their attorneys-hat usually associated with them a few persons known as their council, though, as a matter of fact, its powers and functions had been 

almost purely formal. In 1832 the minutes of the comncil indicated considerable legislative activity, but in earlier days any real functions which it exercised had been judicial, and this primary characteristic of the council disappeared but gradually. In 1835 . however, a distinct step in adrance was taken. The Council of Assinihoia, as then constituted under Sir George Simpson, acting executor under Selkirlis will, and Alexander Christic. Governor of Assiniboia, consisted of these two officials and thiteen other promincut citizens.

For the next five years the chict topic of public interest in Rupert's Land was the persistent agitation for the abrogation of the Hulson's liay Compriny's monopolies. The company constituted the sole purchaser in the market of the settlement, it controlled all imports and cxports: it alone conld legally engage directly or indirectly in the fur trade; and no opportunity seemed to be neglected of enforcing the company's charter rights in all their obnoxions details. In ISff Gorernor MeTarisle went so far as to command all persons importing goods from Fingland to leave their business correspondence open for his inspection.

Among the most spirited opponents of the company monopoly was Jancs Sinclair. Ife belonged to a family long and homoralbly astociated with the service of the great company and this sated him from persomel proscention, though the IJuclson's liay Company refused to bring out goods from lingland in his name. Ilowever, in spite of the company's protests he enbarked independently upon the trattic in peltries and, having collected a considerable quantity of furs, offered them for purchase by the company"s agent at Fort Gary. Lneler the circumstances that official thought fit to refuse them. Sinclatir then took his furs east wia the Linited States and presently appeared with them in Iondon. Rather than have a competitor arise in the open market, the company now paid him handsomely for nts peltries, and he returned to the ked River to further prosecute his andacious enterprise. I'resently the company undertook to talie a test case before its courts, and in IS $\&_{4}$ William Satyer, another free trader of less prominent social position, was prosecuted. James Sinclair acted as Sayer's counsel. The trial. however, wis but a farce. Sayer made no attempt to deny lis participation in the fur trate; but as Louis Riel, Sr., with four hundred armed halibreeds, all ardent free traders, was present to see that no ill befell Sayer, he was released. This broke up the monopoly. Henceforth the company made practically no attempt to enforce its right to the exclusive trade in furs. However. Sinclair was manifestly a dangerous man from their standpoint. To get him out of the settlement, the company, with the funancial co-operation of the Rritish Govermment, employed him to conduct overland parties of settlers destined for Oregun. Where the company still drove an extensive trade. 

In 1859 the first newsyper was established in Rupert's Land, the Nor" Wester, by Messrs. Buckingliam and Caldwell, in opposition to the IIudson's bay Company. This was the beginning of the end of the old regime. The great company was essentially fendal in character and when confronted by the persistent impertinences of a popular press it became manifestly an anachronism whose despotic atthority must presently be latughed out of existence. Prior to 1850 there hat heen jostal scrvice but twice a year ata York Factory in the summer, and overland sia Canada in the winter. This was then replaced in 1855 ly a monthly service and by 1862 the settlement was in weckly communication with I'embina.

In the great West beyond Fort Garry the chief trading forts were the nenclei of tiny villages, but otherwise there was no settenent further West than Pontage la I'ratic. However, through the activitics of the fur traders and of other explorers, the conntry was gradually becoming better known. In $18_{45}$ Kane, the Canadian painter, had undertaken his renarkalle journey of four years' duration througin the West. The record he has left of it in his jounal and pictures is of permanent interest and valuc. In $8_{5}$ ) gold was discovered in the bed of the Saskatchewan River, and greatly quickened popular interest in the mnknown land. Little came of this discovery, hut it kept the eyes of enterprising men nyon the West for a number of years.

lietween 1857 and 1860 Gaptain Palliser conducted important exploratory investigations under instructions from the Imperial Government. His operations covered a vast teritory frem Lake Superior to Britisil Columbia. In 1857 he travelled up the Issiniboine to Fort Ellis, thence at the Q $11^{\circ}$. Ippelle, to the "Elbow" of the Saskatchewan, from which point his party procceded to Fort Carlton, where it took 11], its winter quarters. The report of this expedition was presented to the lmperial Parliament in 186,3 . Copics of it are now rare, but they deserve careful examination by those scriously interested in the history of exploration.

Valuable services were also performed by private parties. In 1865 Viscount Milton and Doctor Cheadle ptiblislied the account of a rather remarkable journey begun in 1864 , which carried them across America from Quebec to Victoria. Their purpose was to discover the most direct land route through Lritish territory to the regions of the far West, and to call attention to the remarkable opportunities for colonization presented by North West Canada. The travelles reached Victoria in September, 1863 . In 1862 the country was also visited by the Earl of Dummore and a party of other distinguished Englishmen whose writing aroused much interest. Probably the most inportant publicity: work done in the interest of inmigration and industrial development was that performed by James IV. Taylor, the American agent at Fort Garry.

In $1 S 67$ there ocenred an event memorable in the commercial history of 

the North Went; this wan the attempt sucessfully made hy . Mexander liegg. the historian, and WI. L. Saniord, of IJamilton, sulsecquently Senator. to establish regular trade between Canada and the Red Jiver settlement.

Meantime, the rule of the great company wat tottering to its fall. To the agitation which terminated in the surrender of its territorial rights, and to the prolonged disorders which culninated in the disturhatices of 18 - 0 . separate chapters must he eicroted. 



\section{CHAPTER IX}

THE VORGOTTEN COMMUNWEATH OJ M.NTTOH, AND

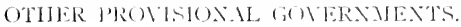

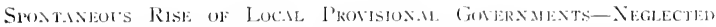

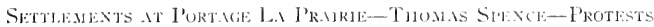

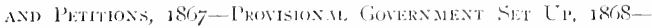

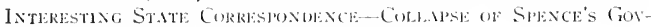

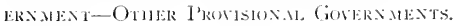

The setters of Western British. America have ever ben characterizen equally by the love of frectom and by distaste for anarely. Consepuently when on accument of the remoteness of a settement or its temperary pulitical conditions, the arm of the central anthority was paralyzed, Jual provisional governments lave been estatblished at varions times.

In 1868 there existed in part of the Xorth West a shortlived provisional government of this kinel, lle very tratition of which has lecen almont forgotten. Its brief history justilies recall.

It will be remembered that the ancient colong of Assinibeia was of very small geographical dinensions when compared with the emmmons provinees into which the Nurth VIest is num suludiviled. Beyond its western limits one of the first settlements of importance was that centering roumd Portage la Praticie, or Caledonia, as it was then ealled. I Here the peeple did not even enjoy the perhays doubt ful alvantages of being moler the ancient Conncil of Assiniboia. They were subject immediately and only to the paternal

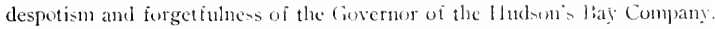

The sturdy pioneers of P'ortage la Tratirie objected equally to buth despotism and forget fulness. Their chief spokesman was Thumas spence. an interesting character whom many old timers in the prenent l'rovince of Manitolat well remember. While le never cane to alfluence nor to importan office under any recognised gorernment. he was a man of consiclerable parts. and was possesied of the esinential phalitications of a successiul agitator. Ile conld recognise the anomaly of the existing state of allairs: he manifestly enjoyed letping his neighlors to see their grievanes : lo loved making speeches and writing letters: he had unlimited self-contidence and an inperturbable sense of his own dignity; and he would not and conkl not be sileneed. He must have been a man worth knowing? 

On the 3Ist of Xay, I86\%, a gromp of the settlers of Portage la Prairie assembled in the little store of Thomas Spence, of Caledonia, to protest against the existing system of govermment, or lack of it, and to make their grievances known afar. Mr. Spence occuried the chair, aml at the close of the proceedings, the records slowed that he received the formal thanks of his fellow citizens for "the dignified manner in which the meeting had been conducted." The settlers crystallized their views in a series of interesting resolutions. (ne of these sets forth that "already efforts harl lieen made by the people to organize and carry on a local government." (of this experiment we know nothing except what is contaned in the last clanse of this resolution, wherein we read the mowninf news that the settlers of l'ortage la Prairie had "failed to continue the same strcessfully, through a want of unity and dignity in the Government."

The discontented pioneers called the attention of the powers that were. to the anomalous conclition of the colony at Portage la Prairic. "Peing beyond the fifty miles limit from Fort Gary and the jurindiction of the Conncil of Assiniboia, this settement, containing a poptation of nearly five hundred, is totally without law or protection, civil or criminal, and entirely at the nerey of lawless bankls of lnclians and others." The meeting placed upon record it desire " to lay hefore lhe Irritish and the liritish North Anerican Confeclerate furemments their regret and elespondence as loval Britisle stbjects leit to continue in their anomalous condition." To this resolution is appended a publicity advertisement in the framing of which we can see the hatnd of Mr. Spence. The setters of Caledonia "inhabit at section of the comutry which for salubrity of climate, richues of snil am luxurionsness of vegetation, and as an agricultural conntry, capable of supporting in comparative aftluence millions of people, cannot be excelled, if equalled, in any part of the world."

"With a view of reflecting the sentiments of this people to the British Govermment." it was resolved that "a memorial be adklessed to Her Nont Gracions Majesty, the Oucen, praying for redress and British law and protection being extented to them as loyal British subjects, and that Messrs. Spence, Mclean and Garvin Garnoch be a Commitlee to draft and forwarl the same to the proper authorities and that a copy of the resolutions be transmitted to the Canadian Govermment with a request that the same may be laid before the Honse at the first meeting of the Confederate Parliament of Britisl North Mest America."

This Committee performed its luties, lut the far-away Eastern statesmen failed to respond with a promptitude at all commensurate with the earnestness of the Caledonian settlers.

Consequently, on January 17, 1868. Mr. Spence and his colleagues notified Mlr. Angus Morrison, M. P.. in a lengthy letter, that the delay in con- 

sidering their requests harl culminated in the cstablishment of a provisional govermment. This letter runs as follows:

Portage la Prairie, via Red River Settlement, Jamuary I7, I868.

"Dear Sir:-The President and Council of Manitoba, Rupert's Land. have the honour to request that you will lay before the Govermment and Parliament of the Duminion of Canada this communication and information, and to request on on behalf from the Govermment at the earliest convenience after consideration, a reply for the ultimate guidance and consideration of this Govermment.

"I. For the information of your Government we would in the first place beg to state that the election of the President and Comcil and organization of this Govermment only took place in the early part of the present month, and that the election was regularly conducted by the vote of the people. ( $\mathrm{In}_{n}$ the adjoining colony of Assiniboia the election of the Council, the supposed representatives of the jeople, takes place in London, England.)

"This settlement had hitherto leen trtally unprovided for with law or protection, either by the Imperial Govermment or the Hudson's Bay Company, without eren a flag of acknowledgement, anomalous to any British settement in the Empire, all of which has been twice fully laid before Ifer Majesty"s Govermuent by petition of the people, praying for redress and protection, and to be almitted into the Confederation of the Dominis of Canarla (or even attaclied protem), of which no further acknowledgement has been received than the mere ofticial replies of receipt, and that the same "lad been laid at the foot of the Throne."

"Meantime, in view of the increase of crime, and the overbearing tone of the Indians towards the settlers, - some of them immigrants of recent date from Canada,--plunder and roblery daily going on, self-preservation demanded the immediate organization of an independent Govermment.

“2. The boundaries of the infant Govermment of Manitoba for jurisdiction are declared to be as follow:

"South, by the boundary line between the United States and British North America. East by the boundary line of the juriseliction of the Govermment of Assiniboia; West, by the River Souris, or Mouse River, running to the North and the Little Saskatchewan ruming to the South into the Assiniboia: and on the north by Lake Manitoba, as far as Manitoba house. which area embraces a large portion of the garden of the North West.

"3. The Council of Manitoba have recently with much saticfaction learned the resolutions regarding this country, and brought down to the House by the Honoturable Mr. MeDongall, on 3 oth November, last: but, previous to this knowledge, this Council was pledged to the Electors to act resolutely on either of the two following pledges, viz. : First; to know from the Gov- 
ernment of the Dominion of Canada, in consequence of the 1 foth section of the "British North America Act of $186, y$, , if that Govermment wonld be disposed to at once, under existing urgent circumstances, recognize the existence of this petty Government, or if we can be assured by your government of our admission or attachment to the Dominion within six montlis. Second; that should the reply of your Goverument prove unfavourable, as a last and desperate resource to throw onrsclves upon the liberality and protection of the United States Govermment for recognition and ultimate ammexation.'

"This step as a last resort and after grave deliberation is to this Council and people an extremely reluetant one; but when all the circumstances of their total neglect and patient enduance of many years' disappointment, and daily perceiving the rapid advancenent of their Anerican neiglibours are consideresl, any liberal Government could not but sympatlize with a neglected people, compelled to renumce their loyalty under such circumstances. But this Council sincerely hope and pray that the early and favourable reply of your Govermment will avert such a humiliation and calamity, through which serious and complicated evils might arise between the several Govermments interested. We have cte.,

(Signerl) Tuos. SPl:xce, l'resident of the Cutncil.

David Cusitik, MaLCoLm Cumming, Frederick A. Bird, Willam Carsoch.

Council of Nanitoba.

A month later we find President Spence serving the Imperial Government with a similar notice, through the Secretary of State for the Colonies, and indicating to the home authorities the active measures already inaugurated by his Government for the welfare of Nanitoba. This letter will also bear quoting.

"La Prairie, Manituba, via Red River Scttenent, I9 February, I868.

"My Lord:-As President elect by the people of the newly organized Govermment and council of Manitoba in British Territory. I have the dutiful honour of laying before your Lordship, for the consideration of Her Most Gracions Majesty. our beloved Queen, the circunstances attending the creation of the sclt-supporting petty Government in this isolated portion of Her Majesty's Dominions; and as loyal Dritish subjects we humbly and sincerely trust IJer Most Gracious Majesty and Her advisors will be pleased forthwith to give this government favourable recognition, it being simply our aim to 
develop our resources, inprove the condition of the people, and generally advance and preserve Britial interests in the rising far- lle t.

"An humble adkless from the people of this settlement to Ifer Majesty the Queen was forwarded through the Governor-Gencral of Canata in June, last, bricfly setting forth the suferior attractions of this portion of the liritish Dominions, the growing population, and the gradual influx of immigrants, humbly praying for recognition, law and protection, to which no reply or acknowledgement has yet reached this people.

"Early in January, last, at a pullic meeting of settlers who numbered over four hundred, it wa manimonsly declared to at once proceed to the election and construction of a govermment, which hat acorelingly been duly carried ont, a revenne imposed, pullic buildinge commenced to carry out the laws, provisions made for Indian treatics, construction of roads and other public works tending to promote the interests and weliare of the people.

"I have the honor to remain, my Lort,

"Your Lordhip"s obediem servant.

"T. STEXe:,

"Pres. of Council.

"To the Secretary of State for Colunial Affairs, London, England."

The regine of the Cinncil of Manitula was unfortunately of bric flumation. The new gorermment fell a victim to the disrespect of it own subjects and to the legal difficulties of its situation as thene were set forth by Her Majesty's Secretary of State.

A contumacions shoe-malier in Caledonia, Macpleren ly name, circulated the runour that the new riders of the colony were uning. for the purchase of lic|uter for their private consumptiem, mones's collecter as public taxes. This accusation involved a manifen care of lese majesty. The offending shoe-maker was consequently haled into the back shop to be examined by the President in Council. The friculs of the accused thereupon riotonsly effected his release, and the first provisional gowemment passed ont amil laughter and profanity.

In acknowletgement of Mr. Spence's letter, the British Colunial Secretary on May $30,18(\mathbb{s}$, wrote as follows:

"In these communieations you explain the measures that have been taken for creating a seli-supporting government in Manitola within the territory of the Indson's bay Company.

"The people of Manitoba are probally not aware that the creation of a separate govermment in the manner set forth in these papers las no force in law, and that they have no authority to create or organize government, or even to set up municipal institution (property so-called). for themselves, without reference to the Ifudson's lay Company or the (rown. 


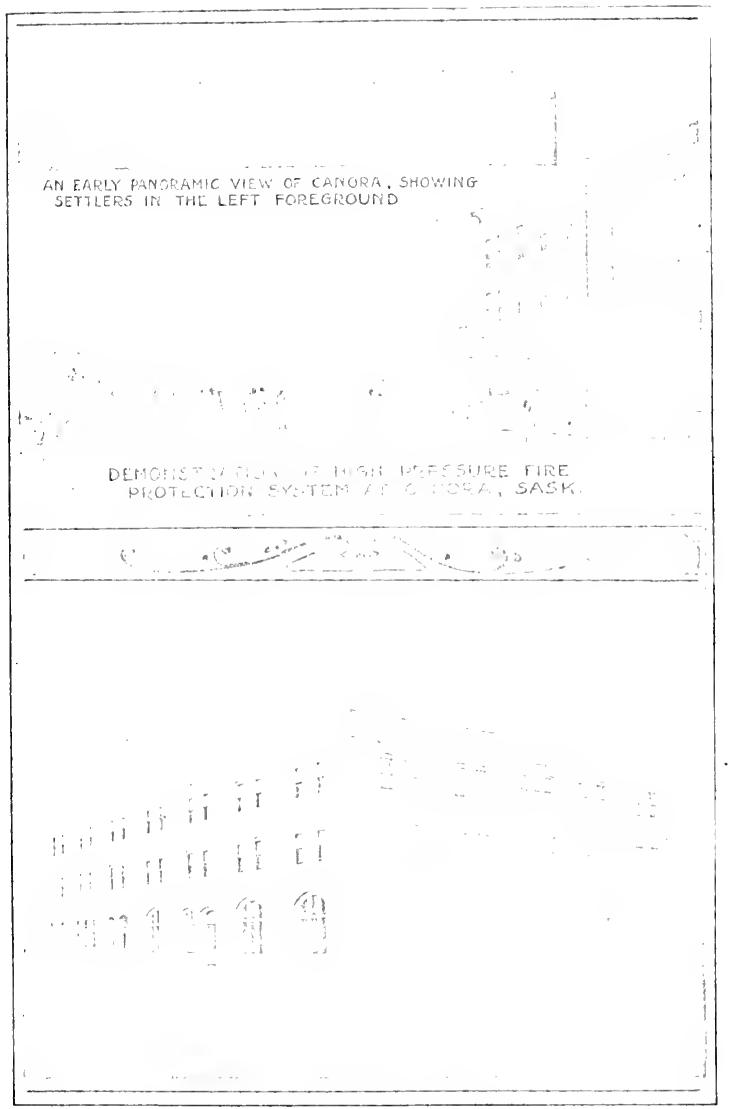



"Her Majesty"s Government are advised that there is no objection to the people of Manitoha voluntarily submiting themselves to rules and regulations which they may agree to olserve for the greater protection and improvement of the territory in which they live, but which will have no force as regards others than those who may have so submitted themselves..

"As it is inferred that the intention is to exercise jurisdiction over offenders in crininal cases, to levy taxes compulsorily, and to attempt to put in force other powers, which can only be exercisel by a properly constituted government, 1 am desired to warn you that you and your coadjutors are acting illegally in this matter, and that, by the course you are adopting, you are incurring grave responsililitics."

One cannot help smiling at the simplicity, directness and self-confidence of those responsible for the establishment of the provisional government in the "Colony of Manitoba," lut the thonght ful reader, conversant with the conditions of the times, must likewise feel some genuine admiration for these sturdy politicians. In a commmity containing any number of such men as Thomas Spence, Mavid Cusitar, Malcoln Cumming, Frederick A. Bird, William Carnoch, Thomas Inderson, John Melean and the like, it was manifestly preposterons that self-governing institutions should he longer delayed. As a matter of fact, in accordance with their repuest, their grievances were lail before the Dominion P'arliament at its first session and their petitions, backed up by their practical activities, played a part in hastening the annexation of the llest to the new Dominion. Noreover, it is interesting to remember that when a real provincial government was established, the new province was not named after Assiniboia, the ancient centre of the Red River Settlement. It perpetuates the name adopted by the settlers of Portage la Prairie, and their P'rovinional Conncil.

Other provisional gorernments were those of John Bruce at Fort Garry, 1869; Louis Riel at Fort Gitry, 1870; Gahricl Dumont at Batoche, in 1875; and Louis Riel at Patoche in 1885. Each of these will be in dne conrse treated of in later chapters. 


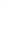




\section{CIIAPTER $\mathrm{X}$}

THE SLRRENDER OF THE NORTI WEST TERRITORIES BI THE JIUDSON'S H.AY COMPANY

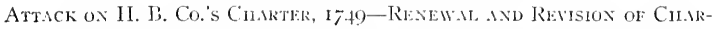
TER, 1821-CORRESPOXDENCE OF $1837-3$, WITH RENEW.LL FOR 21 Years-Agitution Revifed in Iluese of Commoxs is 49 -Local

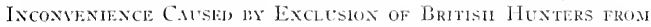

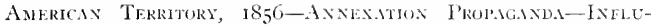

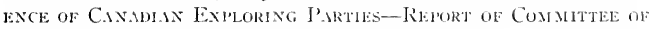

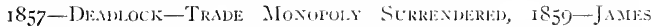

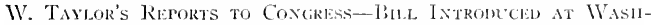

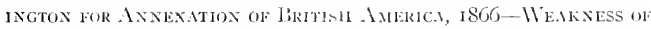

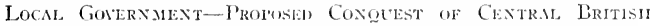

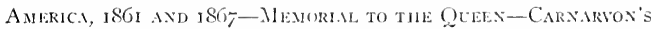

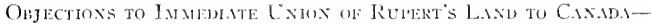

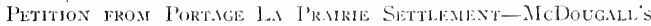

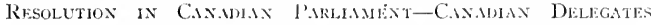

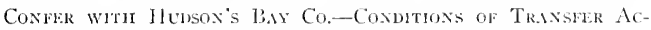

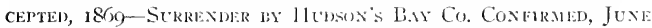

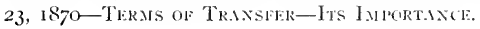

The transfer of the North West, including what is now the Province of Saskatchewan, from the jurisdiction of the IInlson's Iay Company to that of the Dominion of Canadia involves an interesting story. Some of the most remarkable incidents in comnection with this momentons surrender has been all but forgotten by the Canarliaus of the present generation, and to recall them should be valuable, especially to the sons and daugliters of the new provinces that have arisen in what was once the Inulson's Bay Company"s territory. The very fact that these provines are today part of the British Empire is itself a result of the action of the company and of the Gorernments of Canada and the United Kinglom half a century ago.

The agitation for the cancellation of the extraotdinary rights and privileges exercised by the Fiudson's Bay Company dated back to more than a century even from that time. In $17+9$, as we have scen elsewhere, an mnsuccessful attempt was made in the Pritish Parliament to deprive the company of its charter on the plea of "non-11ser." One of the duties devolving npon it. 

accoreling to the terms of its charter. was that of promoting colonization and settlement. but in the year mentioned the company hat only some four or five forts on all the coast of IJudson's Bay, and employed only one hunched and twenty servants, though it had leen carrying on an chormous trade for over eighty years.

Emerging trimmplant from this battle with its enemies in the british Parliament, the grat corporation entered upon the prolonged struggle with rival companies, which has been treaterl of in an earlier chatpter. This rivalry involves the establishment of a very latge mmber of trading centres thronglott the whote western area of Pritish. America, and culminated in the amalgamation of the Jludon's liay Company and the North llest Company in 1821. The lease was renewed for a period of twenty-one years.

Linder the legislation of 1821 the eriminal and civil jurisdiction of Ganadian Courts had been extended into the company's territories. but povision was made for the mantenance of concurent juriscliction on the part of the company, and, as a matter of fact, the Canalian antherities had very little occasion to exercise their powers. Generally speaking, the whites in the lliest had semed pretty well satisfied with the company's policy and methods. In 1837 , however, the Diekon disturbance took place, when that self-styed "Liberator of the Indian Race" assembled his halif-hreed followers and attempted to raine a revolt in the Red River settlenent.

In February of 1837 , (iovernor l'elly callew the attention of the Covernment to the approaching termination of the grant of exclusive trade and proposed its renewal. The comtry in which the Iludison's Ray Company then traded was divided into fom distriets. known as the Corthern, Sotthern. Coltumbia atud Nontreal lepartments. In these were 135 establislments, employing 25 chief factors, 27 clice traters, 152 clerks, and about 1.200 regular servants, besicles the oceasional lalor of a great number of natives in lonating and other services. ${ }^{2}$

Lord Glenelg turned the matter over to the Foard of Trade, which borly atvised him.that it would approve the extension of the charter for a definite period. Glenelg emplatsized the necesity of protecting the present and future colonies within the Iludon lay. Territories and of exempting them from the company"s jurislictim. Cinsequenty in 1838 (ilenelg's secretary wrote Governor I'dly; proposing the exten-im of the grant sulpect to such exemption for settled communities. The charter was renewed accordingly on this hasis for another period of twenty-one years, at a yearly rental of five shillings.

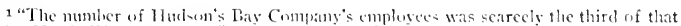

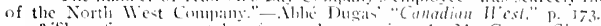

= these figures were taken from a letter written hy Xlr. George Simpons. They are somewhat in exese of the ligures quoted chewlice in the ofteial correspondence with the Rritish Government. 

In 1849 another agitation adverse to the company's monopoly was aroused in the British House of Commons by Mr. A. K. Isbi-ter, and a select committee was appointed to determine the status of the IIudson's Bay Company with respect to territury, tratle, taxation ant govermment. Little came of this investigation so far as the Irritish Government was concemed, but it gave support and enconragenent to the resistance of the company monopoly in which James Sinelair fignred so prominently.

In 1856 the discontent of the inhabitants was further atumented by a proclamation isued under the instrtetions of the L'resident of the L'nited States, notifying "such of the imbabitants of the Iiritich l'usessions as are in the habit of crossing the boundary line between the Linited States and Great Britain (49th l'arallel of North Latitude) for the purpose of hunting and trapping, ete, on American soil, that such depreatation will no longer be permitted." This proclanation was probably issucd with the idea that the people of the Red River settement Would agitate for annexation to the United States if they fomm themselves cut off from access to the buffalo comtry. These hmonting grounds stretched acrosi the line to the Missouri. and to them the British setulers anmally resorted to procure skins and provisions.

Indect, ten years carlier, a petition had gone from Issinilusia to the American Govermment. In the recorded evidence of Mr. Isbister be fore the Honse of Commons Committee in London the following ynestions and answers occur :

Q. Is it within your knowlerge that any application or complaint was ever made to the Govermment of Imerica on the subject?

A. There was a petition adtresed by the Red River settlers to the American Govermment, I believe.

Q. What is the date of the petition?

A. It was abont 1846 , at the time of the excitement comneted with the Oregon boundary Question.

Q. What was the general purport of the petition?

A. I believe that they desired the American Govermment to anex the Red River Territory to the Lnited States, and promised their assistance against the Hudson's Bay Company in the event of war.

The prestige of the Company was also being weakened by the activities of the Canadian exploring parties muler Palliser, and later under Dawson and Ilind, whom everyone looked upon as forerumers of a change of sovereignty.

In IS57 a committee of the House of Commons drew up a lengthy report on the IItudson's Bay Company and its affairs. In this document it was pointed out that districts in the Red River and Saskatchewan were anmng those likely to be desired for carly occupation, and the hope was expressed 

that there would be "no difficuly in effecting arrangements as between Her Majesty's Government and the Hudson's Bay Company by which these districts may be ceded to Canada on equitable principles." The Privy Council beliered it to be desirable that for the present the Company "should continue to enjoy the privilege of exclusive trade," but recommended that a bill should be prepared forthwith to lay the foundation for a new order of affairs.

In the controversies of 1857 the interests of Canada were represented by Chief Justice Draper, C. B., who presented important arguments supporting the claim that considerable territory under the sway of the Hitulson's Bay Company rightifully belonged to Canada alrearly. IIe quoted a letter from the Company dated ryor, in which it was asked that the French be prohibited from travelling or driving trade "beyond the midway between Canada and Albany Fort." The Company had defined its territory as then including "but a very" small district of land from the South-East of the Bay necessary for a fronticr." This line wonld lave given to the authorities of French Canada territories now chamed as within those of the IItdson's Bay Company. The claim to all the comntry the waters of which ran into the Hudson Bay was not advancel until consilerably later, and in the meantine Canadian traters harl well established themselves in the disputed district. The Hon. Willian McGillivray, in $18 \mathrm{~s} 8$, had stated undet oath that there were no Iludson Jiay traters established in the Indian contuty abont Lake Winnipeg or the Red River for eight or nine years after he had been used (as a partner in the North-IVest Company) to trade in that country. IJowever, the vested interests and long atmitted rights and privileges of the Great Company were too strong to be imperilled by any sucl legal subtleties as those advanced on bchalf of Canada.

In this same vear, 1857 , a petition signed by 950 settlers at the Red River and by the leading Indlian Chiefs had been addressed to the Canadian Legislature with a view to the annexation of the North-West Territories to Canada, but in vain. In 1858 , the Governor of the Company was advised by the Home Government that the license wonld be renewed for a further term of twenty-one years, after its expiration on the zoth of May, I859, subject to certain conditions. Vanconver Island, and any other present and prospective colonies should be definitely excluted from the juristiction of the Compans, and the boundary hetween the Ifudson Bay Territory and Canada should be anthoritatively determined. Districts suitable for settlement slould be rendered free for annexation to Canada. Iler Majesty's Govermment proposed that the pecuniary compensation dne the Company should be setled by a Board of three committees, representing respectirely Canada, the 
Company and the IIome Govermment. With these propositions the Company expressed themselves in general agreement, but an impasse was presently reached, delaying for several years a solution of the difficulty.

The Company was quite prepared to acquiesce in the submission to the Privy Council of the question of the extent of its territory, but refused to he a party to any proceeding which was to call in guestion the actual, validity of its Charter. Accorlingly, in 1859 , the Home Govermment suggested as an interim settlement the issue of a fresh license of monopoly, valicl only for one year. The Governor of the Company replied that "the intelligence of the renewal of the license for a year would not exen reach a large portion of the pusts of the Company before that period had expired. If better means can be devised for maintaining order and peace in the Indian country, and for the protection of the Indian tribes from the cvils which have hitherto been found inseprable from competition in the trate, as well as for the colonization and agricultural improvement of the territory, the question of the abolition of the Jumlson's Ray Company should only be one of just indemnity to the shareholders for their legal rigluts and interests."

Consequently this proposition was rejected by the Company, and afier 1850 the monopoly of the tracle was not again renewed. The Compan!, however, still continned to exercise the right of administration.

In I86 there appeared at Fort Garry an American official who was long and prominently associated with public life in Western Canada, and in Fort Garry, or IVinnipeg, in particular. This was James $\mathrm{IT}$. Taylor, a special agent sent by the Hon. H. l: Chase, the Seeretary of the American Treasury, to investigate conclitions in North-West Jritish Imerica, in their bearing upon American interests. In a letter to his superiors at Washington, dated July, IS6r, Mr. Taylor wrote as follows:

"I anticipate also, if further exploration shall attract the attention of the world to the sources of the Saskatchewan and Athabasa in the same degree as in 1858 to liraser River, that the scale will be decisively turned in favor of the following meatstes. Which are even now prominent in Lnudon.

1. An Act of Parlianent organizing a Crown colony North-ll'est of Minnesota, with an inhabitable area of 300,000 square miles.

2. A Cnion of all the American provinces of England, having for a prominent object a common highway from ocean to ocean on British territory:

3. In overland mail, to be speedily followed by colonization, adequate to the achievement and support of a continental railway.

"One thing is very apparent: unless the English Government shall promptly respond to the manitest destiny of the great interior of Iritish America-the basin of Lake llimnipeg-the speedy Americanization of that fertile district is inevitable. The indispensible requisites to the 
integrity of british Dominion on this continent are such action in behali of the Saskatchewan and Red River districts as the Fraser River excitement secured for the area fronting on the North Pacific three years since."

For a time much anxicty seems to have been aronsed by the presence of a considerable military force on the American Fronticr. However, in Narch. 1864, an armed American foree was given permission to cross the line to attack refugee Sionx Indians, it heing only stipulated that nu bluod shonld the shed in honses or enclosures of the settlers if the Sionx took refuge in these places.

In 1866 , Sir Edmund I Iead called the attention of the IJome Government to Taylor's renarkable reports. Ile spoke of the recent gold discoveries along the Saskatchewan and of the probability of an inrull of setters. and added the following recommendations:

"We think therefore that we are the more bound most respectfully to suggest whether, if it is intended to retain the territory north of the $f^{4}$ th Parallel as liritish soil. some steps ought not to be taken for atserting its British character, and maintaining law and order within it.

"This may, no dould, either be effected by the dircet action of the English Govermment, or be attempted by the agency of Canada, lutit, ats we understood the latter comrse to have been deliberately selected, the Cimnmitlee (provided the Company atre fairly dealt withs in the matter of compensation) can have no right to offer any remarks (m) the sthject."

How urgent the situation really was, and how seriously the Imericans were considering the proprity of annexing the British Wen, is indicated in the following facsinile of the preamble to a bill introduced this year in the American Congress:

"39tui Coxgress, ist Sessiox.

"Printer's No. 266.

"H. R. 754 .

"IN TIIE HOUSE OF REIRESENT.ITIVES.

JULY 2, I 866.

"Read twice, referred to the Committee of Fureign Affairs, and ordered to be printed.

"MIr. B.ıKer, on leave, introduced the following bill:

"A BILL for the admission of the states of Nova Scotia, New Bruns"wick, Canada East and Canada llest. and for the organization of the terri"tories of Selkirk, Saskatchewan. and Colmubia.

"The opening by ns of the North Pacific Railway seals the destiny of 

"the British Possessions west of the grst Meridian. They will hecome so "Anericanived in interests and feelings that they will be in fact severed "from the new Jominion, and the que tion of their annexation will be but a question of time.

Next year Governor MeTavish called attention to scrions lndian outbreaks that had oceurred within the sight of Fort Garry. The culprits were Americans and immediately escaped across the border. Ont of this ontrage had developed a violent animesity towatels the Indians, and one of them had been murdered by a half-breed within the very walls of the fiort.

"The Half-breed is now in gatol," said the Governor, "awaiting his trial for murder at the August guarterly court. No attempt has yet heen made to set him free, but many are of the opinion that the attempt will yet be made, and in the circumstances in which the Govermment here is placed will. if made, probably be successful, as for some tme past the Government may be said to have existed on sufferance." Note the ominum plutase with which the foregoing quotation closes.

The Blackfeet were also reported to be in a very unsettled and violent frame of mind, and alogether the Govermment had plenty cance for anxiety. It was well known that mischievous persons were at Work in the Red River settlement inciting to renistance of the establisherl Govermment, and the local authorities begged for military aid from the JIome Govermment.

Taylor's correspondence contains quotations from the Noriaster newspaper, referring to unchecked disorders and commenting upon the situation in the following terms:

"This is a signal proof of what we have frepuently affirmed, that the Govermment at lied liver is umsuited to the times. IV require a cliange: we neel more vigor, more encrgy, more strength, more vigilance, more general effectiveness. Let it come how it may, and whence it mas, but a change is absolutely necessary. Allowing that we should have to pay some taxes, we would rather do that and have sceurity of life and property than continue to be under a rule which is cheap, certainly, but which fails to afford security."

The following paragraph from Taylor's report makes rather startling reading:

"I hasten, sir, to lay before you these facts in regard to the Red River settlement, as confirming my comviction that no portion of the liritisin territory on this continent is so assailable. so certain of occupation by American troops in case of a war with Fugland as Font Garry and the immense district thence extending along the valley of the Saskatchewan to the Rocky Momtains. If our struggle is to be in the fullest semse a struggle for national existence, against foreign foes as well as domestic trators, Ninnesota, howcver remote from the secnes of the sonthern insurrection, will claim the 

distinction of a winter campaign for the conquest of Central britisl America. I append a rough diagram, exhibiting that portion of british territory (encloser in heavy black lines), which one thousand hardy Mimmesotans, aided by the Frencin, smencan and half-heed population cuild seize before the 4 th of March."

So anxious was the Iluklson's Bay Company at this time to have troops sent to Fort Garry that their Gorernor in Londun offered on behalf of the Company to pay for their transport loth ways, ant for their maintenance. When the American force, bowever, departed from Pembinat it was no longer possible to argme that British interests at large were imperilled by it. Nevertheless, in spite of the oljections of the feneral commanting in Canada, the Colonial Secretary was convinced of the necessity for the presence of a military force of some description, and orders were sent for 120 men of the Royal Canadian Ritles to proceed to lort Garry. But for this imperial protection it is probable that the West wonkl have been invaded by Fenian filibusters in $186 \%$.

From Montreal the officers administering the Government forwarled on the 1 Ith of February, $I \& \%$, a series of resolutions adopted at a public necting of inhabitants of the Red River settlement. Ther wished to join confederation, and to hate a detachment of troops. A committee latel aled been

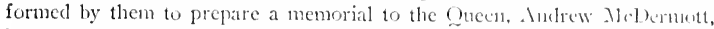
Esq., Dr. Schultz, Colonel Robinson and Mr. Spence. This menorial was signed by eighty-fou persons and dated from the Red River settlement Jantuary $1 \%$, I86\%.

In his dispatch to the Eatl of Camarvon the Canatlian Idministrator advised against the immediate union of the Indson's lay territory to Canada, or the creation of a crown colony at the Red River, for the following reasons:

First-That at present the channel of all the tratle to and from the Red River settlement was in the hands of the United States.

Secondly - That it was doubtful whether water communication, save for defensive purpuses, could ever be mate from the settlement to Lake Silperior.

Thirdly-That, until thorough surveys were made, the possibility of the construction of a remunerative line of railway to I atie Superior could not be estinnated.

Fourthly-That even supposing a water communication or a railway were opened from Fort Garry to Lake Superior, all use of it in time of war would be impossible, unless a British gunboat fleet could enter that lake.

Accordingly the Administrator concluded that "until a safe communication for military purposes is completed between Canada and Fort Garry,

3 Dated December 17th, 1806 r. 
either the union of the Ifudson's liay Territory to Canada, or the creation of a crown colony at the Red River settlement, would be a source of weakness and danger to Canada and England."

Later in the same year, however, still another noteworthy petition, to which we alluded in Chapter JX, was forwarled from Portage la Prairie. At the risk of repetition it seems worth while reproulucing it here at length:

"To Her Most Gracions Majesty Oneen Victoria, Queen of Great Britain and Ireland, etc., etc., etc., in Coumcil assembled.

"The Nemorial of the Inhabitants of I'ortage la Prairie Settement, in Rupert's Land, British North America, humbly showeth,

"That in consequence of Dritish law and protection only extending through the Comncil of Assiniboia for a raclius of fifty miles romed Fort Garry, your Majesty's loyal subject=, inhabitants of this scttlement, are leit totally withont law or protection, civil or criminal, and wholly different from any part of the liritish Emprite;

"That this settlenent contains a pupulation of nearly 5oo, exclusive of Indians, and although nearer to the lnited States frontice than the adjoining settement of Red River, and notwithstanding its vastly superior agricultural resonrces and clinate, your Majesty"s loyal memorialists are left helpless to develop the same or to attract inmigration, from the want of law and protection.

"Your Majesty's memorialists wonld here humbly represent that, in the opinion of settlers here, farmers who have immigrated from Canada, this settlement and the comntry extending westwarel for hundrels of miles is proved by actual experience to be one of the richest agrientumal comutries in the world, and is even acknowledged ly the Government of the State of Minnesota, in its immigration pamplilets, to be vastly superior.

"Your Majesty's memorialists would further himbly represent that. with the proper machinery to develop the resources of this vast, ride and beautiful country, it would become the most attractive point of emigration in the leritish Empire, and that the facilities offered by Nature for the construction of a railway to the Rocky Momtains, for cheapness of construction is mequalled, lieing one vast pratic, and wooled level, and the depth of snow in winter rarely exceels a few inches.

"Your Majesty"s memorialists lumbly trust that with the confederation of the Pritish North American provinces the time has arrived when they may fairly urge upon your Majesty's Govermment the importance of favorably considering this memorial, and immediate action hereon, or your Majesty's Royal sanction for onr development, under the care and protection of the Confederate Govermment of Fritish North America, in the interim of a final settement with the fundson's Fay Company.

"Wherefore, your Majesty's memorialists humbly pray that your 



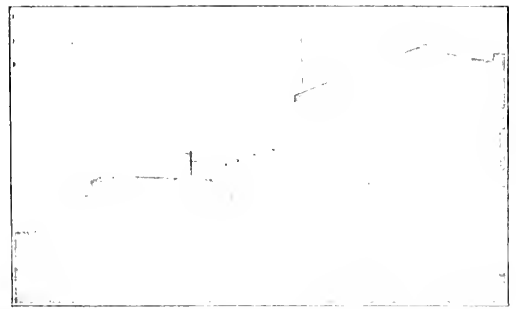

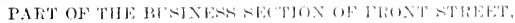
WOIALLEY.

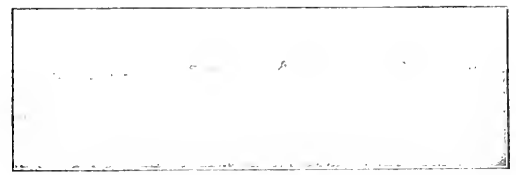

LOOKIXG SOTTH FION THE TOWX HAL, WOLALLES.

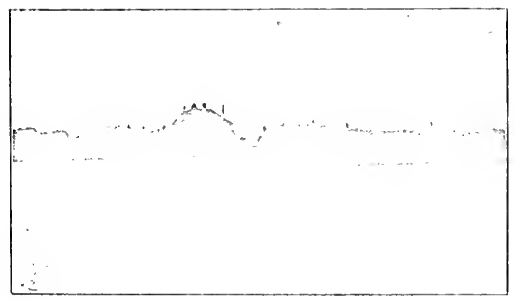

A VIEW OF THE REAERTOH, WOLSELEY. 

Gracions Majenty may be pleased to canse action to be taken as will give immediate protection to your Majestys loyal menorialists, and the privileges of liriti-h suljects.

"And as in duty bound they will ever pray.

"(Signed) Tuns. SirNel IND OTHERs.

"Calcelonia, Portage la Prairie.

"I June, J $867 . "$

A week or ten days later smilar representations were male ly Messe. Spence, Mclean, Garvin Garnoch, Corrigal, Thomas Anchersun, Sinclair, F. A. Bird. C. Whiteford. Ilay and their friends. At the meeting when these representations were drawn mp in the store of Mr. Spence it was "moved by Mr. Ilay, and seconded by Mr. J. Whiteford, "That the IIon-

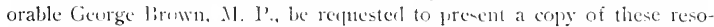
lutions and memorial at the first Confederate l'arliament. and move to bring in a bill for the temporary protection of this settlement nuder the Confederate Government, with IIer Gracion Maje-ty's sanetion. Carried.".

Accordingly within a month of the meeting of the first l'arlianent of the Dominion, the IIon. William Medougalf brouglit forwant a series of resolutions praying for the unim of Rupert's land and the Territories with

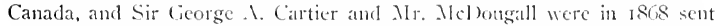
to England as Canadian delegattes to confer with the Indson's Baty Company. Terms were arranged, and an Aet was pared by the lmperiat Parliament in the same year atthorizing the change of control. The proposed arrangement was accepted by the Canadian Tarliament in June. $18(x)$, and on November both the Company male its surreneler to Her Majesty. On June 23 rol of the following year an Order in Council was issted at 11 indsor confirming the surrencler.

Under the terus of the transfer, the Company's special rights were extingnished in consideration of the payment of three hundred thousind pounds sterling by the Dominion and the recognition of the Company's right to claim, in any township within the fertile lect, one-twentieth of the land set ont for settlement. The boundaries of this fertile belt were delined as follows: "On the Sonth by the Lnited States bonndary: on the West by the Rocky Nonntains; on the North by the northern branch of the Saskatchewan; on the Fast l, lake Minniper and the lake of the Woods with the waters connecting them." In 1 s6 $\%$. In accordance with the Dominion Lands Act, it was agreed that "the said one-twenticth will be cractly" met by alloting in every fifth township the whole of sections eight and wwentysix, and in each and every other township, the whole of section eight, and

+ June 10, IS67. 

the South hatlf of section twenty-six." The Company, of eourse, retainerl its liberty to carry on its trade in its corporate capacity, and it was agrecd that no exceptional tax was to be placed on the Company"s land, trarle or servants. While the terms of the surrender hat leen nnder consideration the London directors had officially informed the employees that "should the Company surrender their chartered rights, they would expect compensation for the officers and servants as well as for the proprictors." The spirit and letter of these promises were forgitten when the surrender was madea circumstance pregnant with trouble for the future.

The retired servants of the Company, with their fanilies, included very many of the whites, a large proportion of the English IIalf-brecds and the great majority of the French Inalf-brecels in the Eritish West. As we have previously pointed out, these people believed that one-tenth of the territory formerly ceded to Selkirk belonged rightfully to themselves ant their heirs, and that these lands were therefore legally incapable of being surrendered by the Hudson's Ray Company. These facts seem to have been deliberately concealed by the Company inuing the pregress of negotiations with the Governments of the United Kingdom and Camada. Consequently the people of the East never to this day have been able to understand the bitter sense of wrong eherished e-precially by the Half-breeds of the West. Those who were in a position to realize their grievance cooperated in a conspiracy of silence. This was a prinary cause of the troubles of 1870 and 1885 .

However, whatever may have been the errors attending the annexation of the British North West to Canada, the importance of the transer camnot be exaggerated. Already the danger to Pritish connections was serions indeed, and within the territories themselves the old regime had becone an impossible anachronism. A "government existing on sufferance" is not a govermment at all, and in 1870 the condition of the British possessions from the Lake of the Woods to the Pacific Ocean was one closely approaching anarchy: No mighty upheaval occurred, but the dangers incirlent to the situation must be apparent to every thonghtful reader. Many strong reasons were urged, both in the list and in the West, against the annexation of Rupert's Land to Canadil; its justification lay in the fact that there was no alternative if British territory in America were to be preserved intact and eseape a deluge of blood. 



\section{CHAPTER XI}

\section{A LESSON LOST: TIIE TROUBLES OF 1870}

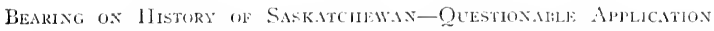

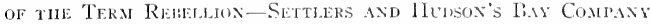

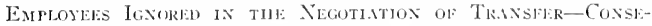

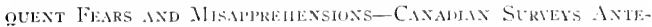

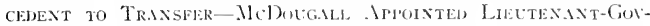
ERxOR DY CANADA PkHoR TO THE Crssion OF THE Mest-MC-

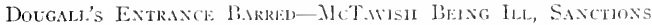

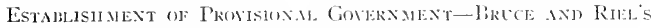

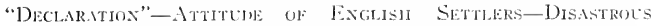

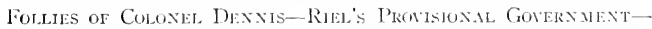

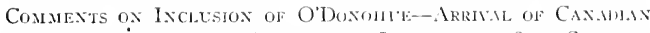

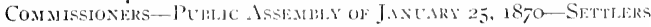

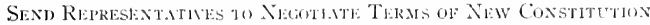
-Risixg of Portage loymasts-Exlection of Thomas Scoti-

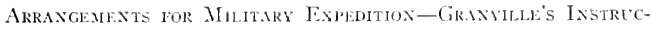
THONS-RHE, IND THE UNION JACK-THE MANITOHA ACT-NHW

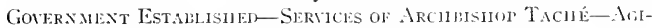

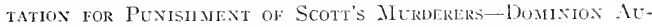
thorities Pay Riel and Lepine to Lenve tile Couxtry.

The story of the uplheaval in the Red River Settlement in Is $n$ and 1870 belong especially to the history of Manitoba, but its bearing upon subsequent events in Saskatchewan makes it necessary for us to briefly. review it. Whether from the point of law and equity the uprising should he called a rebellion is a matter in which there may be difference of opinion. Riel persistently clamed to be loyal to the British Crown, and it is harr to see how obstructions offered to the illegal encroachments of the Government of a sister colony could be defined as rebellion. In the report of a Committee of the Honourable the Privy Conncil. Decenber 16, 1869, the Canadian Premier declared that the resistance of the Half-breeds "is evidently not against the sovereignty of Her Majesty or the govermment of the Hudson's Pay Company, but to the assumption of the govermment by Canada." 

The essential fact remains, that hy way of protes against the colosal folly and mupratonatble loungling of the Iniperial and Dominion Authorities, an extra-constitutional gorernment helif full sway for a period of alout nine months. Iatd the manifes lessons involved in this minfortmate affair been duly taken to heart, the more serious and bloody uprising of 1885 in Saskatchewan would have been averted.

In negutiating for the annexation of Rupert's Land to Canada, the British and Canadian Authorities ignored (almost ostentation-ly) the ten thousand white and Jlalf-lored setters of the Red Rirer district. The terms of the proposed transfer were neres discunsed with them or their representatives, and indeer reached the suttement only in vague and inaccurate rmors. While a consideralile numler of the letter informed colonists, concisting chichly of recent immigrante from the Fast, were exceedingly anxiens for the annexation, at large juoportion were indifferent, and many others were bitlerly opposed to it. The suberdinate officials and traders of the Hutson's liay. Compruy ludieved that their interests were being ignored in the transier, and the I Ialf-breeds, who, ly virtue of their Indian blownl, felt themedies to be, wh the Indians, the natural possessors of the land, resented a surrender by which thes heliesed that their birthriglit would be iorfeited.

Moreorer, the servants and retired emplenees lxelieved that, as regatrels the lands assigned to them and their heirs under the terms of the Selkirk grant, but now tacitly incluted in the territory the Great Company assumed now to be surrendering Canada, the action of the Company was in law and equity invalicl.

These misapprehensions might hate becn corrected before any serions mischicf transpireal had it not been for the action of the Dominion fiovermment in sending surverors into the comntry even before the terms of the transfer hat been agreed upon. Thus before the country was legally a part of Canadia at all, its officials proceceled to lay ont the land upon approved modem rectangular plans of survey, entirely ignoring the prinitive system already in rogne among the settlers. The existing farms almost all took the form of river lots ui narrow frontage and a comple of miles in depth. These coulel not be made to fit into the new system, and the settlers naturally concluded that they were to he robbed of their holdings. The domineering tone and stperciliuts atrogance of many of the officialemplosed in the survey serionsly aggrarated the indignation of the inhabitants.

As if follies enongh had not alrealy leen committed, the Dominion Government, still prior to the acquirement of any legal title to the territory and withont any consultation with the colonists, appointed as LientenantGovernor the Ifonorable Willian McDougall, whose sulsecquent humiliat- 

ing experience gave him the unfortunate title of "Vandering Willie," and practically drove that energetic politician ont of public life. The unlucky Governor was himself treaterl with scant courtesy by those who appointed lim, and had every reason to resent the character of the support with which they seconded his ill-starred efforts to earry out their vague and foolish behests. Mr. MlcDongall jonmeyed westward ria St. Panl, then the terminus of the ratway system, and prepared there for his journey of four humdred miles across the prairies. Ilis retinue was a comsiderable onc, including Mr. Kichards as Attoney-General and L'remier. Mr. Provencher as Provincial Secretary, Captain Cameron, who was to command some future monnted constabulary and mantain the peace, together with varions other officials and their families. All of these were complete strangers to the comntry and its people, and although (iovernor McDougall wats to have anthority to fill one-foutl of the places of the Conncil from anong the residents of the settlement, the people were kept in ignorance of his plans in this connection.

For onr present purposes it will he sufficient to ontline the secunence of events very bricfly.

Mr. MeDongall reached Penbinat and prepared to enter his prospective domain. The excited Half-breeds haw determined. however, that no such entry should ocen nutil negotiations between the Red River Settlers and the Federal Government had crystallized in a constitution satisfactory to the pioncers. Accordingly an armed force seized the lighway between Fort Garry and the botmelary to prevent $\mathrm{NcD}$ Dugall's ingress, while the I Taltbreed leader. Lonis Ricl himseli, took positession of Fort Garry, and Governor McTavish being incapacitated by sickness and really on his deathbed, Ricl called a convention to establish a Provisional Govermment. The English delegates at this convention insisted on consulting Mr. McTavish and a Committec consisting of Messrs. Sutherland and Fraser interviewed him. Mr. McTavish saicl to them:

"Form a Government for God's sake and restore peace and order in the settlement."

On December 8th Bruce, who till December 28 th was nominally President of the Provisional Govermment, and Ricl rlistributed among the Colonists what was called their "1)eclaration to the people of Rupert's Land and the North Viest." In it Ricl dcclared, anong other things, on behalf of himself and his associates, "that we refuse to recognize the authority of Canada, which pretends to have a right to coerce us and impose upon us a despotic form of government still more contrary to our rights and interests as Pritish subjects than was that government to which we had subjected ourselies througl necessity up to a certain date. . . (Ve) sluall continue to oppose with all our strength the establishment of a 

Canadian Anthority in our country under the announcel form. Meanwhile we hold ourselve's in readiness to enter into such negotiations with the Canadian Government as may be favomalle for the good government and prosperity of this people."

The English settlers generally held aloof from the whole disturbance. In a subsequent report by Mr. J. S. Dennis, on the attitude of the Engliahspeaking portion of the colony, the following communication is rnoted ats fairly indicating the position taken hy them: "We fed a disposition to extend a sincere weleonxe to the Ilommalsle XeDongall as a gentleman who has been selected for our future Governor. We regret sincerely that the good name of the colony shoula be prejudiced by any such action as that which we are told is contemplated by a portion of the French llalfbreeds. We consider it a most outrageons proceeding on their part, and one that we would he glad to see put a stop to. It the same time, should an appeal to arms he necensary, we could hardly justify ourselves in engaging in a conflict which would be in our opinion one of nationalities and religions. and of which we could hardly at present foresee the termination.

We feel confielence in the future administration of the Government of this country; at the same time we have not been consulted in any way, as a people, in entering into the Dominion. The charater of the Govermment has been settled in Canadit. . . We are prepared to accept it respectfully, to obey the laws and to become good subjects. But when you present us the issue of a conflict with the French party, with whom we have hitherto lived in friendship. . . in which conflict the aid of the Indlians would be invoked and perlaps obtained by that party, we feel disinclines to enter upon it, and think that the Dominion should accept the responsibility of establishing amongst ts what it, and it alone, had decided upon,"

The dignified course for Mr. McDungall and his party, on being refused admittance to the Colony, would have been to retum to the East. but Sir Joln A. McDonald wrote to him: "I hope no consideration will induce you to leave your post,-that is, to return to Canada just now:" Accorelingly the humiliated official remained through long weeks vainly knocking at the door of the Red River Settlenent. Under date of the ist of December, he issued a proclamation that he was the Licutenant-Governor of the North West, which was not the case, and appointed Colonel Dennis his Lieutenant-Conservator of the Peace, with authority to rally loyal sthjects for the dispersal and overthrow of the insurgent faction. This proclaniltion was posted in public places in the settlement during the night of the I3th of November. Dennis then enrolled volntnteers, who suceceled only in getting themselves into troulle and strengthening the hands of Riel. Demis himself fled the country, and numerous loyalists became prisoners at Fort Garry: 
Early in January a formal previcional foremment was definitely organized with Ricl as T'resiclent, O'bonoghne, an ont-spolen Fenian, as Sceretary-Treasurer, and Lepine as Idjutant-(ieneral. Evirlently Riel did not feel himself strong enongl to exclude from his conncil the fenian clement, but Archbishop Taclee is authority for the statement that "smus of money" amounting to more than stono,mo. men and arms hat been offered" lov Americans on condition that Riel would espouse annexation, but had been refused. ${ }^{1}$

Norice points out that one reason for the retention of ollonghane in Riel's administration "may be fomel in the fact that the roung Irisman had uncommon aptitudes in bookkeeping and all that pertains to the dutics of an accountant. In an umpublished . Vemoir on the troubles of $18(x)$ and 1870 kev. Mr. L. Kaymond Gironx, one of the l'rieste stationed at St. Boniface at the time, has the following: "N1r. Riel, who hat at heart the British connection, wate one day complaining to me that o'bonoglue was striving to give the movenent an amexational complexion, hut he ratil. "I an in absolute neer of him; he adminimers his department with ease and treats cxcechingly well the halibeerls, of whom he had heente the ithl."."

Neanwhile the Deminion (owermment was doing what it shonld have done long lefore. Commisnimers were sent to explain the sitnation and

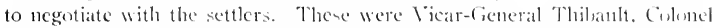
De Salalerry and Domald . S. Smith. Ilis fellow commisioner arrived ahead of him and their credentials were seized by the insurgents hut Mr. Suith was more strecestul.

Prior to this, aceorling to liegg. "the intentions of the Canadian Goverment were never made known to the porple of the settlement by Xr. AIcDongall, or anyone else in his behalf." ly the exercise of much commom sense and shrewd diplomacy, Mr. Smith secured the privilege of presenting his papers before a mass-meeting of the settlers. which was held in the open air on Ioth of January, with the thermometer at twenty degrees below zero. The Governor General's proclamation, rearl by Mr. Smith, conchuded as follow: :- "And 1 do lastly inform von that in case of your immediate and peaceable obedience and dispersion, I thall order that no legal procedure be taken against any parties inplicater in these mifortuntte breaches of the law."

On motion of Ricl, a consention of twenty English and twenty lirench representatives was callerl for Jamury 25 th to consider Mr. Smith's mission. The chairman of this gathering was Jurge Black, a prominent loralist. I Bill of Rights was framed as a hasis for legislation creating a pro-

1 A letter to His Excellency the Governot-General of Camala, July 23rd, I870 (found on p. 42 of $\mathrm{N}$. $1 \mathrm{~V}$. Cimmitte evidence)

a Catholic Church in Wentern Canatia, whi. 11, p, 14 
vincial government, and protecting the landect interests of the retired servants of the Hution's bay Company, and Mr. Smith invited the convention to appoint delegates to $g_{0}$, to Ottawa and lay their wishes before the Govermment. Father lichot, Il hed Scott and Judge bilack were thereupon selected to negotiate at the capital on behali of the settlers.

At the close of this public meeting on ]anuary 25 th at which Mr. Smith presented his creflentials and his message from Canala, kiel spoke as follows:

"Before this Isembly brealis 11p, I cannot but express my feclings, however briefly: I came here with fear. We are not yet enemies, but we came very near being so. As snon as we unclerstool each other we joined in demanding what our linglish fellow subjects in common with us believed to he our just rights. I am not afraid to say our rights; for we all have rights. Ile clam no halt-riglts. mind you, lut all the rights we are contited to. These rights will be set forth by our representatives and what is more, gentlenen, we will got then."

The meeting then lowke 11 ) with the utmost goxd feeling on all hand

On their arrival at (Ottawa bather kichot and $\mathrm{Nl}$. Scott were, however. twice subjected to arrest, as rebels, hut there being no case against them, they were finally set at liberty abent the mialle of April.

At Portage la l'rarice on February 1 1 th, a large number of loyalists took up arms against the l'rovisiunal Government. Of this act of wellintentioned folly. Mr. 1). A. Smith suke as follows in his official report:

"Ifad these men, properly amed and organized. leen prepareat to support the well effected french party when the latter touk ation about the midelle of Jamury, or even in the beginning of february during the sitting of the Convention, order might have been restored without the necesity of firing a single shot; but now the rising was not only rash but purpo-eless. as without its intervention the prisoners would mupestinnably have been released. . . Captain lioulton led the party and he and his friends at the Jortage assured me that he exerted himeelf to the utmost to lieep them from rising. and only joined them at the last noment when he saw they were determined to go forward." Jioniton and a large number of his companions were captured on lebruary 17 th and boultum was condemned to be shot. Various prominent citizens, inclueling Mr. Smith. intereced with Riel on Boulton's behali. On the evening of the roth, say's Mr. Smith:

"I reasoned with him long and earnestly, until at length about 10 o'clock, he yielded and addressing me apparently with much feeling, said. "Hitherto I have been deai to all entratics and in now granting rou this man's life, (or words to that effect) 'may I ask you a favour'" 'Anytling,' I replied, that in lonom [ can do.' I]e continued: 'Canada has dismited 
us; will you use your influence to unite us? You can do so, and without this it must be war-blomly ciril war.' I answered that. as I had sail on first coming to the combry, I would now repeat that I would give my whole heart to effect a peacealle mion of the comtry with Canada. "IVe want only our just rights as British subjects; he sairl. Then I remarked, -I shall at once see them and induce then to $\mathrm{g}_{0}$ on with the election of delegates for that purpose."

Meantime the difficultics of Ricl and his colleagnes were increasing, and. on March fth, Riel, to assert his waning anthority, committed the unpardonable crime and bhunler of executing, muler circum-tances of exceptional brutality, one of his prisomers, at hot haded, irrepressille and iresponsible loyalist and Orangenan, Thumas Scott.

The Canadian Government had already undertaken arrangenents for sending a military furce to restore and guarantee order in the llest while the new government was being set afoot, and on the day following the execution of Scott, Earl (iransille cabled the Governor-General in the following terms: "Her Jajecty"s fovernment will give proposed military assistance prosided reasonable terms are granted Red River settlers and provided your government enable ller Majesty's Gormunt to proclaim the transfer simultanerusly with the moxement of the force." In a subsequent communication liarl firanville adked the following pregnant warning: "Troops shotild not be employed in enforcing the sovereignty of Canadit on the population, shoukl they refuse to adnit it."

On April 20 Riel ordered the Lnion Jack to be hojeted at Fort Catry in place of the enblem of the l'rovisional Government. This called a violent altereation with O'Donoglue and his amexationi-ts. Riel in-isted. however, on keeping the british flag lloating from the centre flag staff at Fort Garry, but to please $0^{\circ}$ bonoghue be allowed the Provisional flag to be erected in front of (iovernment Ilonse.

When the arrest, at Ottawa, of the two delegaten of the provisional govermment was learned. (O'Donoghme wished to replace the British. Hag by that of the Lnited states. but Riel forbate this and placed Nault at the foot of the flagstaff with orelers te fire on anyone who tried to tonch it.

On May 2, Is7o. Sir John Matedonald introducel the Manitoba . Ict in the House of Commons. In its original form the bill so defined the boundaries of the new prosince that the important settlement of Portage la Prairie would lave been left out. This feature was anended and a few other alterations were introluced in the first three liass. The Govermment then forced the bill through, defeating every other proposed change. The measure was framed sth stantially in confornity to the [3ill of Right s lrawn up by Riel and his associates, except at regards clate's $I$, Io and it of 

the Ne-tern Manifesto. These provisions had been inserted to protect the clams of those believing themseleses entilled to a share in that tenth of the selkirk lands which had been intended for the ex-employees of the Indson's Bay Company. Iowerer. the Act mate provision for the equitable extinction of special I Ialibred and Indian rights to the soil and for the jomediate establishment of provinejal automony. The bill became law on May 12. On the preceding day the indennity of three hundred thonsand pounds was paid over to the IIurlson's liay Company.

Early in April Colonel Woleley, Who subeefuenly rose to high rank and dignity in the comncils of the Empire and its military forces, had been appointed to command the Red River experlition. On the 21 st day of May he left Collingwond with part of his forecs, and after a jomrney momoralide for the stupendems dificulties wereome, he reached the lied liver on Angurt 23. marching in to Fort Garry the following daty:

As Wolseley apporached. Riel and his officers. realising that munler exjsting ciremutances their remaning at liort Garry whuld intennely condanger the peace and their own lives, took to flight. retiring to the Linited States." There is no reason to believe that at any time Riel had contemplated armed resistance to 11 olseley, coming as the champion of a new contitution accepted by the anthorised representatives of the people of the Red River. "J anly wish to retain power until I can resign it to a proper government." said Riel to General lintler: "I have done everyhing for the sake of peace and to prevent blookhed among the perple of the land.".

Wolseley thus fomm limself in peaceable possession. but in a proition of very great difficulty, nevertheless. Rupert's land was now a dependency of Canada, but the new Lientenant-Governor, the Ilonourable Adams G. Archibald, diel not arrive until September 2, and Volseley limself had mu civil authority. In the emergency he called npon Donald A. Smith to ad-

3 There is a clash of dates in the recorls: nome authorities make August 23 rd the date of Wolueley's entry into Font Gatrs.

"During the intervil between Riel's departure and the entry of the Comadian forces

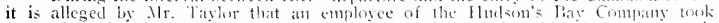

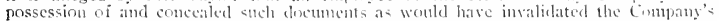

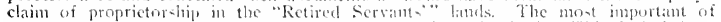
these papers were those in what was called Reginter look A. This included an

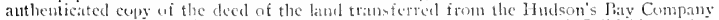
to Selkirk. Junc 12, IRII: a map of the land derede : copy of Selkirk's Indian treaty, with accompanying map: Sclkirk's will and the letters probate: and power of

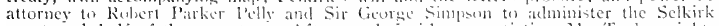
grant on hehalf of the evecutors. After much fruithes nequtiation, Mr. "Taylor. eight-

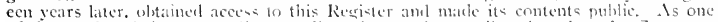
of the results of the extraordinary policy of concealment alleged against the Company. many of the original -ettler were never alle to secure patents for the lanels in their

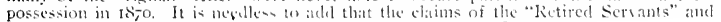
their heirs have never leen admited hy the Goverument of Camada.

" Great Lome Land, p. 1,34 

mininter affairs penfling the Lientenant-Governor's arrival,-a task which he performed with characteristic efficiency.

An important influence verating to bring about this peaceable issue was that exercised by Ji-hop Tache. Fearing that the mision of Messes. Snith, Thibatt and Salaberry wonlel prove mavailing. Sir John Nacionald took the precatution to request the Archlishop to return fortliwith from a visit to kome, fo exercice his womeriul presige for the avoilance of bloolshed. [jem this summons the Srehbithop promptly acted, braving the hardehips of a winter jonmey to the Red River district, where lifs exhortattion and remon-trances had an induhitalsle effect in restraning Riel and his compranions. I'rior to his arrival, however, the settlers hat dhosen their delegates and had ensenterl to treat with the Canadian Guxernment.

Scott's murler arouserl, especially in () matrio, a will outhreak of indignation, dangeronsly tinged with fanaticion. The sitnation was further complicated by an ammesty which the Archbi-hop had helieved hinself authorised by the Camadian Government to jwotaim, and ly the fact that Liculenant-Governor Irehibald aficially acepted, with promi-e of safe conduct, the armed support of leiel and leppine and a large number of their followers, to repel an expected Fenian invasion, ()etober $;$ and $8,18-\mathrm{s}$. Into the details of this episode we cannot here enter. The mplhet of the matter was that the Dominion. Iuthorities patid kid and lepine. who had returned to Canada, again to leave the country, which they diel. pretected hy a police escort. Lepine subsepuently came lack again, stood his trial and was condemmed in death, but on the recommendation of Lord l)ufferin the penalty was commuted to two years imprisomment with forfeiture of politicat rights. The fate of kiel will be recorded in later clapters.

We have now reached the end of the second century since the establishment of liritish interests in that vast region of North Viestern America of which the modern Province of Saskatchewan is the centre. We have briefly reviewed the feats and feuts of rival exploters and traders, to the outenme of which we owe the fact that Saskatchewan is today hitish soil. We have endeavored to picture the character and manners of our aborigines, so often and so oppositely misrepresented and misjudged by the sickly sentimentalist and the hasty man of affairs. Ne have noted the small beginnings of the tide of settlement that his since swept over Vestern Canala, and have secn in what a crucible the early pioncers were tried. We have recorded the abdication of its territorial and administrative rights by the Great Company and the beginning in Is;o of the process of provincial organization, the last great step in which was the pasting of the Saskatchewan Act twenty-five yeats later. Finally we have seen the French IJalfbreeds 
already once in arms against the ignorant arregance of ()tawa, thus inftiating a movement to which many page of an! hintory of Saskatchewan must be devoted. Acorrlingly at this point in our halxurs we might write

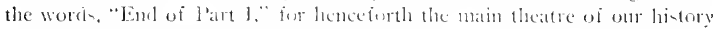
will be, not in the acone of arlient werem -ettenent, but in the Farther North West of which Silkatchewan is a part. 



\section{Cl1. IPTIR XII}

THE lHSST SETTLEMEXT IN S.SH.ITCHEWAN; J'RELIAHXARY OLTHIXE OF TIIE l'lRIOD, I870-1876.

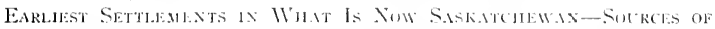

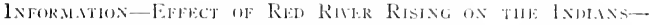

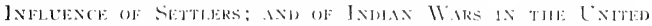

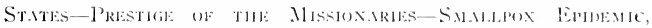

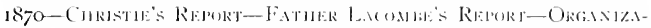

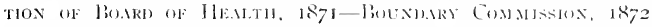

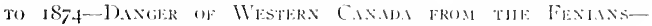

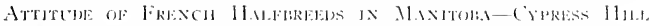

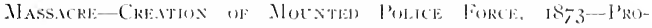

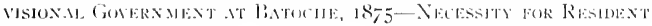

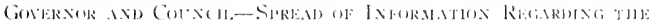
IVE:T.

When, in 18yo, a little district. approsimately one humbled miles wide and one hundred and forty milen hong, was organized into the l'rovince of Nanitoba, the remainder of the enormons ferritories just cerled to Camata by the Hudson's bay Company wa ahnon entircly whlout setters. The following quotation is from I'alliner's famous report of his explorations, $1858-1801$ :

"The Qui. - prelle lakes may be considered the most western part of the territory east of the Rocky mountain to which the Hlut-on liay Company trasle: westward of this I may say is nuknown, and the whole comntry in this latitude is untratled by the white man."

Tiny settlements were, of encurse, to be fomml at the various "iorts." The most important trading posts, apart from those in the Red River settlement, were Fort Fllice. at the junction of the Qu1. Ipelle and Issiniboin Rivers: Fort Pelly, on the Isiniboin: Norway House, at the north end of Lake Minnipeg; Cumberlanel llouse, on lhe Saskatchewan: lort I li Corne, near the junction of the Nortl and South Saskatchewan: Fort Carlon, and Forts Iit and Ednunton, on the north branch: Fort Tunchwool, anong the Tonchwond llills; and Fort (Dit. Ippelle. Captain Palliser reported in s.862 that the Jlurlson's liay Company had lomg since given up all posts in the Blackfoot colnury. Edunonton in Palliner's time wats a trading pont, quite 



as large as fiort fiarry. It was built of wood and furnished with strong bastions and palisades. Fear it was a farm attacherl to the establishment, the only one in Saskatchewan, sme thirty acres in extent. The population of the fort was one lnundred fifty, one-third of these being the Company's employees. Fort On Appelle was then situated sixteen or eighteen miles south of the present plice of that name. Is the facts in this connection have been disputed by some, it may he worth while to gute the following extracts from the journal of Doctor Ilector, who accompanied Captain Pallliser:

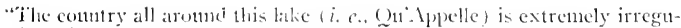
lar, rising into high hills withont any covering but at seanty growth of grass: boulders ate also very alumblant. . . At one o'chek we reached our destination, a small trading pert of the Hudson's laty Company, which from having first been sitwated at the (Jn'- Dpelte Lakes, is known by that name. . As this was the place we were to remain at to await Captain Palliser's joining us, I emplened the time in making at visit to the Qu'Apelle Lakes, jying alont eightecin miles to the north. IJaving procured a gunke and a note from the gentleman in charge to a missionary who lives there, we departed after dimer, intending to return next day. For the first four miles the track, which is almost due north. passes throngh open wooks, . . . making a concislerahle derecul. Siter that, with the exception of at few clumps, we saw no woril. but crossed a level open plain. Ile again commenced to descend steadily. It was smiset before we reached the Oun ${ }_{1}$ pelle River, and descended into its profound valley by a dim twilight, which greatly exaggerated its proportions. Kivling along the river we soon eame to the house of the miscionary, guided by the bay ing of the degs. We were very hospitally received by $\lambda \mathrm{i}_{\mathrm{r}}$. I'ratt. who is a missionary of the Clutrch of England from Red River settlentent, aind a pure Stoney Indian by birth. IIe has a very comfortable little lanse and cultivates an excellent garden, in which he rears, anong other things, hops and Indian corn."

When the North West was amexed to Canala, Ifalflureed settlements: were gradually being established in varinus parts of what is now Saskatchewan, notably alout Prince . Illert, Batoche, and Wood Monntain (Willow Bunch). Practically all the whites and IJalflorects in the conntry lived by the chase and agrieultural seftlenent can scarcely be saicl yet to have begun.

Almost our only means of information regarding this wiklerness empire in the early days is derived from the writings of missionaries, such as Father Lacombe, the Reverend John XeDongall and the Reverend Mr. Nisbet; the famons report make to Lientenant-Governor. Archilsald by Captain W. T: Butler and that made to the leeleral anthorities by Col. Robt. Ross; the personal correspontence of IIndson liay factors and traders; the reports of explorers and wandering adventurers; and the reminiscences of the very few other Old Timers who hat already penetrated through the Western wilderness and are yet living. 

The institutions of law and oreler as understood in civilized communities were as yet wholly unknown in what is now Saskatchewan and Alberta. Serions crines were committel from time to time without any vindication of the law being possible. The Ifulson's Bay Company, itself heing a commercial corporation dependent for its protits on the goodwill of the inlabitants, hesitated to exereise even the slight repressive powers within its grasp. Free trade in furs, which really meant uncontrolled trate in whisky, hat further demoralized the natives. The rumors of the so-called rebellion. which had marked the establishment of Canaclian authority, hat most dangerously disturbed the tradition of relative peace that had characterized Western and Central British Imerica, as far as the relation between the whites and the Indians were concerned. The native tribes of the Fatr West were still involved in ceaseless bloody fends among themedves.

Norcover, the Indians viewed with the greatest anxiety the gradual inroad of white and Halflored settlers. The promiseuous use, ly settlers and hunters, of poisons for the destruction of wolves and foxes, was eatsing the death of numerous alogs and horses belenging to the Inelians. Noret of all, the extinction of the buffalo was already a calamity within sight: and for this and all their other misfortunes, the aloorigines held the new-eoners responsible.

South of the American horder a war of extemination was in progres: directed against the Sionx. Blackfeet and I'jegans. In the Spring of rsjo an encampment of the last-named tribe, dwelling close to the Intermational boundary line, was surprised at dabreak by Imerican soldiers. The tribe attacked was suffering severely from smallpox, and unable to offer any real resistance. In consequence one huncleed and seventy men, women and children were massacred within a few moments. The extreme bitterness of the Indians against the Imerican traters was the further aggravated by the belief general throughout Saskatchewan that the Llackfeet laal been deliberately subjected to infection from smallpox by Misenuri traters,- an opinion which, says Butler, "monstrous though it may appear, has been somewhat verified by the western press."

The Halfbreed element in the population was chiefly of French extraetion, and largely male up of fomer employees of the IIndion's Bay Company. They had established scattered settlements along the Saskatchewan at Batoche, Prince Albet, Battleford, Nillow Bunch, Nood Mountain, and in the neighbourhood of various IJudson bay trading posts, notably Qu'. Ippelle. Is a general rule they devoted little attention to agriculture. Most of the summer they spent upe on the plains, buffalo hunting, and in the winter they traded with and freighter for the lluk-on's Pay Company. Says liutler. "They are gay, iclle, dissipated, unreliable and ungrateful; in a measure brave; hasty to form conclusions and quick to act npon them: possessing 

extraordinary poller of endurance and capable of mudergoing immense fattigue, yet scarcely ever to be depended on in critical moments; superstitions and ignorant, having a very deep ronted distaste to any fixed employment: opposed to the Indian, yet widely separated from the white man." Politically, Butler found among them "an exact counter-part of French political feeling in Manitoba . . . kept in abeyance by the isolation of the varions settlements, as well as by the dread of Indian attack."

Along the North Saskatchewan and various other rivers in what is now Alberta, gold had been discovered. lut it was only in the neighbourluorl of the forts of the Hurlson's Bay Company that continued washing for the precious metal cotnld be carried on. This was owing to the hostility of the Indians and to the practical impossibility of procuring supplies. Nevertheless there was a very strong belief among the best informed that the gold fields of the npper Saskatchewan would presently be the scenes of tumultuous activity akin to that of American mining settements in the carly days. The reader need hardly he told that the prospect of the approaching ingress of large numbers of lawless miners greatly atded to the anxicties of thutght ful mell.

The famous missionary piuneer, John McDongall, in his book entitled Western Trails in the Farly Serentits, gives a vivid picture of these chaotic times. liy virtue of their personal forec of character and superior intelligence, the missionaries came to be looked upon somewhat as were the Judges in Istael in those far-away times, when, as we are told, "every man did that which was right in his own eyes."

"At this time," says Mr. Mel)ougall, "there was not a bona fide settler south of the Nortli Saskatehewan. We were there by ourselves, a few Euglish-speaking men and women amonget thousands of natives, and these speaking different languages, and out of the long past still at cmmity and in a condition of war with each other.

Under these circumstances it was a serions problem to keep the peace. In each camp were those who desired it: but the crowd who did not care. and those who had personal grievanes to be adjusted and revenge to be gratified, these kept out fricnds and myself on the move. We had to he on guard day and night. Many a time I was called upon to pass judgment between partics of the sane tribe, and often between those of distinct nationality. Horses and women were, almost in every case, the reason given for the trouble.

"I made it a rule to listen to the quality of evidence rather than the quantity thereof; but to arbitrate or give julgment with all parties before you fully armed, and their several constitnencies behind them realy to fight. made me feel somewlat nervons. Ilowever, we knew we were preparing the people for the Government, which we now hoped would soon come 

upon the secne. In the meantime 'John's' ruling prevailed, at any rate in the vicinity of un fort."

The year 1870 wat marked he one of the most devatsating epriemics of smallpox that ever cursed the 11 cst. It was abut lifty years since it had first appeares anong the Indians and allealy amones the British tribes the Stoneys of the (Ou'. Iprelle plaine hat been ahmest exterminated by it. In 1860 and s8 80 reperts reached the saskatchewan wi the prevalence of smallpox of a very malignant type anong the Biackifect. from whom it spread to other Indians of the Sonthwestern plains. Neverthelese in April. 1870, a small band of creen vinited the infected combry an a war excursion.

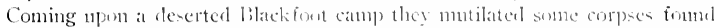
there and carried awaty the scalps atud clothing ats trophice. L lpon thin act a terrible penalty followed. The pillagerl canp hat ledemgerl to victime of the plague. On their retum lowe the thenese, carried thither by the exulting

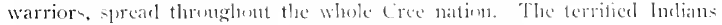
scatteres and the infection wat thus spreat hrosteat.

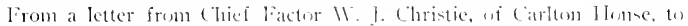

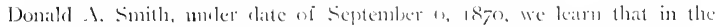
plains whole banels of the aborigines were being abliterated and that the deadly malaty was at work ameng the whites ats well as the ludiams. Mr. Christic begged earnestly for medical assintane and for military or pollice

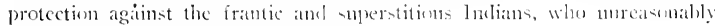
blamed the whites for the pestilenee.

"At Fort l'itt," he salys "two hundred Indians died, and they bronght their dead and threw them atganst the stodkates te try and give the infection to the Whites. In all cases, we have $(1)$ go and bury their deat, and I an told the sench is awful. In the plains, the air for miles from a deas camp is infected from the dearl lying unlmriecl. From the Rucky Jountains to this place it rages, and lyy repert it is in l'ace River, but this is not confirmed by any letters 1 have received from State Lake. . . We trade nothing with the lndians: We in all we can to save them, scattering them in the wexds, and giving then :mmmition, etc., yratis, and ater all they blame us for the maliuly. At Fort P'itt, a party cance in, thinking w that Chicf Trater IV. II. Witt there, and were to murder him and Traill if they found them. They say they sent the malady among them,-poor deluded creatures."

On the terrors of this feartul year still more luriel light is east by letters from the heroic misionaries, such an Father lacombe. The reader will be interested in perusing the following extracts from a letter from that great Indian apostle to Rishop Tache:

1 Dominion Seme papers 20 to 46 , Vol. 11t. No. 5, 18,1. 
$x^{2}$ 


"Nission of St. Paul (Crees), Saskatchewan, I2th, Sept., is,o.

“. . . Yon are aware, $1 / y$ Lerel, that I spent all last winter anidst the Crees and Blackfect. Having left the Keverend Father Dupin and Brother Scandon with the Crees, I came hatek here for the passage of Monceigneur Grandin. Aiter taking leave of IIis Lorclship, I set ont for the camp of the Blackfect, where I arrived after a jommey of twenty days. and remained until spring. It was then that I first became acepainted with the terrible epiclemic disease of whicli we still continue to suffer. At that time the contagion was not so dangerous ats it is now, particularly in the camp in which I was statincel, but information reached me that at Riviere des Ventres' and near the Missonri, a great number of the Piegans and Blood Indians were cut off by it.

"After a long and trying jomrney to little Slave Lalke and Peace River. I arrived at Lac la liche in the midelle of July, and convidered myself cntitled to a few day' rest, lut the time hat not yet come. I received intelligence that the Indlans were on the eve of arriving at St. I'anl stricken by the discase. Bidcling farewell to rest, I hasteneel to the relief of my dear coplytes. En route, I met Reverend Father Dupin on his way to I ac la Biche, to be attended,- he was langeronsty ill. I got here on the isth July. None but those who wine-eed it can form an ieleal of the spectacle offered to my viow. L parats of onc lumbed and thirty families were busily occopiecl pitching their tent atromel my dwelling. Jlardly alighted from my horse. I had to respencl to the cries of the poor sufferers, calling on me with all their might. When I now recall to minel the two months I passect, exposed to the plague, and worn out with fattigne. I most gratefully acknowledge the visible and special protection of P'rovidence. Poor Indians! What a pitiful sight they then offered, and still ofler, as a great number still labener under the painful disease. Every one implored my aid and charity--some for medicine, others for the bencfit of the last sacraments. 1)ay and night I was constantly occupied. Scarcely had I time to say Mats. I had to instruct and baptize lying infidels, confess and anoint our neophytes, at the point of death, minister to different wants. give a drink to one and food to another, and kindle the fire during the cold nights. This dreadinl epidemic has taken all compassion from the hearts of the Indians. The lepers of a new kind are removed to a distance from the others and sheltered witl branches. There they witness the decomposition and putrefaction of their Lodies several dars hefore reath. I camnot define the nature of the contagion; some say it is smallpex. other scarlatina. For my part, I am lect to believe that it is a complication of several dincases and putrid fever. The patient is at first very teverish, the sin becomes red and covered with pimples, these blotches in a few dars form scabs filled with infectious matter. then the flesh begins to decompune and fall off in fragments. Worms swarm 

in the parts mon afiected. Inflammation of the throat imperles all pasigre for meat or drink. While enduring the torments oi this crucl agony, the sufferer ceatses to breathe, alone in a poor shed with no other assistance than what I can afford. The hideous corpses must be huried, a grave must be dug. and the budies carried to the burial ground. N3l this flevilues on me. and I an alune with Indians, disluetrtened and terified to such a degree that they hardly dare approach even their own relatives. (ind alone knows what I have hat to endure merely to prevent their mortal remains being devoured by doge. On the other hand, my toil atre amply repatil by the consolation 1 experience in witnessing the happs aspesitions of the poor Indians at the hour of leath. This tacit teaching of the "Master of life has done mote among the savage Tribes than all our ectmons. While I was thes employed an Indian arrived fon lictorias sent hy the Chief of his Camp. The messenger eagerly hesunght me to come ame visit his people. With difficulty I escaped from the gratsp of my own Indians, and the sime day, before sunsed, I was in the midst of the Judians of Victoria. They also were affleted ly the epielemic and thought themedves entirely forsaken.

"I baptized several at that place, and did all I could to reliese the suffferers, during the two nights and a day that 1 deveted to them. I then came back to my lndians, many of whom had expired during my alsence. but they had all received the sitcrments lefore I hat leit.

"At last the news of 11 y situation reached St. Mlleren immediately two lay brothers were sent to my aid, amel were of the greates service to me. The plague having beeome les intense, I anticipated a little re-t. Surklenly a courier from st. Whert conveyed to me the deleful news that the epiclemic had just reached that station: the only misionaries left there, being the first infected with the dicase, were then dangerouly ill, and owing to thi. several of their people had died withont religinn asistance. You, kind and Reverend I'astor, can readily imatgine with what speed 1 Hew to assint my dear and afticted brethren. I rejoiced on fincling them out of danger on my arrival, and during two days 1 was comstantly oecupied in assisting the dying. The Orphanage of the Sister of Charity had become an hospital. All their orphans were laid up at onec, and rediced to extremity. Seeing that the Fatlers were recovering. and semewhat able to assist the sick of their mission, 1 cane back to those 1 hat left at mine. Reverend Father Dupin arrived yesterday. The is hetter. lut still very weak. and umble to hear much exertion. Nevertheless. he willingly consents to remain alone, and benctit the poor sufterers that are still close to our habitation. I am therefore enabled to rejoin the camp of holians in the l'ans to afford them assistance. and profit of the good di-positim produced hy the hand of God.

"Your Lordhip is undoubtedly aware that the sane contagion is cruelly 

ravaging at Carlton. Mons. Granclin arrived there at the nonent of most painful emergency. You know enough of his zeal anel self-sacrilice to form a just idea of the prorligious acts of charity he has accomplished. Is soon as he heard of the illness of the missionaries of St. Mlluest, he decided to leave Carlton and start for Edmonton. The venerable Prelate passed this way a few days ago. and appeared exeesively fatigued. I te camot lic otherwise, for amidst the horrors of his situation he has had as much to culure from his tender-heartedness, as from his delicate constitution. Ifow could we spare ourselves when we behold such a Chicf!

"P. S., 2oth Sept-Xy. Lord, what a melancholy sight in all our Missions of the Saskatchewan; onr poor population is more than ileeimated, as many as six burials in the day at some of onr Stations. What a trial! This evening I received heartrending letters from St. Mlbert. Our hest families are entirely cut off by the pestilence. bishop Grandin having foumd the missionaries of St. Albert and J alie St. Anne sufficiently recovered to attend the sick, has already gone to the plains to suceor the hunters who are dying in great numbers. Nay God have pity on us. "Paree Domine, parce populo tuo!" "

To cope with this fearful plaguc a Saskatchewan linarel of llealth wats organized in 18ja, with the follewing gentlemen at members:

Rev. (ieorge Mel)otgatl.

Rev, lather Luduc.

Rev. Father. Indre.

Richard I lardisty, (hiei Iactor, Jludson's liay Company.

Father Lacombe.

Bishop Grandin, St. Nlbert.

Bishop larrant, La liche.

Father Fonrmond.

Rev. Jlenry Steinlieur.

Rev. Peter (amplell.

Rev. John .MeDougall.

John lium, Ermonton, Secretary.

This body forbade the sencling of furs ont of the Saskatchewan region during the current session, reported the sanitary conditions of the territory to the II imnipeg anthorities, and took all other precautionary measures possible under the circumstances, and gratually the pestilence was stayed.

Meantime, as a frist provision for the coming development and settlement of the Far IVest, the task of determining the boundary between Canala and the United States was mulertaken $(\mathrm{I} 8-2)$ by a commision representing the Govermments of America, Great Britain and Camada. Two years later the line hat been matked as far west as Mlilk River in Sontlern . Mherta.

Had certain plotters hat their will there wothl have been no need of 

surveying any international boumlary in North llestern Mnerica. The story of the Fenian rajels which theatened the Canadian Vies in the early seventies belongs in a special sense to the llistory of Minitulat, hut as crents connected with it stubefuently hat an important bearing ujon the treatment of Jonis Riel and are of much intrin-ic interest, the whole disgraceful episode will here bear review. Mforeover, it is manifent that if Manitoba hat been wrenched from the Empire, at the insane filimeters desired, then what is now Saskatehewan would certainly not he under the britich flag foday.

The following extract is from a memoramelum acempanying a report of a committee of the l'riry (inncil printed in the sessional papers in 1872

$$
\text { "January 25. 1871. }
$$

"In the montle of Xisember, 186 iz, a comgress wif perems styling themselves the fienian lirotherhoul, and consisting chictly of natural borm and naturalized citizens of the Lnited States of . Imeriea, was eomened at Chieago, in the State of Illinois. Since that time there han been a regulatly organized body, styling iticlf the lenian Jirotherfuod. It healepuaters have been in the City of Xew Jork. It has hat a Presielent. Sinate, and House of Delegates, and has ocenpied lutillings on which the Fenian flag has been openly dieplayed. The Fenian foremment hat collected a revenuc. and has issucd bonkls and notes; it hats a regularly organized army with prescribed uniforms, and ofticers regularly commissimed, and sworn. There has been no secrecy about this arganization, and wo attempto conceal its objects, one of the principal of which las been the compuest of Camadit, against the people of which, it is not pretended it has hatd any callse of complaint. The drilling of the Fenian troops has been carried on in the most open mamer, sometimes in the open air, and at other times in halls procured for the purpose.

"In the month of August, 1865 , the Canadian fiovermment received confidential information that a Fenian expedition againet Camala was being organized in the Western States, and from that time forward preparations for an invasion by a large foree were active and increasing, and contributions were levied from. Anerican citizens to a very large amount. Is an instance of the publicity of the proceclings, reference may be made to a meeting held on Sejtenuber 27, I\$65, in Mozart I Iall, in Cincinnati, at which Jurlge Noodruff presiderl. On that oceatsion one uf the spealiers satil, according to a report in the (incinnati /)aily Engincer, of the 2sth September. 1865. '250,000 men with bristling haynets will be secu hattling for the cause of Irisl freedom before the snow of next Deecmler."

"The same paper reported that alter the speaking "it was amumuced that committees womhl be apjointed in the varions 1 atr ls who would vi-it citizens during the coming week for purpose of raing funcls for the purchane of 

rille to be used by an lrish army. The same procedings which tork place in (incinnati were arlopted in many uther cities and towns of the Cuited State during the Autumn of 1865 and IVinter of 1865 -6o6.

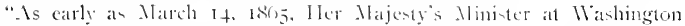
called the attention of the finsermment of the Linited States to the fact of the existence of an exten-ive conspiraty on the part of the so-ealled lienian Brotherhosl, and peinted out that officers in the service of the Lnited States had taken part in the proceenlings of that twoly. There ean lie no dentht whatever that the (iovernment of the Lnited States were fully cognizant of the preparations mate for the inva-ion of Cantala. which culminated

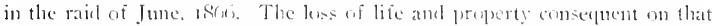
ontrage com titute one of the clams for repatation. Mthough the forem-

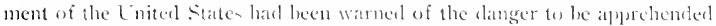

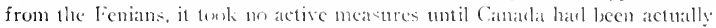
invared, when is is atmitted it displajed on -iderable atetivity.

"The leater of the invalling furce was convicted and sontenced to imprisomment, together with other ringleaters, amd large quantities of armwere seized by the fisernment of the Linted titater. Cinfortunately at very short time claped before the lenian leater were momelitionally reteacel

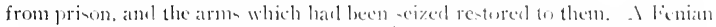
Congress was hele in September, 186 , little more than three menthe ateer the rais in Camatla, and on that occasion it was puldicly ammonced that the Fenians would not be content until Catlatat was invarterl agatin.

"From that time forth numerens meetings were helil, as well ats halls. pienies and other demenstrations, all avowedly with the object of raing fund for the invacion of Canadit. It some of these meetings there were imposing military displitys of masses of me.t in Fenian uniforms, ollicered. armed and eynipped. Gentlemen in high positions in the lnited stites attended these meetings, as will appear in the following instince:

"In Chicago, in Augunt. 1866 , a pricnic was held and it was announcerl in placarts and hand bills that General logan. Covernor Oglesty and Speaker Colfax wouk attend a speakers, and that the lenian soldiers would parade the gromuls. In the course of at yeech, delivered on the oceation by Speaker Colfax, speaker wi the llome of Representatives, he saicl, as reported: 'I confess I was humiliated when our army was sent to act an police ofticers on the Canatlian line. I was humiliated when our army wan sent to do the dirty work of spies and cletectives against the Fenians."

"On the 28th May, 18 \&, it was stated in the announcement of a "Grand Civil and Military. Pienie, to take place in Xew Vork, that the fth Regiment Irish Revolutionary Army will parale. and he reviewed by General O'Xeill." Drilling was openty catricel on in liufialo, on the Terrace, and in Chicago. on Wabash Iremuc. 



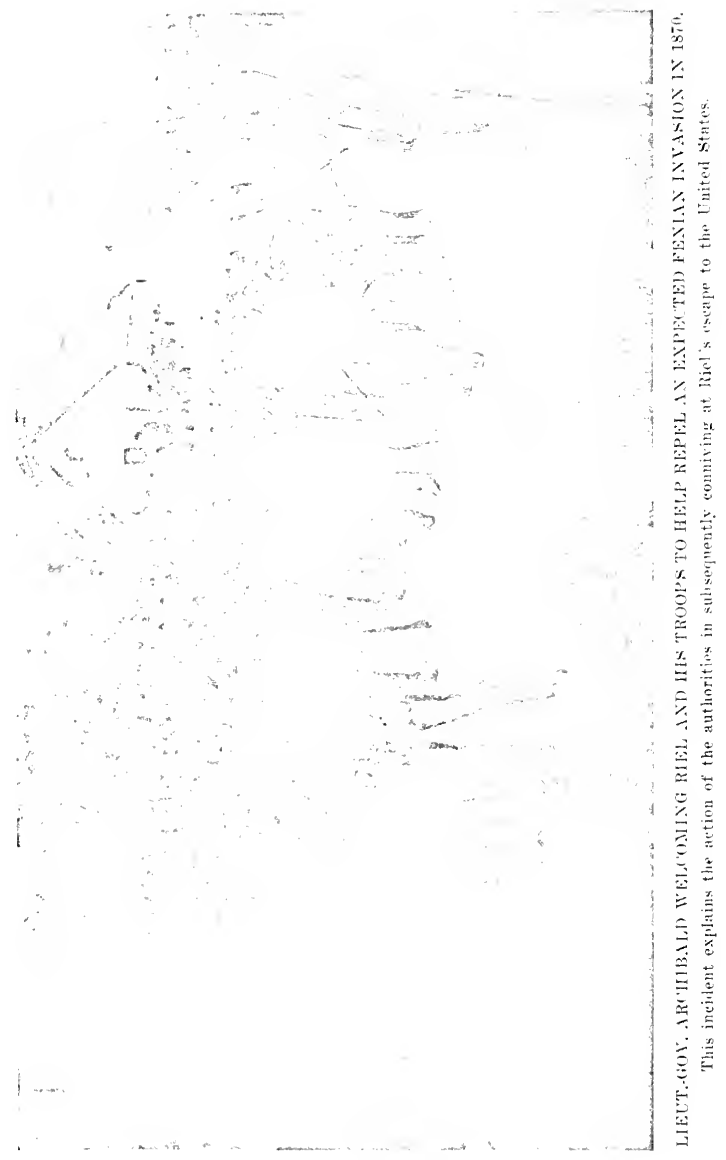



"In November, isos, a Fenian Congreas was held at Philatelplia, at which three regiment of the Irish kepullican Irmy, mumbering fully 2,000, were paraded in line, commanded hy Cohmel William Clingen. There were likewise present General $0^{*}$ Yeill, J'resident of the lienian lirutherhood, and the following: Stafi-General Smolenski, Chief of Staft; Colonel John II. Byron, Aljutant-General; Colonel J. J. Donnelly, Engineers: Xajor J. O'I.cary, of Ordnance; and others.

"In 186\%, Gencral liarry of the Luited states Army, commanding on the fronticr. lis leadquarters being at Biffale, had a mumber of his men tried and convieted of a breach of military discipline by leaving their guarters and joining a Fenian military display. In a very short time after their sentence, and when their term of imprisomment had scarcely legem, a pardon was granted to the soldicrs from headfuarters, at Mislington, and soon after General liarry was removed from his command. It has been positively asserted by the Fenians themedres that they had received assurances from very high quarters that if al demand shutel be mate on the State anthorities for troops to aid the regular troops. they need not feat that this would be speedily given. In April, 1870, arrangenents which were well known to the authorities of the Cnited States, hat been male for an invasion, but no steps whatever were taken to prevent it. Fortunately, the Canadian (iovernment ascertained that a raicl was in contemplation, amel ealled otn a large force at considerable cxpense, which detered the leaders for a time. So soon as the Canadian volunteers hat been di-binded, the preparations for invasion were renewed, and the rail of May, 1870, took place at a time when it was supposed that Canada was completely oft her guard. Gireat stress is laid on the fact of General ONeill: arrest hy the United States Marshal, but it must be borne in mind that no attempt wats made by the Narshal to prevent the invasion, and that it was after the complete defeat and dispersion of the Fenians, by the Canadian voluntecrs, that Gencral $O^{\prime}$ Neill was atrested, as he hat been in $186 G$, to be again tried, convicted, and again pardoned unconditionally:"

To meet the raiders expected in Manituba in 1870 l.ientenant-Governor Archibalel felt compelled to acept the services of Riel himedi. Mr. Archibald reported to the Ottawa authoritics that the French Ilalfbreeds loyally rallied to the suppert of the govermment irrespective of the troubles of $186 x$ ) and isfo, and that in the ranks of the ritiders there was only one French Metis. The capture of ()Donoghue, the Fenian leader, was made by a number of French J Jalibreds. Is in this episode the Lientenant-Governor officially and publicly recognized the lowal services of the leaders of the late so-called rebellion, the central anthorities very properly felt that the subsequent enforcement of capital sentences mould be grosily inproper. These facts acconnted for the fovernment's attitude in connection witle the 
prosecution of Lepine for his share in the murcler of sontt and for the of ficial connivance, and indeed the official financial asi-tance, b which Riel's second eseape to the Enited Sitates was hronght about.

In I873 occurred the infamons Cypress I lills Masuacre, which convinced even the most earcless of our Candian politician of the presing necessity of establislung a Momnter Police Joree of adepuate size in the North West. The white desperadoes engaged in this affair were a grump of American whiskey traders of whom J'hilander logel wats one of the ringleaders. Vitrions pretexts for the outrage were subsegnently offereil, but it seems erirlent that the white renegades were simply bent nom acouning the glory of having wiped out an Indian village. One evening at a tine when the Indian encampment wa- leveted to bilitrity, and the Indians were mote or less under the influence of liquor, the traters actranced into a river leed, the banks of which gave them complete coter. Irom this position they had the village, which lay near Massacte or Ihatte Creek, entirely at their nerey, as the Indians were gathered romel their canp lires in open view. The Anericans murdered thirty-odil, wounderl probally twice as many, and hove the others into the hills.

The whiskey tracles after thi- horrid affair burned their fort and retreated into. Anerican teriters. The ontrage wa bronght to the attention of the Presielent of the Lnited States, as at that time it was supposed that the massacre hat occurred south of the numarled International Fomdary. When the American authorities learnet that this was not the catee, the matter was referred to Ottawa. In 1875. Najor Trvine succederl in effecting the arrest of some of the ontlaws concerned. This in itself produced a most salutary effect uyon the lawless inclined, and especially upon the Canadian Indians, who began to see that the Dominion anthorities were intent upon protecting them from the impositions and violence even of white men. No convictions were secured, lut the energy shown by the anthorities made this the last event of its kind to ocent on Canalian soil.

At best, however, a govermment operating from Fort Gary conld exercise but little infuence in the far away settlements of the IVest. consepuently in $1875 \mathrm{We}$ find the IIalfhecels of liatoche and Carlum district establishing among themselves a provisional govermment, generally ummentioned in the histories and now all but forgotten except by a hamdful of our oldest inhabitants. The head of the movement was the famons hunter and warrior, Gabricl Dumont, who had come to the Saskatchewan from the Red River settlement in IS68. Tuder his presidency the Metis organized themselves upon the basis of the laws of the buftalo hunt. Now, however, these laws were no longer to depend upon mere voluntary acuniesenee: Dumont and his associates arrested varions hunters who declined to join the Halfbreed Confederacy, and issued orders forbidding all others to approach his terri- 


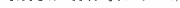
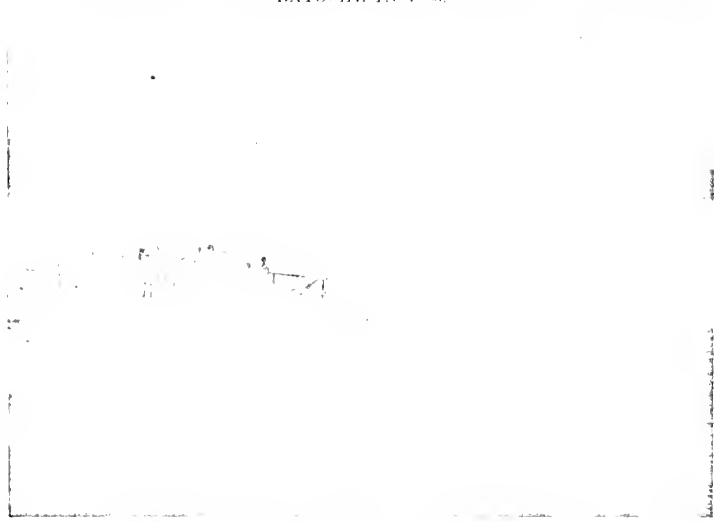

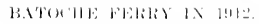

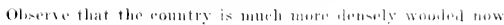
that at the time of the liebullion. 


$$
\text { . }
$$


tory. One camot hut sympathive with the unletered thetis in this sporatic attempt to establish something approaching an effective gorermment, but of conrse the procedings were illegal and licutenant-(iovernor Morris was obliged to intertere. To avoid arest aud prosecution, Dumunt released his prisoners, gave them back their confiseated property and the fines which had been collected from them, and made his peace with the police.

Towards the encl of the period to which this portion of otr treatise is devoted the settlements in Saskatchewan aml elsewlere through the West had so increased in population that it was manifesty imposible longer to entrust their govermment to a nom-resilent official whose hands were alreaty more than full as Lientenant-Guvernor fur the I'rovince of Manitoba. I luw the duties of govermment hat leen fultilled, and how the new order of affairs was introducel we shall see in later chatpters.

Apart from the event- to which we have already alluderl, the most nuteworthy ocenrences of the period of 1850 to 18,6 are connected with the surrender of their lands ly the Indians from the South. The storics of these events, however, are so interesting aml impotant as 10 reduire treatment in separate chapters.

In 1875 the Earl of Southerk pullished a work entitled Saskatiheran and the Rocky Mountains, in which he gave an exedlent aceount of his journey and observations the preceling year throngl the North West. Nhout this same period Nilton and Chealle's gossipe narrative also appeared, and somewhat later, 1)octor G. M. (irant publisleel lis work contitled Fron Ocian to Occan. These and other similar books of tratel and reports of explaration did much to make the far Viest hetter known, and to attact the attention of the Federal Governnuent to the needs of the commiry. 


\section{CIIAI'TER XII]}

\section{POLITICAL HISTORI OF THE TERRITORIES FROM IS7O-1876}

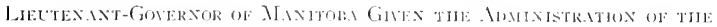

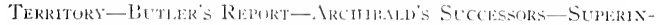

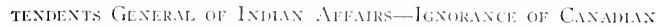

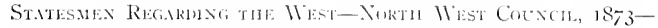

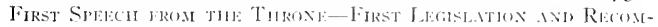

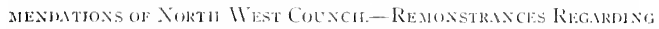

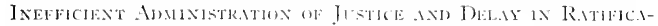

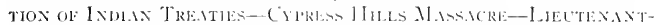

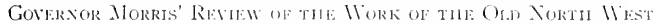

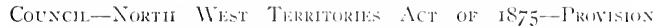

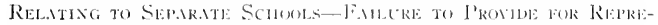

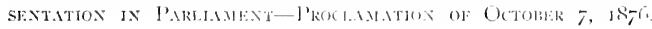

On the zoth day of July, isfo, there wan tramsmitted from the Guvernor-

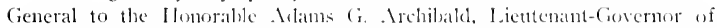
the l'rovince of Manitoba, a commi-sion appointing him also lictententGovernor of the Nurth Mest Territorien. Jive days later, detailed instructions were issued informing $\mathrm{Mr}$. Archibald of the duties he was expected to perform. These were to inclube, among other things, the perfecting of plans for the establishment for the fricndlicat posible relations between the Dominion Government and the lutian tribes. and reports upon such lands in the Territories as it miglt be lesirable to open up at once for settement. The Lientenant-Governor presenty issued to Captain IV. F. Butler. F. R. G.S., the well-known suldier, traveller, explorer and anthor to whom references were male in the precerling chapter, a commision instructing him to make an extencled tour of the North 11 est with a view to collecting information of value to the atthorities. On returning from this jonrney of 2,70o miles, Captain Putler submitted a lengthy report which now constitutes an historical document of the very greatest value. To it the present writer is indelted for much of his information regarding conditions at this time.

Archibald's regime encel in is-2. For a few months the position of Lientenant-Governor was held ly Mr. Francis G. Johnson. On December and of the same year, lientenant-(inernor Morris assmmed the reins, which 

be held untit the inauguration of the Forth Viest Council, with the I Ionorable David Laind as resident Lientenant-(ionernor of the Jerritories, October. I876.

In view of the importance of Indian affairs during this epoch, it may be well to mention the superincudents General of this department. The Honoralile Nr. Howe hele! the office from is 8 . to 1873. Nr. Gibbs succeeded him in June of that year. hut on the first of the following month he gave place to Mr. Camplodl, and he, fom montls later, to Mr. Iaird. The services performed by the last named gentleman were of the highest value to the people of Canala and to the Indians and western setters in particular. The office of Indian Commissioner for the North West was for a time held by Mr. Wemss Simpson. who was steceeded in Is/2 by Mr. I. A. X. Provencher.

During the sesion of the Dominion Ilonse in 18; the Govermment was interpolated by I) onald . I. Smith, menl)er for Sellirk (now nore faniliarly. known as Lord Stratleonat), as to the steps it inteneled to talie for the regulation of tracle in the Territories and for the control of the traflic in intoxicating lipuors. However, very few Canadian statesmen really linew anything about western conditions and it was not until the following year that any provision was mate for the establishment of a real govermment in the far llest.

A curious illustration of the extraordinary uncertainty regarding the West and how it was to be goyerned occured a couple of monthe after the arrival of $\mathrm{Mr}$. Archibald and mon his assumptiun of thitics as I.icutenantGovernor of the North West Territuries. The Let of Jume 22, 1860, entilled "An Act for the temporary Govermment of Rupert"s Tand, and the North Western Territory when united with Canala" authorized the (ioxernor-General in Council to appoint a Nimth West Council of seven to fiftecu members. This arrangement, as regards the Territories proper, was left undisturbed by the Act defining the provincial constitution of Manitoba. When confronted by a small Wox $_{\text {epdemic }}$ in his distant territories, the new Lieutenant-Governor felt the necessity of the immediate creation of a. North West Council to deal with Territorial interests. Astonishing to relate, he had no copy of the Rujert's Iand Act of rolio in his ponession, and indecel there was none in the Colony! Now, Mr. Archibalil's memory played him the scurvy trick of deluding him into the belicf that the appointment of the Council lay in his own hands. Consequently. on Octoler 21. If;o, he appointed the IImorable Francis G. Jolnson, Ex-Governor of Issiniboia : Donald A. Smith, Chief resident Executive Officer of the IIndson's Pay Company: and Pascal Préland. a leading French Halibrecd. They were sworn in the following day and promply entered upon their supposed duties. The most urgent of these had to do with the pasing of Ordinance for the suppression of smallpox and of illicit sale of intoxicants in the Terri- 

tories. Whether valid or not from a legal standpoint this peculo-legislation had all the force and effect of law in the 'lerritories. Mr. Archibald promptly reported these transactions to the Secretary of State for the lrovinces, who in reply called his attention to the provisims of the Act of 1 isfo hearing on the constitution of the Conncil. Mr. Arehibald's explanatum of the part he had played in this amusing political burlespuc reals in part ale follows:

"Lnfortunately, though 1 had been in the provine from September 3 rd,

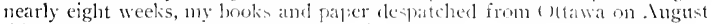
Gth had never reached this place. and in all Manitolat not a single copy of the Acts of $\mathrm{I} S(6)$ was to be ionud.

"I had but a vague recollection of the terms of the Rupert"s I and Act, but I assmoled that substantially it wuld be the sane at the Manitolna Act so far as ny power of apprintment was concerned. Jutere Jehnsun, with whom I conferred, conld not adel to nuy information. Mir. Donatal I. Smith. who was the Commissioner of the finverment of Candal during the line the Act was applicable to the whole North Vest, conld give no particulars. Accordingly, I diel the best I conld in the emergency."

A long time elapsed before any properly constituted Comeil was created. On December 9, I87o, Mr. Archibakl submitted to the Foderal Govermment the names of ten gentlemen suitable for appointment, and on November 2.3. I87, he sent in alditional names. On December 28th of the fullowing year the Canada Gazette announcel at last the appointment of the Nortl lliet Comncil to which eleven members were named. In the meantine lientenantGovernor Archibald had retired from office, so the first legally combituted North lleet Comncil was organized under the presielency of Licutenant Goveruor Morris.

At the lirst meeting of this boly, March S, IS7.3. the Humurable Mlesses. Girard. I1. J. Clark, D. A. Smith, Pascal Bridancl. Nifred Boyrl, Jos. 1)ubnc. and A. G. B. Bannatyne assembled. Other members of the Conncil were Messrs. John Schultz, William liaser, Rolert IJamilton and Milliam J. Christie. The last named gentleman was the lludson Bay Company's dhief factor from Fort Simpson. To attend the Cumbil a journey of two thonsand miles by dog train was necessary, repuiring almost two nuntle of actual travel.

The special feature of the first mecting was the following interesting abdress to the Council delivered by lieutenant-Guvernor Morris:

"Honouralile gentlemen of the Council of the North llest. I have much pleasure in calling yon arome! me to assist une in the administration of the affats of the North 11 ese Territories. The duties which dewhe upon you are of a highly important claracter. I comuly of vast extent which is in possession of abundant resources is cutru-ted io vour kecping: a country. which though as yet hut sparscly setted, is destined. I believe. to become the home of thomsands of persurs. by means of whose industry and energy 

that which is now almost a wilkerness will le ruickly transfurmed into at fruitful land. where civilization and the arts of peace will flomish. It is for us to labour to the ntmost of our power, in oreler to hring about, as speedily as possible, the settlement of the North II e-t Territories and 1 lo development and mantenance of peace and order, and the welfare and happiness of all classes of ller Majesty's subjects resirent in the Territories. The seple and nature of your aubority are set forth in the let of the Dominion Fatratment where the formation of this (ouncil is anthorised, and in the Oreler of the (noverner fieneral in Comncil. coptes of which will be lajel before your.

"Among other matters which swould claim your immediate attention will be the taking of means for areertaining in what portions of the North Ilest Territories settlements lave leen formed. and suggesting to the Dominion Government the propriety of survering and dealline with the lands in those dietricts. It will also be advisable to asectain the mumbers of the varions native triles, with the localities in which they reside, and to suggest meatsures for concluding satisfactory treatics with then. Means must be devised for the proper administration of Justice, the prevention of trade in intoxicating liyuss. and the vigorous assertion of the law in ali cases of crime and dierorder.

"I will also take your comusel at to the most appropriate locality in

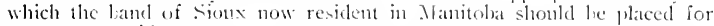
permancut residenee.

"I now invite you to anter mon the duties of your affice. well assured. as I am, of your sincere desire to atsi- me lovally and fathifuly in the administration of the affation of the Forth West and in the development of that mighty region whose future I helieve to he so full of promise."

The powers of this Commcil were narrowly circumserileel, hut it passed much important legislation and male many valualble recommentations to the bominion anthorities. An invitation was extended to the new GovernorGeneral to visit the Mest. The appoinment of Stipendary Magistrates, Justices of the Peace, and a resident Judge. Was recommended. The nise of poison by the settlers was prolibited, and attempts were make to prevent the traffic in intoxicating liepurs, the orlinance of licutenant-foscrnor Archibald and his still-horn? Council of 1870 being re-enteted. A resolution hoking to the establishment of the North West Momnted J'olice was also carricd.

When the Comncil met again in September, the Dominion Gorernment had passed acts elealing with lhe creation of a police force and administration of justice in the Vorth Mest. hut, to the clagrin of the Council it had not given effect to its act will reference to the appointment of Justices of the Peace. The Council again, therefore, directed the attention of the Gorermment to this matter. and petitioned for a still larger military forec. They commented upon gross outrages committed upon the native population and Her Majesy's subjects generally by American desperales in the 'Territories. 



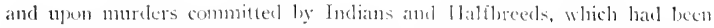
allowed to go unpmished because there were no mean at land to cuforce the law. ${ }^{1}$

Mneh of the time of the conncil was devest to debite and resolutions upon the urgent neeessty of the constmmation of treaties with the Indians. Repeated representations in this eonnectim were necesary before the wis

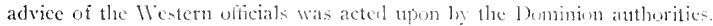
Indeed in this and other comnections the Comncil fomml it necesary time and again to protes in the most vigorons language again the libtory proceedings of the Ottawa atulorities. I typieal resulum in this regaril closes as follows :

"Sensible as they are of the great importince of the dutics which they are called upon to jerform, and eamesty desirous ats ther ate to discharge those duties loyally and efficiently, the council feel that they will be mable to do so if matters which they helieve to be of urgent importanee, and which they have taken oecasion to represent as steh, be permitted to remain altogether unwoticed for a perion of months. They ther fore derm it their duty most respectully to call the attention of llis Excellency in Conncil to this important subject."

Such protests occur continually throughout the mintes of the Conncil. Still another may be quoted:

"That this (ouncil decply regret that the l'rivg. Commeil has not luen pleased to communicate their approval or disaproval of the legitation and many resolutions adopted by (iomeit at their meetings heli on the

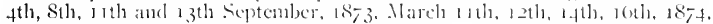
and Junc ist and end, $185+$, and they respect fully repre-ent that such long delay has paralyzed the action of the Conncil."

The Council was also serinu-ly lampered by entire lack of funds, a circumstance which it is hard to recall without mingled ammsement ame indignation.

Among the important resolutions in 187,3 was one calling attention to the fact that there was at present no public provion for postal communication in the Jorth 17 est Territories. In another interesting and suggestive renolution the thanks of the Comncil were voted to the liev. Mr. Mekay of Stanley Mission for translating. printing and pulblishing in the Cree language certain Nanitola Ordinances, the provisions of which had been extenrled to the North Vest Territories.

On May 3. 18,3, provicion was made for raising the maximum mumber

${ }^{1}$ In introducing the Nerth 11 est lerritorice let of $18-5$ Premier Mackenyie staterl that the Government had ancertained from the most anthentic soures that within the preceling year and a half there hatl heen nearly one humber and fifty murders committed in the North 11 en Territories, chiefly in fight leetween Indians and. American traders-for which no person hat heen brought to trial. 

of (ouncillors from lifteen to twenty-two and on ()etelere 22, 1873 , the natmes: of the llonorable Mesors. Joseph Renal, l'ierre Delorme, Walter R. Brown, James XeKay and William X. Kentey were athed to the roll of the North West Council. Serious attention was given cluring this session to the Cypress Hills massacre and "the langer of an Inclian war ant of international complications which might emboil at any mument the Liritish amel American people."

It is of course impossible w report here in any detail the varions procedjngs of this inlustrious ant intelligent gronp oi llestern Conneillors. P'erhape the best way to review their work will be ly reproducing an addres delivered by the licutentat-fovernor in the (inncil's last session, 1975.

The lientenant-(iovernor referres to his apeech when council fir:t net after its formation ( .1 arch $R, 1873$ t, and continued as follows:

"I think this in a fitting oceasion to review the work the Council hats alecomplished, and to place on record the result of it legistation and of its sugge-sions. The present Council are now only acting provicionally and a new Conncil is to be organized. partly mominated by the (rown, and partly elected by the people, with a view to exercising it a functions under the presdency of a resident cosernor within the Territories themedes. I am confi-

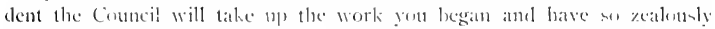
endeavoured to carry out, and I trust that they will prove suces- ful in their efforts to develop the Territories and attract in them a large pepulation.

"Though you had many dificulties 1w contend with, you summented most of them, and will hatre the gratification of kwwing that you in a large meatsure contributed to shate the pelicy which will prevalil in the Govermment of the Territories and the anlministration of its affitirs.

"At your first meeting you pased an . let to prohibit, under ecrain restrictions, the importation of spirituon lipuers into the Territuries. and the l'arliament of the bominion has since atepted your views, and given effect to them by the passing of a law of similar import to that you framed. I am glad to say this meatse has proved effective ant will, I believe, contribute largely to the prometion of the well-being of the popmlation of the Territories, and to the prevention of disorder and crime.

"Yon also made provision for the applointuncent of luntices of the Peace, and in comection therewith yon represented to the Governument of the Dominion that certain legivlatinn, effective elewhere, slonlit be extended to the Territories, and that a Xenuted Polies force under military discipline should be establinher in the Territories for the mantenance of order therein, and the enforcencent of the laws. Vin have had the saticfaction of seeing thene suggestions adopted, and of hnowing that the lolice Force which you proposed has proved. and is proving of the greatest serviee in the Territorien.

"Sucin were sme of the results of your first meeting. and your sublec- 



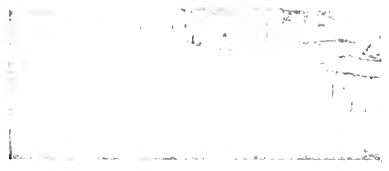

FurT WI.11

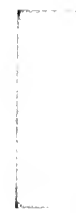

I'Hi' M.11 1.6.61\%

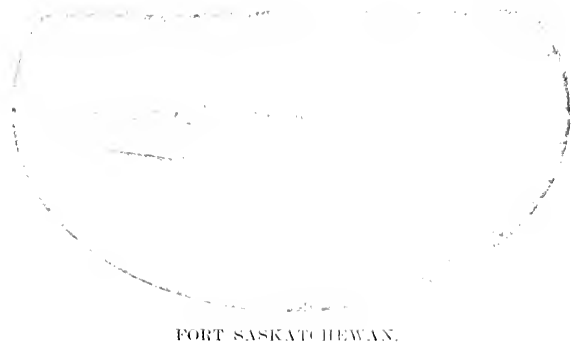



quent sessions were not unproductive of good. I will only mention generally some of the more important subjects you dealt witl.

"You were and are of opinion that the Nilitia battalion shoukl be maintained and should be so increased that an effective force should be available in the Territories.

"You proposed that treaties shonld be made with the Indians of the plains, at Forts Carlton, Pitt and (Ji: Ippelle, and you suggenterl that schools should te provided for, that agricultural implement and cattle should be given to the Indians, and that teachers should be furnished to teach them the arts of agriculture.

"You have seen a treaty concluderl at Qu'Appelle, and I am glad to inform you that treatics will be made next year at the other points indicated.

"You urged that Stipendiary Nagistrates should le appointed, resirlent in various portions of the territory, clotherl with powers to deal with certain classes of criminal offences, and also with a limited juristiction as regards civil cases, and that a resident Jutge, with (Juecn's Pench powers, shoulu be appointerl to deal with graver matters, with an appeal to the Court of Quecu's Tench in the Province of Manitoba, in certain cases.

"Yonr recommendatinn as to Magistrates has been adopted by the Dorminion, and thougl power has been given to Juglges of the Xanituba Courts in the Territories, this can only be regarded as a provicimal measure, so that I doubt not your proposal will be eventually carried into effect.

"You called attention to the necesity of steps being taken to punish the actors in the Cypress Ilills tragedy and your recommendation has been acted upon by the Privy Council with the best effect as regard the Indian population.

"You proposed that a monthly mail should be established between Fort Garry and Fort Edmonton for the convenience of the public, and it is to be hoped that the private nail now carried for the wse of the police and the Pacific Railway service may prove the precursor of a much-needed boon to the people of the North Wiest.

"You urged that measures should be adopted to collect duties in the region of the llest known as the Belly and Bow River country, and your representations were complied with.

"You passed laws for the appointment of Coroners, for caring for orphan children, for regulating the relations of Masiers and Servants, for the prohibition of the importation of poisons in the territories, and of their use in lunting game.

"You asked that the existing highways, portages and watering places in the Territories should he set apart for pullic use, and that as soon as treaties with the Indians were completed surveys should be taken, and some 

of these subjects have heen dealt with by the Privy Comcil, but others still remain for their action.

"Such then is a brief review of the work yon have accomplished, and I need scarcely tell you that you have reasun to be well satisfied with the results of your executive and legislative action, for during your regime, most important steps have been taken towards the establishusent of law and order in the Territorics, and towads the creation of respect anong the people for the anthority of the Crown.

"The fonndation has now heen laid for peace, security and the advancement of the sctlement of the vast region you have muled ower, and for the securing of the good-will of the Indian tribes, and I can only express my confident trust that those who follow you will rear wisely and well a noble superstructure on the bisis that you have established.

"I will now, in conclusion, ask yot to enter upon the ordinary work of the session, and will suggest that you houkl. lxefore you separate lay down some mode of dealing with a subject which is of the ntmost importance, at respects the relation of the (ioverument of the ()neen with the lndian tribes and as regards their means of livelihood. while they are passing through the transition process of lecing prepared to earn at living from the soil. I mean the regulation of the buffake hunt in such a way as to proleng the subsistence afforded to the native triles by the wild eattle of the North 11 est, and thus to give time for their gradual civilization and acem-tomment to practise the arts oi agriculture. I woukl also strggest that yeu should atopt measures to prevent the spread of prative and forest fires.

"You will now procech to the discharge of your duties, and I am confident that harmony will prevail among yom, ant that you will exhibit the same ciesire to arlvance the best interests of the Dominion which hats hitherto actuated you."

The hopes and plans of the Governor with regard to this lant session were amply inlfilled.

In 1875 the Honorable. Mexander Nackenzie introduced in the I'arliament of Cinada. and passed, lis North IVest Territories Act under which the aftairs of the Territorics were conducted for the next thirteen years. This Act separated the office of Licutemant-Governor of the Territories from that of Jientenant-Governor of Manitoba and provided for an appointed Council to consist at first of five members. The Governor-fieneral in Conncil was given authority to athlhorize the Liententunt-Governor by and with the consent of his own Conncil to make provision for the administration of justice, and the framing of ordinances on many matters of local corcern. When any portion of the Territories not exceeding une thonsand eptare miles in area should contain at least a thousand adult white British subjects. the Lieutenant-Governor was by proclamation to erect such a district into 

an electoral divisins, and shonld the population of the district increase to two thonsand, it would be entilled to eleet a second representative to the Forth West Council. At such time ats the clective members would be twentyone in number the then existing Conncil woukl cease and determine, and the elected members wotld constitute the first leggislative Assembly of the North lVest Territorics. Elective members were to hold office for two years.

Clanse 1 i of the Act related to schools, and as its provisions subequently proved the cause of mucl debate and agitation, the reader will be interested in examining it :

"Wïen and so soon as any svstem of taxation sluall be adopted in any district or portion of the North West Teritories, the Lientenant-Conernor, by and with the consent of the Comcil or Assembly. as the case may be. sladi pass all necessary ordinances in respect to education: Int it shal! thercin be always yowided that a majority of the rate-payers of any district or portion of the Nurth lles Territories, and any lesser portion on sublivision tinereof, by whatever name the same mat be linown, mat cstablish such schools therein as they may think fit, and nuake the neresuity assessment and collection of rates therefor: and further, that the minority of the rate-payers herein. Whether l'rotestant or Roman Catholic. Maty establish separate schools therein, and that. in such latter case, the rate-payers establisluing wels l'rotestant or loman (atholic separate sehouls shall be liable only to assessments of such rates as they may mpore upon themedies iil respect thereto."

An important omission from the new Territorial Constitution was that of any provision for representation in the J)minion l'arlianent.

On the 7 th of Oetwher. I8-6, the North 11 ent Territories . Let was brought into force by proclamation. With this event the era to which Part Il of our Inistory is devotel came to an end. liefore leaving it. however. it will be our duty to discuss in some detail the Indian situation and certain important events associated therewith. 


\section{CHAPTER XIV}

\section{UNREST OF CANADHAN INDIANS AND INCURSION OF TIHE SIOUX}

Discontext and Suspicion of Inding in Liter Years of: Hedson's B.h

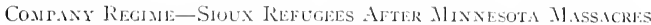

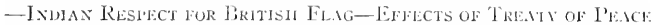

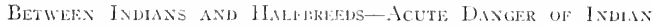
War, 1873-Second Ixcersiox or Slovix Refugles, I876-

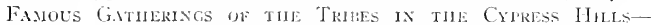

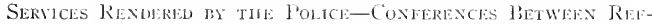
Ugee Indins axb Ambricix Commissiuners-Depletiox a

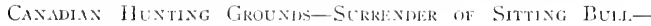

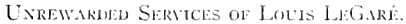

Already during the latter part of the Ifucton Baty Company's regime the Indians of the British II est were developing a spirit of unrest which cansed profound anxiety among all thought fnl men familiar with the facts. Even so long ago as is 37. petitions hat leen presented on belialf of the Indians, complaining of the non-fuldillnent of the Sellirk treaty. As the prospect of settlenent by the whites increased, and buffalo and other game decreased, the spirit of opposition to any further influx of white men became steadily more and more pronouncel.

In 1860 , Hind and his company were clecked in one of their expeditions by the lndians, and he reports the following speech delivered by a chief:

"The reason why we stop you is becittse we think you do mit tell us why you want to go that way, or what yeu want to do with these paths. You say that all the white men we lave seen belong to one party, and yet they go by different routes; wiy is that? De they want to see the Indian's land? You gather corn in our gartens, and put it away. Did you never sec com iefore? It is hard to deny your request, but we see how the Indians are treated far away. The white man comes: looks at their Howers, their trees and their rivers; others soon follow; the lands of the Indians pass from their hands, and they have now here a home."

At the close of the conncil the chief sait to the interpreter:

"Let these men not think bad of us for taking away their guides. I.et them send us no presents: we do not want thent. Ne do not want the 

white men; when the white man cones he brings diecase and sickness, and our people perish; we do not wish to die. Natry white men would bring death to us, and rum people would pass atway. Ne nisto to live aud to hold the land our fathers won and which the Gireal Spirit has given us. Tell these nen this, and the talk is finisherl."

Hind also reported that the plain Crees had in comeil detemincel that. in consequence of promises ofter made and broken ly the white men and halfbreeds, and of the rapd destruction by them of the buffalo, they would not permit the white men and halibrects to hunt in their conntry, or travel through it, except for the purpose of trading for their dricel meats, promican, skins and roles. Ilind speaks of war with the northern prairie tribes as "sometling to he expected at a diy"s notice."

The dangers of the whole situation were most seriously angmented by the great incursion of warlike .merican Indians which occurred during the period to which this section of the present look is devoted. The Sious had been unfriendly with the French in old days for airling their enemies, the Chipeways, and after the fall of the French power in America, they had allied themselves with the Englioh. Inicet, in the troublous period of the seventies, it was not mommon for refugees from American territury to claim that they were still Pritish, and to produce, as native evidence of the fact, old George III medals presented to their ancestors a century before.

In 1862 there occurred in Minmesota one of the must fearful ontbursts of savagery of which modern listory gives us a record. - Mbout aight humbed men, women abd children anong the whites died terrible deaths before this revolt was quelled. Many American lutians wo had tatien part in these ontrages fled to Canada to escape the vengeance of the Lnited States. In some cases the American authorities were alluwed to purste their Indian foes even npon british soil, but in general the refugees found them. selves sate under the aegis of Victoria, "The Great White Nother." Consequently, even when peace was restored south of the border, many of those warlike miscreants persistently refused to return to their former homes. Some of them even olstined reserves, and the present representatives of these and other nomadic bants of Sionx still live under the British flag.

As a general rule, these refugee Indians have shown a grateful loyalty to the British Crown for harbor afforded them. The well-knewn missionary. Egerton Ryerson Young, m his work entitled "By Canoc and Dog Train," relates an incident interesting and illmumative in this connection. Ile and his party entered the country a $i a$ Minnesota. That veteran missionary, the Reverend George MeDougall, acted as guide. The missionaries were warned by the settlers that it would be impossible for them, with their valuable horses and other property, to make their way through the Indian country without falling victims is the treacherous and blootihirsty Sionx. "Oh! 

Yes, we will," saicl Mrr. MeDongall; "we hate a little flag that will carty us safely throngh any lnelian tribe in America." The prophecy proved true. for whens a few day's later, the trateller met a band of sions, the sight of the Lnion Jack, fluttering from a whip--itock, cansed them to throw down their arms and approach to shatie hands with the britishers. In passing

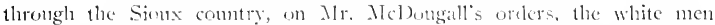
stowed away their atmon, and met the Jndians as friends. It nights the

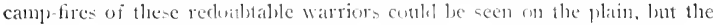

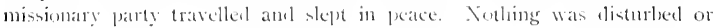
stolen.

Nevertheles, it must never be forgotten that if an Indian war hat really broken ont in Canatia, these statwat satages wonkl certainly not have been on the side of the white men. Their perence, therefore, wats an important factor in hatening the comsummation of the Indian treaties, the story of which will be related in the next chapter.

The Sionx were the hereditary enemes of the Canarlian Fndiam and halfbreeds. In 1862 , however, a great peace was comsmmated through the

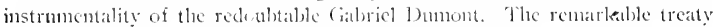
which bronglt to an end the regulatrly recurring wat expeclitions of the precerling century was signed at lace in biable. The Sirmx declaterl that the country would helong to them, to the halfheeds, and to their Canatlian Indian friends in common; hat atl parties to the atgreement should be permitted to lunt the buffalo in peatee. This notable event reducet the danger of any immediate resort to hostilitics on the part of the Indians. On the other hand, by the settlement of their own internicene fends, the native races were really rendered in some respects more dangerons, from the point of view of the whites. Shonld trouble arise, the struggle would not be with isolated bands, but with a conferleration extending far and wide over the plains for hundrets of miles.

In I8 83 the danger of war with the Indians was the sulbject of important correspondence letween Lientenant-Gesernor Norris and the Ottawa anthorities, and the records of the old North VIes Council contain varions evidences of the gravity of the situation as viewed by the members of that body: The Itonorable Xr. Noreuar, a prominent English Halthreed, who subectunty hecame Prime Ninister of Nanitoba. the Ilonorable lames Mackay, another Métis, who was also a prominent menler of carly Manitoba cabinets and sulsecunently speaker of the Legislative Comeil of that Province, and the llonorable Xr. Breland, a prominent French-Canadian. were appointed to investigate the situation and to extend promises of an carly settlement of Indian grievances by satisfactory treaties. Mr. Brélant's services in this comnection were of special importance, as is indicated in 

the following extract from an official report written by the JientenantGovernor:

"I have the honor to inform you that I have arrangexi for Mr. Brélands immediate departure to lort lillice. I hate authorized lim to teil the Indians in the neiglonerhood of liort Fllice that the Commissoner will visit them in the stmmer. [ am nuch pleased with the spirit displared he Mr. Préland when he acepted this mupertant and somewhat diflicult mission. He was on the point of starting on a visit to his old hone in lise rrovince of Queliec, after an absence of thirty years."

The Commiscioner of the Government amply corrulutated the report: of the general anxiety which was incleed all too justiliable. Jndeed, Mr. Norquay organized the people of l'alestine settlement for the purpose of self-defonse, and in varinus localities the settlers prepared themselves for a life and death struggle with the red men. For the fatet that no suct calanity. occurrer, Camala owes unlying gratiute to the North Mest Momnted Police and to Messts. Archibalkl. Morris, Lairel amb others who will be mentioned in the followiag clapter.

Thongl the topic lechng specially to the period covered in a later portion of this hisory, it will he most convenient to refer here to a second wave of Sionan immigration, which eccurred alnuet simultanenuly with the transfer of the Gerernument from the Lientenant-( inernor of Nanitolsa and lis North Viest Conncil to the resichent J ientenant-fovernor and Council provided for in the Act which came into force on Octoluer $8,1876$.

Dakota was at this time the home of a large Sionan population. Into their midst suddenly came a throng of more or less lawless immigrants. greatly excited by the eliscovery of valuable gold deposits. The races clashed and the unpartomble brutality of the whites precipitated a serions Indian outbreak in 1876 .

The Indians were under the leatership of a number of distinguished chiefs, of whom the most notworthy was Sitting Full. It the lattle of Little Big Ilorn of June 25. 1876. Sitting Bull ontgeneraled bis foes. IJe succeeded in enting off a detachment of cavalry consisting of two lumelred and sixty-four men, moler the commant of feneral John Armstrong Custer. This regiment was absolutely annilibated. To avoid further fighting, Sitting Bull and his warriors then withdrew to Canala, where he attempted to secure the support of the Canadian Indians, but the recent Indian treaties and the admiralde conduct of the North West Motnted l'olice checkmated their plaus. Indeed. Sitting Pall himself conceived the heartiest admiration for the Camarlian police.

When Sitting liull fir came into the conntry there were with him only abont one humbled and fifty lodges. Ile was presently followed, however. 

by many other bands mut they totalted some seven hundred lodges, or alwout live thousand six lumedred souls.

During this dangerous crisis a great gathering of the Indian tribes was held in the Cypress Hills. It was estimated that three thousand warriors were present, representing the Pcigans, Blackfect, Bloods, Assiniboins. Crows, Gros Ventres, and Anerican sioux. The eastern newspapers called upon the Government to send troops into the Wiest, hut those familiar with the circumstances recognized that any show of force, to be of value, nunst be overwhelmingly strons. It was therefure thought more discreet to leare the Mounted Police to deal with the excited Indians, at these representatives of law and order already enjoyed their frienclship, and so well knew their character and custons. Accordingly. Xajor Irvine, with at -ulaltern and ten men. was instructed to attend the great Indian conference. In the Toronto Globs, July, 18 ga, the following anussing dispatel appeared. Thetween the facetious lines may be reakl a story of comage, slurewelness and successful audacity such as have uo often and so honcurally fonnd a place in the records of our famons price force:

"Fort MeLeom, July I, 18-6. White the American papers are tecming with telegrams referring to the movements of fenctat lerrys army of fotre thousand three hundrer! nen, and of the advance of these roopis in three flivions against the sioux in the Jallowstone region, at sinilan movement of troops on this side of the line has heen succeshinlly made, of which no notice has yet been talken. (O) Jaly lith list. Ascistant Commissioner Irvine, commanding the North West ifonnterl I'olice in this district, advanced on and completely denoralized a large encampment of Indians at Cypress Hills. The camp ntimbered over one thound lodges, of which one hundred lodges were of Sitting litull's band. Colonel Irvine advancerl his troops in a mass of coltumus, the whole numbering ten men. llaving stecessfully pierecol the centre of the camp, he threw amonget the Indians. at close quarters, hand grenades of a new pattern, patented by an eminent firm in Canada. These nuissile were composel of sea biscuits, tea. sugar and tobacco. The Indians never recovered from the first discharge. On the following riw, the left wing of the riglit division, consisting of one man, was dispatelied to a mixerl camp of Indians, numbering one hundrerl and fifty lodges, with orders to seize a certain number of horses stolen by then from the South Peigans. peacefully, if possible, lat in the case of resistance, to capture the entire band. The horses were recoverel."

- Nevertheless, though the expatriated Sim refrainet from litwless violence, their presence in such large numbers greatly disturlect the Canadian Indians and settlers. In the Saskatiheian Jferuld of February 10, 18,0. the following comment upon the dangerons situation occurred:

"The principal event that brought alout the exintings state of things is undoubtedly the presence on the lunting grounds. Formerly accupied by our own people, of the harge hands of Thited States Indians who recently einered upon them. Their numbers are varionsly estinnted at from six 

to ten thousand souls, and the bufialo killed amomnt to hundreds daily. This wholesale slaughter, and the exclusion of our Jutians from their hunting grounds, are undoubtedly the cause of much distress that prevailed last summer, and gave rice to the rumoss of coming trouble. Providentially, great bands of fat buffalo cane down from the nountains in the attumn, and furnished a good supply of food for the winter, thus removing all cause of alpprehension for the present. The incursion of these foreign Indians could not be forescen. nor could it hare heen arerted, so that it was impossible to guard against it or puovide a remedy for the hardships it brought in its train."

An American priest, Reverend Father . Ibbot Martin, and two companions visited Sitting liult's camp in June, I877, with a view to infucneing him favourably to returuing to Anerican territury. Sitting Bull notified Irvine of their presence and the assistant commissiuner visited their encampment, and presided at a conference. Speaking of Sitting bull, lrvine rejurted as follow: :

"His spech showed hin to be a man of wonderful capalbility, and I was much impressed."

The following is a dialogue taken from the reports of the conference:

The Father: "J am not sent by the Government, but I an atsured that what I promise will he carricel cul. Do yum intend to return to the other side or remain?"

Sitting liull (curning to Colonel [rvine): "If I remain lece, will you protect me?"

Colonel Irvine: "I told you I would as long as you helave vourself."

Sitting liull: "What wouid I return for? to have my horses and arms taken away? What bave the Imericans to give me? Once I was rich: plenty of moncy; but the Americans stole it all in the lilack IItls. I latse come to remain with the White Mother's children."

On the 2fth of August, I877, David Mills, Minister of the Interior. wrote Commissioner Macleod that the Lnited States had appointed General McNeil and General Terry commissioners to negotiate with Sitting Bull. The ensuing conference took place on the $\mathrm{I} / \mathrm{th}$. Sitting Bull shook hands warmly with Commissioner Macleod, but passerl by the Interican commissioners in the most disdainful manner. He and his companions sail distinctly that they would believe nothing the Imerican commissioners might say.

In his report of the conference, Colonel Macleod writes:

"It is a matter of common notoriety all over the western country that the Indians are systematically cheated by he agents and contractors. The former on a salary of fifteen hundred follars a year have nuny of them been known to retire witl fortunes after two or three vears of incumbeney with their ofices. The Indians know of these scandals and as a consernence have lost all faith in the Goversment under which all such fratds are 

perpetrated. I think the principal canse of the difficulties which are continually cmbroiling the American Gosermment in troulde with the Indians is the manner in which they atre treated be the swarms of adventurers who have scattered themselves all over the indian comntry in search of minerals beiore any treaty is matle giving title. These men always look upon the Jndians as their natural cncmics amd it is their rule to shoot at them if they approach after being warned off. I was actually asked the other day by an American who has settled here, if we hat the same law here as on the other sicle andi if lo wan justified in lunting any Indian who approached lifs camp after leing warnet not to alvance."

In the course of the conference Sitting binll arose, and, after shaking hands with Commissioner Macleod and with Inspector Walsh, spoke as follows:

"Ny fathers, yeu know well bow the Ancricans have treated 11 , and what they lave jone for ws. They take me for their son, lout they have come helind me with their gums. Il len jirst one nation learned to shoot witle the gun to kill meat for one children and wemen it was ly the finglish we were taught: but since that tince ] bate been in misery: I tell vou the truth! since I was raised I hate tone nothing load. The Anericans tried to get our combty from as: otw country. the liack Ililts comntry, was filled with gold: they knew hat the gold was there. I told them not to go into it. I diel not wish to leave mi golden conntry: I latd not given flem the iand any more than you would hille given it. The Gieat llmighty and the Qneen know that there is no harm in me and that I diel nothing wrong. $\widehat{\Lambda}$ the present time in my own cotintry me people snfer from the Ameri-

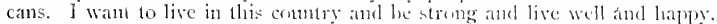
I knew that this was our lircat Mlohler"s house when I canne here with mo people. Now I see plainly that there are no more deer, elk or huthalo on the other side of the line! all is blond. I don't beticve you will help the Anericans to do me harm. as long as I ledave. Today vou heard the sweet talk of the Americans. They would rive me flour and cattle and when they got me across the line they would fight nue. I dent want to distarl, the gromul or the sky. I came to raise my children here. fiod Almighty always raisec! me buffalo meat to live ons. Nie will pay for what we want here. We asked the Mmericans to give us traders, but instead of this we got fire lalls. All of the Americans rolbed, cheated and laughed at us. Now 1 tell you all that the Americans have done to us and I want yout to tell our Gireat Xlother all. I could never live over there again. Ther never tell the truth: they toid me that they did not want to fight, but they commenced it."

Prolonged efforts were made by both the American and the Canadian authorities to induce Sitting Bull to returut to the Lnited States. Indeed. the Anerican Govermment insisted in very emplatic terms that the Guvernment of Canala should either compel the return of the reiugees or olslige them to withlraw from the boumlary so as no longer to he a menace. The Canadian authorities, however, refused to take eitluer contse so long as 

Remmants of a vanishing race. Property of lominion fioserment.

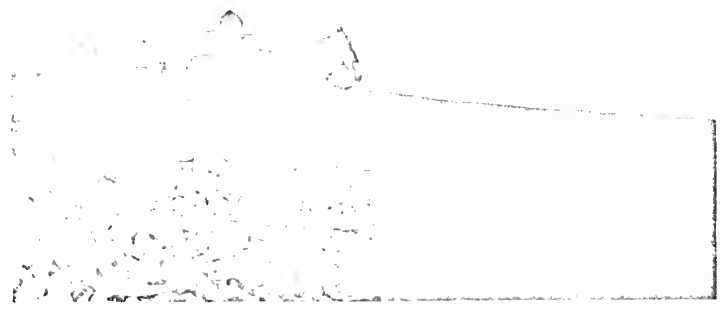

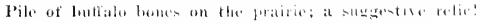

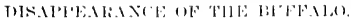



Sitting bull and hiv companions refraincel from lawlessness. It the same time steady moral pressure was applicel and crery eflort male to restore confidenee in the good inith of the Anerican Government. This argument was poweriully seconted by humger. It was the policy of the Cantulian authoritics to prevent atual starvation en the part of the refugees, but to promise them nothing in allanee and to male no permanent atrangenent with them for their maintenance. In conseyuence, many of Sitting bull: followers kept returning south of the line from time to time. The following

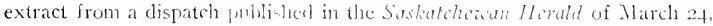
1879, purports to be a cony of a messige sent by Sitting liull to some of his relatives at Standing Rok. Igeney. If it is anthentic, it indicates that at this time the great chief himself was anxions to go back home, if favourable terms conkd be obtained:

"Once I was strong and brate and my people had hearts of iron. lut now I will fight no mure forcter. My peolle are cold and hungry. My. women are sick and my chihlren are frecoing. 1 will the as the circit Father wishes. 1 will give nuy guns and ponies nuto his hatuls. My artows are broken and my wat paint tistown to the " inds."

Nevertheless, the Sioux chief did not yet return to his reservation, and

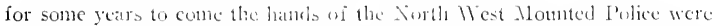
kept full in the effort to look after him and his followers.

Superintentent llatsh, speaking of the contuct of the sions amb of their relations with the pulice, wrote ats folluws in his report for 1880 :

"The conduct of those starving and destitute people, their patient endurance, their sympathy, the extent to which they assinted each other, and their strict observance of all order weuld reflect eredit turon the most civilized commmnity. I am pleased to inform youn. as no, doulh it will give you pleasure to know, that the greatest good fecling and consideration was extended to these poor sulferers by the men at IVoxl Mbuntain l'ost. The little that was daily left from their talue was careiully preserved and meted out as far as it would go to the women and children. During those five or six wecks of distress I do not think that one ommee of ford was wasted at llood Mountain J'ost: every man appeared to lo inlerested in saving what little he conld, and day iffer day they divided their rations with those starving peopk. I must further mention that the Indians received assistance from the halfhreels."

Walsh also says that Sitting Bull promised not to place any obstacle in the way of those people of his cantp who wished to return to their agencies, and that he kept his worrl.

"If the White Nother," -aid Sitting liull, "is determined to drive me out of her country and to force me into the hands of people who I know are but waiting like hungry wolves to take my life, would the Superintent- 
ent not see the Tresident of the Linited States and ascertain the best conditions wpon which i may be permitud to return :"

Walsh replied that if the Canadian Government would permit him to do so, he would comply with this regtest. This proposed mission to the American cajutal is said, in police circles, to have been prevented unly by the personal vete of Sir John Machonald. In the summer of $188 \mathrm{~s}$, Sitting Bull came to Qu1. Ippelle with those of his band yet at large in Canala. He expected to meet Colonel Walsh, who was absent on leave, pre-umably in connection with the business allurlect to above. He found Colonet sitcele in command, and when he presented his request for a reservation such as other Sionam bands had oltained in the preceding seven years, Stcele told him that it was not to be expected that the Canadian (iovernment would assume this buden, when he hat a reservation in his own country, awaiting his return. Sitting bull then reguested provisinns. Fitele told him that it was quite impossible for him to malie any standing arrangenents, but that since Sitting bull and his band had hitherto been law-abiling Indians in Canada, he would give them one good feed, and strongly urged them to return to their homes. Shortly after this lientenant-Governor Dewdey came to Qu'Appelle and arranged to feed the Siotn on their way back to Wood Jlomntain, with a view to enconraging their early return to the States. On their arrival at Diri 1 lills, provisions presently gave ont, and sitting Bulls Indians were in desperate straits.

The well-known fur trader, Louis Le Gare, of Willow Bunch, informs the writer that at his own expense he supported the starving Indians with a large amount of food, and that he hat numerous serious conferences with Sitting linlt and his stbordinates. In his store at 11 illow Punch he induced many of them to surrender ani retmon home, and ultimately succeeded in convincing sitting Bull himself of the wislom of following the same course. Sitting litull then visited the late stperintendent. A. R. Macdonell, who was in charge of the Momnted Police at Wood Monntain. To him he renewed the requests previunsly pressed upon Colonel Steele and others, but with like unfavorable result. In his desperation he then even threatened to violently seize the food supplies of which his penple stond in need. Nactonelt told him that the police hat been his friends and would continue to protect him and render him all the assistance that lay in their power so long as he and his followers reirained from violence. It they appealed to arms. however, or attempted intinidation, they would he treated as national enemies, blood would he shed, and Sitting Inll's position would be rendered very much worse than ever.

Sitting linll mate a gesture of despair and cried ont in Sionx. "I am thrown away!" Mackonelt toli him, however, that he should not take any stich view of the case, as he had been well treated in Canada, and wonld 

escape his destitution by an immediate return to the Lnited States. To 1his, then, Sitting IBull finally agreed. Nacronell immerliately accompanied the Indian chief to Joplar kiver, where they arriveel next day, and met Major firotherton, representing the Inerican anthorities. To him sitting Bull gave up his rifle. Meantine, Le Gare harl been collecting the Sioux whom his bonnty had saved from starvation. They were taken by him, in carts, across the horder and fed at his expense for a considerable time. Mr. Le Gare states that his ontlay in tliis connection anomnted to eight thousand dollars. IJe, of conrse, looked to the American fovermment for rembursement, but recesved from that source after long delay, only five thousand dollars. The important part played by Le Gate in this entire episode seems never to have been officially recognized, and incled, as far as I am aware, this is the first time that it has ever been mate public. ${ }^{1}$

However, the matter has been bronght to the attention of the federal authorities on varions occasions. In his ammal report, dated February, ISS2, Commissioner Irvine wrote as follows:

"I also wish to bring to the fitrorable notice of the Dominion fovernment the good and loyal service rendered by Mr. Lonis le ciart, the trader, who at all times nsed his persull infuence with the sions in a manner calculated to further the policy of the fosermment. His disinterested and homoralble course leing decicledly marled, particularly when compared with that of other traders and individnals. It the final surrender of the Sionx, Mr. I.e (iaré must have been put to considerable expense, judging from the amount of food and other aid supplied by him." =

Two years after his returm to the Eniter Siates, in 1881 . Sitting Bull settled at Standing Rock Igency. Rumors of a coming lndian Messiali. who would sweep away the whites, disturhed the Indians of Dakota for some years subseguent to this event. The Judian unrest was so acute that it was ultimately detcrmined by the American authorities to arrest Sitting Bull as a precantion. This was done in Decenber, IRyo. An attempt was made by his companions te rescue him, and in the mele the unfortumate old warrior met his death.

1 At the time of writing it is not too late, thongh it soon may be, for Canada to show in a tangible way her appreciation of Mr. Le Gare's unrewarded services on this and other crucial occisions. Iide Chapter 2r.-Canarla's honor is involved.

Fatith has been broken by men presuming to speak on behali of the Dominion, else some suitable mark of pullic gratiulue would have been awarded years ago. 


\section{CHAPTER XV}

\section{LAIRD'S ADMINISTRATION AND COUNCILS, I876-188,}

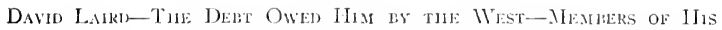

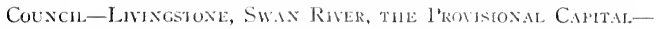

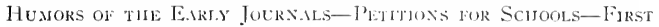

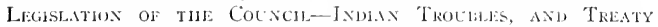

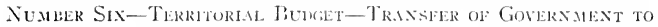

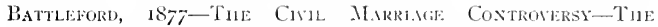

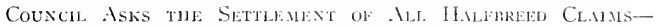

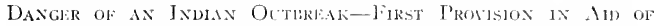

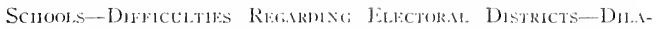

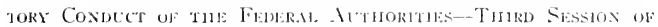

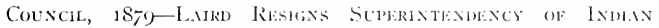

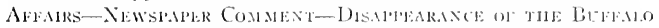

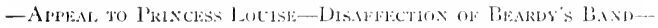

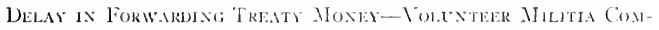

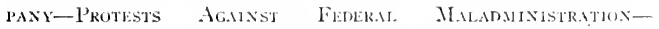

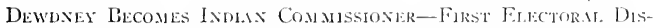

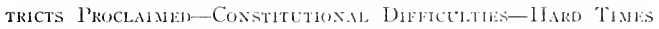

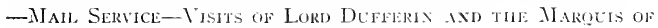

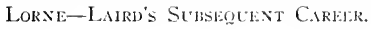

When, on October $7,18-6$, the IJonorable David Laird became Lieutenant-Gosernor of the North IIest Territories, a new era was opened alike in the government and the development of the Mest. Mr. I.aird was already well known to the public as a journalist and statesman. Ife had been a memler of the Ifaythorne administration in Prince Edward Island, and was a delegate to Ottawa from the island coluny when negotiations were undertaken for its entry into the Dominion. In 1873 lie was elected to the Honse of Commons, and in Mr. Afackenzic's administration he held the office of Minister of the Interior. In that capacity, as we have seen in a previous chapter, he had already played a very important part in relation to the negotiation of Indian treaties, especially the Treaty of Qu Appelle. Mr. Laird was subject to his share of acrinonious party criticism, but now that the smoke of battle hits cleared away it is agreed on all hands that there 

are few men who have given to the VTest services more characterized by fairness, breadth of sympathy, integrity and public spirit. The following paragraph is quoted from a well-known puldicist who, though a political opponent, was cognizant of the problems confronting our first resident Governor :

"Nr. Laird's position was far from being a sincenre. Jlis time was taken up with receiving deputations of discontented and often defiant savages. His residence was the central figure of an Indian encampment, for his followers loved to ohserve and comment upon his every movement, and his hitelen was an Indian restanrant, where meal were served at all hours while the guects waited. To add to the pleasure of his enviromments, his actions and motives were misconstrned and misrepresented by some of the eastern newspapers, which were ready with their criticism despite the fact that they displayed a vast iguorance of everything pertaining to the Nortl: West in the very articles in which they censured the LieutenantGovernor. The North West owes a great deal to Mr. Laird; more than can be realised by those who only know the conntry in the present conditions of estalblished civilization and peace."

What may be termed an inside opinion of Mr. Laird's athinictration was expressed by Jonorable Senator Forget. Lientenant-Governor of Saskatchewan, when the corner-stone of the Jeegislative and Execulive builling of that province was laid on Octolser f. 1909, hy His Excellency, Earl Grey, then Governor-General of Canada. IJonourable Mr. Forget, who declared the stone weil and truly laid, then remarked:

"Before resuming my seat I wish to say that it was the intention of the members of the Government of the Province to have the latter part of this ceremony, that is, the witnessing of the laying of this stone and the declaration of its being duly done. perfurmed lye the Ilonorable David Laird. first Lieutenant-Governor of the North West Territories, of which this Province was.then a part. The connection of the Honorable Mr. Laird with the events of those early days and the very great services rentered by him to the whole liest in those difficult times eninenty entitled him to this privilege. We therefore deeply regret his inability to be present here on this interesting day. Personally, having hat the advantage as his secretary during the whole of his term of office of living in his close intimacy, I was in consequence in a position to know and fully appreciate his worth to the country as an administrator. For these and other personal reasons I particularly deplore his not being with us." "

The original Council consisted of the Governor, with . Iméclée E. Forget,

${ }^{1} \mathrm{Bcgg}$. Vol. II, page 251 .

= The ahove extract is taken from the Pullic Works Report of Saskatclewan, for the year inog-10, page 166. 

Clerk of the Council, Mathew Ryan and Lientenant-Colonel Jugh Richardson as members cotofficio in their capacily as stipentiary magistrates, and Licutenant-Colonel James IF. McLeml, C. M. G., Commissioner of the North Went Motnted Jolice, who held his seat at fret hy special appointment ant linter c.r-oficio. To llese names that of Paschal Prefind, who had rendered such valuable asistance on I ientenant-Governor Iturtis, was presently adred. Before forernor latel's regine ended, the (inuncil also in-

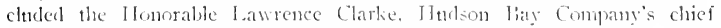
factor, who was chosen by the voters of Jorne in the first election held in the North 11 est, Is8I.

The memlers of the Conncil were sworn in on November 27, 18,6, at Livingstone, swan River. where the first session of the Territorial Conncil

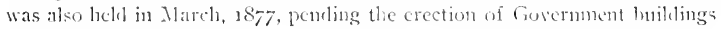
at Batteford. Livingstone was therefore the first provisimal capital of the Nerth llest.

It is hard to restrain a smile as one reats the jomrnals of this miniature legislative berly. It was possessed of a thoromglily alequate anception of its own dignity, and duly olyserved tinc-lunomred customs in acordance with which, for example, the Governor would wake his speech from the throne to his three or four issocittes, and they in turn veuld present an address in reply. From time to time, howerer, the entries in the jommals

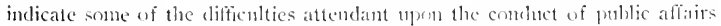
by so small a group of legislatnes, reguired to tratel vant distances to attend their official meetings. Such entries ats the fullewing are not ancommon:

". It two ockock p. m. Mis Ilonor the Lientenant-Governor took the chair.

"Present . . . Mr. Ryan.

${ }^{3}$ The following gentlemen were for the seseinu indicated members of the North

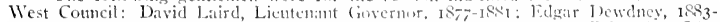

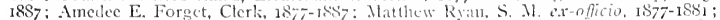

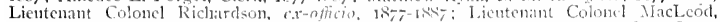

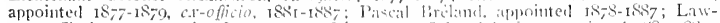

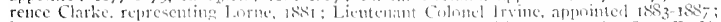

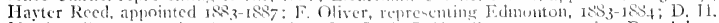

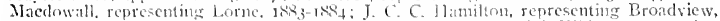

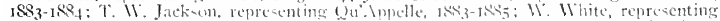

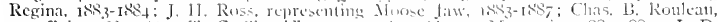

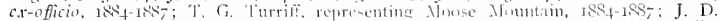

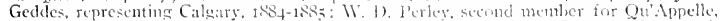

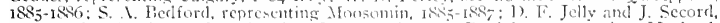

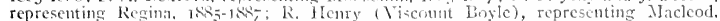

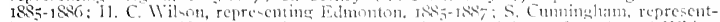

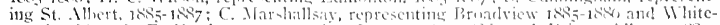

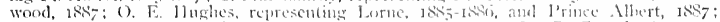

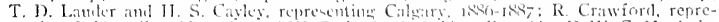

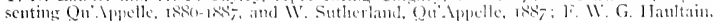
representing Nacleod, 1 sis. 



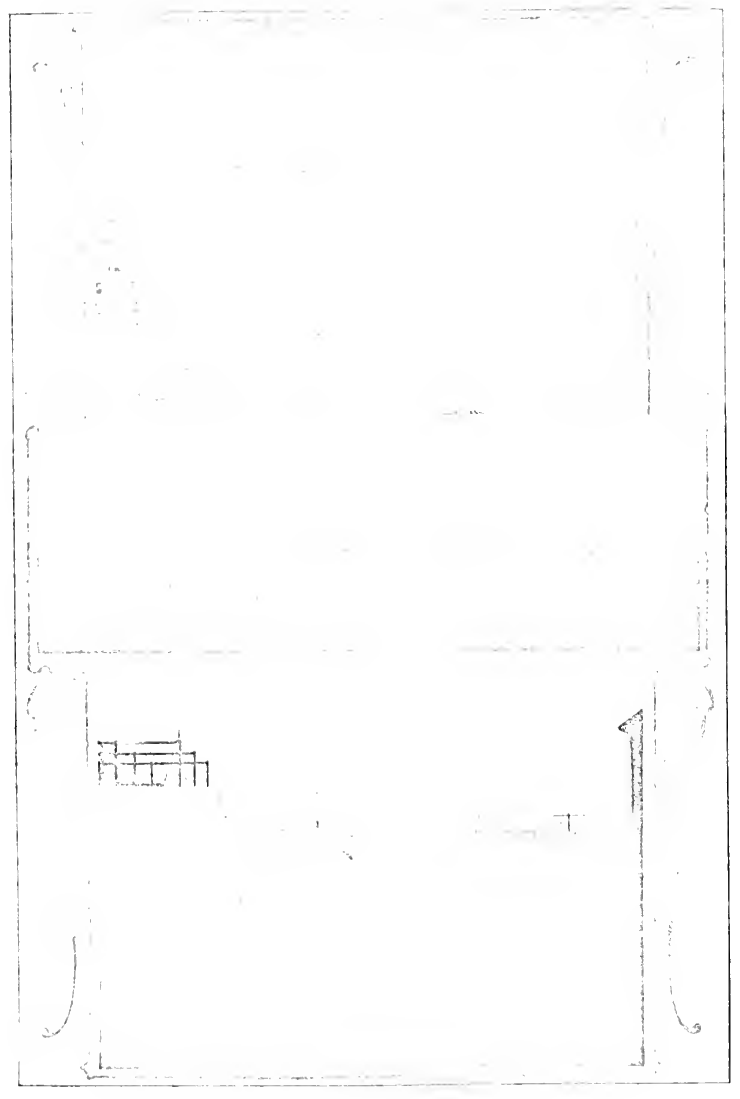



"There not lieing a quortum of members present, His IIonor adjonmed the Conncil."

To attend the sessinn at Swan River, Colenel MacLeod was obliged to travel from Maclecol to Franklin, thence by rail to st. Patul aml Moorehead, ly stage to 11 immipeg, and from there ly dog train 3.30 miles to the provisional capital.

It is interesting to note the nature of the first petitions laid on the table of the Conncil:

"No. I. Petition of Alexander Stuart praying to be granterl a ferry jicense on the Sonth Saskatchewan.

“No. 2. Petition of John Tanner praying that he may be authorized to charge tolls on his bridge on the little Saskatehewan.

"No. 3. I'etition of Moise (Juellette and Pierre L anuly pras ing support for a school at St. Laturent."

Thus the question of education toreed it:elf upon the Conncil from the very furst. but that looly foumel itself in a very minfortunate position in treating of the matter. The attitude of the Council is set forth in the following resolution on Narch $2 \mathrm{I}, 1877$. When the entire diy's sesion was devoted to the question:

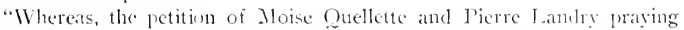
ior assistance tomarols the establishment of at schend at St. Itatrent and salary of a teacher, has hy the Lientenant-Governor leen laiel lefore the Council for consideration:

"Resolved, therefore. that the Conncil reptest Ifis IIonor to reply to the petitioners and inform then that there are no funds in the handi of the Conncil applicable to educatiunal purposes, and that the Council do not think it expedient at present to consider the yuestion of entablishing a y :tem of taxation; and also that His Ifonor he good enough to express to the petitioners the regret of the Council that it is mable to grant a-sistance for so laudable an object as the adrancenent of education in the North Nest.

"The Conncil to likewise desire to suggest that I lis Itonor do forward the above petition to the Honorable the Mlinieter of the Interior. in order that whe Dominion Gorermment be made acyuatinted with the desire of the people of St. Lantent, which is helieved to extend to other settlentents in the Territories."

Ilowever, restricted as the powers of the comncil were, it lost no time in franing important legislation respecting registration of deeds, the protection of the huffalo, the prevention of the spread of infections disease, and other important maters. A number of these topics represented uncompleted busines inlerited from the old Sorth West Cunncil at Fort Garry In all, thirtecn bills were passed at the first session. 

The protection of the buffilo precented a problem of the unost seriomsness and difficulty. The ordintnce of $18-7$ forlack the use of buffald, pounde, the watuton destruction of buffalo at any season, the killing of animals under two years of age, or the slatughter of fente luffalo during a stated clone scason-bricicr for Indians than for others. This bill was framed in the best interest of the Indians and halfhrech, but their very destitution made the protection of the waning herds a hardship, and it was found necesary to repeal the measure in the following vear. Indeed. the discontent of beth bulians and halfbreeds in comnection with these wise gane lews provided sitting liull with a dangerous card, which he wats not slow to pliay in his efforts at this time to rally the Cantelian Indian again the whites. I formidalble onthreak was narrowly averted. Ilowever, Governor Laird and his eollengues pacitied their troultesome wards, and in Octoler of this year Latird's motalile treaty with the lalakfeet was effected.

In these negotiations the prwertul influcese of that wive old warrior, Crowfoot. was on the itle of the atuthorities. In acepting the treaty, Crowfoot expresserl special gratitude to the pelice. who. he said, were protecting his people against bat men and whiskey "as the feathers of the bircl protect it from the frost of winter." In our clapters om "lhe murest of Canadian Indians and the Incurion of the Sirux" and "The surrenter of Saskatchewan by the luclians," we hate already treated of some of the most important events of Governor Laird"s regime.

It is rather interesting to compare with a provincial lonkget of the present day the following statement of receipts for the North Weet Territories from March, 1875, to July, I8;8:

Jicenses for billiard and other tables................ \$1 30.00

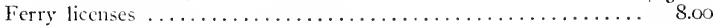

Fines under l'rairie Fire Ordinances..................... 37.50

Fines under Masters and Servants ()rdinances............ I6.00

Fines under the () rdinance for the l'revention of ( iambling....... 302.00

Fines tunder the binffalo ()rdinance.................. I 2.50

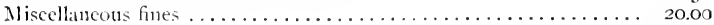

Deposited in the (ntario liank. Winnipet.......... $\$+8_{3} .50$

$\$ 526.00$

Palance in hand of Lieutenant-Governor............ 42.50

$\$ 526.00$

On August I, 18 77 , the seat of the Govermment was transferred from Livingstone (Swan River) to Pattleford, and there the North West Council

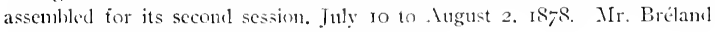
had received his appointment during the recess. 

Apart from the repeal of the bufialo legislation, the consideration of ordinances regarding the fencing of property, the promisenous une of poisons and provision for civil marriages ocenped the major portion of the Council's time. The marriage ordinance authorized clergymen of every church, duly ordainerl and resiclent in the ferritories, to solemnize marriage, and simply rendered optional the performance of the ceremony by a civil magistrate. This latter provision was intended to meet a manifest need in the many healities which were rarely visited by a clergym. This provision, however, provoled the displeasure of the Archbishop of $\mathrm{St}$. Boniface, and produced a somewhat lengthy correpondence, and at length, in June, 1881 , the law was so amemed an to cancel the powers of magi-strates to perform the ceremony, hat at the same time (1) provite that commissioners, appointed for that purpose by the Lientenant-fovernor, might solemnize marriage. The whole episole throws interesting light upon the great influence exercised in the Territories by the dignitaries of the Catholic Church.

Upon the $2 \mathrm{~d}$ of Angust, 1878 , we find upon the jonmals a lengthy resolution with regard to the issne of scrip to halfbrects in the Territories, a matter that appears and reapears year by year thereater. Apparently. no lesson less cmphatic than that involved in the rebellion seren years later could teach the Duminion Govermment that satisfaction among the halflorects of the North West was something not to be expected unless and unite in the matter of land grants, they henld be allowed terms similar to those given their brethren in Manitoba muter the Nanioba Act of 1870. The Council advised that non-transferable foeation tichets shonld be issued to each halfbreed head of a fanily, and each halfhect child of parents resident in the Territories at the time of the transfer to Canadia. These location tickets should be valid on any unoceupied Dominion lands. The title should remain vested in the Crown for ten years, and if within three years after entry no improvenents had been made upon the land, the claim of the halfbrecd locatee should be subject to forfeiture. Fiurthermere, to induce nomarlic halfibeeds to settle and avid the restitution which the approaching extinction of the buffalo rentered imminent, the Conncil recommenterl that some initial equipment of agrieulural implements and grain l:e granted them. Had these wise proposals been received with favor, much misery might have been avoidecl.

The constant danger that petty strife between settlers and lndians might provoke a serious outbreak was ever in the minds of the authorities in these critical days. During the session of 18,8 a petition was presented praying for an ordinance to compel Intlians, camping near a settlement, to kecp their dogs secured, on pain of the animak being lawiully subject to destruction by the settlers. The Conncil pased a suggestive recolution, dechar- 

ing it "inexpedient in the prescut state of the Indian question in this country to grant the prayer of the petitiuners."

In the course of the session, the lientenant-Governor reported to his Conncil that the Honorable Davisl Mills. Minister of the Interior, had suggested the legality and wisdom of action on the part of the Conncil to allow local school corporations to tax themselves for educational purposes. If govermment aid were reguired to suppliment local contributions, the fientenant-Governor shonfel place the amonnt of the reytired sum in his estimates. It was decided to act upon this suggestion, so far as practicable, and in the estimates for the financial year $187 y-1880$ we find an item of $\$ 2,000.00$ in aid of schools.

In these same estimates provision is male for $\$ 1,000.00$ for probable election expenses. This was the dawn of representative institutions. The Lientenant-Governor was manifestly anxious to mect the wishes of the people by introducing an elective element into the Council at as early a date as possible. Mr. Lairal called the attention of Sir John A. Macinmald. Premier and Minister of the Interior, to scrions difficulties in connection with the establishment of representative institutions under the North West Territories Act of 1875 . Ender it the lientenant-Governor had power to erect into an electoral district any territory containing a thonsand synare miles with one thousand male non-Indian inhabitants of adult age. Mr. Laird pointed ont that in British Colmbia and Manitoba there were constituencies containing less than half this number. As yet no electoral district had been erected in the Territories on account of the lack of the requisite population, and there were some detached settlements that under the existing law it wonld be impossible to include in any electoral district for a long time to come. Further, some amendment to the Nortl West Territories Act was necessary to enable the North West Council to pass an ordinance empowering the people of any settlement, with the sufficient number of children for a school, to assess them-elves for its support.

More than six months after the Lientenant-fovernor hat forwarded his estimates inclucling grants for schools, roals and bridges, he was still in the dark as to the attitude of the central Government in this matter. In reply to a despatch of inquiry, the Deputy Minister of Elucation telegraphed him on August 4. 1879; "Please wire scheme you would reconmend for aicling schools; also scheme expenditure for reads and bridges." The LientenantGovener sent the following reply: which is an interesting document bearing upon the founding of school and local improyement systems for the West:

"Battleford, August I6, I870. Propose airl schools supported by missions or voluntary sulscriptions of settlers to extent of paying half teachers" salaries where minimum average of $y_{5}$ scholars taught.

"Recommend Comcil be anthorized employ competent surverors to sclect 

best trail from Naniboba west and report on muskegs and streams requiring brushing or brielging. These contracts let and carried out under inspection of ${ }^{4}$ stupervision and approval of Jieutenant-Governor at lirst on most needful places."

No reply was received, and when the Council reassembled on the $2 S$ th of Augu-1, I879, the Government still hat no definite iniormation to give upon these extremely important fopics.

Commenting on the situation the Saskatcheran I/erald, a fortnighty newspaper at Battleford, pulli-hed hy $P$. I. Lauric \& Co., in the preceding year had offered the following protest:- - - The Conncil wat unalle to legislate respecting schools for want of sufficient powers and to deal wilh roads and bridges for want of funds. It is about time the people of the Territories, who contribute latgely to the general revenne of the Dominion, should at least have the allowance of cighty cents per head of the population which is granted to the provinces for local purposes."

The third session of lairel's Comncil sat from Aligust 28 to Septemler 27 , I879. Another serious cutbreak of smallpox was threatening, and owing to the urgency of the situation the Comncil put through all ils stages, on the first day of their session, a bill for the more ellicient prevention of the spread of infectious discases. Fortumately no general epidemic actually occurred.

In this year the Lientenant-Governor felt compelled to resign the position of stuperintendent of Indian aftairs, which he had previously held in conjunction with the Governorship.

"His loss will be severely felt," said The IIcrald, "and much anxicty will prevail pending the appointment of his suecessor. Thornughly scquainted with the tletaile of the whole Indian busines of the Xorth Weat, most patient and painstaking in mastering the intriencies of every case bronght unce his notice, with his whole heart cngaged in his work, and enjoung the contidence and respect of those who have hal to do with him, it will be diffictilt to find one who ean so efficiently till the offied If at times in the past some of his suggestions and mot urgent representations to the Department at Ottawa had been complicel with, there is no donlt that matuy of the difficulties that have arisen might fave heen obviated, and, by the timely expenditure of a little money, a large saving effected in the cond. It camint be ton cirnmgly urged upon the Government at Ottawi that the more the details of the work of this superintendency are left in the hands of the officers hete, the more efficient will he the service, the greater the true economy to the combs, and the more beneficial and satisfactory the result to the Indians themselves."

The papers and correspondence of these times are full of references to the misery of the Indians and the dangers of an Indian rising. The bufialo were disappearing with feariul rapidiy. From Fort MacLeod 30,000 buffalo robes were exported in IST, in the following year the number fell to less than I3.000; and in 1879 only 5.764 were handled. Similarly. at Fort Walsh in IS;S, IS.235 robes were exported, but in I879 only \&.6I7. While

4 This dispateh is copied from the appendix to the journals of the North West Council for I8,9. Probably an error in transcription necurred in the telegraph office; perhaps "of" should be omitted after "inspection." 

some hase thotght that the praticat extinetion of the buffalo within so brief a period could le accounted for only by a general epirlemic, the prevailing opinion is that the wholeale destruction of the herds. without distinction of age or sex, w supply the fur marlet provides an adequate explanation. Doctor Mackiac, of Calgary, in his Ilistory of .lllerta ([3. 377), quotes Colonel Ilerchmer, formerly Commissioner of the lioval North West Motnted I'olice, as having expresecel to him the belief that the extinction of the buffalo herds was consummated muler the delilerate matnagement of the American military antherities, with a view to reducing the sioux to submiscion. Startling as this suggentim may be, it comeites with the opinions expressed to the present writer ly well informed buffalu traters, such as Mr. Jouis Le Gitre, of Willow Bunch.

Through sulb-inspertor benuy, a number of Blackiced chiefs at this tine sent an appeal to the I'rincess Lonise, the Governor-Gencral's Consort. "Our people are starving; (h) help us. for soluc of us have nothing to cat, and many of to could find neme anywhere. Ne have heard of the danghter of oter Great Nother being now on this side of the fireat Lalic. She hats her mother's heart. Let her linow that wonen and little ones ask her to give them life, for our Circat Mother's sahe. Slic is gant, and will hear are and

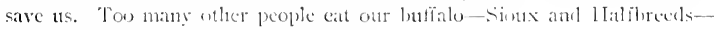
and we hatve nothing to eat onrselves."

It is a satisfaction to note that the Inelians confidence was mot altogether misplaced, as sub-inspector 1)enny was provieled with means for the relief of some of the nost distressed of the lnelians who alplitict wh thin. There is, however, evidence all too convincings, showing that the interents of the red wards of the Govermment were receiving scant netice at ()tama. Statvation recured in varjous camps, and resulted, some sily, in a case or two of cannilsalism.

From The Herald, of January 27, 1879, we learn of the restlessuess of the Indians at Duck Iake. Chief Bearly demanded that his reserve should be cnlarged, and that setters in the alded territory should be his tenants and pay him hali their crops. If these and other demande were not granted. he and his warriors would take from Fort Carton and from Sitobarts stomen at Duck Lake, such proviejons as they might require. The Indian even went so far at this tine as to warn their missimary. Father Oudre, that "mucle as they would regret having to strike their father, he would have to go with the rest."

Ow ing to the official delaty in forwareling the treaty mency, much distrest and anxicty had hecn cattsed in $18-8$, and in 1870 matters were still wore. In The Herdel of August i I. IS79. the following elitorial comment occur-:

"By the tast mail we see that the ()ntario people had a little sensation in the rumored sacking of a number of dwellings, the (ievermment I Louse 
responsible for the present muriclle. Is ustall on all occisions of importance, the telegraph line is not worlingr."

On account of the prevaling anxiety, steps were taken to provite the Halfbreeds and other settiers with arms, and volunteer militia companies were organized. As these were niterly neglected. howerer, their supplies were soon lost as far as the Government was concerned. Some of the rifles. however, were said to have been recovered at Batoche and elsewhere some years later!

The same policy of neglect was eviclent in all directions. In February, 1879, a number of Indian agents were appointed in the East, lunt by . Ingust 9, The Hcrald informs us, not a single one of them hat put in an appearance. The choice made in selecting farm instructors for the recerves also aroused much disapproval in the Mest. It is fairly reflected in the following passage from the editorial columms of The Herald:

\section{MALADMINISTRATION (OF INDIAN IFI MIRS}

"It is currently reported in Ottawa that the Government has appointed three or four farmers to go to the North $/ 1$ est to teath the fucliams farming. Had they been selected from famers in the Jorth 11 est who understand the language of the Indians, it would have saved both travelling expenses and the salaries of the interpreters.

"There is but one way out of the difficulty. The Indians must be provided with food; and there is no difference of opinion as fo how that conld hest he done. It could only be satisfactorily done by getting them to settle on their reserves, and to do so willont providing them with instructors in the simpler branches of agriculture would have been useless. This Was arged upon the Ottawa atuthorities by the Superintendent twe years ago. and it has also been stmoly and continuonsly pressed on thein attention by Mr. Mlorris. Colonel Macleod, Mr. Dickinson and others; yet their warnings were almost unheedcal. True, during the past winter the Superintendent received permission to hire men to help them to put in their crops on their reserves. The permiscion came rather late to be as useful as was desirable, but under the guidance of the (invernment insiructors, aided by the misionaries of the several churclies in the Saskatchewan district, a snuall acreage of land has been put nuder crop.." 

So unsati-factory was the support griven the local anthorities by their superiors at (nawa that considerable dificulty was experieneed in securing the services of any qualificd suecessor of Mr. liatird as Indian superintendent for the Territorics. Llimatcly, howerer, the position was given to Ergar Dew lney, X.I'. for Lale, British (ulunbia, and English Civil Engineer, at one time engatget on the Canadian l'acific Ratilway constrution. As a sub-department under the Minister of the Interior, a Department of Indian Affairs was also organized at ()tawa at this time.

In 1880 ne mecting of the North Vest Conncil Was called, as proclamations had been issuel crating three electoral districts,--Kinlerly, Salisbury and Lorne. (Jwing to the fact that liettenant-Gosernor I-aird received intimation from Uttawa that it wats the intention of the (ionernment to submit a bill tu l'arlianent to extend the benndary of Jlanithat westwated which took place on March 21, 1881), and that the contemplated cxtension would include the townshipe embraced in the proclaimed districts of Kimberly and Salisbury, no elections were hed in these two constituencies. The election in I,ome did not oceur until Matrch, ssi, the date at which the territory includer in the proposed constumeies of Kind:crly and Salivbury was annexed to. Manitolua. IJowerer, the fonth legislative session of Jaird's Cotmcil was licld from Mity zi, to Junc 11, s88, and in it sat the new and only elected member, J Jonoralile Jatwence Clarke, member for lorne. All bills of this session were introduced cither hy the Licutenant-Governor himself or by $\mathrm{Ir}_{\mathrm{r}}$. Clarke.

During this session an interesting legal or contitutional complication was pointed out by Jicutcnant-Colonel I lugl Riclardson, stipendiary magistrate. The North West Territories. Ict of 1875 and 1877 had been recently amended, and under Section 95 of the North Viest Territories Act of I88o. the legislative anthority of the licutenant-Govennor in Conncil was made subject to Order-in-Conncil of the Governor-Cwencal. As the GovernorGeneral's instructions had not yet arrived at the time of the meeting of the North West Council, Mr. Richardson, in lis capacity as official legal advisor of the Lientenant-fovernor, expreseed in writing the view that the existing Council had no power to pass any ordinances: and thereupon the protesting magistrate withdrew from the sessions of the Conncil. However. the Council scems to have taken the will for the deed, as far as the authorisation of the Governor-General is concerned, and calmly proceded to malic such laws as it thought fit.

During a greater part of Laird's regime the settlenent of the Viest proceeded rery slowly. Of transportation facilities the comntry stood in urgent need, but it was not until the Winter of JES that the Honse of Commons at Ottawa passed the Camadian Pacific Ratway Act. Prices for what the settler required were almost prohibitive, and there was almost no market 

for what he might proluce, except in the form of foor-stufis to supply the few little towns. At battleford, in 1s-s. eggs were worth $75 \mathrm{e}$ a dozen and onions four dollars a bushel. ()n May io, 18-g), The Heruld declared that "no bacon, no beei, no pemmican, no fish, no gatme, and until M[onday, the Izth, no flour" was to be hat in liattle forel "for lwe or money." Ordinary building lots at I'rince - Ibert at this time were puoterl at $\$ 25.00$, while comer lots were offered at $\$ 50,0$, with a year in which to make the payment.

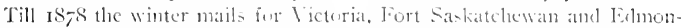
ton were carried by dog trains. The primitive mail service contimed for a long time to le exceelingly unsatis iactory. I telegraph line wats entablished through the West, lut it was continnally lreaking down, ant it managenent by the Dominion - Duthorities presents some ridules to the student. For example, after leing carried seven hundred mile out from Wimipeg, the line ended for a long time nowlere in particular, eighteen miles from Edmonton. The neare-t telegraph office, morcover. was not at this point. but serenteen miles further back. I telegram oi ten words from Mimipeg to the end of the line cost $\$ 2.50$, and it delivery at Edmonton cost an adelitional \$ro.oo.

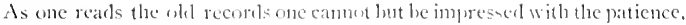
courage. and suod temper di-plated by the Governus, the Comncil and the people of the North West Territuries thromghout this depressing and precarions stage in western development. Why so few immigrants presented themeclees requires less explanation tham why anyone stayed in the country if he could get away.

In the . Iutmmu of $18-7$. Governor-Gencral Lord J bufferin, with a numerous and distinguisher suite, visiter the West, and in 1881 , the Marquiof Lorne, who hat succeeted him, made a more extensive tour. crossing the Territories to Macleod, and remining at Battleford two days, the guest of Lientenant-Convernor Laircl. Both of these fitting representatives of Her Majesty did much ly their speeches and writings to unify the Dominion, and to sprearl alroul information regarding the recources and possibilities of the Territeries in particular. That their efforts to induce immigration were not more successful is due in large measure to the extreme commercial depression that at this period lung not only ofer Canada, but also over Great Iiritain anel the [nited States, throttling the spirit of optimism and initiative necesary for great colonizing enterprises.

Lientenant-Goternor Lairl's term of office expired December, ISSI. During a great part of the time that has parsed since then, Mr. Lairil has continued to be actively and uefully associated with Indian affairs and with North Western interests in general. 


\section{CIIAPTER ATI}

\section{THE SLRRENDER OF SASKATCHEIAN BY THE INDIANS}

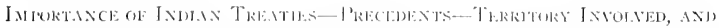

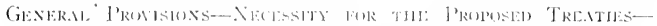

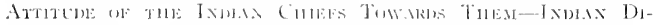

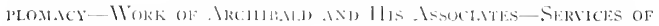

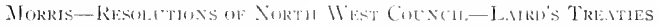

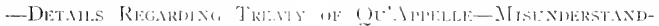

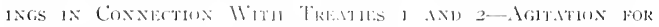

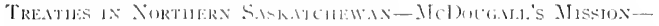

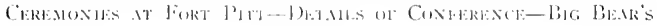
REQLEST.

Few episoles in the hishore of Western Canala ane charaterized by such inferest and patho- as the surender of the valet, fertile plains by their Indian ocemants. This cession was concummated ly a serice of ten treaties. Of these the first seven were negentated between $18-1$ and $187 \%$. The eighth. covering the Athabasca and leate River conntries. Was wot signerl until

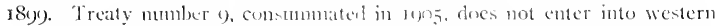
history, as the territory it involved lies in Vurthern Ontario. The tenth in the series covers that portion of the l'rovine of Saskatehewan, till then unincluted in any surrencler. It is tated August, 1006 . In the present chapter we will be concerned chietly with the early treat tes. with special reference to those involving territory included in the l'rovince of Sakkatelewan.

Other treaties hat precerled this motable series, and constituted a linul of precedent. Indeed, in the older fanst, scores of such formal surrenders had taken place. They hat been numerous in the United States, and, in Western liritish North Aneriea, lonel Selkirk harl similarly obtaned the extinction of the Indian claims were the lands of his settlenent along the Red and Issinilusin Rivers, in return for the annual pannent to the natives of one humbed ponnds of tobacco. This treaty was extinguinher in IS7I. The Robinson treaties. matle in 1850 with the Indlan of the Lalie Superior and Latie IJurom dintriet. also constituted valuable precelents: and in 1862 the Honorable 11 illiam .1el)omgall, then superintendent (ieneral of Indian Afïairs, amel later apponted hirs Governor of Manitolat, hat lorouglu to at 


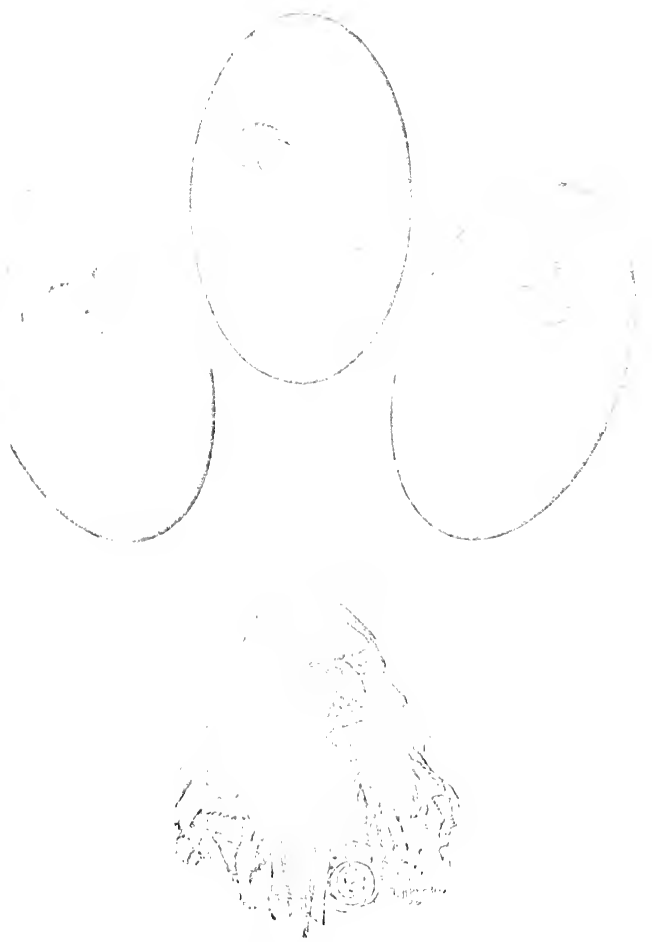

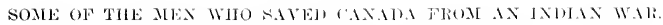

Rev. Geore Mallounall, famous missionary

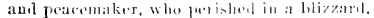
1877. Reprouleced from a portrat foum at lac lat Inche post after it was lented by Intians in laxis.

Hon. A. G. Arehibalu, Lient.Gov, of Man, and N. W. T., 1<, 10-1<i:

Hon. Mlex, Morris, Lieut.diov, of Man. and N. W. T., 1972-1576.

Crowfoot, the erat Chite, batriot am Statesman. 

successful consummation similar negotiations with the lndians of Manitoulin Islanel, Ontario.

The seven treaties of 18, I to 1877 were, however, much more momentous in their significance in Canadian I Tistory. They involved the surrenter of the great fertile belt extending from the height of land west of Lake Superior to the liocky Mlountaint.

The terms of the treaties were substantially unifurm. Provision was made for reserves, and it was agreed that, except upon accupied lands. humting privileges were not to be abridget, unless by regulations for the protection of game. Each clice was to receive an ammity of twenty-five dollars, each of his head men fifteen hollars, and cach uher menber of his band fire dollars. I'rovision was also macle for the supply of agricultural implements and other neecsaty touls, and for the estalilislment of schools upon the reserves. By these and other means, it was lopect by the Indians themselves, and by the Dominion antlorities. that the red warls of the govermment would le gradually introduced to the arts of peace and civilization, and enabled to take their place in the new ureler of things that was being establisted in the Great Mest.

The necessity for these treaties is olvions; and, in most instances, the Indians themselves were most anxions to bring them aluont. In the linited States, the contace of the adrance guarel of white finneers witle the alwo rigines had heen marked everywhere by hloody excesese. Through these terrible lessons Canada learned that she could guarautec seeurity through

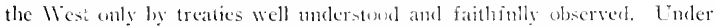
the old regine, the Iludsonis Pay Company had becin, npon the whole, notably successful in its dalings with the Indian tribes, which, however. bitterly hostile among thenselves, generally mantained friendly relations with the great trading corporation representative of white civilization. When, howeyer, the sway of the 1Indson's bay Company was brought to a close, the minds of the aborigines were filled with perplexity at to how their relations with the whites were thenecforth to be guived. This matural perturbation was accentuated by the unfortunate rising of isjo in the Red River settlement. Noreover, settlers were, for the first time, commencing to enter the Nest in relatively large numbers. Kailways were heing built or projected; mysterions telegraph lines, or " speaking wires." as the Indians called them, were extending into distriets hitherto remote from civilization: surveyor were appearing with extraordinary instruments of magic, and, unfortunately, too often with mamers of ostentations contempt for the traditional rights and natural prejulices of the primitive occupants of the new land. Mloreover, along the southern fronticr. much troulle was being experienced on account of the lawless violence of American miners and other such representatives of the typical "Wilk West" element of the Tnited states. 

Is we have already seen, the trate in alcoholic liquors was at all times an unspeakable curse to the Indians. They themselves recognized this fact, and their cliefs made frequent applications to the anthorities for the talsing of such stejs as would put an emil to the traffic. It was rightly thought that the consmmation of official treatics momlel assist in this nost necessary reform. Moreover, the distppearance of the lunfialo, together w ith the horrible ravages of smaltpox, and other contagions and infections denciscs, had reduced most of the Indian tribes to the direst destitution. The wi-ce among their numbers saw that the only hope of their survival rested in the adaptation of their modes of life to the circmustances of the new crat dawning before them.

One camnot but be impressed by the mingling of artlessness, sluewriness and dignity that characterized the Jndian Chicfs thronglout their negotiations with the Commissioners of the Canadian fiovernment.

They stood firm upon their primary rights an the ancient oceupants of the soil. "This is what we think," said Ma-we-do-pe-nais to Governor Jlorris during the negotiations of the third treaty. "When the Great Spirit planted us on this gromul, we were as you were where you came from. We think where we are is our property:" They recognized clearly enongl, however regretfully, that they must acquiesce in the new oreter of things. Speaking at liort Carltun, the following sentiments were uttered ly. Chief Wah-wee-kah-mihk-kah-wo-kah-mall-hote "the IIan yots strike in the Back"): "Pity the voice of the Inclian. If you grant what we reppest. song will go throngh the land upon the way. I speak for the children that they may be clad. The lanel is wide; there is plenty of roon. My montly is full of milk: I am only as a steking child. Have compassion of the manner in which I was brought up. Let our children be clotherl; let us stand in the light of day to see ont way on this eartl. Long ago it was goorl when we were first made, and I wish the same were back again. Bnt now the law has come, and in that I wish to walk."

Of the value of the heritage they were surrendering, the Indians spoke frequently with much feeling and cloquence. "Ny terms I am now going to lay down before you: the decision of our chiefs. . . The sonnd of the rustling of the gold is under my feet where I stand. We have a rich conntry; it is the Great Spirit who gave us this. Where we stand upon is the Indians' property, and belongs to them. If you grant us nur requests. you wil! not go back withont making the treaty." This spirited passage is from another speech by Ma-we-to-pe-nais, who has already been quoted above.

All things considered, the chiefs generally showed remarlable selfrestraint, but occasionally their sarcasms were very telling. In onc instance, the Commissioners having amnonneed that they held in their hands the dele- 

gated anthority of Queen Victoria, and that she hat filled their minds with her thoughts, they subsequently fommel thumselves mable to acquiesce in certain requests withont excecting their powers. Thereupon one of the chiefs rematked, "IV unlerstool yesterday that the (2ncen had given you the power to act wpon; that she had filled your head with her wisdom and your body with her power, and that you hat only to throw them round about you: when it seems that it is is not so, hut that you have only half the power she has, and that she has only hali filled your hearts."

The consmmation of the treaties would have been entirely impossible had not the chiefs themselves exercied patient liphonacy in the management of their turbulent followers. Long and discouraging delaty frequentiy occurred, for which the nominal heads of the tribes were in no way responsible. The whole current of recent events in lndian history hat tended to weaken the authority exercised hy the clicis,-an authority always precarious enongh, and depending chictly mpen the inherent forec of claracter marking hin who exercised it. The rejoicing of these hard pressed chieftains when the negotiations were sucessfully completed, was expressed by many of them in language of great dignity and high emotion. Let us quote a passage frum (iovernor Nlorris's account of the signing of the North West Angle Treaty (Xo, 3):

"The business of the treaty laving me been completel, Chich Ma-wedo-pe-nais, whe, with fow-has-san, hat with such wonclerinl dignity carried on the negotiations, stepperl wy to the fovernor and said, Now you see me stand hefore you all. What has been thone here to-day, has been done openly, before the Great Spirit and the Nation: and 1 hope that I may never hear anyone say that this treaty has becn donc secretly: and now in clusing this council. I take off my glove, and in giving you my hand. I deliver over my birthright and lands; and taking your hand, I hold fast to the promises you have made, and I hope they will last as long at the sun goes round and the water flows, as you have saicl.' The Governor then took this hanel, and said, 'I accept your hand, and with it the lands, anel will keep all my promises in the firm helief that the treaty now to be signed will bind the red men and the white together as friends forever."

Everyone in the Weat recognimed the necessity of negotiating Intian treaties at the carliest possible moment. Numerous disconcerting delays occured before the entire series of surrenclers was conclurlerl. but they arose chiefly from procrastination at Ottawa and the apparent inability of eastern statesmen to recognize the gravity of the situation.

However, in the fall of Is;o Lientenant-Governor Archibald promised certain Indians who male application to him that the initial treaty would be made the following year. Accorlingly, the Secertary of State, the IIonomable Joseph Howe appointed Mr. Nemss Simpson to the office of Indian 

Commissioner with instructions to arrange for the session of Indian lands. In July, I87I, he commenced his negotiations. In these he was assisted by the Lientenant-Governor, Messrs. S. J. Dawson, Robert Pether, and the Honorable James Mackay, to whom special reierence has been made in a precerling chapter. To Mr. Mackay's knowledge of Indian languages and mode of thought, and to the confidence which the Indians reposed in him was due a large measure of the success which attended the subsequent negotiations.

A Proclamation was issued by $21 \mathrm{r}$. Simpson summoning the Indians to meet him, and after some delay more than one thousand chiefs and warriors asscmbled at Lower Fort Garry in July, 1871. The Comissioners were hampered by instructions from Ottawa unduly liniting their power to meet the just demands of the Indians. Moreover, the redmen stated that there was a clond before them which made things dark and that they did not wish to conmence the proceedings until the cloud was dispersed. The Government ultimately found that this meant that they would do no business until four Swampy Crees. who were in gaol for breaking contract with Hudson's Bay Company, should be released; and Mr. Archibald thouglit it discrect to exercise his power of executive clemency by the pardon of these ofienders. This produced an excellent effect, and Treaty Number One was presently concluded.

It was followed very shorly by Treaty Number Two. These two surrenckers covered a very large part of the Province of Manitoba and considerable adjacent territory. Efforts to conclude a treaty with the tribes between Lake Superior and the north west angle of the Lake of the Woods proved unsuccessful until 1873 .

Meamwhile Mr. Simpson had been succeeded by Mr. J. A. N. Provencher as Commissioner of Indian affairs, and the I Ionorable Mr. Archibald had been followed by the Ilonorable . Mexander Morris as Governor of Manitoba and the Territories. Messrs. Morris, Provencher, and Dawson in 1873 took up the task of negotiating a treaty with the Ojilways, whom they met at the north west angle of the Lake of the Woods, in September. The negotiations were attended by much difficulty and discomagement, and might lave failed but for the good sense and moral conrage displayed by Sak-katch-eway, the chicf of the Lac Seul band. Swepping aside the petty disagrements that threatened to render the efforts of the Commissioners nugatory, he stated that he and his four humbed people carnestly desired a treaty, and wished to learn the knowledge of the white man. His band in the far north country had already begm to till the soil and desired the assistance of the Government that they miglt become self-smpporting. The speech of this clicitain turned the day, and a Great Council of the cliefs was held, attended atso by llonorable James . lackay, Charles Nolin, Pierre 
. 
Lavaillier, Mr. I'rovencher, and Mr. St. John. In consequence the negotiations were renewed and ultinately proved successful. Fifty-five thousand square miles of territory, and four thousand Indians were involved in this surrender.

Meantime the situation in what is now Saskatchewan and . Mlberta was month by month becoming more dangerous. Strong representations were contimually being made to Ottawa. Among these may be quoted the following resolutions passed by the North West Council on September 8, I873:

"Resolved:

"That the Council of the North West Territories atre of the opinion that, in view of the rapid increase of settlement in the North llest Territorics, and the present disturbed condition of the lndians and their anxiety as to the future, it is imperatively necessary that a treaty should be concluded with the bands of Indians living between the western homdary of that portion of the territory in which the Indian title has already been extinguished, and Fort (arltun or therealonts.

"The Council are of upinion that to defer the negotiations of a treaty of this nature beyond the earlies time possible in the year $187+$ would be attended with unfortunate results."

On Mareh I of the following year the Council entered a respect ful but vigorous protest regarding the inaction of the central anthorities. Recalling their resolutions of the last sension respecting Indian treaties and other matters, the Comncil placed their sentinents on record in the following terms:

"Council regret that they have not as ret been advived in relation to His Excellency pleasure concerning these sulijects, the urgent importance of which is, day by day, beoming more and more evident. They, therefore. beg most respectfully, but, at the same time, most earnestly, that Ifis Excellency's views in reference to these subjects may be made known to them without delay:

"They feel that the affairs of the North West Territories are growing daily in importance and that any delay in dealing with them may be, and probably will be, attended with infortmate results.

"The Comcil are aware that exceptional circumstances may, during the past few montls. have prevented that prompt action which they trust will. in the future. characterize the dealings of the Privy Council with North llest affairs."

In pursuance of these urgent recommendations which in the interval had again been reiterated by the Council. a commission was issned to LientenantGoverno Morris, I Ionorable David I aird, Mininter of the Intcrior, and Mr. W. J. Christie, ex-chief factor of the Inthen's lay Company, atuthorising them to effect al treaty with the Indians of the Quidppelle plains. Successful negotiations here involving the surrender of 100,000 square miles of fertile territory were followed a year later by like conferences on the shores of Iathe Wimnipeg. when Treaty Number Five was concluded. This was 

signed in September. 1875. but the athenion of a consiclerable number of the Indians concerned was not secured till a twelve-month later. Neantime Treaty Number Six was igned at Forts Carlton and Pith in August and the early part of september, 1876 . The seventh traty,-concluded with the Blackfeet and their neighbors ly Mr. Laird, then Lientenant-Govemer, and Colonel NeLcod, and dated September 22 and December + 1877,-completed the surrender of Indian territories at that date desired for setllement. In 1899 . however. the ticle of immigration was encroaching wpen ohl Ithabasca, and, as will be narrated in due cour-e, Mr. Latirl. Mr. James Ross and Mr. Janes Mchemma negotiated the last great Indian -nrrencler, involving the basin of the Ithabasea and l'eace Rivers. Treaties Seven and Eight leclong, however, especially to the Ilistory of . Vlberta, and Treaty Number Nine to that of Ontario. The tenth treaty, as intinater above. completed the surrender of Saskatchewan, involving the region moth of that covered by Treaty Number Six.

In its bearing on the llistory of Saskatchewan, the treaty of ()ui: lppelle, number four in the famous series of which we have been spealing. is perhaps the most interesting of all. The tribes concerned were the Croes and satulteaux, who, by this agreement, surrentered seventy-live thou-and sumare miles of fertile territory, chicfly in south east saskatchewan. lientenantGovernor Morris Was assisted by the llomorable David latird, then Minister of the luterior, and by the 1 lomorable 11 . J. Christic, a former Ind and Bay Company clice factor of wirle experience with the lndian. The commissioners left loort (aary in . Iugust, I8Ft, uneler an eseort of militiat commanded by Lientenant-Colond Osborne smith, C. M. ti., and journefed to the vicinity of I ake (211: Ippelle. They arrived at the appointed rentezvin on September 8. A large number of Indians were there assembled, and, when the Commissioners smmmoned them to the marpuee tent adjoining the militia encampment, the Crees dnly appeared, led hy their chici. I oudVoice. Chief Cote, of the Saulteanx, ahsenterl himself, however, though a number of his followers were present. Ifter the Lientenant-Guvernor lat explaine: the object of the gathering. Lond-Voice annomeer that his followers were not yet realy to proceed to lusiness, and a day's delay was agreel to. On the morrow, however, several armed Judians came as ambarisadors to ask for a further delay of two days, and after consirlerable parleying, the morning of the 1 th was agreed upon as the time of the next cmference. That the chiefs were by no means freely exercising their own volition was manifest. Their armed followers kept them under the strictent supervision, and in many ways hampered proceeling by their turbulent comduct. Indeed, on the inth the sanlteanx kept away alogether. and alid all they could to prevent attendance on the part of the Crees. On the 12 th business really commencel. The formal Indian ceremony of daborate hand- 



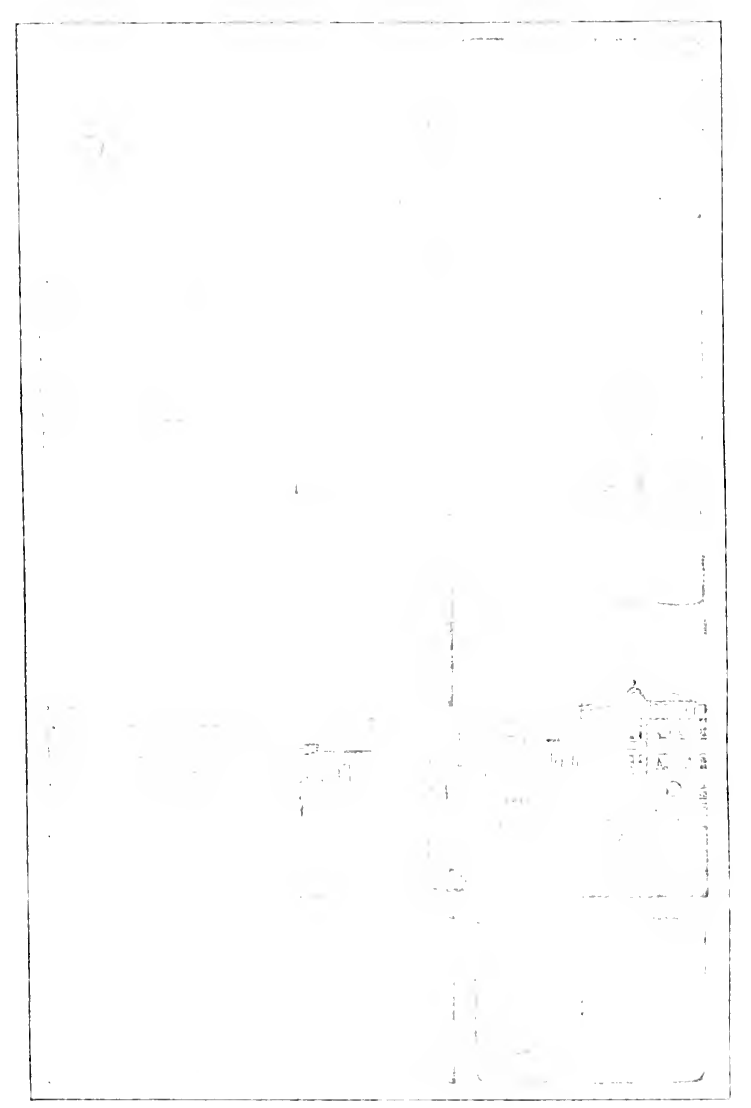



. 
shaking marked the opening of the interview, whereupon the Dominion Commissioner ontlined the terms they had to offer.

Much difficulty was experienced by the Commissioners in finding ont exactly what were the special canses of discontent on the part of the savages with whom they had come to treat. The original place chosen for the meeting had been upon a Iludson's bay Company rescrve, and to this reserve the Indians olijected with a great rehemerice, as it had been surveyed without consulting them. They considered that the Company was robling them of their property. "When one lndian takes anything from another, we call it stcaling," said a notable Indian chicf, The Gambler. "What did the Company steal from you?" said Lientenant-Gorernor Morris. "The earth, trees, grass, stones; all that which I see with my eyes," replied the Indlan. The Commissoncrs told how the company hat become entitled to this reserve. and explained the vesterl rights for the surrender of which Cantula had paid the company the sum of three hundred thousand pounds.

The whole proceedings so far hat been of a most umpromising nature, and still further delays vecurret. The Crees were indeed ready to enter into a treaty, as were some of the Satultanx; but those of the latter tribe who lived in the Qu Appelte district systematically endeavored to coerce and intinidate their brethren. At one stage, with this end in view, they placer six fully armed warriors in the conference tent, a move which wats checkmated by the summoning of an equal number of mititia men. Utimately the Crees and the Sattleanx, who were separated by hereditary feurls and jealousies, detemined to treat with the Commiscioners indepentently of each other; and soon thereafter, a treaty in sulstantially the same terms as that previonsly consummated at the north west angle of the lake of the Woods was signed. Even at the last minute, however, difficutties arose. One of the chiefs refused to sign until he had received the promised financial gratuit:. The Lientenant-Governor held ont lis hand to him, saying, "Take my hand. It holds the money. If you can trust us forever, you can th so for half an hour. Sign the treaty." The chief theretnon took the Commissioner's hand, and touched the pen. The other chief sthen proceeted in like manner to ratify the treaty.

The seriousness of the occasion was apparently felt by all. Said Che-ekuk, the "Worthy One," to the lientenant-Governor: "My ears are open to what yon say. Just now the Great Spirit is watching over us. It is goorl. He who has strength and power is overlooking our doings. I want very much to be good in what we are going to talk about; and our chicfs will take you by the hand."

A few days later the artherion of certain Santeanx at Fort Ellice, who had not been present at On'Appelle, was secured. The chiefs of that group rejoiced in the picturesque names of Wa-wa-se-ca-po, "The Man Proud of 



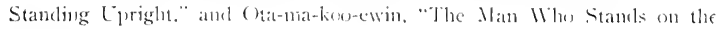
Eartl."

In part, the difficultie of the Commissioners in securing the treaty of

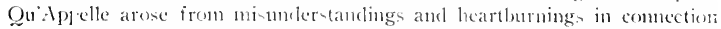
with Treaties One and Two. When the e treaties were signed, cortain verbal promises mate by the commisioners were, mufortmately, not included in the text, and conseguently were not carried ont he the lominion athorities. who, indeed, seem to have leen contirely ignurant of them. Ilide spread dissatisfaction resulted, and, mon examination of the original treaties, there was fomml, attacherl. a memorandum signed by Commissioners simpson and St. Johu, by Ciosernor Arehibald and by the I lomorable Mr. Mackay, containing their statement of the report of these arflitional claims, to which verlal approval had been given. The l'rivy Comeil prompty agreed to consider this memoranthm ats a part of the treaty, and also made certain other concession with a view to the resturation of gool feeling between the Indians and the Dontinion anthorities. The snepicions of the Indian had been aroused, however, and long and patient negotiation was necessary before the tribes and bands affected by Jreaties (t) and low declared themsetves satislied that goul fatith was being bown. Lientenant-fovernor Morris, Lientenant-Cibnel l'rovenchere and the llomorable Mr. JameNackay visited several of the bands in 1875 , and whimately snecered in fulfilling their misson an peacemaliers in the cane of most of them. Some. however, were still recalcitrant, owing to their mismolerstanding of the extent of the reserves which latel becen alketted to them hy their tratty. Their demand: were most exurbitant, incluting nearly hali of the l'rovince of Manitolad, instead of the thirty-four thomsand acres w which they were entitled. Numerou comferences were held before the vexed question of the verbal promises in connection with the Treaties One and Two wat finally settled in $18-6$ to the apparent sitistaction of everyborly:

Another treaty affecting the l'rovince of Saskatchewan was the one signed at lorts Carlton and P'itt, which involved the surrenter of about one hundred and twenty thousanel spluare miles of iertile conntry ( Number Six). Agitation for such a treaty hat existed for several years and variom Indian chiets had, through $\mathrm{Mr}$. IV. J. Chrintie, the chief factor of the Hurlson's lay Company, at Edmonton Honne, sent mesciges to LientenantGovernor Archibali in $18-\mathbf{x}$. The realer may be interested in secing a verbatim copy of these rather curious communications.

"Messages from the Cree chiefs of the 1'kin, Saskatchewan. to I lis Excellency, (iovernor Archibalel, onr Gireat Mother's representative at Fort Garry. Red River Settement.

"1. The chief sweet (irass, the chief of the comntry.

"Great liather: I shalie hands with you. and bid son welcome. $11 \mathrm{e}$ 
heard our lands were sold, and we did not like it; we dont want to sell our lands; it is onr property, and no one has a right to scli them.

"Our country is getting ruined of fur-bearing animals hitherto our sole support, and nuw we are poor and want help-we want you to pity us. We want cattle, tools, agrienitural implements, aud assistanec in everything when we conc to settle-our comntry is no longer able to support us.

" Malie provision for us agains years of starvation. We have had great starvation the past winter, and the smallpos took away many of our people, the old, young and children.

"We want yout to stop the Aincricans coming to trade on our lands, and giving lire vater, ammunition and arms to ont encmies, the liaclifeet.

"We made a peate this winter with the lilackfect. ()ur young men are foolish: it may not last long.

"We invite you to come and see us and speckl with us. If you can't conc yourself, sent onncone in yonr place.

"We send these words by oin master, Mr. Christic, in whom we have every confidence. That is all,'

“2. Ki-he-win. The kigle.

"Cireat father: let us be frichdly. We have never sled any white man's blood, and have always been friendly with the whites, and want workmen, farmers and eapenters to assist ws when we settle. I want all my brother sweet firass asks. That is all."

"3. The Little Ilunter.

"You, my brother, the freat (hief in ked River, treat me as a brother, that is, as a Cireat (hice.'

"4. Kos-ki-on, or Slorert Tiail.

" $\mathrm{Ml}$ brother that is coming close. I lowk upon you, as if I sam you: I want you to pity ne, and I want help to cultivate the ground for myelf and my descendants. Come and see us,".

The North West Council had also presed upon the Dininion Anthorities the necessity of entering inte treaty relations with the lndians of these parts: and ultimately [ientenat-fovernor Morris. Whas as we have seen, had steceeded the IInorable Xfr. Irchibald, obtained anthority to send an official messenger to convey a personal pronine that proper treaties wonld be negotiated in the nearest possible futne. The well known missionary, the Rev. George Mel)ougall, acted at the fovernor's nume, and performed an juxaluable errice to his country lug epieting the discontent of the turbulent tribes.

Mr. MeDongall found the natives manimously determined to prevent the opening up of their cotmetry to settlentent until a treaty had been signed. The wiser chicfs were alrealy finding it very hard to restrain less responsible leaders from actual violence, and dangerons suspicion was everywhere manifest. To illustrate the inthaned state of public opinion among the Indians. Mr. Mel)ongall quotes the following remarks of lig Dear: "Me want none of the Queen - presents; when we set a fox trap. we stick pieces of meat all around. but when the fox gets inte the trap. we hnock lim on the 
. 
head. We want no bait. Let your chicfs come like men and talk to us." Mr. McDongall in his report also recounts a suggestive conversation between a land speculator and one of the Indian chiefs. When the former desired to stake a claim on Battle River, the latter sprang to his feet, and, pointing eastward, cried, "Jon see that great white man coming:" "No," said the speculator. "I do." said the Indian, "and I hear the tramp of multitudes behind him. When he conses you can drop in behind him, and take up all the land claims you want. But nuntil then 1 caution you to put no stakes in our comintry,"

At last the Canadian Commissioners made a jomrney of over six hundred miles from IVinnipeg to Jiort Carlton, where, on the 23 t and 28 th of August, 18,6, the long desired treaty was effected. Certain of the Willow Crees and Saulteatix indeed conspired to prevent Lientenant-Governor Horris and his company from crossing the Saskatchewan and entering their country, but this proposition was ballsed by the Plain Crees. One of the latter, pointing to the river, expressed the views of his nation in the laconic question, "Can you stop the flow of that river?" It was chietly due to the influence of the Honorable Mr. Mackay and of the missimaries that the Willow Crees were prevailed upon to cnter into the treats. Representatives of the Church of Lingland, the Mfethodist Chumel, the l'restrterian Church and the Catholic Church were present at the consummation of the treaty. The difficulties met were very great, and the satisfactory issue of this affair reflected great credit upon the Commissioners and their assistants.

The ceremonies attendant upon these important proceedings were frequently very picturespue and imposing. Let us endeavor to picture the scenes enacted at Fort I'it, where the Commissioners arrived on the 5 th of September. Nore thatn a hundred lorlges of Indians were already assembled, but others were arriving constantly, w the formal opening of proceerings was postponed until the seventh. In the meantime. Chief Sweet Grass and about thirty of the principal men called upon the fovernor to express their pleasure at his arrival. Lpon entering his tent, they cmbraced him in their arms, kissing him on both cheeks.

On the seventh, the Commissiuners went to the Council Tent, which was pitched upon a high plateat overhoking the beatiful plain. In the distance were tree clad hills, and in the ioregrommel the beautiful meadow, dotted here and there with little copscs.

When the Governor and his party had aken their places, the Indians assembled near the tents of their chiefs, amid singing and dancing. the beating of drums and the discharge of arms. Then they advanced in a great semicircle towards the Governor's tent. In the foregronnd a company of their most expert horsemen galloped abont in circles, shouning and singing and performing many feats of horsemanship. When the semi-circle had 

reached about fifty yards from the Governor's tent it halted and attendants came forward with blankets and robes, which were spread upon the ground for the use of the chiefs. When the latter had taken their places. the stem dance began. One of the chiefs advanced before his brethren, carrying a magnificently decorated Indian pipe, which he solemnly raised towards the heavens, turning it, with due ceremony, towards the four points of the compass. The pipe was then given to a singer, who, intoning a weird chant, performed a cercmonial dance to the accompaninent of drums and the singing of the concotrese in the backgromml. This was several times repeated by. other picked braves, after which the horsemen hegan to gallop in smaller circles, and the whole body advanced with slow dignity to the tent of Iler Majesty's representatives. The Commissioners then aroce and met the chiefs, receiving from them the pipe, and repeating the ceremonies which had been performed with it by the Indians. Thus the tribes of the North formally offered their friendship to the Commissioners of Canada, and that offer was symbolically accepted. The chiefs and heat men were then introduced to the Commissioners, and, with picturesque dignity, assumed their places immediately in front of the marquee tent to hear the Givernor's opening speech.

The following day was Sunday, and no official business was tranateted. On Monday the chiefs held a separate Council, and on Tusday the first husiness session of the joint conference took place. "Pondmalier" was the orator chosen to open the proceedings. Addressing the Governor. he sail, "We have heard the words that you had to say to us as the representative of the Qucen. We were glad to hear what you had to sar, and have gathered together in Council with the words over amongst us. We were glarl to hear you tell us that we might live by our own work. When 1 commence to settle on the land to make my living for myself and my children I beg of yon to assist me in every way possible. When I am at a lose to proceed I want the advice and assistance of the Government. The chitdren yet umborn I want you to treat in like manner as they advance in civilization like the white man. This is all I lave to say now. If I lave not said anything in a right manner, I want to be excused. This is the voice of the people."

Some misapprehension of the Govemment's terms having anc to light, Commissioner Mackay addressed the Indians in the Cree tongue. "My friends, I wish to make you a clear explanation of what it seems you to not understand. It has been sail by your Governor that we to not come here to barter and tracle with you for the land. You have mate lemands on the Governor, and from the way you have put them the white man wonld understand that you ask for daily provisions, also supplics for your hunts and pleasure exenrsions. Ay reasnns for explaining to you are 

bated on my past experience of treaties. Fior no sunner will the Governor and the Comminsioners turn their backs on you than sone of you will say that this thing and that thing was promined and the promines not fulfilled: that you cannot rely on the Quecn's representative; that even he will not tell you the truth-whilst you yoursclves are the falsifiers. Now, before we rise from here, it must he understool, and it must be in writing, all that you are promiced by the Gowernor and the Commisioners, and I hope you will not leave until you hate thoroughly understoesl the meaning of every word that come from us. We have not come here to pacily you; we have not come here to rob yout: we have not come here to take away anything that belongs to you: and we are not here to make peace as to hostile Indians; for you are the chillen of the Great Queen, as we are, and there has never been anything but peace between ns. What you do not understand clearly we will to our best to make perfectly clear to you."

In this spirit the whole conference was conducted, and the good-will of the Indians was secured in almust every cane.

An incident. pathelic in view of subequent events, oceured when Big Bear came to visit the Civernor on the morning of the ${ }_{1} 3^{\text {th. }}$ " "Ny friends." said he, "I heard the (iovernor wan come, and I said, I shall see him. When I see lim I will make a reruest that le will save me from what I most dread-the rope put alout my neck!". The fiovernor assured him that while he could not promine immunity to the Indians from the enforcenent of the laws of the land, no one need fear them who lived at peace with his brethren. Big lear remained until the other chiefs had withelrawn. and then, taking the Governor's hand, he saicl, "I an glad to meet you. I am alone, but if 1 had known the time I would have been here with all my people. I am not an undutiful child, and 5 do not throw back your hand, hut, as my people are not here, I cannot sign. I will tell them what I have heard, and next year I will come." This unfortunate Indian subsequently suffered imprisonment and narrowly escaped eapital punishment for his share in the mourniul tragedies attendant upon the rising of 1885 .

1 Through the influene of Commisinner Irrine. Big Bear, after long negotiations, finally gave his alliesion to Treaty No.6. 


\section{CHAPTER XVII}

\section{THE BULLIING OF TIIE CANADIAN PACIFIC R.IIMAY}

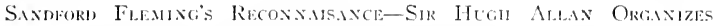

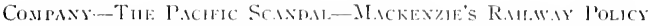

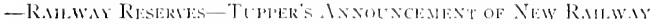

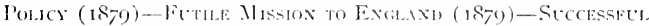

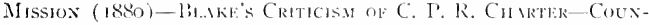

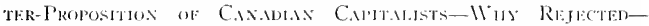

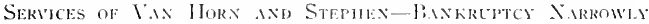

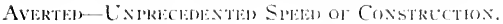

The building of the Canterlian Pacitic Railway hat exercised, and will for long continue to exercise, an extraordinaty influence on the history of Saskatchewan. To this great cuterprise we shall therefore devote the present chapter.

An exploratory reconnainance was made for railway purposes in 1871 by Mr. Sandford Flening. acting for the Dominion Government. The task set Mr. Fleming and his associates Wats stupendous. From Ottawa to the Red River the line paseed throngl a conntry hitherto all but unpenetrated. The vast prairics presented relatively fow engincering difficultics. but any previous accurate knowledge of the gengraphical details regarding the Territorics was meagre in the extreme, and it was necessary to prospect the line to avoid the most formidlable river crossings, to serve the best agricultural country, and to follow the shortest possible route to the mountain passes throngh the Rocky Xountains. The difficulties of the survey are beyoud all description. The cost of these preliminary operations ran well over three million dollars up to December 3I, 1879. and they were unavoidably marked by much hardship, and even by many tragerlies. Fleming and his colleagnes favored a ronte much to the north of that linally adopted in the North IVest, and in consefuence much of the fruit of their labors was lost; but their investigations rendered available a wealth of information regarding the country and diel much to facilitate its settlement.

It is to be remembered that we the terme upon which bitish Columbia entered Confeleration in 187, the Feeleral Cinvernment promiced the immethate contruction of a railway from the Pacific toward the Rocky Moun- 

tains and thence eastward to connect with the railway systems of Canada. and that the Dominion agreed to complete this transcontinental railway by I88I. During the session of 1871 a bill was introduced to charter a Pacific Railway Company. However, most of the prominent members of the proposed company were American capitalists, and the terms they offered were unsatisfactory to the Govermment. Consequently this bill was dropped. Next year an act was passed to provisle for the required railway. The Government was given power to arrange terms with any railway company and to subsidize it to the extent of thirty million dollars of money in addition to a vast land grant. Two companies presented themselves for incorporation in competition for the charter-The Canadian Pacitic Company, organized and under the presidency of Sir Ifugl Allan, and the Inter-Oceanic, under Senator D. S. MePlierson. An attempt was male to amalgamate these concerns, and on its fatilure Sir Hugh organized a new company, composed exclusively of Canadians. Its board of directors included a group of men widely known and trusted.

In the session of 1872 the charter of this company was duly ratified, but in the following year matters came to a standstill as a result of the charge that Sir Hugh Allan had obtained the favor of the Government ly corruptly furnisling money for election purposes. A committee of the flouse commenced an jnvestigation which was utimately transferred to a special royal commission. The evidence adduced proved that Allan had contributed largely to the political funds of the dominant party, and, though no personal appropriation of any of the muney by any of the calinet was proved, public indignation over this so-called "Pacilic Scandal" obliged Sir John A. Macdonald to announce his resignation in Novemher, 1873.

The new premier, the Hon. Alexander Mackenzic, declared that, while the speedy construction of the transcontinental railway was essential, it should be consumnated at the minimum expense; consequently use should be made of all possible natural links in the way of navigable waters and the building of the line througl regions unsuited for settlement should be postponed and obviated for the time heing by establishing communication with American lines. He considered that the original bargain with Dritish Columb:a was incapable of fulfilhnent, and proposed to treat with that province for some modification of its terms. The road, moreover, was to be built by the Canadian Govermment itself. Mackenzie's railway policy was unsatisfactory to the West, and to the people of British Columbia in particular; and, indeed, for a time it endangered the unity of the Dominion. In I 876 the Government published an advertisement calling for tenders for the building of sections of the Canadian Pacilic Ratway between Lake Superior and the Pacific Ocean. This proposed departure from the cabinet's policy of building the road as a Government work met with a discouraging recep- 
$+$ 


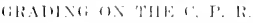

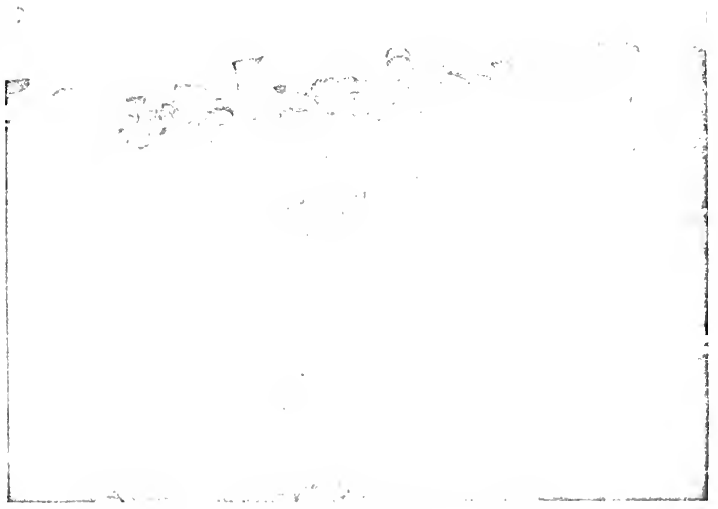

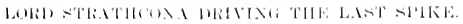


tion, as capitalists coukd not be indeced to mulertake the contract. Accordingly the building of the road under the Govermment supervision continned.

The Pacific Railway Act, under which provision was made for its building, had provided for the resertation of large areas along the line, the sale of which would ulimately remburse the Government. The Territories had no representatives in the Ilouse of Commons, but the members from Manitoba vigurously protested against the locking up of these reserves, and in 1877 the law was slightly changed, and the purchase of such land by actual settlers was rendered possible. Even yet, however, in the settlement belt, there was left a tract of about a hundred and fifty thousand acres of public lands, upon which munerons pioneers were alrealy living. but which was officially declared to be withdrawn from sale or settlement. The J Jonoralble Mr. Mills, however, after visiting the comntry, opened these lands also for purchase at $\$ 5.00$ in scrip per acre, which really meant $\$ 2.50$ per acre. The disputes orer these land regulations of course delayed the building of the railway, and relatively little had been accomplished, when in October, 18-8. the Nackenzie Government was defeated and Sir John . Machonald returned to power.

In May of the following year the IJon. Charles Tupper, Minister of Public llorks, announced the new I'acific Railway policy. It provieded for the appropriation of ten million acres of land for the purposes of constrncting the roacl. This again filled the West with alarm, and the first land regulations were so objectionable that the Government was forced to amend them a few montls later. Into these we camnot enter. Those ultimately adopted by the then Government were some improvement npon those introduced by Mr. Nackenzie, but they entailed upon the West the loss of many thousand of desirable immigrants, who turned to the westem States, where the laws relating to the settlement and the acquirement of public lands were less oncrous.

In this same year Messrs. Macdonald and Tupper visited England in an effort to raise capital for the railway, but the mision failed, and the Govermment was obliged to fall hack on the policy of its predecessors, conducting the building of the road as a Govermment work. A resolution was now passed to increate the appropriation of land for construction purposes. in Manitoba and the Territories, to the stupentotw area of a lumedred million acres. In other words, the Went was to pay for the railway.

liy the end of $1879.86,3$ miles of the road hat been completed. By June 3o, the clone of the fiscal year, the total expenditure on the work to date amounted to abont welve and a half million dollars.

In July. 18 so. the l'remier and Sir Charles Thpper, together with Lientenant-Colonel Dennis and the Ilon. I. C. Pope, again went to England to secure the aid of capitalists. and on their retum sir foln announces the 

successful formation of a great syndicate. On December 10, when Parliament assembled, the contract was laid before the House. The historic debate upon the terms of the charter commenced three days later and closed on January 28 , $\mathrm{I} 88 \mathrm{I}$.

The terms of the new charter were bitterly resisted by the Ilon. Edward Blake, now leader of the opposition. IIe pointed out that the Act of 1874 provided for the submission of tenclers, and that the (iovermment, while materially altering the conditions under which the work was to be performed, had departed from the Act by failing to invite tenders under the new terms. Ender the Act the land grant to the company wonkl have been taxable, while moler the contract it was exempted from all taxation, Dominion, Provincial or 11 micipal, for a period of twenty years, muless previously sold. by the Act, Parliament had reserved to the Government unrestricted power in the regulation of tariffs; but by the contrate this right was to be in abeyance unless and until the company should be making a net revenue exceeding ten por contum on the capital inverted. The (iovemment had also forfeited its control over the accommotation to be provided and its right to acquire the railway at any time that public interent might demand. In many other important respects the proposed charter violated the provisions previonsly latil down by l'arlianent, and in every instance to the company" immense advantige.

Mr. Bake pointed ont that fire weeks after the new conditions had been macle public Canadian capitalists of high standing, inclurling Sir William P. Howland, Willian Hendry, fohn Walker, George A. Cox and many other men of ample means, credit and business ability, hatel caused to be faicl on the table of the Honve an offer in terms much more favotable to the comtry. While the proposed charter called for a cash subsidy of $\$ 25,000,000$ and a land grant of $25,000,000$ ateres, these gentlemen offered to mudertake the work for three million dollars less in cash, and three million acres less in land. The new tenderers proposed to acejt $\$ 6,600,000$ and $9,000,000$ acres instead of $\$ 9,000,000$ and $11,250,000$ acres for the prairie section of nine hundred miles. I similar reluction was offered upon the western section to Kambooss. While the contract exempted the company from customs duties on construction material, the new offer involved no such exemptions, and even surentered the proposed immunity from ordinary taxation. The tenderers were furthermore willing to leave with the Governor-in-Comeil unrestrieted powers for the regulation of their tolls, and hat placed on deposit, as security for the iullilment of the contract if their tender were accepted, the sum of $\$ 1, f 00,000$.

To present-lay westerners familiar with the grievances restlting irom the Canadian Pacific Railway Company's immunity from taxation and from 

Government supervision regarding accommodation and rates, it is rather bewildering to find a Gorernment rejecting the offer of the IIowland Syndicate on the plea that it was not genume, and confirming the contract as introduced ly the Govermment. However, Sir John believed that the proposed agrement embodied the only chance of having the road built within a reasonable time, and on Jannary $2 S, 1881$, he introduced a bill for the incorporation of the Canadian Pacific Railway Company. Resistance to his policy now entered on a new stage and the opposition fought the bill persistently; nevertheless, it became law on the 15 th of February.

Mr. William C. Ian IIorne (who was subsequently knighted) was presently appointed general manager of the new company (upon the recommendation of Mr. James J. Hill), and Mr. George Stephen, better known by his later title of Lord Mount Steplen, was chiefly entrusted with the charge of fmancing the company in England. The difficultics surmounted by these two remarkable men were enormons. Incidentally, by persistently advertising Camarla, and especially the North West to facilitate the sale of their lands, they unciuestionably performed an indirect public service to the Dominion, the value of which can never be calculated.

By the fall of $188_{3}$ only $\$ 65,000,000$ of the $\$ 100,000,000$ capital stock had been sold, and the company's lands failed to provide as yet any considerable reventuc. Nearly all their funds had already been expended, and for a time the company was face to face with hankruptcy. Even the action of the Dominion Government in now gnarantecing three per cont dividends on C. P. R. stock failed to reassure the investing public, and in 188. it was necessary to apply to the Government for a loan which rajsed the indeltedness of the company to the Government to the stm of $\$ 29,880,000$. Furthermore, Mr. Stephen and Mr. Donald A. Smith (I.ord Stratheona), in order to tide over the crisis, pledged their own personal means. But for the heroic faith of these two men and their immediate colleagues, the enterprise would have collapsed in general failure and ruin. Nor must we of today, who enjoig the results of westem development that the building of the Canadian Pacific Kailway rendered possille, fail to accord the gratitude justly due to the Government of the hour. When the public realized that the Dominion . Authorities were determined to ensure the immediate and successful performance of the work, no matter what the odds against it. the company.s position in the money market commenced to improve, and by 1887 it had freed itself from all indebteluess to the Govermment. Had the company failed, it wonld not only have bronght about the defeat of the Government, but would have overwhelned Canada in funancial disaster.

While Messrs. Stephen, Smith, R. B. Angus and their co-directors were fighting the financial battles of the company, Mr. Van Horne was pressing 

forward its construction with a speed mexpected, and, indeed, unprecedented. The contract had allowed ten years for the work, but on Norember 7, 1885, Mr. Donald .1. Smith was called upon to drive the last spike. Two thousand four hundred miles of new railway had been built, equipped and put in operation in five years. More than three hundred miles of the road consisted of cutting throngh the solid rock, and space woult fail us to detail the engineering difficulties that had been overcome. 



\section{CHAPTER XVIII}

\section{DEIWDNEY'S MDNINISTR.ITION IND COUNCILS (I8SI-ISS8)}

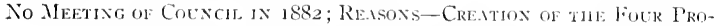

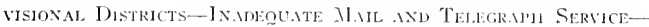

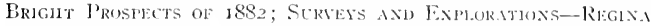

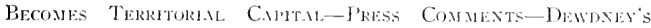

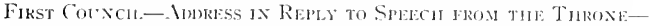

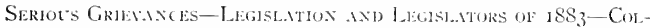

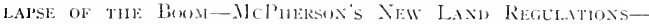

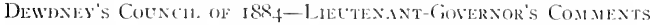

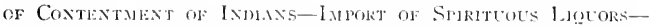

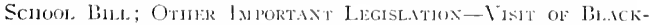

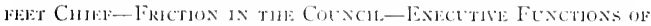

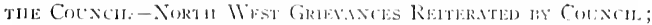

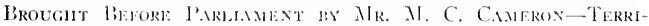

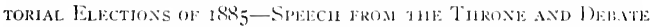

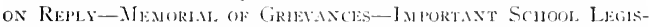

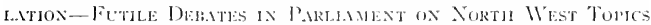

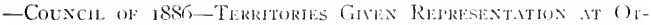
TAWA-CREITION OF SLPREME COLRT-TORRLAS TAND TITIES SIS-

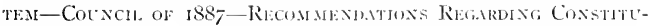

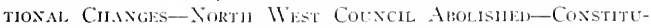

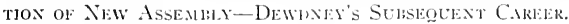

The Honorable Edgar Dewdiney, who for the two previous years had filled the office of Indian Commissioner, succeded the Ilonorable Datrid Laird as Lientenant-Governor of the Territories in December, 1881 . No meeting of the North West Conncil vecurred, however, until August, I883. The choice of the sonthern route for the main line of the Canadian Pacilic Railway rendered it undesirable to retain Battleford as the Territorial Capital, and doubtless the conflict of various interests to be affected in the choice of a permanent Cajuital were in part accomtable for this long delay. Moreover, half a dozen districts in the Territories had by this time become sufficiently advanced in population to he entitled to erection into electoral constituencies. This involved arditional delay. Furthermore, as we pointed 

out when treating of the work of Mr. Laird's last Council. grave doubts had been raied as to the council's peswers, and the sati-factury scttlentent of this difticulty involved lengthy eorresponelence with the (Ottawa Authorties. Still another explanation was at the time offered by the Saskatchead Hirald. That journal was probably not alone in its belief that the decision wat to eall the Council during 1882 arose from "the manifest expectation of the early creation of two provinces." This "expectation" was not fulfilled. however, until twenty-three years later.

In May, 1882, the Dominion Gorerment, on the snggestion of Lord Iorne, by Order in Conncil created in the North Ilest Territories four provi-inal districts, chichy for the convenience of the Post (office Department. Certainly the postal conditions of the llest repuired attention, at fact clear by the following newspaper clipping. dated June 10, I882:

"The Govermment has abolished two light litu vexatious taxes-the stamps on promissory notes and bills, and the postage on newspapers. The wording of the latter. Act defines a newspaper to be a pulblication issted at intervals of not more than seven dits: and this just lets the IIcrald in as about the only newspaper that has to pay postage. Ile will try and stand it for the present. But when the promised more freflicht mail service is given ts we will get even, for then the Jherald will le issued every week, which will bring it within the operations of the litw. Cuder existing arrangements there is no use in publishing a pajer every week when there is a mail but once in three."

The people of Battleford district were at this time promised a weeliy mail, and in the attumn an annonneenent was mate that the cuntract hat been let. Many months elapsed, however, before it came into effect.

The four provisional districts were called Assiniboia, Sankatchewan, tlberta, and Athabasca. These districts have sine then disappeated from the map of Canada, so it may be worth while to recall their extent am positions. Assiniboia inclueled an area approximately 95.000 square miles. boumder on the east by Manitoba, on the west by the line lividing tenth and eleventl ranges of townships, on the north by the townships of reries nine. and on the south by the forty-ninth parallel of latitule. Siskateliewan lay nortl of Assiniboia, and included alout i f 4.000 square miles. It was bounded on the west by the continuation of the houndary line of . Asinibuia, and on the north by the eiglitecntl correction line. Alberta included about 100.000 square miles between Assiniboia and liritish Colmubia. It was bounded on the north by the eighteentl correction line, near the hify-fitth parallel of latitule. Athabasca, the largest of the provisional districts, covered approximately 122,000 square miles. It lay north of . lberta and west of Saskatchewan.

The Dominion Government also intimated to the people of Prince Albert 

that it would establi-h a line of telegraph from the crossing on the south branch to their settlement. and maintain stations at The Crossing, St. Laurent and Prince Allert, on condition that the people should lay the necessary poles on the ground. They were also to have a special telegraphic service wilh the East during the remainder of the winter, and, unt the missing link was constructed, depateles would be receiverl at Touchwood Hills fiom the East, and from the West at Ilumboldt, and exchanged between thinse points once a week.

During the summer of 1882 more than one humbled parties of surveyors were busy resurveying base lines and surveying town-hips in the North West, chichy along the ronte of the Cantdin Pacinc Railway.

Hope and confidence were returning. Mr. Clarke, the member for Lorne, hat devoted himself with appatrent sucess to the task of securing satisfactory terms for the llalfbreeds and squatters in the unsmveled districts, the Dominion Govermment promising throngl him its early and favoralule consideration to the setlers' demands. This year we find recorder 2,753 homentead cutries in the North Viest. Even the Far North was becoming better and more favorably known, through the explorations of Dr. R. Bell, who was conducting carcful investigation in districts never previously visited by scientists.

The original Battleford reserve of 18,6 covered an area of sisteen squate

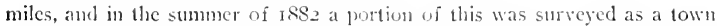
plot by the Dominion Government. Sad have was played with the streets as laid out by the old settlers. Scarcely a house was left standing squarely on the lot it was supposed to occupy. IIowever, the people of Battlefort were so pleased at obtaining any official surver, and orer the fact that battleford was the first town plot in the North Viest to be laid out by the Dominion Goserument, that they accepted pretty plislosophically the apparently. arbitrary decisions of the Government surveyors.

Meantime Licutenant-Governor Dewhlney was endeavoring to locate a capital. Troy or South OuAppelle and Fort Qu'Aplelle were vigorous clamants. However, for reasons which long remaned the subject of acrimonions dispute and disagreeable insinuation, Governor Dewelney ultimately seleeted as the site for the new headyuarters of the Indian Department of the Momnted I'olice "the point where the raitway crusses the Pile of Bones Creek, about fifty miles southwest of Fort Ou'lppelle and twelve miles sonth of that river, in or near township eighteen, range twenty-one. west of the Second Meridian."

The name proposed first for the new capital was Leopold. The Governor-General, however, was appealed to, and his consort chose the name "Regima," in honor of Oneen Victoria.

1 Saskatihioan Herald. Junc 24. 188.. 



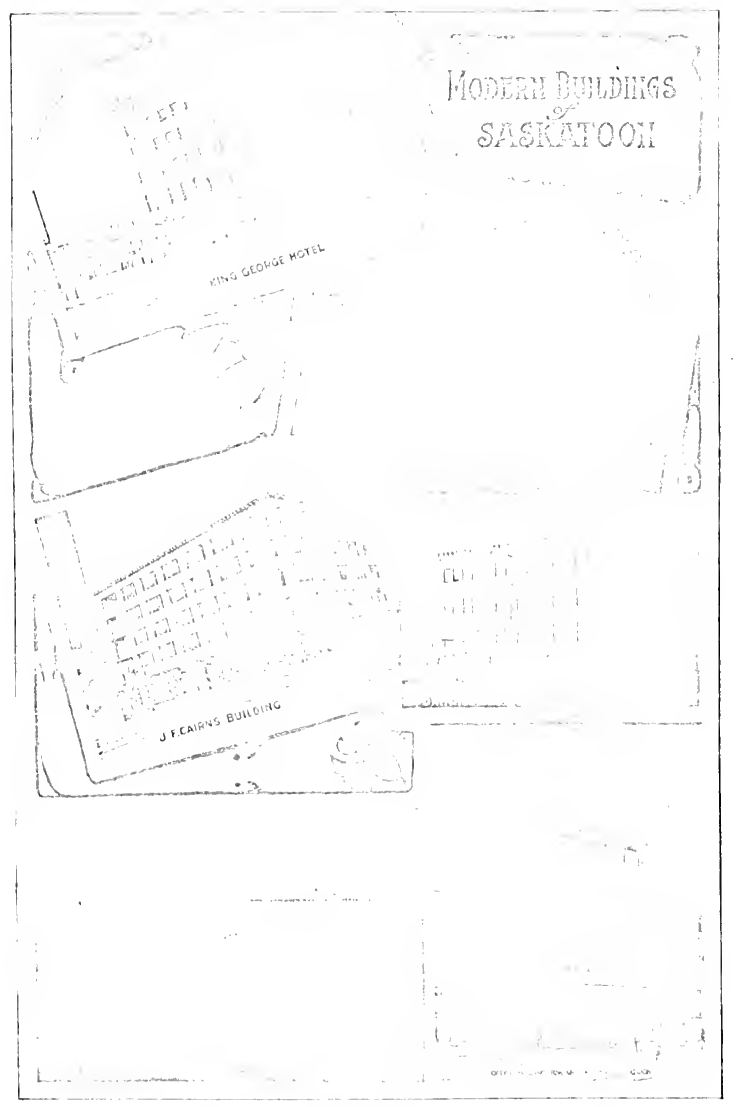



The Jonotable Mr. Dewelney's chrice of this site aroused a storm of protest in the contempurary pres, but on the 2 th of the following March the fovernor-fiencral passed an () reder in Conncil removing the Capital from liattleforrl to kegina.

"One thing is certain." saikl the II "innipeg Fres Press, "Regina will never amount to anything more than a comber village or town, for the simple reatsom that in neither its postion nor its surrommelings is there anyllumg to give it the slightest commereial impurtance. Situated in the midst of a vast plain of inferior soil, witl hatrlly a tree to be seen ats fat as the eye can range, and with alsout enough watter in the miserable litte creek known as Pile of Bones to wats a slecep, it would scareely make a respectable farm. to saty rothing of heing fixed 11 pon a a site for the captal of a great prowince. The place has we a single natural atyantage to commend it."

Nevertheless, a thriving settlement was established at Regina witlin a few month. Of its subsefucut histury we will have something to saly eleewhere.

Governor bewelney"s lirst Council met at kegina on lugut 20, 1883.

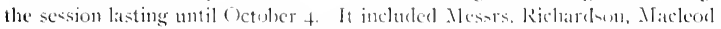

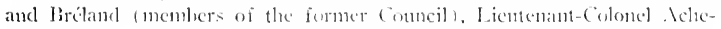

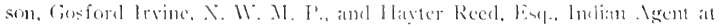
Battleford, in adklitin to sis elected members. llomorable lawrence Clarke had been suceceded by (aptain 1). I1. Machowall as memler for lone. Francis Oliver appeared as member for Felusentem. James llamilon Kum had been elected by the Mouse Jaw dietrict. T. 1:. 11: Jickson representer

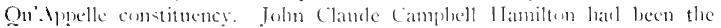

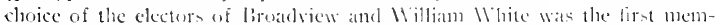
ber for Regina. Mr. Forget still retained his office an elerk of the Cunncil.

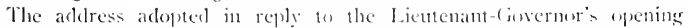
speed reflects in an interesting nanner the hopes and opinion of representative Westerners at this tince. It is therefore here reproduced:

"The members of the (ouncil of the Dorth West Perritorics desire to congratulate Four Ilomer on being able to speak so lopefully and so trutlifully of the prosperity of the country. We believe with you that the rapid growth and development of the North West Territurie is whithont a parallet in the history of the world. Within a short space of a year and a lalf a comitry containing more arable land than the whole of continental

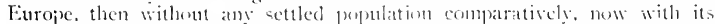
broad and fertile acres. the home of thusamels. happy in their choice of a lume in the New Land, and sanguine of a perefol and prosperous future.

"We helieve that a very great meanure of the stecess which has attended

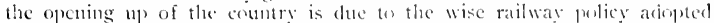
by the bominion (iovernment. We wish alon to speak in terme of pretice of the manner and rạjiclity of construetion of the line of railway new atsont 
completed from the Great Lakes in the East to the Roekl Mlountains in the IVest. And notwithstanding the rast labor involved and the large number of men emploved. all has ben done we helieve withont interference or inconvenience to the repuirements of the public, atud without breach of the law or hindrance from the Indian or white nan. This haply state of affairs must be, and we believe is, a matter of congratulation to Jour Honour as well as to the comntry at latge. Ne desire also in this connectom to acknowledge the services which the North VIest Mounted folice finec have rendered the comntry. and ieel that no small thate of creclit ior peace and good order preserved is duc to them.

"As the iederal authorities have selected kegina as the new eapital of the North IVest. We venture to express the hope that the future will hut the clearer demomstrate the wiskm of the choice. Ile believe it to be the duty, as it is we think the desire, of every one interested in the prosperity of the country, to witness the prosperity of the country sapital.

"We wish to thank Your llonor for the repreentation given to the people in the Comneil of the comber, and, as foreshartowed by four Jonor in your adfress to the Conncil. tru-t that by revinion of the boundaries of the present clectural di-tricts and the erection of new ones, a fuller and broader representation maty be given at no distant day.

- Ile assure lour Honor that the assistance you expect from the recently elected members, and wh which you refer in such gratifying tems. will be given you. He feel atetuted as we are hy a desire to legislate for and in the interests of the geofle at latge, that with an honest rndeatsor to fromote the general good, withent regard to seetion ot people, the result will be satisfactory to enrselves and to those who are fooking anxiously forward to the course legislation may take in this Conncil, as well as to the action which may be taken by us woward assisting to remove law and regulations over which we as a conncil have no direct power. To this enel

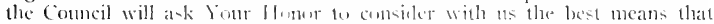
can he adopted to convince the bominion fovernment of the necessity that cxists of some definite action leing taken with regard to those matters on which repeated menorials latve lieen presented by the people, ats well as matters and complatints which hate arisen as the results of more recent legislation lw the iederal autlurities.

"We share with Your llonor in the regret expressed by you at the approaching departure of the Governor-General and his Roval Cousort. We are aware that in a very large measure the attention of the ontside world has been directed with favourathle results to these territories through the exertions of Ilis Ficellency, who has lost no opportunity of maling kmown the resources of the conntry, with which he was greatly impressed on the occasion of his risit to the Nonth Veet, and we assure lune llonor that we wiil heartily join you in an aldress expressive of our regret that Ilis lixcellency and IJer Royal J lighness are alout to kave us.

"We further wish to assure Yout Ilonor that the several important measures spoken of by lour Honor will have our most careful consideration.

"We would fect remiss in our duties were we, before concluding. not to give that expression of lovalty and attachment towards Her Most Gracions Majesty, the Oneen. who has so long and prosperomily reigned over 

this great empire of which this Dominion of Canada is a component part, who, by her ruling as a Sovereign as well as in domestie affairs, has made herself a model to the world at large."

Before the end of the session a lengtly memorial to His Excellency the Governor-General in Conncil was adopted, calling attention to sixteen important grievanees or requests. The newspapers, particularly The Regina Leader, which had recently been established by Nicholas lilood Davin. were full of protests against the Regina reserve, and the North West Comncil added their remonstrances against any such large blocki of land, otherwise available, being deliberately withleld from settlement. The Council vigorously championed the rights of I lalfbreeds, and other stultters: prayed for more extended surveys, especially in set1led localitics; protested against the leasing of arable land for grazing purposs: asked that cancelled homesteads should be reopencd for entry, not held for sale; petitioned for proper vaults for the land and registry offices; called for additional Stipendiary Magistrates; asked for increased powers with regard to the incorporation of territorial companies; desired that all trails and highways should be vested in the Council; protested against the existing duties on agricultural implements and lumber; requested a largely increased sum for the improvement of navigation of the Saskatchewan River: prayed that the mining litws should be assimilated to those of British Coltmbia and Montana; protested against the proposed alolition of pre-emption rights: urged that the territorial grant should be based on a definite sum for capita; deelared the system of granting immense tracts of land to colonization companies to be vicious; and asked for the representation of the Territories in the Dominion Parliament.

The influence of the elective members was now powerful, and may be seen in many clanses of this notable memorial. However, even yet the Ottawa Authoritics semed to care very little about the Territories, and many manifest grievances remained for long years unredressed.

Legislation regarding municipalities, the relief of indigent children, the prevention of the profanation of the Lord"s Day; the disposal of found or stolen horses, the herding of animals, and other important Ordinances occupied the attention of the Council. The following editorial on the Council of $1 \mathrm{IS}_{3}$ is quoted from the Regina Lcader:

"Nr. Nacdowall of Prince Albert has a clear, business-like head, and whenever he spoke he showed a grasp of the question in hand and the fruits of careful observation.

"From Mloose Jaw we have Mr. Jas. H. Koss, a man of whom we in the North West nay feel prout-a young man, full of truth and courage, with a single eye to the good of the country. He has been diligent in his altendance and given eareful attention to the work brought before the Council. 


$$
\text { ' }
$$


“Mr. T. IV. Jackson, of Qu'Appelle, has proved a most useful member. He has worked hard at the Municipal Jill. Nany persons thought he would make the work of the Conncil difficult, and would display a hostility to Mr. Dewdncy and Regina which would be inconvenient in discussion. So far from this, he allowed an address to pass which afiorded hin an opportunity of attacking both. Mr. Jackson may therefore be credited with a desire to pave the way for the good fceling which has prevailed. Reginians, after the way the city has been assailed, nuy well-feel proud that the North WVest Council has endorsed 'the wisdom of the choice,' and Mh. Jackson cannot be too highly jraised for his patriotism. Ile was able to boast last week that though a course opposing the Lientenant-Governor would have been popular with his constituents, he rose above the instincts of the demagogue and dictates of anger, and indeed there has been no more decorous or assiduous member of the Council.

"Mr. Clande IIamilton, of Broadview, has, when present, shown both intelligence and spirit.

"Mr. Wu. White, of Regina, has been attentive. He has wrestled with the noxions weed, and the Canada thistle has felt him at its throat. He has been most desirous of dring all he could to please the people of Regina. Indeed, this desire has been so strong as almost to denude him of selfreliance and make it seem that he almost shrank from responsibility. All that was in his power we may be sure he has done.

"Anong the appointecs, Ir. Hayter Keed has been most diligent, and Colonel Richardson's exirentence, legal knowledge and familiarity with the North West cannot fail-even though he necessarily takes an ultraconservative view of every question-to have been mosi useful. Colonel Macleod is intelligent, knows the western ranch country well, but he seems to fecl-for there is a good deal of soldier in him-that galloping across the country would be more in his line than legislating. Colonel Irvine's duties called him away nearly the whole period the Council was in session.

"The Governor has been very zealous as regards legislation, and when he had occasion to speak, spoke with force and clearness-more force and clearness than we should have expected from one so reticent in his habitual demeanor. Even persons disposed to regard him with hostile feelings acknowledge that throughout he has displayed brearth and grasp, readiness and statesmanlike instincts. Altogether, the Council has shown itself a businesslike assembly, and has done good work.

"One member we have not yet mentioned, perlaps the most remarkable man, in some respects, in the Conncil. MIr. Oliver, of Edmonton. If this gentleman is a type of the pcople of Edmonton, we take the people of Edmonton to our heart, for Mr. Otiver is a man not only of independent thought and great natural ability, but a man of transparent honesty. Such men the free air of our North West breeds. Mr. Oliver's name will be always connected with the foundation of the school system in the North West.

"In the article in which, we commented on the opening of the Council. we expressed our confidence in the appointed members, that they would show 'an intelligent appreciation of the situation.' If they did nothing but vote the memorial they voted on Tuesday, they would have justified this confidence." 


\section{.}


The year 1883 marked the end of wo years of wila speculation. The number of persons who eame up to the North llest not to farm lntt to make fortune: were ont of all prenortion to the munber of real wealth producers. Paper towns sprang up everywhere, and the aftermath of the ill-statred borm canced widespreal disilppointment and con-iderable suffering.

During this year the Marquin of Lesme's term of office was brought to a close, and he wan snceceren by Lord lanslown. Toward the clone of the year the Hnorable 1). 1. Mellherson lecame Minister of the Interior, and immediately promulgated new regulations apening nj) "the mile belt" for

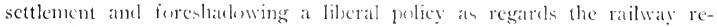
serves. The even sections of the railway lede within at mile of the railway were theswn alen on condition that the settlers should prepare ten acres the first year: shoukl crop ten acres and prepare fiftecn the second year; and. in the third and final year, crop twenty-five acres and prepare fiteen. The even mumbered sections in the Regina leenerve were placed on sale to bone fide settlers at live dullars an acre. I'nrehanes were linited to one humbled and sivty acres by any one individual, and settlers cultivating a quarter of their land within the three-yeatr period were to le granted a relsate of halli the purchate price. (On the other hant, if the settler fated to cultivate the minimum of at quater of his lanel within the three-geat period the sale might be cancelled. The object of thene and other analugens regulations was, of course, to prevent valuable lands arljacent to the railway from being nonnolized ly speculator:.

In Governor Dewelney's Cinncil of 1 sist Charles liorromee Rouleau, an addlitional stipendiary Magistratte. Wats athed to the list of ch-officio and appointed members. Twe new elected members also presented themselves bow for the first time, Joln (iillander Turrift. For the electural die-

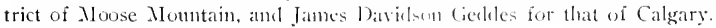
The elected members were now eight in number and the appointerl and exofficio members six.

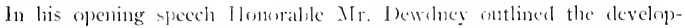
ment of the electoral system and proposed varione important sulojects for legislation. During the recess copies of a school bill, submitted lut later withdrawn by Mr. ()liver during the preceding session, hat leen distributed and Governor Dewdiney expressed the hope that during the present session it would be possible to patss a Scleov Ordinance acceptable to the people

In view of the startling event occurring eight month later, the folluwing quotation from the Governor's conments on the Indian situation is especially interesting:

"The exaggerated reports of Indian difficulties which have lately. appeared in some of the newspapers and which ment wh the comntry harmi. induce me to say a few words to you on that subpeet. From what I hate 

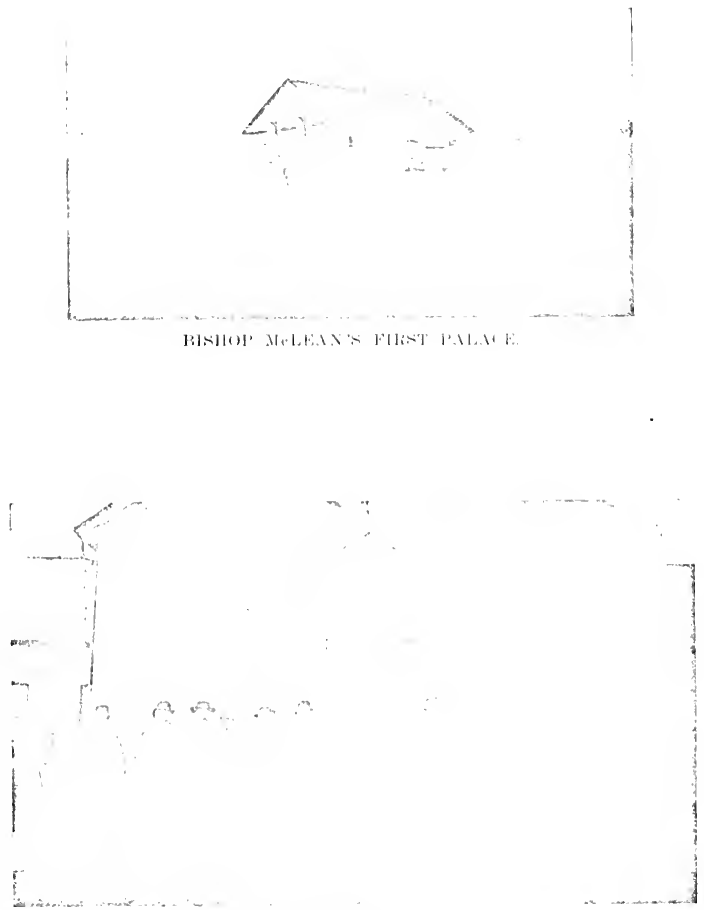

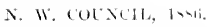

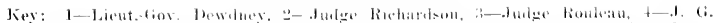
Turrifl, i- llavter lised. fi-de.

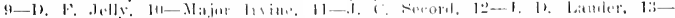

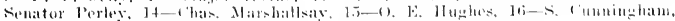

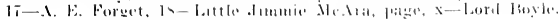


scen myself during my travels in the spring, and from what I gather from the correspondence which reaches me as Indian Commissioner, I can confidently say that our Indians are generally more contented than they have been since the treaty was made, and the progress they are making in agriculture is most gratifying.

"It camot be expected that with a population of some twenty thousand Indians, scattered on reserves in bands all over the territory, we can escape without a little trouble and at times excitement. 'This is incritable where Indians fresli from the plains are tirst l, ronght on their reserves and come in contact with white settlers. It has been so with those who are now enmparatively well oft, and will be so until the new arrivals recognize the fact that they must settle down, and work to make a living; lut that there is any cause for alarm $J$ deny. I an sure the general teeling is one of security, and the exaggerated reports that have becn circulated are to be regretted."

In the preceding year, with the advice of his Council, Guvernor Dewdney had imposed a fee of fifty cents per gallon upon spirituons lipuors brought into the country under Govermment permits. The Governor called attention to the fact that a large amount of lipuor was being smuggled into the conntry withont permits and that many illicit stills were in operation. However. he was "glad to be able to inform" the Council "that very little alsuse" of the permit system had occurred. Against this dictum Messrs. Oliver and Turriff protested. They considered the enforcement of the law at present to be most unsatisfactory and disagreel with the Governor and the majority of the Council, who thought that the establishment of local breweries would improve conditions by discouraging smuggling and illicit distilling. From this time on for many years the control of the licuor traffic provided themes for ever recurring debates. It is, of course, to be mulerstood that as yet the North IVest was theoretically under a prohibitory system, so far as the legal sale of intoxicants was concerned.

A very large proportion of the session under review was devoted to Mr. Oliver's School Bill. Already under the Governor-General's Orders in Council the Lieutenant-Goverimor was paying out of the appropriation for the North West Govermment half the salaries of the teachers engaged in ten Protestant and one Roman Catholic Scliools. The regulations, however, required that a school must have an attendance of fifteen before it was eligible for assistance, and the Conncil were unanimonsly of the opinion that this mumber should be reduced to ten. Mr. Oliver's School Bill was read a first time and referred to a special committee. As a result of its deliberations a second Sclool Bill was introduced by Mr. Rouleau and ultimately passed, Angust 6, $188_{4}$.

The other chief topics of debate in this session was the LieutenantGovernor's Municipal Ordinance, which, after vigorous scrutiny in committee and numerous amendments, duly became a law. Mr. Jackson was a 

special champion of the Bill. The measure, however, did not prove very popular in practice. It was an attempt practically to transplant Ontario Institutions into a sparsely settled territory, where local conditions differed widely from those of Older Canada.

The Conncil of $188+$ devoted attention to many other topics. In all forty-three Bills were introduced, and thirty-six were passed. Recommendations were made in accordance with which the elective members were to be paid $\$ 400$ and travelling expenses.

On July 9 the Comncil was visited wy Crow foot, Red Crow, Eagle Tail, and Three Bulls-distinguished Blackfeet chiefs. They were duly welcomed by a formal resolution, to which Crowfoot returned thanks.

Evidence of friction betwcen the elective and appointive clements in the Council sometimes manifested itself. Messrs. Oliver and Ross were particularly emplatic in maintaining that no person not directly responsible to the people in the North West should be allowed a voice in local legislation, or a seat in the Comncil. The majority of the Comncil were, however, peaceably inclined, and when Messrs. Oliver and Ross introduced this and other grievances in a fiery resolution we find Messrs. Jackson and Turrift presenting a substitute, which all the other members supported. In it they expressed the belief that the feeling of the country was strongly against "any action of the Council being taken in such a way that either pulitical party in the Dominion J'arlianent could use it for political purposes." One seems to see the hand of the party politician even in this rebuke to Messrs. Oliver and Ross, though it manifestly was not seen by some who supported the amendment.

The Council reaffirmed the statements contained in the Memorial of the preceding session, but protests against the continuance of many of the grievances complained of were referred from the Committee of the Whole to the Comncil in Executive Session. Consequently we have no further record of the matter in the Journals of the House.

However, the North West grievances had already been brought prominently before the attention of Parliament by Mr. MI. C. Cameron, member for Huron, Ontario. He introduced a lill for the representation of the Territories in Parliament, but it did not reach the later stages. Again on November 27 Mr. Cameron moved in amendment to a motion that the House go into Committee on Supply, "that the House should resolve itself into Committee to consider the conditions, complaints and demands of Manitoba, and the North West Territory, with a view to devise some means of remedying any well founded grievances and complying with any reasonable demands." Mir. Cameron referred to the Nemorial of the North West Conncil, and, while admitting that some of the grievances complained of had been remedied, declared that still others were deserving of serions 
consielcration. Ile aloo called attention on the bijl of Rights which had lecen adopted by the larmese Luin of Mantuba and the North llest complaining chictly of the land laws and tariff. llowever, he fonnd only fifty-seven supporters, and the fovemment s policy was endored by a majority of fifty-nine.

1)uring the year Mr. IV. Pearee visited Prince Vlbert, Battleford and other point on hehalf of the Dominion. Iuthoritics to investigate the daims advanced l:y old settlers on the grounds of long wecupation. A com-ialerable number of these dams were sat isfactorily di-poned of but . Mr. l'earee could not speak french, and is the empleyment of an interpeter would have entailed expense, no enquiry was made into the special grievanes of the French llatibreeds. Comment is unnecesary.

Mr. A. M. Murgess, Depuly Mininter of the Huterior, also mate an official tour aleng the lines of the Canatian l'acitic Railway. Ite met with a serious accident, however, and was obliged to cut his vinit shert. But for this untowarl incident onler grievances which ultinately helped to bring about the North llest Rebellion of the following year might have been remelied in time. As it lias, the brealing of an official's arm seemed to involve that of the Government in inevitable and incurable paralysis. The events leading up to the rising and consequent therenpon will be discunsed at length in other chapters. The rebellion was over when the Council again met on November 5. 1885 .

In that year the electoral district of the lerritories were rearanged. and on the 1 th of September elections were heli. . Mr. Oliver. of Edmonton, was defeated by 1)r. Herbert C. Wilson by a narrow majority. Captain Macdowall, of Lorne, did not contest his seat, and Owen T. Hugles was elected to represent it. Mr. I Inmilton also retired in Proadriew and was succeded by Mr. Charles Marchallsay. Regina district was given two members, and in the new Council it was represented by Messs. David fo Jelly and Jolm Second in place of Mr. Mr. White. Thus apart from the appointed and crofficio menbers, the only gentlemen who had sat in the Council of 1884 and retainch their seats in that of 1885 were Messs. I. M. Ross. IF. IV. Jackion, J. G. Turriff, and J. 1). Gedhles. Mr. M. D. Perley was elected a second member for Qu: Ippelle clistrict. Spencer 1 . Beclford was elected by acclamation in Mlossomin district, and Samuel Cumninglam in South Alberta. Richard Henry (Viscomu Boyle) was elected as member for Nacleod.

The Council net November 5 and remanerl in session until December 18. In the Speed from the Throne the (iovernor ammoneed that since the last session sixty-five applications-including only one for the establi-hment of a Separate sehonl-had heen received for the ereation of school dis-

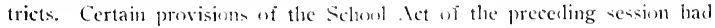



in practice proved morkable and would refune anendment. As an evidence of the opening up of the Territories it was pointer out that local receipts had more than doubled during the las year, and that numerons flomishing agricultural societies had been extablished. The Governor also linted at the necessity of some mean being devised by which he could be assinted by and kept in touch with his Council during recess. This was a tentative suggestion pointing toward the creation of a permanent Fisecutive Commitee. The recent rebellion was but very slightly touched upon in the Governor's speech.

The reply to the speech from the throne involved the Council in a prolonger and exciting discussion, and when finally adopted it constituted something very like a vote of non-confirlence in the Dominion Government's policy in the Territories.

It reads in part as follows:

"While congratulating ourselves and the country on the increased representation afforded. We camot omit to point out to your Honor the still greater right of representation which we jeel we are entitled to. !nt have not yet received. Sictled as these territories in a large nueatsure are, by men who have heen aceutomed to the constitutional rights and privileges of the British Fimpire, and its colonics, it is incvitalle that a fecling of distress and uneasiness should he prevalent owing to our not cnjuging the same. . . Ne confidently look forward to the next session of the Federal Parlianent granting our repuests and alling to their councils representatives of these territories.

"The position of several townsites in which the Government and the Canadian Pacific Railway are interested is very unsatisfactory. It was never intended. we believe, that the exemption from taxation for twenty years granted to the Canadian l'acific Ratilway should apply to -ections of lands subdivided into town lots, and it is higlily unsatistatctory to have the Crown claim exemption from taxation in towns allowed to be incorporated by it. The effect is to retard the growth of these centres of trade, and to create distrust, and besides, the resident owners are compelled to pay the mumicipal taxes which are expended in improving the properts of the Crown, which in this instance reaps the hencfits of speculation without bearing the burdens.

"Knowing as we do the great influence always had over the Indians by the llalfbreeds, we have to regret that the repeated representations made to the Govermment of Canada by the North II est Council on behalf of the Halfbreeds and their clams did not receive more immediate attention. We trust Your llonor will give this Council your help in bringing the matter of the many existing mostted claims to the notice of the Dominion fiovermment by a memorial or resolution."

Much time was spent by the Comeil in the discussion of rebellion clains and in the registration of formal protests against unjust, inadeguate or unnecessarily delayed settements. However, the Conneil expressed the belief 

that the Govermment's policy faithfully carried out would prevent future Indian outbreaks and endorsed the action of the Dominion Authorities in allowing the law to take its course in the case of Riel, the rebel leader. The Halfbreed political prisoners, however, were recommented to exccutive clemency.

A very lengthy memorial was presented to the Dominion Government by the North West Council involving twenty-seven distinct grievances and requests. This course was rendered necessary by the fact that the Territories harl no official representatives at Ottawa to present their views before Parliament. Messrs. Perley, Wilson and Ross were chosen as delegates to present the memorial at the capital, which they did in February of the following year. While many of their requests were not fully complied with at the time, the delegates expressed the view that much good would accrue from the Council's action.

During this session the North West School System wat formally established with provisions for separate schools as required by Section if of the North West Territories Act. As school legislation will be given a separate chapter, we need not here further discuss this most important reform.

Territorial affairs were very prominent in the Dominion Parliament of 1885, though the debates restlted in but little good. I'artisan feeling ran so high that the opposition was freptently unreasonable and the Government Party blindly subservient to its leaders. "Nltogether," as Alexander Begg very truly says (Voltme JII, page I 66 ), "the record of the session of 1885 might profitably he expunged from the pages of Canadian history. It contains nothing that can redound to the credit or prestige of the Dominion. and much that is deplorable."

In the Council of I886, Calgary had two representatives, Messrs. John D. Lauder and Hugh S. Cayley, AIr. Geddes thus disappearing from the House. Mr. Jackson had resigned his seat for Qu'Appelle and been succeeded by Mr. Robert Crawford. Otherwise the membership was the same as in the preceding year. The Governor commented upon the drought of the summer, but reported that, upon the whole, marked progress had been made by the Territories, especially as regards the cattle industry. The Canadian Pacitic Railway had been completed and the Long Lake Railway: was ruming as far as the Qu'itppelle Vailey. Other railway developments, actual or prospective, were also mentioned with approval, including a "not improbable Hudson Bay Railway" with its "initial point at Regina."

Out of the twenty-seven subjects upon which the Council of ISS5 had memorialized the Dominion Govermment, seventeen were reported as agreed to, and others as having been dealt with in a manner which the LieutenantGovernor believed would prove satisfactory. The Governor congratulated the Comcil upon the present condition of Indian afiairs, offering his as- 

surance that there never was a time when the lndians were more contented, more cheerful or better disposed toward their white brethren. A few of the leading Indian chiefs of the North West harl been sent to attend the unveilitig of the lirant Memorial in the City of lirantford. Ontario, a step that would doubtless have a beneficial effect. Indced, the general outlook of the North II est was hopeful, and a large increase in immigration was in evidence.

This year the reply to the Speech from the Throne was much more pacific than it had heen in the preceling sescion. The members of the Council, however, mited in believing that the time had come when it shonkl assume the character of a legislative assembly. I Committee of the Comncil reported at length upon the matter of pensions to mumerous rebellion sufferers or their heirs who had not yet received proper recognition, and the details were transmitted in due conrse to Ottawa. The anmul Temorial to the Federal Govermment this year included twelve items. Twenty-one bills were passed by the Comncil and three others fell by the way. It is perhaps not without significance that much of the Comncil's time was devoted to legalizing defective Mmicipal By-Laws.

The Council sat from October 13 to Nowember 17 , and evidently worked very steadlily: On Wednestay; the 18 th, however, a quormm wals not present and the Governor adjourned the Council until the following linday. On that occasion only two members presented themselves. [lis Honor expressed special regret at the somewhat cavalicr desertion of their posts by the other weary legislators, as important matters were still pending. However, as the great majority of the members had alrearly left for their homes, he bowed to the inevitable and prorogued the Council.

The time had at last arrived when representation of the Territories in the Parliament of the Dominion conld no longer be slelayed. The Terriiories were given two representatives in the Senate, and four electoral districts for Dominion purposes were also created in the North West, In the Alberta constitnency D. W: Davis was elceted; in Saskatchewan the candidates were D. II. Macdowall and the IIonorable David Laird, of whom the former was successful. The first member for East Assiniboia was IV. D. Perley, and the first member for West Assiniboia was Nicholas Flood Davin, who defeated James II. Ross. The latter gentleman, however, retained lis place in the local Conncil as member for Monse Jaw:

The treatment of the Territories in the framing of the Dominion estimates-was distinctly more favorable this year than hitherto.

In this same year the Territories were sub-divided into five judicial districts. A supreme Cont was constituted. consisting of the Honorable IIngl Richardson, the Ilonoralse James I: Macleod, the Honorable Charles 13. Rotuleau. and the llonorable Edward W. Wetmore, who was 
the Lietitenant-Governor carry on his executive functions by and with the advice of an Executive Comncil of three persons who should be summoned to office by the Lientenant-Governor and must hold seats in the Xorth West Council; that the Conncil should have power to amend its own constitution from time to time and should lee sulject as regards money bills, disallowance, and similar matters, to the prorisions of the British North Ameriea Act applicable in the case of Provinces. This .lemorial was presented in the Council by Mr. Ross, but all the elected members of the Council, and Mr. Hayter Reed as well, had places in the Special Committer appointed to draft it.

Every year had seen the old Lignor Permit Law failing mere conspicnously than hitherto. between January I, 1882, and Octoler 20. 1887, the fines for the violations of the Territorial Liquor Laws amomnted to \$5. $63 \mathrm{I} \cdot 50$, and it was notorious that but a small fraction of the total number of instances in which the law was infringed were ever punsled. The Comeil placed on record its disapproval of the system as unsatisfactory and ineffective either as a temperance or prohibitory measure. After much debate on the subject, it was tuminously resolved that the Comncil should be given the same powers in dealing with the liquor question as those exercised ly the Provinces, and that the provisions of the Scott Act should be extended to the Territories.

This ninth and final session of the North West Council closed on Saturday, November 19, I88\%. When the Dominion Parliament met early in I888 the North West Territories Act was passed abolishing the Conncil. and creating a Legislative Issembly. Of the twenty-five members, twentytwo were to be elected and thee others were to be chosen from the Territorial judiciary as legal experts. These latter, however, were to have no vote. The Assembly was given, by the statute, powers analogons to those of Provincial Legislatures, but substantially the same as those latterly exercised by the North West Council uncler Orders in Council issued by the Governor-General. Members were to be elected for three years, but the Assmbly was to be subject to dissolution at the discretion of the LieutenantGovemor. Provision was also made for an Advisory Council of four menbers, who, with the Lieutenant-Governor, Would constitute an Executive Committee in all matters of finance. The Assembly would henceforth conduct the proceedings under the presidency of the Speaker, elected from among its members.

In his report for Is8s the Commissioner of the Royal North West IIounted Police conmented on an almost entire absence of crime in the Territory during the preceding year. In all quarters of the Territories, except the sonthwest, the Indians were making rapicl strides toward selisupport and some of their chicis rencleded very valualle assistance to the 

police in the enforcement of the law and the capture of criminals. This year considerable treaty money had been paid to the rebel Indian tribes upon the recommendation of the Inclian agents. In speaking of the numerous lndians in the I'rinee Albert district, the Superintendent was able for the third time to comment in his ammal report upon the excellent conduct of the Indian population. Not a single crime hat been committe! among them.

For several years after the Rebellion it was necessary to issue relief to large numbers of the llalfbreeds who had been rumed in the rising.

The IJonorable Mr. Dewdney's term of office as Licntenant-Governor of the Territories expired in July, I888. The seven years during which he held this important appointment were a period of unrest and transition and the difficulties of his office had been very great. In those days a Gorernor really governed. It was his duty to preside over and dircet the proceedings of his Advisory Council, and personally to superintend the administration of public affairs in all parts of his enormons cloman. In this. moreover, he was far from exercising a free hand. He wats subject, in important regards, to the control of ill-informed officials two thousand miles away. True, it was his duty to reuter them well informed, and in this hecan scarcely be said to have succederl. Indeed, the opinion han heen very prevalent that the responsilsility lies at his deor for the notorious ignorance prevailing in official circles at Ottawa regarding the actual needs and wishes of the llest. An impartial study of arailable records, however, leads one to the conclusion that he habitually and earnestly lalwred in the interests of the Territories, where he has always hacl wam supporters in the best informed circles. The Councils in whose deliberations he tuok so prominent a part left behind them a very creditable legislative record. Their recommendations to the Federal. Authorities were, npon the whole, surprisingly free from political animus and in almost all instances characterized by shrewd insight into and familiarity with conditions throughont the Territories. Had the Nemorials of the Council, transmitted to the Dominion Government by Mr. Dewdney, been given the prompt and decisive attention they merited. Lientenant-Governor Dewdney's regime would have been marked by still greater development of the Territories, and by such an increase in prosperity and contentment as would have rendered injossible the deplorable rebellion of 1885 .

Mr. Dewdney presently entered the Dominion Cabinet as Minister of the Interior, being elected for the constituency of East Assiniboia. The seat was racated by Mr. Perley, who was shortly afterwards created a Senator. Four years later Mr. Dewdney became Lieutenant-Governor of Biritish Columbia, holding that distinguished pust from $18(9) 2$ to $I 8 y 7$. 


\section{CHAPTER NIX}

\section{DISCONTENT IN THE INEST AND PRENONITJONS OF REBELLION}

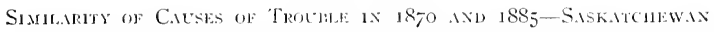

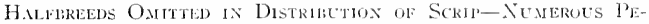
TITIONS OF RFPRES $(1872,1873)$-P.THETIC l'ITTTONS HRoM St.

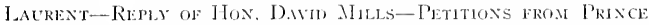

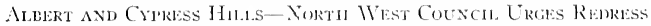

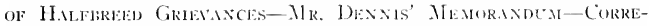

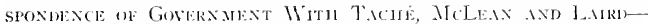

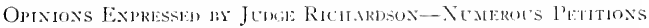

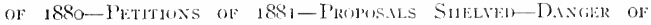

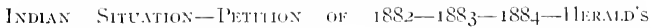

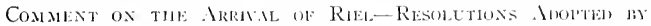

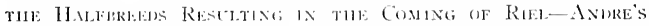

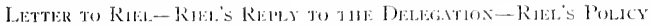

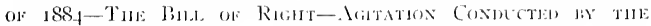

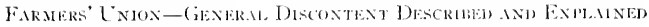

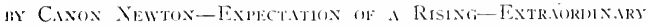

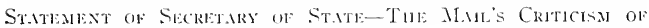

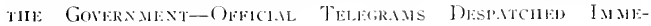
Ditely Before the OUthenk.

The rebellion of 1885 arose chicfly from causes the same ats or similar to those that brouglit about the rising of 1860 and 1879 : delay in recognizing the riglats of I lalfbreets in connection of the extinguishment of the Indian title to the soil; uneasiness consegtient upon the mexplained policy of the anthorities entrusted with the surveying of the lands; and the total neglect of formal protests entered by the aggricied parties.

Uncer the Manitoba Act of 1870 a large area in the new Province was set apart to be divided ameng the Jabfbreerin and by subsequent legislation it was provided that [Jalfbred heads of families shoukl receive scrip for 160 acres apiece. It the time the census was taken to form a hasis for the issue of this serip many Red River J Ialfhreeds were alsent or resident in the Territories, and were therefore not included: manifestly, however, their rights were ats valid ant binding as were those of their brethren in Manitola. 



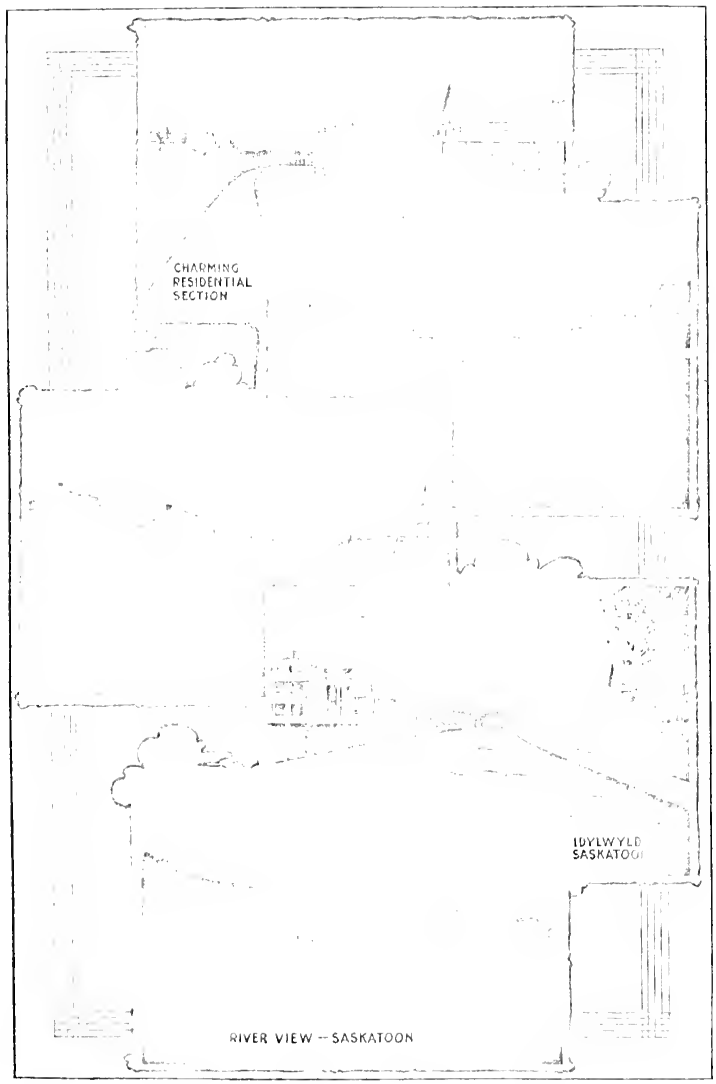



The question did not hecome nrgent in the North Vest at a very early date. However, in May, is73, we find John Fisher and a number of other Ialfbreeds in the Territories petitioning throngh Jientenant-Governor Norris for equitable land grants in extingnishnent of their Indian rights. In I87t Mr. Joln McKay, of I'rince Allert (brother of the IIonorable James Mckay, of Fort Garry,) informed the North West Conncil that at Prince Albert there were already between 300 and 400 Einglish Ilalfireeds, who, like the French Halfbreds of St. Jiturent on the south branch of the Saskatchewan, were excectingly anxions to have the land guestion settled. In the same year the Reverend Father Decorby, missionary at Lake Qu'Appelle, wrote $\mathrm{Mr}$. Laird, then Minister of the Interior, regarding the anxiety of the Halfbreeds in that locality lest they shonld be distmbed in their holdings, and about the same time thirty-ne of the latter petitioned LievitenantGovernor Morris in the same regarel. In I $8-6$ In pector James Ilalker, N. IV. M.P., wrote Mr. Lairel regarding the disputes and dissatisfaction arising from the unsettled condition of the land question among the settlers at Prince Abert Mission, which then had about I 50 families. In 1877 , forty-three Halfbreeds at Backfoot Crossing presented an address to Lientenant-Governor Jaird imploring assistance with a view to maintaining themselves ly agriculture. So far, however, the agitation wats somewhat sporadic. There was lut little interference with the Metis of the Territories in early days, but with the gradual influx of white settlers and the disappearance of the buffalo, the necessity of pressing their claims hecame evident. Accordingly, as long ago as $18-8$ a more formal agitation took shape.

On Jebruary 1,1878 . the Ilalfbreeds of St. I anrent had a public meeting, at which Gabriel Dumont was president and Alexander Fisher secretary. It was declared in the memorial signed on this occasion:

"That the sudden transition from prairie to agriculural life. necessitated by the rapid disappearance of the buffalo, and the ordinance respecting hunting, of the North Vest Council, have brought your petitioners to their last resources and foreed them to apply to the Federal Governinent for assistance in agricultural implements and seed grain, like assistance having been granted to certain foreign immigrants in the Province of Manitolua. Those instruments, besides being extremely scarce, are only sold here at prices so exorbitant that it is impossible for your petitioners to secure them; if. theretore, the Govermment were tmable to grant this help many of your petitioners, however willing they might be to devote themselves to farming. would be compelled to betake themselves to the prairie at the risk of infringing the ordinance providing for the protection of the buffalo. however good it may be, since the time during which hunting is permitted is too sliort and the butialo too scarce to enable them to lay in a sufficient supply and provide for their own needs and those of their families during tiue rest of the year." 

They further petitioned:

"That there be granted to all halfbreeds who have not participated in the distribution of serip, and lands in the l'rovine of Manitola, like serip' and lands as in that province."

In the precerling month a petition to the same effect had been signed by the French Canatlians and 1Talfbrects of St. Albert.

In reply to Mr. Lairl's letter forwarding these pathetic appeals, the Honorable Darid Mills wrote a curt refusal as regards ail in commencing agriculture, lut promised that a fair survey and allotment of lands would be made in lue time.

In June a petition signed by 151 persons was forwarled from l'rince Albert arking for a census of Ilalfbreeds and old settlers "with a view to apportioning to those not alsearly included in the census of Nanitoba their just allotment of land and scrip."

A petition analogots in clatacter to those referred to above, and bearing 269 signatures was presented from the Halfbreds of the Cypress Ilills in the same year.

A resolution in the same comnection was pansed by the North IV est Council on Augut 2, and on September 3o, Lieutenant-Gosernor Laird wrote the Ottawa Authorities to "urge upon the Deminion forernment the neces. sity of taking early action with respect to the claims set forth." . Dbout the same time a deputation of I Ialfbreels waited upun the Lieutenant-Governor at Duck Lake to enquire what reply had been received to their petitions.

In Decomber Mr. Dennis, Deputy Minister of the Interior, presented to his Minister a very long nemorandum urging "that it is expeclient with as little delay as possible to deal with the clams to consideration preferred by the Halfbreeds of the North West Territories." He proposed to offer the Halfbreeds certain inducements to settle on land. and to teach them to farm, especially to raise cattle, and of this plan he says:

"The immediate effect wonll be, assuming that the I Halthreels themedres are willing to give it a trial, that we hould inave the whole of this element in sympathy with the (iovermment in clealing with dhe platin tribes of Indians. In this way we should attract to our side a morat power which in the present critical relations of the varions tribes of Indians towards each other and towards the (iosermment, would prove of the greatest value to the Dominion. . . The mincersigned regards the state of affairs in the Territories in relation to the Indlans and I lalfbreeds as calling for the serious consideration of the Govermment in view of adelitional complications which are not unlikely to arise, owing to the presence on our soil of large numbers of armed Indians, refingees for the time being from the seat of war in the adjoining territory. The is of opinion that further means should be adopted to cultivate and maintain relations with the Indian and IIalfbreed poptiations calculated to attach them to us, and to convince them that 

the Government is desirous of fulfilling its ol)ligations to them in the utmost good faith."

Mr. Demnis then suggests a scheme of industrial schools, and choses thus:

"The undersigned respectiully repuests for the whole question discussed in this memorandum the early consideration of the Ninister of the Interior, in order, if thought desirable, that a measure slould be prepared, embodying such policy as may be decided upon in good time for the ensuing session of Parliament."

In consequence of these representations Mr. N. F. Davin was appointed a Commissioner and Colonel Demis' memorandum was forwarded for the consideration of Archbishop Taché, Mislrop McLean and Governor Laird.

On January 29, 1879, Archlishop, Tache replieal in a very lomg letter:

"A liberal policy on the part of the fiovernment would attract to its side a moral and physical power which in the present critical relations of the various tribes of Indians towards each other and towards the liovernment would prove of the greatest value to the Dominion. ()n the other hand, the Halfbrect element in chisatisfaction womld form a standing menace to the peace and prosperity of the Territories. There is no doubt that the state of affairs in the Territorien in relation to the Indians and I Ialloreeds is calling for the serjons consideration of the fovernment, and measures should he adopted to cultivite and maintain relations with the llalfbrect populations calenlated to attract them to 11 s.

"The formidable lndian (juestion hats not yet atrisen in ont midst, owing largely to the inlluence of the I Ialfloreed element. The disappearance of the bufialo and especially the extension of the setters into the ludian conntry. are preparing difficulties which may be avoided. I hope. but which would otherwise involve such terrible and expensive results that it is the duty of all the friends of the Govermment and of the comntry to do all in their power to prevent such misfortune.

"The result depends in a great measure on the way the Ilalthreeds wonld be treated. Friendly disposed, they will mightily contribute to the maintenance of peace: dissatisfied, they would not ouly arld to the difficulty, but render the settlement of the country the next thing to an impossibility.

"The Halfbreeds are a lighly" sentitive race; they keenly resent injury or insult, and daily complain on that puint. In fact, they are daily lumiliated with regard to their origin by the way they are spoken of not only in rewspapers, but also in official and semi-official decmments.

"It is desirable that the Halfbreed question shonld be decided tumn without any further delay. The repuisite legislation ought to be passed in the coming session of the Legislature. Immediately afterwards inspectors ought to be appointed, and I would particularly recommend Mr. Ingus Mckay as one of the inspectors.

"There is no doubt the dificulties increase with delay. . . ."

The replies of Pishop McLean and the IIonorable Mr. Laird were much to the same effect, though as to details of policy there were maturally dii- 

ferences of opinion anoung the various gentlemen engaged in evolving a solution to the problem.

In the Saskatchearan Herald of March 24. 1879, reference is made to a rumor that Lotuis Riel was to conne in the summer with at large number of French Ilalfbreets from the Red and l'embina Rivers to make settlementalong the Silskatchewan.

In Maty, 1879, a recolution was passed empowering the authorities of the Department of the luterior "To satisfy any clabue existing in connection with the extinguishment of the Indian title prefered ly IIalfbrecds, resident in the Corth West Territories outside the linits of Manitola, on the 13 th day of July, 18\%o. by granting land to such persons to such extent, and on such terms and consirlerations as may be elemerl cxpedient."

In December of the same year Judge Richardson was in Ottawat and approved of the schence suggested by Colonel Dennis in his memorandum. Six weeks later he again wrote (olonel Dennis, in part, in the following terms:

"I may be permited to exprese the opinion that opportmities present themselves for remoring the diesatisfaction exinting anong these people. and securing their good-will towards the (intermment, becathe: (1) Their former occupation as hunters is gonc: $(2)$ they are at al class destitute. I further reasen for urging, at l respectfully do, early actum, is that they are scattered among the Indians and lately subjected to the evil inlluences of leading spirits of the Manitolat troubles of 1870 , who, during the patst seatson have been traversing the conutry doing, at least, no good."

On February 23. 1880, a meeting was held at Duck Lake at which Father André, in a speech widely reported in the press. almitted that the IJalfheedhad grievances requiring redress. In the spring of the sane year the lalfbreerls of Nanitobal Village, North West Territories, signed a petition setting forth the general demands.

On April 3 .Mr. M. L. Orde. Indian . Igent, liattleford, wrote that a credible report was prevalent that Riel was then agitating anong the IIalfbreeds. Sionx and Crow Indians.

On the Ifth of May, I880, Mr. Thomas Mackay, of Prince Albert, transmitted to the Minister of the Interior a petition enclosed in the following letter :

"I herewith forward yon a petition from the halfbreeds of Edmonton and Prince. llbert, North IV est Territories. Is we have no representative for the North llest Territuries through whom we could make out wants known, the petition is forwarded direct to you. Trusting it shall receive your early and special attention-

The petition was signed by one hundred and two names. On July 10. 1880, Mr. Mackay"s letter was ackinoledged.

In the -mmer of $18 S$ a a like petition to the fiovermor-fieneral with one 
hundred and twelve signaturen was presented by the Italibreeds of Qu'. Ppelle. In June, Mr. Lawrence Clarke. Member for Lorne. presented to the North Vest Combil a nemorial conched in the following words:

"The unclersignet has the honor to represent: That a feeling of dissatisfaetion and discontent exints anumg the Ilalflureed clement of the North Nest Territories.

"That such a feeling has arisen from what these llalfbreeds consifler a disregard of their rights, and in the opinion of many whose standing in the country gives snch an opinion weiglit. has, to some cxtent at leasl, increased the diffenlties encometeres bo the bonmion forernment in their dealings with the Indians. between whom and the whites the llatflureed form a distinet class, possessing, as a rule. great influence oner the lundians.

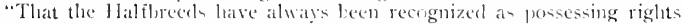
in the same soil, strlject to which the (iosermment acepterl the transfer of the Territories, and while ample faros ision has been made for those resident in Manitolsa on the I.5th of July, 1870, nothing has heen done towards extinguishing that portion oi the inclian title to lands and territories out -ide the Irovine of Maniteba as originaliy formed by the . Net of 1870.

"The andersignel further draws attention to the fact that, by law the Ilablorecds are excluded from the benetits conferred mum the findians.

"That the undersigned has lacen given to understand several petitions from various quarters have been prescuted to the boninion fiovermment on the stbject of the llablibeeds particularly referred to. but no wetice taken thereof.

"That the mulerigned knows that a considerable portion of these Ifalfbreeds were and are still residents of the electoral district of lorne, and feels it, as the electoral representative of that district. his chity to bring under notice their grievanees in the lope that some action mal be taken at an early date towatrels removing what seems to be just cauce for complarint.

"The undersigned recommenth that, through vour Honot in the Council, the attention of $\mathrm{Hl}$ in Fxcellency be respect fully drawn to the stluject. and he be menorialised to direet the attention of his nimisters to the position of the Halfbrecks, wh at the transier to Canala were, and still are, resielents of the North llest Territories. and hate not lecome parties to Indian treatics, and the taking of stuch steps as may lead to a speedy adjustment of the grievances they labot under."

On June 14. IS8, the I.ientenant-Governor transunted a copy of this memorial to the covermment, adding:

"I was repuested by a resolution in Conncil, passed on the roth inst.. to transmit copries theresif to he laid before His Excellency the fiovernorGencral. and to express the hope that His Excellency nay be pleased to draw the attention of 1 lis Ministers to the gricuances complained of.

"I trust you will have the goodness at an early dity to bring these stibjects to which these memorials refer uner the cunsideration of flis Excellency. the Governor-General. . . . . part from the representations in the memorial in gtestions. I ann aware that seriots diuptestes are arising in the Prince Albert. St. I aturent and 1)uck I ake settlements regarding claims for 

bands, and I wothl therefore respectfully urge that, in so far at it may be consistent with the policy of the Dominion fovernment, the prayer of the menorials may receive early consideration."

On receipt of these papers the Deputy Minister mate up a file which contained his memorandum of December, I 8 - 8 , the letter of Archbislup Taché, the letter of Bishop McRae, the letter of Bishop McLean, the letter of Mr. Laird, the letter of Colonel Richardson, the memorial of Mr. Clarke, and the letter of Governor Laird, and he laid it before sir David MacPherson, then Acting Minister of the Interior, but nothing came of it. Though his responsible ministers and advisurs could not be stirred to consider the grievances of the Metis, the Marquis of Lorne, Governor-(ieneral. who visited the North West Territories in September of this year, clearly recognized the importance of contentment among the Ifalfbrech, and cxpressed limself as follows:

"In cementing the friendship, which, thank God, has reigned between the whites and the red men, the Metis has heen the valued confidant, as he is the brother of both. Ile las aided in the perfect understandling which exists."

While the Saskutchadan Herald and other newspapers from time to time denied that any real danger of an Indian rising at this time existed, serinus tronble with the ludians was, as at matter of fact, narrowly averted in June, 1878. The Herald reports that an Inelian violently assanlteil Instrinctor Craig, engaged in issuing rations on Lucky Man's reserve, and that Superintendent Crozier, upon visiting the reserve with about thirty police, foumd the Indians holding their annual Thirst Dance and in a high state of excitement. He considered it alvisable to remove the cattle and provisions lelonging to the Government from Lncky Man's reserve to that of Poundmalier. where he fortified himself, sendling to Battleford for additional men and anmminition. Next day Crozier despatched a messenger to the Indians,who harl sent their women and children away and lung ont their medicine bag-asking them if they intended to give up the men he had come to arrest. Some reply was received, wheretpon Major Crozier, unarmed and nnaccompanicd by anyone save an interpreter, visited the Indian canp and helel a council with the chiefs. Next morning he left the camp again, having received a promise from the Indians that they would cone down at nine o'clock with the prisoner. As they did not do so he again visited the camp. where he found that the advice of their responsible leaders was loving little effect upon the excited braves. Pomemaker adtressed the Indlians, and said, in effect, that as he found his men unwilling to yickl up the prisoner. he would deliver himself up to the police. He accordingly left for the barracks in company with Big Bear and two or three other Indians. The original culprit presently arose and tokl his version of the fracas, and fonr men 

vere orfererl by Cruzier to arrest him. "Then ensued," says the Herald, "a scene of almost indescribable confusion and uproar, many of the Indians crying rut, 'Now is the time to shoot,' while others implored them to wait until the prolice fired the first shot. In the mele two policemen were overprwered and disamed. IIal a revolver or rille accidentally gone off in the scuite there is no telling what might have licen the result."

The prisoner was ultimately ludged safely in the folice guard room, lut the whole episorle showed how easily a serious Julian outhreak might be precivitated. When Crozicr's messenger had come to Battleford, rifles were izued to volmueers. An offer of the assistance of fifty armed men was also telegraplied from Saskatoon.

Aiter this affair it was thought that the anthoritics should organize effective volunteer companies in every settlenent. Some such companies had been establiched a few years earlier, but the Government refused them uniforms. The settlers considered a uniform essential, believing that it was a impressive to the savages as were the rifles themselves. HJowever. nothing was done, and the companies were practically disbander and their. rifles lost to the authorities.

Al! through these years frequent letters regarling IJalfheed claims were being wan-mitted to Ottawa by private citizens and public officiuls, such as Mr. Join Mackay, of Prince Nlhert, Bishop Grandin, Hon, Mr. Ryan, Stipendiary Magistrate, Inspector James Walker of the Mounted Police, and others. without effect. Mr. George Duck, Jominion Jands Agent at Prince Albert. Wrote on March II, regarding the possibility of resurveying the land in the vicinity of St. I.atrent in accordance with the way it harl actually. been taken up by the settlers resident upon it. Jn accordance with well rec gnizel precedent, this letter was left unanswered for a little over six months. Then Mr. A. Burgess, on belalf of the Ninister of the Interior, replied in the negative (September 2r, r8S2). Meantime, the following petition had been forwarded to Ottawa. While it does not differ materially trom many others of which we have been speaking, it deserves the reater's carefut consideration:

.. $\overrightarrow{\mathrm{St}}$. Intoine de Padou, South Saskatchewan. Septemler 4. 1882.

"To the Right IIonorable Sir Joln .1. Mac')onald.

Minister of the Interior. "Ottawa, Ont.

Sir:

"Ve, the undersigned French Hattbreeds, for the most part settled on the west hank of the Saskatchewan in the district of Prince . Vlbert. Nortli IVest Territories, hereby approach you, in order to set forth with contidence the faintul position in which we are placed, with reterence to the lands occunsed by us in this portion of the Territory, and in oreler to call the 


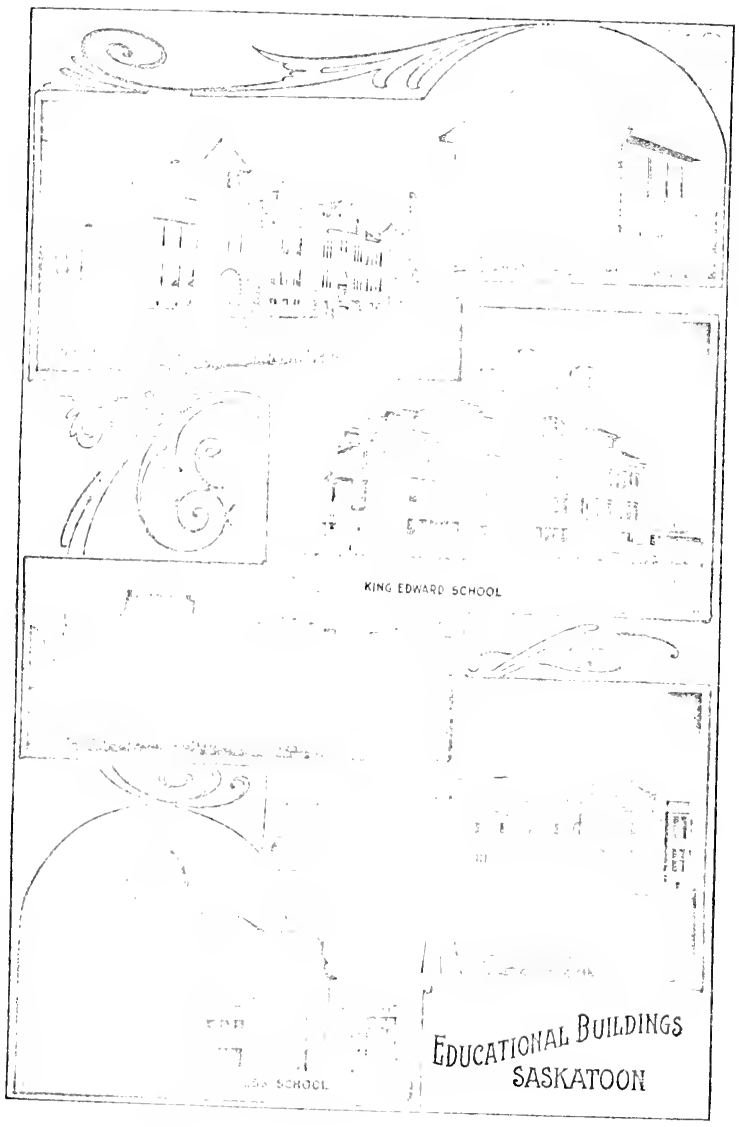




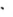


attention of the Govermment to the question which causes us so much anxiety.

"Compelled, most of us, to abandon the prairic, which can no longer furnish us the means of subsistence, we came jn large numbers, during the course of the summer, and settled on the south branch of the Saskatcliewan. Pleased with the land and conntry, we set onrselves actively to work clearing the land both in the hope of sowing next spring and also to prepare our houses for the winter now rapidly approacling. The surveyed lands being already occupied or sold, we were compelled to occupy lands not vet surveyed, being ignorant, for the most part, also, of the regulations of the Govermment respecting Dominion lands. Great was our astonishment and perplexity when we were notified that when the lands are surveyed we shall le obliged to pay \$2.00 an acre to the (jovernment if our lands are included in the odd-numbered sections. We desire, moreover, to keep close together, in order more easily to secure a school and a church. We are poot preople, and camnot pay for our land without utter ruin and losing the fruits of our labor and secing our lands pass into the hands of strangers, who will go to the land office at frince tlbert and pay the amount fixed by the Government. In our anxiety we appeal to your sense of justice as Minister of the Interior and head of the Government, and beg you to reassure us speedily, by directing that we sliall not be disturbed on our lands, and that the Government grant us the privilege of considering us as occupants of even-numlered sections, since we have oecnpied these lands in good faith. Having so long held this country as its masters, and so often defended it against the Indians at the price of our bloot. we consider it not asking too much to request that the Government allow ws to occupy our lands in peace and that exception be made to its regulations by making to the IIalfbreeds of the North Viest frec grants of land. We also pray that you would direct that the lots be surveyed along the river, ten chains in width by two miles in depth, this mode of division being the long-estalblished usage of the country. This wottd render it more easy for us to know the limits of our several lots."

On October 13, I882, Lindsay Russell answered bricfly on Sir John's behalf :

"In reply I am directed to request you to inform the petitioners that when the proper time arises the case of eacl bona fide settler will be dealt with on its merits: but as regards the survering of the lands in guestion, that all lands in the North llest Territories will be surveyed according to the system now in force."

In the preceding August, Mr. Dewdney lad addressed a letter to Sir John Macdonald in which he spolie as follows regarding the Métis claims:

"I would respectfully suggest that either Mr. Commissioner Walsh or Mr. Inspector Pearce be instructed to examine into and arljust them on an equitable basis, and that without delas. as the Halfloreds interested are very uncasy about their lublings, and may he looker upon as the pioneers of the districts." 
On Jannary 16, 188,3. Father Andre, of St. Laurent, again laid the ease clearly lefore the Minister of the Interior in the following letter: "Sir :

"I write you for the purpose of calling your attention to the painfully embarrasing position in which the French I Ialfbreels settled on the sontherly hanks of the Salkatchewan are placed.

"According to an old custom in Matuitoba, they took wip their lots ten chains wide in front by two miles in depth, trusting that the Government, acting on the rule alrearly estalolished. Would survey these lands into lots ten chains in widtl by two miles in depth.

"Their surprice may he imagined when they say the land abong the Saskatchew:m measmed off into squares of forty chains withont any heed being given to their just elaims and protests.

"What is the result of this ahmormal division? Ome lJalfureds are overwhelmed with difficultics on account of their lands and this proceeding will now sow division and diccord among them, and will render the fovermment odious in their eyes, they considering it as guilty of a gross injustice towards then.

"This survey bamentably mixes things: some lose their land, which is being grabled by their neighloors: others see the fruits of their industry and heir improvements dissipated.

"This monapy state of things wruld casily be mate to cense by giving ear to lheir just claims. Ind how can this be refund them when you granted a similar favor to Prince . Vlbets? .ll the lands along the branches of the Saskatchewan have hecn surveged in this mamer; everybody was satisfied. and not the least complaint was heard alout the surver.

"I camot understand. sir, why your surveyors hould have two different methods of parcelling the public domain: ane for Prince. Nlbert ten chains in width ly two miles in depth, which we approve, and which we claim as a right, seeing you have granted it to I'rince. llbert; the other, of hlocking ont the land in squares of forty chains without taking the river nor locaten of the settlers into consideration. The latter method we protest solemnly against, all of us, and humbly pray, sir, that you order a new survey, and thus validate our requests.

"Already the people of this colony have addressed to you a petition on this subject, but the answer given under your directions is not one caleulated to inspire them with the loje that you would riglt the wrong of which they complain.

"Knowing the difficult situation in which our people are placed, I have resolved to make another effort, which I trust will bring haply results, and I dare hope that you will accede to their just refuests, and no later than next summer order $a$ new survey of the land on the south branch of the Saskatchewan.

"Isy your kindly concurrence in this matter you will do an act of justice to our people and render them a service for which they will ever be thankful."

Lientenant Dewdney wrote to Honoralble Mr. Maclherson, March 19, $188_{3}:$ 

"The sooner the claims of these Hatfbreds are detcmined. the better. as a number of them are bona fide settlers and deserve consideration."

On Jantury 19, 1880, Father V'égreville. of St. Lonis de Langevin, wrote Mr. A. M. Burgess as fullows:

"I myself have several times got Mr. Duck, D. L. S., of St. Albert, to write to Otawa, and in every case withont success; so that I myself lost all hope, and several parties went away, some of them selling their lands for a nominal price. and others abandoning them withont any indemnity. In February, 18\&3. Reverend Father Leduc and Mr. Matoney were deputed to set forth our grievances and present our clain to the Government. They were promised, in writing. that the lands we occupied should be survered as river lots ten chains in iront ly two miles in depth, and that the survey should be made in the following antumu (IS83).

"The atutumn lats passed, winter is adrancing. What las become of those promises? Jlas some surveyor been entrusted with the work and failed to perform his duty: To you, sir, we put these questions, and this is also, sir, what I ask you today.

"I do not put these questions merely" in my own mame or merely in the name of the two missions I have founcled on the right lank of the Sonth Saskatchewan. I repeat what Father Leduc and Mr. Maloney said to the members of the Govermment in the winter of $188_{3}$ : I repeat to you what our settlers say to the land agent at I'rince. Illort; I an the faithiful interpreter of the whole popmlation.

"Ihe good enough, sir, to consider the conseruences of a painful detay. The scttlers hate made scttlements and are working them day by daty, without knowing where the lines of their future properties are to pass. These inflexible limits, right lines, and parallels. will traverse fictels, pass through houses, cut off farm louses from the fields connected with them. This must inevitably occur where parties have alrcaly put up buildings, and wherever buldings are erected until the surver is made. What serious hardships, what deplorable results must flow from all this! Three-fourths of these miseries might hatre been avoided had the survey been made when asked for and promised. . . . If I were on the spot I could get this letter signed by heads of families representing a population of two thousand souls."

St. Lonis de Langevin was settled in the years 1873 . I874 and 1875. The settlers had petitioned the Minister of the interior at Ottawa in 1880 . On Novemler 19. 18\&3. they sent another petition in part as follows:

"Finally Father Leduc, who hat heen sent as a delegate to Ottawa by" the peopte of Edmonton and Sit. Albert. slowed us the answer of the Government promising a special survey for all the located lands on the Saskatchewan. Since then we have wated in vain for the new survey."

In the following year, $188_{4}$. Father Andre laid before the LientenantGovernor in Council the following specific example of the kind of wrongs: he and his people were subject to, through the neglect of the Uttawa autherities: 

"I beg your indulgence in heing olsliged to malke you alequainted with a grievance of mine, which, however, will give you an idea of the tatte wi things calling for a prompt remerly. I hold at Duck Lake a tract of land of about 200 acres, of which I have been in peaceinl possession for oxer seven years. The land was fenced in and cont me a good deal of mone! and was always respected as the Catholic 11 issons property at buck latie. I was one of the first settlers at that place, and thromgh my exertions the settement increased raphlly and noludy ever troubled me in my lawful posscssion of that land until last Marchi, when a man of the name of J. Kelly jumped my claim, and, motwithstatuling my protestations, clamed the land as his own, and put the frame of a heme upon it, elepriving ne, in that manner, of hali my property. This is not the only occurrence of the kind at buck lake."

In the Herdd of July 12, ISE, a further watrning of impending tronble was to be found in the form of an editurial regarding lonis Ricl, who by this time had acter on a fomal invitation to return ar Canala. Sain the Herold: "It is a suspicions circumstance that inmerlately following his arrival in the country, threat of armed relollion should be indulged in, and that stories of the couppration of the lnclians shonld be put in circulation as they" now are."

The circumstanee attending the return of the Metis leater in 18 ; 0 mut now be considered in srme detail. It a meeting of llathluecels in the smmmer of $18 s_{+}$the following among other restutions were passed:

"That the French and English natives of the North West fhose that have not participated in the Manitolat Lands firant, want free patent for the land they posiess and oecupy at the present date, without any prejuclice to any more grants to which they are entitled for the extinction of their Indian title to the lands of the Jorth llent.

"That the natives, French and English, protest against the dues and charges on timber and forest nutil their rights within mentioned be recognised and granted by the Dominion fiovermment.

"That the managenent of the ludians stelt as lndian agencies, instructorships or other offices for the benefit of the Indlians in the North. Nest Territories be entrusted to natives, as they are more familiar with the labits, character and wants of those Indians, and to prevent any regretable occurrences such as have happened in the past.

"That the French and Fonglish natives of the North 11 est, knowing that Louis Riel has made a bargain with the fovermment of Camala, in $18-0$, which said bargain is contained mostly in what is known as the Manitoba Act, and this meeting not knowing the contents of said 'Manitolat . Let.' we have thought it advisable that a felegation be sent to Louis Riel, and have his assistance to bring all the matters referred to in the above resolutions in a proper shape and form letore the Ciovernment of Canada, so that onr just demands be granted."

Accordingly a delegation consinting of Gabricl Dumont, James lsbister, 



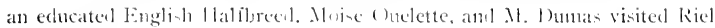
in Montana.

Noreover, Father. Indre, an intluential misionary among the llaltbreesls, had sent kiel the following letter:

"Ny dear Mr. Riel: The opinion here is so prominent in vour favor,

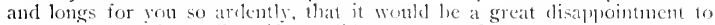

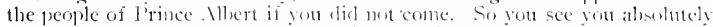
must come. Sou are the most popular man in the country, and. with the exception of four or five person, all the world impaticnly expects you. I have only this to say--Come; come quickly. With kind remembrances. J am,

1. Axbri:"

Riel's acceptance of the llalfbredn' invilation wan published in the Canarlian newspapers, and dhe forermment was urged us prevent his return. However, he arrived in Satiatchewan abont !ny 1, 184. Thronglan the summer and fall he addrened many meetings, one of these loeing held in Prince Alloert and very largely attended ly citizens of all clases. Ricl himself was advi-ing patience and mederate meatsure, amel the eatuse he hat champoned was appresed by pratically every one in the country. So unconstitutional measures were arlorated u expected, exeept pusibly in the case of a few fire brands. (ne of the is stated to hate aicl at the l'rince

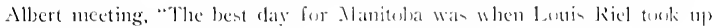
arms there, and the best day for the North llest will be when loure lied takes up arms liere."

In September, meler Kiel's guilance, a "lill of Rights" wats arlopted

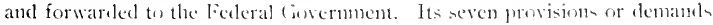
were as follows:

"First: The sululivision intu l'rovinces of the North West Territories.

"Second: The llalthreels to receive the same grants and other atrantages as the Manituba llablineeds.

"Third: l'atents to be issued at once to the colomists in possession.

"Fotrth: The sale of half a million aces of Dominion lands, the proceeds to be applied to the entalishment, in the llalibred -ettlement, of sehools, hospitals, and such like institutions, and to the erpupment of the poorer llalfbreels with seed, grain and implements.

"Fifth: The reservation of a humbled townships of swamp land for distribution among the children of llalthreed during 120 years.

"Sixth: A grant of at least \$1,000 for the maintenance of an institution to be contucterl by the nums in cacts / labibreed settlement.

"Seventh: lietter provision for the support of the Indians,"

These demands the (iovernment received with absolute silenes.

It must not be thonght that serious grievances were conlined to the llalibreed party. For two years back the Farmers [nions hat leen conducting a serions agitation for the redres of effensive land laws and other alleged 

grievances. Is indicating the dangerous form this agitation ar-uned. the following letter to the Secretary of the L nion will be read with interest.

"George Purvis, Esq.:

"June $18,1884$.

"Sec. Farmers" Lnion,

"Prandon.

"Dear Sir :

"I think there has not been, since the commencenent of the agitation, a better time to strike than the present; everything seems ripe for it. I am certain that seven-eighths of the people of 11 innipeg are in on favor, and I am certain four or five hundred gool men will acemplish our object without any diffeulty whatever. The fact of the matter is this: We lave nothing to resist us. The military here is nothing more than a pack of boys, and we have casy aceess to the store rooms. We had a smatl mecting tonight, and the parties present were nninnmons in making a strike at once. Now I think that if we delay we will only be losing gromme, and the thing will never be accomplished. Tould like to know the possible number of men who can be got from the conntry to assist in the scheme. I hope yon will come to seme definite comclusion at yonr enuncil meeting.

"Relicve me; 1 am in perfect smmpathy with you, and 1 am ready at any time to take part in the more active part of the husines and see if we can't get the people their rights. Kindly let me hear from you at your earliest com enience, and oblige. Jours fraternally.

"Мï.ıк IIOWE, J. G."

The Reverend Canon Newton, a well-known and highly respected missionary, in hi, book entitled Ta'cnty Jious on the Saskatihea'an, makes it clear that deep and well fomberl resentment was prevalent in the most loyal circles.

Some of the canses of the discontent almost nuiversal among the inhabitant of the North West may be learned from such a note as the following. in which Canon Newton records a personal experience:

"On ny land I had a beantiful grove of spruce firs, and being fond of trees, I spent time and money in clearing the grove. Once, on returning home, I found persons lad, in my alssence. taken down the fence, cut down some of the trees, scattered the waste around and carried the timber away. Presently I found the man who had done this wrong, and told him not to come on such business again. Instead of being asliancel. he wh me he should do as he pleased with the grove and that he would not hesitate to take it all awas. When I complained to the only civil anthorities we had, they replied that they had no instructions abont crown lands and timber limits, and so refused (1) give me protection. . . Just then there was a small band of Anerican ontlaws and others who stole horses and cattle from whom I suffered and conld get no protection.

"In the years following the relinquishment of lludson Pay rights, the question of the ownerslip of any kind was execedingly difficult and nncertain. The Camadian Government was far ofi and did not seem to know 

that it had any responsibilities, or that people situated as we were could possibly suffer any inconvenience.

"Sirveys were not makle for several years, and no one knew where his homestead was or what land would he allowed him when the surveys were made.

"There semed to be no recognised law except the decision of a Magistrate, and no one could tell what this would be or the code that might rule him. There was, in fact, nu law, althongh there was supposed to be a Gosermment. We were not in ()ntario, or ()nelec, of Manitoba. Vie were in an undefined territory. subject to the man who happened (1) be in office. and he was a great distance from his superiors and fomd no dificulty in shiclding himself lyehind his own reports. If a man tork a pair of stockings from the Iludson's liay (ompany store he was quickly arrested and punished, but if he trespassed on land, and cul down timber of great worth to the setter who had fenced it and protected it from prairic fires, the settler was informed that he had no property in the soil or in the trees. Outside the circle of fovermment men a Commitue of liblic safety was instituted (Edmonton), and it seemed necessary, if the commonest order was to be observed. The lawless saw that there was very little to restratit them and they acted accordingly. England was a long way off and Canadat lay between and effectually hindered the cry for justice reaching the Notherland. If an able Commissioner harl heen sent from lingland to the Indians, llablereeds and settlers of the North 11 est during the three years preceding the events of 1885 there would in all probability have been 110 outbreak. Lurest secmed to be in the air. as when a storm is brewing, and the clouds are preparing for a furious tempest, ret no one knew where the centre of the storm would he or when it would inust."

Very many warnings were offered to the Governuncut in adclition to those that have been enmmerated in the foreseing pages, but in vain. To be sure, as will subsequently be pointed out. thone best fitted to judge of the trend of events did not till the rery last believe that an armed rising would occur. Nevertheless. the possibility and probability were freely discusserl on all hands. In his book entilled Troopir and Red Skin (page 103), Mr. Joln C. Donkin, formerly of the Royal North West Munnted I'olice, speaks of the situation of affairs in the early spring of 1885 in the following terms:

"Everything now was approaching a crisis. Indeed, we of the rank and file used to talk in quite a faniliar way, in the barrack-room, of the coming rebellion, as a matter of course. We even had the dite fixet. I remember our corporal singing out from his bed, "Il ell, boys, old kiel will lye starting in on the 18 h.' (The speaker had his thigh broke by a shot at 1)uck Lake on the 26th.) A civilian-an Englishman-who had been a guest for some little time of our commanding officer, came over to take his leave of me in the early part of Mards. 'Good-bye, old man,' he said, 'I want to get through before this rebellion begins.'

Apparently, howeser, the authoritics at Ottawa had neither ears nor eves, mor any knowlelge of the long period of agitation, petition and ex- 



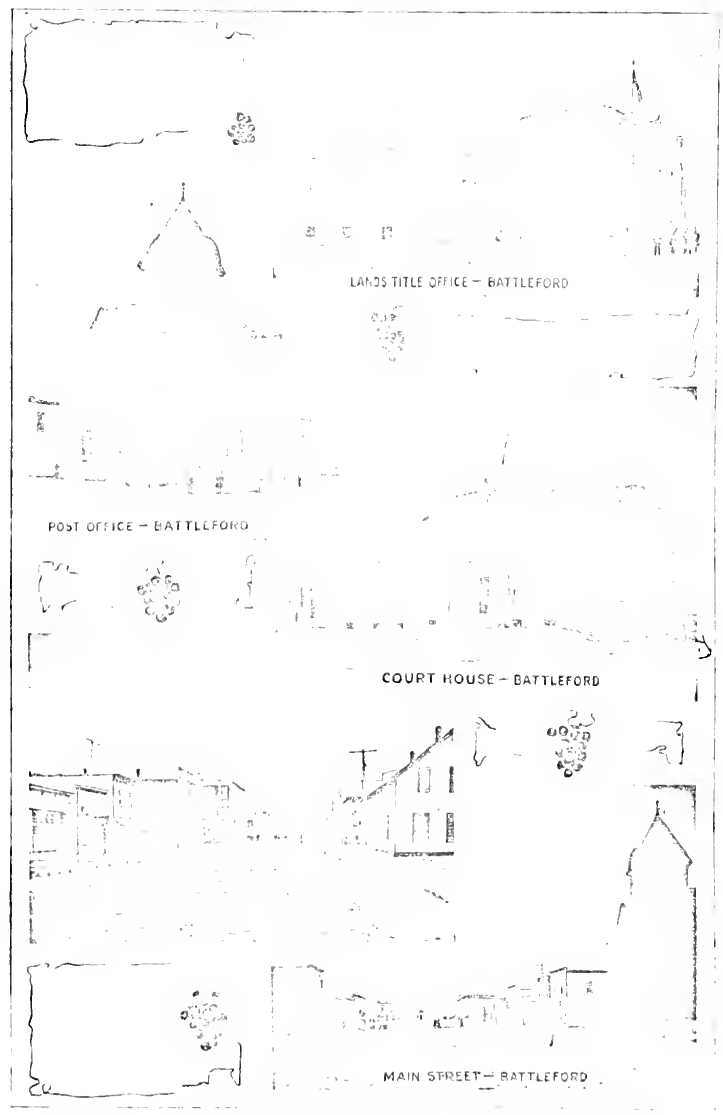


postulation that had passed since any steps had been taken ly the Government to inquire into western complaint and to remove their causes. On the Gth of June, 1895 . the Secretary of State was bold enotigh to say in a public letter:

"If the Jalfbreed had serium complaints against the Camadian Gorernment, the ordinary methods of petition was open to them as to every free citizen. They have not atrited themselves of it."

In view of the facts set forth in the preceling pages of this chapter. this ministerial utterance involved a most clamaging confesion.

When the cloud broke the Government had pratetically mo defender. In the Teronto Mail of July \&, 1885 , the following editorials appeared:

"It has never heen denied by the Mail that the Metis had good ground for grievances.

"By the passage of the Manitoba Act of 1870 old Canarla had formally and frankly recognised the rights of the I Ialfibreeds of that province to share in the Inclian title, and it follows as a matter of course that if they bad rights in the soil of Manitolia, those of them dwelling in the region beyond had rights in the soil there.

"This admits of no dispute.

"It must have been well understoud by Jarliament in I870; at all events - the records show that the Government of the day recugnised the point, though a settement was not then asked for.

"In spite of this recognition, however. and of the manifest and unanswerable logic of the J Jalflired case, the department for years had stealily refused to move in the matter.

"It was a tangled question: it would involve the appointment of a commission and no end of trouble. St. Nbert and St. Laturent were far distant dependencies without political influence; it was a claim that would be none the. worse for bluemoulding in the pigeon-holes.'

"This was the way in which the officials treated the just demand of the Nétis, and we agree with Mr. Blake that their negligence was gross and inexcusable, and contributed to bring about the insurrection.

"J Had they had rotes. like white men, or if, like the Indians, they had been mumerous enougl to command respect and orerawe red tape, without doubt the wheels of the office would have revolved for them; lut, being only Halfbreeds, they were put off with an eternal promise. until patience ceased to be a virtue.

"We repeat again that the departmental system under which such callous and cruel neglect of the rights of this portion of the community was possible was wrong, and should he censtred."

Our study of the premonitions of the rebellion may very well close with an examination of the following telegrans received at or sent from the office of the Comptroller of the North West Mounterl Pulice during the three weeks immediately prior to the outbreak. 


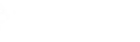


FROM THE COMMJSSIONER: “Regina, Narch 12, 1885.. Just received the following telegram from Gagnon, dated torlay, from Carlon. Have shown it to Lieutenant-Ciovernor. Jlalflreeds excited; move about more than usual, preparing arms. Do not know cause or object of these preparations."

FROM SLI'ERJNTINDDENT CROZJIER: "Carlton, March 1I, IS85. Halfbreed. greatly excited. leported they threaten attack on Carlton before I6th. Halfbreeds refu-e to take freight of employment for Government; will stop all freight coming into country after ifoth of this month. (ietting arms ready. leader will not allow people to lave home, ats they mat he required. Origin of trouble I think because letter received stating kiel iot recosnised British subject; they expect arms from States. Have ordered twenty-five men from liattleford and one gun to come here at once."

FRON SLI'ERINTENDENT HRINE: "Regina, Narch $14.188_{5}$. Lieutenant-Governor received telegram dated Carlton today from Crozier, saying Halfbreed rebelliom may hreak ont any moment and joined by Juelians and asking that his division be largely increased. Would recommend that at least one hundred men be sent at once before roads break up. Please instruct."

TO SLIPERINTENDENT IRVINE: "Ottawa, March I5, I885. Start for the north as quickly as possible with all arailable men up to one hundred. Telegraph marching out state, and report when passing telegraph station."

FROM SUI'ERINTENDIENT CROZlER: "Duck Lake, March s7, 1885. Our movements and preparation have quieted matters; no cause for alarm. Prince Albert people did splendidly."

FROM SUPERINTENDENT DEAN": "Regina, March 19, 1885. The following received from Sulerintendent Crozier. Rumor tonight lndians being tampered with. Large force should be sent without delay that arrest may be made if necessary to prevent further and continuous trouble from Riel and followers. Militia arms from Battleford will be here in a day or two."

SUPERINTENDENT CROZIER: "Carlton, March 21, 1885. Rebels seized storehouse south branch, Lash, Indian agent, and other prisoners. Threatened attack on Carlton tonight or tomorrow. Rebels by last report assembled at Batoche's crossing."

In treating of the discontent in the Territories and of the attitude of the Federal authorities in relation to the grievances of the white and IJalfureed settlers, l have encleavored to present merely a fair, plain and unvarmished statement of the evidence available to any serious student of Canadian History. Even at the risk of tediousness, I have iterated and reiterated the ever recurring attempts unsuccessfully made through a long term of years to obtain the attention of the Government. It would have been easy to present the matter in more alluring literary form, but it was thought wiser with the minimum of personal comment dispassionately to present the outstanding facts of an affair regarding which judgment has frequently been blinded by party prejudice, and to leave each reader to draw his own conclusions. 


\section{CIAPTEK XX}

THE OUTSREAK OF THE REIELLION: PATTLE OF DLCK 1. $\mathrm{AKE}$

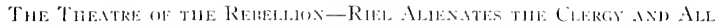

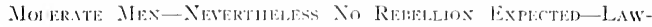

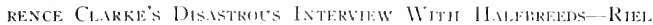

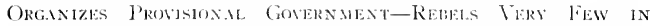

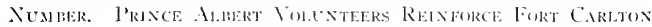

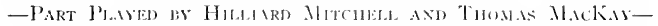

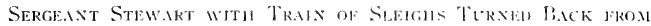

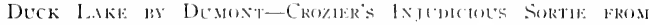

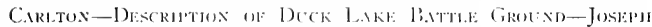

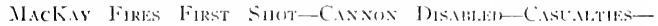

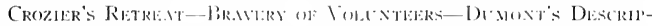

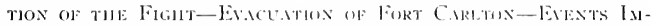

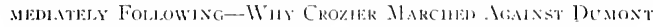

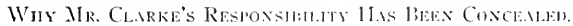

If it should so happen that the reater is not entirely familiar with the geography of our prairie I'rovince. it will be worth his while, before proceeding to the story of the rebellion, to turn to the map, and impress upon his memory the relative position of a few important points.

Some forty-two miles east from Regina is the flourishing town of South Qu'Appelle Station, which in rebellion days was knww as Troy, or Qu'Appelle Station. Eighteen miles north is Fort Qu'Appelle, nestling in the beantiful valley of the Qu'Appelle River, ant the Jishing lakes, into which the stream here expands.

About two hundred miles due north from lloose Jaw he will find the chicf theatre of the rebellion. The city of Prince Albert, then a town of about 700 inhabitants, lies chiefly on the south bank of the North Saskatchewan, abont thirty miles west of the Grand Forks. Further up the river. and about forty-two miles away, is Fort Carlton, then the heachuarters of the Hutson's Bay Company and the Xlounted Police of this district. Just about opposite Fort Carlon, lut on the South Saskatelewan, is Batoche. eightee: miles distant by trail, and between these points lies Duck Lake. Adjacent to Duck lake and Batoche, and here and there in various parts 

of the surrounding listriets, he will motice ludian reserves. The next important centre of polulation to the west will le lattleford, situated where the battle kiver these into the North Sarkatchewan. This is alout one hundred and serenty-fire miles north of the matin line of the Canadian P'acific Railroatl, when which, and at little to the east. is Swift current. Several Indian renerven will be moterl alout fifteen miles south of lattleford, and others a little west. Some of the latter lie between the battle River and the Saskatchewan. Following the latter river still further to the west and north, we rcach Fort l'itt, near the western homdary of Sakatchewan. Approximately twenty-five miles farther to the northwest, a little stream flow: into the Saskatchewan irom lirng Lake, a dozen miles distant, adjacent to which are the important rescres, still on the Sakkatchewan: and a third of the way across . Iberta, in the cappital of that l'rovince, Edmonton, and on the main line, almost due south from it, is Calgary.

After this preliminary geographical review, let ns now retum to Ricl, and trace the stury of the onthreak uf the Reledlion.

During the lirst months of 185 a a great and deplowable change had taken place in Riel's attitude and policy. Many loyal sympathizers had refused their support to the Ilalflucel asitation as som as the former rebel chief

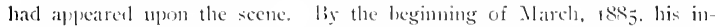
creasing violence, tanaticiom and egotion had alienated all hut a iew score French Halfhreels. While at first representatives of the Catholic clergy had sujported Riel and otherwise vigurously championed the indeniable rights of the Ilallmeets, they by this the had entirely withdrawn from the movement. Indeed. the impending insurection was a protest against their leadership and influence, ahnost as much at it was against the policy and condact of the Government. Ricl and his friends had practically established a new church and thronghont the unhappy events that followed, a naive but genune religions fanaticism is writ large in the reends of their doings.

Mlost people can be wire after the event, and almost everyone who was not in a position to be acquainted with the fact, afterwards clamed to have known that an armed ontbreak was impenling. The writer has conversed. however, with many persms who were living in the disturbed regions and who intmately knew practically every man emected with the subsequent rising. These persons are almost unanimens in confessing that right up until the twenty-sixth of March, they fully expected that the tronble would be settled without tiring a shot. This also was the impression in the East. On March 16th, the following paragraph appeared in the Toronto Mail:

"The report that lich is inciting rebellion among the llalfbreeds in the Saskatchewan district is started from time to time. emplatic denials from Ottawa producing no effect upon the energetic liar at the other end of the 

wire. As a matter of fact. Riel comle] not create tromble there if he were ever so much inclined. the llabloreet being in a lupeless minority, and having too much good sense to attempt violent measures."

On the following daty. Acting lumlian Igent Lash reperted from Carlon:

"I have the homour to state that I visited l)uck lake yesterday, and remained over night in that neighlsuthlood, and am pleased to report the Indiatns are all puict. and not interfering with the llatflireed movement. The latter are still a little meatsy. but I trust the preations taken by the police have cooled their ardor, as they are starting on freighting trips, and I am inclined to think their excitement will blow over."

How did it happen that even those in daily and familiar intercourse with the Jirench flabloreed did not foresee amed rebellion? There is a reason and, as a generation han clapsed since thone tromblons days, the truth may now be plainly told.

As a matter of fact, the actmal resort to arms was cansed by an indisereet remark of the llonorable Lawrence Clarke. Ile had long and justly sympathized with the llalfluecds, and labored carnestly to secure redress for their grievances. Since the arrival of kiel, lumever, his arlent spirit of loyalty had caused him to withlraw his support. Nevertheless. he still enjoyed high prestige anomg the llalfhreeds, and even those of their number who distrusterl him hat a very exalted notion of his inlluence and familiarity with the comnsels of thuse in high authority. Early in the Spring, Mr. Clarke visited Ottaw. () his return, while elriving north from Qn Appelle to liort Carlton. he met a gromp of Halfhreeds who inguired of him what answer the Govermment was going to make to their petitions. IJis reply was that the only answer they would get would be bullets, and that, indeces. on his way northward he harl passed a camp of 500 policemen who were coming up to capture the llalfbreed agitators. While this incident hars not figured prominently in former English accounts of the rebellion, the facts are common property to this day all throngl the Batoche, Duck Lake and l'rince Albert country.

On the seventecnth of March, Ricl, aldressing a meeting of his excited Halfbreeds, referred to them as his police, and spoke in terms threatening and contempttous of the Govermment police who wished to effect his capture. On the follewing day he and a consiterable party of his body guard were riding to St. Laturent, where they intended celebrating a Mlis religions festival in honor of $S t$. Joseph, their patron saint. Ostensibly to fire a $f c$ de joiv on this oceasion, many of them had brought their gans. As the cavalcade passed St. Antoine, lalf a mile from Datoche, they were met by the party of their startled linsfoll that hat just interviewed Mr. Clarke.

Their announcement of an immediately impending attack by the police was like a burning match cast anid tinder. I hasty comncil was held in which they detemined to defend themselves and their leaters to the deatlo. 

Those who were not already armed hastened to get weapons, and the excited I halfbreeds turned into a fortress the lonse of Norbert Dolorme and seized all supplies available in the stores of Messrs. Walters, Baker and Kerr Lros., of St. Lanrent. At this juncture Indian Igent Lash, who on the preceding day had written the reassuring report quotel above, unfortnnately appeared upon the scene, in consecuence of hearing a rumor that the Halfbreed agitators were tampering with the Indians. He was promptly. surrounded by an armed mob of aldut forty llalibrecds, commanded by Riel and Dumont, who gave orders to take him and his interpreter prisoners, which they remained till released by Middletun's force on May I 2 th. Mr. Clarke's ill-judged practical joke had suddenly transformed a passing gust of excitement into an émeute, which further folly at fort Carlton was to turn into gentuine civil war.

Ricl now undertook the organization of a Provisional Govermment, making Batoche his headquarters. Ilis council he called The Exovilate (a word he himself had coined), and in his subseduent correspondence he assumed the strle of "l.onis David Riel, Exoverle."

Well-informed loyalists, such as J. E. Sinclair, of J'rince Albert; the well-known legislator, scout and interpreter, 1 Honorable Thomas Mackiy: the IJonorable Jilliard Mitchell, and Mr. Lonis Marion, a loyal French Halfbreed, who was for some time detained by Ricl a prisoner at latoche. affirm that neither at this time nor later did Riel have more than sixty or seventy Ilalfbreed supporters really intent upon rebellion. liany others. however, were gradually drawn into the movement against their wishes, by the exercise of intimilation and by shrewd appeals to their racial feclings and religious fanaticism. Others were in arms simply in an instinctive though hopeless effort to defent their homes.

Father Morice and other careful writers have placed the maximum fighting strength of Riel's forces at three hundred and fifty. The affidavits of Messrs. Harold E. Ross, J. B, Lash and John WV. Astley, however, declare that by actual count there were well over thirty Halfbreeds and Indians engaged in the battle of Duck Lake, and it is notorious that many of those subsequently associated with the rebels joined Riel after that event. Rev. Father Noulin, parish priest at Batoche during the rebellion, informs me that on the basis of his personal olservations and those of well-informed members of his parish who were present from the start to the end of the insurrection, that at one time Riel had under arms Halfbreeds and Jndians: to the number of four hundred and sixty. Nany of these soon abandoned him, however, so that at the capture of Batoche there remained at the last only ninety. Moreover, it is well known that Riel had occasion to complain bitterly that many of his followers were so half-hearted in their support as to be of little real assistance. 
In Commissioner Irvine's report dealing with the operations of the police in connection with the rebellion of 1885 . he calls attention to the fact that the first official wasning of impending troulde was given by Superintendent Crozier on July 13, 1884 . In October a police was formed at Carlon. and the strength of the Xorthern division was increased to two hundred of all ranks, their mumber being distrilnted between Pattleforl, Carlton. Prince Albert and Fort Pitt.

On March 13th, Superintendent Gagnon telegraphed the Commissioner that a. Ifalfbreed rebellion was lialue to break out at any moment, and that large reinforcements were necessary. On the 18 th of 11 arch the Commissioner accordingly marched from Regina with ninety men. Shorlly before reaching the great salt plain, Irvine received a dispatch from Crozier dated the Igth, advising him of the arrest of Indian. Igent Lath and others, and of the seizure of various stures by the relels. Ile also warned the Commissioner that it was the intention of the relsels to seize any tromps coming into the country and to march then to Carlton and from there to Prince Albert.

Major Crozier was at this time in command of the Monnted Police detachment at Fort Carlton. On .llarch woth, he sent Mr. Joseph Mac-

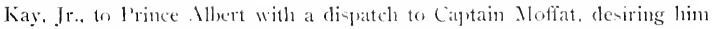
to enroll eighty velunteers to come to Carlon. It eiglit ciclock in the morning, a few hours after Mackay's arrival, a mass meeting of the citizens of P'rince . llhert was held and Captain Moffat read the-dispatch. Loyal speeches were delivered by sume of the citizens and eighty men were promptly sworn in to go to Fort Carlton. Nhuch excitement and enthusiasm prevailed, thengh the universal impression was that nothing more than a show of force would prove necestary. It half past two in the afternoon, the Prince Albert volunteers le it in sleighs to rinforce Major Crozier. Cpon their departure, the remaining men of the town were sworn in as a hone guard, and at night sentries were placed on all sides, and sconts sent out to report any approaching danger.

Meantime, Mr. Hilliard Mitchell, whose trading establishment really constituted the hannlet of Duck Lake and who was on friendly terms witl the disaffected Halibreeds. Was acting with vigor and courage, in his efforts to effect a peaceable settlement. He kept in close touch with Major Crozier. and also with Riel, whose headyuarters he visited no fewer than three times. Indeed, his activity nearly cost him his liberty, and both Riel and Crozier were all but convincel that he was acting as a spy for the other side, and he narrowly escaped arrest in both camps. Riel tried to induce $\mathrm{Mr}$. Mitchell together with a priest hearing the cross to head a procession of the Halfbreeds to Fort Carltum. Cpon reaching that place, Mr. Mitchell and the priest were to step aside. and Riel would seize the 

Fort. (n) the Ninetenth, Mr. Mitchell reported to Crozier his interview with Riel, and on the twenticth, he received the following letter from Major Crozier, which clearly shows that, as yet, that officer disl not expeet that any fighting would really take place.

Dear Mr. Atitchell:

Carlton, March 20, 1885.

I am much obliger to you for the information. It is a great pity that there is so much unnecesary talk and so many ad)surd rumors about. I will be greatly obliged if yum will keep me informed.

1 sall Mr. Arkand this morning. I tolel him of the absurdity of the rumors he mentioneel.

Hilliard Mitchell, Esq.. Duck Lake.

(Signed) Ckez.l1:k.

On the sane day, Mr. Nitchell and $.1 \mathrm{r}$. Thoma Mackay were sent by Crozier to batode in an endeavor to reach some understanding. (1) this occasion Mr. Mathay Wan for seme time in imminent danger of losing his liberty if not his life. He escaperl anly by virtue of Mr. Mitchell's influence. Indeed, he was actually tricel and sentenced to kath by the rebel Council, at the instigation of Riel. Whe was beside himseli with insane rage and excitement. Fortunately, however, some mentsers of the Cinneil were adverse as yet to the shedeling of hlowd, and when lied withelew from the Comeil rome it was agreed to alluw the envers to leate in peate. It was proposed that kiel and (rozier shonlel have a personal interview at an appointed rendesous, halfway between batudhe and Carlton. both the Major and Riel preferred, however, to senel representatives, and llessts. Thomas Mackity and Mitchell met two / lallibeed delegates, Charles Volin and Maxime lepine. The two latter were armed with the following letters from Riel:

To Mlajor Crozicr.

$$
\text { St. Antoine, X. W: Ter., March 21, } 18.5 .
$$

Commander of the lolice at Forte Carlon and battleiord.

Najor:

The Councillors of the Provisinal fiovermment of Saskatchewan have the bonour to communicate to you the following condition of surrender: You will be reguired to give up iompletely the situation which the Canadian Government placed yon in at carlon atnd liattlefort, logether with all Govermment properties.

In ease of acceptance, you and four men will be set iree on your parole of honour to keep the perice. Ind those who chonse to leave the combry will be furnished with teams and provicions to reach Qu a . Ippelle.

In case of non-acceptance, we intent to attate you, when, tomorrow, the Lord's 1)ay is wer, and to commence, withom delar, a war of extermination upon those who have shown themselves lustile to our rights.

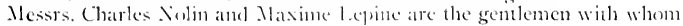
you will have to treat. 



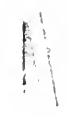

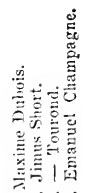
$\therefore \dot{\equiv}=i$

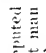

穿 西苍

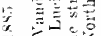

-

不荡

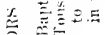

$\overline{2} \approx-$

is

0
0

产要总

$\therefore+$ is

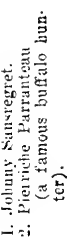


- 
Major, we respect you. Let the canse of humanity be a consolation to you, for the reveres which the Goremmental misconduct has bronght mon yout.

(Signer1) Locis "D.rid" Ria., "Exorede."

On the other side of this docmment was written:

To Messrs. Charkes Nolin and Maxime Lepine:

Gentlemen-lif Major Crozier acedes to the comditions of surrender, let him use the following formulis, and no other:

"liecause I love my neighlow as myedi, for the sake of God, and to prevent bloodshed, and principally the war of extermination which theatens the comntry, I agree to the above conditions of surreneler." If the Major writes this formula and signs it, infom him that we will receive him and his men . Monklity.

Yours,

Lots "D.wit" Rier, Exovede."

On the other hand, Major Crozice 's representatives demanded the nanee of the leaders of the movement, whom, they declated, would have to answer to the law, although these wh had been frawn into the insurrection unwillingly were pronised lenience. The propesal to surrender Fort Carlton was, of conrse, rejected withont discuscion.

After his third and lant visit to liatode as a peatcemalier, Mr. Mitchell received warning from a friendly llatflorect that hiel intoncled seizing him forthwith as a hostage. Aecordingly. Mr. Mitchell determined to leave Duck Lake, and join Major Crozier at fort Carlton. The place was alrearly practically in the hands of the insurgents, but before evacuating his stores, Mr. Witchell suceceled in having a considerable quintity of powder and ammunition removed. This was effected ly John Paul, hy a remarkable excreise of pluck and audacity. The ammunition was placed in a "jumper" and over it was thrown a iew arm loads of hay, upon which the plucky driver sat as he drose away from the village in broad daylight.

Most of Mr. Mitchell's effects, hunever, were of course left behind him, and immediately fell into the hands of the insurgents, who took possession of the deserted village within a few hours of his departure. Ilowever. this was not known to Major (rozier, and he accordingly sent Sergeant Stewart with teans and a mumber of volumtecs and policemen to get Mlitchell's personal effects, and especially to bring a supply of oats from his store.

Ibon seren miles ont of Carlon, this convoy met Dumont with a party of Halfbreels and Indians. They surromuled the head teams. The foremost sleigh was driven by $\mathrm{Mr}$. Xeilson, later Sheriff of Prince Alhert, with whom was Mr. Thomas Xackay. The volunteers and police came forward from the rear and the situation was very tense during the excited interview between Mackay and Dumont. I conflict was almost precipitated by the 



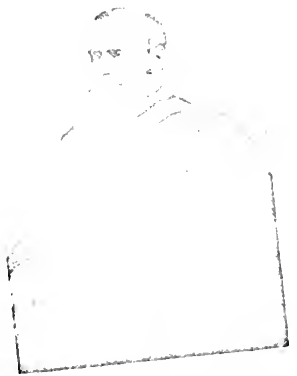

Supt. (rozier (afterwarels Anst, ('ommr.), the heroie oflices who met dinanter at Duck Lake. Marth oti. lut.

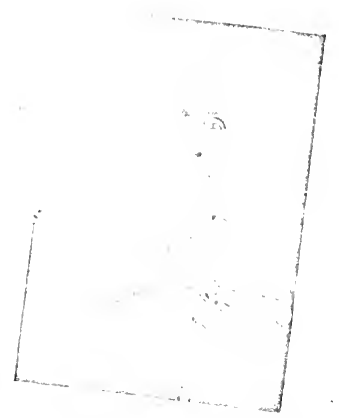

licut. fol. stecle. C. P., M. T. O., famous memlure of the X. W. M. T. ioree, 197019ui: f'ommandant of Stratheona Horse.

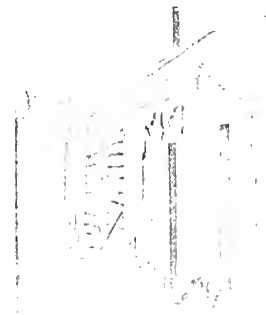

Typieal pioner awehiny-Mr. Hillyand Mithell's house at Durk Lake, 1986. 

accidental discharge of Dumont's rille, the bullet passing through MacKay's hat. Howerer, it was agreed between the leaders of the two parties that they should not fight, for the present, at all events, but Dumont insisted that the train of steighs should at once return to Fort Carlon unless prepared to surrender.

When Dumont and his men had come upon the convoy, they were in pursuit of two Momnted f'olice scouts. These latter eseaped and hurried back to the Fort to inform Crozier of the pllight of his teansters and Sergeant Stewart. Of course, the Major had no chosce now but to move out to the support of his men. Ilowerer, his force hat just left the Fort when it was met by Sergennt Stewart with the returning convoy.

In his motable warch from Regina to the relief of Prince Vlbert and Fort Carlton, Commissioner Irvine had eluded the rehels by crossing the Saskatchewan at an mexpected point (. Ignew's Crossing). He hat reached Prince Albert on the twenty-fourth, after at week's marel of nearly three hundred miles in severe weather and over heavy trails. It had been Irvine's intention to proceed at once from Prinec Albert to Carlton, hut the best informed people in the district believer that the situation had alrearly ceased to be immediately dangerous. Norcover, his men were ahmost cxhausted and several of them were snowhlind. Accordingly a delay was mate to have the men and amms inspeted and the horses shod. On the morning of the 26th, Irvine left Prince Albert at $2: 30$ A. M., taking with him twenty-five volunteers in addition to eighty-three non-commissioned officers and men from Regina. It was his hope to quash the rebellion before it could assume formidable proportions. When but a short distance from Fort Carlton, he received a dispatch from Superintendent Gagnon of that post informing him of Crozier's advance on Duck Lake, and shortly afterwards he received a second message amnonncing that unfortunate officer's retreat. In his subsequent report Commissioner Irvine wrote as follows:

"I camot but consider it a matter of regret that. with the knowledge that both myself and command were within a few miles and cn routc to Carlton, Superintendent Crozicr should have marched ont as he did."

If Crozier had obeyed what must have been the dictates of his own judgment, the Battle of Duck Lake would never have been fought, and it is extremely probahle that the whole insurrection wonld have sulsided at once, without bloodshed. Lnder whose infuence Major Crozier made his fatal blunder we will see a little later.

All told, the force Crozier led ont of Carlton to chastise Dumont, consisted of fifty-six members of the Mounted Police force and forty-three voluntecrs. They advanced in sleighs. The snow lay deep and it was necessary to move in a long narrow line along the trail that wound in and out among the immmerable copses and extensive woods that cover the 



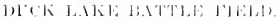

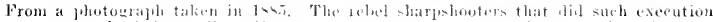

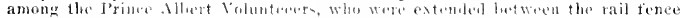

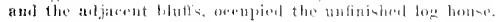

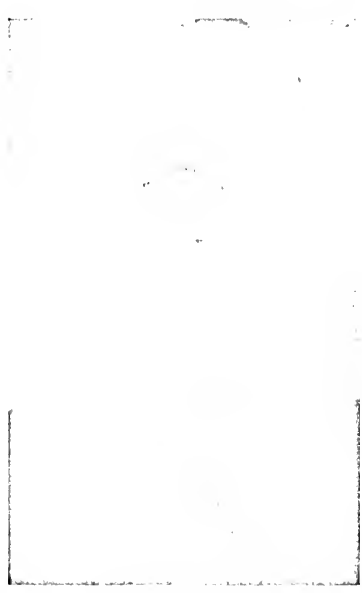

Lothis Ricl.

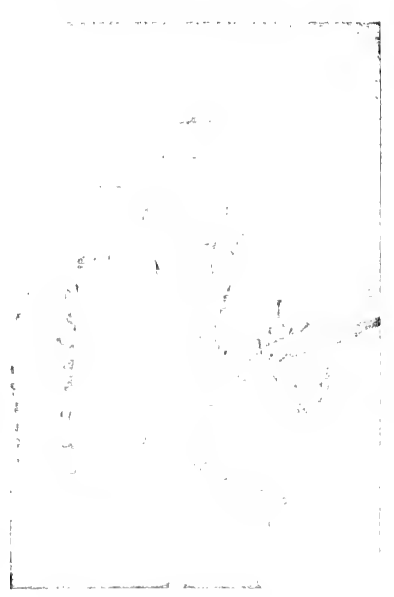

(ialnicl Bumout, who comminulet the relets. 

whole of that district, which for the next few wecks was to become the theatre of war. It would be laard to imagine, ontside of a region of mountains, any locality better adapted for guerilla warfare, and for purposes of defence. Fort Carlon, itself, however, lay on the lank of the North Saskatchewan in a hollow commanded on three sides by adjacent hills, and from these points of vantage a few determined men, well armed and skillfully using their rilles, conld have bottled up a force of fifteen or twenty times their number. The snow was deep, and the conntry thickly wooded and broken ly numerous slutughs, a large irregular lake, and numerous water courses, so that it was practically impossible to move, in any force, except alung the trails, and at every turn these proviled the choicest facilities for ambush. This truth was presently enforced upon the minds of the loyali-t party with compelling emphasis.

Scouts . Mlexander Stewart and James NacDomald rode some zoo yards ahead of the advanced guard of police. They visited the house of Chief Beardy, about thirty yards off the road, followed immediately after by Major Crozier and his body guarel. Leardy protested his loyalty, though, as a matter of fact, mest of his braves had already joined lici, and he himself did so afterwards. About three miles out from Duck Lalke, the scouts came upon a considerable force of the insurgents, and when the caravan of sleigls swung around a wooded lend in the trail, they saw the scouts retreating before pursuing Indians, and probalbly commenced to realize that Dumont had succected in entrapping them in a place where they would be at the utmost disillantage. The front sleighs moved out, slightly, to the side from the trati. The six rear sleighs advanced through this alley to the foreground and were quickly drawn up across the road forming an impromptu barricade. The horses were detached and taken to a bluff in a slight depression to the left rear of Crozier's forces. The police and volunteers occupied an open space, with wooded country on either hand and with a slight hill perhaps sixty yards in front of them. In the cover thus provided on three sides, the insurgents were concealed. To the right of the trail and perluars a hundred yards back was a log house which proved to be oceupied by some of the hest sharp-shooters of Dumont's forces. The police took up positions about the sleighs to the centre and left, and Captain Mlorton, followed by the Prince Mlbert volunteers, moved out at right angles to the trail toward the right. Pehind them was a bluff, and why it was not used for purposes of cover is hard to understand. As a matter of fact, however, the l'rince Albert volunteers operated with practically no cover at all, unless the top of a straggling rail fence almost buried in the snow could be so described.

While these preparations were in progress. Major Crozier, with Joseph Mackay as interpreter, advanced to parley with representatives of the op- 

posing force, who came to meet them. These were a half-lilind Cree chief called Falling Sand, with a couple of his comsellors. Crozicr asked who they were, what they wanted and why they were accompanied by such a foree of armed men. These questions, Falling Sand parried by returning them. As Joseph Mackay, the interpreter, was carrying on his share of this exciting interview in alernating Cree, French and English, one of the Indians caught hold of his rifle, which he held in his left hand. As the interpreter wrenched his weapon free, his assailant attempted to seize his pistol, which MacKay immediately drew. Neantime, the second of Falling Sand's comnsellors, who was kneeling nearly at a fence, was cndeavouring to cover Mackay with his rille, and the latter was keeping his immediate assailant between him and the marksman. At this juncture, Crozier asked what the rebels were saying, and Mackay replied that nothing could be done with them, as they would not listen to reakon. Thereupon Major Crozicr turneal back toward the police and voluntecrs, and raising his hand, gave the command: "Fire away, boys!" The first slot rang from Joseph Mackay's pistol as he felled his asiailant and followed Major Crozier back to the loyatist lines. Almost at the same instant came an exchange of volleys. The insurrection had become a rebellion inded. Blood had been shed, the first battle had commenced, and from that moment it was apparemt that the campaign would open with a reluel victory.

In weighing fuestions of responsilility, the details surrounding the opening of this first engagenent are of exceptional importance. The prevailing reports of the aflair cast on Dnmont and his men the onus of firing the first shot. For the facts in the present narrative, however, the writer has relied upon the definite statements given by Joseph Mackay hinself, and supported hy eye witnesses who were close at land. ${ }^{2}$

Perlaps the affair might have terminated somewhat differently had not the only cannon been disabled after fring but two shots. The gun and the men workirg it were the special target of the Indians and Halfureeds. Beside it, three men were killed and two others womnded. Doctor Miller was also hit at this place, but the lullet struck the case of surgical instruments at his belt, and he thus escaped. In the excitement a shell was rammed home into the gum before the charge of powiler was put in, and the cammon was thus rendered ueless for the remainder of the engagement.

The rebels were firing from cover and the police and volunters had but little opportunity to use their lirearms with effect. Dumont, himself, however, received a severe sealp wount, from the effects of which he never completely recoverel during the whole campaign. Several other rebels were wounded and four Halfbreels and an Indian were killed. Of the ninety-

${ }^{1}$ In Crozier's report of the Iattle of Duck Lake he states that the relels fired first, and this version found its way into the Commissoner's report a well. 
nine police ant whinters some of whom necessarily remained with the horses, and were therefore not in the firing, three policemen and nine Prince Albert volunteers were killed. ${ }^{2}$ Abont twenty-five others were wounded, nine of them seriously:

It is a recognized principle of Indian wartare that an attacking force should nerer come to a stamcl, especially in the open. The natives show an instinctive skill in making we of crery possilse corer, and if given an opportunity will slalk their enenies so cleverly as to involve them in alnost inevitable destruction. On the other liand, if the circumstances are at all favorable to the attacking party, it is, as a rule, relatively easy to dislodge them from their position by direct attack. In the present instance, however, such movement was out of the question. The snow wals so deep that anything in the form of a rushing charge was a plyysical impunsibility, and even if Crozier's forces had succeded in driving the enemy from the rising ground behind which those in iront had taken cover, the josition of affairs would not have been inproved. Inumont's main foree would simply have fallen back behind the next rise and the volunteers and police would hatse been still more completely at the merey of the sharpshooters concealed to the right and left of the trail.

Accordingly, recognizing the incvitable, Crozice ordered the horses to be attached again to the sleighs and his men to retreal. The last sleigh to leave the battle-fied was that driven by Sherill Xeilson. In so far as possible, all their fallen comrales who showed signs of life were carried away by the retreating hyalists. The dead were left, however, and some of the wounded. Cnly one of these, Charles Nenitt, eseaped assasmation at the hands of the lndians. There is some reason to believe that he was saved only by the personal interposition of Riel himself. Newitt was taken back to Duck Lake as prisoner.

Alexander Stewart, in a letter written while recorering from a wound receired in the engagement, says: "If we had not retreated when we did, we wonld all in les than live minutes have been massacred." Already the enemy had atwanced far around the flanks of the loyalists on both sides. Indeed, had the rebels acted in accordance with the wishes of Dumont, no successful retreat would have leen posille."

The hattle had lasted about thirty-five or forty minutes, and from first to last the police and volumeers displayed unwavering coolness and courage. Those who fell, fell as became bratwe men, and there was no unseenly outcry. In tribute to these defenders of the honour and dignity of Canada,

2The following are the names of those numbers of Crozier's party who were killed at Duck Lake or died of their wounds: Comtable T. J. Gib zon; Constalle G. P. Arnold; Constable G. K. Garrett; Captian Jum Mlorton of Prince Alberi Volunteers; W. Napier, privalte; James Bakic, private; Shetfington Courier Elliott, private; Rolsert Niddleton, private; Daniel Mackenzic, private; Daniel MePlail, private; Joseph Anderson, private; and Alexander Fisher, private. 
let us quote some of their last words, graven ineffaceably, henceforth, on the memories of their companions. Said William Napier, a young Scot from Edinburgh, "Tell my Mother I died like a man." "I an shot!" said William Baker, "God have mercy on my soul." "Fight on, boys," cried Elliott, the policeman, "rlon't let them beat us." When Captain Morton, second in command of the Prince Albert volunteers fell, one of his men, William Harlan, raised him in his arms. "Yon can't do anything for me," said Morton, "I am shot throngh the heart. Take care of my wife and family and tell them that I died like a man on the battle-field."

Nor were the sences of pathos and conrage confined to the ranks of the loyalists. The following picture of events in the rebel lines is translated from the narrative of the wounded Dumont himself.

"While we were fighting Riel was on horsclack exposed to the bullets and having no arms except a crucifix which he held in his hand. Upon seeing me fall, my brother Edouard hastened to me to drag me into the ravine, but I told him rather to go to our people who seemed disheartened by my fall. He rallied them; they checred and commenced firing again. My cousin, Auguste Lafromboise, whom I had heen advising a few moments before not to expose himself too mutch, then fell near me. A bullet struck him in the arm and passed throngh his body. I dragged myself to him, creeping, saying to myself that I wonld go to say a little prayer for him, but in trying to make the sign of the cross with my left hand, my right being paralyzed, I tumbled over and said to him, smiling, 'Cousin, I owe that to you.' I wislied to say for him the prayer I had composed when we received the blessing of the priest at Jelton in Montana-Lord, reinforce my courage, my confidence and my faith so that I may profit all ny life from the benediction ${ }^{3}$ I have received in Thy Holy Name.' This is an invocation that I have always recited after ny prayers, morning and evening.

The eneny then commenced to flee and my brother, who after my fall had taken command, cried to our people to pursue and destroy them. Riel then begged for the love of God that no more should be slain, saying that already there had been too much blood spilt."

Some time after Crozier's return to Fort Carlton, Coloncl Irvine had arrived with eighty police and thirty additional volunteers from Prince Albert. However, as we have already pointed out, Fort Carlton lay in an utterly indefensible position; and if the IIalfbreeds and Indians, flushed from victory, had attacked it at night, a still more serious catastrophy might have occurred. On the night of the 27 th, therefore, Irvine who was now in conmand, determined to evacuate the Fort. While this movenent was in progress, a fire was accidentally started, and when the loyalists left the fort it was in flames. ${ }^{4}$ Much anmunition and many valuable stores were destroyed. On the 28 th the retreating forces reached Prince Albert.

${ }^{3}$ Le recit de Gabricl Dumont.

4 In the evacuation of Fort Carlton it took two and one-half tours before the last sleigh reached the top of the hill. If, during this interval, an attack had occurred, a terrible disaster would have had to be recorded. 
At Duck Lake, on the day following the battle, Riel drew up his combatants in two lines and said to them: "Vive Gabricl Dnmont! and thank God for having given yot1 so valorotts a leader." The rebels passed the day in praying for their dead, whom they buried at St. Lanrent. Dumont then suggested scnding a prisoner to Carlon to invite the encmies to come for their dead. This was done, Dumont sending a letter promising saie conduct. Ifowever, when the messenger reached Fort Carlton he was seized as a spy and the evactation of the fort occurted immediately afterwards. Dtmont wished to prepare an ambush along the road which the police and voluntecrs wonld have to follow. Had his advice heen taken, a terrible massacre night have resulted. IJowever, as Dumont himself tells ts, Riel forbade the project, endeavoring all the while to moderate Dumont and his followers. Three men were at last sent out from Prince Albert to recover the bodies of the dead volunteers. The halfbreeds had placed them in an old hotse to preserve them from desecralion, and gave what assistance they could to Crozier's emissarics. They also restored to them their wounded prisoner.

Shortly afterwards the rebels burnt all the building at Duck Lake except the mill, and retired to Batoche.

We have told of the part unintentionally played by the Ilonorable Lawrence Clarke, in catning the Halfhreeds to take nip arms and seize available stores, and we referred in passing to the mystery surrounding Crozier's rash sortie from Fort Carlton. In cansing it, Mr. Clarlie again played a prominent part. When Sergeant Stewart's convoy returned to the fort, and Crozier had quite properly given up the idea of making any onslatght upon the armed rioters at Duck Lalke, Mr. Clarke and other leading Prince Albert voluntecrs "were so ill advised as, in the heatring of

"I do not wish to cast upon the respected memory of $\mathrm{Mr}$. Clarke an unfair share of the responsibility for the rash movencut netime Dumont, for which in the last analysis the commanding officer himself was ancwerable. Sergeant Stewart informs me that when he came to Crozier to report, he told that officer, in reply to guestions, that he did not think he had men enough to make an adrance successfully. Crozier then gave orders for his force to return to Fort Carltun. Thereupon a gentleman, who in the ensuing skimish paid for his rashness with his life, said in Mr. Stewart's hearing that "if Crozier retired he wonld brane! hin as it coward." "Very well," said Crobier. "if you want to go to Duck Lake. I'll take you." Jhe then recilled his previous order and commanded Sergeant Stewart's contingent to turn their teams and accompany the column to Duck Lake.

It must be remembered that Crozicr was accustoned to over-awing hostile Indians by the audacity characteristic of the North $11 \mathrm{ces}$. Nomuted Police, ind it is highly improbable that on the present occasion he cxpected any real resistance on the part of the Halflureeds.

In justification of his sortic from Carlton, Crozier says he was influcucel by the

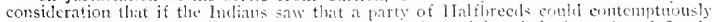
drive back and prevent officers of the Govermment from doing their duty, thus defiantly seizing property with impunity. they would be able to gitim the firm allicenance of the wavering lumin trilies. "Nevertheless." he adds. "lad I expected I shonk be attacker by them as I wair. I certininly would wot have taken the matter in hand." 



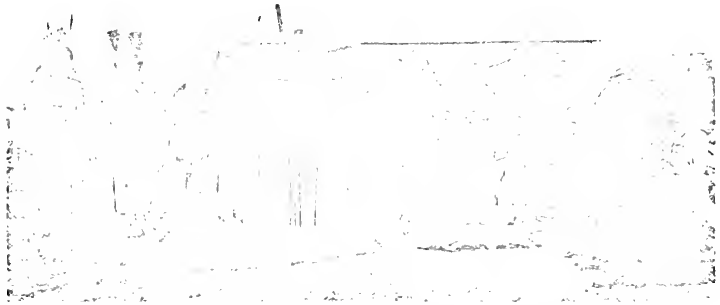

Scele in Fort l'iti jut prior to the Frog Lake mansacre.

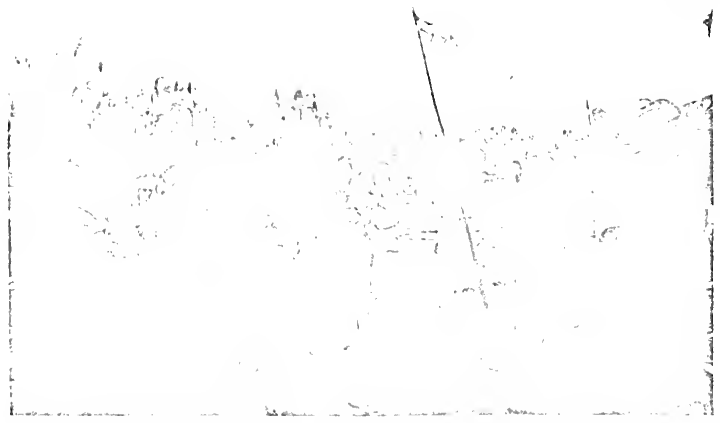

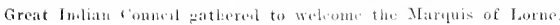


different people, to challenge Crozier "to teach the rebels a lesson if he were not afraid of them." Few men in the North West need have felt less under the compulsion to disprove an insinuation of cowardice than did Major Crozier, who was known far and wide through the Territories for his dauntless comage. Ilowever, it is unfortunately true that he allowed himself to be so influcuced by. the snggestions of the volunteers that he ordered his men to turn abont and proceed to Duck Lake. This act transformed what might have been a passing riot into a genuine rehellion.

From these circumstances it is evident that no source of information short of inspired prophecy could have allowed the central anthorities to foresee the events that actually happened. That the country was in a state of dangerous excitement, every one knew, but no ane could foresee the ill-considered statement which first induced the disaffected IIalfbreeds to take up arms against the Govermment, nor the foolish challenge, foolishly accepted, which was responsible for the actual precipitation of the rebellion.

In view of the severe criticism to which Mr. Dewdney and the Ottawa authorities were naturally subjected for not foreseeing the rebellion, the question arises of why, in self-defonce, no public reference was ever made to Mr. Clarke's share in bringing it about. No doubt, respect for that gentleman's ardent loyalty. unquestioned courage and subsernent valuable services "would partly account for this reticence. I believe, however, that I can point to a still more potent factor underlying the silence of the authorities.

Among the sessional papers bearing upon the rebellion, which were laid before the Honse, and pullished in 1885 , was the following letter. It will be noted that in the printed copy both superscription and signature were omitted to prevent the identification of the writer.

\section{Dear Sir:}

The French IIalibreeds on the Saskatchewan River, and a section of the English Halfbreeds living between the two rivers, have been holding meetings at St. Lanrent, at which meetings all the members were sworn to secrecy. Notwithstanding this, enongh has transpired to show that grave trouble will arise in the cotntry uniess repressive measures are adopted by the Govermment.

A number of resolutions were passed of a violent nature. Amongst others, Resolution No. 3-"That they, the Ilalfbreds, do not recognise the

o "Although it might appear invidious to mention any names," says Irvine, in his report to Sir John NlacDonald, regarding the defense of Prince Albert, "I must beg to be allowed to bring before you that of the IIonorable Lawrence Clarke, who, besides the arduous dutics of supplying iood for the garrison and inlualitints generally, provided shelter for them on their arrival from the country, and that of Mr. Thomas MacKay, chicf of the Scouts, whose unremitting efforts tended greatly to my aid." 


$$
\text { - }
$$


right of the Government to the North WVest Territories," and appointed delegates to proceed to Nontana, U. S., and invite Louis Riel to come over and be their leader in any further action that they may determine on.

The delegates so appointed-nanes: Gabriel Dumont, Moise Oulette, Michel Dumas, and James Isbister-left yesterday for Montana to carry out the objects of their mission. The French Halfireed race, living on the Saskatchewan, number about Seven Hundred male adults, and are gathering force every year by inmigration from Manitolat and the southern part of the Territories.

These men are not famers. merely cultivating small patches of land little larger than kitelen gardens. They live by hunting aud freighting. Their occupation as hunters was ended ly the disappearance of the buffalo and there is not sufficient overland freighting going on in the country to afford labor to one-third of their number, hence they are getting poorer year by year.

This in reality is the real source from which this agitation arises, although pretended grievances against the liovernment are ruslied to the front.

These men arow that the Judians are in smpathy with them.

The French Halfbreeds are closely related to the plain lntians and there is danger of the Halfbreeds persuarling the Indians to join them should an uprising take place.

'The Indians have no arms or ammunition, it is true, lut loth arms and ammunition in considerable yuantities, belonging to the defunct Saskatchewan Militury organization, are seattered throughout the cumbtry without protection and conld be seized at any monent.

These seattered arms and ammunition shonld be collected and placed under police-surveillance at Prince. Albert, and the force increased to the extent of thirty men with an officer in command. A strong detachment should also be stationed at st. I aurent. I have an intinate knowleclge of the character of these Ilalfbrects and, as rou are aware, some influence over them. Many of the men I have spolien to are averse 10 any agitation leading to a breach of the law, but a mumber of Ricl's abettors in the Red River troubles are resident in their midst and are pronoters of this movement, and eandidly state that they believe that if Riel is allowed to visit their settlements serious disturbances will arise therefrom.

In my opinion, and it is also the opinion of Rev. Father Andre, who is the superintendent of the Koman Catholic Missions on the Saskatcliewan. these delegates should be shadowed and if Riel accepts the invitation and attempts to cross the boundary line, he should be made prisoner.

The Rev. Father also agrees with me that if Ricl is not allowed to enter the country, the inflence we can bring to bear on the body of the people will counteract the influence of that section of them who are leaders in this movenlent.

Any letters Riel might write would be of little avail. This matter I thonght of such importance that I wired Lientenant-Governor Dewdney, who arrived at Battleford on the 13 th inst., as follows:

"Are you coming east? If not. like speak you over wire; important."

Next morning I spoke to Governor Dewdney over the wire, telling him it was important that I should meet lim if possible, giving him a mere ontline of what had taken place. Ile could not then state what his move- 

ment - would be, but said he would wire me in a day or two of his decision. since when I have not heard from him on the subject.

It is therefore well. I think, that you shomlal put the Government in possession of these facts with at little telat ats possible, impressing on the Premier the necessity of prompt investigation.

This interesting communication I brought the the attution of $\mathrm{Mr}$. Joseph Parker, Regina, who, in 185. was secretary to Mr. Clarke. Mr. Parker jolentifies it as one written by himself at Mr. lawrence Clarke's dictation. Jad the Government acted on Mr. Clatlic wise and timely suggestion, and prevented Ricl's coning into the comitry, that ill-balanced agitator comld manifestly not hate led a second alpeal to arme against the Canadian Government, and if Mr. Clarles's atvice regarding the grievances of the falfbreds latel heen listened to, the discontent culminating in the ontbreak would have licen removed. In view of these facts, therefore. it was entirely impossible for the forcrmment to criticize his subsepuent words or actions, however unfortmate their results. Itence the official silence regarding the reat innnediate cattse of the outloreak of an unforesecn insurrection. 



\section{CHAPTER XYI}

\section{IROG L.IKE MISSACRE}

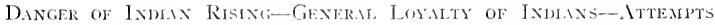
to Rouse the Trimes AFter the Patree of Duck L.AKE-

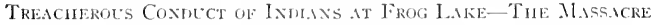

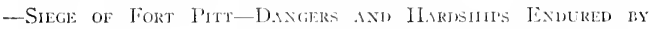

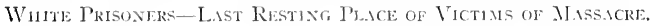

In the foregoing chapters we have frequently called to mind the tunsleeping dread of an Indian rising, the dinger of which was ever present. Thanks to the policy of the lludson's liay Company and the tradition it handed down to those who had directly to do with the management of the Canadian Indians, and thanks to the services of those men who bronght about the peacealle surrender of the West by treaty, Canada had never seen an Indian war. In 1885 the census returns reported four thousand four hundred and ninety-two Indians in Assiniboia-more than one-fifth of the population; sis thousand two hundred and sixty in the provisional district of Saskatchewan ont of a population of only ten thousand seren hundred and forty-six; nine thousand four hundred and eighteen in . Iberta. where the total population was only fifteen thousand five hundred and thirty-three; and in Athalasca and the Great North West, many thousand other red men roamed the wilds. I tarl a general conflagration broken out in this inflammalle mass, few indeed of the settlers would have survived to tell the tale.

Fortunately; the tedious work of inducing the Indians to settle upon reservations had just been all but completed, and in general the reserves were relatively small and scattered, as compared with the enormons reservations common in the western States. This rendered concerted action more diffieult, on the part of disaffected bands. Moreover, the more intelligent chicfs realized the futility of any attempt permanently to expel the whites, not to mention the certainty of terrible reprisals when the armed fores of the Dominion would be seriously aroused. Consequently, the majority of the Indians everywere remained loyal. Chief Mlis-to-was-sis and It-tak-a-koop, the most important Indian leaders of the Carlton section, and Chiefs John Smith, James Smith and Willian Twatt of the Prince . Mhert district, and Moosomin and Thunder Child whose reserva- 

tions were near Battleford, all withdrew their people from the scene of disturbance and attempted with almost entire success to keep them well in hand. Pecan, of White Fish Like, even induced his band to take sides with the authorities. To these chiefs and others like them, especially the famous Iblackfoot chief, Crowfoot, Canada owes a great debt of gratitude for difficult and mipopular chuties well performed.

The disaster at Duck Lake prodiced such widespread excitement anong the aborigines as, howerer, to render them almost uncontrollable, and for a time the whole Indian sitnation was perilons in the extreme. Many of the wiser among the French halfbred relels themselves were profoundly adverse to any attempt to arouse their Indian linsmen to assist them in their quarrel. Others, however, and these the more influential, did all in their power to secure the co-operation of the red men. Letters addressed to the Indians were sent in all directions, the following, found in Poundmaker's camp, being a sample:

"Praise God for the success IIe has given us. Capture all the police yon possibly can. Reserve their arms. Take Fort battle, lut save the provisions, ammunition and arms. Send a detachment to us of about a hundred men."

In another such missive (this time addressed to Halflureds), Riel saicl:

"Dear relatives and friends: We advise you to pay attention. Be ready for anything. Take the Indians with you. Gather them from every side. Take all the ammunition you can in whatsoever storelouse it may be. Murmur, growl and threaten. Stir up the Indians."

As a more or less direct result of this systematic agitation among the Indians, isolated depredations were commitied by them in various quarters. Four days after the Iiattle of Duck Lakc, an Assiniboin Indian murdered James Payne, an official of the Stoney Reserve, near Battleford, and another nurdered Bernard Tremont on the following day. These were but samples of the deeds of blood and violence done in various quarters. The most serious, however, occurred at Frog Lake in the early days of April. This blood-curdling affair was a terrible object lesson of what a general Indian rising would mean, and as such it must here be treated of at some length.

Frog Lake was a little hamlet that had recently been established as a trading post and the headquarters for dealing with the numerous Indians of the vicinity. There were but two white women in the hamlet, MIrs. Gowanlock, wife of the owner of grist and saw mills, and Mrs. Delaney. wife of the farm instructor for the adjacent reserves. From their narratives and the evidence given at the state trials, we learn the details of the sanguinary story.

On Narch $z^{\text {oth }}$ a message was received from Rae, of Battleford. 
announcing the Duck Lake Battle, and asking the officials at Frog Lake to keep the Indians of that district from leaving to join those who were contemplating or already engaged in relollion. On the same day a letter was received from Captain Dickens, who was in command of a small detachment of police at Fort Pitt, summoning the whites to come to him for protection. The whites, howerer, were not serionsly alarmed, and Indian Agent Quinn and Mr. Delaney felt that their duties required them to remain where they were. Howerer, a message was conveyed at midnight by John Pritehard, a halibreed interpeter, telling (jownlock to bring his wife to Delaney's to accompany Mrs. Delaney to Fort Fitt. Lfter a consultation among the whites, they decided to summon the Indians together next day and communicate the news of recent erents, thinking it wiser that the tidings should come from themselves, rather than through the distorting medium of rumor.

When the Indians gathered on April Ist, however, the officials found to their dismay that the savages were already in possession of full particnlars. The Indians of the local band were on good terms with the whites and no fear was felt or subsequently justificd in that quarter. There was at Frog Lake, however, a considerable band of destitute and disaffected Plain Crees, nominally under the leaderslip of Big Bear. Unfortunately, that shrewd and peaceably inclined chieftain was absent on a hunting expedition. He did not get home till night, and was not seen till next morning. His absence facilitated the machinations of some of his rebellious sub-chiefs and helped them to get control of affairs. They assumed an apparently friendly attitude, however, and promised to defend the whites against any rebels. They reported that an attempt was to be nade that night by halfbreeds to steal the horses belonging to the settlement, and insisted that the animals should be given to them for safekeeping. At dawn on April 2d they announced that in spite of their precantions, the horses had been stolen. This was untruc, but the removal of the horses rendered flight impossible on the part of the whites.

The Indians, with the exception of Pig Bear, had by now assumed their war paint and were hour by hour becoming more dangeronsly excited. Big Bear warned Delaney that trouble was impending, though as yet the Indians had shown no ill will to the white people in the settement. "It is hard to say how far they intended to go on with the bad work they had commenced," says Mrs. Delancy. "So far from their manner seeming strange or extraordinary, I might say that I have seen them, dozens of times. act more foolishly, ask more silly questions and want more ridiculous things, even appear more excited. Only for the war paint and what Big Fear had told us, we would have had our fears completely lulled."

Early in the morning, however, one of Rig Tiear's sons had attempted to 

enter Quims bedrom to murder lim in his bed, but had been prevented by the latter's Cree brother-in-law, Loving Nan. Quinn was himself a Sioux halfbreed and consequently was recognised by alt as being in special danger from the Crees. Ile was summoned downstairs and boldly went, in spite of the remonstrances of Loving . Nan. . I group of savages, headed by Wandering Spirit, one of I'ig liear's most troublesome subordinates, took him to Delaney's. After some discussion the Indians then went to the IIndson lay Company's store, where they forced Cameron, the trader. to give then additional arms. lig Ficar appeared on the scene and forbade his men to take anything by force, but when he sulsegnently departed the stores were lotted. Neantme, the party of whites were being hurried from house to house by the riotous members of Iig Jicar's band, though Big Bear himself and his youngest son, King lird, were evidently doing what they conkl to protect them from violence.

After breakfast the Indians, who still declared that they wished only to protect the whites against a possible attack by rebels, insisted upon their attending mass, but the services were cut short on account of the threatening and disorderly conduct of the red men. The whites, who had been deprived of all arms, were then compelled to march out towards the Indian encampment. Quinn demurted, however, and Wandering Spirit arldresserl him as follows: "You have la tite dure. When you say no, it is no, you keep your word. Well, if you care for your life you are going to do what I tell you. Go to the camp." "Why shonlel I go there.". said Qnim. "Never mind abunt that," answered the Jurlian. "I shall stay here," sairl Quinn, calmly. Thereupon Wandering Spirit cried out: "I told you to go!" and shot him dead.

The general massacre was an affair of but a few monents. A group of the Indians rushed upon George Dill, a trader. When pursued by mounted Indians, he gave up an attempt at flight ant was immediately murdered. The next victim was William Camplelt Gitchrist, a bookkeeper and an assistant surveyor in the employ of Gowanlock. IJe iell close beside George Dill. The Gowanlocks were toward the front of the little party of whites moving out from the village. Suddenly they were overtaken by Williscraft, an old man of seventy-five years, shouting. "Oh, don't shoot, don't shoot!" The Indians fired again, and Williscraft fell amid the bushes. "Ny dear wife," said Gowanlock, "be brave to the end!" With these words on his lips, he fell, dying.

The next victim was Delanes. When he was shot, the heroic priest. Father Fartard. who all the while had been endeavoring to restrain the Indians, threw himself between the wounded man and the savages and. kneeling beside him. asked it he could say the confiteor. Mr. Delaney repeated the prayer. As he finished it the priest said. "Nly poor brother, 


$$
\text { . }
$$


1 think you are safe with God." As the words left his lips he received his own death wound, and fell prostrate across Delaney's lifeless form. Another priest, Father Marchand, was endeavoring to protect the women and to rescue Farfard's body, but he also was assassinated a moment later. C. Gouin, a Sioux IIalflureed carpenter, was also killed.

Meanwhile, Cameron, the IIudson's Bay Company trader, was at his store under the protection of Big Bear. With his assistance, Cancron escaped to the woods, where the chief of the Frog Iake Indians gave him shelter. The widowed white women, the only other survivors of the fearful massacre, were torn away from the bodies of their husbands and dragged to an Indian encampment, throngl water waist deep. They were saved from a fate worse than that of the dead by Pritchard and other Halibreeds, who ransomed them from the Indians by the gift of two horses and thirty dollars. "I fully trusted to Pritchard's manliness and good character," says Mrs. Delaney, "anel I was not deceived. He not only proved himsclf a sincere friend and a brave fellow, but acted the part of a perfect gentlenan throughout."

On April 3d Big lear came to the tent of the white women and wept bitterly over the conduct of the evil men he could not control.

This was Good liriday. Next day some of the bodies-which had been mutilated-were placed in the clureh by the Halibreeds, but the little sanctuary was soon afterwatds burned down by the Indians. They also destroyed the other buildings at Frog Lake, and gave themselves up to savage revelry.

On the 6th the band of Indians went over to Fort Pitt and denanded its surrender. This was, of course, refused lo Inepector Dickens, and Mr. McLean, a Ifudson's liay Company officer, went to parley with the savages. His efforts as a peacenaker wete unavailing, however, and le was taken prisoner. He now believed the encampment to be safer than the fort, and sent for his family, who were then added to the list of eaptives. Several days elapsed anid great anxiety. On the 15 th the savages returned again to Fort Pitt with a prisoner, Pritchard, to act as interpreter. A number of settlers and others who were at the fort at the time were seized. On this day three sconts were fired upon as they returned to the fort, and one of them, Constable D. 1. Cowan, was wounded and subsequently massacred. One oi his comrades was also wounded, but escaped into the fort, while the other was made prisoner. All hopes of successfully defending Fort Pitt were now abandoned, and indeed, as was shown by the cridence at the subsequent state trials, it was probably owing to Big Bear's influence that Dickens and his men were allowed to escape on a scow. They reached lattleford after terrible hardships, on the morning of April 22d. 

Meantime, the white and IIalfheed priconers, including Mrs. Gowanlock and Mrs. Delaney, were being held as hostages. Their captors were soon pursted by General strange and Colonel Stecle. During the skimishes which followed, and the headlong flight of lig bear's hand through the morasses of the northern wilderness, the prisoners suffered great hardships, and were of 1 en in peril of their lives. The watch kept over them was vigilant-indeed, nerveracking. Mrs. Delaney writes, "I used to sleep in a siting position, and whenever. I would walie up in a started state from some feverish aream, I invarially saw at the tent clwor a hmun eye riveted upon me." On May ath the Jndians contemplated forcing the white women away from their Jfalfbred protedors, but they were saved in this desperate juncture by a report that the police were alproaching. This caused a surden panic and stanpede. I'ritchard and his protegees escaped two days hater, on the first and only time that the Inlians were not on close watch, falling into the hamds of Mackay and Balentyne, two of Strange's scouts. At the moment preceding their rescue, their real danger was greatest, for the police had mistaken the refugees for a band of the rebellions Indians.

Such is the tragic story of the mascacte of lirog Lake, which is fortunately without a comnterpart in the hisory of Saskatchewan. Twelve years afterwards, the bones of the murdered men were removed from their first resting places to the little cenctery at Frog Lake, where small iron crosses mark the graves of the nine victims. 


$$
\text { + }
$$




\section{CHAPTER YXII}

MIDDLETON'S PLANS: TIIE ADVANCE TO TIE SEAT OF INSLRRECTION

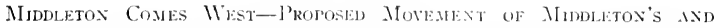

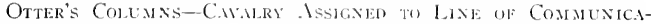

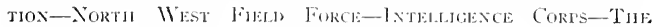
Nortil Sifore Route-Conmission Ampontel to Investigate

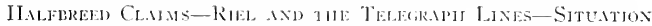

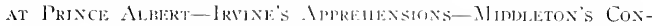

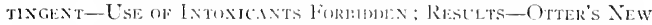

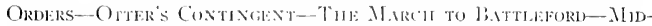

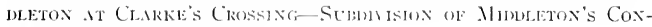
TINGLNT-KHEL'S Scot'Ts.

It will he remembered that Ricl's followers torek 11 , arms on the 3 sth of March, cight days prior to the first engigement-the Battle of Dnek Lake, which we have described in a preceding chapter. On March $22 \mathrm{~d}$ a despatch was received by the Premier stating that a group of Ilalfbreeds had scized the mails near Duck Lake, looted several stores and were generally terrorizing the community. (n) the afternoon of the 23ral, Gencral Frederick Midlleton wals notilied by the $\mathrm{H}$ lon. Arklphe Caron, Minister of Militia, that conditions in the saskatchewan would probalny necessitate military action, and he at once set on for the west, traveling by rail a'ia Chicago. He arrived at 11 imnipeg on the 27 th, and there learned of the disaster of Duck Lake. Neantime the local military authorities had been active, and on the evening of the same diy General Midklleton proceeded west with 260 members of the goth battalion, one company of which had left the night before. The left wing of the battalion minder Major Bosworth har

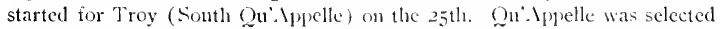
as the primary lase as it was the place nearest to 11 innipeg with direct trail to Batoche, Riel's headquarters.

Middleton's plan was to move with the principal colmun direct to Clark's Crossing, a telegraph station and ferry on the Sonth Saskatchewan, about forty-four miles by trail from Batoche.

The second column muler lieutenant-Colnnel (Otter of the permanent militia was to proceel from Swift Current, abont one lundred and fifty 

miles west of Sonth Qu Ippelle on the main line of the Canadian Pacific Railway, which town Middleton intended stleeguently making his chicf base. Otter was to meet him at Clarke's Crossing. When the two columns would advance, one on each side of the river, to attack liatoclse. They were then to separate, one marching to Prince .lliert and the other to Batleford. where in the meantime the Mounted lolice were to be reinforeed ly a detachment under Jicutenant-Colonel Herchiner.

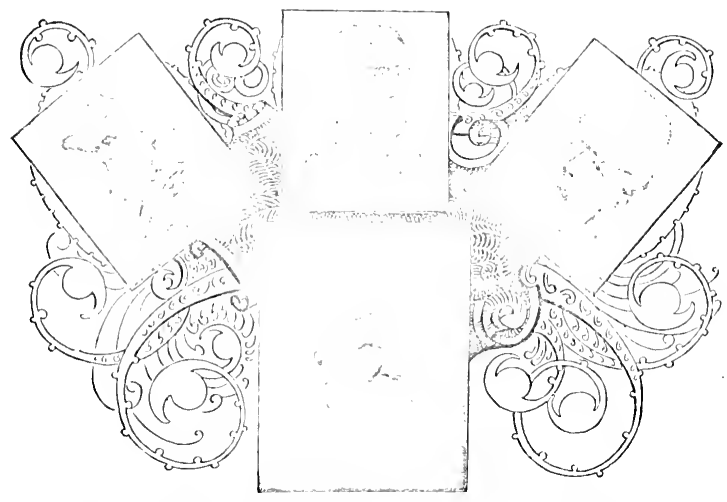

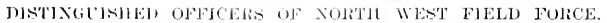

Major-General Strange, Allerta Column.

Lieut-Col. Williams, who led the charge

Lieut-Col. Otters, Battleford Relief Column.

at batoche.

General Midaleton, Commander-inthief.

The third main column, under Major General Strange, was to overawe the Indians in the Calgary district, march north to Edmonton and come down the Forth Saskatehewan to Fort Pitt. There Mirldleton hoped to meet him. After the junction of their two columns lie intended to dispose of Big Pear's band. Neantince. munted scouts were to patrol cact and west of the Cyprese IIill between the Camalian Pacific Railway and the American fronticer. as infomation hat leen receised that a body of three humbed Chicago Fenians had bound blumselves thegether by nath to invale Canada in support of the reled Jlalilreer's. If they cante they were expecterl 

to head for Moose Jaw in the first instance. Furthermore, this force was intended to prevent retreat to the Lnited States on the part of defeated rebels and Indians. The ordinary cavalry Middleton did not consider suited for active cmployment at the fromt on aceount of the nature of the country and the style of warfare which the Ilalfbrecels and the Indians might be expected to adopt. They were, therefore, to be posterl an the line of communication between (Ji'Appelle and IImmboldt, to hold in check the disaffected Halfbreeds and Indians abont Touchwood Hills. In due course, accordingly, the Governor General's boty guard (ciglity-cine) from Toronto, under lientenant-Cohnel (eorge Denisun, was posted at I Immboldt and a small mownted troop of the permanent forces (forty-eight) was placed at Touclwood under Lientenant-Colonel F. Turnbull.

Middleton's columm was at Qu' Huptle ly the 2nd of April and spent four days there, chichly in drill.

Meanwhile the transport and commisariat departments and the hospital corps were being organized and more troops were being gathered from all parts of the Dominion. These included "The Midlanders" ( 386$)$, consisting of two companies of the froth liattalion and one each from the I5th, 4oth, $47^{\text {th }}$, $49_{\text {th }}$ and $57^{\text {th }}$ Lattalions, organized by Lientenant-Colonel A. Williams, ג1. P.; "The simeve Kangers" (3.2), consisting of four companies eacl of the 35 th Sincoes and the rath Jork Rangers, under Lieutenant-Colonel O'Prien, M. P.; "The 65 th Mount Royal Rifles" from Montreal (340), under Lientenant-Colonel Ouinet, M. I'.; the g1st Battalion from Winnipeg (432), under Lieutenant-Colonel Thomas Scott, 11. P.; the Winnipeg Light Infantry (327), under Lientenant-Colonel Osborne Smith; a company of sharpshooters from the Governor General's loot Guards (5I), under Captain Todd; the 7 th Fusiliers from London (257), under Licutenant-Colonel $\mathrm{V}$. Williams; the gth Battalion (232), under Lieutenant-Colonel Amyot, M. P.; the Halifax Forces $(38 \mathrm{I})$, under Colonel Bremmer, and a regiment from Quebec and Kingston (225), under Licutenant-Colonel Nontezambert; a small cavalry troop from Wimipeg (36), commanded by Captain Kniglı: the IJimipeg Field Battery (62), uncler Major Jarvis, and the goth Battalion, also of Wimipeg (3I4), under Lientenant-Colonel Mackeand, Montreal Garrison Artillery (206), Lieutenant-Colonel Oswald commanding, did not arrive at Wimipeg from the east till May 20 , but should be mentioned.

The promptitude with which they answered the call to arms and the spirit with which they performed their unaccustomed military duties has ever since been a source of pride to all Canada. Momnted intelligence corps and other scouting bodies were organized muler Captain Dennis from among the survey parties $(5.3)$; by Captain French (late N. IV. M. P.) from among the settlers around Qu' Ippelle $(30)$; by Captain Stewart 

(Rocky Monntain Rangers, 154); and Captain White (Noose Mountain Sconts, 54); by Major boulton at 11 immege (113); and a valuable corps of police scouts were organized ly Mlajur Sicele. Hlome gtiards and local companies of volunteers were also organized at liegina, liattleford, lurkton, Qu'Appelie, Prince Albert and clswhere. The total strength of the North West Field Force. exclusive of the Momned Puliec, reached, on paper, approximately 5,000 .

Enormons difficullies were orercone in transporting troops from Eastern Canada to the iremt, as there were still several gaps aloug the line of the Canadian lacific Railway. For example, about four hundred miles of the road cast from Port Arthur rernirel the continual enbarking and disembarking of gums and stores from flat ears to sleighs, and aice iersa. The weather was cold and the snow deep. Orer one piece of road it took the guns seventecn hours to moxe thirteen miles, and eren when the railroad was open long distances lake to lxe corered on umprotected flat ears, thongh the thememeter frefuenty registered forly to fifty degrees below zero. $^{1}$

Nontizambart, in his repert of the journey west, remarks that when they reached Xipegon? on the norlh shore of Lake Superior, the men latel had no seep for four nights. Even when the volunters reached the North

I have copical the following passage imelicative of the nature of the North Shore journey in 1\&8, from one of the -ereral diartes of which I hate hat aceess:

"Thursday, April 2. 1.8. . We drove all night through a very wild and heatutiful country. It was not till cight this murning. after at drive of thirty-live milen, that we

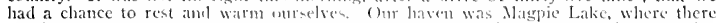

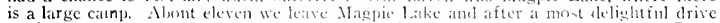
of five hours we reatch the track agatin at a point hereafter known to fame as Campl Desolation. No train awatits ne as we expected at Camp Desolation, and we have to stand shivering and humery for thee hours before the ears arrive, and hich we find that we have to ride one hundred and seven mites in ofen flat cars. There is no help for it and we pack in as lest we may. Bach man hat but one thin Goverment hlankiet.

"Friday, April 3. The horrors of lant night are simply indescribable. We leave Camp Desolation abut seven, rather culd and humsty, but for ame time enjoy ourselves fairly well. The mole of progeres is. to saty the leant of it, somewhit novel. The ties are merely laid on the snuw; unballated and moleveled; sometimen we seem to be plunging down veritalile precipices, on teep are the wrades, and at all times oicillation is so great that one monentarily expect the car in leave the track bodity. Sonn we thind, however, that it is becoming too cold to allow any interest to be taken of andhing but the question of how net wo frecze, and exen that question, in spite of the rigorous efforts of some of the more cheerful and pluckier spirits to lieep the men's crumate up: ceases ere long to bother our ponr, despondent fellows. The thermometer, by actuat observation, goes down to thirty-five hew gero; the wind is liting: wur cramped quarters render mosement of any kind imponsille. and at last we simply make up our minde to freeze. Jack Nelemun, who hias heeri the life rif No 4 so iar, works hard, hut when, as a last sally he rings up Ilis Sattanic .llijenty informs him that a collection of thirty-one eents has been taken up for llis Mijenty's excliequer, and begs lim $t$, turn on the hot tube for fifteen minutes, anel is then not rewarded with a latgh, he, too, curls up and prepares to dic.

"All things have an end. Dlout $2: 30$ a. mo weach a camp called Iferom Bay, ninety miles irom Camp l)esulation, and hare a meal. I was about to say breakfast. lont it is really the dimer of the day hefore yesterday. Many of our poor follows have to be lifted out of the cars, so tiff with cold are they." 

West. the winter had not yet broken up, and the men were called upon to endure very serious hardships in their march north.

It may he remarked in passing that on March 30 a commission consisting of Messrs. II. T. R. Street, A. T. Forget, (). C., of London, Ontario, and clerk of North West Council, and Roger Goulet, D. L. S., St. Boniface. Nanitoba, was appointer to investigate the Halfbreed clams. Had such a step been taken a little earlier ne rebellion irould have occurred.2

After the outbreak of the disturbance Riel had cut the telegraph wires so as to isolate Prince. Mlhert; beyond this he apparcntly thought it best not to interfere with telegraphic communication. Evidently it was his opinion that when the particulars of the Battle of Duck Latie should be known in the east and in the United States, he would be likely to secure moral and material surport that would be of ereat value.

Among the few messages that came ont from Prince. Illert was the following letter, which speaks for itself :

\section{Dear Sir:}

$$
\text { Prince Albert, 3oth Marcl, s } 88_{5} \text {. }
$$

Telegraph the following cipher in my name to the Commissioner: Kiel warned all settlers from farms. Would be forced to foin him or be slot, gave them forty-cishlt homr wetice. I'conle tlocking in. Irvine appointed me supply officer. Send llour, hacon to Troy, send 2,000 sacks flour atia Calgary to Edmonton, and $4.000 \mathrm{ll}$ s. hacon if safe. Siteamer from here will be sent to bring it down. Carlton lumed to the ground, lave saved all furs and bulk of provisions, lot of goods destroyed. Pupulation all in arms. Police here; tell my people I am safe: just got our dead in from Duck Lale, nine in all. Will wire every opportunity. L'rovisions for further transport already at G. Lake.

Wm. MacKay, Esq., 1I. D. Co., Battleford.

Advices, were also received by $\mathrm{Mr}$. Dewdney from Lieutenant-Colonel Irvine, in which, according to General Midd]eton, Irvine declared that the General's force should be $\mathbf{1} .500$ strong. as matters were in a very critical state, and Irvine believed that all the Indians would join the rebels wnless decisive actions were taken at once.

The forces immediately under Midlleton's command numbered a little over eight hundred, though all these were not yet with him when he commenced his march northward from Qn'Appelle on April 6th. It may be remarked in passing that the thermometer dropped to ten degrees on the evening of that day, and stood at 23 degrees below zero next morning.

Some little time later Niddleton divided bis fores into two columms. The left consisted of:

A An Order in Cotuncil had hecn passed in I:unuary, authorizing the appointment of this Commission. and Flonorable D. L. IIacPlersum is authority for the statement that the IIali-breeds were notified of the Order on February 4. 

Strcnglh.

The Ioth Royal Grenadiers. Lientenant-Colonel Grassett commanding..250 Two Guns, lVinnipeg Ficld battery, Major Jarvis commanding....... 50 Detachment from A Battery, Lientenant Kivers commanding........ 23 French's Sconts, Captain Irench commanding .............. 20 Detachment of boulton's Scouts, under Sergeant Brown.......... $3^{\circ}$

Total .......................................

The right column was mate up as follows:

Rank

and File.

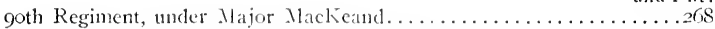

A Battery, R. C. I., under Captain I'eters................ 82

C Company, l'ermanent Force, under Major Smith............. to

Scouts, under Major Boulton..........................

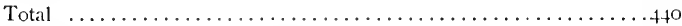

With Licutenant-Governor Houghton as staff officer.

Middleton's decision in comection with allowing the use of liquor by the troops and his subsernent experience in that regard may here be indicated:

"The question for my consideration was whether I should allow the troops to have a certain ration of liquor, in which case, of course, the Government would allow of its being adnitted for their use. It was pointed out to me that most of the men in the militia, thongh not by any means drunkatrols, were in the habit of having a certain amount of stimnlants daily, some few a good deal, and that, with the cold weather and hardships they would have to undergo, the sudden withdrawal of stimulants might have a deleterious effect, \&c. After due consideration, bearing in mind that Lord lVolseley allowed no liquor in the Red River expedition of I87o, I resolved that I would allow none to be issucd to the troops on this expedition, or to be carried with them by either officers or men, except a certain amount as medical comiorts. It was a bold step to take under the circumstances of the case, but I was fully bornc out by the result.

"At first a few men sulfered from pains in their limbe from sleeping on wet or damp ground, and there were a few cases of frosthites, and colds and conghs, also a few cases of snow blindness, to meet which the Government had supplied goggles, but in a short time this was got over. and there was little or no sicliness, severe as was the weather, and men who believed that they would surely succumb to this deprivation of their accustomed stimulants found themselves at the end of the campaign in better health than they had been for years before."

As Middleton proceeded northward, he, of conrse, maintained close communication with the varions posts affecterl by the insurrection. The messages from Superintendent Morris at Pattleford indicated that the danget at that point was so acute that on April is the General changed his plans 
with regard to the movements of Licutenant-Colond Otter, and telegraphed him to start at once from Swift Current to the relief of Battleforl. Otter accordingly ptrished forward on the 13 th, with a force mate up as follows:

Men and

Officers.

B Battery, Royal Canadian Artillery, Major Short conmanding-two

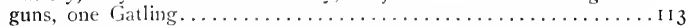

Detachment C Company, Infantry Scliool Corps, Lieutenant Wadmore

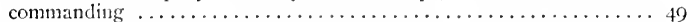

Detachment Governor-General's Foot Ginards, Captain Todd commanding $5 \mathrm{I}$ Queen's Own Rifles (two regiments), Lientenant-Colonel Xliller conn-

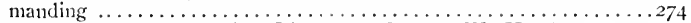
North West Mounted l'olice, Lientenant-Colonel WV. Herchmer con1-

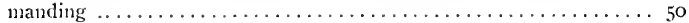

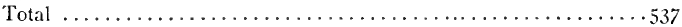

The teamsters and tramsport officials numbered 200 .

He was to push on to Battleford witl all speed and hold that town until Middleton's arrival. The march performed by his force aiter crossing the river at Saskatelewan Landing was most creditable. The distance covered 160 miles and it was done in five and a half days. Otter had a long and cumbersone train, and it was necessary to carry twenty-live days rations, twenty days' oats, ten days hay and a supply of wood. There were also wagons for a portion of the infantry and. indeed, for the whole colum on the last day's of the march. Is Otter had not sufficient transport force to move all his supplies at once, it was necessary for lis teams to make donble trips. This involved leaving large quantities of provisions and ammunitions practically unprotected on the prairie, and it is extraordinary that they were left unmolested by the disaffected Indians, through whose country he was traveling. Some of the supply trains were, of course. captured."

An interesting feature of Otter's movements is involved in the fact that, after all lint completing so creditable a march, he halted in the afternoon within two miles of Battleford, and allowerl a considerable portion of the town, including Judge Ronlean's residence, to be looted and burned that night by the Indians. ${ }^{*}$

3 Extract from the diary of an officer of Otter's Relief Column:

"The supply train captured yesterday was a small one and not important, but the next time we may not be so licky. Perhaps now an escort will be sent with the supply trains and a proper guard kept on the halting places. We hear of one station where one solitary man is in charge and there are stored thotisands of boxes of feed and biscuit, and, more valuable still, a great many rifles and ammunition. This is a station only forty miles away and easily within reach of the Nitehics."

${ }^{4}$ From the diary of Nemler of Otter's Relief Column:

"We make only thitty miles, however. halting quite early about five miles from Battleford. We are disgusted to notice clouds of smoke rising from the settlement. We are ordered to camp, however, much as we should tike to press on and render 

When Otter arrived to relicve Inspector Morris at Battleford, that town had been in a state of siege for a munth. Refugees latal crowded in until Morris had in his care nearly four huntred women and children. He had organized two companies linemu as the liatteford Rifles and the IIome Guard, and had done what he could to render the settlement capable of resisting attacks. In his official report lie mentioned with special gratitude the assistance rendered him by Sergeant-Najor Kirk; Mr. Nacrae of the Indian Deparment; Mr. Ilarvey Nash; Mr. Frank .1. Smart, who was killed by skulking Indians upon moving out beyond the line of protection, and Constable Stores, who volunteered to carry a message to swift Current and $i n$ so doing was chased sixty miles by rebels. Later on, March 14. Constable F. O. Elliot, X. W. M. I', was killed near battleford while scouting."

Now let us return to Middleton's column. On Novenber if his advance I guards marched through a hizzard to Clarke's Crossing, the main body of his column arriving there the next day. Here they were reinforced

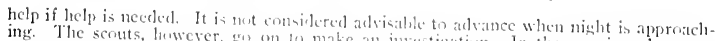

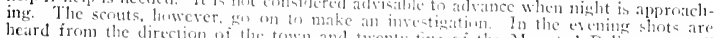
heard from the direcion oi the tewn and twenty-tive of the Alounted Police start aff

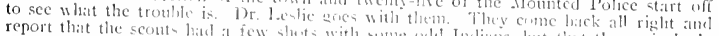

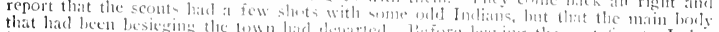

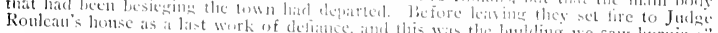

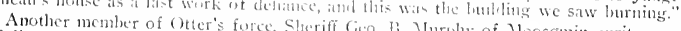
as follows in defense of his commandme officer: A. Aturphy of Moosomin, writes me

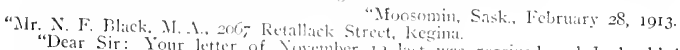
answered sour inguiry ats to Of November 12 liat Wals received and I should have away.

"The column camped. as stated, two miles out of Battleford, conth, as it was night-

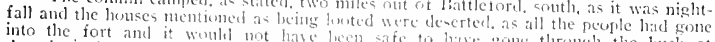

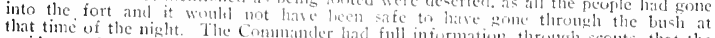
that time of the night. The Cotmunder had full infurmation, through scouts, that the
residents of the buildings had escitped. "Witl-kindest regards, yours truly,

"G. B. Murphy."

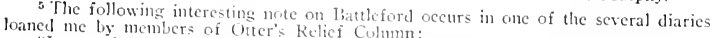

"I must describe the situation of things over in

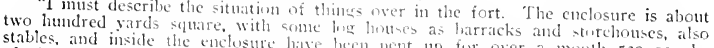

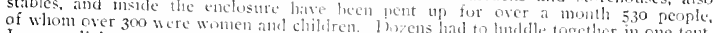

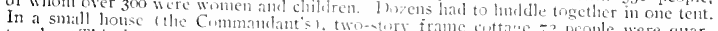

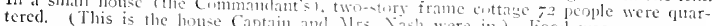

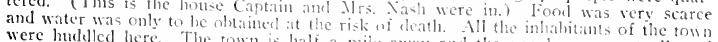

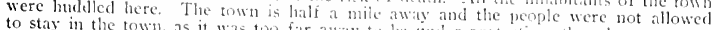

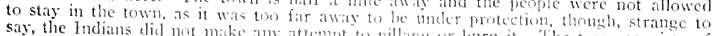
say, the Indians did mot make any attempt to pillage or linron it. The tewn consiste of

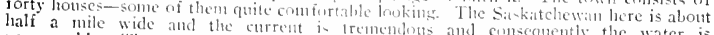

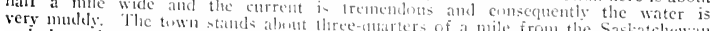
and about the same from the liattle River." 

by the Royal Grenarlicrs from Toronto. With a few extra wagons to assist the men in marching, this capital militia regiment lad in nine days, including one day's halt, covered the distance from Qu'Appelle, igs miles, over a wet and heary trail.

Middleton now determined to divide his force, sending what we have called the left coltum across the river, under Lieutenant-Colonel Nontizambart, with Lord Alygund (subsequently Larl of .Jinto, Governor-General of Canada) to take the place he hat intended jor Otter's column. To transfer. Montizanbart's force across the river wals no easy task. It was done by means of two scows, one of them brouglit from Saskatoon for the purpose. The scow's were worked by pulleys running on a wire rope, the current of the river providing the motive power. Ilis task was performed on the 2oth and 2 ist, after which the columns procecled down the river, one on cither side. 
$+$ 


\section{CHAPTER NXIH}

\section{THE BATTLE OF INSII CREEK}

\section{Dumont Restr.uned ay Riel- Atrempted Sukplse at Tourond's

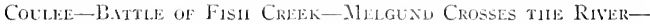

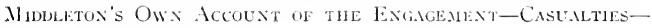 DUMONT'S REPOET.}

During the advance on liatoche it is notorious that Dumont was in favor of systematically harasing the Canalian forces, which he conld easily have done with much effect. Jntimately knowing the conntry as he and his warriors did, it would have been relatively safe and easy for him to have severely strained the nerves of the militia by oft-repeated alarms, especially at night. However, he was overruled in this by Riel, and indeed Lord Melgund subsecuently pointed out that the IIalfbreds seemed governed simply by a desire to protect their own homes and settlements from aggression.

On the morning of the twenty-fourth, however, Nidlleton's forces elashed with the rebel ontposts at Tourond's Conlee. which in the newspaper accounts was called Fish Creek. This was a steep and winding ravine lying direetly in Middleton's path and leading down to the river. Here Dumont and his associates had carefully planned a surprise. It was not entirely successful, as Mlajor Boulton's sconts were feeling their way. ahead of the advance guard. ${ }^{1}$ They informed Middleton that at the left of the trail they had come across a camping place, not long vaeated and the fires still smonldering. From the number of the fires and other signs it was believed that nearly two hundred men had camped there. A few moments atter the receipt of this warning the skirmish began. Men in the advance guard of the Ninetictl afterward declared that "the first indieation of the enemy's presence which they hat was in seeing several of the seouts in front fall from their saldles under the leally fire of the Half-

1 Moreover, we are told in Lic Recit de Gubrid Dumont, that, much to his chagrin. some of his men rode for some distance on the regular trail hetween Fish Creck and Middleton's camp on the night hefore and this le fit such traces of their presence as to necessitate a departure from the original flan determined upon by the reliel captain. 
$$
\text { . }
$$ 



$$
\text { . }
$$


breeds concealed in the bluffs."2 Major Botnlton's description of the opening of Fish Creek Battle is as follows:

"I gave the command, 'Left wheel, gallop, and we charged down upon thirty or forty mounted men who were standing in the slselter of a bluff. When we cane upon them they at once turned their horses and bolted for a ravine, or gully, about a hundred and fifty yards distant, dismounting as they galloped. I instantly' gave the word to my men, 'Halt! Dismount! Extend in skirmishing order and lie down.' Simultaneously the eneny, who were in a ravine, and out of sight, opened a murderous fire upon us. I said, 'Fire away, boys, and lic close: never mind if you don't see anything, fire,' my object being to kecp the enemy down in the gully and hotel then in check till the supports came up. The rebels would pop up from the ravine, take a suap shot, and disappear in an instant. The General at once sent back Captain Wise, A.D.C., to hurry up the main body, in which duty his horse was shot. We here sustained the whole of the enemy's fire, which was very hot and unfortunately fatal. Captain Gardiner, who was beside me, was the first to say, 'Najor, I am hit.' Almost immediately Langford called ont that he was hit. Bruce was the next victim. Then poor D'Arcy Baker called out, 'Major, I'm hit," and he reccivert his death wound by a bullet crashing into his breast. Then Gardiner called ont, 'I am hit again.' Langford, too, was hit a second tinc. I told the wounded to drag themselves to the rear the best way they could and get ont of further danger, ordering the remainder to hold on and fire away."

One Indian in full war paint came forward, dancing and shouting his war cry apparently out of sheer bravarlo. II was immediately shot and fell in the open, where his body remained all day. The advanced guard of the infantry under Captain Clarke, of the Ninetieth, who was wounded shortly afterwards, presently arrived, and was extended to the right of the scouts, and when the main body arrived under Lieutentut-Colonel Houghton and IIajor Mackeand two additional companies were extended to the right. Captain Peters brought the two guns into action, but with such little effect, owing to the cover in which the enemy fought, that Middleton, after a few rounds, willdrew them.

The firing line pushed on to the edge of the bank of the creek. Ilere many casualties occurred, and Middleton has been criticised for thus exposing his men. It has been said that he shoulh have taken advantage of the superior range of his riffes. Ilowever, I do not think criticism valid in view of the nature of the country in which the fighting occurrel. Granting that it was necessary to clear the Indians and Ilalfbreeds out of the steep

2 Macbeth: Malsing of the Canadion If'est.

3 Boulton's Reminiscences of the Forth $11 \%$ 'st Rebellion, pages 225 and 226 . 
. 
ravine in which they were concealed, it seens evident that such action conld be accomplished only by bringing the Canadian forces right to the erlge of the coulee, and even into it. The rebels were entirely invisible almost from first to last even at this close range.

Towards the right of the Canadian lines the rebels set fire to the prairie, and under cover of the smoke made a gallant attempt to dislodge the volunteers. The serionsness of the situation at this juncture was candiflly armitted by Midclleton in articles which subsequently appeared in the Unitod Service Magazinc. However, the volunteers hept their nerve, and a gromp of teamsters under Bedson's directions advanced, and with great pluck beat out the flanes. "If anything had been requirel," says General Middleton, "to keep the men steady at this rather critical moment, it would have been found in the extraordinarily composed and cool belavior of IVilliam Buchanan, a little bugler of the Ninetieth, who, while calmly distributing ammunition along the line, kept calling ont in his childish slurill voice, "Xow, boy's, who's for more cartridges?"

Neantime the left column on the other side of the river could plainly hear the firing, but were, of course, unable to render any immediate assistance. Melgund with the Tenth Grenaliers, lowever, under Captain Mason, crossed the river and were extended along to the riglit centre.

"The scow," says Midalleton, "unfortmately was not in proper position, having been sent early that morning to onr camp for forage for the left column. It was then on its way down, and nen were sent along the river to hurry it along. When it did arrive it lad to be mloaded before the crossing conld commence. The umvieldy scow, which coukl barcly hold sixty men, instead of having the assistance of the wire rope and current, had now to be laborionsly propelled with oars rouglily inprovised and made with axes by men totally mused to such work, the current being an obstruction instead of an aid. Alded to this was the difficulty of embarking and disembarking, owing to the deep mud, bonlders and blocks of ice, and to the absence of a wharf and of roalways down and up the steep wooled banks, some one hundred feet high on each side. Tet with all these difficulties to surmomnt, two hundred and fifty men and two guns and their wagons, fully horsed, were crossed over a wide and rapid river without an accilent, principally owing to the indonitalsle energy and determination of the officers and the men, and especially of Lord Melgund and Major Jarvis, commanding the gtms of the 11 imnipeg Battery. I force of regulars conld not have done better, if so well.

For the following accomt of the chief renaining incidents of the lattle of Fish Creek 1 an indebted to one of Niddleton's articles ${ }^{4}$ in the United Serice Magazinc, to which reference has already been made: 
"Captain Peters, commanding the artillery, now asked permission to have a party of volunteers to try and dislodge these trutblesome 'Pitties,' which I granled. The party consisted of a few dismomted artillerymen and some of the Ninetictl under Captain Ruttan. They advanced into the ravine, at the bottom of which they were checked by the fire of the enemy, who, as ustal, were invisible. IIere they were joined by some more of the Ninetieth under Lientenant Swinford, accompanied ly Lientenant-Colonel Houghton, who had been sent with orders, and attached himself to the party, and my aidc-de-camp, Captain II ise, who had obtained leave to go. At the same time another small party adranced in another direction to create a diversion. Lfter making several gallant attempts, all hat to retire with the loss of three men killed and five wounded, one of the latter being Lientenant Swinford, who died of his wound. I refused to let them malie a second attempt then, and took Captain Drury, with one gum, supported by a part of C Company, mnder Major Smith, across the ravine to the left, to try and take the pits in reverse, but with no apparent effect, as one of the gunners was wounded, and Major Boulton, who accompanied me, had his horse shot under him. I brought them back and contented myself with detailing a party, well under curer, to watch the place where the pits were. My gallant and ever-ready aide-de-camp, Wise, was now put hors-dc-combat by a shot in the ankle, received white trying to ascertain if the encmy had gone.

"By about 3 p. m., with the exception of an occasional shot from the pits, all firing had ceased; the enemy had fled, and the fight was virtually over. Captain Mason, of the Tenth, and some officers and men were now very anxious to be allowed to again try and rusle the rifle pits, but I did not think it advisable for several reasons to risk losing more, as we certainly shottl have done in a second attempt. The tenants of the pit were evidently reduced to a small number, and could do little, if any, more damage. Moreover. I could not help having a feeling of admiration and respect for their stubborn defense when deserted by their comrades, so I refused, and shortly after the fire ceased altogether.

"I must now refer to the proceeding; of the other column. On hearing the firing on our side Melgund, with the concurrence of Licutenant-Colonel Montizambart. gave orlers to make a secure lager with the wagons, and moved the force down the river bank, leaving a small party on guard. The firing becoming heavicr, they moved down the river, and as they gnt nearly opposite the scene of action-which was not visible to them-they saw somebody on our side gesticulating and shouting. Melgund went down to

4 "Suppression of Relullion in North West Camaln," by General Sir Fred Middleton.

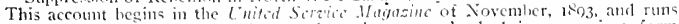
through several numbers. The chapters hate heen scraphooked in convenient form in Teronto Reference Library. 
the river side, and though he could not mate out clearly what was said, he rightly concluded that they were wanted to cross, and immediately set to work to do so.

"The band of the goth did most excellent service in bringing in the wounded, not hesitating to expose themselves to the fire of the eneny in so doing.

"My men had borne their baptism of fire well; and if they had notas was only to be expected-clisplayed the dash and rapidity of movement of regular troops in their first essay of war, they had clearly evinced great staying and dogged courage."

Middleton had something less than 400 men actually engaged, of whom ten were killed or died of their wounds, and forty others were wounded. This heavy casualty list shows how effective was the firing of the rebel sharpshooters, who at no time during the engagement numbered more than 130 , though they were credited with being present in much greater force. In General Midelleton's account it is stated "That the rebels had eleven killed, or died of their wounds, and eighteen wounded, besides three Indians left dead on the field." However, from the parish register at Batoche and the monument ratsed to the memory of the fallen in Batoche country we learn that as a matter of fact only four of the IIalfbrects were slain.

The names of the volunteers who lost their lives as a result of the Battle of Fish Creck were as follows:

Killed-Gunner D. H. De Manolly; Gunner WV. Cook, Privates A. IV. Ferguson, James Hutchins, George Viheeler, Villiam Ennis.

Died of wonnds-Lientenant Charles Swinford, Corporal John Code, Private Arthur J. Watson, Trooper D'Arcy laker.

Middleton remained a week at Fish Creek awaiting the arrival of the steamer Northeote, which was to convey the wounded to Saskatoon, and did not reach the crossing till May 5 th. It was therefore necessary to carry the wounded, in improvised amlulances, a distance of about forty-two miles. Boulton's scouts formed the escort, and the wounderl were placed under the care of Dr. Willonghby of Saskatoon, and other physicians.

When at last it arrived, the steamer brought, besides supplies, about eighty Midlanders, under Colonel Williams, M. P., Lientenant-Colonel Van Straubenzic and Captain Ifoward (late of the U. S. Army), with a Gatling guin.

Let us now turn to a consideration of the Fish Creek engagement as seen from the point of view of the rehels themselves.

It is to be remembered that Gabriel Dumont had heen wounded at Duck Lake fight, and it is believed by many who had exceptional opportu- 
nity of knowing the facts. that thereafter he was never entirely hinself again, during the rmainder of the campaign. Indeed, his conduct on the occasion of the skirmish at Fish Creck was severely disapproved by some of his associates. I have carefully weighed the available evidence, however, and have concluded that the flattering judgment of the Canadian soldiers was more junt, and 1 believe that Dumont's story of the affair may be accepted as suljstantially relialle.

In his account Dumont informs us that on the evening of the 23 d he set out from Batoche to meet dliddleton with a force of two hundred of the insurgents, made up of Métis, a fow French Canadians, and a motley company of Indians-Saulteaux, Crees and Sionx. "Ricl accompanied us," he says, "and in the halts he matle us say our beads." The company halted for supper at Roger Goulet's farm, where they were overtaken by Noël Champagne and lloise Carriere, with worl that the mounted police were believed to be advancing on liatoche by the On'Appelle road. Edouard Dumont, with a little garrison, had been left to defend liatoche and he desired either his brother or Riel himself to return with thirty additional men. Gahriel refused to go back, but kiel consented and the former gave him fifty of his two hundred men.

Dumont then arlvancerl and at daybreak he and his men sighted Middleton's camp at .lichutosh's farm. After this preliminary recommaissance, Dumont catsed the main body of his party to fall back upon the precipitous coulce of Fish Creck. Jte himsclf, in company with Napoleon Naud, continuer the scouting operations, approaching at + . I. N. to within a half-mile of Middleton's canp, after which they returned to Tourond's. There he was when one of his rumners brought word that Xliddleton was approaching. Dumont then placed one hundred and thirty men in the coulee opposite Tourond's and set out with the remainder of his force, consisting of wenty picked horsemen, to prepare another ambuscade on Middleton's flank, but upon sceing recent marks inadvertently left on the trail by some of his men, he was obliged to abandon this plan. At $7: 30$ Dumont's advanced guard came under fire. Several of its members fled, as also did a considerable mumber of the Halfbrects and Indians whom he had left in the conlee. Dumont and his more stalwart companions, by gigantic efforts, stopyed their retreat, rallying their men to the number of sixty-two; forty-seven of these were in the main ravine, and fifteen were witl Dumont in an adjacent coulec. Dumont was separated from the main body in the ravine during most of the day and it is commonly said that defections from the insurgent ranks reduced their number to forty-five." Those that remained. however, put up a most courageous fight. Isadore Dumont, to keep up the courage of his companions, started an old chanson

s Dumont gives the number lifty-four. 
of Napoleon the First, and all joined in the chorts. Maxime Lapine's report of what he saw and diel in that fatal coulee will he found quoted at length in the chapter devoted to religinus aspects of the rebellion.:

Riel would not allow reinforcments 10 come from liatuche during the battle, but towards evening Gabriel Dumont's brother Edouard refused to remain any longer in the village and came to the support of his bother with eighty mounted nen. By this time, however, the figliting was practically over. Dumont, with his handful of men, had successfully withstood Middleton's overwhelningly superior force, and when in the evening he retired to Batoche, he carried away his dearl and wounded.

${ }^{6}$ Chapter XXIX. 


\section{CHAPTER XIIV}

\section{THE BATTLE OF CUT KNIFE CREEK}

\section{Mrdpleton's Comment on Otrer's Rlcondussince-Poundmaker's Atritude-Ihis Visit to Bittiefoled-Otrer's Sortie-B.ittee of

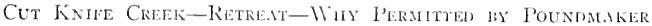 -Casumites--Conllicting Oprions Regarding Otter's Conduct.}

While Middleton's column was recuperating after the Battle of Fish Creek, the Gencral received the news of an encounter between LieutenantColonel Otter and Poundmaker about thirty-eight miles west of Pattleford. "The movement which led to the engagenent," says Middleton, "was made withont my orders, thongh Licutenant-Colonel Gter had the approval of Lientenant-Governor Dewdney,' to whom, howerer, he should not have applied on such a purely military matter." The foregoing written criticism is currently believed to be considerably milker than were the General's verbal comments on this unlucky affair.

Let us first consider the erents leading up to it. It was lnown that the rebels had been for some time endeavouring to induce Poundmaker and his Crees to cooperate with them. Their rejreentatives were in his camp, and evidently cance determined to bring him into sympathy with the movement. They were attended by the Stonies, whom they brought over to Poundmaker's camp, where the Stonies pitched a "soleliers' tent." Poundmaker's influence, strch as it was, seems alway's to have been expereised in the interests of peace and humanity, but he was apparently now thwarted. He was, indeed, a prisoner in his own camp, and attempted three times to escape from it and was brought back. Poundmaker might well have been in fear of his life. In order to commit the Indians, the Halfbreeds

1 The Correspondence that passed hetween Colonel Otter and the Lientenant-Gov. ernor, in this connection, consistel of the following telegrams:

(1) Otter to Dewdiney, dated Battleford, April 26: "Propose taking part of my force at once to finish Poundmaker. leaving one hundred men to garrison Battleford. Great depredations committed. Immediate decisive action necessary. Do you approve?"

(2) Dewdicy to Otter, dited April 26: "Think you camot act too cnergetically" or Indians will collect in large numbers. Herchmer knows country to Poundunater's reserve. Sand hills most dangerous ground to march through. Be sure to secure good, reliable sconts."

(3) Otter to Dewdney, reccived April 30. "Have sent sconts to find Poundmaker's whereahouts. All reads then to nowe" 

seem to have absented themselves at the last: but were represented by Chicucin. There was only one of Ponnduaker's men at the meeting, the rest being Stonies. An incriminating letter was dictated by the Conncil.

It is to be remembered that an Indian chici, however influential, is not like the commander of a disciplined force. The influence he has is just such as his character and oratorical ability may give him, and enables him to lead men only where their inclinations jump. He has no court of justice or means of punishment.

Shortly afterwards Poundmaker went to Iattleford. The Indians were armed, but there was, of course, nothing unusual in this, and there is nothing to show that Poumdmaker organized a body to come with him. Apparently he went to ask for tea and tobacco, and found ont what had happened at Duck Lake. At Battlefori, however, they found the south part of the village deserted, and in all directions there were goods and all manner of thing to arouse the cupidity of the natives. What was to be expected then happened, and the houses were looted, thoughl, as has already been stated, there is nothing to prove that this violence was pre-considered. Indeed, at Poundmaker's trial, one of the witnesses declared that Poundmaker did what he could to prevent ham being done. Whether Poundmaker himself came into possession of any of the stolen goods or not, it is impossible to say, as the evidence at the trial was conflicting. The next morning the Indians disappeared, returning to their reserve at Cut Knife. The Stonics came in, and the Halfbreeds with them, and thenceforth Poundmaker was helpless, whatever his wishes may have betn.

When Poundmaker's party went to Battleford, Ponndmaker asked Peter Ballantyne where the agent was who wished to interview him. That official, however, had crossed the river to the north side from fear of the Halfbreeds from Duck Lake. Poundmaker said he was very sorry that the agent had withdrawn, as it would place him (Ponndmaker) in a very bad light. The lattleford people had withdrawn to the barracks, which. with the police, they had fortified: ${ }^{2}$

Colonel Otter mistrusted Poundmaker's intentions, belicving that he was merely waiting to make a junction with Big Bear's band. Consequently, althongh the unfortunate chief had, doubtless with the utmost difficulty, succeeded in corralling his unruly followers upon their reservation nearly forty miles from where they conld do any further harm, Colonel Otter marched forth against him on the night of May ist with about three hundred and twenty-five men, two seven-potuders and a Gatling gun. In his official report he describes this movement as an armed reconnaissance.

2 The foregoing statement of Poundmaker's attitude is based upon and amply corroborated by the evidence given at his stlisequent trial in Regina. 

His force was conveyed in a train of forty-eight wagons. After a six hours' march, Otter h-lted for the moen to rise, then pressed forward again, reaching the Indlan encam monent about daybreak. It was necessary to ford Cut Knife Creck, which was deep and mudly enough to make the manouvre awkward. The advancel guard had crossed and were approaching Poundmaker's camp when they were sighted. The Indian, who apparently first saw them, galloped allont the camp in a circle and this signal was immediately followed by the alpiearance of some thirty braves. Orders had been given that the troops were not to fire unless hred upon, but in his evidence at I'oundmaker's trial, Scout Charles Ross, of the Mounted Police, was unable to say which site really conmenced the engagement However, someone shonted, "Yes, the Indians have started. We have the privilege to shoot," and presently the firing was general and continued."

The main body of troops was still at the ford when the police scotts galloped back with the cry. "The Nichics are on us." The troops dashed up Cut Knife Hitl, as also did the Indians on the other side, but the Monnted Police won the race for this position. The Indians then moved down ont of sight into the numerous gullies to the right and left of the hill. Otter's forces were thats so placed at to be olifiged to fight in the open against an invisible enemy raking loth tlinks. Some of the Gorernment force rushed forward to storm the enemy's camp, which had been left alnost defenceless. One of Poundmaker's licutenants, Piacutch, later admitted that if Otter's forces had followed up this movement instead of remaining cooped up) on the hill, the camp, would have been captured, and the Indians would have been compelled, if they desired to defend it, to come out into the open. "If the police had stayed on their horses," said P'iacutch, "they could

${ }^{3}$ The following pasatge is frorrowed from the diary of one of the volunteers:

"In the early dawn we reach Pomdmaker" Rescruation. Here there are a few houses but no one is vicille and we hurry on. Alout half-past four we come to a wile open plain and find that here there ha- cvilently heen a very large camp. The marks of numerous tepees and fires can le planly wen and it is evilent that the camp has been but lately vacated. Il e halt at this comp for sme time while the sconts sentch some clumps of hush that are nearly. In front of the camp and quite cloce to it is a large creek and rising from it, an the iat sicke, are high hills intersected with numerous ravines. After a short delay the seouts return and by this time it is quite light. WVe can see far away on the distant hill- at herd of cattle grazing and one or two monted men riding ahout. Here evidently are our friends. As they are at least two miles away. it is decided to cross the creck, climb the hill, have breakfatst and rest the horses before pushing on.

"The stream proses to le rather hard to crose. After crossing it we have some five hundred yards of serubls, marshy lands to go through and then we begin to climb the hill. The seouts are quietly riding near the guns. The men have dismounted and are walking by two and three along the trail, when sudchlyly, just as the sconts reach the top of the firt steep ascent. I hear a ratte of ribes ahead and then, in a minute or two, see the police ant some artillery lving desw firme liriskly over the erest of the hill and the guns and gatlings alw workmy for all they are worth. At the same time bullets begin to fly around $u$ - and puffen smoke floating from the bushes on right and left show wh whe they come from. Evidently we are in a trap." 

have got through to the camp, for the Indians could only bave fired one shot as they passed." ${ }_{4}$

However, by a most unfortunate blunder, the advanced guard was recalled, and the policc retreated to the hill, driving the enemy out of the valley to the rear, which the attacking party had just crossed.

For five hours or more the police and volunteers lay in skirmishing order among the hills in the blazing sum, exposed to a hail of bullets from every side, and rarely seeing an enemy. The guns had been promptly brought into action, but were practically useless. "The Gatling," says Howard A. Kennedy, who participated in this battle, "sprayed the prairie with a vast quantity of lead, with a noice that gave the Indians a bit of a scare at first; but they soon got used to that. A gatling may be all very well when your enemy stands in front of it in a crowd, but that is not the Indians' way. They had a wholesone respect for the seven-pounders, which was more than the gumners had, for the wooden trails were rotten and gave way under the recoil, so that one of the guns fell to the ground after every shot and the other had to be tied to the carriage with a rope."

Though Otter's force had planned to take the Indians by surprise, it itself was so surprised by the suddenness of the onset that, again to quote Kemedy's narrative, "Searcely a man had a biscuit in his poeket or" a drop of water in his can when he sprang from his wayon and flung hinself down in the firing line. Exhansted by the all-night ride and the bunger and thirst and heat of the day, many a man went to sleep under fire, while a comrade kept up the figlit-to take a nap in his turn later on. It was weary as well as bloody work. But at last, after liaving charged the Indians out of the flanking conlees and the valley in our rear, we took advantage of the lull to saddle up and go back the way we had come. The Indians, when driven ont of the conlees, had fallen back, disconraged by the white man's bravery, and prepared to defend their camp, which in fact our men were eager to attack. Great was their surprise and joy when they found we were actually in full retreat, and they poured down the hillside after us like a swarm of angry ants before half of us had crossed the creek. Now, however, they were in the open, and a well-planted shell from our rope-swarthed seven-pounder-its companion has been put to bed in a wagon-with the cool musketry of our rear guard, held the pursuers in clieck till the last of our wagons had struggled throngl the creek."

There was plenty of mismanagement in conncetion with this disastrous engagement, but the coolness and courage of the entrapped police and volunteers merits all praise. I detachment of the Queen's Own Rifles were the last to cross the stream, and their method of doing so shows that at all events their retreat was far from being a rout. The banks were

* Howard A. Kennerly Nea Canuda and the lia Canadians, page 168. 

very muddy, and across the creek lay a fallen tree. Rather than wade through the miry stream the volunteers coolly retired over this natural bridge.

Nevertheless, the Indians might easily have turned the defeat into a terrible disaster if they had pursued the retreating forces, and canght them in the woods. "This the young men wanted to do," says Piacntch, "but Poundmaker held them back out of pity." Another Indian in formant, in describing this incident, declared that Poundmaker brandished his whip and threatened to flog any Indian who dared go after the white men. "If you shed any more blood, the Great Spirit will punish us for it," cried the victorious savage. ${ }^{5}$

Otter's slain were as follows: Corporal Sleigh, of the N. W. M. P.; Corporal Lowry, of the N. W. M. P.; Trumpeter Bourke, of the N. IV. M. P.; Bugler Foulkes, of C Company, Infantry School Corps; Private Rogers, of the Ottawa Sharphooters; Private Osgood, ${ }^{6}$ of the Ottawa Sharpshooters; Private Dobbs, Pattleford Rifles; Teamster Charles Winder.

In addition to these the wounded numbered fourteen.

Father Morice states on the authority of A. H. Byoness, O. M. I., a missionary among these Indians, that only five of Poundmaker's braves were killed during this action.

In the retreat the wounded suffered dreadfully in the jolting wagons, and the men chafed bitterly under their sense of defeat as they rode into Battleford at in o'clock that night. In the preceding thirty hours they had ridden about eighty miles and fonght a six-hour fight.

After this engagement, Poundmaker could not longer resist the war spirit of his elated braves, and his tribe was henceforth definitely to be reckoned among the number of rebels.

Various writers have attempted to justify Otter's attack on Poundmaker, among them Major Boulton: ${ }^{7}$

"While Colonel Otter apparently acted upon his own responsibility in making this attack upon Poundmaker, the circumstances by which he was surrounded must be taken into consideration. On his arrival at Battleford he found that several murders had been committed, settlers' property had been destroyed, and their owners were olniged to flee to Battleford for safety. A portion of Battleford itself was also lnirned and pillaged. These doings, no doubt, led him to attempt to inflict some punishment upon Poundmaker's Indians. Noreover, an amalganation betwcen Big Lear's band (which had so recently captured Fort Pitt) and Poundmaker was to be feared, and Colonel Otter decmed it advisable for the safety of the country

5 Missions des O. Xl. I. Vol. XXxum, page 336.

- The body of Private Osgood his companions were umable to carry away. It was burned by Father Cochin, a prisoner in Poundmaker's camp.

7 Page 318. 

to inflict a blow on Poundmaker before this junction was effected. The reports that Big licar's rumners bruught hack to their chicf about the fighting that had taken place, and the luss the lndians had suffered at cut hine, no doubt, led Jig licar and his tribe to feel that they were sater in the neighbourhood of liort l'itt, and no junction was afterwards attempted. On the whole, then, it must be said that this attack was well timed and pluckily executed."

Treating of the same incident, Alexander Pegg, in his history of the North IVest (Vol. 3, page 216), expresses the following views:

"The only advantage gained $\mathrm{ly}$ this leconnaissance was that the Indians were forced to declare themselves, and as they proved to be on the side of war, the military authorities knew what to expect of them, and were less liable to be surprised $\mathrm{h}$ an attack. Poundmaker previons to the Cut Knife fight, though he had abstained from attacling liattleford and there was some doubt about his ultimate intentions, had committed several depredations on settlers in the neighbourhool. Ilis Indians luad killed liernard Tremont, a stock raiser: James Payne, farm instructor on the Stoncy reserve, and Mlr. Smart, a trader, liesides pillaging and destroying property and stealing cattle. Colunel Otter was justified, thereiore, in making the attack which lie did, but after the Cut Knife affair he remained on the defensive at Pattleford, mutil juined by General Miclilleton on May twentyfifth. There is no dould that the Indians lost heavily, and this must have had the effect of deterring them from further hostilities."

The comments of Wilhur F. Bryant, in his "The Blood of Abel" secm to me much fairer and more reasomable than these examples of special pleading. Says he:

"The assault on Cut Linife 1 lill does not reflect especial glory on the attacking forces. The gallantry of the Alounted l'olice and l'oundmaker's magnanimity at the close of the action are its distingnishing features. In all. the fighting lasted seven hours, the homours remaining with the Indians, whose cover gave them an overwhelming advantage over their foes. Poundmalier. who had only 250 poorly armed warriors, showed his generalship in the skilful disposition of his men, and that he succeded in saving his wigwans from destruction against so superior a body must be placed to his credit. After the last shot had been fired, and Colonel ()tter had given the signal to retire, Poumdmaker made no attempt to follow up his victory. His braves rested on their ritles, and througl the thick screen of bushes watched the soldiers fall back across the creek. I lad any spirit of revenge actuated the old clicf, there is little doubt but that his warriors might have cut the flying column to pieces, and the inglorious retreat would have been turned to a terrible disaster."

One more opinion may be quoted. This is that of Captain G. Mercer Adam :

"From a military point of view it was doubtless necessary to overawe Poundmaker lyy a display of our strength on the field, and, if possible, to hem in the insurrection. 
"Moreover, there were scores to he setted with his hand for their plundering and intimidation in the resiem, for the murler of Payne and Applegarth, the local farm intructors, and for the hooting of at least two of the setters. There wats also the need of keeping Foundmaker from joining Ricl and his l balihreets, and of giving aid to lige licat and his bands in the west. But whatever justilication there was for sallying out with an armed fore against the Indians, we could have wished that Colonel otter had met lomblmaker anymlere hut on his own reserves and surrounded by the teepees of his women and clibleren."

It is a fact worthy of mention that Cut Snife Creek and Hill were so named becaure at the same place, many years before, Poundmaker and his Crees had repulsed the attack of Cut linife, a great Sarcee warrior.

8 Page 318 , The lowth-Hest, 1855 



\section{CHAPTER XXV}

\section{TIIE CAPTURE OF BATOCHE}

Mudeletoy's Amince to Denont's Crossing-The Northcote Arrues

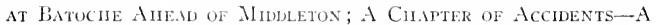
Ciieck-Allegej Profosal of Retreati-Melgund Sext EastSecond D.h's Figiting-First Feignen Attack from the East

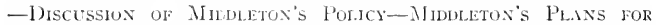
Fourtil Day-Astley's Heroish-Mischirilge of Origin,le Plans-Tie Final Cilarge- Ilenty's Dispatchl-Tife Globe's

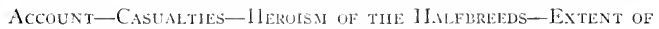
THEIR LOSSES-C.MPUTE UF RIRL-EsCAPE OF DUMONT.

The next event of special importance in the campaign was Middleton's advance upon and capture of Batoche. On May 7 th he set out from Fish Creek with his entire force now upon the right bank, numbering seven hundred and twenty-four officers and men. To these were added, two or three days later, the Land Surveyors' Scouts, some fifty in number, led by Captaili Dennis.

The steamer Northcote was also to take part in the attack upon the rebel healcuarters. Upon it were about fifty combatants under the command of Major Smitl.

On the first day the force allanced as far as Gabricl Dumont's Crossing, where it camped for the night. The next day's journey bronght Middleton's force within abott nine miles of Batoche, and on May gth the siege began. About six a. m. Middleton moved out from camp, leaving it standing with a small guard to aesist the teamsters in case of an attack. According to Midlleton's own report, the Northote was to have moved down the river at such a time as to reach Batoche at nine oclock, when he would also be on hand, and the village would he attacked both from the river and from the land. Apparently there was snme misunderstanding, however. Lientenant-Colonel Houghton, Midlleton's chief of staff, subsequently declared ${ }^{1}$ that the steamer was uncler orders to be at Batoche at 8 a. m., and that its failure to connect with Mirdlleton at the crucial time was owing to the fact that the general was onc hour late in arriving. Who-

1.Montral Gazette, Controversy of February and March, I894, page 2. 
soever was the fault, the steamer actually disl approach Batoche one hour in advance of the land force, and a very hot welcome she received. Sceing no sign of support from the land, she swept with the current slowly past the settlement, exchanging with the relsels a vigorous fire. At latoche's Ferry there is a stecl calle crossing the river. Their attempts to sever this as they moved down stream iailed, and the cable carried away the smokcstack of the steamer, and for a few moments the accident threatened to be even more serious. Had the unlucky steamer been stranded at this point in the river, the results might well have been deplorable. The enemy's fire was kept up for nearly two miles, lut only three of the men on the Northcote were wounded. She then came to a stand, but found it impossible to steam back against the current with the two heavily loaded barges in tow. Accordingly it was reluctantly resolved ly those in command to go on down the river to the Hudson's Pay Ferry, repair damages, leave the barges there, take in more firc wood, and return at once to latoche. Before reaching lier intended destination, however, the unlucky ressel ran upon a sand bank, where she lay stranled for several hours. On reaching the ferry Major Smilh found there the steamer Harquis with a party of Mounted Police. Though it takes us ahead of our story, it may be stated here that the two steamers were not ready to start back until the 12th, and then, as the engines of the Marquis broke down, she had to be towed by the Northcote, so that the two did not reach Batoche until after its capture. Middleton's official comments on this chapter of accidents were very generons: "Though the Northcote was unfortunately prevented from taking part in our attack on Batoche, I have little doubt that the probalsility of her returuing with reinforcenents tended to disturb the cnemy, and Major Smith and his party deserve great credit for the way in which they met the difficulties with which they were beset."

Now let us return to the column. As it approached the river, Middleton heard, to his intense exasperation, a rattling fire and the steamer's whistle. showing that the Northcote was already engaged and that his plans for a . combined attack were frustrated. The elated rebels, upon this first clay, brought Middleton to a stand near the church, a short distance above Batoche. Indeed, the check was so serious that it was confidently affirmed by Colonel Honghton and many others, though denied by Middleton himself, that in the afternoon the General contemplated retreating to the camping ground of the night befure, and was prevented from doing so only by Dr. Orton's absolute refusal to allow the wounded men to be transferred. It is almost impossible to arrive at the facts concerning this and many other incidents of the rubllion, as litter disaffection was rampant among the officers in comnand, largely the product of the mutual jealousy that so universally prevails between professional solkiers and militia men. Had such 

a retreat occurred, its moral effect on both the voluntcers and the rebels would have been very serious indeed.

Towards evening the troops were gradually withdrawn to the four sides of the zareba which Middleton had established on one of the very tew open spaces adljacent to the village and above it. The enemy followed them up for a time, and even when elecked by heavy fire from the zareba they maintained a desultory, long range fire until nigltf fall. No tents were pitched except for the wounled, and, after a hasty supper, the men lay down in a drizzling rain with their weapons beside them. Niddleton's casualties had been two killed and ten womded, including Captain Mason, of the Tenth Grenadiers.

An interesting and suggestive episode of this first day was the departure of Lord Afelgumd. Whatever may have been his motive, Middleton's explanation was that he had determined to send Lord Nelgund with an inportant despatch to the Minister of Militia. The contents of this despateh have never been made pullic, though it still remains in cipher at Ottawa. It will doubless provide interesting reading. Lord Mlelgund reacherl Humboldt (fifty-five miles southeast of Batoche) at four o'clock next morning. From there he sent Middleton's telegrant, and, in the interview with Lientenant-Colonel George T. Denison, he toll of the abortive attempt to drive the enemy out of their position. Colonel Denison says that while Lord Melgund, of course, revealcd nothing of why he was being sent back East, the general impression wat that it was to get us some regulars from Halifax. ${ }^{2}$

The next morning Niddleton's forces were under arms at dawn, and an attempt was made to take up the position from which they had retireal the preceding evening. This proved unsuccessful, as the rebels in high force beld the gronuds about the cemetery and in front of the clunth. The infantry were stationed in as atvanced a position as was possible, and engaged the enemy throughout most of the day. During the afternoon trenches and isolated pits were constructerl, from which in the evening an unexpected flank fire drove back the relels as they attempted to follow up the advanced parties, when, under Nidilleton's orders, they fell back to the camp for the night. His losses during the day were one killed and five wounded.

On the third day of the siege, Niddleton led a mounted reconnaisance. or feigned attack, north from the camp, past the Humboldt trail, which runs west from batoche to a small open plain to the east of the village. This is the only piece of level comtry of any extent clevoid of woods in the vicinity, and is known locally as La Belle Prairic. This region proved to be well protected, but the movement withdrew the rebels from the main

${ }^{2}$ Soldicring in Canada, p. 287, by Lieutenant-Colonef George T. Denison. 

front, and Crlonel Williams succeded in carrying the Indians' position below the cemetery.

Bitter dissatisfaction was prevalent in the evening. when the adranced parties were again recalled to the camp. It was felt that Middleton's policy unnecessarily involved the mightly sacrifices of whatever had been gained during the clay. The rank and file, an well as nust of the Canadian officers, were becoming distinctly restive, and were eager to close with the enemy and bring the siege to an end $1 \%$ a single decisive action. There are not wanting men whose opinion deserves respect, who think that the General

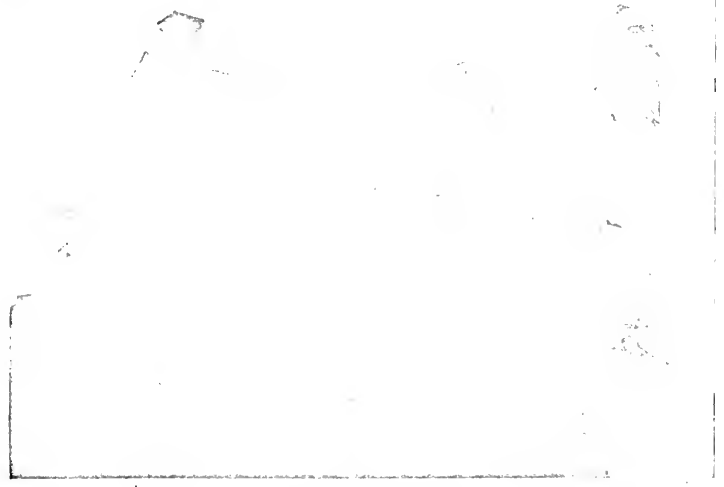

BATOCHL \& IIUESE,

Captain French, who was shot when at the central upper winlow giving the signal to cease firing, when batoche was captured.

showed discretion in not risking everything in a premature attempt to capture the village by a vigorous general assiult. The country in which the fighting took place was admirably adapted to the purposes of defense. The numerous wooded ravines were lined with rifle pits, and to carry them the attacking party would need greatly to ontnumber the enemy or to exhibit the most tenacious conrage and steatliness under the withering fire of an invisible foe. Niddleton was still under the impression that the rebel forces were much more numerous than they really were, and he was manifestly doubtful of the fighting qualities of his inexperieneed militia men, 

at all events if they were called upon too soon to carry ont so difficult and dangerous an assault. His sentiments are indicated in his despatel of May I to General Strange, in which he remarked, "These raw soldiers require whipping tp at first." Furthermore, as Middleton has pointed out, he recognized that his forces conld afford the considerable expenditure of ammmition which such tactics rentered necessary much better than his adversary. However, by May I I, "our men," says Middleton, "were beginning to show more dash, and that night I came to the conclusion it was time to make a decisive attack." "Our casualties for the day," he reported, "consisted of four wounded, all very slightly. This shows that my men are becoming more at home at this sort of warfare." lt was his intention personally to conduct a feigned attack on the settlement from across La Belle Prairic. As soon as the firing was general in this quarter and the enemy had becn withdrawn from their main position to resist the attack from the cast, Van Straubenzic was to seize the position formerly held l,y the Canalian troops and to push on cattiously. The General with his immediate staft wonld then gallop lack and take command of the main attack, which would now be in progress.

Accordingly; on the morning of the fourth and final day of the siege, May 12, operations conmenced with a vigorous firing across La Belle Prairie. During this engagement letters were sent over from the rebel lines by Riel, borne hy two loyalist prisoners, Mr. Astley and Mr. Jackson. Astley's letter ran as follows:

"Batoclie, May 12, $188_{5}$.

"If you massacre our families we are going to massacre the lndian agent and other prisoners.

Lours "DAVID' RiEL."

To this communication General Niddleton wrote the following reply: "Mr. Riel:

"I am anxious to avoid killing women and children, and have done my best to avoid doing so. Put your women and clildren in one place and let me know where it is and no shot shall be fired on them. I trust to your honor not to put men with them.

Fred Middeton, "Commanding N. IV. Ficld Forces."

Astley returned with this missive to Riel, and some time afterwards was sent back with the following acknowledgment:

"Gencral:

"Batoche, May 12, 1885.

"Your prompt answer to my note. shows that I was right in mentioning to you the cause of humanty. Ne will gather our families in one place, and as soon as it is done we will let you know:

"I have the honor to be, General.

"Your humble servant,

“Louis 'DAvid' Riel." 

The desperation to which the relel chief was now rednced was painfully indicated in a postseript written on the outside of this despatch:

"I do not like war, and if you do not retreat and refuse an interview the question remains the same as regards the prisoners."

To this communication Middleton sent no further reply, as indeed, by the time he received it, it womlil have leen stuite impossible for him to have induced the volunteers to withdraw from their attack. However, Astley, with memorable heroism, returned again to the rebel lines with a view to protecting the prisoncrs, and inducing Ricl to surrender withont further umnecessary bloodshed. In passing to and fro between the lines, Astley happily escaped uninjured, though his clothes were rent with lutllets.

We left Middleton conducting a feigned attack from the east. When he judged that the time lad come for the decisise assault, he galloped back to his main body, which he expected to find already engaging the enemy. Owing to the high wind prevailing from the west, however, Stranbenzie had not heard any certain sound of the prelininary attack east of the village; consequently, to Middleton's inexpressible exasperation, he found the troops still in camp. While the General was getting something to eat, Strambenzic moved forwatel towarls the cemetery on the left, with orders to assume the old position and push on cautionsly. To the right of Straubenzic's two companies of Mirllanlers, led by Colonel Williams, were the Tenth Grenadiers, led by Lientenant-Colonel Grasett, extemling heyond the church. Who gave the command to charge, or whether any such command were ever given, is still a matter of dispute. The men were in a mood in which restraint was no longer to be thought of. 'The shonting of IVilliams' Midlanders as they came under fire was the signal for a spontaneous advance of the whole line. "Halt when I halt anel not before," cried Williams, and his men followed nobly. The advance towards the line of occupation of the previous Saturday was a race between the Midlanders and Grenadiers. As Middleton hurried ont from his tent he "fonnd the whole line, which had been splendidly led by Lientenant-Colunel Van Stranbenzie, in the wood facing the village, the line heing perpenticulat to the river; the Midlanders on the left, the Grenaticts in the entre. and the Ninetieth on the right in colnmms commanded by Cajutin Buchan; Major Makeand having sprained his leg early in the day and Major Boswell being left in the zareba with the guard. The guns were now up and cominenced firing from their old position on the village and on the ferry by which some of the enemy were escaping. The Nineticth were now quickly extended on the right of the Grenaliers, the extreme right being taken by the sconts dismounted." It was at this juncture that Astley brought Riel's second message asking Middleton to withlraw his men.

Honghton and others subsernently stated that in this tecisive assault 
the Canadian officers charged the pits on their own responsibility. "Itad they been unsuccessul," says Houghton, "they would have been tried by courtmartial and shot, but being in close totch with their men, and knowing their metal, they drove the relels from cover and broke the back of the rebellion."

The only authentic description of the fight by an independent eye witness was that cabled to the London Standard by G. A. Henty, Jr., the wellknown war corresponkent and author. Ifter speaking of the armed reconnaisance of the morning he tells of Mjddleton's return w camp and of the general advance which took place at one o'clock, Contiming. Mr. IIenty wrote as follows:

"Withont a moment's lesitation ther dashed into the bush, and with a rush carried the rille pits from which the cnemy lad harassed us on Saturday; and then swept the enemy before them down a short valley dotted with bush, into the plain, which extends hali a mite hack from the river banks.

"On one side of the plain the encmy had dug a long line of rifle pits, from which they opencel fire as we advanced frem the village of Tatoche, which stands in the centre of the plain. The ground to be crossed was open, and for the most part under cultivation, thougl, here and there were patcles of lirushwood.

"As the Grenadiers had cleared the valley, the other corps had come up, and the Grenadiers and Ponlon's Ilorse advanced together with the intelligence Corps on their tlank.

"The scene was a pretty one at the troops advanced, the puffs of smoke darting out from the houses of the villages, and fringing the bush-covered hills on our flank from the rifle pits at their feet. On our part there was no attempt at advancing in accordance with any military system. The troops moved forward in an irregular row, firing as they went, at the village in front.

"The enemy were few in number, hut fought well and steadily, keeping under cover of the houses, and seldom showing a head. The troops advanced briskly until near the village, when they hesitated a little, and the officers had to expose themselves a good deal to get them forward; the result was that three officers were killed, Captains lirench and lirown, and Lientenant Fitch, while only two privates fell slain in the whole day"s fighting. This speaks for jtself, and slows also the steadiness and accuracy of the aim of the enemy. We had in all eleven wounded.

"After a short pause, the troops went at the village with a rush, and the rebels fled instantly from the other side. So quichly was the affair over that Riel's men had no time to carry off their prisoners with then, and they were all found minjured.

"Several of the enemy were killed as the Grenadiers rushed the rifle pits, and some more were shot as we cleared the valley. but the total number engaged was small. and there can be no doubt that many of those who fouglit against us on Saturday must have retired before the fighting began."

A. S. O. E.'s dispatch to the Toronto Globe also provides a very spirited 


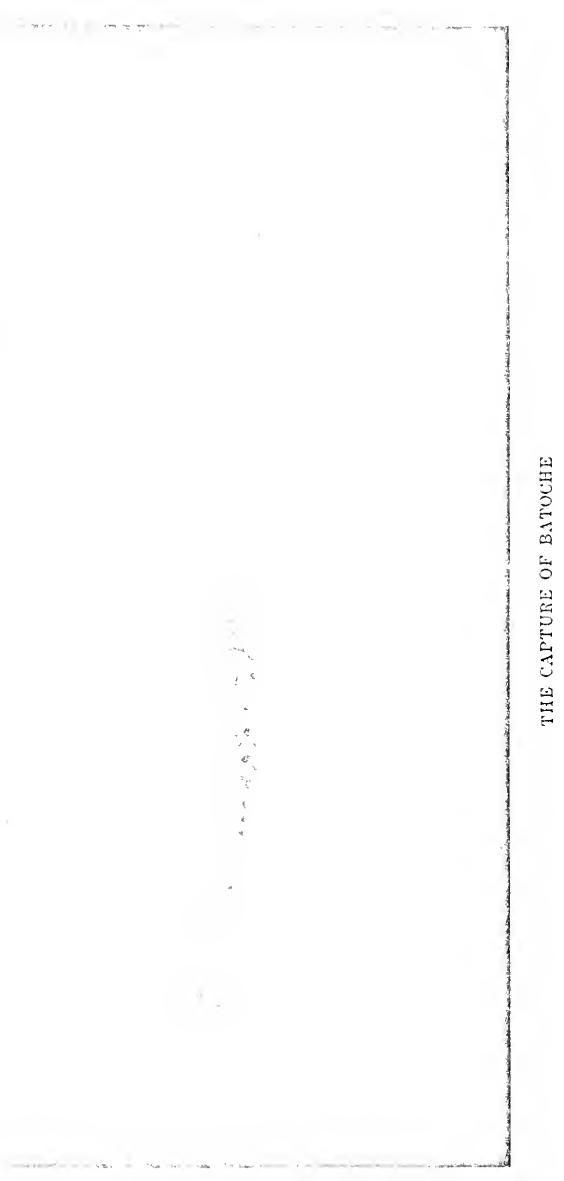



-even if somewhat grandiloquent-account of the battle, and from it the following extracts are borrowed:

"Every man's blood was up and heated with excitement. Nothing could have drawn off the men from their one purpose in view. Another minute and a telling volley was poured by the Midlanders down the slope into the enemy's pits, and then with a 'three times three' rolled into one, they disappeared over the hank and fairly valted over the pits and prodded and bayonetted the enemy out.

"It was a grancl and noble action, and ever thereafter they should he called 'The Irresistibles.' The cheering was contagious, and those behind, looking on from the trenches, canght it $11 \mathrm{p}$, and cheered again and again in loyal style, and as only Iritons can cheer. The Grenadiers, not a moment behind, answered the command of their colonel, and on they went in short rushes, covering the ground as if the very devil was behind them. Without cover, they chose close quarters for their safety. if they thonght at all of their safety, and every rifle seemed levelled at them as they covered the grotud and pushed on past the last of our trenches.

"The whole line took up the charge, and many a teamster jumped from the zareba, and, overtaking the main body, beame thenceforward one of the men. The excitement was intense. The Grenadiers, peppered at in their onward conrse, kept on all the while, answering back the relsels' fire, giving it to them in rapid style, and nearing their pits every monent. It was plain to be seen that the advane was a general one from the extreme right to the left, and the goth, in the zarcha-'the little devils, as they are now called-were formed up ready to do their part on the right, and impatiently they waited. Still the Midlanders kept on, three men falling within as many minutes, their voices hardly missed in the wild cheering of those escaping as they dashed ahead on towards liatoche, still a mile or so distant. Away to the front rushed Colonel Straubenzie, hat in hand and waving it and cheering on the men.

"Just then the horses galloped up with the guns, the entire artillery being under the conmand of Colonel Montizambart, and the remainder of the goth joined the advance on the right. The Wimnipeg guns opened on the rebel houses: Howard crashed away at the bluffs covering the advance of the goth and the remaining guns showered shrapncl into the scraggy and small-growth timber.

"Away to the left the rebels seemed more concerued with the advance of the Midlanders, who were fast gaining on the cemetery, and they made a firm and bitter stand, but all to no purpose; yet it was terrilly hot for the men, and it was a great relief when the right of the Grenadiers gained the upper edge of the slope, and, pelting away at the rebels in their pits, eased things off for the Midlanders, and made it a little more comfortable. This was a great advantage gained, and the Midlanters, with another cheer and a rush, cleared the pits from which the fire had cone so heavily.

"In the meantime the Surverors" Corps had joined the charge, and Boulton's infantry came on, both being cheered to the ccho when they were seen to enter and join the fight. They at once began to force the fighting away to the extreme right in a terrible fashion. Perhaps of all points along the line theirs was the hottest : the reliel pits fronted them as from two sides of a triangle. The Nidlanders, with the assistance of the Grenadiers, had 

got too far ahead. They had cleared everything before them and the Grenadiers' attention was turned once more to their own immediate front. On they went under the disadvantage of getting the fire nore or less from both the right and the left of the enemy's line. litut their advance was as certain and as sure as the wave upon the wave-beaten shore. Too busy to tell who it was who fell, on they went except perhaps now and then one would cry ont: 'Ambulance! Ambulance!'

"Things were by this time beginning fo get mixed, and a black coat would be seen mingling with the red, and a red coat with the black. The Midlanders were catching it from across the river, and remaining still; answering back the rebels' fire was tame work for them. The fire of the eneny came also hot and fast from the small ravine on further than the cemetery. Things were getting to be considerably unpleasant. "I want a company to reinforce me,' said gallant Colonel Willians, 'and I'll clean ont that ravine.' 'I'm here, and here's my company,' shouted lack Ruttan of the goth-an old Cobonrg boy-and on the Midlanders went, followed by Ruttan, down into the ravine, the rebels jumping from their pits and scurrying back as they saw the onslaught that was on them, (On, up, out of the ravine, and onwards, when Lientenant Ialliwell was hit just as he had told Laidlaw and Grace to keep their divisions firing so as to lessen the fre of the enemy. The left, led by the Midlanlers, was fast sweeping round. With each tresh rush the men would cheer.

"Firing was gradually ceasing, fortelling the final dash soon to come. The rebels secmed to see this, and as the line came on, would scamper back from pit to pit, firing as best they could. The goth, behind the bush to the right of the Grenadiers, darted through the bush and down the slope, on across the hollow and up the other side to the bluff, from whence the enemy kept pouring forth their jagged lullets. In the impetuous rush Major Makeand slipped and foll, and the belief that he was shot incensed his men still more, and on they went for satisfaction. In the meantime, the line had reached the rise, on which, until now, the Gatling had been playing, and it was ordered to take up a position near the rear, from whence it kept up its kettledrum rattle on the bluffs, as now one corps and then another would force on the fighting.

"In less than half an hour the fight was decided, but the battle had to be won. The line came swinging round, and in a short time it was at right angles to the original line of attack. Just then a ferry started from the west side of the river to cross with the rebel reinforements, but a division of C Company under Laillaw sent them back, and here it was he was shot from the bank by rebels expecting to cover the crossing of the ferry.

"The houses then had to be taken, and taken at the double, and Colonel Williams sent back a message to the General that he was going to charge them. The message sotmded very much as if it were nolens rolens. Pefore Stewart returned, the Colonel was up and at it. His men reached the top of the slope, and then down the other side they rushed with the force of a buffalo. The Grenadiers joined in the dash, one of them in his course plunging his bayonet clean through an Indian and carrying him out of the pit with the velocity of his charge. The enemy still contested the ground, firing as they retired, and many a poor fellow bit the ground.

"The Red Cross men were now to he seen here and there and every- 



$$
1
$$

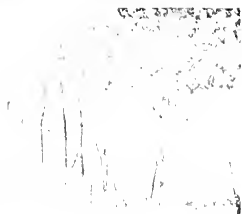

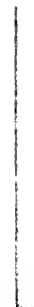

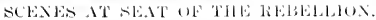

Batoche's store, in the cellar of which the hotalist prisomers were hullled. The eross (X) marlis luole mate by a shell during the siene

Humboldt Trail, enterine Batowhe. This lotil winls among ravines and "blufls", and was so lined with hiblen ribe pits as to be impasible. liebow the mark (\#) may be seen the face of a man standing in one of the trenches. 

where. Amid all the din, the noise and cheering, a poor fellow could be heard now and again calling for a stretcher. Doctor Ryerson's portly form could be scen well up in the front, and his sympathetic word brought a strange reaction to the wotnkled, whose desire for revenge was only intensified by being clean bowled out of the fight. Down came the goth, squeczing up against the Grenadiers and soon all became mixed. The Surveyors' Corps, too, from the right, came swinging round towards the bouses, and they, too, joined in the mixing. It mattered not, for there was but one command: 'Double! On!'

"Down across the open they went, the Midlanders on the left clearing the pits along the bank, and making the race a hot one. A stom of butlets crossed the open, but they came too late. Nothing could stop the force of the rush. The Grenadiers suffered here terribly, but the rusin went on the same. The rebels, from the houses to the front, poured a raking fire into the advancing line, and first one and then another kept dropping ere the ploughed ficld was reached. In front of the houses were long trenches running parallel to our line of attack. Jrom these also the firing came fast and furions. The plongled field was reached at last, and on past it the rush continued. The first house to come nupon was the litte shack on the bank. As a Misllanter pulled back the door, Captain Ruttan slipped in. Helterskelter went the inmates from the back portion of the house. The end had come. Our men knew it and felt it, and, flushed with victory, they pushed ahead and jumped upon the rebels in the very trenches before the houses. They had passed the log stable in front of the prison house, on past it with such a rush that a handful of rebels had escaped notice, and so it was Jicutenant Garden of the Surveyors Corps got his nasty arm wound. Over the heads of the rebels, who lay in the trenches, on into the prison house and with a deafening cheer the men pulled up the prisoners from the poisoned atmosphere of the lark and slimy cellar.

"The fight, though, still went on. Privale Eager, of the Grenadiers, coming out, was shot from the trenches, which our men rushed by to enter the store and release the prisoners. The charge continted on past the houses and on towards the rebel camp. In the meantime batoclie's house had been taken, poor French receiving lis death wound at the upper window of a room that he had just entered, closely followed by Private Skinner, of the Midlanders. There was nothing now left of the line. Every man dashed along and plunged ahead on a "sort of go-as-yon-please style," except that he went at fever heat. Nen from the extrense right got mixed up with men from the extreme left, and men took orders from the officers nearest them, regardless of what reginent he belonged to. On past the houses dashed portions of the regiments, determined to be in at the finish, and on up to Riel's Council House, where (alpain Young secured important papers. The Grenadiers, in the meanwhile, led by Grasett and the Midlanders, on the slope and water's edge, charged and carried the pits in front of the IIalfbrecl and Indian camp, and by the time the Northcotc came up the stream close on to the evening. to join the force once more, the last shot was fired, the rebels routecl, the fourth day's fight was over, and the Battle of Batoche was a thing of the past."

The names of the Government volunteers who lost their lives at Batoche are: Grenadier Willian Ihilips, of A Pattery: Lientenant W. Fitch; Pri- 
vate T. Noore, of the Tenth Grenadiers; Private R. R. Ilardisty, of the Ninetieth Ihattalion; Private James Fraser, of the Ninclieth Battalion; Captain E. L. Lrown, of the Scouts; Joln French, of the Scouts : Lieutenant A. W. Kippens, of the Intelligence Corp; ] Private F. A. Watson, of the Ninetieth Jattalion (died of wounds). In addition to these the Canadian wounded numbered forty-five.

Middleton sent back for blanket and food, and bivonacked in and about the houses of the village, having, however, sent the scouts back to strengthen the guard he had left all day in the zarela under lientenant-Colonel Hough-

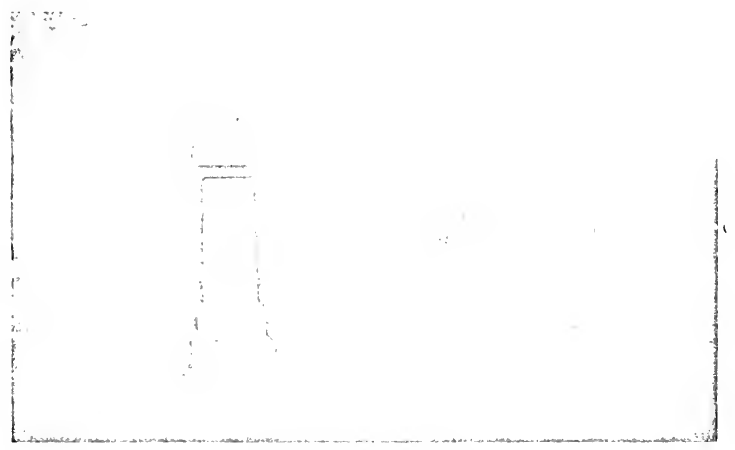

B.TTOCHE CLIETERI.

The monument in the left foresroumd bears the names of Riel and of all the Iritis

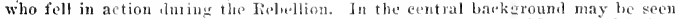
a eluster of crosses marking their graves, In the forewroun! is Mr. lonis Marion, a loyalist llaltbreed, who was detained a prisoner it batoche for refusing to take up arms against the govermment. The ilust of Gabriel Inmont rests in this same historic burying place.

ton, consisting of a party of the Ninetieth under Major Boswell, and a gun of A Battery.

As Canada recalls with pride the courage displayed at Batoche and elsewhere by her civilian soldiery, let her not withhold or grant in scanty measure the meed of amimation so well deserved by her misled chillien, the Ilalibreeds of the Saskatchewan Valley. Among them, doulthless, were rogues and schemers and poltroons, but such renegades were in no greater numerical proportion than in any ordinary community. Hopelessly outnumbered in every engagement, totally umprovided with artillery and pos- 
sessed of but a scanty supply of arms, and those largely of the crudest and most heterogeneous description, the Métis fought gallantly in defense of their rights, their homes and their leaders. Cruel necessity required that the uprising of this handful of misled and ignorant pioncers should be sternly repressed, but it would be an ill day for Saskatchewan if ever the vigor and valor which distinguished them should be extinguished in any body of its citizens, be they white men or Halflureeds. The man who can visit the humble graves of the fallen Jetis in the cemetery at Batouche and not feel for their memory the deepest respect is not worthy of the franclise of a citizen in our Dominion. Thanks to the skill witl which they conducted their nilitary enterprises, the actual loss of life among the Halfbreeds was remarkably small. During the four days of fighting at Batoche there were, in point of fact, only eleven of their number slain-in addition to a young chikl-despite the exaggerated reports that have obtained currency through the pages of various accounts of the rebellion. ${ }^{3}$

At the capture of Batoche on May 12 Dumont, Riel and most of the other leaders escaperl. Next day Middleton sent the following note to Riel by the hand of one of his friends, Noise Ottellette, who consented to carry it only on the condition that he should not be followerl:

"Mr. Riel: I am ready to receive you with your conncil and protect you until your case lias heen ilecided upon by the Dominion Government."

Riel stated that he received this communication towards one o'clock on the morning of the 15 th. He asserted afterwards that he might have escaped to the United States as did Dumont, but preferred to give himself up immediately in the interests of his Nétis followers.

Neantime numerous parties of mounted men were scouring the woods in search of the rebel learler. Two of these sconts, Armstrong and Hourie, fell in with him on the 15 th and brought him to Middleton's tent. Middleton then placed a guard over the fallen learler, as much to protect him from violence as to prevent his escape, ancl he was presently taken to Regina in the charge of Capt. C. H. Young. There he was placed in prison to await his trial.

Having become separated from Riel, Dumont searched for him until

${ }^{3}$ In view of the diserepancy between my figures and those found in numerous other accounts of the rebellion. I may state that I olitained my data from Reverend Father dloulin himself; from the original parich register in his possescion, showing the names of deceased parishinners and the dates of their cleatlis; and from the list of names on the monument in Batoche cemctery. crected July. inos, to the memory of the Xletis that had fallen in $1 R_{5}$. Pesides Ricl, those of the insurgents who gave their lives for this eause were the following: (At Duck Lake) Jean Baptiste, Joseph Montour. Isalinr Dumont and Lafranhoise: (at Fish Creck) Joscph Vernette, Francois Boyer, Xichacl Desjarlais ant Picrse Parenteau; (at Patnche) Joseph Ouclette. Joseph Vandal, Dontalel Ross. Isadore Poyer, Nichel Trottier. Andre Letendre (dit Patoche), Damase Carricre, Jolin Swain. I. Jobin, Calixte Tourond, and Elyear Tourond. The Batoche monument atso records the names of four Indians who fell in one or the other of these engagenents.

N. F. B. 


\section{.}


the 1 toth, when he heard of his surrender. With less than nine pounds of sea-biscuit as rations, Dumont then set out on his six-hundrer-mile ricle to safety beyond the border. He was accompanied by Nichel Dumas, matrmed and also provided with but a few biscuits. It is commonly stated that Dumont's escape was deliberately facilitated by the numerous adnirers of the plucky warrior, who were to be fomnd in all quarters and anong all classes. Dumont subsequently visited Montreal, 188y, where his story was carefully taken down, read to him and formally aplroved, in the presence of Colonel Adolphe ( Himet, Esq., and a number of other wellknown witnesses. ${ }^{+}$

The unfortmate people of Batoche had been reduced to deplorable want and nisery by recent events, and before his departure, Middleton sent two teams loarled with floor, bacon, tea, etc, to the Roman Catholic priesta at Batoche, to enable them in a measure to relieve the prevailing distress.

It may be remarked in pasing that on the morning of the 1 th Father Moulin had been bronght to Middleton's camp with a bullet wound in his left thigh. The General reports that the bullet was fired from the cemetery by the rebels, but a glance at the wall of Father Monlin's house is sufficient to show that he was the victim of a chance shot from the Gatling gun." As a matter of fact, a considerable area of the wall was honeycomber with bullets at the same time.

4Le Recit de Gahriel Jumont was incorporated in an Etude, by Ouinct, cntitled La l'érite sur la Quístion Mitisso.

s This inference is verified by I ather Motnlin's personal statement to me, i. e., that he was wounded by a bullet from the gatling gun.

N. I. B. 


\section{CHAPTER XXY'I}

\section{MIDDLETONS ADYANCE VIA PRIACE ALBERT TO B.ATTLE- FORD, AND TIIE SURRENDER OF POUNDIAKER}

Midileton Marches from B.tuche to Prince Al.bert-Previors Siege

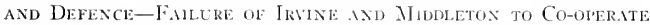
-Poundmaker Asks Terms of Peice-Mnneleton's ReplyPOUNuMiker's StrRENIER.

Middleton remained with his forces at Batoche until May 1 th. He and his troops then crossed the South Saskatchewan at Guard du Puis, marching toward Prince Albert, which they reached three days later.

That town had been practically in a state of siege for almost two months. Though no actual attack had been made upon it during the rebellion, its citizens sufterel much inconvenience and indeed not a little hardship and danger. Colonel Jrvine and his men were prectucled from an active share in the actual figlting subsequent to March 26 th, but neverthe less they served with honor. I'rince Albert was the key to the whole situation, and after the disaster at Duck Lake its security became a matter of supreme moment.

A large number of Sioux did move with the intention of making a raid on Prince Albert, and it is Colonel Irvine's telief that these rebel Indians only abandoned their intended raid when close to Prince Albert they came upon Irvine's trail leading to that place. The task of protecting Prince Albert itself was a difficult one. Prince Albert was a straggling settlement five and one-half miles in length with a normal population of about seven hundred, but refugees had increased this to about fifteen hundred, exclusive of the police.

To reinforce his two hundred police, Irvine enrolled ahout three hundred and nine special constables-practically the whole adult male population-after his arrival from Carlton, but only one lundred and sixteen rilles were available for their use. There were four conpanies under the command of Captain Young (Tice Captain Moore wounded), with Camphell and Wilson; Captain Hoer, with Lientenants Brester and Agnew; Captain Craig, with Lientenants Taite and Dunlop; Captain Brewster, with Lieutenants Sutherland and Spencer. The staft duties were performed by 
Lieutenant-Coloncl Sproat as Supply Office and Mr. Hayter Reed as Brigade Major. The services rendered by Mr. Lawrence Clarke have already been noted. The sconts, forty-seven in number, were organized under Mr. Thomas Mackay, and all the shotguns in the country were gathered in and issued to those not having rifles.

In his official reports, lrvine speaks in the lighest terms of the work done by his scouts, under the direction of Mr. Thomas Mackay. Their constant activity obliged the eneny to keep a strong portion of their force on the west side of the river and restrained the operation of Riel's information corps.

"I feel at a loss to know," says Irvine, "how I could adequately give expression to the appreciation of the gallant service rendered to the conntry by the Prince Albert volunteers. Certainly no body of men ever earned more honorable mention than in their casc is deserving."

This hody of volunteers were disbanded on May $i$ th.

Food was scarce and rations had to be issued for eleven humbled and sixty-five souls in addition to enrolled men. It was necessary to retain the services of the farmers who had volunteced, and this prevented their sowing their crops. Before the date of siege was finally relieved supplies had fallen so low that it had been necessary to use a considerable quantity of flour which had been soaked with coal oil. Most of the citizens lad been forced to withdraw from their dwellings, and to gather within extemporized fortifications.

The decided clieck sustained by General Middleton and his troops at Fish Creek produced a very serions impression in and about Prince Albert. lndeed, a number of Indians and IIalfbreeds who had previously professed loyalty then went over to the rebels.

According to Middleton's account, Irvine urged him to cross the river and march direct to Prince Alsert, so that their forces might be combined before an attack was made on Riel. ${ }^{1}$ This course Middleton considered would be bad strategy, but he directed Irvine to come out with some one hundred and fifty Mounted Police, to co-operate on the west side of the river. His orders he did not think it advisable to put on paper, but they were carried by Captain Bedson and Mr. Nacdowall (later a member of the Canadian House of Commons for Prince Albert). Middleton informed him that he intended taking Batoche on the ISth of April, and instructed Irvine to prepare to cut off flying IIalfbreeds, as Middleton feared, it is

1 When he suggested to Middleton the advisability of combining forces, Irvine states that he was under the impression that the total strength of the force acting under the General's immediate orders was only three humdred and fifty, with a thousand more troops to follow. It was not until the $16 \mathrm{th}$ of April, when Messrs. Macdowall and Bedson seached Prince Alhert via Carrot River that Irvine was aware of the strong atigmentation of Middleton's force. 

likely, that they would make away on the approach of his columm. In obedience to these instructions and greatly to the indignation of the people of Prince Albert, who felt that the safety of the town was being seriously jeopardized, on the 18 th Irvine moved out from Prince Albert with two hundred Mounted Police, but learned from his sconts that no attack was being made on liatoche, and, receiving on that same day a letter from Prince Albert which made it appear not unlikely that an attack was contemplated on that place, he and his force returned.

On April 3oth one of his scouts brouglit a message from Middleton, dated the 20 h, telling Irvine to expect him at Batoche about Thursday. On the 7 th of May he learned through his own scouts that Middleton had changed his plans, but throughout the whole episode he was in the utmost uncertainty as to Middleton's movements.

Irvine was exceedingly disappointed that the force under his command was not given active employment after the fall of Batoche.

"We were able," says he, "to travel twice as fast as the militia troops General Middleton had with him. In addition to this, we not only knew the country and the bands of Indians, Lut even the men in the ranks knew and recognised at a glance the chicf head men and others against whon operations were lecing condtcted."

After resting a daty and a half at Prince Albert. General Middleton set out on the Stcamer North VNest for lattleford with half his force. leaving the others to follow by boat or trail, and on the 23 d one of Poundmaker's prisoners, Jefferson, a farm instructor, met the steamer in a small boat, and delivered to Middleton the following letter:

"Sir:

"Eagle Hill, May 19, 1885.

"I am camped with my people at the east end of the Eagle Iills, where I am met with the news of the surrender of Riel. No letter came with the news, so that I cannot tell how far it may be true. I send some of my men to you to learn the truth, and the terms of peace, and hope you will deal kindly with them. I and my people wish you to send us the terms of peace in writing. so that we may be under no mismderstanding. from which so much trouble arises. We have twenty-one prisoncrs, whom we have tried to treat well in every respect. With greetings,

"(Signed) Pounua.ıker. His (X) mark."

To this communication Niddleton returned the following reply: "Poundmaker:

"I have utterly defeated the Halfbreeds and Indians at Batoche, and have made prisoners of Riel and most of his Council. I have made no terms with them, neither will I make terms with you.

"I liave men enongh to destroy you and your people, or at least to drive you away to starve, and will do so unless you bring in the teams you took, and yourself and councillors with your arms to meet me at Battleford on 
Monday, the twenty-sixth." I an glad you have treated the prisoners well and have released them.

FRED MHDULTOX, "Major General."

Meantime, Father Cochin and the other prisoners from l'oundnaker's camp had already, on May 2oth, reached Isattleford, bearing the following communication :

"To the commandant of the Fort at Pattleford:

"Sir-I and my" men are at the foot of the Eagle IIills, having heard of Riel's surrender. I send yon in twenty-one white prisoners, whom I have treated well. I await termis of peace. I'lease send in writing so that there may be no mistake.

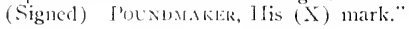

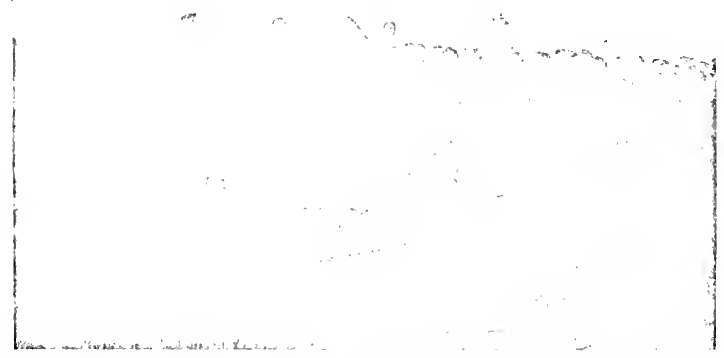

SURREXHER OF POYXDMAKER TO MHALETON, BATTLEFORD, MA Y $26,1 \times-5$.

From a painting, the property of the Duminion Government.

Middleton arrived at Battleford on Sunday, May 2.4th, and on the afternoen of the 26th Pomndmaker and his people cane in to surrender.

The picturesque scene is graphically described in the following quotation from the diary of one of the officers present:

"Just after breakfast the lookont sentry reports that two horsemen are coming in and they turn out to be an Indian and I Jalfbreed who report that Ponndmaker is just behind. Colonel Williams, who just at this time rides up, takes charge of the lndian and gallope off with him to report to the General. Soon we see a hand of horsemen approaching rapidly and ere long the renowned Cree chicf appents befure ns. Fonndmaker is acconpanied by some fifteen sub-chiefs and comncillors, and the appearance of the band is very picturesifue and striking. The great chief is himself a very remarkable looking man, tall, very handsome and intelligent looking, and

2 May 26 wins really Tuestlay. 

dignified to a regree. If wears a handsome war-cap of the head of a cimnamon bear, with a long tuft of feathers lloating from it, a leather jacket studded with brass nails and worked with leads. long. headed legerings coming to his hips, and brightly colored moceasins, while wer his shoulders be has a very gaily eolored blanket. The others are dressed in much the same manner and all are elalorately painted. Poundmaker shakes hands with the ollicers at liort Oner withont getting oft his horse or uncovering, but all the others dismount and take off their headgear hefore they approach. Aiter a short talk they go on to the (ieneral for a pow-wow with the Commander-in-clice."

The unfortumate Indians squated in a semi-circle in front of Middleton's chair, and P'oundmaker advanced into the open space, and through Interpreter Itouric delivered to the General a long and poetical oration. He declared that he knew little of what had been going on, that he had done his best to keep his young lraves quiet, that he had carefully preserved their prisoners from violenee, and that he considered himself deserving of very honorable terms. Cieneral Miklleton was very eaustic in reply. Cpon the whole, in the matter of dignity and moderation of speech, the savage showed to better advantage in this interview than did his victorious enemy.

Middleton now arrested Poundmaker and four of his sub-chiefs, Lean Man, Yellow Murl Lianket, brother of I'otndnaker, Tireaking-through-theice, and White Bear, and demanded the surfender of those concened in the murder of Tremont and F'ayne. Therenpon, Nan-withont-blood stepped out of the semi-circle, and sitting at the fiencral's fect. which he grasped with both hands, confessed to one of the nurders. His example was followed by another Indian, Itka by nane, who first stripping himself to the waist, advanced and confessed to the other murder. The remaining Indians then returned to their reserves. 


\section{CHAPTER XXVII}

\section{THE WORK OF THE ALBERTA FIELD FORCE, AND THE CLOSE OF TIIE CANIPAIGA}

Organization of Allierta Field Force Under Str.lnge-Measures for tine Security or Settlers in Aleerta-Missionaries as Peice-

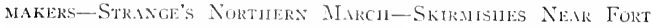
Pitt-A Dingerous Situation-hiattle of Frenchiman's liette; an Unconsciolis Victury- MhHeleton's Chicicisa and Dis-

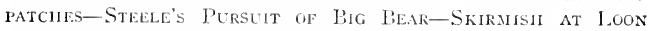
Lake-Siortage of Amuexition-Pursut Continued Among Unexilloked Mokasses-The Sllent Makch-Condect of French Volenteers-Nur.l Impoltance of Closing Puhase of Campaign-Denth of Colonel Willans-Midmetox's Farewell to North What Filid Force-Cust or the Releldiox.

It is now necessary for us to turn back in our story to recount the doings of the Alberta Field Force, under General Strange, a veteran of the Indian mutiny.

On April 16th, the day of Middleton's arrival at Clarke's Crossing, the 65th Battalion of Mounted Royal Rifles, nnder Lientenunt-Colonels Uuinet and Hughes, arrived at Calgary from Montreal. Strange's column also included the Wimipeg Light Infantry, under Lientenant-Colonel WV. O. Smith, the gth Battalion, under Lientenant-Colonel Aymot, a detacliment of the Mounted Police with a nine-pounder from Fort MicLeod, under the command of Inspector Perry (subsequently Commissioner), another detachment of Police Scouts under Major Steele, and still another company of Scouts commanded by Major Hatton. Altogether, Strange's forces amounted to about nine linndred.

Preparations for the defence of the South Country were seriously hampered by the fact that the settlers (owing to the protection hitherto enjoyed at the hands of the Nounted Police) were almost entirely without arms. Noreover, the cowboys, who themselves were but partially armed, could not be withdrawn from the cattle districts among the lndian reserves, without placing at the mercy of the Indian raiders valuable supplies of horses and cattle. Home guards and local patrols were, however, organized. 

General Strange's orders, from General Middleten, as we have seen, were to overawe and restrain the Indians of - Ilberta and Southern Athabasca, to protect the various settlements along the railway and elsewhere, to march north to Edmonton and move thence down along the Saskatchewan and make a juncture with Middleton himself. Strange left Amyot's battalions as a garrison at Calgary, and provided for the protection of $\mathrm{McL}$ eod and the railway lying to the east of Calgary, stationed a company at Gleichen to guard the railway and northern trails, and to keep wateh over the Blackfeet; and then marched his remaning troops in three columns to Edmonton. ${ }^{1}$ The advance force, under Strange's personal command, moved north on April 20th. In addition to Stecle's sixty scouts and policemen, Strange had only one bundred and fifty infantry to guard his long line of one hundred and seventy-five wagons, which were sometimes unavoidably extended from a distance of one and a half miles to two miles. The teamsters were unarmed, there being no wcapons available for them. That the convoy reached its destination in safety was due, says General Strange, largely to the carcful scouting done by Major Steele's force. This column entered Fdmonton on May ist.

Inspector Perry was in command of the second colmmn from Calgary, which marclicd out on April 23d. He fonnd the Red Deer River impassable. The column under General Strange had forded it twenty-four hours before with ease, but owing to the very heavy rains it had risen rapidly and was now fully two hnndred and fifty yards wide. A raft was constructed, but owing to an accident it was carried some three miles down the river before a landing was effected. Here there was a cut bank thirty feet high, up which Perry's gun, carriage and ammunition had to be hatled. A ferryboat was then constructed which proved of great assistance to the column following. On arriving at Edmonton, Perry turned his contingent over to General Strange.

In advance of Strange's contingent went the heroic missionary, Father Lacombe, who, unaccompanied and despite the difficulties of travel at that season of the year, visited all the Indian reserves as a peacemaker, and succeeded in persuading the Alberta Indians to maintain strict neutrality and remain quietly upon their reservations. In these measures he was vigorously supported by the famous Blackfoot chief. Crowfoot, and excellent service was also rendered by the Rev. John McDougall, who had great influence, especially among the Stoneys. Moreover, Lieutenant-

1 Before the arrival of Strange's troops. Superintendent Cotton of Fort MacLeod offered to make a prompt movement on Edmonton and Fort Pitt. In reply to this offer. Major General Strange wrote Suprerintentent Cotton as follows:

"Your valuable services, knowledge of the district, and influence wilt the Indians, render it important that you remain where ron are. I must therefore order you to do so. I can understand your desire to go to what you consider the front, but the front may at any time become the rear, and aice icrsa." 

Governor Dewdney Was communicating with the Indians througl father Scollen.

It is impossible here to relate in detail the valuable work performed ly. varions police officers in the sonth conntry, and thronghout what is now Alberta, but mention must be made of Superintendent Ilclllree, who was stationed near the Cypress llills, of Superintendent Cotton, west of McLend, of Captain C. E. Demny, anthor of "The Riders of the Plains"who perfoned services of special value among the lilackfeet, Piegans, Sarcees, Stoneys and liloods-and of lnspector (iriesbach, of liort MCLeod. Minor depredations had been committed in many places ly the Indians between Calgary and Edmonton, but happily for Canada, the Blackfeet. Piegans, Bloods, Sarcees and Assiniboines and other warlike tribes of the Far West, decided in fatron of peace.

Having placed a small garrison at lied Deer, and having rendered Edmonton capable of defence, Strange, on May Ifth, with his depleted forces, pushed on to Victoria on the North Saskatchewan, and thence toward Fort Pitt, in the vicinity of which l?ig Bear's band was lingering. On May 2 th, the day of Niddleten's arrival at liatteford, Strange passed Frog lake. where the holies of the victins of the massacre were given honorable, if hasty, burial. Then the pursuit of lig liear's followers began in earnest. On reaching Fort Pitt, Strange sent out in every direction scouts, including the Rev. John NeDougall and the Rev. Canon Mackay.

It may be remarked that there were five of the Mackiay brothers engaged in the stupression of the rebellion-Thonas, a prominent member of early Territorial Conncils and Assenblies: Josejh, of the R. N. W. M. I'.; James, the well-known lawyer and member of Parliament: John and George, the missionary clergymen. All of them were men famous for endurance, conrage and skill with the rifle. "One of then, George, a canon of the Angelican Church, accompanied our column as chaplain," says the Presbyterian clergyman. Mr. Macbeth, who was a nember of Strange's Winnipeg force, "and I can vouch for it that he could fight as well as pray."

Major Steele. with his sconts operating on the east or north sicle of the river, were fired upon when about ten niles distant from Fort Pitt. Two Indians were slain in this encounter. Meanwhile. Perry was reconnoitering south of the river." Steele presently reported that his scouts had

2 Prior to the Battle of Frenchman's Butte. Gencral Strange (on Nay 26) sent Perry with five scouts and scventecn other men of his force to recommiter sonth of. the river. He was to travel directly sonth an far as the Pattle River and then circle around to the east and return to Fort Put. IJis mulersianding of Strange's orders was that he shottd establish connection with Battleford if possible. When ahout twenty miles from Battleford he met an Inclian bearing a message from dliddleton 
come upon one hundred and eighty-seven lodges. Leaving a company of the $65^{\text {th }}$ to fortify and protect what remained of liort Pitt, Strange, with one hundred and ninety-seven infantry, twenty-seven caralry and one gun, hastened to Najor Steele on the 2-7th. Together they advanced four and a half miles, and, coming upon the Indians, they drove them from their position and followed them up until darkness. approached. The 65th were hurrying after them, but Strange and Steele could not wait for these reinforcements. Strange's forces were obliged to bivouac that night under arms and without tents or camp-fires. His columns at this time were really in a most hazardous position, as is indicated by the following extract from MacBeth's interesting reminiscences:

"Hunanly speaking, I have never been able to make ont why the enemy, who were in force outnumbering us by three to one, did not make short work of us in the darkness. The clearing in which we were encamped was small and surrounded by dense forest, the wagons were in zareba form, with all the men and horses inside, and the night was intensely dark. The Indians must have been already in panic, or, with their lnowledge of the situation, they might have rushed in, stampeded the horses. and in the confusion done serious execution."

At dawn on the 28 th, Strange moved forward, finding numerous traces of recent trails. About 7:30 he overtook the enemy; whom he found occupying an impregnable position in the forks of a creek. The front and flanks of their position extended about three miles, and were covered by a muskeg. Strange deployed his little force, dismounted his men, and sent Major Stecle forward on the left to turn the enemy's flank, if possible. Meanwhile, a general fire was opened all along the front. The forces under Strange's command had been so depleted that they were now, as we have seen, considerably ontnumbered by the bands they were pursuing, and his staff pointed out that any attempt at an actual assault upon the enemy, who were concealed in rifle pits over the crest of the hill beyond the marsh (Frenchman's Butte), wonld be exceedingly hazardous. Accordingly, after engaging the enemy for some time, he recalled Major Steele, judging it advisable to return to more open ground. This decision rested partly upon the observations of Major Hatton, who could see that the Indians were moving out towards the right, and believed that an attempt was being made to turn Strange's right flank. Accordingly, Strange fell back six miles and encamped, subsequently returning to Fort Pitt. During the four hours' engagement he had but three men wounded and none killed.

annonncing the surrender of Ponmdmaker and Ricl. He accordingly proceeded to Battleford and reported to the General, returning immediately thereafter to General Strange. The ride from Fort Pitt to Battleford by the road traveled involved a jonrney of 130 miles, whieh was accomplished in thirty-six hours. 
It afterwards proved that Strange's operations had been much more successful than he or his men supposed at the time. He was unfortunately. deprived of the services of Major Perry, who was, as we have seen, alsent on a reconnoitering expedition, and would otherwise have been in charge of his gun. Consequently, it was not at first worked to the best possible advantage and its shots went too high. This was noticed by Lieutenant. Strange, the General's son, who accordingly instructed the gumers to fire lower. The next shot took effect in one of the pits, and did considerable execution. The Indians, owing to the favoralle wind, had heard Lieutenant Strange's orders, and their prompt and sanguninary result cansed a general panic and retreat, though the Government forces were unaware of the fact. The movement, which had lieen mistaken for an intended attack upon the riglit flank, had been, in point of fact, the beginning of a general rout. The Indians scattered, permitting the escape of eleven prisoners, and fell back on Peaver River, some eighty miles distant.

"It was a pity," says General Micldleton, "that General Strange had not waited for my arrival, when a more decisive blow might have been struck." This implied criticism is scarcely fair, as Niddleton lad left Strange entirely in the dark as to his wishes or intentions, and indeed, had not conmunicated with him since Min 1 st. $^{3}$

Moreover, General Strange hat notified the Commander-in-chief of his intention of moving eastward with a view to attacks being made upon the Indians from both directions, and he believed the proposal had been approved. Strange now sent two plucky voluntcers, Sergeant Borrowdale and Scont Scott, down the Saskatchewan by canoe, through the Indian country. General Nliddleton sent them back with a letter to Big Bear demanding his immediate surrender, and on the 3 oth Middleton left Battleford with all his force, in three steamers, with the exception of the mounted men, who came by the trail along the south bank.

Meantime, General Strange had sent Major Steele with cavalry to follow the trail of Big Bear's band, and moved his own forces to Frog Lake. Major Dale, on the 2d, bronglit into camp the Rev. Mr. Quinney. Mrs. Quinney, Messrs. Cameron, I Malpin and Dufresue, and five Halfbreed families, who had been prisoners with the Indians. Mr. MacKay, of the Hudson's Bay Company, with ten mounted nen, also recovered Mrs. Gowanlock, Mrs. Delaney and other prisoners, and brought back to Fort Pitt, in addition to these, thirty-six members of Big Bear's band as prisoners.

On June $4^{\text {th }}$ word had been received that Major Steele had overtaken some of the fleeing Indians, with whom he had had a successful skirmish at Loon Lake.

Before the battle. Stecle was jnst ready to offer terms of surrender 3 According to Begg, Vol. 3. page 241 . 

to the Indians, and had Nackay with him to act as interpreter, when, probably as the result of nervousness, some Indians in an amluscade fired their rifles. The engagencent was soon general. Steele had with him only sixty men. An attempt was made to turn his flank, but he detached hifteen men to prevent this and to bring the enemy under a cross fire. This was successfully accomplished. Ifter the battle, Steele had his terms shonted across to the Indians, and the next day one of the white prisoners was sent by the Indians to arrange for surrender. In ignorance of the approach of the released prisoner, Stecle at this juncture caused some guns to be fired to intimate to the Indians his position. This apparently intimidated the messenger, who returned to the Indian camp withont seeing Stcelc.

Major Steele is confident that if the government instead of sending up large detachments of outside forces hat simply sent in an abundance of arms and anmunition and placed the anjuression in the hands of the police and western voluntecrs, it would have leen brought albout much more efficiently. His own men, for example, were, after the battle of Loon Lake, reduced to fifteen rounds of anmunition. Their supplies had heen held up at Winnipeg by a customs officer.

In the pursuit of hig fear's hand through the Loon Lake country, the Canadians were hampered by the presence of bodies of water not marked upon their maps. Nevertheless, Stecle is quite convinced that if he had been given a freer hand and if he had had an adecuate supply of ammunition he could casily have secured the whole band of fugitives.

On receipt of Stecle's dispatch, on June fth, Niddleton attempted to follow him up, but the country through which the Indians were moving was characterized by such a maze of all hut impassable morasses that on the 5th he sent back the infantry. On the same day Stecle joined him. Forces under Colonel Otter from Battleford, and Colonel Irvine from Prince Albert, were scattered north of the Saskatchewan to prevent the retreat of the Indians, and General strange moved northward into the Beaver River country, where his plucky force acyuitted itself with a distinction worthy of greater recognition than it received in some high official quarters. Says MacBeth:

"It was decided to make what hecame known in the rebellion annals as 'The Silent Narch,' and so, leaving our wagon train, the horses being completely tired ont, we started marching again about eight o'clock in the evening. For quite a distance our way was through water, knec deep, and

* This opinion is slaned by practically all well informed old-timers. What was wanted was 500 mounted infantry who knew the character of the men with whon they would have to contend and of the country that was the scene of rebellion. The Indians and Halflireeds were themselves amazed at the folly of sending horseless warriors against them. 

through this swamp, I remember how the Frenchmen of the 65 th, ahmost shoeless and half clad as they were, more than once helped the horses on Perry's gun, next to which they were marching. It was night when we struck the heavy and practically trackless forest, for there was seareely any trail to be found. The darkness grew denser as we advaneed, and the great trees above us shut out the sky. Sometimes in rank and sometimes in lndian file we kept on marching in dead silence, with our arms ready for instant use, until about two oclock in the moning when a halt was ordered, and by little twig fires-larger were not allowed-we tried to bry our wet and well-nigh frozen garments.

"As the day began to dawn we noved on again, and by sunrise arrived at a point near the Feaver River, where the Indians had been seen, but found they had vanished. Evidences of their recent presence, however. were at hand, for we found about one hundred loags of flour cached in the woods. 'This was a 'windtall,' as by thi- time bread was little more than a distant memory, and even "hard tack' was scarce enough to he appreciated."

On June Gh Strange camped near Peaver River When an episode occurred which illustrated the spirit of his men. "My infantry," he says, "were dead beat from marching in rain and awiul mut. The 65th, who had borne the brunt of the marching for five hundred miles, having been in the first advance, had tramperl the soles off their boots. Some were literally bare foot, others with muddy, blood statined rags tied around their feet. Their commanding officer told me the men conld math no more and wanted to know when they would he allowed to go home. I outwarly thanked that officer for his information and rode up at once to the battalion. They certainly presented a pitiable spectacle in their tattered miforms. The misery of their march through swamp and forest had been added to by the mosquitoes and horse flies, which were almost unlearable. Adlressing the hattalion in French, as was my hahit, I said, 'Mles eniants, votre commandant ma dit que vous demandez quand vous pouvez retomrner chez vous. Mais je n’ai qu’une, réponse-c’est celle-là de volre ancienne chanson.

'Nalbrook s'en va-t-en guerre.

Ne sait quand reviendra.

It had the desired effect. The weary litte Frencl Canadians shouted, "Huorra pour le General! En Ivant! Toujours en avant! and they stepped out to the retrain of their ancestors."

By the Sth of June Middleton found himself and his troops floundering through such a network of muskegs that though it was evident he was close on the trail of Big Pear, he did not feel justified in attempting to pursue the fugitives any further. With Batoche captured, Ricl and Poundmaker prisoners. Sig Bear powerless and a fugitive, and almost all the prisoners who had been in the hands of the rebels again at liberty, the

${ }^{5}$ From General Jingo's Jubliled. by General Strange. 



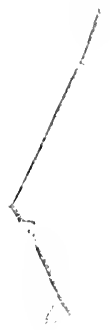


General folt that his work was nearly done and commenced his arrangements for brcaking up the forces.

However, in faimess to Strange and his officers, especially Stecle and Colonel Osborne Sunith of the Winnipeg Light Infantry, the importance of the last phase of the camprign must not be minimized. It was essential that the Indians should know that if they violated the Oncen's peace they could find no place of refuge, however remote. These men tanght them that lesson, and the task kept then engaged weeks after most of the other members of Middleton's forces felt that for them the war was over. One humdred picked mon of the 11 innipeg Light Infantry were detached from Strange's force at Jicaver River to cross that stream and strilie worthward to a chain of lakes where some of Big Dear's band had, as the issue proved, withdrawn. Maclieth hint that the picling consisted largely of selecting those who had some remnants of boots left, and whose uniforms could be counted on as likely to hold together a little while longer. On June zoth scouts from Smith's little colum found the portion of the Indian band that held Mr. MeLean and other prisoners, and on the $23 \mathrm{rd}$ the Indians, in response to a summons, sent them all to fort l'itt safe and sound. They were met on the way by Major Iickon with a detachment of the goth. Accordingly, Smith's adventurous One Humired returned to the brignde, and on July and Big Bear made his way to Carlton and smrendered.

The general rejoicings over the successful issue of the three months' campaign was tempered by the universal regret caused by the ultimate death of Lieutenant Colonel Williams, M. T., commander of the Midlanders, who died on board the steaner from the effects of exposure.

Apart from the fosses sustained by the Ifalibreeds and rebels, the rebellion cost Canada the lives of thirty-nine citizen soldiers, and almost one hundred and fifteen others had been wounder. In the general order with which Middleton took leave of his forces, he expressed himself as follows:

"In thus completing the hrealing up of the North West Ficld Force. which has lieen under the immediate control of Major General Middleton during the late campaign, lie camot let the officers and men comprising it separate without expressing his great satisfaction with them. During the whole time he has not had to assemble one court martial; and, in fact, there has been an almost total absence of crime. The troops have had great hardships to unckergo and real difficulties to overcome, and have borne and met them like men, with ready cheerfulness and without complaint. They, as untried volunteer soldiers, have had to move in a country where an extraordinary seare existed. and against an encmy with whom it was openly prophesied they would be unable to cope, unless with great superiority of numbers. The seare they disregarded, as shown by the fact that during the whole three months not more than two or three false alarms took place in camp. and the prophesy they falsified by beating back the encmy with a fighting force equal, if not superior, to them in numbers. 
Each regiment, corps, or arm of the service has vied one against the otherand each has egually well done its duty; not forgetting the transport service, which, under its able olficers, has so viell aided our movements: the medical department, which has been so efficiently directed, and the draplains, who have so carefully and assiduously ministered to our spiritual comforts.

"The Najor Gencral, in taking farewell of his old comrades, begs to wish them all happiness and snecess in their several walks of hife, and to sincerely thank them, one and all, for having, by their gallantry, good conduct, and hard work, enaljed him to carry to a successiut conclusion what will probably le his last campraign."

All Canada was justly proud of the courage and good conduct of her citizen soldiery; nevertheless, the pride of the thought ful was tempered by the recollection that Duck Lake was a decisive victory for the rebels; that at Fish Creek a handful of men checked the advance of an anny and inflicted losses double those they sustained; that at Cut Knife Creek, Poundmaker drove back the attacking force, which indeed owed its escape to his magnanimity; that on the evening of the first day's fight at Batoche a dispatch seems to have been sent calling for reinforcements from the Last; that on the sceond and third day of the siege Middleton failed to regain ground ocenpied on the first day; that at Frenchman's Rutte the victorious force retired from the field ignorant of its victory; and that it cost Canada the death of some thirty-nine brave soldiers, the maiming of approximately three times that number, and the expenditure of about $\$ 100,000$ for every Indian or Jalibreed killed in action, to crush a rising eansed by the maladministration of officials who escaped umpunishec.

Sucl is the story of the Saskatchewan Rebellion of 1885 . It has been necessary to omit many episodes and much detail of a most interesting character, but so far as it goes, the foregoing accomt may be accepted as fair and authentic. I have been hampered greatly by the gross inaceuracy of many of the official reports and some or other features of every previous extended account of the rising with which I am familiar. Public opinion apparently demanded a certain style of report at the time and the demand created the supply. After the lapse of a generation, however, it is time for a simple statement of facts, and such I have labored earnestly to give, without favor or prejudice. Some episodes I have deliberately omitted, however, because not essential to an understanding of events, and because the reverse of creditable to officials who used the distresses of their country to selfish pecuniary advantage. Names of many of these contemptible parasites are well known, but no good purpose would be served by their publication at this date, to the humiliation of innocent relatives. Let their names pass into merciful oblivion.

Mr. Thompson, in answer to Mr. Blake, stated from his seat in the House of Commons in 1886 that the total number of Halfbreeds committed 

for trial in connection with the North West Rebellion was forty-six, Indians cighty-one and whites two. Jighteen of the Halfbreeds were accused of treason felony, one for high treason and one for murder. Eleven were discharged on their own recognizance, four received sentences, eight were discharged to appear again when called for; one, Adolph Nolin, was set at liberty on order of General Mirdlleton, and two others, who were beld for trial, were discharged on the proceedings being discontinued on the direction of the Mlinister of Justice. Four others Were also released. Of the Indians, forty-four were convicted of various crimes, nearly all treason-felony; one was for manslaughter, three for arson, five for horse stcaling, one for cow stealing, one for hreaking goal; the others were convicted of treasonfelony. Ten were discharged on promising to come up for trial when required. In the case of one clarged with treason-felony no evidence was clicited and he was dismissed; three were convicted. The remainder of the Indians charged with various crimes were set at liberty. Two who were charged with stealing were also released. Of the whites, two were held for trial. One, IV. II. Jackson, accused of treason-felony, was acquitted on the grounds of insanity; the other. T. Scott, accused of the same offense, was also acquitted. 


\section{CHAPTER NAVIII}

\section{RACIAL ASPECTS OF TIIE RELELLION OF ${ }_{185}$}

The Rebellion a Frencit Haterreed Rising - Misunderstinding Between Frenci and Exglish-Allinne of Rebels Witu tire Indians-Character of Big Bear; His Trial; Summary or Evidence-Poundmaker's Case-Dewnetey's Opiniox gF PoundMAKER-WIITE C.jp's EXPERIENCE.

While the Saskatchewan rebellion was the immediate result of prolonged neglect on the part of the Ottawa officials and of gross errors of judgment on the part of others in the territories, it arose in a consiclerable measure from racial and religious causes.

The whole population of the Territories shared and bitterly resented many of the grievances of which the rebels complained, this being, of course, specialy true of the English spealing IIalfbrects. Nevertheless, it is doubtful whether a single white man $^{1}$ could be named who fairly earned the name of rebel, and the non-French Halfbreeds remained loyal ahmost without exception. So also did the great majority of French Halfbreeds, though in a special sense the rebellion was a French I lalfbreed rising.

It is evident that at least some of the seeds of insurrection can be traced to the lingering discontent of the laughty warlike race whose army met disaster on the Plains of Abralam in 1759 . The gulf involved in diversity of languages and national traits is one to be bridged only by generations of mutual forbearance, ly prolonged and general efforts to appreciate a standpoint far removed from one's own and by the exercise of wise and patient statesmanship. The facts that there were no rebels of unmixed French blood, and that the French Canadian volunteers served nobly in the suppression of the rebellion, are among the many indomitable evidences that such a gulf can be bridged, however, and the insurrection is merely a painful reminder that the task of unifying the Canadian uation was not as yet altogether completed.

Indeed, the rebel Halfireeds were disaffected not so much because they were French as because they were Indians. The aboriginal blood flowing in their veins made them feel that in a special sense the country they occu-

${ }^{1}$ Jackson, the white man who for a time was Secretary to Riel, was subsequently adjudged insane and therefore irresponsible. 
pied was their own, and that the whites were interlopers who by force of numbers and by the subleties of the law were rolbing them of their inheritance. The crime laid at the door of Ricl and his associates, which people of the west found it hardest to forgive, was that of instigating an Indian outbreak. Is we have seen, many of the firench lialibreeds themselves were intensely averse to anything that might involve such a conflagration. In judging the moral culpalbility of the others, moreover, one should realize that it would be a very different thing for white men to arouse the warriors of a barbarous race to support them against their foes, from what it was when a handful of Métis in desperate straits sought succor from their brothers-in-law and cousins of the red race, whom they felt to be suifering from the wrongs identical with or kindred to their own.

The amazing feature of the whole situation is, however, that no general Indian rising actually took place. The great majority of the Indians, as we have seen, remained either neutral or definitely on the side of the Government. Of the numerous American lndians residing in Canada few, except some of the Teton Sioux, took any part in the rising. Thuse who did were, it may be remarked, practically exterminated. Furthermore, many of the Canadian Indians who were involved in the insurrection played the part they did very much against their wills.

Most of those who have written on rebellion topics have united in vilifying Big Lear, but the testimony of those who knew him is almost unanimously in his favor and, from a dispassionate review of the available evidence, 1 am personally convinced that he had no share in instigating the outrages with which his name came to be associated. "Personally," says MacBeth, in his Making of the Canadian West, "he was rather a harmless old man who but for two of his band, Wandering Spirit and Little J'oplar, would never have been found on the warpath." Mr. John Dixon, of Maple Creek, knew Big Bear well, and has always been convinced that he was not responsible for the outrages at Frog Lake. "Big Bear," said Mr. Dixon, in an interview with the writer, "was an Indian of whom I caninot say too much good. He was generous to a fault and always faithful to his word. He was constantly endeavoring to educate his people, especially the younger ones, to obey the law. He recognized that the white men had come to stay and he was concerned only to get for his people the best terms that he could." Mr. Dixon won Big Bear's complete confidence and the unfortunate chief frequently discussed his difficulties with him.

The Saskatchec'an Hcrald of June 9, $188_{3}$, said of Big Bear: "He was the only chief around here who has displayed any energy in his operations or who has conducted himself with dignity, and it would have a bad effect on the other bands of the district if, from any fault not his own, he should be made to forfeit his high position as the most industrious, best behaved 
and most independent chief in the district." Iig Bear, Crow foot, and other Indians have alleged that as early as 1879 , while they were visiting Montana, Riel attenpted to arouse them against the whites. ${ }^{2}$

I do not think that any disinterested person can now read the official records of Big Bear's trial for treason-felony without feeling profound sympathy for the unfortunate old man.

Big Bear's trial took place on September 1 r, '1885, at Regina, lefore the Honorable IItugl Richardson, Stipendiary Magistrate and Henry Fisher, Esq., Justice of the Peace. The charge was one of treason-felony-i. e., that, with others, he had designed and intended to levy war against the constituted Government. The occasions of the alleged offense were, first. at the massacre of Duck Lake (April 2nd) ; second, at the capture of Fort Pitt (April I 7 h) ; third, on April 21 when an incriminating letter was said to have been dictated by him; and, fourth, at the Battle of Frenchman's Butte. Big Bear was defended by F. I. Robertson, Esq., while Messrs. D. L. Scott and W. C. Hamilton appeared for the Crown. The following pages contain a fair synopsis of the cvidence upon which Big Pear was convicted.

One of the principal witnesses was Mr. John Pritchard, who had performed such important public services in protecting Mrs. Delaney and Mlrs. Gowanlock, when after the massacre he and they were prisoners of Big Bear's band for a period of two months. Big Pear's son, 'mesis, was the leader of the band of Indians that took him prisoner. Witness aftirmed that Big Bear had tried to save the white families at Fort Pitt, and had arranged for the police to get away in safety. When the Indians moved down on Fort Pitt, Wandering Spirit and Little Poplar were in command and Big Bear had no infuence over their following. He could not have prevented the pillaging of the Fort, and, in Mr. Pritchard's opinion, the best he could do was to help the whites to get away and save their lives. Indeed, the witness made it clear that Big Bear was treated from first to last with much contumely by his umnatural son and the other rebellious warriors. Mr. Pritchard was a Crown witness, but the only item in his prolonged evidence that reflected upon Big Bear's loyalty was as follows: Witness was taken to Wandering Spirit's teepee, where he also found Big Bear anı two French Halibrecls, Nontour and André Néault. Big Bear said he was going to try and compel the Bacana Indians to join them and approved of a letter written by Montour to friends at La Biche, inviting them to come also. This letter was not produced nor was it shown that Big Bear made any actual attempt to deliver his proposed ultimatum to Pecan of the Bacanas. During all the wandering of the band, in spite of the difficult nature of the comntry and the fact that they had more than one

$\simeq$ Toronto Muil, February 22, 1885. 

hundred horses, Big Dear was always on foot. A letter came to Pritchard from Norbert Delorme, and upon this falling into the possession of Wandering Spirit and his companions, a Council was held as to the advisability of joining Poundmaker, but the witness was not aware that Big Dear himself had taken any action in the matter. Imesis, Wandering Spirit and Little Poplar had wished to have all the prisoncrs killed, but Big Bear and others, especially the Wood Crees from Long l:ike, had protected them.

James Kay Simpson visited Frog Lake on the afternoon of April 2, after the massacre, and was detained a prisoner. Big Bear complained to Simpson that his young men would not listen to him, and that he was very sorry for what had been done. He had known Big Bear for nearly forty years and had always found him a good Indian, a good friend to the white man, and always respected by the white people. At the time of the outbreak witness affirmed that Big Bear was not in control of his people. Indeed, as a matter of fact, of late years the younger men in the tribe had looked upon him as a sort of old woman. He had seen Big Bear the day of the skirmish of Frcnchman's Butte early in the afternoon, about sixteen miles distant from the scene of battle. The figlting men were still at the front. When the proposition had been made that the band should join Poundmaker, Big Bear said he did not wish to go.

Mr. Stanley Simpson, Hudson's Bay Company clerk at Fort Pitt, another of the prisoners, stated that somewhere near Frenchman's Butte Big Bear had said something about wanting his people to cut the head off "the Master who was over the soldiers,"--that is to say, the officer in command of the police. At the same time Simpson admitted that this had been said in Cree and that his knowledge of that language was very limited. During the fight at Frenchman's Butte he had seen Big Bear about two and a half miles from where the skirmish was taking place, but the Indian had expressed his approval of the losses inflicted upon the soldiers. The witness admitted, however, that Big Bear had used his influence for the protection of the prisoners, and that the Indian had complained to his followers that there was a time when he was a great clief and they had obeyed him, but that now when he said one thing they would do another. In the cross-examination, to test this witness' knowledge of Cree, Interpreter Houri expressed in that language the following sentence written by Mr. Robertson, and the witness was asked to translate it: "If the Captain of the Soldiers does not give me tobacco we will cut the tops off the trees." In answer, he said: "I am asked by Mr. Houri if he had given me some tobacco, or something of that sort. I can't understand it."

Mrs. Catherine Simpson of Frog Lake was visited by Big Bear on April 2 and warned of danger. Big Bear told her that he could not be every- 
where to look after his young men and that he thought there was going to be trouble. He stayed at her house for a time and had something to eat, and during this interval the massacre commenced. Big licar sprang up and ran out shouting to the people to stop firing.

Mr. W. J. MacLean, Hudson's Bay Company factor at Fort Pitt, considered Dig Bear a good Indian. During his two months' experience as a prisoner he had seen the chief almost daily, if not daily. The chief had taken no part in the pillaging of Fort Pitt. Through the whole trouble Wandering Spirit, Imesis, and Little Poplar had treated Big Bear with utter contempt. Mr. MacLean had worked actively to prevent the band from uniting with Poundmaker's Indians, and Big Bear also sided with him. He affirmed that at least during most of the time of the fighting at Frenchman's Butte Big Bear had been in camp with the prisoners some miles away, and he did not think he had taken any part in the fight. Big Bear had dictated letters to the police strongly advising them to leave Fort Pitt. The witness was very frequently at Big Bear's camp, than which none other was more wretchedly poor, and he was sure that the chief was not in possession of any of the pillaged goods.

Mr. Henry R. Halpin, Hudson's Bay Company clerk, had known Big Bear by reputation for six or seven years, and personally for the last nine months, and as far as he had known and heard of him he had always been a good Indian and friend of the white man. He had met him on the trail on March 19th and told him of the report that Riel had stopped the mails at Batoche and that there was likely to be trouble. Big Bear showed surprise. The Indian was then engaged in a hunting expedition. Afterwards when Mr. Halpin had been taken prisoner by Lone Man, Big Bear had shown himself friendly. He had invited Mr. Halpin to his own tent for security and told him that it was not through his fault that the trouble at Frog Lake had occurred. In the subsequent Indian Councils Big Bear very seldom spoke. When the Indians went down to Fort Pitt, Big Bear was away at the back of the caravan. Big Bear told him to come with him, as he thought if Halpin went down to Fort Pitt and wrote letters for him the white people might be induced to come out of the Fort peaceably and bloodshed might be prevented. He was in company with Big Bear during the whole time the pillaging of the Fort was going on and the Indian did not take any part in it. While Mr. Halpin had been a prisoner with the Indians the leading chiefs of his band had treated Big Bear altogether with contempt. The witness thought the prisoner had been desirous that no blood should be spilt and was sure that his intentions towards the captives had been good. Their chief protection, however, had been the prestige of the Hndson's Bay Company. When the witness had told Mr. Stanley Simpson 
that he had been called for the defense, Mr. Simpson had said that he thought it very strange that any white man should appear in the defense of an Indian. ${ }^{3}$

Mr. W. B. Cameron, Hudson's Bay Company derk at Frog Lake, described an interesting haranguc in which Big liear had spoken to the following effect:

"Long ago I used to be recognized by all you Indians as a chief, and there was not a bigger chief among yon than I was. Ill the southern Indians knew it-the P'lains, the I'iegans, the Sionx, and the Elackfeet. When I said a thing at that time there was some attention paid to it and it was acted upon, but now I say one thing and yon do another."

The chice pointed at Wandering Spirit and his other rebellious subordinates, and then sat with hanging head. When the Indians came to pillage the stores in the charge of $2 \mathrm{r}$. Cameron at Frog Lake, Big Bear had crowded his way through the young men and forbidden them to take anything without permission. In a Council when Wandering Spirit was speaking against the white prisoners in the camp and agitating for their assassination, Big liear got up and said:

"I pity all these white people that we saved. I don't wish harm should come to one of them. Instead of trying to harm them you should be giving them back some of the things you have plundered from them."

On one occasion the witness had heard Mr. Halpin complaining to Big Bear that some things liad been stulen from him by some of the Indians and Big Bear said that he himsclf had had a blanket stolen out of his own tent, and added, "When they would steal from me, the man they call their chief, I cant be responsible for what they do to other people."

Priefly synopsized the salient points of the evidence were these: That Big Bear received his first information of the impending insurrection from his loyalist friend, Mr. Ilalpin, March Igth; that the news did not disturb his hunting plans and that lie did not return to Frog Lake till the beginning of April; that in the meantime he had heard of the Duck Lake affair and that immediately on his arrival he went to the Indian Agent and assured him of his intention to remain loyal; that next morning he interfered to prevent the looting of the Iludson Bay Company's store, from which he went to Mrs. Simpson's to warn her of his inability to control his braves: that while there the massacre broke ont and that he did what he conld to stop it: that a fortnight later when the band moved down against Fort Pitt he reluctantly accompanied them and that by letters and messages to the immates of the Fort he tried to avert bloodshed; that when the police left

3. Mr. Simpson subsequently declared this to be a misapprehension of his remark. 
and the Fort was looted he took no part in the robbery, but that on the other hand he subsequently upbraided his people for having done so; that he said he was going to try to make Chief liacana (Pecan) join him and that he advised Montour to write in the same tenor to friends of the latter, that at Frenchman's Butte it appeared that he took no part in the fighting, though, according to one witness, speaking with manifest animus, Fig Pear on this occasion wished for the head of the oflicer who was driving him into the wilderness; that, on the whole, he enjoyed an exceptionally good reputation, had at one time been an influential chief but liad of late years lost his prestige with his people: that he was a good friend to the whites and continually excreised what was left of his waning powers to protect the prisoners his band had taken; and that the real leaders of his band in their late adventures had been his misguided son, Imesis, certain subordinate chiefs and a mischief-making and influential latfloreed.

Mr. Robinson's address to the jury was very earnest and convincing. He emplasized the unfairness of applying to an Indian, without consideration of his environment and riewpoint, the rules of conduct applicalble to an intelligent white man. With rebellion in the air around him, a white man would have joined himself to the Govermulent forces, but thus to separate hinnself from his band would not and could not naturally occur to an Indian; while on the other hand, in his wish to restrain his son and prevent further bloodshed he had abundant motive for staying with lis people.

Mr. Scott took advantage of his privilege as Crown Counsel to address the jury after Mr. Robertson. Je rested his case simply on the fact that Big Bear continued to associate with rubels, knowing them to be rebels.

Mr. Justice Richardson's charge reads very much like a continuation of Mr. Scott's address and, with it, had the effect of producing, fifteen minutes later, the verdict of guilty. Lig Fear was sentenced to three years' imprisonment, but through the exercise of executive clemency he was released before his term had expired.

The case of Pomndmaker is even more pathetic than that of Big Bear. That he had taken no active part in the reliellion until his camp was attacked by Otter is admitted, as also is that fact that liad he chosen to take advanage of its helplessness he could utterly have amihilated Otter's column. A number of irresponsible Stoneys, who had associated themselves with his band, on more than one oceasion had manifested a desire to murder the numerous white prisoners taken by his braves. Pefore sentencing Poundmaker to three years' imprisonnent. Judge Richardson spoke as follows:

"That you were kind to the white men who fell into your hands is quite clear: that yon were kind to the prisoners and took care of them seems also inquestioned: and probably the friends of these young white men, the teansters. owe their lives to your persontal influence." 


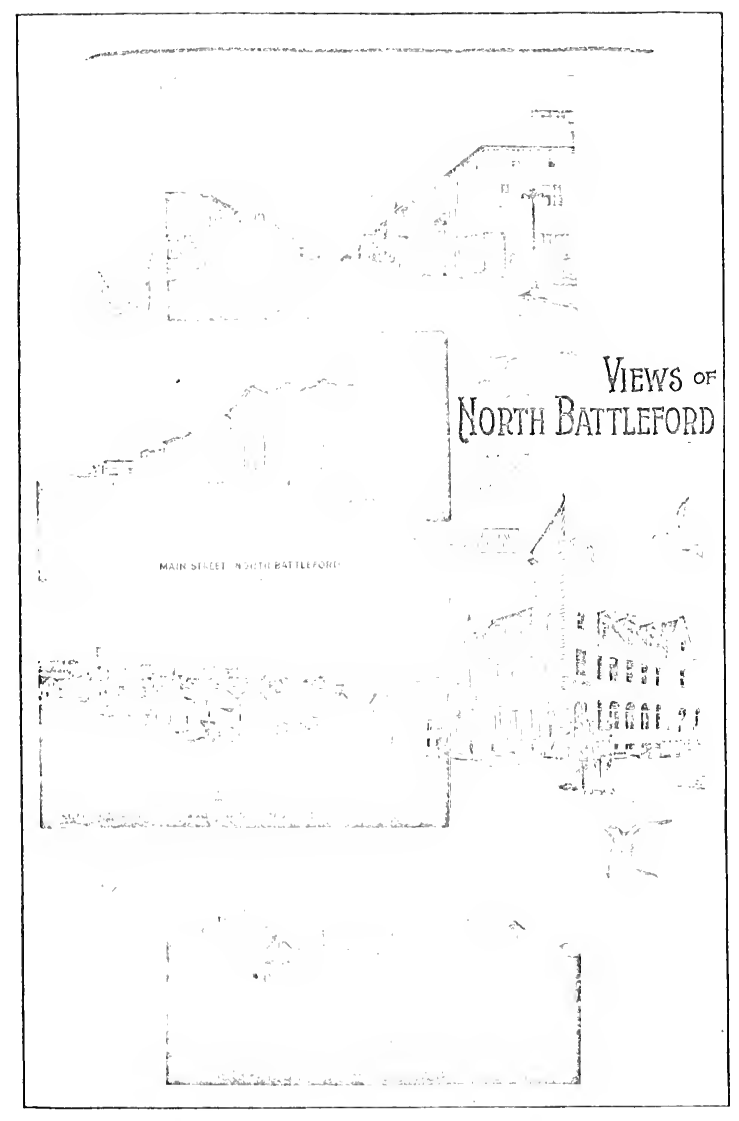


At his trial Poundmaker bore hinself with imprescive dignity and decorum. Before sentence was passed, Mr. Justice Richardson gave him leave to speak.

"I only want to speak once," said he. "Fverything that is bad has been said against me this summer-there is nothing of it true. This stmmer what I have worked for is the Queen and the country that belongs to the Queen. I did everything to stop bloodshed. If I had not done so there would have been plenty of blood spilt this summer. Now, as I have done that much good, whatever sentence yot may pass on me, of course pass it.

"I am glad I stayed where there wottl have been a great deal of blood spilt, and now that I have done so, I shall have to suffer for their sins."

When the prisoner heard he was to be sent to Manitoba penitcutiary he expressed the wish that he might he hanged instead. Indeed, such a cotuse would perhaps have been the more neveiful. Though he was released after some months, his confinement and chagrin liad broken his heart. His death occurred shortly afterwards. ${ }^{4}$

As illustrative of Riel's methols of securing Indian support, the case of White Cap may be taken. The 1 alfbreds came and drove away his cattle and loose horses, practically obliging 11 hite Cap and his band to follow them. Mr. Willonghby, of Saskatomn, endeavored to get an interview with White Cap, but the IIalfbreels diel all they cotld to prevent it. IIowever, a conversation occurred. White Cap scut for Mir. Willoughby and complaned that he was being taken up to liatocle against his will, and wished the citizens of Saskatoon to assist him to escape from the IIalflureeds. Unaided. he said he was afraid to break away, but he said he would have nothing to do with the rebellion. Sonne citizens did try to sectre his release, but either no favorable opportunity presented itself or, when the crucial moment came, White Cap himself failed to take the initiative. Consepuently this old

${ }^{4}$ The Honorable Edgar Dewdney, in a letter to the anthor, speaks of this unfortumate Indian in the following terms:

"Poundmitier was a good Indian and a great friend of mine. If I conld l have reached him I know I could have kept him in check. He stood anong the Crees very much in the same position thit Crowfont did among the Plackfect. Crow foot called him his son. He had spent many years with the Blackfect and spoke their language thoroughly. When the Crees were at war with the Flackfect he always traveled between the two camps and was a 'peacomaker' at the same time he was a brave Indian and had good control nver his men which' I was made aware of more than once when I had charge of them. II had most heantiful hair, which he wore in two long tresses which humg down almost to his knees. When ent to the penitentiary he begged me to save his hair fur him and to request that it should not be cut off. This I did.

"After he came ont of jail he canc to me and thanked me at Recina for doing this, and asked to be allowed to go diree from there to see Crow foot at the Blackfoot reserve. I did not think this adviculle at the time and advised him to go home to his reserve and when I thought he might go to Crnw foot I would and him word.

"This I did in about twenty-six weeks $O_{i n}$ his visit to Crowfoot, and while he was in Crow foot's lodec, a berry stuck in his thront, which hrought on a fit of coughing and he broke a blowl vesud and died. 1le was an arlopted son of Crow foot and the old Blackfoot chicf felt his ieath very much." 
Sioux Indian, who could not speak a work of French or Cree, was brought in fear to Ricl's headquarters at liatroche. The was taken into a meeting at which all the procectings were conducted in French and Cree, and it seems certain that he knew nothing of what was transpiring. As a matter of fact, he had just been marle a memlser of Riel's Council whether he liked it or not. Mr. Rolertson's pathetic appeal for White Cap proved successful, and it is a relief to read that the jury at Regina returned a verdict of not guilty. I have thought it worth while to report the cases of Big bear and Poundmaker thus at length, becanse they remind the student of history of important practical truths. In times of public excitement irresponsible newspapers and orators may so prejudice the public mind that unless citizens learn caution from past miscarriages of justice, cruel wrongs may be inflicted even in our British Courts, of which we are so justly proud. The proverb, "Give a dog a bad name and then hang him," reflects a tendency to be guarded against. especially in times of popular excitement and in dealing with persons of another race. 



\section{CHAPTER XYI}

\section{RELIGIOUS ASPECTS OF THE REBELLION OF ${ }_{1} 88_{5}$}

Reljgious Aspect Gexiek.t.ly lgnoren-Rief a Propiet and His FolLOWER Regiglocis REForMlers-CHRISTENING the NiMes of THE DAYS OF THE WIEK-RESTOK.JTION OF THE S.IFR.TTIL TO THE Seventil D.h - Extracts From Rifi's Commonilate Book-

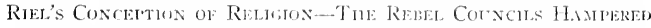
hy Riel's Vistoxs-Ljepine's Reiort or the Battie of Fish

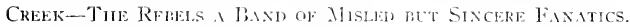

To an extent, realized ly very fow, the insurrection of 1885 was a religious rather than a racial or pelitical movenemt. This aspect of the rebellion has hitherto been so generally ignored or treated so briefly and superficially, that the serions attention of the thonghtiul reader is specially invited to the facts set forth in the following chatpter.

Despite their crimes and follies, the llalibreds associated with the insurrection were to a large extent simply a group of misled religious fanatics. All their official documents bear evidence of this fact. During the winter preceding the rebellion Riel had gradually alienated them from their priesthood, but he was very far from assuming an attitude of enmity to religion itself. Indeed, to a marvelons extent, he succeeded in imbuing these simple people with the idea that they and he were specially called by God to effect not merely a political but a religious reformation. They lad no idea of allying themselves with Protestantism, but, through their instrumentality, they hoped that the Holy Church of their fathers would be rendered purer and more alive to the right ful liberties of its children and to the ancient faith, as they understood it. Their confidence in the divine mission of their leater was profound and touching. Indecd, the minutes of the rebel council at Batoche $^{1}$ are more suggestive of a conference of child-like theologians than a Council of War. Take the following extract as an example:

"Moved by Mr. Boucher, seconded by M. Tourond. That the Canadian Halfbreed Exovidat acknowledges I_onis Riel as a prophet in the service of Jesus Christ, and Son of God, and only Redeemer of the World; a prophet at the feet of Mary Immaculate, moler the powerful and most favourable protection of the Virgin Mother of Christ: under the visible and most con-

1 Published in Sessional Papers, 1886. 

soling safeguard of St. Joseph, the beloved patron of the Halthreed$\therefore$. the patron of the universal church; as a prophet, the humble imitator in many things of St. John the laptist, the glerions patron of the French Canadians and of the Fench Canadian llathibeds.

"Ayes:-11. Henry, M. l'arenteau, Mr. Dmont. M. Tourond, M. Jobin, M. Trottier, M. Boncher, M. Lepine, Mr. Carriere.

"NIr. Onellette did not vote at all, but saicl that after a time, if his views changed, he would record his vote."

With the thunder of Middleton's gun atmost audible in the distance, we find the Council calmly considering the apromriateness of changing the names of the days of the week from the present ones with their pagan associations to others of a more Christian character :

Sunday was to be lire Aurore.

Mondiy, Christ Aurore.

Tuesday, Vierge Aurore.

Wednesday, Joseph Aurore.

Thursday, Dire Aurore.

Friday, Denil Aurore.

Saturday, Calme Aurore.

The Sabbath they determined to transfer back to the seventh day:

Apri1 25, 1885 .

Moved by Mr. Parenteatu, seconded by D. Carriere:

"That the Lord's Day be put back to the seventh day of the week, as the Holy Ghost appointed it, through his servant Mloses; and that if there be any memlers of the "Exovidat' who are not as yet prepared to vote for this resolution, those of their brethren who this day take the lead cordially invite them to join as soon as thicy can conscientionsly do so: and thai, though their adhesion be declared it shatl be accepted when it comes, as freely as if it had been given today. May these adihesions soun render unanmous the act by which the Canadian Halfhreed 'Exovidat' restores, in God's Name, the Holy Day of the Lord's Rest.

"Ayes:-Mlessrs, Poucher, Dumont, Trottier, Parenteat, Jobin, Carriere, Henry, Tourond, Bte. Parenteau.

"Nays:-Messrs. Ross, Onellette, Lepine."

Riel's Commonplace look, written at I3itoche." throws much interesting light upon these religions aspects of the rising. It is a curious milange of piety, puerility, posing and mad prifle, but in general it offers unquestionable internal cridence of sincerity. It is full of dreams and visions, which were evidently believed to be prophetical of future events, and it throws light upon the difficultics experienced by the rebel chief himself in controlling his colleagues and followers. Frequently the entrics are very pointed prayers for or against particular individuals. The following

2In the following pages I have mincle une of the translation of Ricl's Commonplace Book published in the Toronto Globe. 
extracts are characteristic and some of them evidenty bear wpon the delates in connection with the theological questions referred to in resolutions quoted above:

"I have seen (iabriel Dumont. He was afflicted and anhaned. He did not look at me. Ile looked at his table stripped of everything. Ihut Gabriel Dumont is blessed. IIs faith will not fail. He is frm by the Grace of God. His hope and confidence in forl will he justified. Ile will come ont of the conflict loaded with the spoils of his encmics."

"I entered the meeting with Maxime lepine and ancther. I saw nuscelf in the mirror of justice. Wistom shone forth from ne. It illuminated my countenance. Lepine flicl not appear to be patying attention. I Ie kept away from me. He did not leave nic. but did not follow me very closely. Maxime! Naxime! It is human opinion ant your self-love which destroys you, and which estranges your good will."

"O God! I pray Thee in the Name of Jesus, of Mary, of Joseph: be pleased to sustain me when alone: support me in the enterprise and in the army! Since Thou art my support, lielp me! Thon alone art able! Oh! grant to guard the army and the entire council against Maxime Lepine! Give me grace to treat him gently and with humility, but sincerely and frankly, so that he may change his conduct and he maly case to have a fecling of repugnance and hostility against us. ( ) n account of the kind feelings which he has had towards me, grant him the opportunity to turn with a good grace to all those ifleac with which "Thou hast inspired me."

"Oh! my God, grant me grace to re-establich Thy Day of Rest; to restore to hononr the Sabhath Day" as arranged hy. Thy "Spirit in the person of Moses, Thy servant."

"O Jesus! O Mary! O St. Joseph! () St. John the liaptist! Pray for us. Pray for me to the Amighiy that the Nitis penple and myself may do the will of God, nur Father, so that I may accomplish my mission in all details."

"O my God! make me to see that I to nothing of myelf. O Jesus! work for the glorv of our Heavenly liather, and at the same time canse that I speak His livord with all boldness."

"O Mary! I do not deserve that God should direct and assist me, but for the love of Jesus Christ, pray that lle ma continue to me His perfect direction and His victorions and trimmphant assistance."

"O Jesus, Mary., Joseph, and St. John the Baptist! change the evil disposition of Moses Ouellette, and cause, through thy piety, that he shall voluntarily and with good grace, receive carte blanche to turn back from Rome. Pray God to graciously soften his heart, so that he may entirely. devote himself to the heavenly reform of worship and of everyining that is not right in the religion which kome has inculcated upon nations and peoples. Grant unto ne. grant unto all the Métis French Canadian Exovides, and to all who volunteered for the support of Thy cause, grace to act from this time forward without ceasing, and to the end steadily. expeditionsly, immediately, with rapidity and all together. for Thy greater glory, for the honour of religion, for the salvation of souls, for the good of society, and for our greater happines, both in this world and the next." 

Occasionally the entries indicate expected revolutions within the church itself, and the choice of a new Pope:

"On the sixth of April, during the night, the Spirit of God said to me, 'In cight days, Taillefer, the Great Captain of the Ecternal City, will bring his arms to Ste. Thérese, and twenty-four hours thereafter he will be at Montreal, at nine o'clock in the morning.' ".

"The Spirit of God, throngly the intervention of His Angel, informed me that the anplearance of Captain Taillefer was a providential act in celebration of the inanguration of Ignatius Pierre Pourget as Universal Bishop."

Riel's anxiety" regarding the attitude which the Indians were to assume is reflected in a number of the visions and prayers:

"I sec a great number of oxen and wagons, which are going toward Fort La Corne. They are the Indians who have forsaken us."

"O, my God! I pray. Thee in the Name of Jesus Christ, of Mary, of Joseph, and St. John the Laptist, pardon me the sins I lave committed among the Crees, the Sionx, the Blackfect, the Jblood Indians, the Sunteaux, the Sarces, the Assinibones, the Gros Ventres, the I'iegans, the Nez Percis. the Redants, the Crcilles, the Flat IIcads, and deign to send then all to our assistance, so that Thy jity may camse them to come from the rising smo; that Thy charity may lning swiftly to us on the wings of the wind. those who come to us from the setting smin; that Thy power may send then quickly to us from the North; that Thy providence nay despatch them to us, from the South. O. my (iod! for the sake of Iesus Clirist, of Mary, of Joseph, and St. John the liaptist, canse that they all cone to us speedily, armed with good weapons and with a great quantity of ammunition.

"April nineteenth--l hear the voice of the Indian. He comes to join me. He arrives from the North. His mind is for war."

The presence of the French Canadians among the Govermment forces was vicwed as something horribly unnatural:-

"O, my God! I pray Thee in the Name of Jesus Christ, Mary, Joseph, and St. John the Baptist, condescend to remember Alderic Quimet and all French Canadians who are with Middleton. 0 , dispose their hearts and minds in my favour, in favour of Thy doings, and in the midst of battle have them love withont limits to save them and to save us by breathing into them that greatness of soul which will lead them either to lay down their arms or to make peace with us."

At the Battle of Fish Creek the Jalfbreeds lost a large number of horses. This is made the occasion for some curious moralizing:

"Oh, my Métis nation! You have long offended me by your horse races, by your bets on this detestalle matter of horse races, by your stubbornness, by your hateful contention over these bad horse races. It is on this account that the Etcrnal Clirist said that 'yesterday, while sparing you, I have killed your horses." "

"April twenty-sixth. The Spirit of God, in speaking of the Métis nation, has said to me, 'I have come to be annoyed at it, for it is too negligent. It is not sufficiently vigilant and obedient.' 
"O, my God, for Christ's sake have pity on it. Behold how charitable it is, how pleasant, how easity guided. Consider favouraluly, O great God, the great works which the Jictis nation has done for Thy greater glory, for the honour of religion, for the salvation of souls, and for the good of society."

On the twenty-seventh a general fast seems to have been celcbrated from which the best results were hoped:

"O, my God, consider in all kindness that Thy people give themselves to fasting and prayer in order to gain Thy good graces. O, lead it to repent bitterly of the fault which it committed in sayng 'Te's' too quickly. $O$, bless the fasting of Thy children, inspire the prayer of Thy people, accept the desire which it has to please Thee. (), pardon Thou its sin. Introduce this day into Thy Paradise, and at once, those whom Thou has chosen in the conflict, and whose spirits "Thum las called to Thyself."

"The road of the Metis which they follow to victories here below is also the heavenly road which conducts to Paradise the souls which the Saviour has chosen on the ficld of battle."

"April twenty-ninth-The Spirit of God made me look upon the Métis nation under the resemblance of Genevieve Arcand. It was not altogether so large as Genevieve. Its comutenance had a rather bad appearance. One could read there certain marks of a good deal of carnal haseness. It loved the pleasures of the flesli. The thought, the desires, the calculations of the flesh were the things to which it give the most attention. Still its line of progress was towards the right. It diel not wish to turn aside from that. It took a great deal of pains and gave itself a great deal of trouble to prove to me its love of justice, etc. Oh! who shall tell me the clianges which fasting and prayer can bring around in a nation of good disposition. Four days of fasting, well attencled to, can cause so much good that there is no reason why it should not change a nation that is a dwarf to one that is a giant."

"O, my Métis nation, take conrage! Your four days of fasting, prayer. and mortification have produced in you the admirable points of conversion. I see your change. It is grand."

"O, my God, grant me, for the love of Jesus Christ, etc., the grace of soon and surely making a good arrangement with the Dominion of Canada. Mercifully so arrange all things that this may be accomplished. Direct me. assist me, so that I may assure to the Xletis and the Indians all advantages which there is prescutly any means of obtaining by treaty. Accord us the favour of making as good a treaty as Thy Charitable and Divine Protection and the favourable circumstances permit us to make. Cause that Canada consent to pay me the indemnity which is my due; not a little indemnity ; but one just and equital,le before Thee and before men."

On May $2 d$ the prophet shows an tunusual tendency to self-criticism. His prayer and reflections regarding the extension of pricstly functions and characteristics are of special interest in the entries of that date:

"The Spirit of God shows me that my righteous actions were mingled with certain feelings and opinions which tarnished the whiteness and innocence of my soul.' 

"May second-The Spirit of God has given me His IJoly Approbation and has praised the for having explained religion by setting forth that in which it consists:

"Irirst-To have great confidence in God, 1hrough Jesus Christ, Mlary, Joseph, and St. John the Laptist.

"Sccond-To keep His commandments faitlıfully.

"Third-To pray withont ceasing and to he devout. Triests have been appointed to sustain the spirit of religion: They have power only so long as they are faithful to their mission. As soon as they turn aside they have no more place or usefulness. Priests are not religion. The Spirit of God has told that this was, is, and always will he true.

"May third-O, God, spread over me and my wife and children, over the Exovidat, over all my nation, the waves and torrents of Thy amiable and compassionate benclictions. I pray Thec for this for the love of Jesus, Mary, Joseph, etc. O, my God, I humbly ask of Thee in the name of Iesns Christ, of Mary the Immaculate, whon we especiatly honour during this beautiful month, and in the name of Joseph, that Thoin wouldst condescend to enroot in the hearts of our French and dear Netis the most perfect faith and the greatest confidence in Thy Holy Catholic, Apostolic, and loring Church in the New W'orld."

"Cause to descend upon each member of the Métis French Canadian Exovidat all the charitable grits of the pricsthood, all the evangelical graces of the clergy, alt the admirable iruits of Thy Iloly Spirit, that each of them may be acceptable in Thy Sight, that cach may celebrate in a gracions manner the solemn and consoling offices of the true religion. Come to all of them! Dwell in them!"

"Establish Thyself in the very midet of their spirits. Take entire possession of their very beings, that they mat receive from Thee power to forgive the sins of those who slatl confess to then, and that they may relieve from the weight of his transgressiuns every one who shall, to their satisfaction. perform acts of penance by asking Jesus Christ the spirit of repentance."

As Middleton's army approaches Batoche, Riel more and more realizes the difficulties of his position. He perceives that his "men were nothing more than little hoy's and their wives little girls, good only for fooling." and trembling between hope and despair he foresees on Nay 6th the coming capture of Batoche, which, in his vision, is called De Ponne Chairville. This event, it is to be noted, is to occur not because of the strength or wisdom of the victors, but on acconnt of the sins and folly of the Métis.

"May sixth-The place. De Bonne Chairville, formerly well situated, is now abandoned. The town of Ponne Chairville-but yesterday in good condition-has no longer anyone to protect it. I ask for help. I wish to rouse up those who simmler in the deep sleep of their sins. They don't understand. They don't hear. They don't oley me. The enemy comes up the river. He arrives. IIe proceeds to lombart the town. How is it going to resist? Nobody takes its interests to heart. It is going to fall into the hands of the conqueror, for having first almandoned God. God also abandons it. It is all over with it. 


$$
\text { . }
$$


"Oh, how many times hast Thot, O Prophecy, revealed Thyself? How many times in a century? How many times in a generation?"

On May gth, the day of Midclleton's first attack mpon Batoche, the following entries occur, of which the second quoted is the last in the journal:

"O my God, assist me. Very charitably direct me, that I may properly" arrange our perple, and that I may superintend their movenents without usclessly exposing myscli and without pusillanimous fears. O condescend to stustain me that in the hands of Thy f'rovidence I may be as trancuil and calm as a little child on its nother's breast."

"O my God, I pray Thee for the sake of Jesus. Alary, Joseph and St. John the Baptist, grant me Thy Holy Spirit of foresight and prudence, Thy Holy Spirit of comrage. Thy Holy spirit of power and of good designs, from this time forward withut coising. till the very last sigh, that we may come to the end of all our good mulertakings, and maly have the happiness of completing them with an entire regard for Thy Holy Will."

From the minutes of the Conncil we see now the military operations of the Metis were shaped and at times hampered by the interpretations placed upon the signs or omens occurring in Riel's disordered visions. On the twenty-second his lientenants were strongly desirous of attacking Middleton. To this Riel was opposed. though his reasons seem like the incoherent ravings of a mad man. Nevertheless, something of the spirit which seems to have been behind the movement is indicated in the following quotation from Riel's written protest against the plans of Dumont and his warriors:

"Respectfully and in the frankest spirit of friendship, I offer these considerations to the attention of the 'Fxovidat,' so that they may weigh my. reasons. What $\mathrm{I}$ wish is that my reason be examined; but be convinced. sirs and dear brothers in Jesus Christ, that when you have examined what I now submit to vou, if you adopt a conrse contrary to my views, I shall look upon it as an expression of permission of God, and I will help you with all my strength to carry ont your views as though they were my own to the greater glory of God."

Nothing could le more pathetic than the simplicity and crident sincerity of the religions spirit animating many not only among the leaders, but anong the rank and file of the rebel party. Passiges from Dumont's story of Duck Lake, which were quoted in the preceding chapter will occur to the reacter's mind in this connection.

Among the papers seized by Middleton at the capture of Batoche is Lepine's report of the Battle of Fish Creek. It is so full of pathos in its naiveti and transparent piety as to deserve sympathetic reading:

"I corroborate the report of Mr. Dumont up to the moment of the departure of Mr. Riel, for Mr. Riel left it to the choice of the people whether he was to go away or stay. The ancwer le received was to go and assist 

the women and cliblen. Abont half-past eight in the morning $J$ started to get something to eat at the house of the widow Tourond, and about nine o'clock we left, Picrre Ifenry, Isidore Dumas and I. to come to the coulee. Our people made signs to us that the police were coming. Then we took up our position to wait for them, and we lad hardly taken our places when shots were hearl at the other end. As soon as we heard the shots we rushed to that side. When we got there our people were already all seattered and the battle had commencel. Not long after I saw that ferome Henry was wounded, and we then took 11) a position in the coulee nearly on the bank, and I spent nearly the whole day there. The time seened so long that I thought it was already evening, but on looking at my watch I saw that it was only nom. before noon we heard slots all around us; but we heard slots also from the direction of Touron's, showing that there were still some of our people in that dircetion. In the afternoon we heard no more shots there, and I thought that our people on that side were all dead. Near us, and towards Mr. Tourond's, we heard shouts, and I think it was Gabricl Dumont and his people who were there. I know that Alec Gervais was there, for I saw him come from that direction, and then we saw that we were surromided, for we saw men on all sides; we then lieard the bugle to the right of our position and we heard the soldiers coming in the wood of the coulee, for we heard the lranches breaking, and there were others along the wool to the left; and we heard voices speaking all around us and in front on the prairie, and then I thought we were lost. When they canc into the wood we heard dreadful firing on every side. It was then between three and four o'clock in the afternoon. Ifter that they retreated, and it scemed to me that the volleys were less frequent: and about five o'clock all was quict for a good while, only a few sentinels seemed to be stationed at intervals watching us. During that period we thought they were getting ready to come and tilke us. Ifter that we said to one another. "Ve must try sometiow to kill one eacli if they come, and we must each of us dire a good shot.' Ind Charles 'Trottier counted the men there, and out of one hundred and sixty that were there at the beginning there remained but fifty-four. I do not know whether he counted the wounded. And then we consulted as to how we were to get away, and we decided to wait until night and then to run the risk of breaking our way out. But we knew that many of us must be killed in that undertaking. And then we also thought of onr wounded and it seemed to me that the only assistance I could leave them was the crucifix I had held in my hand all day, but when 1 spoke of that no person answered me; and we were praying all that time and I had the crucitix and I said, "Te shall commend ourselves to God and pray that we may have perfect contrition, so that if we die we may save our souls.' And then I prayed; for I thouglit we were about to die and I had doubts as to the justice of onr cause. Ind I thought all our people were dead and that on small party were all that remained. But Delorme did me good when he saisl to me, "The must pray to Gorl to take us out of this. And almost immediately they again commenced firing, not many rifle shots, but four canmon shots, and two or three out of the four seemed to me to burst over our heads. Ind all the halls scemed to fall like hail. And after these four cammon sluts all became quiet, and we heard a man from among the police slout to 11 , speaking in the Cree tongue. 
He said, 'His name was Borie,' and, it seemed to nue, 'that we must be hungry,' and he asked to be allowed to vi-it ws. He also asked us to tell him how many we were. And some of the others answered him, but I do not remember what they satid to him. liut they would not het him come. I was inclined to let him come, and felt tempted to tell him to come, lut I thought it better to ay nothing for fear of making a mistake and being blamed afterwards. li occurred to me that while he was with us the police would not fire, and meantime night would set in and we should be able to get away. But almost innediatcly afterwards our people cane up and the soldiers fled and rivl not fire again and we came away.

"We prayed all the day, and I think prayer did more than bullets. Often when the soldiers appeared on the hillencks our people fired and that made them fall back and others canc to remove them."

Such was the religious spirit, largely by virtue of which a handful of ignorant Halfbreed peasants withstood so long and so successfully Canada's bravest soldiery. It is the same spirit that suctained the Covenanters, hunted to the death by Claverhonse on the bleak hillsides of Scotland: that made Cromwell's Ironsides invincible; and that has inspired with heroim ten thousand humble hearts in every land where nen have truly believel themselves in immediate contact with the Divine. Poor, simple, mistaken falnatics! In the failure of their plans, the sacrifice of their lives. liberty or property, and the ruin of their hopes for the establishment through their prowess of the Kingdom of God upon earth, the rebel Halfbreeds in Saskatchewan learned the same lesson that many others, wiser and better instructed than they, have had to learn hefore and since. 


\section{CHAPTEK NXX}

\section{LIFE, CHARACTER AND FATE OF RIEL}

Parextage of Riel-Beiruended by Taché-Educated in MontrealEarly Delusions-Distetiances or 1869, i 870 -Exciting Career Prior to B.lnisiment, i875-Confinement for INSAnity-Sittlees in Western States-lnvithtox room Saskitchewan HalfBREEDS AND TIIEIR SYMPATHIZERS-REFORT ON RIEL'S MANXER OF Life-Gradual Relapse Into Par.nom-Observations and Orinions of Dr. Diniel Clarke-Evidence from Riel's Com-

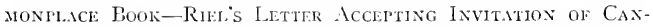
adiln Agitators-Trial-Rilis's Amiress to the CourtHoxorale: Mr. Justice Richlirinon's Sentexce and Comalents -Appeals-J_etter Audressed to Richarison by Riel_-Canada

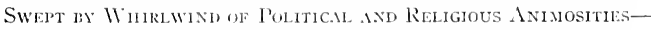

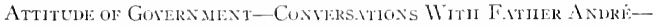
Pathetic Letrer to Riel.'s Motuher-Execution.

Louis Riel was born at Reel River in the year 1844. His Indian bloxd he derived from his paternal grandmother. His father was a bold and energetic defender of popular riglits, - as witnessed by his successful organization of an armed force of Métis to intimidate the court into releasing Sayer in 18.9 , and thus overcome the IIudson Bay Company's claim to a monopoly of the fur trade. The son of such a father might well prove an uncontrollable tribute of the IIalfbrced people. Iis mother was Julie de Lagimodière, the first white woman born in the West. According to Ilayilon. Ricl came of a very mixed stock,--Indian, French, Irish and Scandinavian,and Riel himself seems to have believed that he could trace his ancestors from Sweden to Germany, France, Ircland, and finally to Lower Canada. The accuracy of this genealogical tree is, I think, open to very serious doubt. At all events, his faults, virtues, nanner and general appearance were those typical of the French Ilalfbreel.

On returning from a prolonged Episcopal tour, Archbishop Taché fomucl in the little college attaclied to his Sce at St. Bonjace, three Mretis lads of special promise: MacDougal, Scotch ; Schmidt, German : and Ricl, French. The Archbishop took strong personal interest in the young students and also interested in them a wealthy and pious French lady, while in Montreal 

in 1858 . Accordingly, the young men were given an opportmity to attend colleges in Lower Canada. Nine years later, while in Montreal on a visit. the Archbishop again met Riel and told him that as he had now secured an education, he must endeavor to carve out for himself a respectable carcer.

It had been intended that the lad shonld become a priest, but Taché had already realized that he was unfitted for holy orders. The erratic nature of the boy's disposition was already crident. He was subject to delusions which led him into some astounding escapades. On one occasion he entered the lome of a wealthy citizen of Montreal and demanded ten thousand dollars, with which to carry on some Quixotic crusade. This request was, of course, refused. On another occasion during his school days, he induced his fecble minded old mother to sell her effects in order to supply him with the funds necessary for his plans. The poor old woman did as she was bid and set out on a three weeks' journey of four hundred miles in a Red River cart to meet an appointment with her son, in I867. On reaching her destination she found waiting her only a letter from young Riel, explaining that still another important mission had presented itself which required him to remain in Montreal. This same year, however, he returned to Manitoba where his unquestionable ability, superior schooling, fervid imagination and oratorical powers soon won him a position of leadership among the Métis.

The part which he played in the disturbance of $I S(n)$ and $I 870$ has already been related. His apologists have made numerous but unconvincing attem!̣ts to palliate his condnct in connection with the execution of Scott. but it seems probable that that tragedy was simply the product of homicidal mania.

In $I 87$, on the occasion of the threatened Fenian invasion, it will be remembered that Riel responded to the summons of Lientenant-Fovernor Archibald by raising and placing at his disposal an armed force of some two hundred and fifty mounted Halfbreeds. In the following year, Riel was a candidate for the Dominion Parliament in the constitnency of Provencher, which he could certainly have carried. However, through Taché's influence, he was induced to retire in favor of Sir George Cartier, and at the request and with the financial assistance of the Ottawa Cabinet, he left the country for a time. Sir George Cartier died in ${ } 8_{73} 3$ and Riel, who had now returned. was elected by acclamation. He went to Ottawa, but found Ontario then too hot for him, as on November 15th. Henry J. Clarke obtained from a grand jury a true bill against him for the murder of Scott. He was never placed upon trial, however, and in the general clections of $1 S_{74}$ he was again returned for Provencher. He attempted to take his seat, but on a vote of 144 to 68 he was expelled from the Honse. On February 15, IS75, he was banished for a period of five years.

Nevertheless, he returned to Quebec, where his mental condition again caused his friends great anxiety. In 1876 , at Montreal, he on one occasion 

made a noisy interruption during mass. He declared himself the superior of any of the dignitaries present and demanded permission to conduct the service. Official inquiry into his mental condition then resulted in his being committed to the asylum at Longue Point, from which he was presently transferred to Beauport Asylum. Being released after a year and a half he went to Washington, where his insanity again manifested itself. He was placed under arrest, but was liberated shortly afterwards and allowed to return to his family.

In 1878 he was for a time in Ninnesota and in the following year he settled in Montana. There he followed various occupations with but indifferent financial success. His unsettled labits and erratic character made him the object of much well founded suspicion on the part of the authorities of that State, with whom in 1879 we find him in serious trouble. Ilowever, after his marriage with a French Canadian Ilalfbreed, he settled down to the useful if prosaic carecr of a school teacher. In this capacity he was employed at the St. Pierre Mission when he unfortunately was visited by the delegation representing the Ilalfbreeds of Batoche and its vicinity, and received the letter elsewhere quoted. ${ }^{1}$ in which his old friend, the venerable missionary, Father André, urged him to come to Saskatchewan. The conditions under which Riel was then living are interestingly portrayed in the following report presented by the delegates upon their return:

"We have travelled the long journey of about seven hundred miles to seek an interview with Mr. Riel.

"We had to go to the Territory of Montana, as far as St. Peter's Mission, situated in the County of Louis and Clark, beyond Sun River, at the foot of the Great Rockies.

"We found him humbly and respectably employed as a teacher in the Industrial College of the Jesuit Fathers of that place. After having acquainted him with the object of onr mission, we handed him our credentials and the six resolutions on which we had to consult with him, also the document whereby our public invites him to the North West. We asked him to come with us if he could and to aid us. This interview took place on the $f_{\text {th }}$ of June. Mr. Riel read our papers of trust, and begged to be allowed twenty-four hours to think the matter over before giving an answer.

"We were received hy Mr. and Mrs. Riel in a very friendly manner; their courtesy was sincere, simple and true. Generally when one enters the house of a very poor man the feeling of the visitor is more or less painful, but, entering Mr. Riel's house, our impression was different. The humble condition of his home reminded us of the opportunities he had for several years to become rich, and even to make an exceptional fortune, and how at all risks he stood firm by the confidence of his people. We know how much he wrought for Manitoba, and how much he struggled for the whole North West, and sceing how little he worked for himself, we came

${ }^{1}$ See Chapter NIX. 
back after a long trip of some fourteen hundred miles, with twice as much confidence in him as we had on leaving to go and seek him in a foreign land."

Had Riel remained amid the quiet and wholesome influences surrounding him in his home at St. Pierre he would probably not again have suffered from the mental disease that had clourled his youth. Indeed, for a considerable time after his return to Canada his conduct was cntirely rational. The long months of excitement and disappointment, the adulation of his followers and the flattering cnmity of his opponents then again unhinged his brilliant but unstalle intellect. He again commenced to see visions. In season and out of season, night and diy, he devoted himself to religious observances, though not many months had elapsed before he liad established himself at the head of a religious crusade directed against Roman hierarchy. He himself assumed sacredotal functions, administering baptism, hearing confession, granting absolution and pullicly celebrating confirmation at the altar. In order to transnit to the congregation the breath of the Holy Spirit, he uttered three long and penetrating cries. ${ }^{2}$ In brief, he developed all the marked evidence of religious mania and his old dreams of a special divine mission took entire possession of his mind.

To quote from Riel's specch at his trial:

"Some persons," he said, "had known beforehand of my supernatural power, but I only knew it myself on the ISth of Deccmber, is74. The late Archbishop of Montreal, Monseigneur Bourget, was the first to inform me of this favor of the Saviour. This learned prelate wrote to me and I have his letter still in my possession, that I had a mission to fulfill. At first I was inclined to doubt it, but later on I recognized nuy error.

"On the I8th of Decenber. I874, while I was seated on the top of a mountain near Washington, in Dakota, the same spirit who slowed himself to Moses in the midst of the fire and clond appeared to me in the same manner. I was stupefied; I was confused. He said to me, 'Rise up, Lotis David Riel, you have a mission to fulfill.' Stretching out my arms and bending my head, I received this heavenly message. I have worked for men, and with what success the world already knows. Events are not finished in a few days or in a few homrs. A century is but a spoke in the wheel of eternity. I have obtained practical resuls, but much more still remains to do."

When the actual outbreak occurred, Riel was, in point of fact, so insane that the real work of leadership had to be assumed by Dumont and his associates.

Dr. Daniel Clarke says: "I spoke to some of the Halfbreeds who were in all the engagements with Riel, and they uniformly said he was not the sanie man after the first fight. If seemed to have changed entirely, and became frenzied. He organized no opposition aiter that time, did no fight-

2Authority: Dr. Daniel Clarke. 
. 
ing, but was looked on as inspired by his deluded followers, and ran about from pit to pit holding aloft a crucifix and calling on the Trinity for aid."

On July 28, 1 $8 S_{5}$, the distinguished alienist to whom we have just referred visited Riel in his prison at Regina and subsepuently reported as follows :

"He was very talkative, and his egotism made itself manifest, not only in his movements, but also in his expressed pleasure in being the central figure of a State trial, which was likely to become historic. The writer stated to him that his lawyers were trying to save his life by proving that he had been insane. At this statement he got very much excited, and paced up and down his cell like a chained animal, until his irons rattled, saying with great vehemence and gesticulation, "My lawyers do wrong to try and prove I am insane. I scom to put in that plea. I, the leader of my people, the centre of a national movement, a priest and prophet, to be proved an idiot! As a prophet I know beforehand the jury will acquit me. They will not ignore my rights. I was put in Longue Point and Beauport Asylums by my perscentors, and was arrested without canse when discharging my duty. The Lord delivered me ont of their hands.'

"I questioned lim very closely as to his plans in the past, but he did not seem to be commmicative on these points. He said he would insist on examining the witnesses for himself. He did not feal disposed to allow his lawyers to do it for him, if they were determined to try to prove he was insane. During the trial he made several attempts to take the case into his own hands, as in questioning the witnesses his importance seemed to be ignored by his counsel. I asked him if he thought he conld elicit more on his own behalf than men expert in law coukl. He proudly said, 'I will show you as the case develops.' II walked abont a good deal as he talked, at the same time putting on his hat and taking it off in a nervous way. His filgety way, his swagger, his egotistic attitudes, his evident delight at sucl a trying hour in being so conspicuous a petsonage impressed me very strongly as being so like the insane with delusions of greatness, whether paretics or not. A hundred and one little things in appearance, movement and conversation, which cannot be described in writing, are matters of everyday observation by asylum medical officers. I may say they are almost intuitions in this respect. Sucl knowledge as this which we acquire by everyday acquaintance of the insane would lie laugled ont of court by the legal profession, who cannot discern any valid evilence that does not tally with a metaphysical and obsolete definition.

"It was evident to me that Ricl was concealing to some extent the inner workings of his mind, and that he lad an object in view in hiding his thoughts. I endeavored to make him angry by speaking contemptnously of his pretensions. He only shrugged his shonlders and gave me a smile of pity at my ignorance. I touched upon his selfishness in asling thirtyfive thonsand dollars from the Government, and on receipt of it to cease agitation. He smiled at my charge and said that the money had been promised to him and was due to him. IIad he received it he would have established a newspaper to advocate the rights of his kindred. It wonld have been a glorious work for lim to lie able to control a newspaper, and to promulgate in print lis mission to the world. 

"Dr. Roy and myself hat a second examination of Riel at the Police Barracks on the evening of the 28 th of Jilly. He was closely catechized by Dr. Roy in French and by me in English. The insanity plea was abhorrent to him and he scorned to take that ground, even to save his life. Friends and foes were convinced of his honesty and candor in his repudiation of this defense. Ile would rather die as a deliverer than live as a lunatic.

"Suddenly he calned down and with great self-possession said, "His legal friends had mistaken his missinn. At present he was an important State prisoner and he was suffering not only for himself but also for others." He also told me that he wrote a book, which was still in existence. In it he clearly proved that he was a great prophet, and as a prophet he knew beforehand that a verdict would be given in his favor. I closely questioned him as to why he thought so, but his only reply was in putting his hand to his heart and saying, pathetically, 'It is revealed to me.' 1 informed hin that there was a bitter feeling hostile to lin ontside, and that so far the evidence was strongly against him and that he would probably be hanged as a felon. Ile smiled cynically at my ignorance, but the alternative did not seem to affect him. 1 told him the feeling had not subsided for the murder of Scott in 1870. In reply he said the North VTest Council sentenced Scott to death for treason. He was only one of the thirteen. He suddenly broke away from this subject and began to pour ont a torrent of vigorons language on the head of Dr. Schultz, of Winnipeg. Whom he associated in some way with Scott and the rebellion of 1870 . Before 1 left he came back to the fulcrum iclea that he was yet to be a great political and religious leader, who would revolutionize the world."

In dealing with so obscure a stubject as the evidence of irsanity lay opinions are of little value. To the Queen's Quarterly of April and July, I905, however, another well known authority on mental disease, Doctor C. K. Clarke, contributed a "Critic Study of the Case of Louis Riel," to which I am already indebted. Says he:

"Riel was simply a case of evolutional insanity. which would, in the modern school, no doubt, be classed as one of the paranoiac forms of dementia. The first manifestations, as were to be expected, were observed when he was at a critical period of his loyhood, and even then the egotism. which is so characteristic of the paranoiac, was apparent.

"Among well-educated people his mental defect would, early in the day, have led to his confinement in an institution, but among the ignorant Métis, suffering from wrongs they thought unbearable, Ricl, with his education, prophetic and inspired pretensions, naturally became a leader.

"Those of us familiar with paranoia do not for one moment think that rineteen months' residence in Longue Point and Beauport in 1876 resulted in a cure, but no doubt there was a favourable remission, and a lapse into a condition of comparative quiet, such as we are accustomed to see every day. If Riel could have been left quiet in the Jesuit school in Montana the chances are that he would never again have been heard of, as in the monotony of that humdrum life there was enough to keep his mind employed in safe directions, but there was no incentive to let his delusions 

and hallucinations carry him and others to destruction. It was certainly an evil hour when Dumont and his associates planned their visit to Montana.

"Before the Duck Lilke fight Riel was a mental weakling; after that event a maniacal paranoiac beyond the reach of human control, useless as a leader and a menace to the lives of friends and foes alike. The contention that he was posing simply to excite lis countrymen who believed in his inspiration to carry on the rebellion is without force. The successful charlatan is built on very different lines from Louis Riel; his mission was no trumped up affair to him, and his consistency was lie consistency of the insane enthusiast. What of it if he did resort to trickery, deception and intrigne at times? Surely sanity has not the monopoly of these things."

The pages of the Commonplace Book, seized at Batoche, are filled with the incolierent outpourings of a disordered mind. Take the following extracts for example:

"The Spirit of Gorl showed me that I had a piece of wood of some length under my feet. I gave it several strokes with an axe. I suppose four. and it seemed to me that these four strokes lad no more force than if I had only given two. I had searcely perceived this, yet I had made formidable notches on the long picce from the aspen tree of good size, which I had under $m y$ feet. I shall hold it under my right foot and remain, axe in hand."

"The Spirit of God has made me see a shadow which passed. It disappeared from before my view almost hefore I had time to look at it."

"When I close my eyes I see a light greater than that of the sun."

On May 6th he addressed a frenzied appeal "To the Citizens of the United States of America," throngh the lrish IVorld. Nevertheless, during the same period of distress and alarm, we find him confiding to his diary columns of bitter vituperation against America and the Americans:

"The Spirit of God put me into a conveyance with Michael Dumas. We set out for the United States. I accompanied him for a certain distance. We talked of the United States. I don't remember the words of the ideas I expressed, but I finished by saying, 'Look on me as an example to thee.'

"I parted from him. I returned. IIe went on. As I was looking at him proceeding on his way. I perceived a large red colored serpent, which went after him. This serpent, however, had no attendants. But it was large. I did not attach much importance to it. I turned back in order to go to the place from which I had come. There was a certain space of the land around me clear and clean. All the rest swarmed with serpents. There were more serpents than I could tell you of. Oln, the invitation of American help is a dangerous one. Take care of adventurers from the United States, for I assure you that they are to be feared. They have neither manners. faith nor heart. They are dirty dogs, foul jackals, raving wolves, furious tigers."

"O, nỵ God, preserve 11 from the misfortme of having anything to ro 

with the United States. Let the United States protect us indirectly, spontaneously, and by the arrangenent of Thy Holy Providence, but niver by a direct engagenent, or by any understanding on our part."

"I have lived miserably in the United States among serpents, in the very midst of poisonous vipers. 1 was there so surrotmder! that whenever I wished to place my feet I saw them swarning. The gromel was positively alive with thent. The United States are, in at sense, a perfect hell for an honest man. The virtuons, respectable family is there held in discredit; it is turned into ridicule; it is made a jest of. $O$, it is an awful misfortune to be obliged to seck a refuge in the Linited States."

A fact that subsequently told heavily against Riel was that during the period of agitation prior to the rebellion he expressed his willingness to withdraw from the country if a sufficient financial consideration was offered by the Dominion authoritics. Even this serious misstep was perlups not entirely in conflict with his grandiloquent claims to be engaged in a great public mission. As has already been indicated, it was part of his dream to establish a great paper which would be the organ of Halfbreed interests in the United States and Canada and it is not improbable that in the suggestion of obtaining a large sum of money from Ottawa he thought he saw the means ultimately of righting his people's wrongs by constitutional methods. Noreover, he had long cherished the idea that the Dominion Government actually owed him a large sum of money and when he came over from Montana it seems quite evident that he expected to return thither. Nuch additional evidence could be quoted in this connection, but the following letter ${ }^{3}$ addressed to delegates will suffice for our present purposes :

"To Messrs. James Isbister, Gabriel Dumont, Moise Oucllette, and Michel Dumas.

"Gentlenen:- You have travelled more than seven lundred miles from the Saskatchewan comtry, across the international line, to make me a visit. The communities in the midst of which you live lave sent you as their delegate to ask ny advice on various diffeultics which have rendered the British North West as yet unlappy under the Ottawa Govermment. Moreover, you invite me to go and stay amongst you, your hope being that I. for one, could help to better in some respects your condition. Cordial and pressing is your invitation. You want me and my family to accompany you, I am at liberty to excuse myself and say 110 . Yet, you are waiting for me, so that I have only to get ready, and your letters of delegation give me the assurance that a family welcone awaits me in the midst of those who have sent yon. Gentlemen, your personal visit does me honor, and canses great pleasure, but on account of its representative character, your coming to me has the proportions of a remarkable fact; I record it as one of the gratifications of my life. It is a good event which my family will remember, and I pray to God that your delegation may bccome a blessing anongst the blessings of this my fortieth year.

${ }^{3}$ The italics are mine. N. F. B. 


$$
\text { . }
$$


"To be frank is the shortest. I doubt whether my advice, given to you on this soil concerning affars on Candian territory, conld cross the boriters and retain any inllucnce. lint here is another view. The Canadian Goa'crnment oa'c me tao hundred and fifty acres of land, according to the thirtyfirst clause of the Manitoba traty. They oace me also five lots, waluable on accomnt of hay, timber and rizer frontagc. These lots were mine according to the different paragraplis of the same thirty-first clatuse of the above mentioned Manitoba treaty. It is the Canatian Government which has depriver me, directly or inclircetly, of those properties. Besides, if they only pay attention to it a minute, they will casily find out that they orec me something clse.

"Those, my claims against them, are stich as to hold good notwithstanding the fact that I have become an Ancrican citizen. Considering then. your interest and minc, I accept your a'cry kind invitation. I aill go and spend some time amongst you. By petitioning the Government with you, perhaps we will all have the good fortune of obtaining something. But $m y$ intention is to come back carly this Fall.

"Montana has a pretty numerous Halflucerl elenunt. If we count with them the white men interested in the Halfbrecl welfare, by being themselves heads of IJalfbreed iamilies, or related to then in any other way, I believe it safe to assert that the I lalfhreed element of Montana is a pretty strong one. I am just getting acquinted with that element. I am one of these who would like to unite and direct its vote so as to make it profitable to themselves and useful to their fricnds. Noreover, I have made acquaintance and friends amongst whom I like to live. I start aith you but to come back here some time in Scptember.

"I have the honor to he, gentlemen delegated to me,

"Your humble servant. "Louis Rir..."

With the public mind still agitated by the great loss of life and property which the rebellion entailed, and especially by the Indian atrocities which had threatened to be the prelude of a general massacre of the white population, the issue of Riel's trial, if it were to take place before an English jury at Regina, was a forcgone conclusion. Moreover, the fact that a capital charge was, in accordance with the laws of the Territories, to be conducted merely by a Stipendiary Magistrate assisted by a Justice of the Peace with a jury of only six persons, excited gencral alarm among his sympathizers, especially in Lower Canada. A considerable fund was raised for his defense by popular subscription and Messrs. Charles Fitzpatrick and F. X. Lemieux, of Quebec, were cmployed as his counsel, and with them were associated Messrs. J. M. Grcenshields and T. C. Johnson. Earnest efforts were made to secure his trial hefore the Supreme Court, and in Lower Canada, but without avail, and on the First of August the jury of Regina brotight in a verdict of guilty. with a recommentation to mercy.

Before sentence was passed. Riel made a long and passionate oration, 
in self-justification, prefacing his speech by prayer for himself, the Magistrate, the jury and all others concerned in his trial. Those who heard this address speak of it as very impressive, but it is not so in cold print. It is evidence not of the reasomablenes of Riel's conduct, but of the persistent and malign influence of an idse firc.

In pronouncing sentence, $\mathrm{Mr}$. Justice Richardson spoke as follows:

"Lonis Riel, after a long consideration of your case, in which you have been defended with as great ability as I think counsel could have defencled you with, you have been found, by a jury who have shown J might almost say unexampled patience, guilty of a crime the most pernicious and the greatest that man can commit. You have been found guitty of high treason. You have been proved to have let loose the flood gates of rapine and bloodshed. You have, with such assistance as you had in the Saskatchewan country, managed to arouse the Indians, and have brought ruin and misery to many families, who, if you had simply left them alone, were in comfort, and many of them were on the road to affuence.

"For what you did, the remarks you have made form no excuse whatever. For what you have lone the law requires you to answer. It is trite that the jury, in merciful consideration, have asked Her Majesty to give your case such mercifill consideration as she can bestow upon it. I had almost forgotten that those who are defending you have placed in my hands a notice that the objection which they raised at the opening of the court must not be forgotten from the record, in order that if they see fit they may raise the question in the proper place. That has been done. But, in spite of that, I cannot hold out any hope to you that you will succeed in getting entirely free, or that Her IIajesty will, after what you have been the cause of doing, open her hand of clemency to you.

"For me, I have only one more duty to perform, that is to tell you what the sentence of the law is upon you. I have, as I nust, given time to cnable your case to be heard. All I can suggest or advise you is to prepare to meet your end. That is all the advice or suggestion I can offer."

Upon the question of the jurisdiction of the local Court, Mr. Fitzpatrick appealed for a new trial, but on September gth, the Court of the Queen's Bench at Winnipeg confirmed the legality of his trial and sentence. Accordingly a new trial was refused. An appeal was then made to the Privy Council in England, but it failed also. Meantime an official inquiry had been made into the question of Riel's sanity. but this we would not err in characterizing as merely an idle form.

When the prisoner was informed of the brief reprieve granted to allow of this investigation he addressed to Judge Richardson a curious and touching letter of thanks. It reads as follows:

"To His Honor "Juclge IItugh Richardson.

"Sir:-God, whose mercy is great for all men, has made nse of your honorable hand to sign in my favor another postponement. When the 
FACSIMLE OF LETTER FION RIEL TO MDGE RICIIARDSON ON THE ANNOUNCEMENT OP A TEMPORART REPRIEVE.

Pegina Gail SHov. 14 the 1885: So His Houn Gudya thugh Rekenieon. Sir,

Or have heisid by cleance nomu. of nuy quars opee thy in the guand roon about a reposter of the Gloke, is theith, vishing is have on intesineve urith me ois that to wres efft on youn

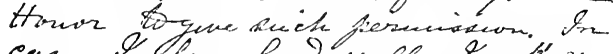

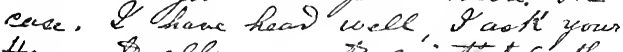
Howor is allow ane is seni that Guatle. man of the Glake.

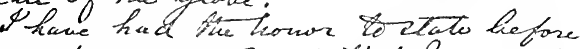
Yom trounable Count ther If am the

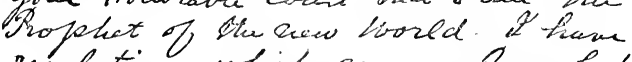
revelotions whide concus from fod

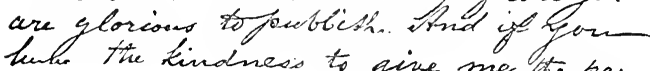
turbe the kindness to gine me tre per- miscion of an intervieu with the Glabe reparter, I will tong that it te not only useful to the nam world but 

498

thet it be agreable on where whon

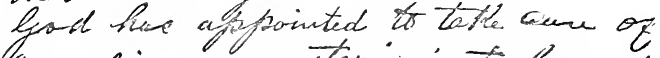
nue bive my attering intis beavene

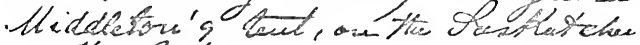
an tloy levat:

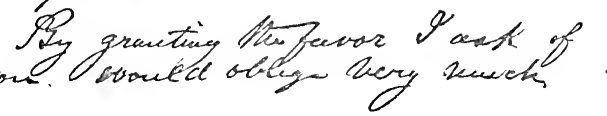

Youn hery respertfuele and obedunis revenas an pressover,

Qonis Paind Rie

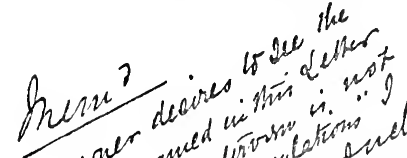

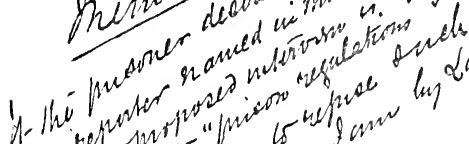

$$
\begin{aligned}
& \text { netrow }
\end{aligned}
$$

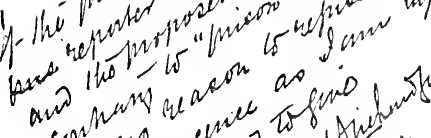

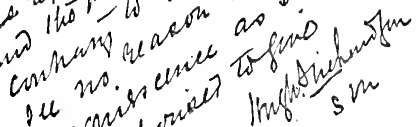

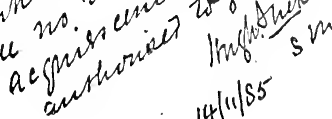

$$
\begin{aligned}
& \text { 14111155 }
\end{aligned}
$$



document was being read to me. I was at the same time hearing the voice which habitually and mercifully speaks to me from above. The voice of my salvation was saying: Acknowledge most openly my help and kneel down before me and before my servants.

"Thus I knelt down, according to the word of my Lord, thanking him for his divine mercy and thanking the Empire for its clemency.

"As to you, Judge, I sincerely pray to God, through our Common Redeemer, that you may be amongst the first who will acknowledge me for the prophet of the 'New World,' and that through our God's mercy, it may be so written, to your injury nor to mine; but to your best advantage in every possible way and to my greatest lappiness. For there is nothing impossible to God. What is not possible to man, is possible to Him.

"Receive with my acknowledgment, my best wishes.

"Your humble and obedient prisoner,

"Nov.

“Louis 'D.IVID' Riel.

12th,

1885 ,

Regina

Jail."

All Canada was now convulsed in the agitation for or against the execution of Riel. A careful examination of the press at that time shows, however, that his fate had become mercly an incident in a general outbreak of racial, political and religious animosities. The leading newspapers of Toronto, for example, clianged front from time to time with astonishing and discreditable alacrity, to defend or to decry the utterances of political leaders, swayed by the ebl and flow of popular passion. Among the extreme wings of protestant fanaticism, Riel's execution was denanded, not for his doings at Batoche, but for the murder of Scott, fifteen years before. This aspect of the case was even publicly defended in Parliament and elsewhere. The Honorable John S. D. Thompson, Minister of Justice, said on this subject:

"The policy of considering what the past history of the convict has been is one which is recognized, not only in the practice of every tribunal administering criminal justice, but is recognized by Parliament as well."

The agitation in Quebec was as unreasonable as that in Ontario, though inspired by the most contrary motives, and it continued for a long time, maintaining throughout its dangerous racial and religious character. It is an exercise making for humility for a Canadian of today to study the newspaper files of the year following the rebellion.

In spite of the storm of protest from French and Catholic quarters, the Govermment stood firm in its ultimate determination to let the law take its course and to refrain from any exercise of executive clemency on Riel's behalf. Consequently, on the 16th of November, 1885 , the rebel chief paid 

the forfeit of his life on the scaffold at Regina. Whatever his past crimes, his conduct in the trying time immediately preceding the final tragedy was calm, courageous and befitting of a Christian's last hours. "Nothing in his life became him as the leaving it."

"All the night preceding his death," said Father André in a personal letter to Mr. F. X. Lemienx, "Riel manifested not the least symptom of fear. He prayed during a great part of the night, and that with a fervor, a beauty of expression and a look which transfigured linin and gave to his features an expression of celestial beanty. All night long he had not a word of complaint against his death sentence, or against lis conspirators. He was happy; joyous to see his captivity about to end. He often said to me: 'I cannot tell you how glad I am to die; my heart leaps with joy!' and he would langh $\dot{d}_{\mathcal{c}}$ bon coeur. He embraced me with effusion and thanked me warmly for having remained with hin to the end. . . . He said to me, emphatically, 'Do not fear. I will not shame my friends nor rejoice my enemies, nor the enemies of religion by dying like a coward. For fifteen years they have pursued me with their hatred and never yet have they made me flincli; today still less when they are leading me to the scaffold; and I am infinitely grateful to them for delivering me from this harsh captivity which is weighing upon me. I assuredly have my relatives, my wife, my children, my cotmtry and my compatriots: the prospect of being free and of living with them would have marle my heart beat with joy. But the thought of passing my life in an insane asy im or in a penitentiary, mingling with all the scum of society and obliged to submit to all insults, fills me with horror. I thank God for having spared me this trial and I accept death with joy and gratitude.

Among the letters to which Father Andre refers, was one to his mother. Nothing but the serious clesire to arrive at a fair and rational julgment regarding the character and mental condition of the writer, can justify the reading of this sacred message: but with that motive as anthority, we may properly consider this last sad communication to an aged mother. from a son awaiting his executioner.

" $\mathrm{My}$ Dear Mother:-I received your letter of blessing and yesterday, Sunday, I asked Father André to place it upon the altar during the celebration of mass, that its spirit might be liffused upon me. I asked him then to place his hands on my head so that I might receive it with efficacy, since I could not go to the church, and it has thus shed upon me the graces of the mass with its abundance of benefits, spiritual and tempora!.

"To my wife, my children, my brothers, my sister-in-law and other relatives who are all dear to me, say farewell on my behalf.

"Dear mother, it is the desire of your eldest son that your prayers for me may mount to the throne of Jesus Christ, to Mary, to Josepl, my good protector, and that the merey and abundant consolations of God may be shed upon you, npon my wife, my children and other relatives from generation to generation,- the plenitude of spiritual blessing in return for those you have called down upon me: and that they may rain especially upon you, 

who have been for me so good a mother. May your faith, your hope, your charity and your cxample le as a tree baden with abundant fruit for the present and for the funtre. May God, when your last hour sounds, be so pleased with your piety that IIe will cause your spirit to be borne from the earth on the wings of angels.

"It is now two oclock in the morning of this day, the last I am to pass upon this earth, and Father Arrlre has told me to hold myself in readiness for the great event. I have listened to lim and intend to do everything according to his desires and recommendations.

"God is holding me in his land to keep me in peace and quietness, as oil is held in a vial, so none can disturb. I an doing what I can to be ready: I am even calm, in accordance with the pious exhortations of the venerable Archbishop Bourget. Yesterday and today I prayed God to reassure you and to dispense to you all manner of consolation so that your heart may not be troubled by care and anxiety. I am brave. I cmbrace you with all affection.

"I embrace you as a son respectful to his duty; you, my dear wife, as a Christian husband in accordance with the spirit of Christian marriage; I embrace your children, entrusting them to the greatness of divine mercy. And you all, brothers and sisters-in-law, relatives and friends, I enbrace with all the affection with which niy heart is capalle.

"Dear mother, 1 am, your som, affectionate, obedient and submissive. "LOUIS D.VID RIEL."

At a quarter past eight in the morning, the Sheriff's assistant appeared at the door of the cell, where he stood in silence, drearling to announce the fatal order of which he was the bearer. Riel came to his relici, saying to him without the least eridence of enotion, "Mr. Gibson, you want me? I an ready."

His habitual courtesy and thoughtfulness marked his conduct to the last. At the seaffold Riel was the most seli-controlled of all the party, and inmediately before deroting himself to his final prayer he endeavored to comfort his revered old friend and confessor, Father André. He was praying earnestly when the fatal bolt was shot, his soul passing to its ultimate tribunal as he uttered the words "Jesu! Marie! Assistez-moi."

Upon the wisdom or justice of his execution, I do not feel called upon to express my personal opinion, but I have endearored faithfully to portray Riel's actual character and impartially to marshal the facts of his case for the consideration of my readers.

Had Riel retained in his grasp the tiller of his mind, and, while paticntly. championing his people, restrained them from foolish violence, any position in the gift of the West might lave been his.-Alas, the pity of it! 


\section{CHAPTER IXXI}

\section{MISCELLANEOUS REBELIJION ANECDOTES}

Deatu of D'Arcy B.Aker-John Pate, axi the Gunfowder-"Grand Rounds"-The Forgottex Countersigx-The liefegees from Poor MAn's Reserte-AN Audicioes Fishermax-Foragixg-

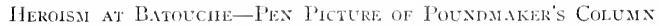

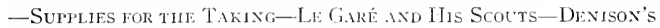
Buglers-Ax Unlucky SextiNel.

In connection with the rebellion of 1885 , innmerable interesting and illuminating anecdotes might be related, illustrative of hoth the humorous as well as of the pathetic and tragic aspects of the insurrection. Of the many that have been brought to the writer's attention, a few have been selected for the present chapter.

One of the most inspiring is the story of the death of Private D'Arcy Baker, who was fatally injured at the battle of Fish Creek. After the engagement, poor Baker was lying in one of the hospital tents when he heard the shots of a night alarm. Staggering to his feet the heroic fellow called aloud for his horse and rifle, and then fell dead as he endeavored to make his way from the tent. This pathetic incident called forth a poem by Mr. Murdoch, of Birtle, in which occur the following verses:

" 'My rifle and ny horse, the soltier said, As forth with vigorous step he quickly came: On his young brow the morning sunlight playd And life was centered in his active frame.

"By winding streams far cier the plain we go, Where dark ravines and woody bluffs appear, Where er a swarthy, treacherous Intian foe May hide, to burst upon our flathing rear.

"The sulphurous smoke is drifting to the sky. And horse and rider on the plain are spread; The ambushed foe, in sullen terror fly.

The bold and brave are now annongst the dead.

"With shatterest heart, the stricken soldier lies, The fatal womnd has almost ceased to bleed, The dying warrior vainly secks to rise.

And hegs once more, his rifle and this steed. 

"Forever more the youthful limbs are still,

The young, the gailant, and impulsive lirave

Now rest beside the far-off western hill,

And wild flowers blossom by his lunely grave."

A notable example of cool courage occurred at Duck lake slortly before its evacuation by Mr. Hilliard $\lambda l$ itchell and his subordinates. Among these was the daring scout, John Paul, since then well known in Saskatchewan. The district was already in the hands of the enemy, and as there was in $\mathrm{Ml}$. Mitchell's stores a considerable supply of ammunition, the keenest anxiety was felt lest it should fall into the hands of the Halfbreeds. Some of these dangerous supplies Paul removed to safe quarters by a courageous stratagem, a few days before the Battle of Duck Lake. He placed the anmunition in a sleigh or "jumper" and covered it with a few arm loads of hay upon which he himself sat withont any attempt at concealment as he drove away. The disaffected Halfbreeds and Indians dicl not guess his purpose, and allowed him to escape in safety.

It is not surprising that among the focal volunteers and home guarrls it was difficult to maintain anything approaching to strict military discipline. Indeed, the pranks of the men were often like the escapades of irresponsible school boys.

After the battle of Duck Lake, Mr. Neilson, now Sherift of Prince Albert, was made sergeant, and in company with two of his superior officers, it was his duty to ride on tours of inspection around Prince Albert during the night, visiting the sentries on "Grand Rounds." On one occasion he and his companions went to a spot where they shonld have found two IIalfbreed sentinels, but no one was to be seen. They stood quietly in the darkness for a few moments, listening for any sign, and presently heard heavy trampling in the snow some distance away. Sergeant Neilson challenged, "Who goes there?" and received the astonishing answer. "Grand Rounds." Fortunately, however, the party who really constituted "Grand Rounds" held their fire, and presently descried through the darkness their two delinquent Halfbreeds. They had wearied of the monotony of their duties and were making the rounds by themselves, one mounted on the other's back.

On a certain occasion, Joseph Mackay, the well-known scont and policeman, was returning to Prince Albert on a scouting expedition, when he was suddenly brought to a halt as he was crossing a culvert, by the challenge of a sentinel concealed in a ditch. Immediately after he stopped his horse, the command was repeated, the sentinel shoving his gm into the horse's face. "Can't you see that I have halted?" said Mackay. "Well, halt?" shrieked the sentinel a third tine, "and give me the countersign." "Say, Lill, do you know what the comntersign is yourself?" said Mackay, who by this time had recognized the man on duty: "No," said that worthy, "I don't." 


$$
\text { - }
$$


"Well, then, what the devil's the use of giving it you?" said the scout, who was then allowed to pass.

Jos. Mackay's father-in-law, whose name was also Jos. Mackay, was the farm inspector of Poor Man's reserve. He and his wife and daughter were wakened up one morning at two oclock by a wild band of Indians, who looted the house, and ordered the instructor to come ont with them and unlock the stables so that they might more easily get possession of the Govermment horses. I Cree woman who was present whispered to Mrs. Mackay that they intended to murder her husband. Mrs. Mackay then turned on the chief, speaking to the following effect: "When I came to this reserve your children were sick and I tended them myself. I clothed them with the clothes supplied by the Government for my own children. When your baby died I myself bathed and dressed it and prepared it for its funeral. My husband has lived among you all his life. He has traded with you from the forest country down to the American border, and has never done any of you any harm. Even if he had, none of you was ever man enough to stand up before him in the daylight, and now you come to murder him by a shot in the back at night. I would never have believed you had so little manliness in you."

As Mrs. Mackay ceased speaking, her husband took the keys of the stable from his pocket and gave them to the chief, telling him to get the horses himself. The chief sent his band to the stables for this purpose, and as soon as they had left the house he cried to Mackay and the women to follow him. IIe ran in the opposite direction down the river bank, where he produced an okl canoe from among the bushes. The river was frozen to about one-third on each side, but was open down the entre, into which he placed the canoe, imploring the white people to enter quiclily and cross to the opposite side. The canoe was leaking badly, lut if they made haste they would get across. He also gave Mackay his hunting knife, and ordered him to slit the canoe from end to end when he hat reached the opposite bank. Having crossed the river, Mackay and the women proceeded twelve miles through the darkness and made for Bresaylor, the headquarters of Bremner, the well-known IIalfbreed fur trader. Father Cuchon, of Bresaylor. warned then that they were still in imminent danger, as the Indians and Halfbreeds throughout the district were disaffected. While they stayed there the heroic French priest did guard over their tent at night. A few days afterwards Mackay found a discarled skiff near the bank. Il plugged up the cracks with "liard iat," and in this boat he and his wife and daughter eseaped down the river. Cltimately they landed on an island, where for nime days the party lived on tallow. At the end of this time they saw Indians signaling from the banks, at each side, and knew they were discovered. Once again, therefore, they took the desperate chance of re-entering their miserable skiff, in which, however, they ultimately reached Prince Albert in safety. 

The young woman of this party afterwards became the wife of the scont and policeman, to whom we lave previously referred.

Mr. K. G. Naclieth relates an amusing episode that occurred in the vicinity of Fort Victoria. The wolnteers were in the milst of the enemy"s country and were accordingly forbidden to leave the camp. One of the soldiers apparently failed to understand these instructions and went a-fishing. The Colonel himelf witnessed the delinquent seturn and commanded his arrest. The fisherman, however, insisted on bringing with him his string of fish, and when conducted before the Colonel he solemnly declared that he had intended the best of the catch for that officer's own dinner. The culprit's audacity, coupled with his provions excellent reputation and record of valuable services, won him his liberty at the expense merely of a formal reprimand, which his commandling officer had difficulty in administering with due solemnity:

The following extract from the diary of another voluntect indicates that the officers themselves conlel not only appreciate a joke, but were not unnecessarily scrupulous with regart to the sources from which they obtained their own little extras:

"As soon as the men are dismissed, they begin to forage, not openly, of course, for it is forbidelen. ()ne lucky inclivilual was seen depositing quietly in his tent a very func looking turlicy. The story of its capture he related witls mucl glee. I sergeant of a sister corps, who had managed to malie hinself peculiarly obnoxions to unr fellow's by his orerbearing manner, was observed by him to deposit the turkey in some brush outsile the lines, probably fearing to be seen if he attempted to bring it in by daylight. Our man calmly marched across and bolkly walked wil with the hird. The wrath ful sergeant had to hok on $i n$ grim silence for the betrayal of himself would have been the necessary restit of any outcry.

"Another case of the biter bitten was that of um wortly orderly. The good lad heard the joyful clucking of a hen at sone distance from the camp, and on proceeding to investigate, found that the noise came from a little shed at the rear of the school. There he found, and immediately caught, a fine, fat fowl. and then he began to look alout for the contidently expected eggs. He crawled through a smoll opening into a little hay bin, carrying the unfortunate hen with him. Ilere he was overjoyed to discover some eight or ten heautiful eggs. These he immediately jut carefully, one by one, throngh the opening, placing them upon a shelf near by: Just as he was about to crawl out again, our gallant Najor entered the shed, accompanied by a parson, the owner of the place. The Najor saw the eggs at once, hacked towards them, kept the attention of the parson carefully engaged, and pocketed the spoils. The original finder's rage may be imagined. but not described. Great was his difficulty in preventing the discovery of his own whereabouts by the noise occasioned by the struggles of the halfstrangled hen, and trembling with anger and fear he had to witness in silence the disappearance of his treasure." 


$$
\text { . }
$$




$$
\theta
$$


Many inspiring stories might be told of the gallatutry displayed on numerous occasions by non-combatants. The following extract is taken from the official report of Surgeon-General D. Burgin, M1. P.:

"At Batoche I am told that during the fight a flag was thrust from a window of the cliurch and was olserved by a surgeon and a student who were under shelter from the firc, a conple of hundred yards distant. The student, immediatcly le perceived it, proposed that a party should at once go to the relief of the one denanding succor. No one appeatred willing to second his proposal. To go to the church through the open under such a terrible fire as was being poured from the IIalthreed pits seemed to be like proceeding to certain death; but persisting, lhe surgeon said, 'If yon are determined to go, and we can find two voluntecrs to assist us in carrying a stretcher, I am with you.' 'Two men from the grenadiers of Toronto at once stepped forward; and the four statted upon their perilons jonrneycrawling upon their liellies, taking arlvantage of any little inequality of ground to cover them, and to shielil them from the bullets of the Halfbreeds. They reached the church, the bullets tearing up the earth all around them, withont a scratch, and brenthing a short prayer for their deliverance thus far from death and danger, they looked around for him for whom they had risked, and were still risking their lives, to suecor and to save. They found him in the person of a vencrable pricst who had been wounded in the thigh, and they at once proceded to remove him, after administering temporary aid. To remain in the churcl was to court certain death. To return to their corps seemed to be no less perilous; but they ehose the latter. When they sortied from the church, so astonished were the IIalfbreeds at their daring that they ceased their firing for a moment. This time returning they had no cover and were obliged to march erect. Bullets flew thick and fast; but the condition of the wounded man precluded anythink like luurry, and they hastened slowhy. God watelicd over them and protected them, and they reached their comrades in safety, their wounded charge also escaping without further harm. Such conduct deserves recognition."

In May one of Otter's supply trains was captured by Poundmaker's braves. The story of this affair is contained in the following somewhat biased but picturesque report from The Montral Star. It is of special interest on account of its spirited description of an Indian caravan on the march :

"About nine o'clock on Thursday, the Ifth instant, the forage trains were passing through a piece of open ground surrounded by wooded blufis, about eight miles from Rattleford, when the teamster in front observed mounted men closing in upon them from all sides. At first they were inclined to think that the newcomess were friends, but a few piercing warwhoops, uttered from a place of eover, convinced them that they had been ambushed. Notwithstanding the ntter suddenness of the attack, many of the drivers did not lose their wits, but male a hastily improvised laager. By this time the Indians, who numbered about a hundred, led by paintbedaubed Halfbreeds, approached, gesticulating and shouting at the same 
monkent, without firing at single thot. The rear was not well gttarded, and while the excitement continucd in front, six or seven teamsters, who owned horses, cut loose and made their escape, anid a heavy fusilade. Meantime, the Indians approacherl ncares and neater the lager, while twenty of their number went in pursuit of the retreating horsemen. The enemy finally sent a Halibreed towards the waguns. Throwing down his weapon to show his good intentions, the man advanced within fifty yards, and ealled for one of their number. The head team-ter responded, and walked towards him. A brief discussion folhwed, the breet promising that their lives would be spared if they wonld quietly strrenter. The teamsters immediately gave up their arms, consisting of sixteen IVinchesters, aw Snilers, and three shot-guns. After robling each prisoner of every valuable, the Indians, who were overjoyed at their sucecs, began to examine the contents of the various wagons, and in a few minutes a start was made for the Indian camp, which was pitched in a raine alout four miles west of the Swift Current trail. The prisoner-teamsters were compelled to drive the oxen. Soon the warlike 'Stoneys,' who had not been present at the capture, galloped up and attempter to shoot the prisoners. The Ifalibreeds, however, proved themselves to be endowed with some redeening traits, and frustrated this cruel design. Rifles were levelled by both parties, and the determined stand taken by the Ilalfluceds alone saved the teamsters from a cruel death.

"As the train approached the Indian camp, squaws, and torldling papooses poured ont from every tepee, and advanced with cheers of joy to greet the returning braves. The fcmales, at the sight of the prisoners, were especially boisterous, and shoutcel to the braves to put them to death. Through the jeering, howling, yelling mass, the frightened drivers were hustled, every moment expecting to be struck down from behind. Finally they were conducted to a ravine close to the camp, and after receiving a parting shont from the ngly squaws, they were left to their own reflections. A strong guard surrounded thens, preclinding all possibility of escape. The Indians held a formal council to disenss the propriety of shooting the teamsters, but decided not to do so. Shortly afterwards, Poundmaler put in an appearance in the ravine. After shaking hands with each man in turn, the redoubtable chief assured them, througli a Halfhreed interpreter, that their lives wonld be spared. He added that he was aware there was a Manitou above, and that he could not permit them to be slain withont caise. Poundmaker then left, and shortly afterwards the Indians struck camp. Tepee-poles were thrown down in a twinkling by squaws, who, assisted by young boys and girls, rapidly packed everything away in carts and wagons. already in line for the start. Braves lolled alout. whiffing 'kince-kinick' (tobacco) fron long-stemmed pipes, or attended to the trappings of their horses, while youngsters, scarcely able to crawl abont, drove in the cattle. Finally a start was made, and preceded by twenty-five or thirty sconts riding a mile ahead, the disorganized mob moved eastwards on their way to reinforce Riel. Instead of proceeding in colnmn, the Indians moved along in extended order, leaving a trail bchind them over two miles wide. First came about three hundred and sixty war-painted braves, nounted on wiry ponics. or on more powerful animals. stolen in the early raids. Next canc Red River carts, wagons, and every other variety of vehicle 

ever manufacturcel. Each was loaded with plunder, or tepee-poles, while perched on toj were scated old men, amed with bows and arrows. Behind. followed a chaotic mass of wagons and carts, surrounded by lowing cattle and little boys on foot. ()ther Indian lats added to the grotesqueness of the scenc, and, monnted on young colts, lept up to the moving outfit. Further in the rear, at a distance of half a mile, came other herds of cattle. while bringing up the whole, came another herd of loorses. Young girl and squaws were momted, several of the females riding along on oxen. In this manner the followers of I'otintmaker covered three miles an hour with ease."

The surprising way in which valuable supplies were sometimes lost and found is illustrated in the following aneclote communicated to the writer by $\mathrm{Mr}$. Horace C. Adams, of Fenton, Saskatcliewan:

"During the rebellion, flour was very searce and expensive at Prince Albert, and I wis sent by my father to Troy to buy some. I started with a consin, Robert Foulds, with a good voke of oxen, and a wagon. We reached a place called 'The Salt Plains, and leaving the main trail a short distance. we came upon three humbler sacks of flour. many firkins of butter and lard, camned beci, barrels of hard tack, and sacks npon sacks of oats. WV emptied one sack of flour, cleaned out the caked flour from the inside. opened another sack and took from it the good flour and so on, until we had the quantity we required. We cached this, ant then went on to Ou'. Ippelle. where we secured freight for l'rince Ilbert at five dollars a hundred weight. We made considerable profit from onr freight, and took home nearly all our money, besides the flour we needed. These supplies were in a deep ravine where, as we subsepuently fouml, they had been unloaded by IIndson's Iay Company freighters when they hearel that the relels were up in arms. The Iludson's Thy Company put in a claim to the Govermment afterwards and got pail for it all. I remember that there was no sellishness manifested hy anborly in connection with the find. Every one took enongh to do him and his dependents, informed his neighbors and let them get their share also. In this way a great many of the hard pressed settlers were greatly benefited and nobody was the loser."

Here is a story of another kind: Lientenant-Colonel George T. Denison was in charge of the post of IIumblelt during the campaign. On the way to Winnipeg his trumpeter was taken ill and he was obliget to secure another. A retired Major of the Tmperial army, an experienced veteran of the Crimean Vrar and Indian Mutiny, was in Wimnipeg and so anxious to get to the front in any eapacity that he inducel Colonel Denison to take him as trumpeter. An intantry regiment was passing IIumboldt, and its Bugle Major, a youngster of twelve or thirtcen years, called on Colonel Denison's trumpeter, inquired his rank and pay, and the amused veteran informed him that he was a simple trumpeter drawing fifty eents a day. The boy drew himself up with great dignity and annonned that he, on the contrary, was a Bugle Major, drawing eighty cents a day. When Colonel Denison heard 
of the absurd incident he solemnly i-sued orders promoting the old soldier to the same exalted rank and remmeration, much to the amused satisfaction of all concerned.

While the focts of Halfbrect discontent was in the Batoche district, it is a mistake to suppose it confined to that locality. For example, the Nétis of Wood Mountain and Willow Bunch were in a half-starving condition, owing to the recent collapse of the trade in buffalo slins, and to their inability as yet to adapt thenselves tu conseguent social and industrial changes; and many of these minfortmate people lecame very restless during the rebellion. Indeed, a consideralke number of them trekked northward in the direction of the actual disturbance. Accordingly the people of the little town of Moose Jaw were presently perturbed to see on the ontskirts of the settlement a number of encimpments of disaffected IIalfbreeds.

Lientenant-Governor Dewdney accordingly came to Xloose Jaw and telegraphed for the famous trader and sturdy loyalist, Mr. Louis LeGaré, to come in from Willow Bunch to induce the Halfbreeds to return south. LeGare told the Governor that it would be useless to argue with men with empty stomachs, and arlvised that the Ifalfbreeds be given employment, or, at all events, pay, on some pretext or other. Objection was raised on the score of expense, to which the trader shrewdly replied, "There are eighty men at the Bunch that can carry arms. That might cost a good deal." Accordingly the proposal was referred to Gttawa and Sir John A. Mlacdonald authorized the employment of forty men.

A plausible pretext was at hand in the fact that the authorities had received advices warning them that a force of American sympathizers was likely to come to Ricl's support. Accordingly steps were taken to organize a corps of scouts under the supervision of the Mounted Police, and $\mathrm{M} / \mathrm{r}$. LeGare was entrusted with the task of turning the buldeling rebcls among the Halfbrecds of his district into supporters of the Govermment.

The first thing necessary was to induce them to return to their homes, eighty to a hundred miles away. This was accomplisherl by means of an ingenious and courageons stratagem. The Halibrecks cansing the immediate anxicty were scattered, as we have said, in isolaterl encampments about Moose Jaw. Mr. LeGaré visited one of the camps, and with a great show of secrecy told the Halfbreeds that he wanted then to take something back to Willow Bunch for him. There would be good paly in it, and it was very important but secret; so that they were not to let anyone clse know of their departure. They were to stast at twelve oclock that night. Ife then visited another encampment and told the same story. They were to break camp at one oclock. The next camp he similarly induced to move south at two o'clock, and so on, until he had arranged for all the struggling parties to be moving southward before daybreak, one hour apart. He then started off 
himself for the Bunch to be there to receive them. As one party alfter another arrived, and realizerl what had occurred, their excitement and rage grew, until they were apparently on the point of buming the trader's store and murdering LeGaré himself. He, however, kept his head, and convinced the Jalibreeds of the folly and hopelessness of any rising, backing his argument by the announcement that he would give them work at two dollars a day as scouts. In the course of the next ten days he enlisted forty men so selected as to represent practically all the Ilalibreed families in that part of the country, and scattered them over the district at such a distance apart as to render them harmless. For his services in this connection the shrewd and plucky trader received the munificent smm of two and a half dollars a day as special constable. This hody of senuts was placed under command of Inspector Nactonnell from Medicine Jfat. Mr. LeGarés experience in connection with this episode and that of the surrender and maintenance of Sitting Bull's warriors, the story of which we have related elsewhere, has not been of a character to strengthen his faith in the gratitude of governments. His services in 1885 received sone slight mention in the police reports, but the details have never been printed before, so far as the writer knows.

With an account of one other curious incident this miscellaneons collection of Rebellion Anecdotes must close. The members of a certain coltum were subjected to considerable annoyance by sentries whose nerves betrayed their eyesight into seeing intruders that were not there. Shots would be fired and the slumber and temper of the soldiers equally disturbed. Accordingly one officer announced thit the man who gave the next such needles: alarm would get three days' "knapsack drill." That night, however, the usual occured. The sentinel vigoronsly protested that he had dintinctly seen a spy, but no trace of the latter was discovered, and for the next three days this discomlited volunter carried his ontfit on his back as a nerve sedative. At the end of this time scouts came into camp, who announced having found the body of an Indian spy whom the sentinel hard shot. The unlucky sollier had got three dars "knapsack drill" for efficiently performing his responsible and, in this case, sanguinary duties! This is the kind of story that does not get into official reports. 



\section{CIIAPTER IXXII}

ROYAL'S ADMINISTRATION: POLITICAL HISTORY, I888-I893

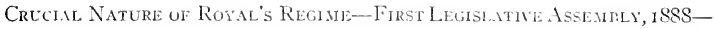
Royal's Confmextial Advisers-Consolidition of Ordinances Undertakex-Legislative Disableities in Nortil West Assembly-Haliprerd Claims, 1 gof-Dual Language System Abol-

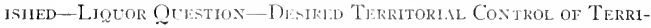
torial Exienditlots-First Finince Bhli-Coxstitltional

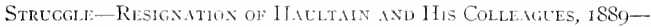
Brett C.lli.ed to the. Premileshif-11is Resigratiox-. Issembey's Memorials-Brett's Reidiontmext Durixg Reciss-Assenbly's Protest, $18 g 0$-Debate on Rerly to Sreecil from the TilroneRoyal's Stitedient of His Constitutional Position-Assemply's Reply-Reiter.tition of: Representations to Ott.uWA-Attitude of Westeri Meminers of Parlinmext-Did the Assemely Repre-

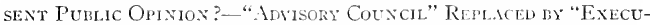
tue Conmitee"-Ixcreised Fixixcial Control ho the Assenbly-Hacltain's Administration Defeited, 18yz-Deadlock Caused dy Resigxation of Sreaker Ross-Hhult.my's Mhinifesto - Newspaper Comments-Extriordinary financial Position

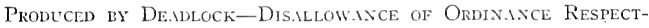
ing Executive Conmitee-Victory for Resroxsible Goversmext-Striggle for Better Finaxcial Teras-Persoxal Relations Betwey Royal ind the Assembly-Roral's Farewell SPEFCII.

The five years during which the Honorable Joseph Royal, formerly of Manitoba-journalist, lawyer, legislator and historian-occupied the Lieutenant-Governor's chair in the North West Territories constitutes a period of exceptional political interest. The era immediately preceding it had seen the Legislative Council gradually clanging in character from an appointive to an elective hody. With Royal's regime we met the first Legislative 

Assembly proper. ${ }^{1}$ Nevertheless, many traces of the former quasi-Crown Colony system still survived, as complete responsible Government was not established for some time. It maty be that a certain transitional period from Crown Colony to responsible Govermment is practically mavoidable: but the universal experience of other parts of the Empire was (Inplicated in the North West in that this period was marked by bitter controversy and unfortunate deadlocks, montil the leginlative Assembly established its control over the executive.

The first elections under the new North West Territories Act were held on Jume 27 , I88S. Nr. Royal took the oath of office on July ith, and in the autumn issued the following proclamation, summoning the First Legislative Assembly of the North West Territories, which sat till December I Ith:

\title{
PROCLAMATION
}

\section{CANADA. NORTII WEST TERRITORIES}

Victoria, by the Grace of God, of the Lnited Kingdom of Great Britain and Ireland, Queen, Defender of the Faith, etc.

(Seal.)

\author{
Joserit Royat, \\ Lieutenant-Governor.
}

Grecting:

Know ye that we, being desirous and resolvel to meet our people of our North West Territories. lo hereby summon and call together the Legislative Assembly of the North Vest Territories, to meet in Legis-

1 In view of the important constitutional battles which ocenred during Lientenant Governor Royal's administration, it may he well for the reader to fevote special at tion to the personnel of the First Legislative. Asscmlyly. Mr. J. W. G. Matlain, who had sat in the Conncil of 1887 as member for MacLeod, was returned to the First. Assembly by acclamation. Messrs. Thomas Tweed and James Ryerson Neff* were also elected. by acelamation by the clectoral districts of Medicine Hat and Mloosonin respectively. The other nenbers were the following gentlemen: Messrs. Jocl Reaman,* for Wallace; Alexander Gillin Thornhurn,* for Whitewood: John Gillanders Turriff (iwlo had sat for Moose Mountain in the Council since 1Sat), for Souris; Benjamin Parkin Richardson* for Wolesley; Willinn Sutherland felected te the Council in ISS7), for Qu'Appelle; David Finley Jelly* (elected IsS;), for North Regina; John Secord, for Somtl Regina; James Hamilton Ros; (elected Ides) for Moose Jaw; Hugh St. Quentin Cayley (elected is86), and Joln Linchan, for Cilgary: Rolsert George Brett, N. D., for Red Deer; Frank Oliver (first elected in 1883), and Herbert Charles Wilson, X. D., for Edmonton; James Clinkskill, for Battleford: William Plaxton* and Jolm F. Betts, for Prince Albert; Hillyard Mitchell, for Batoche and James Hoey, * for hinistino.

(The names marked with an asterisk are those of menbers representing constitnencies in what is now the Province of Saskatclicwan.)

In addition to the twenty-two elected menliers of the First Assembly, the North West Territories Act of 1888 provited for the appointment of three legal experts With authorify to take part in delute. but mot to vote. The gentlensen summoned to MacLeod, Mr. Justice Richardson. 1 Mnowable Mr. Justice Court of the Sorthe Justice kouleau, the three clice of the Supreme Western legislation and adninistration. 
. 
lative Session at our town of Regina, in our said Territories, on Mednesday, the thirty-first day of October, instant.

In testimony whereof we liave caused the Seal of the Nortl West Territories to be hereunto affixed. Witness His Honor Joseph Royal, Lieutenant-Governor of the North West Territories, this tenth day of October, in the year of Our Lord, one thousand eight hundred and eighty-eight, in the fifty-second year of Her Majesty's reign.

By Command.

R. B. Gordon,

Clerk of the Legislative Assembly.

The first meeting of the Legislature was marked by the numerous quaint forms and ceremonies associated with such bodies under the British Constitution from time out of mind. The members having been sworn, and having taken their places, the clerk, in the Governor's name, called upon them to elect a Speaker. Whereupon Herbert Charles IVilson was duly chosen and elected to the chair. The Lientenant-Governor then entered the House and took his place upon the throne, and after approving of the election of Mr. Wilson as Speaker he delivered his inaugural address.

In his spech from the throne the Licutenant-Governor announced his appointment of $\mathrm{Mr}$. Justice Richardson and $\mathrm{Mr}$. A. E. Forget, late clerk of the North West Council, as a Committee to prepare for the consolidation of the ordinances. This most important matter engrossed much of the attention of the first Legislature. Consequently the fact that, in addition to the supply lill, only seven ordinances were passed this session is not to be taken as evidence of indolence or indifference on the part of the newly created Legislative Assembly. Ordinance No. I is a voluminous document. consolidating numerous cnactments of the North West Council.

The Assembly found itself contintally hampered by the limitations placed upon its lawmaking powers by Dominion legislation. This resulted in the continual disallowance of important measures by the Governor-General in Council. In various instances, however, subsefuent action on the part of the Dominion athorities rendered practicable the reforms aimed at even in the bills that were declared ultra sircs.

Numerous memorials were from time to time forwarded by the Assembly to Ottawa. These had to do not only with the great problem of responsible Government but with recommended changes in the land regulations, with the providing of a special bonus for the destruction of gophers and with the old question of Ilalfbreed claims and rebellion losses. The Asscmbly declared in this connection, by resolntion, that numerous persons well known to be directly implicated in the rebellion had had their claims allowed by the Dominion, while those of certain loyal Haltbreeds living along the Saskatchewan River were unjustly disallowed.

In April, 1892, a notice was accordingly published calling upon all 

Halfbreeds or original white settlers entitled to scrip to file their claims, together with the necessary proof, on or before May I, 18y4. With the investigation of these claims it was intended that this long outstanding question should reach its final settlement.

The local House also secured, by petition, the repeal of Section 110 of the North West Territories Act, which provided for the printing of Territorial public documents in the French language. The resolntion recommending the discontinnance of the dual system in the North West, as opposed to sound public policy and the sentiment of the people, was passed On October 28, 1889, by a vote of seventeen to two.

One of the first important topics considered by the Honse during Royal's administration was the better control of the liquor traffic. This sulject was debated at great length through seteral sessions, and ultimately, upon receiving the necessary authority from the Federal Government, the second Legislature passed a license ordinance, under which intoxicants might be sold by hotels or liquor shops if the majority of the residents in the district conerned did not oppose the issuc of the given license and certain other conditions were complied with.

The most interesting political events of Royal's administration were those associaterl with the attenpt of the Assembly to establish control over the Territorial expenditures, either directly or through a Council or Committee. The North West Territories Act did not clearly provide for such at system. The following were the provisions of the Federal Statute in this regard:

"The Licutenant-Governor shall select from anong the elected members of the Legislative Assembly, four persons to atet as an Advisory Council on matter of funance, who shall severally hold office during pleasure; and the Lientenant-Governor shall preside at all sittings of such Advisory Comncil and have a right to vote as a member thercof, and shall also have a casting vote in case of a tie."

The first Advisory Council appointed under the act consisted of Messrs. Hattain. Jelly, Sutherland and Mitchell. The Governor was manifestly: bound to submit to the Legislature a report of the use made of funds supplied him by the local Assembly; but a very large part of the public expenses were defrayed by Dominion subsidies, over which the Issembly was long denied any right or control. In the first session, however, Mr. Royal, perhaps inadvertently, established a precetent of which. $\mathrm{r}$. Iaultain and his supporters took the utmost advantage. The supply bill for that year was allowed to include funds not only of Territorial but Dominion origin, and in assenting to the bill Mr. Royal did so in the special formula used only wherever responsible fovermment is in vegue. After the Royal assent to the other bills of the session had been annomed in the following words. 



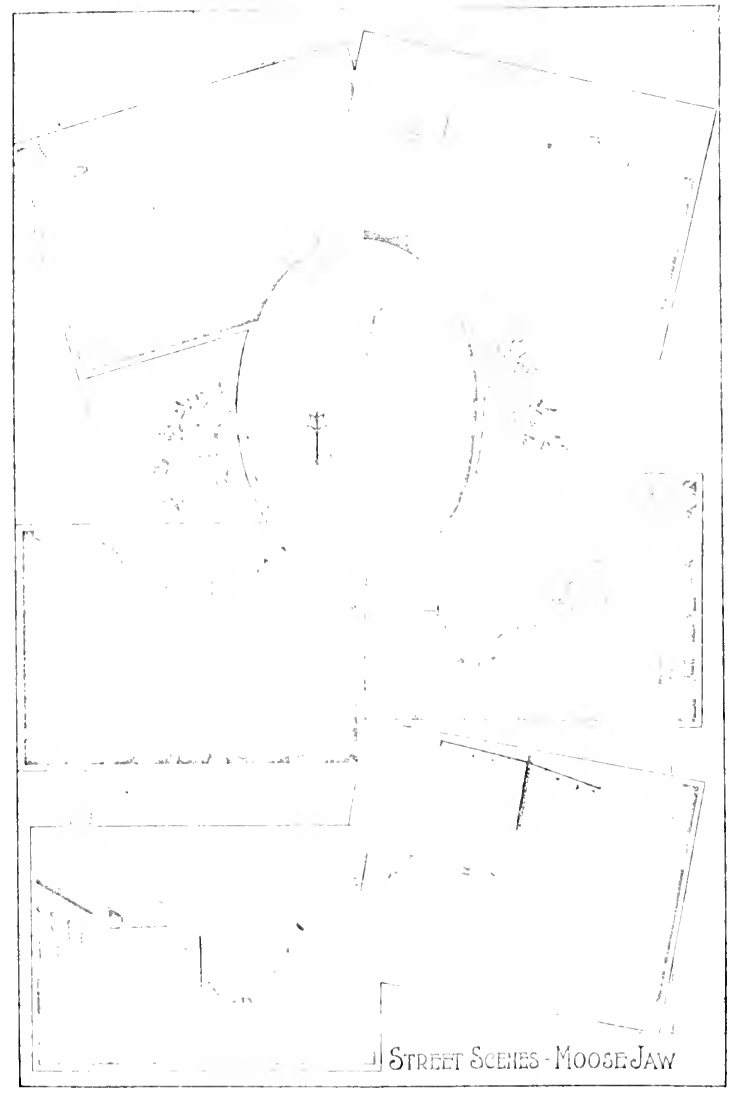


"In Her Majesty's name, IIis Ilonour the Lientenant-Governor doth assent to these bills," Mr. Speaker then addressed him as follows:

"May it please Your IIonour:

"We Her Majesty's most faithful and dutiful subjects, the Legislative Assembly of the North West Territories in session assemblerl, approach Your Honour at the close of our lallours with sentiments of unfeigned devotion and loyalty to Her Matjesty's person and government, and humbly beg to present for lour llonour's acceptince a bill entitled 'An ordinance for granting to Her Majesty certain stms of money to defray the expenses of the public service of the Territories for the financial year ending Jume 3 , I889, and for other purposes relating thereto.' thus placing at the disposal of the Crown the mean by which the Govermment can be made efficient for the service and welfare of the Territorics."

Thereupon the Royal assent was announced in the following words:

"His Honour, the Licutcnant-Gozernor doth thank IIcr Majesty's dutiful and loyal subjects, accepts their benciolence and assents to this bill in Hor Majesty's name."

It is difficult to stuppose that at least some menibers of the Legislature did not recognize the fact that hidden in this time-honoured mass of verbiage was the formal acknowlergment of the Assembly's financial autonomy and right of control over all public expenditures.

The second session of the first Legislature was held in the autumn of 1889. Early in the session signs of disagreement between the Advisory Council and Ilis llonour were evidenced by Mr. Hatlain's replies to varions questions with regard to estimates that were to be laid before the House, and on the 29th of October Mr. Inatulain amounced on behalf of the Advisory Council that they had tendered their resignations, which had been accepted by the Lientenant-Governor. Thus was precipitated a constitntional strtiggle marked by much bitterness and extending over several years. This whole episode is so important that the reader will be interested in perusing the letter of resignation:

"Legislative Issembly, Regina, X. W. T., October 29 . I\$S9.

"To His Honour, the Lientenant-Governor of the North Went Territories.

"Sir:- We have the lonour to tender our resignations as members of your Advisory Council. We have come to this decision reluctantly and only after serious consilleration.

"While recognizing that Your IIonour has, on the whole, carried out the position which was accepted last year, there have been some departures from that position which we cannot accept responsibility for. These matters do not involve serious departures from the general principles adopted by us, but they do, in our opinion, involve the Council and liny us open to censure for at least grave faults of administration.

"We fully appreciate the practical difficulties in the way of carrying out an anomalotis system like the present, and have always been ready to make 
the best of an imperfect maclinery. The attitude of the Assembly has not helped to lighten the burden imposed upon us. Ever ready to criticize and always prone to judge us by the standard of the ideal system, which they wished for, they have not given us that support that in the nature of things we might reasonably have hoped for. Knowing this fecling of the Assembly, and being with the rest of our fellow members jealous of the rights which were granted to us, we are naturally more sensitive to criticism than under a more completely responsible system there would be any necessity for.

"The constant discussion at Conncil meetings on the general theory of our Constitution showed us plainly that Four Ifonour only conceded what we claimed as a right. While differing from Your Honour in this matter, we are ready to acknowledge the generous spirit in which Your Honour yiclded control in matters which you believed within your own personal province. But in so important a matter as the construction of the Act under which we have our existence as a Council, such a grave difference of opinion can only lead to friction, whicl numst inevitably destroy our usefulness.

"We, therefore, tender our resignation because we cammot continue to work under a sistem in which our most important powers are only granted to us in the form of concessions, and because we are mwilling to accept responsibility without a corresponding right of control. We belicve that our withdrawal from the Council will tencl to bring about a nwe definite understanding with regard to the various pow ers and authorities of the Territories, and we can assure Your Honour that our successors, if true to the policy. outlined by yourself last year, will always receive from us a loyal and gencrous support.

"In conclusion, let us assure Your JIonour of our most grateful appreciation of Your Honour's personal kindness to all of us, and of the continuance of loyalty and attachment on our part.

"IVe are,

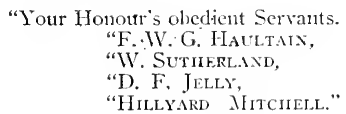

In reply to this communication Lientenant-Governor Royal wrote a bricf and rather caustic letter to Mr. Ilatultin, in which he confessed his failure to remember cxactly what the "grave faults of administration" were of which his Council hat conplained, and requested Mr. Haultain to assist in refresling his menory. As far at the Assembly's journals show this contmunication does not seem to lave called fortl any reply.

On November sth the Speaker amounced the formation of a new Advisory Council, including Mr. Jelly, of the last Council, together with Messrs. R. G. Prett, J. F. Tetts and B. P. Ricliardson. Dr. Brett, from the new Advisory Council, then made a statement, in part as follows:

"The Council of II Is Innour's Advisers, formed under the law, will exercise the functions of an cxecutive in matters affecting the Territorial 
finances only, as well as in the discharge of the dnties assigned by ordinances to the Lientenant-Governor in Cotncil."

The phrase of 1)r. Brett, wherely he annonned his intention to deal, in financial matters, only with the Jerritorial finances, involved a surreneler with which the Jlouse was very far from satisfied. Consequently, on November $g^{t h}$, the Assembly passed a vote of non-contielence. Theremon Mr. Brett, on behalf of himseli and his colleagues. tentered his resignation to the Lientenant-Governor, but in an interesting letter if consieleralle length His Ifonour refused to accept it. 1le considered that the question at issuc was distinctly one of law, and that, having selected his Comeil in accordance with the conditions cmbodied in the North Ilest Ferrituries Act. he could not accept its resignation in the absence of any act showing that its members had proved themselves mworthy of the trist reposed in them.

On the I Oth of November, hewerer, when the llonse went into Cimmittee of Supply, it was determined at the end of a long delate that the House would not consider a further supply until the funcls of the preceeling year had been fully accounted for, ancl atn aleliess was ordered to be presented to His Ilonour, pritying him to aceept the resignation of the preacent $\therefore$ Advisory Council and to select suceesors possessing the contielence of the Assembly. This action called furth the folluwing letter from 1)r. lirett:

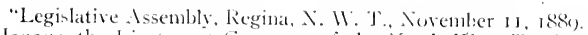

"To His Honour, the Lientenant Governor of the North Viest Territuries. "Sir:-1n consecpuence of the Ilutse having adopted at its last sitting the following resolution. aiz. That the postion assmed ly the Idvisory Cinncil, as set out in the statement of their leader. When amouncing same. Waassumed contrary to the wishes of the llouse, and the Advisory Conncil flo not possess the conficlence of the. Issembly, I heg leate to terider Your Honour my resignation and that of my colleagues.

"While believing that the position we have taken on this matter was in strict accordanee witl the law and interest of the ferritories, at the sane time we feel you are entitled to this action on our part.

"I have the honour to be,

"Your obedient servant,

"R. G. Binett,"

His Honour now deemed it his duty to aceept the resignation of the Conncil, as it had failed to secure the support of the Assembly in defending the action of the executive and in its efforts to secure supplies. His Honour Mr. Royal then entered into negotiations with Messrs. Tweet, Clinkskill, Cayley and Neff with a view to forming an Idvisory Council in accordance with a majority of the Iscembly. Mr. Tweed, however, speaking for his proposed colleagues. refused to accept office unless the Government contd accede to the demands of the Assembly, and on the zoth 
of November, in accordance with a motion of Mr. Manltain and Mr. Cayley, the Governor transmitted to Ottawa the following telegram:

"1. That whereas on Saturday, November oth, a rote of want of confidence in the Advisory Council was passed by this House on a division of thirteen to eight;

"2. And whereas in consequence of such vote the Advisory Council tendered their resignation to the Lientenant-Governor.

"3. And whereas, His Honour the Licutenant-Governor refused to accept the resignation of his Council and the Council persisted in retaining office ;

"4. And whereas a full account of the money voted to Her Miajesty" by this Assembly at jts last session for the nublic uses of the Territories has not yet been rendered to this Assembly by the Advisory Conncil, selected by His Honour the Licutenant-Governor to assist him in matters of finance;

"5. And whereas at the last session of this Assembly $\$ 105.484 .40$ was voted (sce Ordinance No. 8 of ISSS) and the statement of T'ulblic Acenunts brought before the Isscmbly only accounts for $\$ 18,0,8.74$ :

"6. And whereas on Thursday, Noxember 1 Gth, on motion marle by the leader of the Alvisory Council to consider of the suprly of the current year, an ancudment was moved to the effect that this i louse do not consider any further supply, until an account has been rendered of the sums voted last session;

"7. And whereas this amendment was opposed by the members of the Advisory Council and was carried by a vote of twelve to seven:

" 8 . And whereas the result of the vote proved that the advice tendered by the Advisory Council to His Honour the Lientenant-Governor was not in accordance with the wish of this Assembly;

"9. And whereas the estimates laid on the table of this House do not mect with the approval of the Ilone, inasmuch as they do not inclucle the amounts voted by the Parliament of Canada at its last session for expense of Govermment, etc., in the North West Territories:

"10. And whereas on Friday, November 15th, an humble address was adopted by the Assembly reguesting that His IIonour the LientenantGovernor be pleased to accept the resignation of the present Advisory Council and select another Council;

"11. And whereas the continuance in office of a Council not possessing the confidence of the Assembly was a gross violation of the rights and privileges of the Asscmbly;

"12. And whereas the Advisory Conncil have since then resigned and His Honour the Lientenant-Governor has been pleased to accept their resignation;

"I3. And whereas no new Advisory Council can be formed which will have the confidence of the Assembly, until His Honour has signified his intention to accede to the just demand of the Assembly :

"1.t. And whereas in consequence of the position taken up by" Ilis Honour the Lientenant-Governor, no estimates can he laid hefore the Assembly, and the business of the Territories is seriously impeded; 
"I5. Therefore, be it resolved that an lumble address be presented to His Honour the Licutenant-Governor praying that he will cause this resolution to be transmitted today by telegram to the Right Honourable the President of the Privy Council of Canada."

The Assembly subsequently memorialized the Dominion Government for a declaration that the Dominion grant should lie expended on vote of the Assembly. It was also recommended that the Lientenant-Governor should himself not be a member of the Conncil, and that the sitting of the lexal experts with the Astembly should be dispensed with. Furthermore, it was pointed out in this memorandum that the existing Territorial Constitution did not provide for any permancut responsible body to prepare legislation for the Assembly's consideration, and that in consequence its legislative functions were much hampered. The Assembly has inded ich compelled to withdraw from the Advisory Comeil, as at present constituted, even those powers previously granted to it by ordinance and after a trial reaching well into the second year had been fored to the conviction that the present system of Government in the Territories was radically defective and should be amended by the Dominion Govermment at the carliest possible moment.

In his spech relieving the members from further attendance upon the session the Lientenant-Governor, on the 2nd of November, spoke as follows:

"The various incidents which followed the resignation of my first Advisory Council, the attitude assumed by the majority of the members, and the carnest desire of all that the business of the country should not suffer in conscquence, are circumstances which will tend to mark this session as an historical one. I earnestly hope that the proceedings of the Assembly may result favourably for the peace, order and prosperity of the North liest "Territories."

On the prorogation of the IIouse the Lientenant-Governor lad not yet succeeded in securing an Advisory Council. However, during the recess, his efforts were more successful, and Messrs. Brett, Betts, Richardson and Secord agreed to cooperate with Mr. Royal.

When the third session opened on the 2011 of October, ISgo, the constitutional battle was resumed upon the reply to the speech from the throne:

"The Assembly regrets that Jour Honour has not scen fit to allude to the circumstances which have led to Jour Honour's selection and retention in office of an Adrisory Conncil not in accord with nor possessing the confidence of the majority of this Assembly. It appears to to to be necessary to the good govermment of the comintry that the measure of control, if any, possessed by the Legislature over the acts of the Exceutive should be clearly detined. Having been left without guidance of Your Honour in this matter, the Assembly can do 110 less than assume its rights 

to be such as the North West Territories Acts and constitutional usage having the force of law appear to give. They are therefore compelled to believe in the right of the majority not only to pass legislation, but to advise and control in the matter of its being given effect; that the North West Territories Acts interpreted in the light of constitutional usage, provide for control of the Executive by an Advisory Conncil having the confidence of a majority of the House; that the assumption of such control by any Members of this IIonse not possessing its confidence is a violation of the spirit and intent of the North West Territorics Acts, and an infringement wpon the rights of the House, against which it feels compelled to enter its most solemn protest and to take such measures to protect itself as best it may.

"The disregard for and violation of all constitutional rules, the infringement upon the rights and privileges of the House and usurpation of its prerogatives by its Nembers composing the Advisory Council. in our opinion, renders those Menbers wmorthy of taking any part in the business of the Assembly. As the only means in our power of vindicating in our case the common rights of majorities in representative Assemblies, it is our duty to refuse all legislation and motions offered by these members. ${ }^{2}$

"To further mark its disapproval of the course of the Stvisory Council in ignoring its rights, the House has seen fit not to allow the sereral members of the Council to serie on any of its Standing Committecs as long as they maintain their present attitude of defiance."

As indicated in this rather startling ultimatum, Messrs. Brett, Betts, Richardson and Secord were ostentationsly excluded from all committees; their resolution of protest was negatived on a vote of thirteen to seven. Messrs. Reaman, Plaxton, Hocy and Jelly voted with the Governor's party. Mr. Richardson seems to have been absent.

The entire reply to the speech from the throne was very critical in character. The House commented upon the "cold rosponse" of the Duminion authorities to the yearly appeals made for assistance in the work of populating the many million acres of Dominion lands in the Territories, and upon the scant attention paid by the authorities at Ottawa to the memorials forwarded them by the Assembly, the disallowance of certain Territorial ordinances, and the Lientenant-Governor's omission of all mention of the unliappy differences which had existed and which still existed between an overwhelming majority of the Assembly and His Honour's Advisory Council.

This address was voted at hali-past three in the morning on Tuesday, November I Ith, after thirteen lours' debate.

Three days later the Honourable Mr. Royal, through the Speaker, conveyed to the Assembly a written message explaining his understanding of the legal position in which he found himself in the matter under dispute.

2 The italics are mine. N. F. L. 
. 
He pointed ont, furthermore, that a recent ruling of the Minister of Justice, in his opinion, sustained his position, and that he was the more bound to abide by his original position in that the Minister was the legal adviser to the Governor-General in Conncil, under whose instructions the LieutenantGovernor administered the Government to the Territories. He had accordingly been obliged to select a Council from among those members of the Assembly who were willing to comply with the law, and. it was evident that no such Advisory Council could be formed which would commant the confidence of the House.

During the remainder of the session the Assembly maintained its attitude of hostility towards the administration and severely criticised the execttive in many regards, especially as the means taken to promote immigration. Unavailing attempts were made by. Dr. Brett and Mr. Betts to induce the House to go into Committee of Supply, and on the 27 th of November, after a long and stormy debate, a lengtlyy and cxtraordinary reply was passed in answer to His Honour's message of explanation, to which we have alrearly referred. In the course of this address the Assembly oftered the following observations with regard to the opinions expressed by the Minister of Justice for the Dominion Government :

"The Asscmbly feels bound to point out to Your Honour that the words of the Honourable Hinister of Justice quoted . . did not relate to or purport to be an expression of opinion regarding the position which Your Honour takes-that control of the Territorial Revennes rests with Your Honour and such Advisors as Your Honour may choose, and not with this Assembly-and that therefore the ruling of the Minister of Justice, quoted by Your Ilonour, does not apply to the case.

"The Assembly feels also further bound to inform Your Honour of its belief that the North West Territories Act, calling it into cxistence and defining its constitution and powers, is for the information and guidance of its several members and for that of the Honse as a whole, as well as for that of Your Flonour or of the Nlinister of Justice, and that the members of this Assembly are severally responsible to the people of the Territories for their own interpretation of the $\mathrm{Act}$, and the course they take based upon that interpretation: which responsibility they are not relieved from by an expression of opinion on the part of anyone, or by anything short of a declaration from a superior authority. The Assembly regrets that Your Ifonour has not seen tit to point ont the section of the $A \mathrm{ct}$ which invests Your Honour and vour . Jdvisors with what appears to us to be the very extraordinary and exceptional measure of financial control which Your Honour asstmes to possess."

The Assembly furthermore declared that "Govermment by the minority against the expressed wish of the majority is a violation of the intent of the act. . . Your Honour may govern under instructions from Ottawa (in cases when for any reason you cannot act with the House), or by and 
with the advice and consent of the I.egislative Issembly, hut we can find nothing to show that your Ilonour is empowered to govern with advisers responsible only to yourself." The Ilouse hased its daims t" control moneys voted from year to year by the Parliament of Canada for Territorial Government, on the fact that these appropriations were voted in general terms for the purposes of local Government, which local Government must he carried on by and with the adrice and consent of the Legislative Ascembly, and that, moreover, these grants were apportioned to purposes controlled by or depending upon the action of the local House. If the Territorial legislation were to be of full benefit to the people of the Territorics, the Assembly must be made aware from year to year of the amount of funck which conkl be depended upon. Noreover, these funds they considered cuite as much the property of the people of the North West Territories as that part of the local revenues derived directly from the issne of licenses. The Govemor's attention was called to the fact that on December 11,1888 , he had given, as we have noted above, his assent to a Supply lill in which the Assembly had actually voted upon the sums derived from Dominion sources. and that thus an inviolable precedent had been establisled. In view of His Honour's announcement that "Ilis Excellency the Governor in Council for many years past had assumed without question the control of the expenditure of the moneys amnally voted by the Parliancut of Canada for school purposes in the Territories, the Hlouse would henceforth consider itself entirely relieved from any responsibility in regard to school expenses." Whether inadvertently or otherwise, it appears from the records of the IJouse that no special person was designated to conver this indignant reply to the Lieutenant-Governor. Consequently, we read in a footnote of the Journal:

"This address was not presented to His Honour the lieutenant-Governor."

On Novenber 28th the Housc adopter still another address to the Governor for transmission to the Ottawa authorities, stating that in the preceding session it had presented a memorial with regard to the present form of local Government in the Territories, the finances of the Territories and other matters: and that as no action with reference to many of these matters having been taken by His Excellency's Govemment the Assembly humby reiterated the representations then made and prayed that action be taken thereon.

This stormy session terminated on the 20th of November, I8go.

In the following May, Messrs. Prett and Betts visited Ottawa with a view to securing for the Territories a fully responsible system of government, and thus relieve the extraordinarily complicated situation in which the Governor, his Adviory Council and the Assembly found themselves 

entangled. In the Doninion general elections of the preceding March Messrs. D. W: Davis, Innourable E. Dewdney, N. F. Davin and D. H. MacDowall, all of them supporters of the party in power, had been the members elected by the Territorial constituencies to represent the North West in the House of Commons. These gentlemen, together with the North West senators, Messrs. Loughead and Ferley, were consulted by the cabinet in connection with Dr. Brett's proposition. The majority of them, however. believed that the proposed change should be postponed until the Territories were divided into provinces. The agitation for a form of Government modelled after that of the existing provinces was, they believed, not the product of a general popular demand, but merely of the personal wishes and ambitions of members of the Territorial Assembly. Furthermore, it was urged that the prenature establishment of any form of cabinet government, with its associated departmentalization, would imolve the Territories in unnecessary expense.

To understand this clash of opinion between members of the Assembly and Territorial representatives in Parliament it is necessary to recall the social and political conditions of the times. Railways, telegraph lines and newspapers were few, postal facilities were inadequate, and the overwhelming majority of the people of the West were struggling with stern poverty. such as newcomers who hate been in the country for only the last decade can scarcely realize. Moreover, the population was exceedingly small and scattered in isolated groups over a country of vast extent. When it is said that there was no very definitely organized force of the public favourable to or eagerly demanding responsible govermment the assertion is true, but it is true simply because under the circumstances there could be no very definitely organized force of public opinion on any subject. In so far as any: public opinion on political subjects existed at all, it seems generally to have been favourable to the principle of Territorial control of local financial interests. An impartial examination of available evidence leads me to the opinion that the members of the Assembly more truly represented local sentiment than did the lederal members. Moreover, these were the days of open voting. and when the majority of the people were still dependent on the reports of government officials for the issue of the titles for their land it was not easy to get a free expression of opinion in Dominion elections. It required some courage and force of character to run the risk of alienating the good-will of the Federal Government; and the expressed opinions of Dominion nembers for the Territories were too frequently mere echoes of the opinions held by a cabinet at Ottawa astonishingly ill-informed regarding every Western interest and desire.

However, during the Dominion session of this year, 18y, the Honourable Mr. Dewdney intronluced a new North West Territories Act which was duly 
. 
passed. It gave the Lientenant-Gorernor authority to dissolve his Issembly and cause a general election when such action secuned necessary in the public interest. The powers of the lssemlly were srunewhat increased, perhaps, but a portion of the Domiuion subicly was still lefit under the immediate control of the Licutenant-Coxernor. The new contitution clininated from this assembly the appointed "legal experts" provided for in the $\lambda$ ct of 1888 . The Advisory Cumcil was not formally and definitely abolished, but provision was mate, though very obscurely, for a Committee of the Assembly, that canc to be fooked upon as right fully inlueriting the special functions of the Advisory Conncil and exercising others ats well." Provision was marle for the establishment of a ballut system by the local foverument, and the number of membets was raised to twenty-six.

The first Ascenlly elected under this act met in the following December, the election having taken place the preceding month. Mr. James II. Ross, of Moose Jaw, was chosen as Speaker. The new constitution leit the Assembly with consideralle latitude as to the details of administration and for some time the members devoted themelves to the discussion of the best form of government for them to arlopt. As a result of these deliberations they passed "An Ordinance liespecting the Executive Gorermment of the Territories." This provided for an Executive Committee com isting of four members of the Assembly appointed by and holding nffice during the Lientenant-Governor's pleasure.

Mr. Haultain, as I'renter, tngether with Messrs. Clinkskill, Neff and Tweed, were now appointed to the Territorial Executive Committe. Ilowever, Mr. Clinkskill wilhdrew very shortly, owing to a difference in opinion will regard to school matters. Ife favoured having separate inspectors for Protestant and Catholic sclools, and his views having met with disapproval, he resigned from the Executive Committec, being succeded by Mr. Cayley, of Calgary. The school controversies of this cra and the important legislation associated therewith will be treated of at some length in a future chapter.

Ieantime, in pursuance of the new North West Territories Act, the Governor-Gencral in Conncil had passed an order assigning to the Lientenant-Governor, acting by and with the advice of the Assembly or a committee thercof, the control of certain speciferl pertions of the Dominion sudsidy, totalling over $\$+3.000$. This constituted a distinct advance toward

${ }^{3}$ The relevant pasrages in the Amending Act of $189 \mathrm{r}$ are as follows:

"The Legislative Ascembly sliall, culbject to the provisions of this Act, or of any other Act of the P'arliament of Canalia, at any time in force in the Territories, have power to make ordinances ior the Gosermment of the Territories in relation to the expenditure of Territorial funds and such portion of any moness appropriated by Parliament for the Territories, as the Lientenant-fivernor is anthorized to expend by and with the advice of the Legislative Assembly or of any committee therent."

In practice the Assembly elected an Execulive Commintee under this clanse, and the Liententant-Governor accepted its members as his Advisory Comncil. 


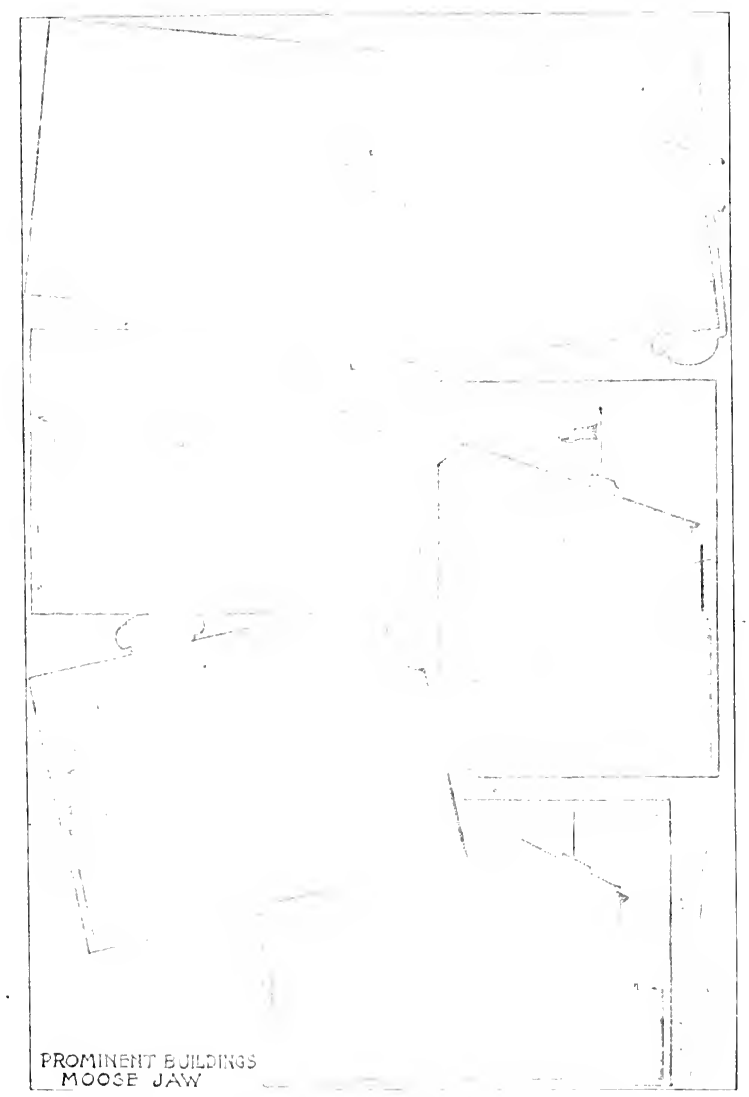



Territorial control of Territorial tinances. The following year the corresponding anount was one-tiiird greater.

In August, I892, during the second session of the Second Legislature, Mr. Cayley headed a revolt against Mr. Inaultinin, and by a vote of thirteen to twelve carried through the Assembly a resolution of non-confidence. The next day Mr. Haultain informed the House that the resignation of the Executive Committee had been tendered to and accepted by the LieutenantGovernor. Mr. Cayley was selected by His Honour, and associated with himself Messrs. NacKay, Nowatt and Reaman; but the new administration was rendered helpless by the unexpected resignation of Mr. Speaker Ross, who had been an ardent supporter of Mr. Hanltain in his efforts to establish responsible government.

Mr. Ross has been severely criticised for his action in this regard on this occasion by his political opponents and by others who hold uncompromisingly to the principle that, by accepting his office, the Speaker of a British Legislature precludes himself entirely from, with propriety, participating in any partisan dispute. In judging Mr. Ross's action it should be viewed in its relation to the constitutional listory of the preceding five years, and to the part he himself had played therein. Accordingly it is but fair to give his reasons in his own words, spoken from the floor of the House:

"In resigning the chair of this Ionse, I desire to make the following statement: I was elected Speaker of a IIouse, to which a large majority of those who for two years previously had heen struggling for Responsible Government, had been returned, as one of the party which had been engaged in that struggle, and had been unsuccessinl in the late general election. I reasonably expected that any Advisory Council or Committee which might be formed would be composed of those, and those only, that belonged to that party. In view of the defeat of the Executive advocating the principles which I lad struggled for longer than any other member of the House, and the success of a party evidently, indeed necessarily, opposed to those principles. I feel that in duty to myself and my constituents I must place myself in such a position as to be able by voice and vote to advocate those principles and protect the interest of those who elected me to this House."

Mr. Cayley insisted on nominating Mr. Sutherland, despite that gentleman's protests, but as the proposed Speaker voted against his own election a tie resulted, and the business of the House was thus brought to a standstitl. The record in the Journal of the House accordingly ends with the following abrupt announcement :

"The question having been put by the Clerk, the members divided, and, the votes being equal. the Clerk declated that no election had been held; and the Clerk having left his seat at the table, the members then dispersed." 
. 
On the following day the comedy was renacted. Mr. Cayley was stil! impotently determined to put Mr. Sutherland in the chair and he and Mr. Haultain's other supporters wete equally determined not to submit. As the members again dispersed, Mr. Cayley announcel that the House would be prorogued.

Mr. Haultain was accordingly deputied by his adlerents to interview the Lientenant-Governor that crening to protest against this threatened prorogation. Mr. Iaultain pointed out to His Honour the futility of attempting to compel any member to be Speaker of the Legislative Assembly, willy nilly. At the same time it was the manifest duty of the leater of the Execntive Committe to secure the organization of the Hotrse so as to prevent paralysis of the business of the country. If Mr. Cayley coukl not end the deadlock, it did not follow that it was therefore irremediallic. If the Government simply left matters alone the situation would soon be relieved in the natural conrse of events. As it matter of fact, though he could not tell the Lieutenant-Governor in so many words, Mr. IJaultain hat already leen approached by some of his former supporters who had jomed the Cayley faction, who felt that things had now gone far enough and were prepared to cöoperate with their formet leader in the choice of a Speaker. Mr. Royal. however, was very inligniunt over the turn affairs had taken and determined to maintain Mr. Calyley in power.

Next morning Xiessrs. Jittuttain, Tweed and Mlagrath waited mpon the Lieutenant-Governor, and informed him that the opposition was willing that Mr. Magrath be elected Speaker in order that legislation hefore the House might be completed, lut the lientenant-Governor had alrealy signed a proclamation prorogning the Assembly. Mr. Haultain and his supporters then issued a manifesto protesting against the Governor's conduct, and specifically charging him "with having taken the position of a political partisan in thus unnecessarily and unjustifiably proroguing the Ilonse to the injury of public business and in defiance of constitutional law and usage." This indignant accusation was signed by half the members of the Assembly, and telegrapled to the Dominion Government.

In the Leader of August 25th $\mathrm{Mr}$. Marin expressed ectitorially the following views upon the situation that had arisen, and his opinion may be taken as representative of that of many others:

"Shortly after three o clock in the afternoon of the 2fth, Mr. IIaultain, leader of the Executive, rose to move the Ilonse into the Committee of Supply, and delivered his budget special. Messrs. Petts and Mowatt introduced a motion of non-confidence, which was followed by a debate of more than seven hours. Then IIanitain's administration was defeated by a majority of one.

"The affairs of last night we cannot but regard as unfortunate. Its effect on the public business and on the eastern mind cannot he otherwise 
than bad. Nith regard to who is to blame, the public will quickly iudge. It needs no great discermment to see faults in both parties. Mr. IIatuliain is an able man, young, cultured and intellectually strong, and the country gives him credit for having, to the best of his rights, attempted to carry on the Govermment. But he is young in statesmanship, and, like the rest of erring mortals, makes mistakes. He has commited errors of judgment; he has sometimes been deficient in tact; he has perbaps gone on the idea that Haultain and the Fixecutive were syonymous terms; this is the rock on which he has stranded. He is too wise a nan not to profit by lis present experience and not to see that perpetual watchfulness will alone save him from splitting on that rock. At the same time, it must be remembered that he was the choice of the country for position of J.cader of the Executive, and that he was given the unanimous support of the Assembly. He and his colleagues liad got well into harness and the business of the country was going on with complete satisfaction."

In September Mr. Royal went to Ottawa to consult with his Federal advisers regarding the deadluck. It is well known that they disapproved of his action in proroguing the Assembly. The situation of the Territorics was certainly extraorlinary, from a constitutional standpoint. Under the law of the land, unless the money at the disposal of the North West Govermment was appropriated by ordinance. by act of the Parliament of Canada, or by order of the Governor-General in Conncil, the Lientenant-Gorernor in Council had aththority to appropriate it for purposes of public services, reporting in detail sucl expenditure to the Assembly at its next session. This ncant that Mr. Royal and Mr. Cayley, with their three colleagues, were left in absolute control of public money to the amount of three hundred thousand dollars. During the recess Mr. Cayley and the other numbers of the Executive Committee proceeded with the conducting of public affairs, but the death of Mr. Reaman, being followed by the election of Mr. F. R. Insinger, a supporter of $\mathrm{Mr}$. Ilatllain, the executive manifestly faced defeat when the third session of the Second Legislature met in December of the same year, from the th th the 3 tst. Accordingly; the day before the session commenced, Mr. Cayley and the other members of the executive resigned, and with the approval of the House by a rote of fourteen to eleven they were succecded by Messrs. Haultain, Neff, Tweed and Mitchell. Messrs. Ross and Sutherland were unaminously clected Speaker and Deputy Speaker.

Several important bills passed by the Asscmbly in recent sessions, notably that defining the composition and duties of the Executive, had been criticised as ultra aircs by Sir John Thompson. Minister of Justice. Indeed, this was the ostensible reason for Mr. Cayley's resignation. Accordingly, the objectionable clatse in the ordinance relating to the executive was climinated and terms were substituted corresponding literally to the provisions of the Dominion Act. This involved an apparent surrender of the demand that the Lientenant-Governor shonld administer the Government as to all matters 
according to the alvice of his Executive Committee, but such it was not. The ordinances of Mr. Royal's administration embody the persistent efiorts of Mr. Haultain and his supporters to secure the maximun degree of territorial independence practicalle muler existing Federal laws. No loophole was surrendered by the westem insurgents unless rendered untenable by further Federal cnactment or the decision of the Governor-General in Council. When checked in one direction, moreover. Mr. Hatlain and his friends simply changed their weapons or their mode of attack. In the present instance, upon amending its ordinance regarding the Executive Committee to conform with the Federal law, the Honse passed the following resolution and telegrapled it to Ottawa:

"That the Inouse claims the right of the Ilouse through its committee to advise the Lientenant-Governor in relation to all exceutive acts and appointments made necessary by Territorial Ordinances."

In point of fact the Governor and his Ottawa advisers lad all but receded from the uncompromising attitule they had hitherto assumed, and the latthe for responsible govermment was nearly won. Nr. Royal's present attitude was indicated in his speed of becember 31 , 1S92, when he prorogued the Honse:

"I feel conficknt that my relations with the representatives appointed by you to advise me in matters of finance will be of the most cordial nature. 1 shall deem it my duty to give careful consideration to their advice in relation to the expenditure of public monevs in the manmer determined by you for the carrying on of pulslic service."

It is also interesting te read in the Jommals of the 3 int of December, I892, that the supply Bill was again presented and aseented to in the constitutional terms that had been in listlse ince 188.

On August 17. Igo3. the last session of the Legislative. Issembly for Royal's administration was convened and sat for one montl. This session was, upon the whole, relatively peaceable, but, when moving to go into supply, Mr. Haultain made an explanation and registered a protest regarding what may be considered as practically the last manifestation of the autocratic attitude hitherto adopted by North West Territorial Governors, or imposed upon them by the law of the land. Lientenant-Governor Royal had franed his estimates and forwared them to Ottawa without the knowledge or consent of his Fxecutive Committee. Indeed the estimates so submitted were in inportant regards disapproved of by Mr. Hattlain and his colleagues and were contrary to a memorial recently passed by the House praying that the Federal Goverument slotuld grant a lump sum rather than detailed amounts for specific objects. Nowadays, if a Lieutenant-Gov- 


\section{.}


ernor were thus to ignore his responsible advisers, a very serious crisis would be precipitated; but Mr. Haultain evidently thought that on this occasion a memorial to the Dommion Government and an explanation to the Legislature were sufficient to clear him from responsibility for the Governor's act and to prevent the repetition of sucl arbitrary metlods. He knew, and the House linew, that the probability was so small as to be negligible that a future Governor would attempt seriously to thwart the wishes of his Legislature.

In addition to controversies with the Donninion anthorities regarding the legislative powers of the Territorial Ascmbly, the establishnent of responsible institutions and the detcrmination of the special forms under which a constitutional government slould be administered in the Territories, and unnerous memorials as regards multifarious other grievances and requests, a struggle for better financial terms in the matter of a Dominion stubsidy engaged the Territories throughout Royal's regine. From the first the Territorial subsidy was found insufficient to supply the public service required in the growing West. Moreover, as the Crown lands were still retained by the Federal Goverument, and as the Territorial Legislature was precluded from borrowing money, it was justly argued that the Territories were entitled to special consinleration in the matter of subsidies. A memorial on this stbject was presented in 1899 and thereafter from session to session. Hitherto an indefinite sum had been voted from year to year by the Parliament of Canada for the expenses of the Govermment in the North West, but its limited amount and uncertainty serionsly lampered the Territorial Assembly and Executive. Consequently a fixed payment in the nature of a provincial subsidy was asked for. Owing to the rapid increase in population, the amount of such subsidy, it was concluded, should be revised at least every five years, but even in 1889 the population of the Territories was estimated at one hundred thousand, and would, in all probability, so increase during the next five years as to justify basing the subsidy on an estimated average population of one hundred and fifty thousand. The regular allowance to the Provinces was eiglity cents per head, and if the Territories received a similar grant on the estimated population aforesaid it would amount to one hundred and twenty thousand dollars. Manitoba was in receipt of fifty thousand dollars as a specific grant for govermmental purposes, and the Territories petitioned for a like sum, as well as for one hundred thousand dollars on acconnt of the Crown lands remaining vested with the Federal Government. Other claims were also advanced, including which the Territorial Legislatture felt that they were entitled to an annual subsidy of slightly over four hundred thousand dollars. which was considerably nore than twice what they were getting.

${ }^{4}$ Journal of November 2r, $18 S$. 
In $18 y 0$ these representations were repented, as no action had heen taken on the matter by the Federal Govermment. Many needed public ntilities had to be starved or postponed for lack of funcls, and when the estimates for the year ending December 3r. ISor. Were brought down the Govermment nevertheless faced a deficit. Even if the mean pupulation of the next four years were estimated only at one bunded and twenty-he thousand an ordi nary provincial subsily of eighty cents per head would yield one hundreri thousand dollars, aml the other grants curresponding to those previous? asked for would make a total if more than three humeled and sixty-eight thousand dollars.

As a result of these representations $\backslash[$ r. Hathtain was requested by the Government of Canada to go to Ottawa, March, s\&yz, to confer with regati: to the funancial clams of the Territories. A sub-committee of the l'rivy Conncil, consisting of the Ministers of Finance and the Interior, were aypointed to confer with him and reported favomally with regard to his requests. This report, however, was not acepted by the Council, and Mr. Ilaultain was requested to make alternative propositions. He, howerer, insisted upon the terms as set forth in the Assmbly's menorial, and the Premier and his Minister of Justice were added to the sub-committee io consider the matter. Again the Privy Comcil was olvlurate, and Mr. Haultain then suggested that insteat of an itemized rote, Parliantent shouki vote a lump sum for the expenses of govermment in the North West Territories. Accordingly, by order in Council the bulk sum of $\$ 193.200$ was plited. under the control of the Assembly-an advance of some fifty thonsand dollars. A supplementary vote of twenty-six thousand seven humdred dollars was also allowed to cover a deficit in school moners.

The circumstances under which this deficit had arisen require some explanation. The estimate for schools in I 8 gr to $1 S y 2$ was over one humdred and eighteen dollars, but Parliament actually granted only one humdred clollars. Ender the Governor-General's order in Cumncil of July 18. 18yo, the expenditure of this vote, according to the terms of the Territorial ordinance. was authorized, but on the 22nd of Jume, I80), this order in Conncil was cancelled. Neantime trustees had engaged teachers and had incurred varions expenses in their reasonable expectation that the grants mentioned in the ordinance would be available, and great public inconvenienee resulted. Moreover, $\$ 5.752 .55$ of a supplementary vote from a preceding year had lapsed, becanse circumstances rendered it impossible to expend it within the time it was available. The result was that for more than a year the Legislative held out grants which could not be paid, and so was involuntarily obliged to break faitls. The Assembly felt so keenly the invidions position in which it was thus placed that it set apart ten thousand dollars of the local revenue to reduce the deficit in the school grants. It had accordingly requested that 
$\cdot$ 
moneys voted by I'arliament for the Territories should hereafter be in a lump sum and not lapsalole.

Mr. Haultain's efforts to secure hetter terms had met with at least a measure of stccess, but he was very far from being satisfied. Accordingly. in the last year of Royal's administration the Premier renewed his financial negotiations with the Dominion anthorities. IJe had several conferences at Ottawa and obtained the time-worn promises that the Territorial clam: would receive due consideration. Ilowever, for the time being. he had to be content with nothing more tangible than a mere promise.

We have seen that the regime of the IIonomrable Ir. Royal was from first to last marked by keen political battles and that in many of these the Governor himself stood for political principles very ohjectionable to the elected refresentatives of his people. Nevertheless, he always enjoyed a high degree of personal good-will and he shomld not be hlaned for having been called 11 on to arlminister govermment umer an impossible constitution. At all events friction between him and his I, egislative had ceased he fore the expiration of his term of office, and this review of the political history of his administration may conclude by the quoting of the amicalle arldress with which MIr. Royal bade farewell to his last. Issembly:

"As this is the last public occasion wpon which I may expect to meet you, allow me to say that, in resigning the Idministration of the Government of the Territories into the hands of my successor, I shall do so with mingled feelings of regret and satisfaction.

"I shall regret to leave you lecause I have never failed, even under trying circumstances, to receive at your hands the loyal treatment due to the Representative of Her Majesty. notwithstanding the fact that at times our duty assumed to lie in opposite directions.

"It was mine to carry into effect what I considered to be the law, as laid down by the Parliament of Canada, for regulating your slare in the responsibility in the administration of pullic affairs, and. whilst you clamed to exercise a more complete control over the expenditure, that Law placed me in a somewhat invidions position of appearing to oppose the popular interests. Notwithstanding this controversy, no umpleasantness ever arose between me and the Assemlly.

"When on the 4 th of July, ISSS, I was sworn in as Licutenant-Governor of the North Vest Territories, the innetions of that office were as totally different from those of the Iientenant-Governors of the Provinces, as they will be from those to be performed by my successor. I was responsible to the Prive Conncil alone for all executive acts done in the Territories. The Assembly had hardly a voice in the Govermment of the country and the Lientenant-Governor was practically a Political Commissioner under whose direct supervision and anthority the affairs of the Territories were conducted and administered.

"Now all this had been materially changed, and hence nu satisfaction.

"The Legislature tolay practicaliy enjoys the rights and privileges of self-govermment. Let ne congratulate you sincerely upon the wislom and 

discretion you have displayed in undertaking your new and important dutics.

"My satisfaction is further derived from the fact that these Territories are at the present time enjoying a measure of peace and prosperity unsurpassed, if not unequalled, by any other portion of the Duminion of Canada. In this happy confition of affairs for which we lave to thank the Divine Providence, I now take my leave of this Assembly." 


\title{
CHAPTER XXXII
}

\section{ROYAL'S ADMINISTRATION: SOCINI AND INDUSTRIAL DEVELOPMENT}

\begin{abstract}
Drovgat and Agricultukal Deiresston-Conditon or the Ranching Industry-Rise of Daikying-Burdensome Land RegulationsRailifay Develop ment-Iamigration Propaganda-Conthanental Immigration-Educational Detelopanent-Territorial Board or Education Creited-First Saskatchewan University Act.
\end{abstract}

During the later eighties and early nineties the North West Territories saw considerable development along many lines, but during this time the farmers suffered from many depressing circumstances. In I889 an unprecedented drought prevailed practically all over the Territories, and in consequence prairie and forest fires were reported by the Governor as more extensive and disastrots than ever. The Mounted Police were unwavering in their endeavors to enforce the provisions of the fire ordinances, and very many persons guilty of criminal carelessness were brought to justice. Nevertheless it can easily be seen that in the conditions then prevailing it was a very easy thing to start a conflagration which, despite all efiorts for its suppression, would in a few hours spread over many townships, causing much loss and distress.

On the whole, ranching proved more remunerative and encouraging than grain farming-yet the cattle men had their troubles. These arose in part from the spread of settlement both on the part of regular homesteaders and of numerous squatters, and in 1892 a large deputation of western ranchers interviewed the Minister of the Interior to explain their grievances and difficulties. In the spring of the following year a settlement was made with the cattle men on a new basis: the outstanding leases were cancelled and the ranchers were given the privilege of purchasing one-tenth of their holdings at one dollar and twenty-five cents per acre. This gave them the needed security and at the same time threw open large areas for settlement by grain growers. Moreover, in that year almost three million acres were surveyednearly twice as mucl as in the preceling year.

In the American states sonth of the Territorial border a scrious epidemic of cattle disease occurred, and it was therefore necessary to rigidly enforce 


quarantine regulations. Many Canadian ranchers complained that, though their herds were free from disease, they suffered much loss from the restrictions under which they were compelled to conduct their business. This was especially so during the last years of Royal's administration.

In the nearly nineties dairying developed into an important industry, and in 1892 a dairymen's association for the Territories was organized at Regina, which did much to stimulate this important industry. The association received sthbstantial aid from the Legislature.

Much dissatisfaction manifested itself from time to time with regard to land regulations. Under the existing system a very large proportion of the land in the settlement districts was not available for homesteading. This seriously interfered with the organization of school districts and with various improvements, but the protests of the Assembly and the general public bore little fruit. Efforts were made to have the registration of land titles vested in the Territorial Govermment, but with no success. Under the regulations enforced in the Territories the settlers found themselves at a considerable disadvantage as compared with those of Manitoba. In a memorial passed by the Assembly, September I3, ISy3, it was declared that the Homestead Commission's Estate Act had prover so muworkable and generally objectionable that under it only one registration had taken place in the Territories, although the act had been in force for a period of sixteen years.

In 1889 there was nuch agitation for the completion of railway lines to connect Saskatchewan with the sonth and for extensions in varions directions. In this year the Qu'Appelle, Long Lake \& Saskatchewan Railway between Regina and Prince Albert came into operation. Before the end of 189I an important line was opened from Calgary to Edmonton and another from Calgary to MacLeod. This last named enterprise was associated with the attempt on the part of the authorities of the Canadian Pacific Railway to establish a new town to the detrinent of MacLeod, but happily for the latter the prospect failed. In 1892 the Canadian Pacific Railway built a line through the Souris district to where the new town of Estevan was rapilly. developing into a coal-mining centre of importance. Work was also progressing upon a road entering the Territories in the southeast, which would join the main line of the Canadian Pacific Railway and thus open up a new ani highly important route between the IIississippi Valley and Vestern Canada.

From the first, Royal and his Territorial advisors gave serious attention to the task of bringing before the European public the natural advantage:, of the West, and the opportunities it afforded intending immigrants. These endeavors were supported by the Assembly in so far as the local revenue would permit and the matter was persistently brouglit to the attention of the Dominion anthorities. The Canadian Pacific Railway was also devoting considerable attention to the problem and, largely through its efforts, foreign 

colonies were established beiore the end of I 888 in many parts of the North West on lands controlled by the railway company. The Scandinavian settlement of New Stockholm was established north of Whitewood. A Rottmanian colony settled at New Toulecha, near the village of Balgonia. Germans and Galicians in considerable nmmbers founded homes at Rosentlial and Josephburg. Swedish immigrants settled at Flening; IIungarians at Esterhazy; Fims at New Fimnland; Icelanders at Medicine River; Russian Jews at Wapella, and Poles and Danes near Yorkton. By IS92 there had been a considerable immigration from the Dakotas. The settlers from that quarter were especially welcome, as to a large extent they were former Canadians from the East.

The World's Fair at Chicago in 1892-3 was an crent of much interest throughout the Territorics. Active measures were taken by the authoritics in coöperation with agricultural and other societies to sccure an exhilition of a suitable collection of Western Canada products, including timluers. cereals, mincrals, grasses, fruits and vegctables, and the IIon. Senator Perley was appointed commissioner to represent the Territories at the Exposition.

Perhaps the best test of develomment throughout the Territories is sipplied by the records of the growth of the school system. In IS89 it was very widely discussed in the newspapers of the Territories. There was already a widespread conviction that the schools should be rendered entirly non-sectarian. This opinion was voiced by the Prince. Albert Times, the Regina Journal, the Moosomin Couricr. the Vidette and the Progress of Qu'Appelle, and by varions jonmals in what is now Alberta.

In his speech from the throne, October, I889, Mr. Royal reported the existence of $16+$ schools attended by $4.57+$ children, an increase of 33 schools and I,I2I pupils over IsSS. Provisions had becn made for instruction of a more advanced character than that hitherto available, and under them Uniun Schools were established at Regina and Calgary, in which high school work was carried on. In the following year similar schools were establishel at Moosomin, Moose Jaw, Prince Albert and Lacombe. Parents in these ditricts were now afforded an opportunity of obtaining for their children at high class education within easy reach of their homes. The Territorial emrollment for I8go showed an increase of well over 800 pupils. In the following year fiften new schools were opened and the enrollment was further increased by over one thonsand.

In 1892 some important changes were introduced in the school system. The new Territorial Board of Education was to hold office "during pleasure" instead of for two years, and was to mect whencver called by the Executive Committee of the Territories. The agitation adverse to sectarian schools resulted in the appointment of inspectors, who were under the control of the 
executive, to inspect all sclools nuder one system, whether frutestant or Catholic.

Provision was also made for examinations for teachers certificates under a general board of examiners appointed by the executive. School grants were increased to $\$ 20$ and provision was made for the establishment of the single tax system as far as rural schouls were concerned if threefourths of the rate payers so decilet. Linimproved lamks were to bear the same taxation as improved lands, and all bulding and other improvements were to be exempt from assessment.

During I 892 difty-three new schnol districts were established and the attendance continued to show a marked improvement. In this vear a Council of Public Instruction was organized, being composed of the numbers of the Executive Committec and fon appointed members, wo l'rotestants and two Roman Catholics. The Lientenant-Guvernor was chaiman. Messrs. Jolnn Secord and Charles Marshallsay were the Protestant representatives and Messrs. C. B. Roulean and A. E. Furget represented the Catholics. Mr. James Frown was the first secretary of the board.

An interesting evidence of the increased interest in efucation is fotund in the fact that on November 20, 1890 , a rescilution was arlupted whereby the Assembly petitioned the IJut1se of Commons, suggesting the arlvisabifity of selecting and setting apart land for university purposes, so that the same might be available when the country was divicled into separate provinces.

A convention was also called in Kegina in Jantury, 1801 , to which all university graduates resilling in the Territories were invited for the purpose of discussing the formation of a miversity. The up hot of this movement was the passing of the Saskatchewan Iniversity Act by the Dominion Government.

It will be seen that the social and industrial progress of the Territories during Royal's regime was not rapit, but upon the whole teady and healthy. All Canada was suffering from conmercial depression and the stringency of the money market, and this was especially felt in the new settlements of the Vest. European enigration was still directed amost exclusively to the United States, but the farseeing recognizel the fact that the long era of tardy development in the Territories was nearing an end and that better things were in store in the near future. 


\section{CHAPTER XXXIV}

\section{MACKINTOSH'S ADMINISTRATION: POLITICAL HISTORY, $1893-1898$}

Aprointaent of Mackintosit-The First Election by Ballot in the Nortil West--School Controversy-Recognition of Justice Macleod's Seritices-Lieutenant-Governor Witiliolds Assent to Scilool Ordinance-Bowell's Comment-Newspaper Criticisms-Difficulties of the Lieutexant-Governor's PositionHis Defense-Mackintosil Exonerated-Agitation for Better Terms-Finat. Victory for Responsible Government-Mackintosh's Fareweil to the Assembly.

On the IIth of November, I893, Mr. Royal's term of office having expired, Mrr. Charles IIerbert Mackintosh, well-known Ottawa journalist and politician, arrived at Regina to tndertake his duties as the newly appointed Lieutenant-Governor of the North West Territories.

On the I6th of January following, a by-election occurred in the constituency of Whitewood, which is of special historical importance as the first Territorial election in which use was made of the secret ballot. Upon the suggestion of the Honourable Frank Oliver, territorial ballot papers were at first perfectly blank. The voter's choice was indicated by the color of the lead in the pencil he selected, each candidate having a distinctive color. The aim of this curious system was to enable the numerous immigrants, who were now exercising the franchise but could not read English, to register their wisles in an indisputalle way. A somewhat amusing incident in this by-election, however, showed that complications might arise even under a variegated learl pencil system. Mr. Josepli Clementson, of Broadview, was the most popular candidate. Voters favoring lim marked their ballot with a green pencil. At one polling station the supply of green pencils ran short and to procure another forthwith necessitated a thirty-mile ride through a January snowstorm.

Lientenant-Governor Nackintosh assembled the fifth session of the Second Legislature on August 2, 1894. A prominent feature of this session was the receipt by the Ifouse of a very large number of petitions for the suppression of the liquor traffic. Messrs. Oliver and Dill were the leaders 
of a snall group who favored a probibition measure, but the majority of the members considered it undesirable that any legislation should be passed for the suppression of the traffic until the views of the comntry had been ascertained by a plebiscite.

Very interesting and important debates upon the scliool system occupied much of this session. At the request of the Governor-General in Comncil the Lientenant-Governor laid before the Assembly copies of various memorials and other documents ly Roman Catholic citizens of the Territories, including a memorial of IIis Grace the late Archbishop Tacle, of St. Boniface. The Governor in Comcil expressed the earnest hope that the Issembly would take into consideration the various complaints and atopt speerly measures for the redress of any genume gricrance that might be found to exist. Numerous reprenentative Catholics clamed the right to have under their control the general management of their schools, the arrangement for the examining and licensing of their teachers, the selection of their textbooks and the inspection of their schools by qualified persons of their own faith. They also clained the right of establishing separate schools with boundaries irrespective of those of pullic schnol districts, the right of 11 sing the French language as a merlium of instruction and the right of opening their schools with prayer.

On September 6th a lengthy report was tendered to the Honse by its Stauding Committee on Education, which recommended that it should be permissible to open school with the Lord's Prayer and that no general regulations respecting (a) the management and discipline of schools. (b) the examination, grading and licensing of teachers. (c) selection of text books, (d) inspection of school, or (e) normal training should be adopted or amented except at general neetings of the Council of Public Instruction duly convened for the purpose. Otherwise the committec deened it inadrisable to recommend any important change with regard to the matters under consideration. A report to this general effect was concurred in by a vote of nineteen to three.

Subsequent debates also occurred upon the best means of meeting the situation created by recent serions crop failures. This topic, however, will be treated of in another place.

The Honse adjourned on September 7. 1894. having passed a rery large number of important ordinances.

Among the resolutions transmitted by the Assembly to the GovernorGeneral in Council was one called forth by the death of Mr. Justice Macleod, whose services to Canarla lad been of so important a claracter. Having joined the North Vest Mounted Police in I873. he became Assistant Commissioner in 1874 and Commissioner in IS77. Three years later he was made a Stipendiary. Magistrate and in 1887 a judge of the Supreme Court 



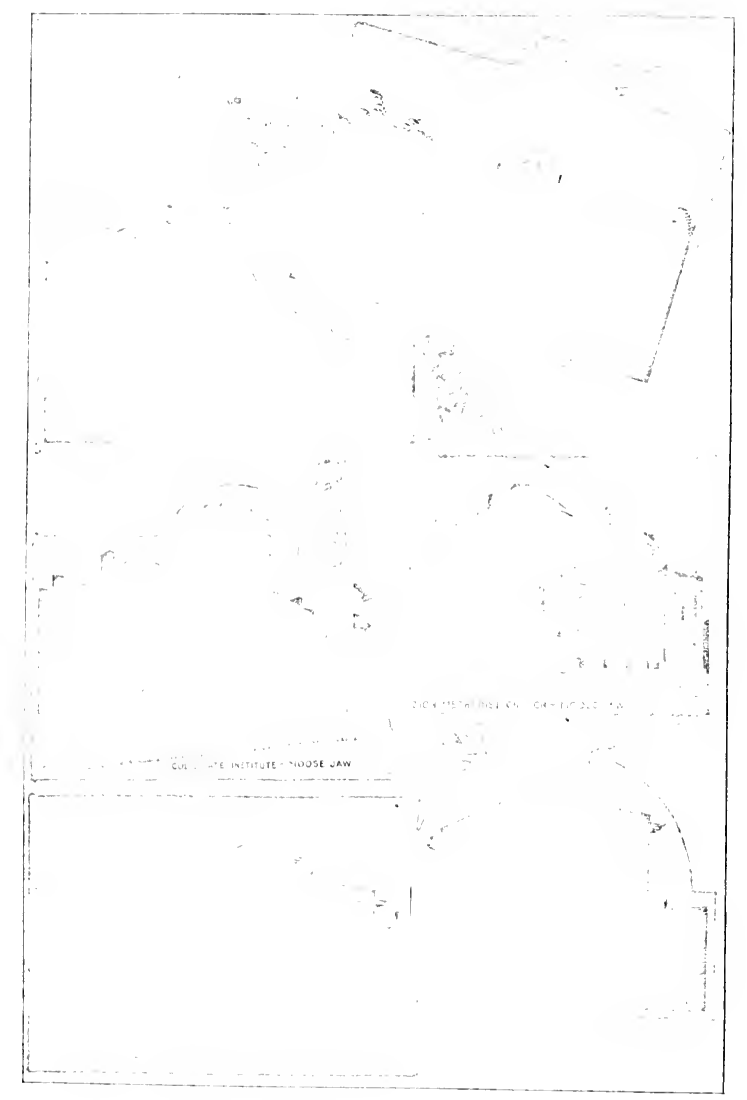


of the North llest Territories. The House was of the opinion that the services rendered by him in the icarless enforcement of the authority of the Canadian Govermment in the Territories in early days merited special recognition, and it was therefore recommended that a suitable annuity be conferred by the Dominion Govermment to make provision for his widow and children.

On October 31,1894 , a general election was held in the Territories and on August 29, 1895, the Third Lecgislature of the North West Territories opened its first session. Mr. James H. Ross becoming a member of Mr. Haultain's Executive in place of Mr. Tweed, who had resigned, M[r. G. F. Betts, of Prince Albert, was clected to the Speakership, an office which he filled with much credit. Mr. Samuel Spencer Page was elected Deputy Speaker.

In his speech from the throne, Lientenant-Governor Mackintosh referred to the death of Sir John Thompson, K. C. M. G., K. C., P. C., the Prime Minister of Canada, which had occurred in London on the thirteenth of the preceding December, and was the occasion of universal mourning. He also mentioned Sir Nackenzic liowell, 1 Iononrable T. M. Daly, Ninister of the Interior, and Lord Aberdeen, Governor-General, as having recently paid important official visits to the Territories.

After the regularly recurring debate on the liquor question, the House this year passed by a vote of fifteen to thirteen a memorial praying the Parliament of Canada to cause a prebiscite on the question to be taken at the time of voting at the next 1)ominion general elections.

The most interesting political event of this session and, indeed, of Lientenant-Governor Mackintosh's whole administration, was his reserving, for the signification of His Excellency's pleasure, two bills, one of them being a bill to amend and consolidate the School Ordinance, to which the Assembly had devoted a great deal of consideration throughont the session. The action of Mr. Mackintosh in this connection is of sufficient constitutional concern to demand a careful review of the controvers growing ont of it.

In the Senate on January 2 st, Sir Mackenzie Bowell, replying to a cuestion by Senator Perley, said the Govermment was aware that LieutenantGovernor Nackintosh had refused to give his assent to the School Ordinance passed last session by the Legislative Assembly of the Territories, but that in so doing he was not acting on the advice of the Dominion Government. The Premier also rearl a report of the late Minister of Justice, which had been adopted by the Council. The report stated that the Minister had under consideration the School Ordinance passed by the Legislative Assembly of the Territories at its last session, which was reserved by the LinetenantGovernor for the assent of the Governor-General. In his report LieutenantGovernor Mackintosh had given as his reason for withholding lis assent 
that the bill had been passed by the Assembly on the last day of the session, and that he, consequently, had not an opportunity of examining its provisions. The Ninister had pointed ont that the Lieutenant-Governor had stated no question for consideration, with regard to the constitutionality of the measure. and no representations had been made to II Excellency from any otler quarter that the Asscmbly had, by its enactment, exceeded its authoriy. The Minister was therefore of the opinion that the Lientenant-Governor ouglut not to have reserved the bill for His Excellency's assent. For the reasons stated, he had therefore recommended that the Lientenant-Governor be informed that IIs Excellency did not propose to signify his pleasure with respect to the reserved bill or to take any action upon it.

The Regina Leader was among the western papers most outspoken in criticism of the Lientenant-Governor's action.

On January 16 , 1806 , the following comment upon it appeared in its columns :

"That act was the gravest offence of which His Honour has been guilty since the inauguration of his administration. It was as incomprehensible as it was unreasonable. No principle of the former school law had been infringed in the drafting of the new Ordinance. The clianges made were merely clanges of detail. Some of the clanges were important in the direction of perfecting the feasibility and satisfactory working of the law, but none were of any constitutional significance. In the old law there were some incongruities and anomalies. Some of the clauses regulating the money grants to sclools were contradictory. The ouly intrinsically important changes proposed to be made were changes in the methorl of apportioning the grants. These changes involved no constitutional question, and were entirely within the power and prerogative of the Assembly. Then why was assent withlheld? Echo answers 'Why?' His I Ionour vouchsafed no reason to the Assembly. He did, we learn, privately state that he had adopted the course becanse he had not had time to review the Ordinance, and that he would give assent by proclamation later. His reason was not good, because on the morning prior to the prorogation of the House, his legal adviser, who is paid to relieve the I.ieutenant-Governor of the burden of personally reviewing the legislation, informed His Honour that the new law was good. His reason therefore was subterfuge, and his promise was eitluer subterfuge or ignorance. He possessed not the power to assent to the law by proclamation during the Assemlly recess."

On the other hand, Mr. Mackintosh very vigorously defended the course he had followed. He visited Ottawa in this connection and withlheld his resignation only because he believed himself vindicated by subsequent events from the charge of unconstitutional conduct.

It is to be remembered that school legislation is a matter which, thongh primarily of local concern, is of exceptional seriousness from the point of view of the Dominion authorities, upon whom may devolve, under the pro- 
visions of the British North America . Ict, the delicate duty of passing remedial legislation in defense of the educational rights of an offended minority. At the time when Lientenant-Governor Nackintosh disallowed the North West School Bill of 1805 , (puasi-religious issues were prominent at Ottawa, owing to the alleged grievances of the Catholics of Mlanitula, and a special moral and constitutional responsibility consecpuently devolved upon the Lientenant-Governor to kecp himself so informed, and exercise such precautions: as would prevent any serious sectarian dispute in conncction with the educational affairs of the Territorics.

The following is a copy of the Lientenant-Governor's letter of defense and explanation:

To the Honourable the Secretary of State,

Ottawa, Ontario, 3ist January, I8g6.

Sir : Ottawa, Ontario.

I have the honour to acknowledge the receipt of a copy of the report made by the Honourable the Minister of Justice, dated December 20, 1805 . and approved by the Governor in Council, upon an enactment passed by the Legislature of the North West Territories at its last session in September, ISO5, and cntitled "In Ordinance to amend and consolidate, as amended, the Ordinance respecting Schools."

As the above-mentioned report involves issues directly constitutional. I venture to give my reasons for the actions taken by me, and the authorities which, in my estimation, justified such procedure.

Section four (54-5.5 Vic., chap. 22), "An Act to amend the Acts respecting the North "West Territories," provides: "There shall be a session of the Legislative Assembly convened by the Lieutenant-Governor at least once in every year, so that twelve months shall not intervene between the last sitting of the Asscmbly in one session and its first sitting in another session: and such $A$ sscmbly shall sit separately from the Lientenant-Governor and shall present bills passed by it to the LientenantGovernor for his assent, who may approve or reserve the same for the assent of the Governor-General."

The list of bills submitted for assent included "The Ordinance to amend and consolidate, as amended, the Ordinance respecting Schools." the provisions of which had in no form been submitted to me, as mentioned in my communication to the Ilonourable the Secretary of State under date October the 24th, ISO5, as follows:

"The passing of this bill by the Assembly took place on the last day of the session, and almost immediately hefore the prorogation of the legislature, consequently, as I had no opportunity to examine its provisions. I reserved my assent thereto."

Being informed by the clerk of the Assembly that the measure was incomplete and not ready for inspection ${ }^{1}$ (a large number of amendments having been passed immedately prior to prorogation), my natural inclination was to withlold assent; but this would have been to assume a serions

1 The Bill had not yet heen printed. X. F. B. 
responsibility, in view of the fact that the North West Territories Act limited by jurisdiction to "approval" or "reservation." Thus I had either to assent to an Ordinance, the purpose of which. save and except the title. I was in utter ignorance of, or arlopt the only remaining alternative under the statute, mamely, to "reserve assent." To have rejected the ()rinance would, it seened to me. have been rather a delicate proceeding from a constitutional standpoint, in view of the provisions of the Territorial Act, and prorogation of the Assembly, being then in active progress, I was far from convinced that I would be justified in staying proceedings, in order that the Bill might be arranged in such form as permitted a consideration of its provisions. Under these circumstances I deemed it wiser to reserve assent, quite aware that the Ordinance was a nullity, mless the federal machinery could be invoked to provide a process of legalization. I realized further that the matter would be sulmitted to the Ninister of Jtstice, for it certainly appeared to be an anomaly to state that the liill was not ready for assent, and yet he obliged to "reserve assent."

I would further respectfully call attention to the difference between the authority vested in a Liettenant-Governor of the North West Territories, and a Lientenant-Governor of provinces having a responsible excentive. Todd in his work Parliamentary Goarmment in the British Colonies thus defines these powers: "It cqually devolves upon these ligh officers of the state (Lientenant-Governors) in the Queen's name to open and to close these asscmblies, and, in conformity with their instructions, or with the usage of Parliament, and pursuant to their constitutional discretion, to give or to withlodd the assent of the Crown to the bills enacted therein, or to reserve the same for the consideration of their superior officer, II is Excellency the Governor-(jeneral." And further (page 586), The Iiritish North America Act, 1867 , section fifty-five as applied to the provincial constitutions, by section ninety, expressly empowers a Lientenant-Governor, in his discretion, to withhold the royal assent from any bill presented to him.

The same anthority points out that, in Nova Scotia, Liettenant-Governor Archibald from $1 \mathrm{~S}_{7}+$ to $\mathrm{ISS}_{3}$ withlield his assent to bills. In New Brunswick the sane course was taken by Lieutenant-Governor II ilmot in 1870 and 1872 ; by Lientenant-Governor Tilley in $1875-77$ : and by LieutenantGovernor Wilmot in ISS2. In Ontario the Crown has never refused to withhold the assent to any bill passed by the provincial Legislature. Hence. while the Lientenant-Governors of the other provinces have this power, a special cnactment deprives and limits the representative of the Crown in the Territories.

$\mathrm{I}$, therefore, venture respectfully to suggest that the attcntion of Ilis Excellency's advisers may not have been directly called to the closing paragrapli of my letter of the 27 th October, IS95, or to the manifest difference between the powers with which the provincial Lientenant-Covernors are vested and the restricted jurisdiction of a Lientenant-Governor of the Territories when called upon to deal with legislation presented for assent. I remain, \&c.,

C. H. Mackintosil,

\section{Lientenant-Governor of the North West Territorics.}

Lpon comsileration of his commmication, the new Minister of Justice, 
the Honourable A. R. Dickey, admitted the justice of Mr. Mackintosh's representations, and practically cancelled the official criticism previously passed on Jjis Honour's action. The salicut portion of the following doctment I have italicised.

Report of the JJononrable The Ninister of Justice, approted by IIs Excellency, the Governor in Conncil, on the Inth day of March, 180 .

Department of Justice. Ottawa, soth February, Isog.

To IIis Excellency the Governor-fieneral in Council:

The undersigned has the honour to report that he has comsidered a despateh from Ilis IIonour the Lientenant-(iovernor of the North West Territories to the Ifonomrable the Secretary of State, dated 3 ist January, last, copy of which has been reterred to the undersigned by lour Excellency in Council.

The despatch relates to a copy of the approved report of the predecessor of the undersigned, by Whicl lour Excellency declined to give effect to a bill, passed ly the J.egistature of the North West Territories, entitled "An ordinance is amend and consolidate, as amended, the Ordinance respecting schools," which bill was reserved by the fichlemantGovernor for Jour Excellency"s assent.

His Ilonour the Lientenant-Governor states in effect, that the constitntion of the Nortl West Territories differs from the constitution of the several provinces, in that no power is conferred upon the LientenantGovernor of the Territories to withlold assent to any measure which, having passed the legislative assembly, is presented to him; that he is required by the statute either to approve or reserve the measure for Sour Excellency's assent; that the hill was not presented to him by the assembly in such form as to enable him to consider its provisions, nor until the procedings for the prorogation of the assenbly had so far advanced as to render delay inexpedient: that his inclination would have been to withhold assent had authority to do so been vested in him, but that having no such authority he pursued the only course which he regarded as open, in reserving the bill.

"The undersigncl ayres acith His IIonour the Licutenant-Goicrnor in the vicu that he could not constitutionally aithhold assent; also that the constitution docs not contemplate that a Licutenant-Gozcrnor shoult be called upon to cicreise the discretion which is iested in him, with regard to any bill which may be prescnted, without hazing had a reasonable opportunity of informing limself as to the naturc of its prozisions." As to the question whether, in view of the circumstances, it would be justifiable to postpone prorogation of the assembly, the undersigned observes that the Licutenant-Governor had anthority to postpone the prorogation and, if the balance of the convenience stood against the exercise of such authority, that circumstance ought not to cast upon Your Excellency a responsibility which should otherwise he borne by the Territorial authorities: nor do any of the other observations of the Licutenant-Governor appear to atfect the view already stated, that a bill of the character in question should not receive effect under authority vested in Your Excellency. In future, arrangement will doubtless be made by the legislative assembly to 
inform His Honour as to the provi-ions of the several bills which are to be prescnter for assent, and the undersigned toes not consider it necessary at present to advise any amendment to the North West Territories Act.

The undersigned recommends llat a copy of this report if approved be transmitled to His Ilonour the Lientenant - iovernor for his information. Respectfully submitted.

A. R. Dicker, Minister of Justice.

The second session of the third legislature sat from September 27 to October 30,1806 . On the $25^{t h}$ of the preceting May, Mr. Oliver had addressed to the Speaker his resignation as member for lidmonton. The general regret with which his lose to the local Jfonse wats riewerl, was accompanied with confident hope that in the arena of Dominion politics which he was entering, his usefulness would be eren greater than it could be in the Territorial House. Few men of the Canadian IVest have enjoyed so high a measure of estecm and reyed from political foes and political frients alike. Mr. Oliver was succeded lo Mr. Mathew Meciunley, who was elected on August 6, isyr).

The most interesting and inportant business of this session hatd to do with a memorial praying for certain amendments to the North West Territories Act, (a) with respect to the batsis mpon which the subsidy should be determined; (b) with respect to the powers and organization of the Territorial Govermment. Mr. Ross and Mr. Haultain were unce more the principal powers in this matter. The memorial reminded Ilis Execllency in Council of the numerous kindred representations mate by the Territories in times gone by. Satisfaction was expresed at the advances that had been granted from time to time with the result that the Legistature now exercised control orer certain fund placed by the Dominion at the disposal of the Lieutenant-Governor, and enjoyed much larger legistative powers than formerly. Ilowever, under existing conditions the Assembly was not in a position to exercise to the best advantage even those powers which it alrearly possessed. The legislation of the Assembly not only was subject to the right of disallowance which was possessed by the Governm-in-Council over the Provinces as well, but was also sulject to any act of the Parliament of Canada. Consequently it frequently happened that Dominion acts were passed, over-riding ordinances and otherwise interfering with the legislative power of the Assembly. Such concurrent powers necessarily produced insecurity and conflict. The Assembly therefore petitioned for exclusive anthority within the defined ficld of its legislative ativity.

It was further requestet that the Executive Govermment be put on a firmer basis by substituting an Executive Council or Cabinet proper for the present Execntive Committee, elected by the .lesembly. The North 


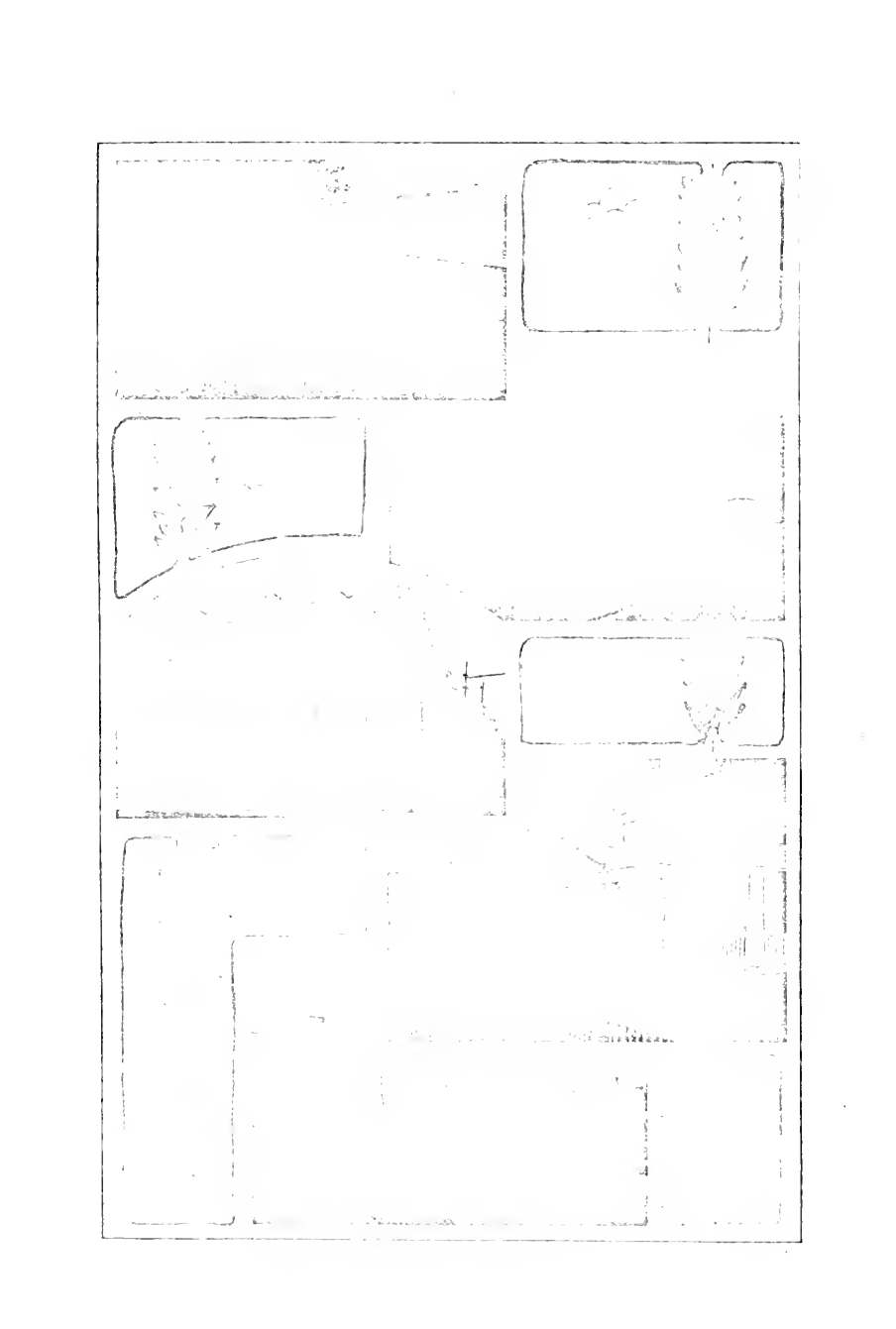


West Territories Act made no provision for any responsible body whose business it definitely was to advise the Lientenant-Governor in executive matters in general, but only with relation to expenditure. In practice the Assembly had, in point of fact, been obliged to make provision in their several ordinances entrusting the administration of their laws to the LientenantGovernor, acting by and with the advice and consent of this Committee. created by Federal law simply as a Board of Finncial Advisers. This course, while under the circumstances unavoilable, was questionalle constitutionally: Moreover, the Executive Committce of the House was manifestly not authorised to advise the Lieutenant-Governor in matters not governed by the Territorial ordinances, - such, for example, as the appointment of Justices of the Peace, the convening of the Assembly, ct cetera. The nature of the Executive Committee was not such as to admit of the organization of departments with responsible heads, - a reform that it was felt wonkl snon be absolutely necessary; and, finally; a permament committee of the House was a creation withont precerlent to guide it, and lacked the well defined constitutional status of British Executive Councils.

Regarding the financial position of the Territories the Assembly reiterated, in part, its memorial oi four years carlier, asking that at fixed amomm in the nature of a subsidy be substituted for an indefinite and variable annual grant. It was pointed out that while the financial resources had always been inadequate, they were stealily growing more so, as the grant. wat not being increased in proportion to the growth of the population. During the preceding five years, the poptlation had increased by fifty-six per centum, and during the four years that a separate amount had been put at the disposal of the Assembly, this grant had increased only sixteen per centum.

On October $27 \mathrm{th}, \mathrm{Mr}$. Sutherland, member for the electoral district of North QuAppelle, from his place in the House declared his wish to vacate his seat as member for that district.

On October 29th, the School Bill, which had failed to obtain the approval of the Lientenant-Governor, was read a third time and passed again. At the same time Mr. Speaker read to the IIonse a special message from Ilis Honour calling attention to the desirability of correcting what he declared to be an error in the Journals of the former session. With reference to the School Ordinance, the Journals stated that His Honour did "withhold his assent to this bill." This, he said, was incorrect, as the right to withhold assent was beyond his jurisdiction. What he had done was to "reserve atssent." Upon this distinction, the Ilouse does not seem to have passed any. judgment or based any action relating to the proposed correction.

Before the Ilouse reassembled on Octoher 28, 1897 , important changes had been made by the Dominion Parliament in the constitution of the Territories. In accordance with certain clamses of the recent nemorial, the Execu- 

tive Committee had been replaced by an Executive Conncil, and the offices of the Government had becn reorganized, and pullic departments created for the more efficient carrying on of the public service. Accordingly, in his speech from the Throne, Licutenant-Governor Mackintosh was able to congratulate the Territories upon the ultimate attainment of a completely responsible system of govermment.

The vacancy created by the resignation of Willian Sutlerland for North Qu'Appelle had been filled by the election of Mr. Donald H. AcDonald. Mr. J. L. Reid, of L'rince Albert, and Mr. F. R. Insigner, of Yorkton, had also retired and been succeeded by Mr. Thomas James Agnew, and Mr. T. A. Patrick. The members of the new Exceutive Conncil were Messrs. F. IV. G. Haultain, James Hamilton Ross, Hillyard Mitchell, Charles Alexander Magrath and George H. V. Bulyea. These gentlemen, in accordance with constitutional practice, had vacated their seats by accepting appointment to the Cabinct, but were reelected by acclamation.

While much important work, especially in connection with the concolidation of Territorial ordinances, occupied the attention of the members during this session, which was of unusual length, nothing of a very startling nature occurred, and lack of space obliges us to pass over their work withont further comment. In proroguing the House on December 15 th, LientenantGovernor Mackintosh spoke in part as follows:

"During no session since the creation of the Legislative Assembly has so much and so important legislation been passed. The consolidation of the Ordinances for which you have provided, and towards the completion of which a large portion of your labour has been devoted. will, I trust, prove of great benefit and convenience. The legislation for establishing and organizing the public service will, I an sure, enable the business of the Territories to be administered in keeping with the larger duties and responsibilities that have been imposed upon you. . . . The year about to close with your labours is a memoralsle one, not only in Territorial constitutional history, but in the larger history of the Enipire itself, as having witnessed the completion of Her Majesty's sixtieth year of her reign. . . . In bringing this session to a close. I an for the last time meeting you in nuy present official capacity. During the four years in which I have had the honour of being Her llajesty's representative in the Territories, the Legislative Assembly has always displayed an assiduity and sense of responsibility in keeping with the important duties devolving upon it, and in now taking leave of you, I desire to express my best wishes for your personal happiness and my earnest hope and belief that your work will always result in the greatest possille benefit to the vast Territories whose interests and welfare are entrusted to your keeping." 


\section{CHAPTER XXXY}

\section{MACKINTOSH'S ADMINISTRATION: SOCIAL AND INDUSTRIAL DEVELOPMENT}

\section{Period of Depression Continles-Inprovemext ix is95 and i896- Territorial Exhimition-Educhtion.le Developalent.}

In the corresponding chapter dealing with the periods covered by Royal's administration, we noted the signs of the dawn of an era of greater prosperity and more rapid development thronghout the Territories, but the end of the long period of depression had not yet arrived. Indecl, in $\mathbf{1 8 9 4}$. as a result of crop failnres, owing to dranght, especially in the Moose Jaw. Regina and Qu'Appelle districts, a very large nmmber of settlers were reduced to such destitution as to require Govermment aid.

On August 2Ist, the Assembly passed a resolution that Mr. Speaker Rosi and a member of the Executive Committee to be named by that Committee ${ }^{1}$ be a deputation to proceed forthwitl to the East to bring the matter forcibly to the attention of the Minister of the Interior. On the 3ist the delegation reported having gone immediately to $W$ innipeg, and having there interviewcd the Honourable Mr. Daly. That gentleman promised to urge upon his Government the necessity of supplying the money to meet the difficulty promptly, and agreed that it should be dealt with through the Executive of the North West. In consequence of these steps. Mr. Haultain was crabled to alleviate the conditions of those most in need by employing them upon the road work and other useful public labor.

In the following year there was a noticeable improvement in agricultural circles. Live stock was in demand at very fair prices, the sale of cattle being fully one-third greater than in the preceding year. There was also a promising increase in the amount of products of mixed farming marketed. and the general harvest was much more bountiful than it had often been in recent years. Indeed, the wheat crop was ncarly double that of the preceding year, and the harvest of barley and oats was equally plenteons. Damage was done by frost in some portions of Northern . Nberta, but it was not general. The records of this period are consequently marked by a distinctly increased feeling of hopefulness and contentment in most quarters. Nevertheless the hard times were not ovcr. In 1895 the best grade of wheat in the Regina district sold for from thirty-five to forty cents a bushel and we read in the

1 Mr. Neff was choren. 
reports of Superintendent Perry, N. IV.M.P., that "some districts which were once well settled are now deserted, and in others there are only two or three settlers left."

However, in I8g6 the farmers' returns were better in almost all parts of the Territories. Cheese and dairy ascociations became numerous, and, under the auspices of Trofessor Robertson, the Dominion Agriculture and Dairy Commissioner, Govermment creamerics were established at Moose Jaw, Indian Head, Prince Alloct and Regina. The question of irrigation had at last been serionsly taken in hand with very promising results. The condition of the people continued steadily to improve throughout the balance of Licutenant-Governor Mackintosh's administration. Even horse ranching, which for a long time had been depressed, again revived and indeed showed gratifying progress.

Despite legislative measures adopted by the Territorial Assembly there appeared to be no diminution in the number and area of prairie fires until 1896. By that date it was at last realized that a principal source of disaster of this character was sparks from locomotives, and the railway companies vigorously unclertook the ploughing of firc guards along their right-of-way. This had an excellent result.

The most important event falling within the scope of this cilapter was the Territorial Exhibition of 1895 . This undertaking was due to the initiative of the Lieutenant-Governor himself. He had urged its desirability from the moment of his arrival, and as a result of his representations, vigorously supported by the Territorial Legislature, the Parliament of Canada voted for this purpose the sum of $\$ 25,000$. It was considered advisable that this initial object lesson on the resources of the North West should take place at the capital, provided a suitable site could be procured. Accordingly, the little town of Regina voted \$10,000 towards erecting suitable buildings, while the townsite trustees, representing the Canada and Jorth West Land Company, the Canadian Pacific Railway, and the Dominion Govermment, agreed to give a site whereon to erect the necessary structures; the result being that a well located and commodions plot of gromul, a little west of the Territorial Assembly huilding, north of the railway track and immediately upon the main trail, comprising fifty acres, was secured. Great satisfaction was expressed when His Excellency Lord Aberdeen, the Governor-General, consented to open the proceedings, and many leading public men, both from Canada and the Lnited States, promised to be present.

The Territorial Exhibition was not umarked by mismanagement in some respects, and the newspapers of the day give evidence of abundant heartburning and lickering. but there is no doubt regarding its general success and the valuable results attending it, and for these Mr. Machintosh deserves the permanent gratitude of the West. 

The exhibition proved the vast resources of the Territories, the vigor and industry of their farming population, and their ability to compete with the world in all things appertaining to intelligent huslandry.

The entries in the varions classes were double the number anticipated, and each of the districts manifested patriotic interest in the enterprise. The stock parade was admittelly the finest ever held in any part of the Dominion, and this was emphasized by the fact that most of the herds of cattle were disposed of at good prices to prominent buyers. Ilis Excellency, the Governor-General, after opening the Exhibition, remained tor three days, the result being a written expression of his opinion, addressed to LieutenantGovernor Mackintosh. From this letter I make the following extract:

"It would be difficult to overestimate the advantages, direct and indirect, which may accrue from the succesinl carrying out of such a display of the capabilities of the vast districts which hive been represented at the Exhibition, and from the incentive and encouragement that is thus offered to all who are interested in their development. Four Honour and your friends will always have the satisfaction of feeling that youn, and those who have assisted you in this work, have given a definte impulse to the increased recognition by the inhabitants of the Territories of the important fact that they are not, as it were, scattered units, but that they are hound together by common interests and aims, with all the great possibilitics which may be attained by judicious cooperation and combined action."

The presence on this occasion of Sir Mackenzie Bowell, Premier of the Dominion, was greatly appreciated.

The Committee lad arranged to accommodate entries for between three thousand and four thousand exhibits, but ten days lefore the Exhibition opened it became apparent that almost double the building capacity would be requisite. Removed from any large business centre where it would have been possible to engage numerous extra employees and workmen, generally, it was deemed advisable to assume the responsibility of meeting the emergency as best the local authorities could; hence, builders and mechanics worked overtime; fast freight was arranged to convey tents and other necessaries; and the advisory committee was thus able to protect all exhibits, and to ask His Excellency, the Earl of Aberdeen, Governor-General of Canada, to open the first Canadian North West Territorial Exhibition promptly at two o'clock on Tuesday, the zoth of July. The total number of entries in the various classes were as follows:

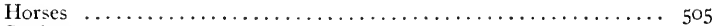

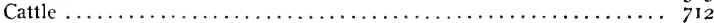

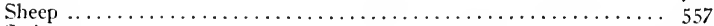

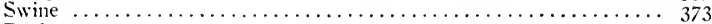

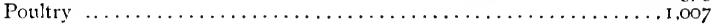

Rabbits $\ldots \ldots \ldots \ldots \ldots \ldots \ldots \ldots \ldots \ldots \ldots \ldots, 3^{2}$ 



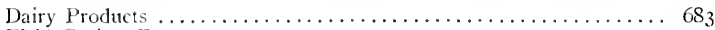

Field Grains, Ete............................ 400

Roots and legetables..........................

Plants and Flowers.................................. 370

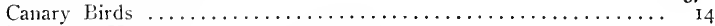

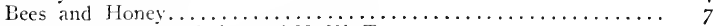

Manufacturers, Manitolsa, and N. W. T................. 122

Fruit, Preserves, Etc............................ ${ }_{154}$

Leather and Leather Work......................... 27

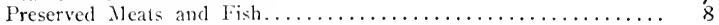

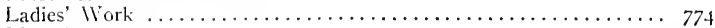

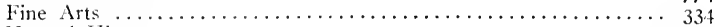

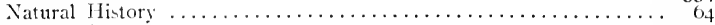

School Work .................................... 246

Indian Products $\ldots \ldots \ldots \ldots \ldots \ldots \ldots \ldots \ldots \ldots \ldots \ldots \ldots \ldots \ldots \ldots \ldots \ldots, \delta_{5}$

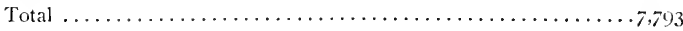

A comparison of the entries in cattle, sheep, swine, etc., at Regina and at large eastern exhibitions, entallished for many years, is certainly significant, demonstrating. as it did, the great resources of this then sparcely populated country. Horses. Cattle. Sheep. Swine.

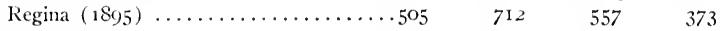

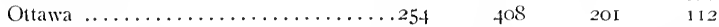

Sclool development may again le taken as affording a valuable index to conditions in the Territories. On August 2, 1894 , there were 376 schools and 8,926 pupils. In the following year the enrollment increased by over 1.000. as the first report of the Conmussioner of Education, covering the last year of the period under review, slowed.

Mr. Mackintosh's first official act was to confirm the incorporation of Calgary as the first city of the Territories, December, 1893. In the following year, Saltcoat, Greenfell, Gainsborough, Medicine Ilat and Yorkton became incorporated toins, and the growth in population throughout the Territories was steady and considerably more rapid than formerly. The efforts of the new Minister of the Interior. the Honourable Clifford Sifton, to bring before the people of Europe and the United States the advantages of the Canadian West were inmensely more successful than had been those of any of his predecessors. In conseguence the last years of Mr. Nackintosh's regime mark the real beginning of the plenomenal tide of immigration that since that time has transformed the Canadian IV est. In the optimism, enterprise and prosperity of the new era, the citizens of the Territories put behind them all memory of the dismal days gone by, never, it is hoped and believed, to return. The lessons of tailure had been learned. New and better methods in agriculture and other lines of activity had been adopted that were bound to bring witl then a secure prosperity: 


$$
\text { . }
$$




\section{CHAPTER XXXVI}

\section{CAMERON'S ADMIINISTRATION}

Mr. Cameron's Appointment-Juhge Ricilirdson" Administrator Dering Caneron's Ildanes-Bulyei's Mission to tile YukonLiquor Permits for tile Unorg.inized Territories-Y'Yuon District Cut OfF from Norti West Terkitories-Comment of the Assembly-Increased Revexte-Uxtaxamle Lanns-Consolidation of Territorin. Ordinancis-Increasing Prosperity-Deati of Mr. Cameron.

In June, 1898, Malcolm Colin Cameron became Lieutenant-Gorernor of the North West, arriving at Regina on July 1. Throughout his long political career he bad manifested the licenest interest in western affairs, and it will be remembered from our discussion of Parliamentary delates of the early eighties that if his views had at that time been supported hy a majority in the House of Commons, the grierances of the West might have been settled without the costly sacrifice of the year i 885 . Unfortunately; Mr. Cameron's regime as Governor of the Territories was excedingly slort. During the first session of the Assemlly the Lientenant-Governor was taken serionsly ill, and the duties of his office had to be performed chiefly by an Administrator.

This officer was the Honourable IIngh Richardson, with whose name the readers of this History are alrealy so familiar. From 1876 to 1887 he lad been a Stipendiary Magistrate and official legal advisor of Licutenant-Governors Laird and Dewdney, and since that date he had with dignity and efficiency occupied the position of Senior Judge of the Supreme Court of the North West Territories.

The Third Legislature assembled for its fourth session Angust 56, i 898 . Since the last session, Mr. Bulyea, representing the Executive Council, had spent several montlus in the Yukon District, where the recent discovery of gold and a conseruent influx of miners required that those responsible for the Territories shonld take steps for the security of law and order. One of the most important duties devolving upon the Territorial Govermment in connection with its administration of affairs in the Yukon District arose from the imperative necessity of regulating and restricting the import and sale of intoxicating liquors. 
The difficult task was very satisfactorily performerl. Satisfactorily especially from the standpoint of the citizens of Alberta, Assiniboia and Saskatchewan. There were distinctly inmorons features in connection with this expedition of Mr. Bulyea s. By a whim of fortune the lukon had suddenly become a gateway through which teening multitules of thirsty miners were crowding into the interior of the North West. The West shuddered at the thonght that there was nobody there to collect funds payable in licenses for the sale of the spirituous liquors those miners would require for the efficient prosecution of their tratle. Nloreover, unless the collector of this revente, acting on behalf of the North West Government, retreated to some inaccessible point forthwith, word might reach him at any time that he no longer harl authority to take the money. The rumour was already in the air that the Dominion Government was on the point of separating, for atministrative purposes, the Yukon District from the rest of the North II'cst, so there was no time to lose. Mr. Bulyea was despatcherl in hot haste to turn to the best possible financial advantage the waning hours of Territorial jurisdiction in the far North. On the last day of 190 - he left Regina upon his long and arduous journey to the Yukon. He, of course. travelled atia Vancouver and Skagway, from which latter point he set out for the Canadian Yukon in February. March 15 th saw him at Lake Bennett, and on April I 2 th he arrived at Dawson. The race was won. In spite of friction with certain representatives of the Federal Government, Mr. Bulyea collected for the benefit of the Territorial Exchepuer some one hundred and twenty-five thousand dollars, the reward of promptitude, before amouncement was made by the Dominion authoritics of the severance of the Yukon District from the North West Territories. The Territorial Commissioner on August 25 th left Dawson on his return journey, arriving at Regina on the last day of the session, September I8th. Incleed. the members had deliberately remained at the Capital in order to welcome home their successful envoy, with his sorely needed contribution to the funds available for the roads and bridges of the prairies.

In connection with this anusing passage at arms between the Federal and Territorial Govermments, Mr. Bulyea's colleagues lad been far from inactive during his absence. The whole circumstance is interesting enongh to call for review.

Under the North West Constitution as amended in 1801 , the control of the liquor trade, in that portion of the Territories that was organized into electoral districts, was vested in the Lieutenant-Governor and his Assembly and Cotmcil, but in the unorganized districts it was controlled by the Lientenant-Governor, acting under the instructions of the Minister of the Interior at Ottawa. In I 897, however, full Cabinet Government was accorded, an Executive Conncil being created. Henceforth, all the official acts of the 



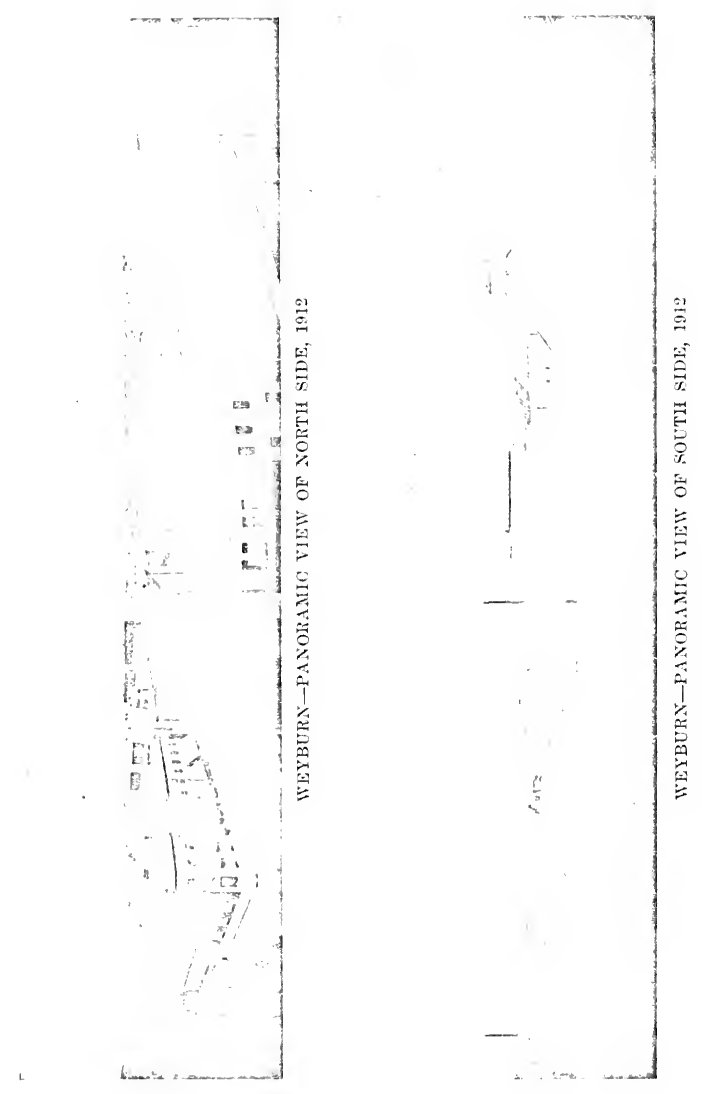


Lientenant-Governor required the advice and consent of the North West Cabinet. The new provisions came into force on October ist. A number of large permits approved by Mr. Mackintosh were objected to by Mr Haultain. The Premicr agreed to recommend all permits that had been promiset prior to October Ist, but reculired the production of the correspondence antecedent to that date by which the Government was committed to the issue. Mr. Ilanitain carried his point and enforced the payment into the North V'est Treasury of a considerable sum that, but for his determined action, would have been lost. A serions conflict between the Federal and Territorial authorities was nnw precipitated. After Mr. Bulyea's departure for the lukon, to regulate the sale of intoxicants and vindicate the jurisdiction of the Territorial Govermment, the Secretary of State advised the Honourable Mr. Justice Richardson, who was acting as Administrator in the absence of Mr. Mackintosh from the Territories, that henceforth he was to issue no permits for taking liquor into the unorganized districts, except on the recommendation of the Ylinister of the Interior, the Honourable Clifford Sifton. Mr. Haultain considered this an unconstitutional curtailment of the jurisdiction of his Goverument, and presently advanced a test case by recommending for approval a specific application. In accordance with his instructions from Ottawa, Mr. Richardson refused to grant the permit and the North West Premier had the case, with his protests, referred to Ottawa. A deadlock now ensued as Mr. Haultain would not countersign and thus make legally valid permits approved by the LientenantGovernor and his Administrator, and that official would not countersign the permits supported by Mr. Jaultain. Consequently, from early in the winter until the end of May, 1898 , no permits whatever were issued. A spirited correspondence took place, $\mathrm{Mr}$. Ross vigorously supporting his chief. Ultimately the Ottawa anthorities realized that their position was constitutionally untenable and the obnoxious instructions were rescinded.

It was not intended, howerer, that this should work to the financial advantage of the North West government. Parliament had passed an act cutting off the Yukon District from the North West Territories for the purposes of separate administration and it was evidently intended that this act should come into force before Mr. Haultain could exercise the powers remitted to him by the cancellation of the former instructions. It so happened, however, that Parliament sat a fortnight longer than had been expected, so that this Yukon Act was not signed by the Governor. General till June I 3 th.

This respite oftered an opportunity, which Mr. Hatultain and his colleagues disl not fail to grasp. Applications for permits had been pouring in and an indefinitely large sum might hitve been realized on pernit fees. However, Mrr. Haultain governed himself by Mr. Sifton's public statement 

that the population of the Yukon was 40,000 , mostly adult males, and by the statistics showing the average consmmption of liejuor thronghout the Dominion to be two gallons per head. Aceordingly permits were issued within the remaining two wecks of the Territorial Government's authority for the import into the Yukon District of 80,000 gallows. Upon this quantity Mr. Haultain collected the sum of $\$ 160,000$ in fees at $\$ 2.00$ a gallon.

The action of the Parliament of Canadi in cutting oft the Yukon District from the Territories did not neet with the entire approval of the Assembly, and the following resolution was incorporated in the reply to the speech from the Throne:

"While the cutting off of the Yukon official district may have been done in the general interests of the country, we cannot but view with apprehension any indication of the disintegration of the Territories as they are at the present constituted, and we note with satisfaction that your Govermment took the necessary steps to exercise their jurisdiction in the lukon District. and we will await with interest the report of the member of the Executive Council entrusted with that duty:"

On September rath, the House passed a resolution affirming the desirability of an early and final detemination of the boundary lines between the North West Territories and other Provinces and Territories, but denying the right of the Parliament of Canada to alter the limits of the North West Territories without the consent of the Territorial Government. The Assembly, on behalf of the people it represented, laid claim to equal rights with the people of the Provinces in this respect. However, the legislature expressed its consent to such revision of boundaries ats would separate from the North West Territories those regions lying North of the boundaries of British Columbia and Nanitola, respectively. At the same time, the Legislature declared itself firmly of the opinion that the political unity of the Territories should not be disturbed. After a lengthy debate this resolution was carried by a vote of eleven to ten.

As a result of the windfall arising from the policy of the Territorial Cabinet with regard to the importation and sale of lifuor, the LieutenantGovernor was this year in a position to make unprecelented announcement that the revenue of the past year had considerably exceeded the estimates. Moreover, as result of negotiations betwcen the Government and the Minister of the Interior, a bill had been passed at the last session of the Federal Parliament relegating the North West Irrigation Act to the administration of the Territorial Commissioner of Public Works.

The old question of nutaxable lands again came up for discussion. On motion of Mr. Haultain, seconded by Mr. Ross, it was resolved that in the opinion of the Assembly immediate action should be talien by the Federal Government to compel the location and patenting of all limds to which rail- 
way and colonization companies were entitled. The failure of the lederal authorities to act mpon this suggestion long enabled great speculating corporations to avoid their share of taxes for schouls, local improvements and other purposes. It was the custom of the companies to make formal choice of a parcel of land within the reserve covered by their option, only when a purchaser had been secured. This anomalous privilege worked great hardship in many quarters for very many years: For example, in one school district known to the writer less than half the land was avalable for taxation, thongh the remainder was being offered in the market by a great land company which paid no taxes. In consequence, though the ratepayers allowed themselves to be taxed for school purposes at the highest rate permitted under the law, they were malse to maintain a yearly school without steadily going deeper and deeper into debt.

The task of the Commissioners who ind so long been engaged in conolidating the Territorial Ordinances still ocenpied to a considerable extent the attention of the authorities, though it was now nearing completion. Anong the numerous new Ordinances passed at this session was one amending the Irrigation Districts Law. This considerably simplified the procelure with regard to irrigation enterprises and rendered it much less expensive, to the great advantage of the soutl western portion of the Territories. The House was prorogued by his IIonour the Administrator, on September 1 th.

The records of the year evidenced substantial prosperity and offered bright prospects for the future. Immigration was rapidly increasing and it was evident that the Territories had entered upon a period of unprecedented growth and development.

Owing to his continned ill health, Mr. Cameron had been compelled to return to Ontario, and on the 26 th day of September, 1898 , the people of the West and of Canada generally were grieved to learn of the fatal issue of his illness. 


\section{·}




\section{CHAPTER XXXVII}

FORGET'S ADMINISTRATION: POLITICAL HISTORY, $1898-1905$

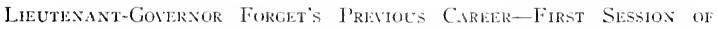

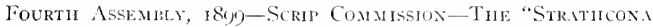
Horse"-The Assember of 1900-Apranest Dischepincies is Purlic Accounts-Ross Ariolntel Commissioner of the l'ukon -Debates on Llglok Trific-Negotiltions for Provincial. Status-Propuseid Wistern Exthession of Minitom-Elections

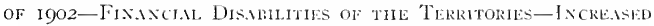
Representation in Hotse of CoMmons-Dominion Eufetions of 1903-Autonumy lille introncted; Resignition ol Claforn, Sifton-Haultun Rerumintes Promosen Constitution-Cux-

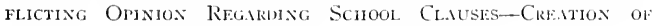
Provine of Siskitchina-Finst Prosincme Elections.

The Honourable Amerlec Emmanuel Jorget was already a well known lawyer in Montreal when in 1876 he removed to the North West Territories as Clerk of the Comncil and Private Secretary to the Lieutenant-Governor. When the Council was transtormed into an Assembly he became its clerk. In 1888 he was appointed Assistant Commissioner of Indian Affairs for Manitoba and the North West Territories, and from 1895 to $180 \mathrm{~g}$ he was Indian Commissioner. Ile had also been prominently connected with educational matters, having been a member of the Council of Public Instruction in the Territories. When, therefore, Mr. Forget was chosen to succed the late $M \mathrm{r}$. Cameron as Licutenant-Governor, in $i 898$, he undertok his duties with most exceptional qualifications. His regime was of umusual length. On April 2, 1004, his appointment to a second term was gazctted, and when in 1905 the Territories were divided into Provinces, he still remained in Regina in the eapacily of Lieutenant-Governor until iglo. The last five years of this period, however, we will treat as a distinct administration.

A general election having recently occurred in the Territories, Mr. Forget summoned the first session of the Fourth Legislative Assemlly to meet on April 4, isg9.

Mr. William Eakin was elected Speaker. The personnel of the Ilouse had been considerably altered by recent cvents; Mr. Oliver was now a mem- 

ber of the Dominion Farliament, Mr. Turriff had in 1 syo retired from active Territorial politics and in $18 y$, he became Dominion Land Commissioner. Of the outstanding figures of earlier days the most prominent remaining were Mr. Haultain, Mr. Ross and Dr. Rrett.

The Speech from the Throne dealt in fitting terms with the lamented death of the late Licutenant-Governor at London, Ontario, and with the departure of Lord Aberdeen owing to the completion of his term of office as Governor-General. The Honourable F. IV. G. Haultain, Premier and Territorial Treasurer, reported to the Honse the details of a lengthy correspondence with the Dominion Government in which he had endeavored to obtain better financial terms and increased constitntional anthority for the Legislature. This report sounded the keynote of the political history of the next six years. That the Assembly had as yet not very definitely made up its mind as to just how much power it should ask for was indicated by a resolution introducel by the l'remier on April $24^{\text {th. }}$. This resolntion claimed that the power to make ordinances in relation to the issuc of land titles should be vested in the Assemlity, and the House divided, fourteen to fourtecn, so that Mr. Haultain's proposal was carried merely ly the Speaker's vote. The most interesting and important debates of this session were probably those dealing with the necessity of opening up the Saskatchewan and Qu' Appelle valleys by railway lines, and of compelling the raihways to give better facilities for the loading of grain. The House was prorogued on April 29th.

In the same year Colonel James Walker, a former distinguished member of the Nonnted Folice, was appointed Scrip Commissioner to deal with the Halfbrecds of Athabasca, and in Igoo he held the same office in the provincial districts of Alberta and Saskatchewan. The Halfbreed title to western land was now at last finally extinguished by the issue of scrip in full settlement of all remaining claims.

On October II, 1890, a state of war commenced between the British Govermment and the Ioer Republics of the Transval and the Orange Free State. Britishers will never forget with what disasters the early stages of the long struggle were marked. When the serionsness of the sitnation was realized, the various colonies, and prominent among them Canada, rose unanimonsly to defend the interests of the Empire. Even most of those citizens who disapproved of the ante-bellnm policy of the Imperial Govermment felt that after Nagersfontein the time had come for all Britishers to present a united front to the world. A Canadian regiment was promptly placed at the disposal of the Pritish military anthorities and proceded to Africa.

In Jamuary, I900, a second contingent was organized, almost wholly in the Territorics, through the munificence of Lord Stratcona and Mount 

koyal. This was the famous "Stratheona Horse," a unicjue cavalry regiment, six hundred strong. It was enlisted chicfly from among the western cowboys,-men inured to hardhip. incomparable as riders, famous as marksmen, and characterized by dare-devil courage and with all other qualifications that especially adapted them for guerilla warfare. It was precisely the kind of force most needed in Sonth Africn and performed services that won for it and the land it represented the profound gratitude of the Mother Country.

The second session of the Fourth Assembly dated from March 29 to May 4, 190o. A new member was Mr. A. L. Sifton, who was elected for Banff and who was sulsequently to rise to such prominence in Alberta.

The most interesting political events of this session arose out of the publication in the Reyina Standard of evidence which had been taken before a Select Committce appointed in $18 \%$, to inquire into certain apparent discrepancies in the Pullic Acconnts. The Standard's version reflected very serionsly on the Government. Noreuver, though no one seemed to know just how the newspaper came by its alleged information, a breach of confidence had apparently occurred sonewhere. Mr. Ilautain demanded that the charge and alt the circumstances attending it should he investigated by the Ilouse and the matter was referred to a Select Committee consisting of Messrs. MacDonald, Machay, Villenenve, Lake, Cross, Sifton, Prince, Elliot and I'atrick. Six days later, on $\lambda_{\text {pril }} 25$ th, the Committee reported that Mr. Richard Bedford Lennett, who was Mr. Haultain's chief opponent, had refused to appear before it, and an order by the House was issued to compel his attendance. The scope of the Committec's inquiry was also extended.

On Nay 3rd, the Committee reported that the account in the Regina Standard was an incomplete report of the evidence, and hat been supplied to the press by Mr. R. B. Pennett. The whole misunderstanding arose out of the fact that, a couple of years earlier, Mr. Haultain had obtained for the Territories a supplementary Federal grant of $\$ 20,000$, which, thengh it had not yet become available for use by the end of the Territorial fiscal year, had been included in the year's receipts, by the North West Auditor. The Committce explained that by this error in bookkeeping, an item of $\$ 45,000$, estimated receipts from the Dominion, had been inserted instead of one of $\$ 25,000$, the sum actually received, and that all this had already been duly communicated to the Assembly. Accordingly, the Government was exonerated from any attempt to mislead the public. This report was confirmed by a vote of thirtcen to three.

Early in 19or, Mr. Ross was offered, and accepted, the Commissionership of the Yukon, and was accordingly lost to the Territorial Assembly in which, for the preceding seventeen years, he had been so conspicuous a champion of 


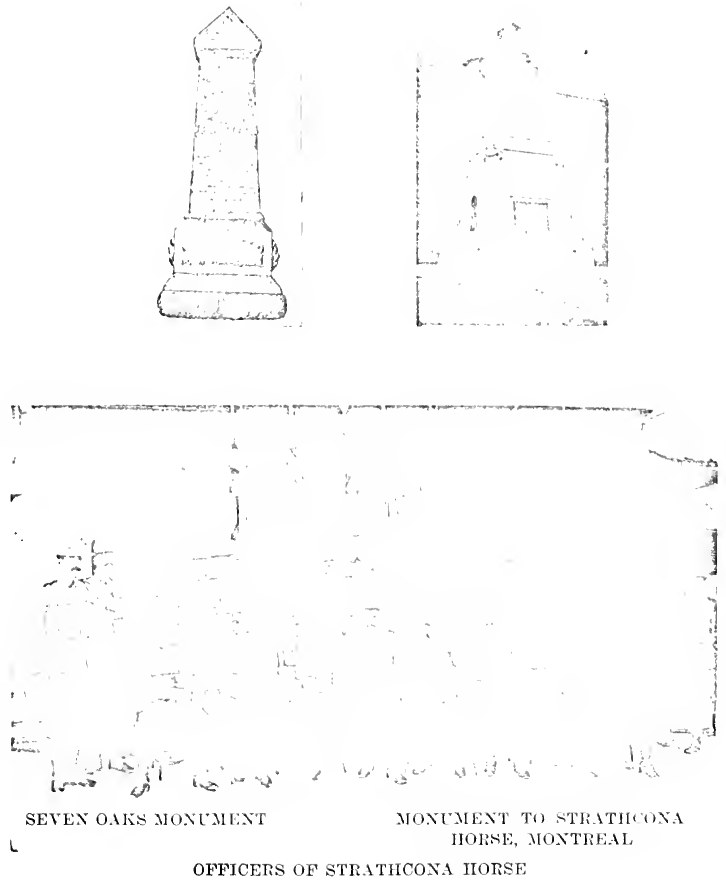

popular rights. Ilis place, as member for Moose Jaw, in the third session of the Fourth. Assembly (May 2 to June 12, Igor), was taken by Mr. Arthur Hitclicock, but on a recomnt the seat was assigned to Mr. George M. Annable.

The death of Qucen Victoria had oceurred on January 22, 1902, and one of the duties of the Assembly in its third session was the presentation of a loyal address to King Edward VII.

Perhaps the most noteworthy debate of the session was that arising on the perennial liquor question. A resolution was ultimately passed that, in the opinion of the Assembly, the interests of temperance would be promoted by a system of state monopoly of the liquor traffic. Accordingly. this tronblesome problem was, for the time being, safely sliclved by a resolition calling upon the Govermment to inquire into this system in other countries where it had been adopted.

Meanwlile the most important topic of serious political debate and negotiation with the Federal authorities had to do with the establishment of full provincial status in the 'Territories, an end for which Mr. Flatultain had so long been agitating.

This, indeed, was the special object of consideration thronghout the Fourth and last session, which was lield fron March 20 to April 19, r902. As, however, a special chapter is to be devoted to the agitation for provincial autonomy, this important topie need here be mentioned only in passing. It may be remarked that the crux of the question was the dispute as to whether the Territories should be divided into two Provinees or remain intact as Mr. Hanlain advised.

During this period, Mr. Roblin, the Premier of Manitoba, was pressing for the annexation of a portion of the North IVest Territory to his Province. His propaganda was received with popular disfavor and aroused a resolution of protest in the Territorial Assembly.

The Assembly was lissolved on April $25 \mathrm{th}$, and the elections occurred on the 21 st of the following month. It is to be remembered that Dominion party lines were not as yet recognized in Territorial politics. The Premier was a Conservative, but his two lientenants, Mr. Sifton and Mr. Bulyea, were Liberals, and Mensrs. MacDonald and Bennett, the leaders of the opposition, were Conservatives. The result of the contest was the election of twenty-four supporters of the Haultain Government, five Independents and six members definitely opposed to the Government platiorm.

Shortly after the election, Mr. Haulatin left to attend the coronation of King Edward VII, and did not return until nearly the end of the year.

The first session of the Fifth and last Legislative Assembly of the Xorth IVest Territories met in April, 1903. Is a result of the rapid increase in population and general industrial expansion throughout the IV est, the necessary expenses of the public service were growing at a rate which the citizens 
of the older Provinces of the Dominion seemed entirely unble to understand. In conseguence, Mr. Haultain had not been able to secure an adequate finaneial grant from the Dominion Govermment, and the administration of Territorial affairs was seriously hampered. Indeed, the Territorial Legislature seems to have grown weary of legislating under such a handicap and relative!y little was accomplished in this session.

However, the West derived enconragement from the introduction at Ottawa of a Redistribution Lill, increasing the number of Territorial representatives at the Honse of Commons from six to ten. There was, noreover, much discussion on the Provincial antonomy in the Federal Parliament this year, but a dissolution was impending, and the political leaders were manifestly hesitant about boldy committing themselves at present on the vexed questions sure to be raised in the creation of new Provinces, of majority and minority rights on matters political, educational and religions.

In the Dominion election, in the Autumn, I904, Sir Wilfred Latrier's Government was handsomely sustained. In what is now the Province of Alberta, Mr. Frank Oliver and Dr. McIntyre were the successful Liberal eandidates, and with them vere sent to Ottawa two Conservative mombers. Messrs. M. S. NeCarthy and J. Ilerron. In what is now Saskatchewan, the Liberals earried every constituency. The members eleeted were Messrs. Walter Scott, R. S. Lake, A. J. Alamson, J. H. Lamont and Dr. Cash.

When the Territorial Assembly met this year on September 22nd, dheir Excellencies, the Earl and Countess of Minto were among the guests and speetators. The Speech from the Throne conmented on the recent more liberal response of Canada to the financial representations of the Territories, expressed regret that the alvocacy of the Provincial antonony had not produeed more tangible restults and intimated that no legislation dealing with large public questions would be introduced during the session.

On September 10, 1904, Earl Grey was installed at Ilalifax as the new Governor-General of Canada. As we have previously seen, Mr. Forget's first term of office as Lieutenant-Governor was completed this year and he was reappointed.

On February 21, 1905, Sir Wilfred Lamier introdnced his bill for the creation of the Provinces of Alberti and Saskatchewan, the famous "Antonomy Bill."

The pathway of the sponsors of the bills was a very thorny one. Many stalwart Liberals considered that the bill involved an minustitiable surrender to the wishes of the Roman Catholic hierarchy. Even within the Cabinet itself, unanimity was manifestly lacking, and on March 1st, the Honourable Clifford Sifton, Minister of the Interior, resigned his post by way of protest.

The Government now called to confidential conference the western Liberals,-Messrs. Greenway, J. 1). Turriff, Walter Scott and Frank Oliver- 

to consider certain proposed modifications in the contentious clauses regarding Separate Schools. Other caucuses were also held, with some of the Ministers present, and on the seventh of Matrch a sub-committee of the Cabinet was appointed to deal with the matter. On the twelfth, Mr. Haultain, at the sacrifice of the certain prospcct of being called to the Premiership of which ever of the new Provinces he would choose, came out uncompromisingly against the bill in a remarkable open letter addressed to Sir Wilfed Laurier. The details of this communication will be found in another chapter. On March 2oth, the Premier announced a compromise embodied in a revision of the obnoxious canse, and two days afterwards he proposed the second reading of the bill. The Prenier's friends considered him vindicated of the charge of undue bias by the fact that the new clanse was cqually distasteful to the extreme wings of both the I'rotestant and Catholic partics. Both of these sections deluged the Govermment with petitions condemmatory of the educational clauses in the bill and various amendments of most contradictory character were introduced and vigorously defended in the House.

Meantime, Mr. Frank Oliver had succeeded the Ionourable Clifforl Sifton as Minister of the Interior, and his reelection by acclamation at Edmonton was interpreted as indicating western approval of the Government's attitude. As a matter of fact, the Territories themselves were much less excited over the controversy than was Eastern Canada. In the North VVest the term "Separate Schools" comnoted very different idleas from those associated with it in Ontario.

On the second reading, the amendment introduced by Mr. R. L. Borden, leader of the opposition, was defeated by a majority of eighty-one, and shortly afterwards the bill became a law.

On the first of September, 1905, the Province of Alberta, and three days later the Province of Saskatchewan, were formally inaugurated. Mr. Rutherford led the Liberals to overwhelming victory in Alberta in the first Provincial election, Novenber 9 th, and on December 13 th, the Honourable Walter Scott, who, in view of Mr. Haultain's hostile attitule towards the new constitution, had been called to the first Premiership of Saskatchewan, won a victory only less decisive over Mr. Haultain and his followers. who entitled thenselves the "Provincial Rights" party. 


\section{CHAPTER XXYVIII}

FORGET'S ADMINISTRITION: SOCIAL AND INDUSTRIAL PROGRESS (189S-1905)

Peice Riner Covnthy Opened-Tre.ity No. 9-Sochal Condition of the Indins Concerned-Orgaizition of Local Improvement Districts-Excessive Rita Fall-First Serious Grain BlockideVisit of the Duke of Corswall-Educational Progress-Railway Develorment.

The opening up of the district of $\Lambda$ thabasca by Indian Treaty Number Nine in the first year of Mr. Forget's administration is indicative of the continued advance of settlement thronghont the West.

It will be remembered that 1897 and 1898 were the years of the first great stampede for the lukon. The desirability and possibility of opening up an all-Canadian overland route was wiclely discussed, and this enterprise was made the occasion of establishing colonization roads in far away Athabasca. Mr. James Ross was entrusted with these important public works and upon his returu he also presented a noteworthy report in reference to the resources of the Peace River conntry and its suitability for settlement. As a preliminary to this settlement and as a preventative of friction with the Indjans, another great Treaty was vigorously advocated by $\mathrm{Mr}$. Ross. In the following year its consummation was entrusted to a commission of three, consisting of XIr. Laird, the former Lientenant-Governor; Mr. Ross and Mr. James MeKenna. The work of treaty-making among the Indians of Athabasca was very different in many respects from the task that had been faced in dealing with the tribes of the South. The northern Indians can scarcely be said to have any definite tribal organization, and there were therefore no powerful chicfs to deal with as the representatives of their tribes. The forest hunters lived in isolated small groups of families, rarely bronght into contact with other Indians or with white men, except when marketing their furs. Each of these miniature clans of families held in hereditary possession a well defined tract of country. which constituted their hunting preserve, and they rarcly moved beyond its narrow linits. There were, however, in every community, some hunters of special distinction, and $\mathrm{M} / \mathrm{r}$. Ross did preparatory work of special impor- 

tance in securing the selection of some of these more prominent Indians to act as the spokesmen of the rest in the negotiations of the Treaty.

The territory ceded by Treaty Number Ninc was enormous. The boundaries were extrenely irregular, but it extended from about $105^{\circ}$ to $130^{\circ}$ West Longiude and from $52^{\circ}$ North Latitude to MacLeod liay on Lake Chipewayan. The Indians included screral tribes of the Chipewayan Indians, as well as Crees and Iroquois.

Mr. Charles Mair, one of the Dominion Commissioners subsequently appointed for the iscue of serip) to Halfbrecels in Athabasea, in his work entitled "Through the Mackenzie liasin," has given at striking picture of the conditions that hitherto had existed in these remote regions:

"It was a region," said he, "in which a primitive people, not without faults or depravities, lived on Nature's food and throve on her winfailing harvest of fur; a region in which they often left their heaver. silver-fox or martin packs-the envy of Fashion-lying by the dog trail, or hanging to some sheltering tree, laccatuse no one stole, and each took his fellow's word withont question, hecanse no one lied. A very simple people indeed, in whose language pofanity was monown and who had no desire to leave congenial solitules for any spot on carth. Solitules which so charmed the educated minds who brotiglit the white man's religion or traffic to their doors, that, like the Lotus-eaters, they, tow, felt litte inclined to depart. Yet they were not regions of sloth or idleness, lut of necessary toil ; of the labourous chase and the endless activities of aboriginal life; the region of a people familiar with its fatma and flora, of skilled but anconscious naturalists who knew no science.

"Such was the state of society. in that remote land in its golden age, before the enterprising "free trater' brought with him the first fruits of the Tree of Knowlerge; long before the hali-crazed gold hunters rusherl won the scene, the 'Klondikers' from the saloons and music halls of New York and Chicago, to whom the incredible honesty of the natives, the absence of money and the strange barter in skins (the wyan or aghti of the Indians) seemed a phantasmagoria, an existence utterly removed from 'real life'that ostentatious and valgar world in which they longed to play a part. It was this inroad which led to the entrance of the athority of the Oueenthe Kitchi Okemasquay-not so much to preserve order, where, witlout the law, the natives had not muisely governed themelves, as to prepare them for the incoming world, and to protect them from a new aggressor with whom their rude tribunals were incompetent to deal. To this end the Expedition of ISgo was sent by the Government to treat for the transfer of their Territorial rights, to ascertain, as well, the numbers and holdings of a few whites, or other settlers, who hatl made a start at farming or stock raising within its borders, and to clear the way for the incoming tide of settlement when the time beame ripe for its extension to the North."

In his first speech from the Throne. Mr. Forget announced that the work of organizing the settled portion of the country into "local improvement districts"-rudinentary rural municipalities-was nearly completed, 
four hundred and fifty districts being ready to commence work. Throughout his regime the social and industrial history was one of steady progress. Immigration continued to flow rapilly into the country, and upon the whole. agriculture, its fundamental industry, was distinctly prosperous.

As illustrating the nature of the stream of immigration flowing into the Territories at this time, the fullowing figures, tatien from the records of the Prince Albert Lands ( ffice for the twelve months ending ()ctober $3 \mathrm{I}$, 1904, are of interest. One thousand seren hundred and twenty homestead entries were registered. The homesteaders and their families included 1,200 Americans (of whom many were former (anadians); 1.000 Germans from the United States; joo Scandinavians, also from the American Repulblic; 500 Eastern Canadians; 300 Mennonites; 200 from the Pritish Isles; $10+$ German-Russians, and 86 Hungarians.

It is noteworthy that where serions loss of crops occurred during this period, it was as a rule resultant from a cause far removed from that usually responsible for such disaster in earlice years. The country now suffered, not from drought, lut from excessive rainfall. Great floods had marked the Spring of 1807 , especially in Alberti. These caused the destruction of many bridges along the line of the Canadian Pacifie Ratway, drove many settlers from their dwellings and entaited heary financial loss upon the country. In the records of the Assemlly and the newspapers of the day one finds frequent reference to unprecedented rains and disastrons floods until about 1903 .

In 1902 a new source of vexation presented itself, which ever since has been a serions grievance among the farmers of the West. This, however, arose in reality from the increased prosperity and rapid development of the country as it consisted in a grain blockade. In 1 joz it was considerably relieved by the extensive shipment of grain to Duluth aid North Portal.

This same year was marked by the visit of the Duke and Duchess of Cormwall, who were destined a few years later to become the King and Queen of the United Kingdom.

A deplorable calamity occurred in the Territories on April 29, 1903. This was the memorable landslide by which the lower portion of the town of Frank was obliterated. In this sad disaster sixty-three men, women and children lost their lives.

During the period under review the school system of the Territories continued to show marked growth and to attract increasing numbers of highly qualified teachers from Eastern Canada. In a cun iderable number of districts in which the settlers were IIalfhreerls or newly arrived Europeans, the local interest in education was not satisfactory, however, ant in a number of eases it was found necessary to remove the schools from the control of local trustees and to appoint commissioners to administer them under 
$$
\text { . }
$$ 
direct government supervision. This involved increased expense, but was amply justified in the interests of both parents and children. Partly as the result of the ingenions system of school grants, - hased upon regularity of attendance, the equipment, the length of the school term and the grade of the teacher's certificate, - a most encouraging improvement is recorded in all these respects. In 1808 there were in the Territories four hundred and twenty-six schools in operation, witli sixteen thousand, seven hundred and fifty-four pupils. In igot there were five hundred and forty-five schools, including six hunded and hirty-1hree departments, and letween January 1st and Sejtember ist, when the new Provinces were inaugurated, two huildred and thirty-one school districts were added.

An event of special importance to western Canada was the passing of a neasure by the Dominion Parliament in Igot providling for the building of a second transcontinental railway, the Grand Trunk Pacific. The measure was severely eriticised by the Opposition, lut it passed its third reading l,y a majority of forty-six. The Canalian Xorthern kitilway System was also rapidly developing into a third transcontinental line, and on $\Lambda_{\text {pril }} 3,1905$. the first through train on this railway left Winnipeg for the Salskatchewan Valley. The Pasqua or Souris branch of the Camadian Pacific Railway. giving direct communication with St. I'aul, was opened for traftic on September 25, 1893, an event of great importance in the development of Southern Saskatchewan. 


\section{CHAPTER XXXIX}

\section{THE AGITATION FOR PROVINCIAL STATUS}

Memorials of igoo axd igol-Siftox's Arguments for Delas, Mlarci, igo2--Haultan's Protests-Demates in Parlanaext-llaul-

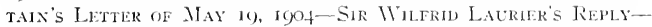
Discession in thie l'Ress-Rise of the School Questron-Shotlu There die ONe or More New Provinces?-Conferences it OtTaWA-Prontachal Institutions Assured.

In the prescnt chapter it will be our luty to review, in its main features, an agitation which extended over a considerable number of years and which culminated in the creation of the present Provinces of Saskatchewan and Alberta. The limits of our space forbid the treatment of the subject in full detail, especially with regard to its initial stages. Indeed, for our present purposes, we may commence with the year 1900.

The Assembly, under the leadership of Mr. Haultain, having passed a resolution praying for provincial autonomy, Premier Haultain and Mr. J. H. Ross visited Ottawa in 1900 and in 1901 in comnection with the matter. An elaborate statement of the whole case was submitted by the Territorial Premier to Sir Wilfirl Lauricr, under date of December I, Igor, and at Sir Wilfrid's request a Bill was prepared and presented to the Ottawa Government embodying the Territorial demands and requirements. Tine proposal was to join the four districts of Assiniboia, Saskatchewan, Alberta and Athabasca into a Province of the Dominion under the terms of the British North Amcrica Act, with four members in the Senate and ten in the Commons, and with the same local constitutional powers and rights as the other Provinces. Mr. Haultain and his colleagues recommended that the new Province should enjoy full control of its Crown Lands and subsidies of $\$ 50,000$ for legislative purposes, and of $\$ 200,000$ at the rate of eiglty cents per head of its population. The Subsidy slould increase at the same rate until the population reached $1,306,001$. Moreover, interest at 5 per cent should be paid to the Provincial by the Federal Govermment on all lands previously granted for settlement by the Dominion Government within the bounds of the new Province.

Under date of March 27, 1902, the Honourable Clifford Sifton, Minister of the Interior at Ottawa, wrote Mr. Iatitain as follows: 

"It is the view of the Govermment that it will not be wise at the present time to pass legislation forming the North Viest Territories into a I'rovince or Provinces. Some of the reasons leading to this view may be found in the fact that the population of the Territorics is yet sparse; that the rapid increase in population now taking place will, in a short time, alter the conditions to be dealt with very materially; and that there is considerable divergence of opinion respecting the guestion whether there should he one Province only or more than one Province. Holling this view, therefore, $i t$ will not he necessary for me to discuss the details of the dratit bill which you presented as embodying your vicws."

In his reply, dated April and, the Territorial l'remier concluded a vigorous protest in the following terms:

"We camnot but regret that the Govermment has not been able to recognize the urgent necessity for the change that has been asked, and can only trust that as you have denied us the opportunity of helping ourselves you will at least be impressed with the necessity and duty. which is now yours, of meeting the pressing necessities of these rapiclly developing Territories. While we may, in your opinion, without inconvenience, mark time constitutionally, we cannot do without the transportation facilities, the roads, bridges, the schools, and the other improwements which our rapidly growing population imperatively requires-and at once. Whether we are made into a Province or not, our financial necessities are just as real, and in conclusion I can only trust that when the question of an increase to our subsidy is receiving consideration, more weight will be given to our representations in that respect than lias been given to our requests for constitutional changes."

A few days later, on April Sth, Mr. Ilaultain moved the following resolution in the Territorial Assembly:

"Whereas, the larger powers and income incidental to the Provincial status are urgently and imperatively required to aid the development of the Territories and to meet the pressing necessities of a large and rapidly increasing poptlation, be it resolved that this House regrets that the Federal Govermment has decided not to introduce legislation at the present session of Parliament with a view to granting P'rovincial Institutions to the Territories."

Dr. Patrick, for the opposition, proposed a 2.000 word amendment supporting the division of the Territories into two I'rovinces, each with ahout 275.000 square miles of territory, arguing that such an arrangenent would cheapen administration and make transportation arrangements easier. It was lost by a large majority, and Mr. Haultain's motion carried in the same way.

The subject was shortly afterwards debated in the House of Commons at Ottawa.-April 18th,-in connection; with a vote of $\$ 357.979$ for the North West schools. Nll the Mestern members spoke. and Mr. R. L. Forden declared existing grants to be inadepuate, and supported Territorial 
autonomy. Mr. Sifton, in reply, stated that the Govermment was considering the funancial question of the future carefully. As to attonomy, he thought a settlement in three or four years would be quite reasonable. The granting of autonomy would not abolish existing difficulties, and many of the people in the Territorics did not yet desire it, and even those who did were not agreed as to whether there should be one Province or two. The Government, he declared, would not be hurried in so important a matter.

On April rn, rgo2, Mr. R. 1;. Bennett, of the Opposition in the I.egislature, moved a long resolution urging antonomy as an imperative necessity. Mr. Haultain, however, declared it unnecessary, and the mover alone voted for it.

On May 19, 1904. Mr. Iaultain wrote Sir IVilfrid Laurier, drawing bis attention to this matter once again. Ile reviewed the correspondence which had passed between them, pointing out the importance of taking action in a matter upon which the members of his Legislature,-both Liberals and Conservatives,-were absolutely mited and representative of the wishes of the pople. He referred to resolutions then being passed at party conventions throughout the Territories as corrohorative of his views, and indicative of the fact that some of Sir Wilfrid's supporters from the West were not giving him advice in hamony with the feelings of their constituents. Mr. Hanltain aslied that negotiations be resumed and legislation introduced into the Dominion Parliament at the earliest possible date for "organizing, upon a Provincial basis, that portion of the North West Territories lying between the western boundary of Manitoloa and the eastern slope of the Rocky MIountains, and extending northward from the international boundary as far into the District of Athabasca as might be recideci upon." He further requested that, whatever else it includerl, the legislation should contain provision for:

r. The application of the Pritisli North America Act as far as possible to the area dealt with.

2. Adequate representation in both Ilouses of Parliament, bearing in mind the difference in the ratio of increase in the poptlation of the Terriories from that of the longer settled parts of the Dominion.

3. Govermment, legislation and administration of justice.

4. The preservation of vested rights.

5. The transfer of the public domain, with all Territorial rights and the beneficial interest therein involved.

6. A subsidy, based as nearly as might be, upon those given to the Provinces.

7. Remuneration for that part of the public domain alienated by the Dominion for purely. Federal purposes.

8. The placing of the burlen of the Canadian Pacific exemption upon the Dominion, where it properly belonged. 
All these matters, he added, had been repeatedly brought to the notice of Sir Wilfrid's Govermment, and he hoped they would now receive some consideration. In a supplenentary note, Mr. Haultain drew attention to the fact that the population of the Territories being now about four hundred and fifty thousand, they were entitled, on the existing basis of Provincial representation, to eighteen members, instead of the ten given them in the Redistribution Act.

Apparently no answer was made to this communication, or to another one dated June ist. Three months later, however, and on the verge of the general elections, Sir Wilfric Laurier wrote to Mr. Maultain (September 3). IJe defended the allotnnent of representatives, under the recent redistribution, as being liberal in its basis of assumed population, and a larger number than would have been given lad the Territories been l'rovinces and therefore subject to the decennial rearrangement only. As to the delay in granting autonomy, he was quite assured of its wislom, not only because of the rapid current development and changing conditions in the West, but because of the fuller and more comprehensive information now available. As to the future, Parliament had just been dissolved, and action therefore would be better justified. The new House of Commons would contain not four, but ten representatives of the North West Territories, who, coming fresli from the people, would be entitled to speak with contidence as to the views and requirements of those whom they represented. Should the present Government be sustained, it would be prepared immediately after the election to enter upon negotiations for the purpose of arriving at a settlement of the various questions involved in the granting of Provincial antonomy, with a view of dealing with this problem at the next session of Parliament.

Prior to and between the dates of these communications, there had been the usual discussion of the subject throughout the Territories, with an occasional reference in the East to the possibilities of dangerous national controversy involved in it. Speaking to the I"innipeg Telcyram, on January 8th, Mr. Thomas Tweet, President of the Territorial Conservative Association, declared the people to be overwhelmingly in favor of autonomy, and referred to the support given that policy by scventeen Liberal members in the Legislature, although its immediate grant was opposed by liberal members from the West in the IInuse of Commons. The Calyary Horald, on March 21 st. handled the situation. without gloves, from the Conservative standpoint. It pointed out that according to its estimates, the Federal authorities had cleared, over all expenses, at least one million dollars in revente from the public lands of the Territories, and nevertheless refused Premier Hattain a quarter of that sum, except as a loan, though desired for purposen of imperative necessity. "The conduct of the Administration of Ottawa," it 



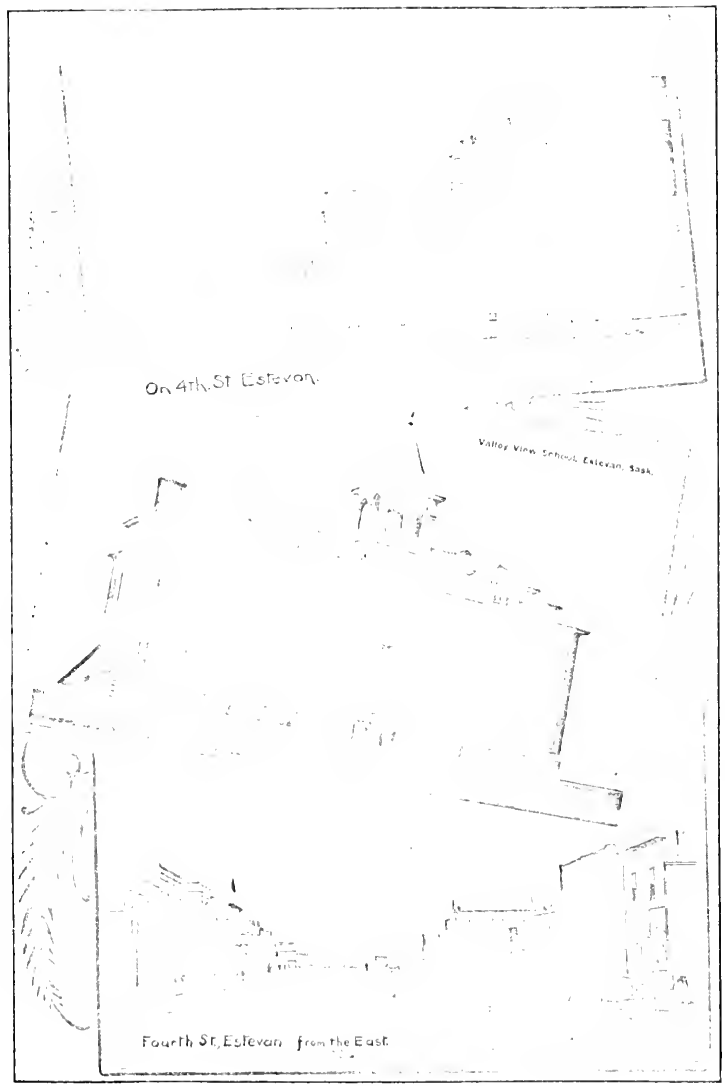


proceeded, "is quite sufficient to raise another rebellion in the North Vest Territories."

An ontside view of existing institutions in these regions was given by the Montral Star of April 8, 1904, as follows:

"The people of the Territories are deprived of the control of their public lands, of their minerals, of their timber. They have no power to raise money on their own credit. They have no fixed subsidy, and are dependent on annual doles from the Dominion Government, small and uncertain in amount. They have no power to incorporate railway, steamboat. eanal, transportation and telegraph companies. They have no power to amend their constitution, as the other Provinces have. They have no power to establish hospitals, asylums, charities, and those other clemosynary institutions which the British Nortl America Act assigns to the Provinees. They are not allowed to administer the criminal law, which is a right possessed by all the Provinces of the Dominion."

Speaking to the Calgury Horald, on March I7, Igo4, Mr. Richard Secord, who had recently retired from the Legislature to run in Edmonton against Mr. Frank Oliver, quoted the local Premier's figures as indicating a revenue ruming from $\$ 1,400,000$ to $\$ 3,000,000$ under I'rovineial status, as against the present $\$ 750,000$ a year. Besides the inadequate sums allowed to the Territories up to this time (accorting to Mr. Haultain s contention) a heary debt of $\$ 4,925,1 \$_{7}$ was being clarged 11 against them at Ottawa. The forec of Mr. Sccord's protest was weakened in Lastern Canda, liowever, by his defeat at the hands of the electors of Edmonton. Noreover, tables were given by supporters of the Dominion Government, showing the steady increase in the Dominion grants during recent years.

Meanwhile, the Territorial Promicr was in the East, pressing upon the Dominion Govermment his claims for antonomy. He was acconpanied by bis colleagues. Mr. G. H. V. Bulyea, and by Mr. J. J. Young, M. L. A. In an interview in the Toronto Star of April 13, 1904. Mr. Hanltain said that he and his colleagues were simply urging that the continued progress of the Vest now rendered it essential that self-government, similar in scope to that of the older Provinces, be no longer withheld. He doubted whether the people of the East realized that the North Mest Territories, if at once organized into a Province, would already, in the matter of population, stand fourth among all the Trovines of the Dominion. The peuple of the Territories had given no reason to suppose that they were incapable of self-govermment, and they wished their request for recognition to he serionsly considered.

This visit to Ottawa was not very frutitul of results, if judged by the above quoted correspendenee and succeeding period of inaction. In financial matters, the Territorial l'remier did, however, gain materially, as we have mentioned elsewhere.

In another direction important developments were occurring. For some 
time The Toronto Nea's had hinted at a serions reason for the delay in granting antonomy, and on Nay th , a subject which the rest of the press either skimmed over or touched not at all was very plainly referred to: "The principai reason for the slowness to give autonomy to the West," said the Nezes, "is that the Ottawa Government dare not give it. The Hierarchy of the Roman Catholic Church has served notice that when the bill to nake a new Province or Provinces is drafted, it mitst contain a provision establishing Separate Schools."

Now it will be remembered that, muder the Canadian constitution, if separate schools have been established by a Province, whether prior to or after its entry into confederation, such schools cannot subsequently be disturbed by the Provincial Legislature without the Assembly rendering itself liable to "remedial legislation" by the Dominion Iarliament, in the interests of the minority affected. This somewhat extraordinary feature of the British North America Act manifestly made the school provisions of the Antonomy Act, matters of the greatest importance. It might mean school legislation not merely for today or tonorrow, but for all time to come.

Le Journal (Cons.) declared that the allegations of The Neres were a mere expression of fanaticism, but The liecs returned to the clarge and it was soon supported by many other influential journals and pulblic men.

Upon the matter of delay and inaction, Mr. R. P. Bennett, N1. L. A., of Calgary, said to the St. John Star of Iecember $24^{\text {th }}$ :

"The opinion prevails that the neglect of the Federal Government to deal with the repeated demands of the Legislature for Automomy has heen owing to the difficulties that surround the sulution of the edncational problem. Whether Separate Selools shall exist by law, or whether they shall be prohibited, is the first question calling for decision; and second, shall the new Province or Provines be given full power to deal with the matter without any limitations whatever."

He pointed ont that while at the present time separate sclools existed in the Territories, they were of a type different from the separate schools of Eastern Canada. The teachers were required to possess the same qualifications and submit to the same training as those in the public schools; the same text-books and conrses of studies were used, and, in the matter of inspection, no distinction was made between the public and the separate schools of a given inspectorate.

While the school question provided the real bone of contention, opinion in the local press also varied considerably as to the area or areas that should be placed under the Provincial system of Government. Thus, for example, The Moosomin II orld argued strongly against Manitoban extension westward (thongh not ohjecting seriously to a northern addition to the Prairie Province), and opposed a multiplicity of govermments, which it thought 
would only serve to satisfy selfish individual ambitions. The Edmonton Bulletin and the majority of the papers in the western part of the Territories desired two Provinces with separate capitals and the boundary running north and somb. The Prince Albert Adrocate, however, favoured three Provinces, -(1) Assinibuia and part of Western Alberta, (2) Northern Alberta and the Peace River country, (.3) Saskatchewan and Eastern Ithabasca. This idea was hased upon the transportativin system. Other papers wanted the division made in harmony with natural productions, as one cxtensive region was distinctly cereal-producing, while another was, to an equally cluarateristic extent, an irrigalole and ranching country. Underlying the diverse proposals advocated by the press in clifferent parts of the Territories is the principle that public interests would be best served by such a subdivision of the North llest as would render the home town of each given new spaper the natural Provincial Capital. The press supporting Mr. Haultain, as a rule, favonter one Province, while in the East, The Globe, on November 9. 1904. supported the extension of IIanitoba's houndaries and the creation of two Provinces.

In The Toronto Globe of January 3, t1905, Mr. T. II. Maguire, lately Chief Justice of the Territories, wrote strongly opposing Mr. Haultain's proposals for the formation of one I'rovince ont of these valat regions. Nr. Maguire clamed that public opinion was in favour of two Provinces, if not three, as he himself desired. Nanitoba should be extended, he thought, hut northerly to the Saskatchewan River and casterly to Ifudson's Bay.

Meamwlile, Mr. Premier Hatultain, of the Territories, and Mr. G. II. V. Bulyea, his Commissioner of Public Works, had arriverl at Ottawa to com-

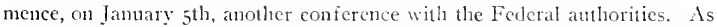
to the details of the succeeding consultations, the public was not informerl, but the correspondent of The Globe, on January isth, declared that there would be nothing in the form of a definite agrecment until the return of the Minister of the Interior, who was not in Ottawa. The conference included Sir Wilfrid Laurier, Sir William Mulock, Mr. Fitzpatrick and Mr. R. W. Scott. On January 19th, the western delegates also discussed conditions with the members of the Commons and Senators from the North West, and it was shortly afterwards amounced that the new Provinces would be two in number. The continued absence of Mr. Sifton. the official representative of the West, ostensibly throngh ill health, occasioned much comment in political circles.

However, it was evident that the first stage of the long struggie was over. Provincial institutions for the Territorics were now assured. 


\section{CHAPTER XL}

\section{THE NEW PROVINCIAL CONSTITUTION}

The School Situation in igo5-Tine Saskitcinewan Act IntroducedCrown Lands to Rlamin Vested in the Federal Gorernmext -Financial Terms-Sir Wilfrid Liurier's Tribute to Separate Schools-Mk. H.nultan's Letter-Dissextions Withix the Parties-Mr. Bordex's Alendient to the Educational Clause-Mr. Chiristorher Rolinson on the Constitethonil Controlersi-The Cospromise-Gener.l Outlines of Siskatchewan ACt-Unwkittex Elements of the CoxstitutionThe Provincine Cabinet System.

Neantime, Parliament had met on January 12th, and the GovernorGeneral's speech had promised a bill for the conferring of antonomy on the Territories.

The population of the region which was to be organized into the new Provinces-Alberta, Assiniboia East, Assiniboia West and Saskatchewanwas, according to the census of 1901 . 158,940, with an accession by immigration, up to May 1,1905 , of 264,182 .

During the twenty years from IS84, when the existing school system was established in the Territories, 1,360 school districts had been erected. of which only sixteen were for separate schools, and two of these were Protestant. Only four separate schools had been organized since 1892 , when Roman Catholic control and management of their separate school districts was abolished, though according to the 1 gor census, twenty per cent of the population of the new Territories was of the Roman Catholic faith. However, the leaders of that church now stood firm for the maintenance of separate school privileges. The Dishops of St. Albert and Mackenzie, and Father Lacombe, all revered throughout the West, to the welfare of which they had devoted their lives, united in the following pronouncenent: "From our standpoint there cannot be any compromise on this question. Our schools are not only places where children are taught (secular learning). but where they receive their religions training, and it shothl ever be so. This is the only advice we have given to all our people and it is this we have urged them to obtain." How effectively these views were urged was indicated, when 

on lebruary 21, 1905, Sir Wilfrid Laurier introduced the long-looked-for Autonomy Bill.

The I'remier commenced his speech by reviewing the history of the West from 1875, when the Nackenzic Administration gave it an "entirely independent government," by virtue of the charter under which its people had developed, and which had never been repealed, although provisions had been added from time to time. The Act of 1875 was the rock upon which had been reared the structure which was about to be crowned with complete and absolute antonomy. Sir IVilfrid called attention to the clause in this IS75 measure which introduced into the Territories the system of Separate Schools in force in the I'rovince of Ontario. Discussing subsequent constitutional and administrative clanges affecting the Territories, he reminded his hearers that in 1886 the North Vest was given representation in Parliament, and that two years later a local Legislature was created with an Advisory Conncil to deal with matters of finance. In 1Sor additional powers had been given to the Legislature, and in 1897 , by Federal enactment, an Executive Conncil, responsible to the members of the Legislature, was established.

The culmination of all this process was the measure now before the Hoise. In framing this legislation, the main questions for settlement had been four in number: (1) The number of Provinces; (2) the ownership of the public lands; (3) the financial terms to be granted; (4) the school system to be introduced or continucd.

As to the matter of size, he first gave certain comparative statistics upon the basis of which he drew the conclusion that a single Province of the extent advocated by Mr. Haultain would be too large for convenient and effective administration.

The ownership of the public lands was the next point dealt with. The plea of the Territorial leaders for Provincial ownership was based upon conditions in the four original Provinces of Canada, and upon the case of British Colmmbia, when, later on, she was admitted to the Union. The Premier claimed that the comparison was not a good one. All the Provinces indicated had had control of their Crown Lands prior to their entry into Confederation, but the Territories were in a very different situation. They never had the ownership of the lands. Those lands were bought from the Hudson's Ray Company by the Government of the Dominion and they had remained ever since the property of the Dominion Government. The main point, however, was one of policy, and upon this the Dominion Cabinet had decided to retain ownership and control, in the interests of the country's immigration propaganda. United States precedents were cited, and also the position of Manitoba lands, which still remain under Dominion control. Sir Vilfrid quoted, in this latter connection, an Order-in-Council 

of the Macdonald Govermment dated May 30,1884 , refusing the demands of Manitoba on the ground that I'rovineial control would seriously embarrass the immigration policy of the lederal authorities.

With regard to financial terms, the Premier pointed out that the compromises necessary to the creation of the Confederation in 1867 had planted in the Constitution of Canada the condition of subsidy payments ly the Dominion authorities to the Provinces for the carrying on of the latter's business. The government proposed in this case to grant a liheral provision. Last year there had been appropriated by the Dominion for Territorial purposes and, in a very small measure raised by local taxation, a total sum of $\$ 1,636,000$, or an average of $\$ \$ 18,000$ for each of the region now being made into new Provinces. It was now proposed to grant Alberta and Saskatchewan each $\$ 50,000$ a year for civil government; \$200,000 for capitation allowance upon a basis of 250,000 population, which would increase pro rata until the population reached $8.000,000$ souls; a debt allowance of $\$ 405.375$; and a compensation allowance, for retaining the public lands, of $\$ 375,000 ;$ making a total of $\$ 1,030.375$. To this would be added in each case, for five years, an allowance of $\$ 62.500$ per anum for the construction of buildings and public works.

Then came a prolonged consideration of the legislation of 1875 by which the Mackenzie Government had established Separate Schools in the new Territories of the $\mathrm{W}^{\dagger}$ est, for, as the Prenier claimed, all time to come. In saying this he quoted George Brown again, as confirming this view in the Senate dehates of that year. Sir WVilfrid's spech concluded with a muchdiscussed personal adrocacy of Separate as opposed to Public Schools.

"I offer at this moment," said he, "no opinion at all npon Separate Schools as an abstract proposition, but 1 have no hesitation in saying that, if I were to speak my mind upon Separate Schools, I would say that I never could understand what objection there could be to a system of schools wherein, after secular matters had been attended to, the tencts of the religion of Christ, even with the divisions which exist among His followers, are allowed to be taught. We live in a comtry where, in the seven Provinecs that constitute our nation, either ly the will or by the tolerance of the people, in every sclool Christian dogmas are tanglit to the youth of the conntry. We live by the side of a nation-a great nation, a nation for which I have the greatest admiration, but whose cxample I would not take in everythingin whose schools, for fear that Cluristian dogmas in which all do not believe might be taught, Christian morals alone arc taught. When I compare these two countries: when I compare Canada with the United States: when I compare the status of the two nations: when I think upon their future; when I obscrve the social conditions in this country of ours-a total absence of lynchings, and an almost total alssence of divorces and murders-for my part I thank Heaven that we are living in a comtry where the young children of the land are taught Christian morals and Christian dogmas as well. Either the American system is right, or the Canadian system is right. 

For my part, I say this without hesitation: Time will show that we are in the riglit. In this instance, as in many others, I have an abiling faith in the institutions of my own country."

The following was the provision in the Autonomy Bill as at lirst drafted relating to Separate Schools:

"The provision of section 93 of the Iritish North America Act. 1867, shall apply to the said Provinces as if, at the date upon which this act comes into force, the territory comprised therein were alrealy a Province, the expression the mion' in the said scetion being taken to mean the said date.

"Sulject to the provisions of said section 93 and in continuance of the principle heretoiore sanctioned under the North Viest Territories Act, it is enacted that the Legislaturen oi the said ['rovine's shall pass all necessary laws in respect of education: and that it shall thercin always be provided:

"(a) That a majority of the ratepayers of any district or portion of said Provinces or of any portion or subrivision thereof, by whatever name the same is known, may establish such schools therein as they think fit, and make the necessary assessment and collection of rates therefor, and:

"(b) That the minority of the ratepayers therein. whether Frotestant or Catholic, may establish Scparate Schouls thercin and make the necessary assessments and collection of rates therefor, and:

"(c) That in such case the rateparers establishing such T'rotestant or Roman Catholic Separate schools shatl he liable only to assessment of such rates as they impose upon themsetres in respect thereof.

"In the appropriation of public moneys by the Jegislature in aid of education, and in the distribution of any moneys paid to the Government of the Province arising from the sehool fund cstablished by the Dominion Lands Act, there shall be no discrimination between the Public Schools and the Separate Schools, and such moneys shall be applied to the support of Public and Separate Schools in equitable shares or proportions."

At the conclusion of Sir Wilfrid's speech on the introduction of the Bill, Mr. Borden brietly and nildly commented on the absence of the Minister of the Interior. Referring to the School question, he expressed the hope that on botlu sides of the House no disposition wonld he shown to make this a party yuestion in any sence. Following this bricf spech an adjourmment of the debate took place during which the country discussed the Premier's deliverance. () March 9, and the succeeding day, Mr. Borden again drew attention to Mr. Sifton's absence.

On March I2, as we have elscwhere noted, Mr. Haultain published an open letter of the greatest political importance, addressed to the Dominion Premier. It was of considerable length, but all readers interested in clearly understanding the details of a controversy involving such important and enduring results, will be interested in an analysis of Mr. Haultain's letter. It commenced as follows: 

"To the Right Hon. Sir Wilfrid Laurier, K.C.M.G.,

President of the Privy Conncil, Ottawa.

"Sir" :

"The somewhat hurried termination of the conference to which you were good enongh to invite representatives of the North West Govermment, and the introduction of the Nllserta and Saskatchewan bills, call for a final statement on the subject. In this statencnt I slatll confine my remarks to some of the more important provisions of the Bill, leaving a mumber of minor matters requiring consideration to less formal mention.

"The first question which suggests itself is the question of the necessity" for the creation of two provinces instead of one. After careful consideration I am more convinced than ever that there is no necessity for dividing the conntry into two provinces, witl the conseguent duplication of machinery and institutions."

Mr. Haultain argued that the machinery involved in provincial government was necessarily expensive, and suitable to the administration of public affairs over a large area with an extcnsive population. The Territories had for a number of years been under one Government and Legislature, exercising many of the most important powers of Provincial Governments and Legislatures, and there had never been any suggestion that the Territorial machinery was in any way inadequate for the purposes for which it was created.

"Our laws and institutions," said Mr. Haultain, "are admittedly efficient and satisfactory. Under them, the people of the Territories have acquired a political individuality and identity as distinct as that of the people of any Province. Up to the I3th of June next, this will continue to be the case, and there does not seem to be any reason, bascd on necessity or convenience, why on the first day of July they should be suddenly divided in two, separated by a purely arbitrary line, and obliged to do with two sets of machinery and institutions what they, to a great extent, have been doing quite satisfactorily and efficiently with one. I must, however, state that this opinion is by no means unanimously shared in the Territories, and that the proposed action of the Govermment will not call forth much hostile criticism. I must also state my opinion that the dividing line between the two provinces should have been placed at least seventy-five miles farther East.

"I must take strong exception to the way in which the subject of education has been treated both in the conferences and in the lills. I must remind you of the fact that your proposition was not laid before my colleague or inyself until noon of the day upon which you introrluced the Bills. Ip to that time the guestion bad not received any attention beyond a casual reference to it on the previons Friday, and I certainly believed that we should have had an opportunity of discussing your proposals before twelve o'clock on the day the Bills received their first reading. No such opportunity. however, was afforded, as mnfortunately you were mable to be present at the session when this section was submitierl; neither was Mr. NIulock. I feel sture that you will acquit me of any feeling in the matter other than that stch an important subject shoukd have been fully discussed before any 

definite conclusion was arrived at by the Govermment and the Bills dealing with it were laid lefore l'arlianient.

"With regard to the question of education generally, you are no doubt aware that the position taken ly us was that the Provinces were left to deal with the subject exclusively, subject to the provisions of the British North America Act, thus putting then on the same footing in this regard as all the other provinces in the Dominion except Ontario and Quebec."

Mr. Haultain stubnitted that Parlianent is manifestly and necessarily bound by the provisions of the British North America Ait, $786 \pi$, in passing legislation of the kind involved in the Autonony Bill. He argued at some length that the British Norlh America Act gave no anthority to Parliament to create, contrary to the wishes of the people directly connected, an inferior and imperfect provincial organization.

"If the Provincial jurisdiction can be invaded by positive Federal legislation such as is proposed in this case," Mr. Haultain inquired, "what limit is there to the exercise of such a power? Similar restrictions might he imposed with respect to any or all of the matters in relation to which, under the British North. Imerica Act, 1867, the Provincial Legislatures possess exclusive powers.

"The only jurisdiction possessed by Parliament in this respect is the remedial jurisdiction conferrel ly sub-scetion four of section ninety-threc of the British North America Act, $1867 .{ }^{1}$ The proposed attempt to legislate in advance on this subject is beyond the power of Parliament, and is an unwarrantable and unconstitutional anticipation of the remedial jurisdiction. (Section 15)-Tre-existing law's, orders and regulations not inconsistent wit regard to a subject coming within its exclusive jurisdiction and necessitating requests for lumperial Legislation, whenever the rapidly changing conditions of a new comntry may reytire them. On the fifteenth of July, is7o, the North West Territories were 'admitted into the union,' in the express terms of section 146 of the British North America Act, I86;."

To speak of the Provinces of Alberta and Saskatchewan being "admitter] into union" on the Ist of July, I905, was therefore an inproper and indefensible use of the expression, in Mr. Ilaultain's opinion. The territory included within the bonndaries of these proposed Provinces had been "admitted into the union" on July 15, 1870, and inmediately upon creation of these Provinces, the provisions of section 93 of the British North America Act, 1867 , would become, as a matter of indefeasible right, a part of their constitution.

1 "In case any such Provincial law as from time to time seems to the GovernorGeneral in Council requisite for the the execution of the provisions of this section is not made, or in case any decision of the Governor-General in Council on any appeal under this section is not duly executed by the proper Provincial authority in that behalf, then and in every such case, and as far only as the circumstances of each casc requirc, the Parliancut of Canada may make remedial tares for the duc crecution of the provisions of this section and of any decision of the Governor-General in Council under 

The Autonomy Bill was framed, he said, in direct contradiction of this principle. It was an attempt to create a Province retroactively. It declared Territorial Schools and laws to be l'rovincial schools and laws: whereas, as a matter of fact the people of the Territories had never yet had an opportunity of expressing their wishes with regard to the mantenance or abolition of a Separate School System, as Territorial Laws passed hitherto in this connection had manifestly becn shaped in accordance with Federal Legislation, which the Territories had been powerless to repeal. The North West Premier continued:

"I, therefore, most respectiully demand, on behalf of the Territories, that the same terms, and no others, imposed by the Oueen in Council on the admission of Prince Edward Island and Lritish Colmmbia, be prescribed in this instance. The draft bill l submitted more than three years ago contains the clause which will he found in the orders in Council admitting those Provinecs. To impose nore or to prescribe less would, I submit, be equally contrary to the law and the Constitution. The clause referred to is as follows:

"On, from and after the said first day of Jamnary, 16\%3, the provisions of the British North America Act. 1867 . except those parts thereof which are in terms made or by reasonable intendment may be held to be especially applicable to or to affect only one or more. lut not the whole of the Provinces under that Act composing the Dominion, and, excent so far as the same may be varied by this. Ict, shall be applicable to the Province. . . in the same way and to the same extent as they apply to the several I'rovinces of Canada, and as if the I'rovince hat been one of the P'rovinces originally united by the said Act."

"The fact that since the acquisition of the North Wiest Territories, Parliament has passed certain laws affecting those Territories does not involve the principle that those laws must be perpetuated in the Constitution of the proposed Provinces. In this respect, laws relating to education do not differ from laws relating to any other subject. To state that the law passed in 1875 with regard to education must forever limit the power of the Province with regard to a very important Provincial right. involves the theory that Parliament might practically take away all the juriatiction of a Province and leave it shorn of every power which it is supposed to possess under the Constitution.

"I wish to lay great stress on the fact that this is a purely Constitutional question and is not concernet in any sense with the discussion of the relative merits of any system of education. The question is one of l'rovincial rights. It is not a question of the rights of a religious minority. which must properly and may safely be left to the Provincial Legislatures to deal with, subject to the general Constitutional provisions in that regard. It is the question of the right of a minority of Canadians in the wider arena of the Dominion to the same rights and the same privileges, the same powers and the same Constitutions, as are enjoyed ly the rest of their fellow-citizens. and which they claim to be their inalienalule posscssion under the one and only Canadian Charter, the liritish Nortl America Act." 



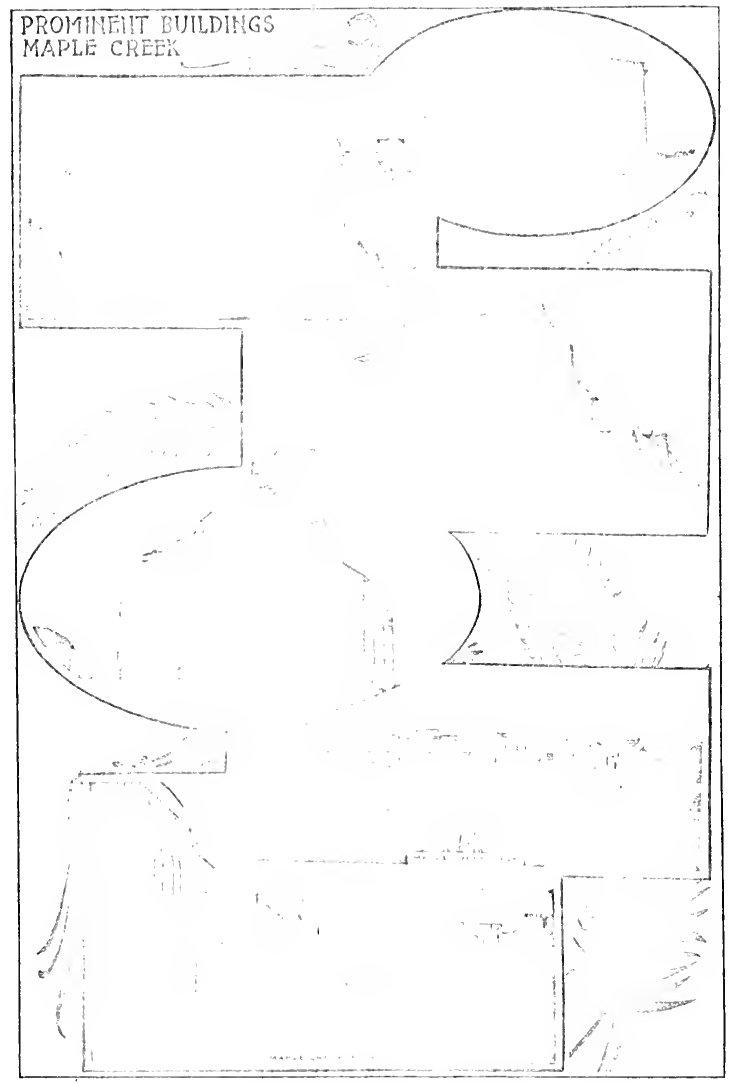



Mr. Ilanltain then discussed at length the bearing the new measure would have on the existing law with regard to the reservation and sale of school lands under the Dominion Lands. Aet of 1872 ancneled $187 \%, 1883$. 1886), and closed his discussion of the educational clanses as follows:

"I, therefore, wish to express my most emphatic objections to the legislation in regard to this subject. I reengnime no power in Parliancut to make laws for the new l'rovinces in contravention of the letter and of the spirit of the Piritisl North Anerica Act. linther, 1 recognize neither right nor justice in the attempt to dictate to the l'rovinces of Llberta and Saskatchewan the manner in which they shall conduct their own lusiness. I very sincerely regret that it is necessary to give this turn to this discuscion. I trust you will believe it is in no sense from any desire of my own to introduce an inharmonions note into these comments. The new l'rovinces have their own future to work out, and I deplore the possibility that they may commence their careers torn with dissention "yon such subjects as these. It seems to me that a great deal of this troulle might have been avoided had we been afforded an opportunity of discussing these proposals, and 1 feel that I must place on record the fact that we are not responsible for the situation.,"

The Territorial P'remier then proceded to a criticism of the provisions of the lill relating to the administration of pulblic lankls. The libll provided that the public domain in each Province should be administered by the Government of Canada for the purposes of Canada. an anmual grant being made, based upon certain varying rates of interest upon the capitalization of twenty-five million acres of land at $\$ 1.50$ per acre. Ilere again Mr. Haultain found it necessary to express dissent. The Provinces were entitled to be recognized as the beneficial owners of the Crown Domain, and as such their right to administer their own property for thenselves was one that should not be taken away without their consent.

A number of smaller matters in the Bill were also criticised and varions suggestions were offered by Mr. Haultain, after which he closed the letter as follows:

"As the conference has come to an end and the Government has expressed its opinion publicly in the form of Bills, the whole of this matter now has hecome a subject for public discussion. and I propose to make this letter public at the very earliest opportumity, and not to treat it as an official communication, only to be made pullic in the ordinary way.

"In concluding this letter I beg to express, on behalf of the North West Government, our high appreciation of the attentive and courteous consideration extended to us by yurself and the other members of the sub-emmittee of the Conncil throngliont the whole conference.

"I have the honor to be, Sir.

"Your obedient servant, 

On March 15 the Opposition leader in the House of Commons once more raised the question of the measure being introduced and, in part. at least, prepared, in the absence of Mr. Sifton and Mr. Fielding-two most important members of the Cabinet, and both rumored to be in opposition to the school policy embodied in its clatuses. He also discussed Mr. Premier Haultain's open letter to Sir Wilfrid Liurier, and deprecated the failure to consult that gentleman as to the Educational portion of the measure.

The Constitutional issue now before the comntry was great enough to overshadow ordinary political affiliations and prejudices and both Sir Wilfrid and Mr. R. L. Borden had to deal with defection and opposition among men who had hitherto been their strongest supporters. Mr. Borden's proposed amendment to the educational clause in the Automomy Bill read as follows:

"That all the words after 'that' be left out, and the following substituted therefor: 'Upon the establishment of a Province in the North VVest Territories of Canada, as proposed by Rill Number 69, the Legislature of such Province, subject to, and in accordance with the provisions of the British North America Act, 1867 to 1886 , is entitled to and slould enjoy full powers of Provincial Government, including powers to exclusively make liaws in relation to education.",

Upon the constitntional aspect of the controversy a widely quoted opinion was given by the well known legal authority, Mr. Christopher Robinson, K.C. His decision was as follows:

"The right of the Dominion P'arliament to impose restriction upon the Provinces about to be formed, dealing with the subject of education and separate schools, is, I think, not beyond question. This would require more consideration than I have yet been able to give it, and must ultimately be settled by judicial decision. I am asked. however, whether Parliament is constitutionally bound to impose any such restriction, or whether it exists otherwise, and I am of opinion in the negative. It must be borne in mind that I am concerned only with the question of legal obligation: what l'arliament ought to do or should do in the exercise of any power which they may possess is not within the province of counsel.

"Such a restriction, J apjorchend, must exist or may be imposed, if at all, under the provisions of Section 93 of the British North America Act, 1867 , and on the ground of their application to the Provinces now to be formed. If that section applies, it would seen to require no enactment of our Parliancnt to give it effect, and if not, no such enactment, so far as I am aware, is otherwise made necessary.

"Upon the whole. I an of the opinion that Section 93 does not apply to the Provinces now alout to be established. Its provisions would appear to me to be intended for and confined to the then Provinces and the union formed in 1867 . There is not in any part of the North West Territories, as a Province, any right or privilege with respect to denominational schools possessed by any class of persons. created by the Province or existing at 

such union, and a right subsequently established by the Dominion in the part now about to be made a J'rovince does not appear to me to come within the enactment."

It soon became evident that a conpromise was essential, and on March 2o, Sir Wilfrid Laurier gave notice of the amendments to the educational clauses of the Autonomy Bills, decided upon by the Cabinet in substitution for the educational clauses in these measures when first introduced. These amendments were as follows:

"Section 93 of the British North America Act, 1867, shall apply to the said Jrovince with the substitution for sub-section one of said section of the following sub-section:

“' $I$. Nothing in any law shall prejudicially effect any law or privilege with respect to Separate Schools which any class of persons have at the date of passing this act, under the terms of Chapters 29 and 30 of the Ordinances of the North 11 cst Territories passed in the year Igoi.?

" "2. In the appropriation of the Legislature or distribution by the Govermment of the Province of any moncys for the support of schools organized and carricd on in accordance with said Chapter 29, or any act passed in amendment thereof, or in substitution thereof, there shall be no discrimination against schools of any class described in the said Chapter 29.

".3. Where the expression "by-law" is employed in Sub-section 3 of the said Section 93, it shall be held to mean the law as set out in said Chapters 29 and 30 and where the expression "at the union" is employed in Sub-section" 3, it shall be held to mean the date at which this Act comes into force.",

After nearly a month of agitation, Sir Wilfrid Lamrier, on March 22, proposed in the House of Commons the second reading of the Autonomy Bill.

Other speakers followed, including the Honourable W. Paterson and F. D. Monk. The latter, though one of Mr. Borden's prominent lieutenants in Quebec, deprecated the needless agitation and mischievous utterances in connection with this question: argued at length in favour of religious instruction in schools; illustrated his remarks by opinions regarding the alleged deplorable condition of the United States public schools; and differed generally from the stand taken by his leader.

Mr. Henry Bourassa dealt at length with the legislation as not granting adequate or just rights to the Catlolic minority.

Indeed, as we have elsewhere remarked, the bill was now abont equally: objectionable to botl the witra-montanes and the Orangemen,- a fact which the majority of molerate men, who had neither time nor inclination to investigate the controversy deeply for themselves, interpreted as an evidence of reasonableness. Resolutions of protest continued to pour in from Protes-

2 The ordinances defining the N. W. School Law as it existed at the end of the Territorial era. 

tant sources, and at Nontmagny, Quebec, on September I8. Messrs. A. Lavergne, M. P., and H. Bourassa, M. P. (Liberals), and Dr. Emile Papuet, M.P. (Conservative), denounced the Goverument for its surrender to the Orangemen of Ontario, and for its gross injustice to the minority in the West; and, in the words of Dr. Paquet, appealed to the perple to "erusli this perfidy."

Largely as a result of the contradictory extravagances of its opponents. the bill passed safely through Parliament and was accepted with reasonable equanimity by the citizens of the Territories.

Anotler act constitnted the new North llent Territories as comprising the region formerly known as Rupert's Land, and the North-Western Territory, with the exception of Nanitoba, the new Provinces, Keewatin and the Yukon, and including also, all other morganizerl British territories and possessions in Northern Canada, and all islands adjacent thereto with the exception of Newfoundland's dependency, Labrador.

As the Autonony Lill of I905,-or to call it by its official mane. The Saskatehewan Act,-constitutes the chief written portion of the Constitution of the Frovince of Saskatchewan, it will be in place here to recapitulate its principal features, especially with a view to renclering its workings intelligible to persons not intimately familiar with responsible government as it exists in Canadia. It recalls in its preamble the provisions of the British North America Act, empowering the Parlianent of Camala to "from time to time establish new provisions in any Territories forming for the time being part of the Dominion of Canada, but not included in anv Province thereor." The introductory sections define the territory henceforth to be known as the Province of Saskatchewan. Then follows the following important paragrapl (Section 3):

"The provisions of the british North Ancrica Act, 1867 to 1886 , shall apply to the Province of Saskatchewan in the same way and to the like extent as they apply to the Provinces heretofore comprised in the Dominion, as if the said Province of Saskatchewan had been one of the Provinces originally united, except.in so.far as varied by this. Act, and cxcept such provisions are in terms made or by reasonable intendment may be held to be specially applicable to or only to aflect one or more and not the whole of the said Provinces."

Section 4 provides for the representation of Sasliatchewan in the Senate by four members and authorises the increase of this number to a maximum of six, by act of the:Federal Parliament. Section 5 provides in tike manner for the provincial representation in the House of Commons for the time being, and Section 6 guarantees that after the next following census this representation "shall forthwith he readjusted hy the Parliament of Canada in sud manner that there shall be assigned to the said Province such a 

number of members" as the principle of proportionate representation on the basis of population should require. In estimating this number Ouebee, with a permanent representation of 65 , constitutes the basis as regards all other Provinces of Canada. Lnder Section 7 the qualifications of voters in the election of Saskatchewan's representatives in the Honse of Commons are made the sane as they had been in the Territories heretofore. In like manner the powers and duties of the Lieutenant-Governor of the North Nest Territories are transfered to the Licutenant-Gorernor of the new Provinces. (Section 10) -..'The Legislature of the Province slall consist of the Lientenant-Covernor and one House to be styled the Legislative Astembly of Saskatchewan." (Section 12) - Ind "until the said Legislature otherwise provides," the Legislative Assembly should he composed of twenty-five elected members. (Section 13)-Cntil otherwise proviled by the Legislature "all provisions of the law with regard to the constitution of the Legis. lative Assembly of the North West Territorics and the clection of members thereof" should "apply mutatis mutandis to the l-egislative Assembly of the said Province." (Section If)-Writs for the first Provincial election were to be issued within six months of the forming of the Saskatchewan Act. (Section 15)-Pre-existing laws, orders and regulations not inconsistent with the Act were to remain in force subject to repeal by the Parliament of Canada, or the Legislature of Saskatchewan, according to their several authorities. Section 17 treats of education. It first refers to Section 93 of the British North America Act of 1867 . which reads as follows:

"In and for each Province the Legislature may exclusively make laws in relation to education, subject and according to the following provisions:

"1. Nothing in any such law shall prejudicially affect any Right or Privilege witl respect to Denominational Schools which any class of persons have by law in the Province of the union.

" 2 . All the powers, privileges and duties at the anion by law conferred and imposed in Lpper Canadi on the Separate Schools and school trustees of the Qucen's Roman Catholic subjects shall be, and the same are hereby extended to the Dissentient Schools of the Oneen's Protestant and Roman Catholic sujects in Quebec.

"3. Where in any. Province a system of Separate or Dissentient Schools exists by law at the inion or is thereafter established by the legislature of the Province, an appeal shall lie to the Governor-fieneral in Council from any Act or decision of any Provincial anthority aftecting any right or privilege of the Protestant or Roman Catholic minority of the Queen's subjects in relation to education.

"4. In case any such Provincial law as from time to time seems to the Governor-Gencral in Council requisite for the due execution of the provisions of the Governor-General in Council or any appeal under this section is not duly executed by the proper provincial authorities in that behalf, then and in every such case, and as far only as the circumstances of each case require. the Parliament of Canada may make remedial laws 

for the due execution of the provisions of this section and of any decision of the Governor-General in Council under this section."

The Saskatchewan . Act provirles that the foregoing section of the British North America Act shall apply to Saskatchewan except that for sub-section (I) of Section 93 the special provisions previonsly quoted in this chapter are to be substituted.

The provisions mate for the financial interests of the Province are contained in Sections 18 to 20 , but as these are of a technical and formidable character they are relegated to a footnote below. ${ }^{3}$

"All Crown lands, mines and minerals, and royalties incilental thereto and the interest of the Crown in the waters within the Province under North VIest Irrigation . Iet of 1808 are to continue vested in the Crown and to be administered by the Federal Govermment as hitherto." Ender Section 22 arrangements were made for an equitable division of Territorial Assets between the two new provinecs. There are a number of other provisions of less general interest. Two of these protect the rights of the Hudson's liay Company and the Canadian Pacific Railway Company.

${ }^{3}$ 18. The following amounts shall he allowed as an annual subsidy to the Province of Saskatchewan, and shall be paid by the Government of Canada, by half-yearly installments in advance, to the said province; that is to say:

(a) For the support of the Govermment and Legishture, fifty thousand dollars;

(b) On an estimated population of two hundred and fifty thousand, at eighty cents per head, two hundred thousand dollars, subject to be increased as hereinafter mentioned; that is to say: A census of the said Province shall be taken in every fifth year reckoning from the general census of one llousand nine hundred and one, and an approximate estimate of the population shall be made at equal intervals of time between eacl quinquenual and decemial census: and whenever the population ly any such census or estimate cxceds the two hundred and fifty thousand which shall be the minimum on which the said allowance shall be calculated, the amount of the said allowance shall be increased accordingly, and so on until the population has reached eiglit hundred thousand souls.

19. Inasmuch as the said Province is not in debt it shall be entitled to be paid and to reccive from the Govermment of Canada, by half-yearly payments in advance, an annual sum of four hundred and five thousand, three huindred and seventy-five dollars, being the equivalent of intercst at the rate of five per cent per amum on the sum of eiglit million one hundred and seven thousand, five hundred dollars.

20. Inasmuch as the said Province will not have the public land as a source of revemue, there shall be paid by Canada to the province by half-vearly payments in advance, an annul sum hased upon the population of the province as from time to time ascertained by the quinquennial census thereof, as follows:

(I) The population of the said province leing assumed to be at present two hundred and forty thousand, the sum payalib until such population reaches four hundred thousand, shajl be three hundred and seventy-five thousand dollars. Thereafter until such population reaches cight hundred thonsand, the sum payable shall be five humdred and sixty-two thousand five htundred dollars. Thereafter, until such population reaches one million two lundred thousand, the sum payable shall be seven hundred and fifty thousand dollars, and thercafter the sum payable sluall be one million one hundred and twenty-five thousand dollars.

(2) As an additional allowance in lieu of pullic lands there shall be paid by Canada to the province ammully by halt-ycarly payments, in advance, for five years from the time this act comes into force, to provide for the construction of necessary public buildings, the sum of ninety thousand seven hundred and fifty dollars. 

Readers unfamiliar with British institutions will, perhaps, be surprised to find such a superlatively important matter as the composition and duties of the Provincial Cabinet defined so summarily and indefinitely as they are by the Saskatchewan Act in Section 8. That paragraph reads as follows:

"The Executive Conncil of the said Province shall be composed of such persons, under such designations, as the Lientenant-Governor from time to time thinks fit."

This, of course, simply relegates the whole matter to the realm of the unwritten usages and conventions which form the basis of Cabinet Government under the British Constitution. These tacit understandings have all the force and indeed more than the forec of any written law, and their violation, if such violation may for the purposes of discussion be considered possible, would entail a revolution.

The unwitten Constitution requires that the King's representative, in any part of the Pritish dominions under responsible government, shall select as head of his Executive Council, a nember of the Legislature who commands the support and is the recogni\%ed leader of the majority of those elected by the people to seats in the Assembly or House of Commons, as the ease may be. This important personage is popularly designated as the Premicr or Prime Minister, and he is in point of fact for the time being the real ruler of the country despite the fact that his extraordinary rights and functions are all but entirely ignored in the written law of the land.

The Premier selects from among his supporters, generally wpon consultation with the Governor or Lientenant-Governor, those persons who, together with himself, are to constitute the Executive Council or Cabinet, as it is popularly called. Each of its members must already have a seat in the Legislature, or must forthwitl secure one. As there is a salary attached to Cahinet appointments, and as the acceptance of any office of emolument under the Crown vacates a member's seat. Cabinet members are obliged to face a new clection immediately after accepting office.

While the Constitution provides for the presence in the Executive Council of "members without portfolio," the esscntial body of the Executive Council is made up of the officials who are the responsible heads of the chief branches into which the administration of state affairs is divided. At the same time, they arc of nccessity the trusted political leaders of the majority of the popular representatives. They thereiore control not only the executive business of the Govermment, but also its legislative functions. So soon as this control is lost, the Cabinet must resign in a body. The ministers must act as a wnit in all matters of political importance so long as they are associated as members of the same Cabinct. Each member is in a special sense responsible for his own department, but he is also answer- 

able to the House for the officin acts of cach of his colleagues and of the Cabinet in its corporate capacity. These are some of the familiar elementary rules under which liritish fovernment is administered in the Nother country and all her self-governing colonies.

Furthermore, it is to be remombered that where the written law assigns legislative and execntive functions to a Governos or Lieutenant-Governor, in a community where responsible government has heen established, it means the Kings representative acting by and with the advice and consent of the Cabinet of the hour or the special member thercof whose department of public affitis is directly concened. The Lientenant-(iovernor of a Canadian l'rovince, however, exercises a dual iunction. He must act not only in intimate cooperation with the Provincial Cabinet, lut also as the representative appointed and paid by the Federal atuthorities. He holds his office "during the pleasure of the Governor-General"-that is, subject to the approval of that officer, acting as the mouthpiece of the Dominion Cabinet. However, he is not removalle within five years "except for cause."

As indicated in Clanse 3 of the Saskatchewan Act above quoted, the written Constitution of the Province includes those portions of the British North America Act bearing on Provincial administration which are not definitely annulled by the Autonomy la itself. Lnder the Canadian Foderal system, all powers not specifically assigned to exelusive exercise by the Provincial Legislatures come within the jurisdiction of the Dominion Parliament. Those concerns in which the Ferleral (jovermment cannot constitntionally interfere are set forth in Scction yz of the liritish North America Act, which is appended to this chapter. As regards agriculture and immigration, the Provincial Legislatures share with the Dominion the right to make laws, but "any law of the Legislature of a l'rovince, relative to agriculture or immigration, shall have effect in and for the said Province as long and as far only as it is not rejugnant to any. Act of the Parliament of Canada." It is to be understood that the Provincial Assembly has no legislative authority with regard to any class of matters not assigned to it by a Dominion statute, such as the Saskatchewan Act, or by the British North America Act itself.

Sections 53 to 57 of the liritish North America Act deal with money votes and royal assent in relation to the Dominion Parliament, and by Section go these are made to apply mutatis mutandis to Provincial Legislatures. Accordingly, it would not be lawful for the Assembly to pass any vote inrolving the expenditure of money for any purpose not previously recommended by a message from the Lientenant-fovernor acting on the advice of the Provincial Cabinet. When any Pill passes the Assembly, the Lieutenant-Governor "shall declare, according to his discretion, but subject to the provisions" of the written Constitution and to his instructions from 


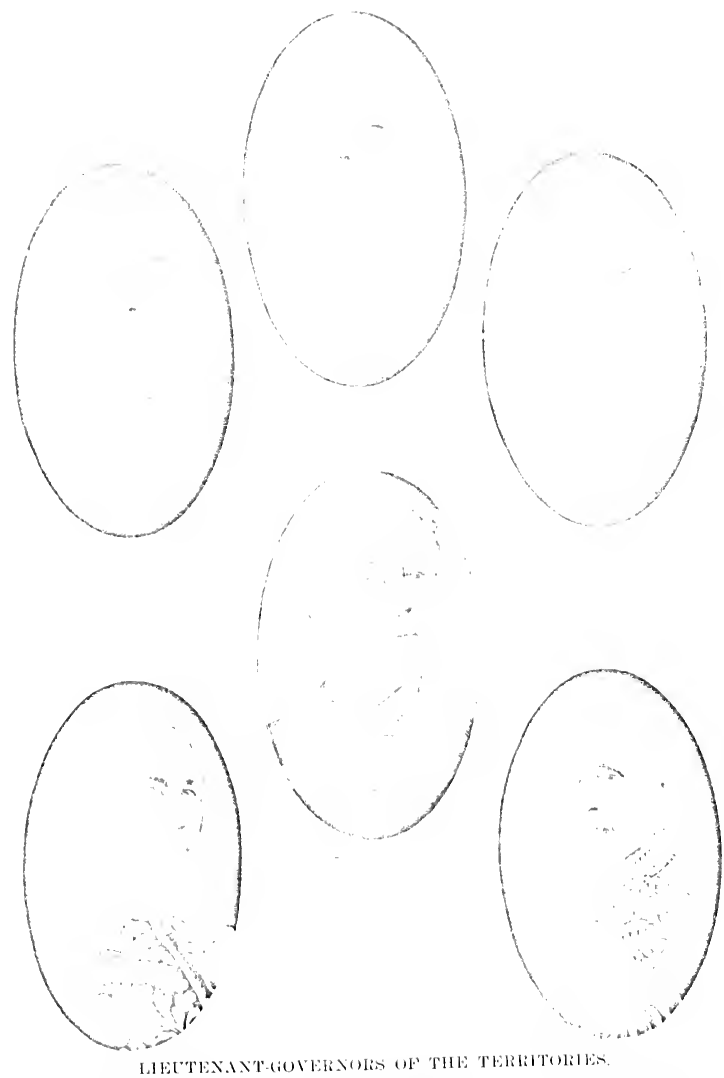

Laird, 1476-j-yl. bewluey, 1s-1.19he. cameron, 1s9s.

Royal, 1x-4-1s?1?.

Mackintosh, 1 $4: 1,1$ 1 :1

Forget, 19!4-1905. 

the Governor-General in Council, either that in his representative capacity he assents to the Lill, refuses to assent to the Bill, or reserves it for the consideration of the Governor-General in Council. He must transmit copies of all legislation to the Federal Government, which, upon the advice of the Attorney-General may, within one year, disallow any Act judged to be ultra vires. A Iill reserved for the signification of the (iovernor-General's pleasure remains invalid nnless and until within one year the assent of the Governor-General-in-Council is officially announced.

Under the amendments to the IBritish North Anerica Act passed in 1871, it is providerl that "the Parliament of Canada may, from time to time, with the consent of the Legislature of any Province of the said Dominion, increase or diminish or otherwise alter the limits of such Province."

Section 92 of B. N. A. Act:

"In each province the legislature may exclusively make laws in relation to matters coming within the classes of subjects next hereinafter enumerated, that is to say:

"(I) The anchdment from time to time, notwithstanding anything in this act, of the constitution of the province, except as regards the office of lieutenant-governor.

“(2) Direct taxation within the province in order to the raising of a revenue for provincial purposes.

"(3) The borrowing of moncy on the sole credit of the province.

“(4) The estallislment and tenure of provincial offices, and the appointment and payment of provincial officers.

"(5) The management and sale of the public lands belonging to the province, and of the timber and wood thereon.

"(6) The establishment, maintenance, and management of public and reformatory prisons in and for the province.

“(7) The establishment, maintenance, and management of hisoutaks, aslyums, charities and eleemosynary institutions in and for the province, other than marine hospitals.

"(8) Municipal institutions in the province.

"(9) Shop, saloon, tavern, auctioncer, and other licenses, in order to the raising of a revente for provincial. local, or municipal purposes.

"(Io) Local works and undertakings other than such as are of the following classes:

"(a) Lines of steam or other ships, railways, canals, telegraphs and other works and undertakings connecting the province with any other or others of the provinces or extending beyond the limits of the province: "(b) Lines of steamships between the province and any British or foreign country ;

“(c) Such works as, although wholly situate within the province, are before or after their execution declared by the Parliament of Canada to be for the general arlvantage of Canada or for the advantage of two or more of the provinces.

"(II) The incorporation of companies with provincial objects.

"(12) Solemnization of marriage in the province. 

"( 13 ) Property and civil rights in the provinec.

"(if) The administration of justice in the province, including the constitution, maintenance and organization of provincial courts, both of civil and of criminal jurisfliction, and including procedure in civil matters in those courts.

"(15) The imposition of punishnent by fine, penalty or inprisonment for enforcing any law of the province made in relation to any matter coming within any of the classes of subjects entmerated in this section. "(16) Generally all matters of a merely local or private nature in the province." 



\section{CHAPTER XLI}

FORGET'S ADMINISTRATION : POLITIC.AL HISTORY (1905-1910)

Inaugerition of Provincin. Ixstitutions-Forget's Inileger.l Speech

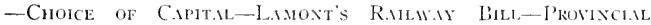
Finances-Acrianonoes Pirty Wirf.tre-Prince Alimert Electrons-Prolincial Edecition.ll Legislatiox and the Suplitementary Rliente ACt-Seprede Colrt and District Colkt Judges-Taxition of Ruhw.M Corpokituns-New Elections Act-Remistribetion Bhli-ProNinchi. Elections of 1908.

In the presence of the Governor-General, the I'remier of the Dominion, and many other distinguished guests, on the occasion of the inaugural celebration of September 1, 1905. Mr. Forget took his oath of office as the first Lieutenant-Governor of the Prorince of Saskatchewan. In reply to the Governor-General's announcement of the new dignity conferred upon the former Lieutenant-Governor of the 'Territories, His Honour spoke in part as follows:

"My first words must he of thanks to your Excellency for the higls distinction just conferted upon me. I tender those thanks most sincerely. I appreciate the honour, and I hope I fully recognise the responsibility of the office on which I have entered. It is no little matter to be the firstly appointed Lientenant of Your Excellency for the new Province of Saskatchewan.

"Even in ordinary circumstances the erent just witnessed by this large gathering would have great interest and significance, and the circumstances are not ordinary. It has often been said lately that the change of status now achieved by the Forth West is the most important event that has occurred to Canada since confederation. This may well be so, for are we not today completing the structure of federated Canada? I say then that the event is one of general interest and significance, and if I may be excused a personal rominisence, I would say that it is to me especially. a matter of peculiar fascination. Torlay this immense throng of North West people have witnessed the swearing-in of the first Lientenant-Cinvernor of the I'rovince of Saskatchewan, and my minl goes lack to a small gathering at Fort Pelly on the 26 th of November, $18-6$, when I witnessed the swearing-in of my esteemed, distinguivhed and venerable friend, Commissioner Laird, as the first Lieutenant-(iovernor of the North West Territories. There is a shade of sadness on the pleasing recollection in the 

fact that Commissioner Laird and myself are the only survivor of those who witnessed that historic erent. From that day to this I have lived a North Wester, have been associated with the Govermment of the Territories and have been closely associated with the growth of the institutions around which we now live."

The political history of the next few years abounded in events of the first importance. Premier Scott, with his Cabinet colleagues, Messrs. Calder and Motherwell, and the members of the Assembly generally, enjoyed such an opportunity for constructive statesmanslip and the handling of large public questions as but rarely, if ever, can occur again.

On March 29, Ig06, the I.ieutenant-Gorernor opened his first session of the First Legislature of the Province of Saskatchewan. Mr. McNutt was elected Speaker, and Mr. Sutherland, of Saskatoon, Deputy Speaker.

The choice of a Provincial Capital was one of the most interesting issues before the First Assembly. Claims were raised in many quarters, but especially in Moose Jaw, Regina, and Saskatoon. The members of the Legislature in a body visited Regina's two chief rivals, and every species of pressure, legitimate and illegitimate, is said to have been brought to bear upon the Assembly. Finally, however, the Premier on May 23d announced the decision of the Government in favor of Regina, and received the endorsation of the House.

An important railway bill was introduced in this session by AttorneyGeneral Lamont, and duly approved by the Assembly. It provided that any railway company obtaining a railway charter from the Provincial Government must complete at least thirty miles of its line within two years, and the whole road within five, and that railway companies must fence their right-of-ways. The bill vested in the Government the power to expropriate any railway constructed under a provincial charter, and to transform it into a government road. Mr. Haultain, the leader of the opposition, criticised the bill in various regards, and in a number of instances his suggested improvements were adopted by the Govermment. The companies incorporated during this first session were: The Saskatchewan Central Railway Company, The Moose Jaw and Suburban Railway Company, The Canada Central Railway Company, and The Saskatchewan Railway Company.

The Hon. I. A. Calder delivered his first budget speech on May i6th. There had been expended under warrant between the date of inauguration and December 31, 1905. \$I18,60I.00. The Govermment estimated the needs of the public services for the fourteen months ending February 28, I907, at $\$ 2,067,567.00$. The revenue for the North IVest Territories for the year Igof had amounted to only $\$ 8+1,8+6.00$. It was thus rendered evident that under the new regime the Govermment was enjoying a much freer hand than had Mr. Ianltain's administration. 

A number of resolutions of general interest were passed during this $\therefore \quad: \quad A_{j}$ first session. The Issembly placed upon record its regret at the death of Mr. Thomas Tweed, who for so long had leen a prominent citizen of the Territories. The Dominion Government was urged to grant an investigation into the claims of the retired servants of the Indson's hay Company, and their descendants, in the matter of Lord Selkirk's lands and deeds. The sum of $\$ 5,000.00$ was voted by the Honse in aid of the sufferers in the

- San Francisco earthquake. A measure was introduced by the Premier raising the sessional indemnity of members of the House from $\$ 500.00$ to $\$ 1,000.00$. In committee Mr. Haultain proposed that the amount be set at $\$ 700.00-$ a proposition defeated only by the chairman's vote. Considerable other legislation was also passed, in all sixty-four neasures.

The opposition, led by F. W. G. Haultain, criticised the Govermment chiefly with regard to financial matters. Under the new system the Prentier was in receipt of a salary of $\$ 6,000.00$, and his colleagues of the Cabinet were to be paid $\$ 5,000.00$ per annum, in addition to their sessional indemnity. Mr. Haultain considered these salaries and the cost of legislation generally to he disproportionate to the I'rovincial income. Seventy-five thousand dollars had also been allowed as the Province's share for the maintenance of the North West Nounted Police force. It was argued that the Govermment should have insisted upon the Federal authorities retaining the complete funancial responsibility for the maintenance of the force. The opposition also disapproved of a vote of $\$ 2,500,00$ for the Western Immigration Association. I vote of non-confidence passed wpon these criticisms was defeated by a strictly party vote of fourteen to eiglit. The House was prorogued May 26 th.

Reference must be made to a series of disagrecable events arising out of the Provincial election. Mr. J. F. Bole had heen declared elected in Regina with a majority of three. Ilis opponent, Mr. H. IV. Laird, together with his supporters, alleged, however, that the ballot boxes had been tampered with, and in due time the case was ventilated in the courts. The upshot of the matter was that Mr. Bole retained his seat.

A serics of suits for alleged criminal libel also arose from the acrimonious party warfare of the day. The Premier won a verdict and trifling damages in his case against the editor of the Regina Standard, but lost a similar action against the editor of the Regina Hest.

The election in Prince Albert County was attended by deplorable circumstances. V'ery shortly before the election the retiring officer ordered the establishment of three new polls some three hundred miles north of the city of Prince Albert. Apart from these polls, the opposition candidate, Mr. S. J. Donaldson, had a majority of fifty-six, but when the deputy returning offecrs from these remote localities returned to Prince Albert, 



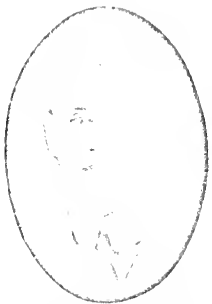

Hon. F. W. G. HALLTAIN, Chief Justice.
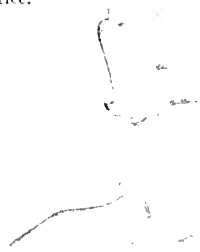

-

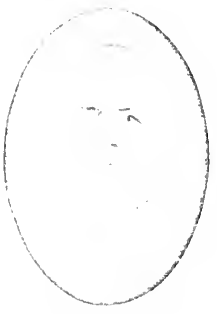

Hon. TAMES II. ROSS. Senator.

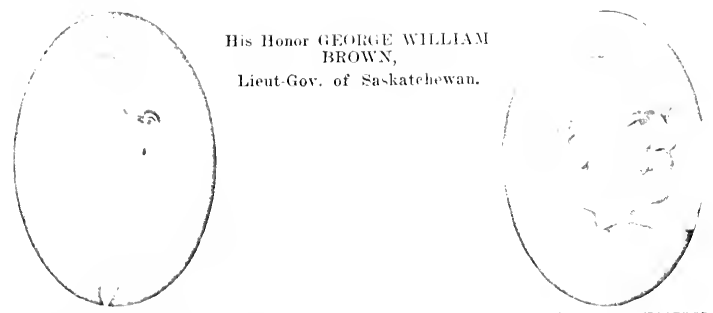

Mr. ARCHIJiAL, MeDONALD,

Retireal factor IIulion s Bay Co. 

some ten days after the election, their ballot boxes were found to contain one hundred and fifty-one ballots all matked for the Liberal candidate, Dr. P. D. Tyerman. This turned Dr. Tyernan's minority into a majority of ninety-five. It was quite evident to everybody, however, that a frand had been perpetrated. One of the deputy returning officers promptly absconded, and the others were arrested. They admitted that they had never even reached the polling places in question, and were fined \$200.00 and costs each. Nevertheless, when the official recount took place before Mr. Justice J. E. P. Prendergast, he decided that, under the law, he had no innction to perform except that of counting ballots actually found in the boxes. In recalling this extraordinary incident it is but just to say that Mr. Donalison himself vigorously resented reflections cast in certain quarters upon the Judge's integrity, and that opposition newspapers, strch as the Regina II ist. admitted that, moder the circumstances, Judge Prendergast could not have acted otherwise. Accordingly, Dr. Tyerman was gazetted as member for Prince Albert, thongl he tid not take his seat. Action was entered against the returning officer, and the matter was before the courts oft and on for more than a year, when at last a verdict was given.

However, in April, inoz, the committee of the Legislature on privileges and elections took into its consideration the clains of Mr. Donaldson, and found them valid. Accordingly, ly a unanimons vote of the Legislature, Mr. Donaldion was declared duly elected.

A large number of other protests laal been commenced, when, to the amazement of the public, Mr. Prendergast admitter the legality of an objection raised ly commel claining that as the Antonomy Bill had not distinctly declared the continued validity of Territorial legislation respeeting elections, the Courts of the l'rovince had as yet no jurisdiction in such matters. This judgment was sulserguently upheld by the Court en banc. Under the circumstances, the Assembly itself alone had power to consider protests.

The separation of the Territories into two Provinces necessitated the organization of a separate educational comncil for Saskatchewan. Its members were Messrs. William Grayson, of Moose Jaw: WV. R. Sparling. of North Battleford; T. H. MoQuire of Prince Allort: A. H. Sinith, of Moosomin, and the Rev. David Gillies, of St. Andrews.

In July, 1906, Messrs. Scott and Lamont visited Ottawa. where they arranged witl the Dominion Govermment for the transfer of the land Titles System and varions other inportant public institutions from Federal to Provincial control.

Toward the end of the year the Premier's ill health obliged him to leave the Province for some months, and during his absence the Hon. J. H. Lamont acted as Premier. 

The second session of the lirst Legislature met on February 20, 1907. Important changes were introduced in connection with the adninistration of justice. A jury act was passed increasing the number of jurors required by law from six to twelve. A new Supreme Court Act provided for a judicial system to replace that of Territorial days. The new Supreme Court was to consist of five judges residing at the Capital, but going on circuit at regular intervals. This Court was to have both original and appellate jurisdiction. Salaries were placed at $\$$,, 000.00 per anmm for the chief justice, and $\$ 6,000,00$ for each of his colleagues in the Supreme Court. The Province was also divided into eight districts, with district courts, the judges of which were given a wide jurisdiction, though in civil causes it did not extend to cases involving a sum of money larger than $\$ 300.00$, which has since been extended to $\$ 500.00$. The Law Society was also reorganised as a Provincial body, and was given large disciplinary powers.

In presenting his second budget. Hon. J. A. Calder. Provincial Treasurer, was able to report that the receipts had been somewhat in excess of the estimates, and that a surplus of $\$+82,280.00$ was carried forward. The chief item in the estimated expenditures for the current year was that for public works. This provided for the outlay of a million and a quarter dollars on small bridges, and a quarter of a million on roads. The estimate for education was only $\$ 25.000 .00$ larger than this last sub-item.

Next day Mr. Haultain introduced a resolution calling for the "early establishment of a telephone system owned and operated by the Province." An amendment was introduced by $\mathrm{Mr}$. George Langley on behalf of the Govermment and duly carried. This proposal was one affirming the desirability of Government ownership of telephones, but instructing the Government first to make thorough inquiry into existing systems.

Much other important legislation occupied the attention of the House, and some of the measures will be further discussed elsewhere. l'rominent among them was an Act defining the scope, functions and character of the prospective University of Saskatchewan, while another bill dealt with the organization and maintenance of a system of High Schools. Closely associated with these measures was the Supplementary Revenue Act, which was introduced by Mr. Calder. It provided for the levying for educational purposes of a tax of one cent an acre upon all taxable land outside of village and town school districts. As a portion of this money would be used for the support of High Schools, the law provided that the children from the rural portions of the Province shotld be admitted to these institutions without fee.

Early in the stmmer of 1907 Mr. Scott was again able to take up his work, and on Jume 2 Ist he was the guest of honour at a very lange and noteworthy public banquet at Regina. 

In the antmon $A$ ttomey-Generat Lamont resigned his seat as member for Prince Albert city, and was appointed to the bench of the supreme Court. Mr. William Ferdinand Mphonse Turgeon succeded him as Attorney-General, and writs were immediately issued for an election at Prince Albert. The opposition candidate was Mr. I. S. Bradshaw, formerly Mayor of Prince Albert, to whom the tucontested ballots gave a majority of one. There were, lowever, 339 contested ballots, ant when these had been reviewed in court, Mr. Turgeon was ultimately dedared elected by a majority of fifty-four. Meantime, Mr. Scott's health made necessary a second leave of absence, during which .11 r. Caller acted as Premier.

The Hon. Edward Ludlow Wetmore was alppointed Clicf Itustice of the new Supreme Court, September Irth. The other juclges appointed to the Court, in addition to the Hon. J. H. Lanont, were the Hon. J. S. I'. Prendergast, Hon. H. W: Vewlands, and the Hon. T. C. Johnson, On November 2Ist the appointment of the district court judges was also gazetted: Reginalel Rimmer for the Cannington Dintrict: A. G. Farrel for the Moose Mountain District: T. C Gorlon for the Yorkton District, and T. F. Forbes for the Prince . Nlbert District.

The third session of the First Legislature was opened by Chief Instice Wetmorc, acting as Administrator. An important measure of this session was the Provincial Treasurer's bill provilling for the taxation of railway companies upon their gross yearly earnings within the Province. A rate of three per centum was to he levied in the case of lines seven years in ojeration, and one and one-hali per centum on those in operation for five years and up to seven. The chicf reason advanced in justification of this mode of taxation was the Canarlian l'acific Railway Company"s claim by virtue of its charter to be exempted irom taxation on its roalled, superstructure and buildings.

Attoney-General Turgeon introduced legislation to take the place of the old Territorial Electims Act. The colored learl pencil system was replaced by printed ballots smilat to these used in Federal elections. Whereas formerly an individual's right to rote, if it were questioned, was investigated after the election, it was now provited that such inquiry should be made before. Toters' lists were to be prepared by registrars and their deputies, on the basis of personal registration in cities and towns and registration by enumeration in rural districts. The district judges were to be revising officers. While the bill was adversely criticised in some of its details by the opposition. Mr. I Iaultain on the whole approver of the measure. "I think," said he on May ist. "that the Government had dealt with an important matter in a hroad and effective manner, and I congratulate the Attorney-Gencral."

Much dehate of a somewhat less amicable nature attended the passing 


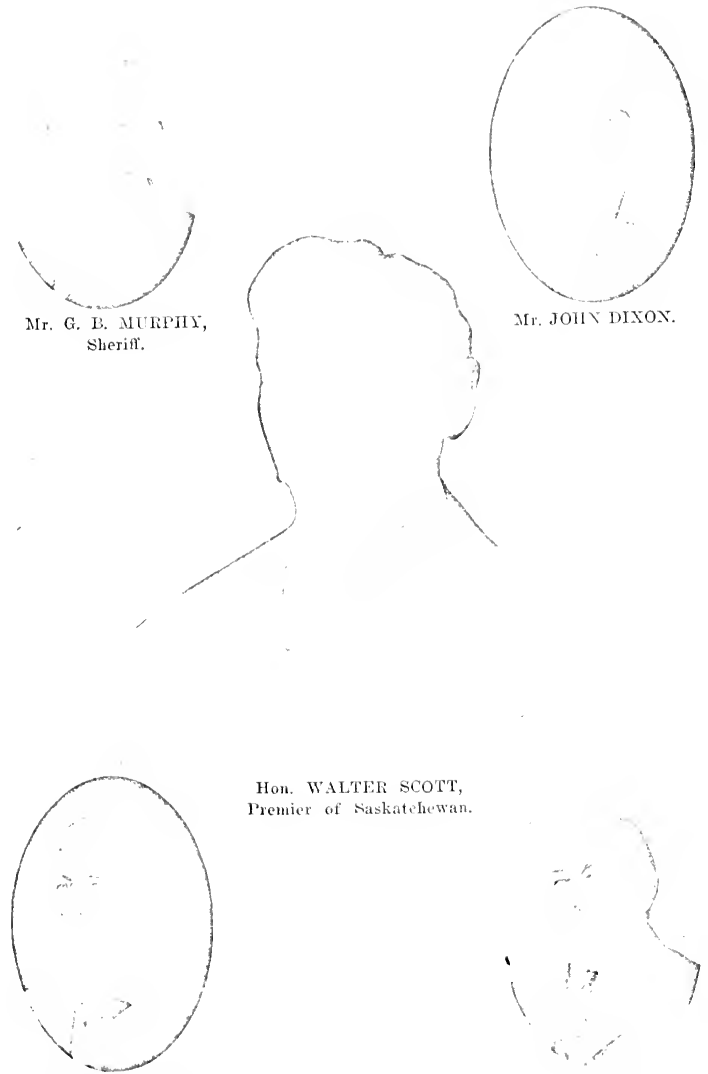

Hon. WALTER SCOTT,

Premier of saskatehewan.

Ilis Worship Wm. TRINT,

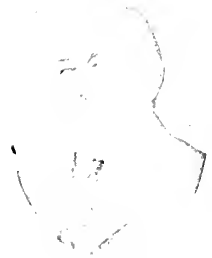

Hon. THOMAS MeKAY.

Police Magistrate. 

of the Redistribution Bill. The whole subject was placed in the hands of a select committce. The members of the committee representing the Government and the opposition, respectively, prepared and exchanged elaborate maps on the basis of which the Province was first divided into four sections to be represented by so many members each, and was uitinately mapped out into forty-four constituencies. This was an increase of sixteen. Among the other bills passed during the session was one providing for a five-year term for future legislatures, subject, of course, to the LieutenantGovernor's right of dissolution.

The House was prorogned on June 12 th and on July 2oth the First Legislative Assembly of Saskatchewan was rather unexpectedly dissolved. The ostensible reason for the dissolution was the passing of the Redistribution Act, and the desiralility of bringing it promptly into effect. However, less than three years had elapsed since the elections of 1905 , and the opposition clamed that the advice given to Itis Honour in this connection was not justified by any public necessity and was based simply on a desire of the Govermment to take their opponents by surprise. The elections resulted in the return of twenty-seven Liberals and fonteen Conservatives, but involved the elefeat of the Hon. Mr. Motherwell, Minister of Agriculture, and the Hon. Mr. Calder, Minister of Education and Provincial Treasurer. A short time afterwards, however, the Federal elections caused vacancies in Saltcoats and 1 fumboldt through the election of Mr. Thomas MeNutt and Dr. D. B. Neely to the Itouse of Commons. Mr. Calder was returned for the former constituency and Mr. Motherwell for the latter.

The election of I9o8, like that of 1905 , was associated with a number of cases of criminal libel. During the campaign the Premier had made deliberate charges reflecting upon Mr. W. II. Laird, the Conservative candidate for Regina. The resulting lawsuit went to the Supreme Court, and on February I, 1909, the jury announcel the impossibility of agreeing upon a verdict. The case, with others that had been based upon it, was withdrawn, as also was one entered by Mr. J. G. McDonald against the Premier, and another commenced by Mr. Scott against the Moosc Jaw Nea's for defamation of character. At the close of 1908 Mr. Scott announced that a royal commission would be appointed to inquire into charges against the Minister of Education in connection with the letting of school book contracts. Wholesale accusation and insinuations in this regard had no doubt been influential in bringing about the personal defeat of Mr. Calder. The commission consisted of Chief Justice Wetmore and Mr. Justice Newlands. Its report, dated April \&, 1909, exonerated the Minister of Education.

As approach is made nearer and nearer to the time at which a history is actually written, difficulties confronting the historian become, in many 

important repects, increasingly disconcerting. The lapse of time is essential in order to any general agreement as to the meaning and permanent importance of the events that might or should find a place in a record of political, social and industrial development. The portion of the present work devoterl to these topics will therefore conclude with the expiring of Licutenant-Governor Forget's term of office and the succession of His Honour, Lieutenant-Governor George William Brown, in 1910. 



\title{
CHAPTER XLII
}

\section{I'ORGET'S ADMINISTRATION: SOCIAL AND INDUSTRIAL DEVELUPAIENT (}

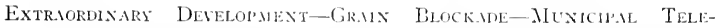

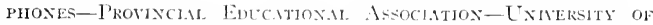
Saskatchewan-P.nthil. Crop Fintere; Distribution of Selid

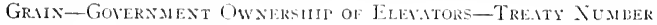
TEN.
\end{abstract}

From the point of view of industrial expansion and the growth of population, the year in which Saskatchewan reached its provincial status surpassed all previous records. Canadian immigration statistics are notoriously unreliable, as no proper recurds are kept of the number of people leaving or merely passing through the cumtry; however, we know that during the year ending with June 30, 1906, about 100,000 persons entered Canada, most of whom settled in the West. Of this number, some 7.000 were immigrants from the Lnited states, bringing with them property in the form of settlers' effects and cash estimated at $\$ 21,000,000$. In the five years that had elapserl since the last decennial census of the Dominion. the population of Manitola lad almost doubled, and that of Saskatchewan had more than trebled. The grain prodtetion of the year 1905 for the three Prairie Provinces was something in excess of $200,000,000$ bushels, while the wheat harrest of Saskatchewan alone amounted to $20,000,000$ bushels-an increase of $10,000,000$ bushels orer that of the preceding year. Dairying proved prosperous; lumbering was excedingly profitable; the export of cattle unnsually large; the horse trade good; and sheep grazing flourishing. New villages were springing up exerywhere and rapidly developing into towns. Railway lines were being constructed or projected in many directions, and everywhere with the rising tide of prosperity land values rose correspondingly: For example, in 190,3 the C. ‥ R. brought into existence the town of Xorth lattleford, which in six months rose to a population of four hundred.

The plenomenal development of the Canadian West brouglit with it staggering problems, especially for those concerned with transportation. In 1907 it proved impossible to market more than a fraction of the grain crop in the fall, and as the winter advanced, the railway companies found 

themselves entirely unable to meet the demands pouring in mpon them from every quarter for the transportation of fuel. The Provincial Government had been obliged to take energetic action in order to prevent general distress by securing supplies of fuel for the public from every available source. Even in Igoo a serious coal famine lad occurred as a result of a strike at Lethbridge.

The citizen body gradually cane to realize that it is not sufficient merely to induce setters to take up land, but that it is also necessary to surround them with social conditions which will keep them permanently a contented and prosperous farming community. Accordingly, throughout $\mathrm{N}$ r. Fiorget's last administration one subject of perennial interest was the development of a teleplone system which would meet the social and business necessities of the growing Wiest. It conventions of grain growers and representatives of Boards of Trade, and at other like assemblies, resolutions were passed in favor of the government ownership of telephone lines. On the other hand, the Lnion of Saskatchewan Municipalities recommended municipal ownership of telephone lines. In view of the difference of opinion the Government appointed Mr. Francis Dagger, its telephone expert, to investigate the matter and report.

On April 3, Igos, he had presented his report. It stated that there were in use in Saskatchewan 3,250 telephones, or ahout one to every ninety-two inhabitants. Nore than half of all the telephones in the Province belonged to the Bell Telephone Company, and the remander, with the exception of about three humbled and ten rural telephones, were the property of four other private companies. Mr. Dagger pointed out that the convenience and interest of the public generally rendered it undesirable that the same private interests should control both the long-listance lines and the local exchange system. The unnecessary duplication of long-rlistance service should be avoided, and these lines should all be owned and controlled by the Provincial Government. In cities, towns and villages the provision of local telephone service, Mr. Dagger thought, should be left to Municipal Councils, to avoid too great a present expenditure of Govermment funds. Mr. Dagger recommended that the Government should sclect three or four sparsely settled districts and, by way of an object lesson, show how cheaply a complete rural service could be established.

Epon the basis of this report a Bill was introduced by Mr. Calder in I9oS, and duly passed. It went even further than Mr. Dagger had for the present recommended, as not only were rural lines established and encouraged, and trumk lines taken over from the private companies, but the system in the towns and cities was also included with the others that had heen brought under Govermment control. The underlying principle of the Scott telephone policy was the building and operation of long-distance lines by 
the Provincial Government, coöperating with rural telejhones owned and controlled by the farmers themselves under necessary regulations. The Department of Railways and Telephones commenced actual work on July I, 1908, and by the middle of Attgust, I910, one hundred and twentythree rural tclephone companies had been incorporated, representing almost three thousand subscribers and practically the same number of miles of line, with capitalization of $\$ 363,628$. The price paid for the Pell system was $\$ 357,990.00$, with about $\$ 10,000$ to be returned for advance subscriptions paid, and the new Govermment enterprise involved an immediate additional expenditure of $\$ 436,000$.

Among the interesting events of Igos was the establishment of a Provincial Elucational Association. At the initial convention held in Regina, some five hundred delegates were present.

Great interest was also shown in the establishment of the University of Saskatchewan, which on October I6. 1907, had held its first convocation, electing chancellor and senate. Saskatoon, Regina, Prince Albert, Moose Jaw and other towns offered themselves as suitable homes for the new university. The responsibility of choice lay with the foard of Governors, which was organized on May 23, 1908, with Mr. A. F. Angus of Regina as chairman. Saskatoon was ultimately chosen as the Provincial University centre, and Professor Walter C. Murray, M. S., LL. D., of the department of Philosophy and Education in Dalhousic Lniversity, Halifax, was appointed the first president.

Despite the general prosperity with which Saskatchewan was blessed in the period under review, the losses by frost and hail were serious on different occasions. Indeed, in 1908 the Provincial and Federal authorities were obliged to coöperate for the distribution of seed grain in large quantitics. Approxinately $1,200,000$ bushels of wheat, about the same amount of oats, and about 200,000 bushels of barley were supplied at moderate rates and under generous conditions as seed grain, to settlers who had lost their crop the year before.

The problem of the Government ownership of elevators was the subject of much discussion. The Grain Growers' Association was naturally keenly alive to the necessity of supplying the farmers of the Province with better facilities for disposing of their products, and the Cabinet Ministers of the Prairie Provinces held important conferences to consider the matter. However, in Saskatchewan the proposal to apply the principle of government ownership was not approved by the authorities and some years elapsed before the Government matured the policy which will be discussed elsewhere.

In spite of the difficulty of handling the Provincial trade and notwithstanding occasional losses from causes not subject to control, before the end 

of Mr. Forget's regine. Saskatchewan stuod third anumgst the Provinces of the Dominion and the States of the Lnion as a producer of oats and wheat. As the cnormous crop was produced from less than thirteen per centum of the estimated acreage south of the fifty-fifth parallel, it was evident, moreover, that only a leginning had been made.

During the epoch under review, there took place the last great Indian surrender affecting the I'rovince of Sashatchewan. This was Treaty No. Io. The natives concerned were the Chippewalys, Crees and other Indian inhabitants of the northern portions of Saskatehewan. Alberta and a part of Keewatin, not covered in previous surrenters - an area of about eighty-five thousand eight lundred square miles. The original commissioner was Mr. J. A. J. McKemma, who had assister Messrs. I aird and Ross in the negotiation of Treaty No. 9: and among those who aided him were Messrs. Charles Fisher of Duck Lake and Charles Mair of (ntawa. secretaries to the commission, Mr. Angus McKay and other officers of the Hudion's Bay Company and of the Mounted Police. and lishop, Pascal. The original treaty was signed at Canoe Latic. Scptember 19, Igof. Further adhesions to Treaty No. to were negotiated in the following year (August IO), 1007) by Mr. Thomas A. Borthwick, among whose assistants was Mr. W. J. McLean, the well-known Huclson's Bay Company clief factor. It helps one to realize something of the vastness of our undeveloped hinterland when we read that Mr. Borthwick's mission involved a canoe jottrney of over two thousand miles. The duties of the commissioners included the investigation of the claims for scrip advanced by Halfbreerls in the regions surrendered. Thus was opened for settlement, immigration. trade, mining and lumbering the last portion of the mighty realm over which the native races of Saskatchewan had for so many generations held sway practically undisputed and unshared. 



\section{CHAPTER XLIII}

\section{COLONIZATION COMPANIES AND ANALOGOUS ENTERPRISES: ANGLO-S.AON IMIIIGRATION}

Regulations for Colonization Companies, i882-Collapse or E.rim Companies-Land Gikints to Colonization and Rallwiy Conpanies-Hakishil's Attexdint Lion the Cremtion of Such Reserves-Gig.intic firming Enterprises-The Bell FaraThe Sir John Lister hiye Faras- "The American lnvision"Imaigration from the likitish Jales-Chofter SettienentsTine Barr Colony.

The problem of peopling and bringing under cultivation the vast prairies of Saskatchewan and other western provinces has iuvolved various experiments of historical interest. In this portion of our treatise we will review as fully as space permits the story of these enterprises, devoting special attention to a few typical examples.

Upon January I, I882, there came into force certain land regulations which guided the operations of colonization companics for a number of years.

Any person or company satisfying the govermment of good faith and funancial stability might obtain, for colonization purposes, an msettled tract of land anywhere north of the main line of the Canadian Pacific Railroad, not being within twenty-four miles of that road or any of its branches, nor within twelve miles of any yet projected line of railway. The even numbered sections were held for homestead and preëmption purposes, but the odd numbered sections would become the property of the colonization company, on payment of two chllars per acre in five cqual instalments. The company would also pay five cents an acre for the sursey of the land purchased, and interest at six per centum would be charged on all overdue payments.

The contract into which the colonization company entered with the Govermment required that within five years the company's reserve should be colonized by placing two settlers on each odd numbercd section, and also two settlers on each of the free homestead sections. When such colonization was completed the company was to be allowed a rebate of one hundred 

and twenty dollars for each bona fide settler. On the expiration of the five years, if all conditions had been fulfilled, such further rebate would be granted as would reduce the purchase price to one dollar per acre. If, however, the full number of settlers required by the regulations had not been placed upon the land in conformity with the official regulations, the company was to forfeit one hundred and sixty dollars for each settler fewer than the required number.

Under what is called plan number two, provision was made for the encouragenent of settlement by those desiring to cultivate larger farms than could be purchased under the regulations requiring two settlers to be placed on each section. A colonization company of this sort was called upon to bind itself simply to place one hundred and twenty-eight bona fide settlers in each townslip.

After the boom of 3882 , colonization companies sprang up like mushrooms, in every direction. As a gencral rule, their careers were likewise of mushroom brevity.

It is impossible in the space at our disposal to treat of these companies in any detail. Nost of them proved financial failures, as far as the original investors were concerned, and none of them succeeded in placing any considerable number of permanent settlers on their lands. Nany of the settlers they did secure were not well adapted to agricultural life in such a country as this then was, and in consequence were soon dissatisfied and restless.

Accordingly, in September and November, $188_{4}$, meetings were held in Toronto by the representatives of many of these companies, with a view to obtaining from the Govermment readjustment or cancellation of their contracts. A petition was addressed to Sir David L. AlcPlierson, in which the colonization companies complained of the unfair competition of interested railway companies, themselves controlling large reserves, of the formidable agitation conducted by a portion of the public press in hostility to their enterprise, and of the opposition of the Farmers Union and other bodies. Owing to these hindrances, immigration had been checked. Moreover, as large areas of land more eligibly situated for railway facilities were yet available for settlement free, the companies found the sales of the odd numbered sections, as required by the agreement with the Govermment, to be simply impossible. Furthermore, it having become necessary to grant the railways lands free, which at the date of the contracts with the colonization companies were to cost \$r.00 per acre, these companies, by paying the price stipulated for their lands, were thereby subjected to unerual and hopeless competition. The petitioners therefore prayed that patents might issue to them for such portions of their lands as they might fairly be judged to have earned, and that their charters be cancelled. They would thus be 



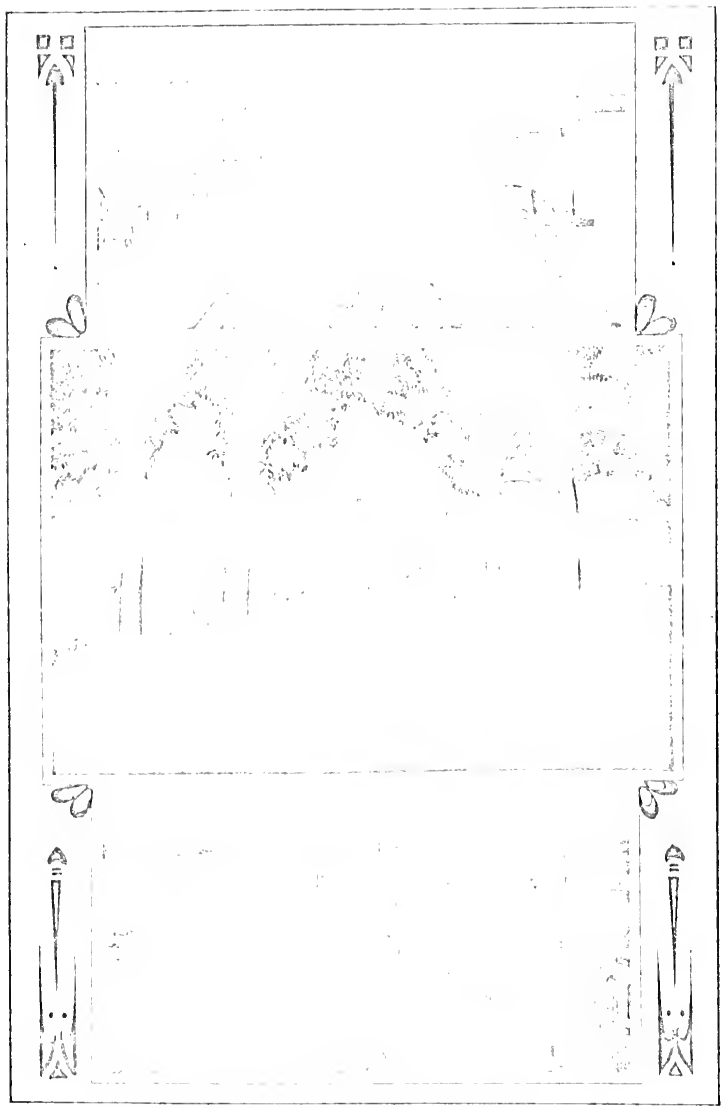



enabled to grant perfect titles in fee simple for those odd numbered sections, for which they were able to obtain purchasers.

The Minister of the Interior recognized that, to a large extent, the failure of the companies was owing to circmustances over which they had no control. Some of them had honestly and carnestly proceeded with the task they had undertaken, and had cxpended large sums of money in promoting immigration, disseminating general information about the North West and in establishing mills, roads, bridges, stage lines and other improvements. But while they had doubtless been instrumental in bringing into the country a considerable number of its immigrants, a large proportion of these had not settled on the companies' tracts, but had homesteaded elsewhere, or purchased from the Canadian Pacific Railway Company.

The Department of the Interior felt that it would be impossible to adopt any hard and fast basis of settlement that would be fairly applicable to all the defaulting companies. However, it was agreed that cvery settler placed by such a company upon its lands should be credited as a payment of $\$ 160.00$ which should be included with such other expenditure as might in the Minister's opinion have materially conduced to the progress of colonization. On such a basis a final settlement was arrived at and the companies concerned were dissolved between 1884 and 1891 , chiefly in 1886.

The Saskatchewan Land and Homestead Company, part of whose holdings were south-west of Yorkton, part at the Elbow, and part at Red Deer River, Alberta, had placed two hundred and forty-five settlers on its reserve of 491,746 acres. It had paid on account over $\$ 150,000$. In the final settlement it was therefore given the title to 119,200 acres and scrip for $\$ 32$, ooo additional applicable on the purchase of public lands.

The York Farmers' Colonization Company, operating near Yorkton. placed one hundred and sixty-four settlers and obtained finally 5 r,358 acres.

The Dominion Lands Colonization Company placed one hundred and forty-three settlers on its reserve in the Fill Hills and ultimately received 56,672 acres and scrip for $\$ 33.586$.

The Primitive Methodist Colonization Company, operating between Yorkton and Qu'Appelle. placed one hundred and four settlers, and obtained in the final settlement approximately 36,600 acres.

The Temperance Colonization Company lad control of fourteen contignous townships sonth of the Saskatchewan, with the Village of Saskatoon as its chief settlement. It placed one hundred and one settlers and received in settlement 100,000 acres.

The Tonchwood and Qu'Appelle Colonization Compay placed ninetysix settlers and received scrip for 48.300 acres. 

The Montreal and Western Land Company, sonth of Yorkton, had paid approximately $\$_{1} 6,400$ on account, which, together with rebates, brought up the amount to its credit to slightly over $\$ 49,000$. It had placed sixty-four settlers and received in settlement of its clam 24,585 acres.

These seven companies were all those included in the settlement that had succeeded in placing fifty or more settlers in what is now Saskatchewan. The records of the Land Department at Ottawa, to which the writer was given access, show the terms of settement arrived at with a number of other concerns which secured some settlers, but fewer than fifty. Their land grants ranged from alout four thousand acres down.

Finally seven other such companies, thongh they had expended much money, had not obtainct a single settler. However, they were granted scrip representing considerable sums; four, eight, twelve, fonrteen to eighteen thousand dollars apiece.

As a general result of this epidemic of colonization companies, upon the $2,8+2,742$ acres set apart for their reserves, I, 243 settlers were placed. I'rior to the final settlement the companies had sold rather less than 1,500,000 acres and in cash payments or rebates had to their credit with the government approximately one and a puarter million dollars. On the cancellation of the contracts, they becane the proprietors of tracts of lind in the lest agricultural districts, aggregating 438,208 acres and scrip in addition to the value of $\$ 375,5 \mathrm{I} S .33$.

It will be seen that the general issue of this disastrous fiasco in colonization was, without any adequate public advantage gained, to place in the hands chiefly of eastern speculators, the absolute proprictorship of vast blocks of arable lands that in coursc of time became exceedingly valuable.

The principalities thus alienated to colonization companies are, however. almost insignificant as compared to the kingdoms given away to railway companies. The land grant earned by the Alberta Railway and Coal Company exceeded I, I00,000 acres. Ly building the Souris Branch alone the Canadian l'acific Railroad earned over $1.400,000$ acres, an area considerably greater than that of the whole province of I'rince Edward Island. The Manitoba \& North West Railway was granted over 1,800,000 acres, an area considerably greater than that of Scotland. Py such a policy, Parliament. prior to 1896 , alienaterl to Railway Companies, in the choicest sections of Manitoba and the North-11.est Territories, the stupendous area of 30.560 .354 acres. When this area has a population averaging five persons to each puarter section it will accommodate a rural population of 955.295 persons. A very large proportion of these lands lie within the Province of Saskatchewan. They represent one special form of contribution for railway and settlement purposes, the burden of which is borne and will continne to be borne by the citizens of Saskatchewan, in addition to their share of the 

cash subsidies voted by the liederal l'arliament and responsibility for bonds guaranteed by the Provincial Assembly.

The practical exemption from taxation enjoyed under their charters by many of these vast corjorations has always been a source of infinite public vexation. Moreover, in the early days, especially when relatively little of the country was surveyed and when means for the publication of information to the scattered settlers was yet very inadequate, it could not but happen that much hardship was wrought by the creation of these vast reserves. A prominent $1 \mathrm{imnipeg}$ physician and politician related to the present writer an instance in point. In 18,9 he "squatted" on a piece of land that was subsequently taken up by a large Colonization Company. He had erected huildings, made other improvements and been alout three years on his land, before he learned that his title was likely to be subject to question. He received his notice first from the company's local manager, who, in the most insulting manner possible, ordered him off the place, for which conrtesy he was properly thrashed by the squatter. As there were a number of other squatters on the tract, an official was sent down from Winnipeg to investigate their claims for indemnity.

Our informant met this functionary on the train and the latter, being in an ultra-communicative frame of mind and of course ignorant of his companion's identity, told him how he had been wined and dined by the company's manager and what an enjoyable visit he had had. He had not troubled to go near the complaining squatters. This was rather interesting information and on reaching Winnipeg its recipient announced his intention of publishing the whole circumstance through the press. To prevent this the company immediately paid him an indemnity of $\$ 4,000.00$ for his improvements. The settler notified two fellow squatters to present their claims at the same time and they were likewise met. So far as he was able to inform the writer, none of the several other squatters on the tract received any compensation. This episode is typical except for the fact that the company were dealing with at least one man who knew how to defend his riglits.

An interesting phase in the development of Saskatchewan has been that involved by the history of a number of gigantic farming cnterprises, financed chiefly by Pritish capitalists. Iust hefore the first notalsle boom in territorial land values in the early eighties, Major IV. R. Pell organized in IVinnipeg and partly with the airl of Tritish funds the Qu'Appelle Talley Farming Company. Large areas were purchased at Indian Ilead. Qu' Mrnelle. Palgonie and other points in what is now Southern Saskatchewan. Most of the land was bought from the Canadian Pacific Railway Company and the Hudson : Pay Company at one dollar an acre. For a time the prospects of those concerned in this venture scemed very bright and it was thought 
that the enterprise would bring into the country a large number of valuable settlers.

The company acquired a tract of $5^{\circ}, 000$ acres of the best wheat land in America, lying to the north of Qu'Appelle and Indian Head. It was, of course, entirely unsettled, except for the presence of a few squatters. Even before any active settlement had been made, the company had secured "upwards of a hundred thrifty and intelligent settlers and their families wherewith promptly to inaugurate farming operations." The general plans were somewhat similar to those that had previously been adopted by the great wheat kings of Dakota and Mimnesota. They involved, however, various novel and characteristic features, chicf among these was an arrangement by which the settlers at once became working share-holders in the company and the recipients of a large proportion of the fruits of their own labor. The enterprise was received with such popular favor that before the publication of the prospectus was completed every syndicate share had been subscribed and the stock was at a very high premiun. Mr. Dewdney himself was one of the first presidents. From his actual report presented in January, I884, we learn that during the summer and fall of 1882 , when active operations commenced, 2,700 acres of land were broken. The land seeded this spring yiclded an average of twenty bushels to the acre. In I 884 about six thousand wcre under crop. In 1883 a thirty thousand bushel granary was built, together with two large barrack cottages for the accommodation of men at the main station, buildings for the storage of implements, a blacksmith shop, a horse infirmary and twenty-two cottages with their outbuildings, costing about eight hundred dollars each. Fencing, bridging, tree-planting and other improvements on an ambitious scale also received attention. During the first two years of its history, the company spent approximately $\$_{250}, 000$. Various means were taken to reduce by co-operative methods the expenses of the enterprise. The whole tract was divided into smaller farms. Two-thirds of each of these, as they were broken, were cropped each year, and one-third summer-fallowed.

The management, however, scems to have been extravagant and haphazard and few of those concerned had any practical knowledge of agriculture as it must be pursued in such a country as Western Canada. The share-holders were soon land poor and their great estates fell to pieces, and were disposed of at a sacrifice to smaller holders.

A similar history has to be recorded in regard to the Joln Lister Kaye farms. Sir John's first investment consisted of some six sections of lands near Balgonie, which he commenced to farm in 1885 . Associated with him in this venture were Lord Queensury and others. In Iss there was formed 

the Canadian Agricultural, Coal and Colonization Company, Limited. This concern took over the Balgonie farm and established nine others. ${ }^{1}$ These various farms averaged thirty-six square miles each in area.

Unfortmately the immediately available capital was invested with injudicious haste in buildings, stock and implements, and the management of the farms in many ways soon manifested deplorable ignorance of prairie conditions. The policy of the company was directed by a board in England, the majority of whom had never secn this country. Is a colonization enterprise the whole scheme proved the same failure that it was as an investment. In a few years, lowever, some of the farms were sold and the control of the others passed to a new organization, the last of these being the Canada Land and Ranch Co, which under the management of practical business men proved profitable.

Of colonization companics drafting inmigrants from Continental Europe, we shall speak in succeeding chapters.

The Province of Saskatchewan has within its broad limits many thousands of Galician, German, French, Scandinavian, Icelandic, Doukabor, Finnish, Hungarian, Roumanian and Hebrew settlers, but it must not be forgotten that the mass of its citizens are Anglo-Saxons.

The first decade of the twentieth century saw a most remarkable immigration from the United States. Many thousands of these newcomers were returning Canadians, and the vast majority of the rest have thrown in their lot with their British brethren so heartily that in a very short time they are properly counted as genuine Canadians. They retain the affection for the Republic that a Scottish Canadian feets for Scotland, but it does not lessen their loyal appreciation of cabinct government, a non-partizan judicial system, swift and certain justice and other ideals for which Canadian eitizenship stands.

The "British-born" citizens of Saskatchewan constitute the fundamental element in the body politic. Most of these have come from Eastem Canada. They are to be found everywhere and the history of their settlement would be simply the history of the Province rewritten. ${ }^{2}$

Various attempts have been made to establish colonics made up entirely of settlers from the British Isles, but the individualism of the race has not tended to enconrage this policy.

In the spring of $\mathrm{ISS}_{3}$, Lady Gordon Cathcart sent ott a number of Crofters from her estates in Scotland, who settled in what is now known

1 The ten farms were situated at the following points: Balgonic. Swift Current, Rush Lake, Gull Lake, Crane Lake, Kincorth. Dumoore, Stair, Bantry and Namako.

2 According to the censts of IDI, Saskatchewan's citizens of British origin numbered 25I,0I0: of these 124.091 were of Englisl origin, 53.865 of Irish, and 70,753 of Scotch. The corresponding figures a decade earlier were $17,54,3,10,644$ and 11,674 ; the total number of settlers of British origin then being 40,094 . 

as the Benbecula Settement, south west of Moosomin. The success of at beast some of these inmigrants caused further attention to be drawn to the advisabiity of assisting a larger boty of Crofters to settle in the fertile North West. Mr. IV. Peacock Edwards, of Edinlurgh, and Mr. Ranalil MacDonald, of Aberdeen, visited Manitoba and the North West Territories in I $88+$ and, not confining thesmeelves to the district of Benbecula Settlement, they drowe through and inspected large tracts of country. The result of their report was the sending cut of about one hundred alditional families in the following spring, some from the estates of Lady Gordon Catheart, some from those of the Duke of Argyle, and some from those of the Earl of Dummore. They were located along the district south of Moosomin. Wapella and Red Jacket. In 1889 , a Crofter settlement was also foumrled at Saltcoats. Progress was slow at first in these various settlements, owing partly to the inexperience of the Crofters with regard to methous of farming adapted to Saskatchewan, and partly to extravagant expenditures, especially upon machinary. The settlers were inadvertently encouraged in their inprovidence by the fact that the promoters of the movement advanced to them loans of $\$ 500$ to $\$ 500$. Many of the first settlers becane discouraged and abandoned their homesteads, but those who tenaciously stayed on the land have prospered in the cnd.

Financial aid was also extenderl to old conntry immigrants to the East London Artisans Colony, south of Moosomin, prospected by Major-General Sir Francis Dellinton and other prominent citizens of London. The Church. Colonization Land Society and various other like bodies alco engaged in assisting emigration movements, but, mon the whole. the policy did not prove very cnconraging, as far as immediate results were concerned, at all events.

The most remarkable attempt to transplant to a given locality in Saskatchewan a large group of Old Country immigrants is that associated with the name of Rer. I. M. Barr.

In igor this gentlentan went to England from the United States, with the purpose of organizing a British colonization enterprise in South Africa. In this he met with insufficient encouragenent, and in 1902 he applied for an appontment in the Canadian immigration service, but was rejected. Nevertheless he risted Canada and made preparation to bring ont a large number of settlers. He led his clients to believe that lie had made full arrangements for the inmediate establishment in full operation of a store syndieate, a transportation organization, a colony hospital and a home building and plowing department for late arrivals.

In all his arrangements, however, Mr. Barr was hampered by inexperience, lack of capital and inperviousness to all suggestions emanating fom immigration officers. For example, a number of bronchos were purchased 

at Calgary and loaded into an ordinary box car, so that they reached their destination smothered! When his party of English inmigrants reaclued Saskatoon-the settliment nearest to the site of the proposed colony-Barr was yet in England, still strenuously refusing to accept the help or advice of the Canarlian immigration officials. However, the Immigration Department erected tents at Saskatoon and did all in its power to assist the inexperienced settlers in their two hundred miles trek westward to their homestearls and in their subsequent efforts to establish themselves there.

At the colony. Barr indeed estallished his store syndicate, hut owing to the excessive prices charged by it, it collapsect, the heatstrong promoter obstinately refusing the coinperation of the Iepartment, which proposed floating supplies down from Edmonton. IBarr was ultimately deposed by the setthers from the leadership of the colony, his place being taken by the Rev. Mr. Lloyd, who had accompanied the party as claplain. This gentieman by his business ability and incapacity for discouragement saved the situation when it seemed almost desperate. A memorial to the services he rendered lis comrades remains in the name of their chief settlement-Lloydminster. In due time the colony tonk healthy root and gradually attained prosperity. Progress in this direction was hastened as other settlers more experienced in the ways of the country came into the district. The settlement thus ceased to be "All English," but all concerned have benefitted by the intermingling of stocks and the opportunities afforded for the comparicon of agricultural methods favored by peoples from various enviromments. 



\section{CHAPTER XLIV \\ IMMIGRATION FROAI CONTINENTAL EUROPE (NORTII IVESTERN)}

Contract Whit Norti Atlante Trading Compiny: Consumated

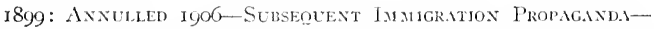
Easi Assiallition of I magrants from Nortuers and Western EUrole-ICelindic IMnigrants-Tine MenNonites-Settlers from Austria lIusgiks-Hebrews.

The census of 1911 indicated the presence in Saskateliewan of approximatcly 160,000 settlers of continental origin, ${ }^{1}$ hailing from North Western Europe. For a number of ycars the immigration propaganda under which such settlers were secured was largely controlled by an organization known as the North Atlantic Trading Company. In I8g9 this company entered into an agrement with the Canadian Government to spend anntally not less than $\$ 15,000$ in presenting to the agricultural classes of Ilolland, Denmark, Gcrmany, Northern and Western Russia, Austria-Hungary, Luxcmburg, Norway, Sweden. Finland and Switzerland the advantages of immigration into Canada. For each fanucr or domestic brought into the cotntry by the company it was to recive from the Canadian Govermment a bonus of $f_{I}$ sterling. In $190+$ the contract with the North Atlantic Trading Company was given a ten ycars' renewal. The agreement, however, was made subject to canccllation on four years' notice in casc of a breach of its terms.

In most European countrics it is illegal to cngage in immigration propaganda, and it was therefore necessary for the company to enshroud itsclf in impenetrable secrecy. Ontside of the innermost circle of the Government confidential officials, no one knew and indeed no one yet knows even who the members of the company were. Such a state of affairs left room for the wrongful manipulation of subsidics and aroused steadily increasing public disfavor. It was belicved that the company was recciving the bonus in the case of very many inmigrants whosc coming to the country was not owing to its influcnce. Noreover, it was clained that undue attention was being given to eastern Europe. On these grounds the contract was therefore annulled, terminating November 30,1906 . In the seven years of its operations this secret corporation had received from the Govermment the sum of

1 Exclusive of 23,251 settlers of French origin, chiefly from eastern Canada. 

$\$ 367,245.00$. This is practically Canada's only experiment in the farming out of immigration propaganda and it entailed such serious and persistent criticism that such a methor of inducing settlement is not likely again to be met with favorable consideration.

Indeed, the need for stich an organization. if it ever existed, had disappeared. The tirle of inmigration had set strongly toward Canadian shores, and the problem was no longer to induce, but to safeguard and assimilate. Formal measures for the securing of continental immigrants liave almost entirely ceased as far as the Canadian Government is concerned. It has continued to some extent in France, where the cutcutc cordiale has resulted in the French Government winking at the operations of Canadian immigration officials. In Scandinavia the Government does not actively discourage enigration, but supervises emigration propaganda carefully in the interests of its citizens. To reliable information, however, from official Canadian sources they have given wide and efiective publicity through the schools and otherwise. Practically all other European countries, however, vigorously suppress any such movement. The Scandinavians in Saskatchewan in I9I I numbered 33.091, as against only I.452 in 100I. Many of these were born or had lived for years in the Lnited States.

No influence for the securing of desirable citizens is so important and effective as personal letters from successful settlers to their friends in the old lands, or reports carried back by prosperous immigrants revisiting the homes of their cliildhood. Consequently the best "foreign settlentents" in Saskatchewan consist largely of settlers who have not come in a body, but who were friends and neighbors in the home land.

Generally speaking, the inmigrants from northern and north western Europe, and from Tentonic conntrics and provinces in particular, are an acquisition the value of which is unquestionable. As a general rule, the rapidly adapt themselves to Canadian institutions. Though, as a rule, they retain their mother tongue for domestic intercourse, they promptly set themselves to the learning of English. Their assinilation therefore presents no very serious problems. The present writer has been the guest in many scores of the homes of stich settlers and has observed with interest the frequency with which certain important topics formed the staple of conversation around the family circle in the evening. These topics included the freedom these new settlers enjoyed from excessive taxation and onerous police supervision; the exceptional opportunities here presented for the poor man to enjoy the bencfit of his own labor; the security of life and property, and the freedom from army conscription. As contrasted with these hopeful themes, the old folks would tell of the hardships and hopeless porerty from which they had escaper. Such topics habitually discussed with the rising generation cannot fail to produce excellent results. 

Though a surprisingly small percentage have come direct from Germany. a very large proportion of our immigrants from continental Europe are German spealing. These include many thousands from Austria; a considerable number from Hungary; and a very large body of settlers from the German provinces of sonthwestern Russia.

A relatively smalt lut exceedingly valuable immigration has come from Iceland. The movement to America commenced alout $187+$ and in 1875 some five hundred lcclanders settled alout Lake Winnipeg. Six vears hater they numberer over six thousand. The early settlers experienced many hardships, suffering severely from epifemics of smallpox. Nloreover, the lands they had chosen had heen favored on account of their facilities for lunting and lishing, and were not particularly gexd for agricultural purposes. In spite of these drawbacks the Icelanders have made extraordinary progress, and the overflow of their immigration into Saskatchewan has been heartily weiconed.

Another borly of immigrants of continental origin, whose settlements in Saskatchewan lave been off hoots from settlements in Manitoba, are the Mennonites. The members of that sect in this country are chiefly German Russians. They are representatives of a religions body dating to early in the IGth century. The most ontstanting tenets of whose creed arc those forbidding all oaths or preparations for wartare, and demaurling the absolute separation of church and state. These doctrines involved them in serious difficulties with the authorities in their mother land, and the $\mathrm{Ca}$ nadian Govermment offered them an asylum, promising them exemption from military service and the right to live in colonies insteat of upon their homesteads. The first settlements of Russian Memonites were chiefly in Manitoba, the Mennonites of eastern Canada being of Peminsylvanian origin. The immigration commenced in $187+$ and by the end of the century the western Memnonites numbered orer thirty thonsant. While they are possessed of many virtues, their exclusive habits have rendered them very difficult of assimilation. In recent years, howerer, rapicl progress has been made, especially through the belated establishment of pulblic schools in the Mennonite communities.

The citizen body of Anstria-I Inngary is made up of very diverse racial elements; approximately forty-five per cent. are Slavs; about twenty-five per cent. are Servian: sixteen per cent. are Magyars; the remainder include. many thousand Croatians, Ruthenians (popularly known as Galicians), Poles, Bohemians, Hebrews and other races. The immigrants to Canada are cliefly from the province of Galicia, and the movenent from that quarter was bronght about by the North Atlantic Trading Company. As a 

general rule these settlers are primarily agriculturists. Those who have settled in the cities, however, have tended to congregate in congested slums where their presence has greatly added to the difficulties of those entrusted with the maintenance of law, order and the proper hygienic conditions.

Since 1906 the Canadian Government has made no further effort to secure this class of immigrants, but they have continted to come in large numbers. In $5907-8$ the immigrants from Austria-Hungary numbered over 21,000; in I908-9 nearly I 1,000 ; in Ifor-10 approximately 10,000; in I9IO-II over 16,000 . Those that have not marle for the urban centres have chiefly chosen timber lands in eastern Manitola, north-central Saskatchewan and Alberta. Thee immigrants, as a rule, were very poor, but large numbers of them are already well-to-d $)$. On account of their tendency to segregate themselves in self-contained communities, their assinilation has so far been rather discouragingly slow. Of late, however, most encouraging improvement in this respect has been prominently in evidence. Numerous Ruthenian districts have establi-hed schools, which, as regards building and equipment, at all events, would put to shame many prosperous and long established settlements in the best parts of eastern Canada. And in these schools, despite many errors in the matter of management, the work of nationalization is proceeding apace.

Various Helorew agricultural settlenents have been established in Saskatchewan, notably at Hurch, at Edenbridge and near Lyton. These, however, have proved a doubtful success. The experience of centuries during whicl the Jews have been deliberately excluded from agricultural pursuits has rendered then essentially city dwellers. In too large a proportion of instances they have not prospered as farmers, and as soon as the titles to their homesteads lave been obtained, the farms have usually been sold and their owners have removed to the urban centres. There are many exceptions to these general statenents, however, and the census of igr i showed in Saskatchewan the presence of $35^{\circ}$. Jewish farmers. occupying with their families, over $-6,000$ acres of land. The grain they produced in I9I 2 was valued at over $\$ 170,000$, and their assets over liabilities amounted to nearly a million dollars. Since 1007 Hebrew settlement has been under the general management of the Canadian Committee of the Jewish Colonization Association.

Our Jewish immigrants have shown a most praiseworthy interest in education. Owing to the provisions made by the Govermment of Saskatchewan for the establishing and support of rural schools, each Jewish colony is provided with an English School. To supply the want of Hebrew and religious education erery colony has a Hebrew teacher. In newer districts where the farmers are not as yet alble to support their own teacher the Jewish Colonization Association is making liberal provision in this 

regard. The llebrew Teachers are carefully chosen. Apart from instructing the children, it is also their duty periodically to arrange lectures and debates for the benefit of the parents and the young men of the colonies. Nonthly reports and close records are being kept of the children's progress, the results proving highly gratifying.

Several of the Colonics are in possession of Modern Synagogues, provided with libraries and recreation halls. Of great importance has also proven the establishment of "Free Loan Associations" in most of the colonies which is materially supported by this association. The Jewish Colonization Association also renders financial assistance in the shape of loans to Jewish settlers coming to western Canada with a view to establishing thenselves on homesteads. A Jewish homesteader, after living on his land from one to two years and showing some progress can apply to this association for a loan which he receives at a very low rate of interest, viz: three or four per cent; thus enabling him to purchase the stock and implements necessary for a farmer.

Since 1907 the Canadian Committee has done a great deal to further the success of Jewish Colonization all through the Dominion, and the increasing success of our Hebrew settlers in recent years has been the result of its wise and liberal guidance. 



\section{CHAPTER XLV}

\section{IMMIGRATION FROM SOUTH EASTERN EUROPE: TIIE DOUKHOBORS, ETC.}

A Peculiar People-Origin of Doukhogor Sect-Peter VhrigrnPetition to Alexantura-Evidences of the Severity of Doukhobor Persecutions - Tile Weapon-Burning of 1895 - Tile Imigigration - Difficulties Regarding Land Regulations, Markiage Laws ind Laivs Regarding Vital Statistics-Petition of Protest-Liber.lL Attitude of Government-Pilgrimage of 1902-Arrivil of Verigin-His Character-Uncontrollable Fanatics-Nudity P.ar.ides-Law Breakers Resort to SelfStakvation-Redection of DoukHobor Land Grants-Dissatisfaction-Partial Emigrition to Britisir Columida-Treatment of Wonen-Educhtion-Assistance Rendered by QuakersGeneral Estuflishment of Scilools-Success axd Failure of the Doukiobor Colonizition Exterprise-Rutheninns, Etc.

The first large party of Doukhobors to settle in Saskatchewan arrived in January, 1899. Ever since that date these peculiar people have been the object of so much public interest, sympathy, distrust and anxiety that the reader will probably welcome a sonewhat lengthy discussion of their characteristics and of the problems growing out of their settlement in this country.

The Doukhobors ("Spirit Wrestlers") are a sect who call themselves "The Christian Community of the Lniversal Brotherbood." The sect is of obscure origin. It first attracted widespread attention of the authorities in the middle of the Eighteenth century, in certain Russian settlements north of the Black Sea. For politico-religions reasons the Doukhobor communities in the Crimean peninsula were broken up by the Russian authorities and their members scattered through the Cancasus between $I S_{4} I$ and $I 8_{44}$.

For many years their most distinguished leader has been Peter Verigin, who, with his section of the Donkliohors, is a profound believer in internationalism, communism and vegetarianism, all of which are taken to be essential elements of Christianity. The first of these tenets involves the doctrine of non-resistance and was the special source of friction between 

the Spirit Wrestlers and the military authorities of Kinssia. It resulted in the hanishment of Verigin and many of his disciples to Siberia. Nevertheless, the morement continued to grow and persecution became more general and severe.

As indicating the point of view of these mnfortmate people, the following petition from Feter Verigin to Caarina Alexandra is of special interest:

"May the Lord Gorl preserve thy sonl in this life, as well as in the future age, Sister Alexandra.

"I, a servant of our Lord Jesus Christ, am living in the testimony and glad tidings of Ilis trutl. I am in exile since the year 1886 , from the 'Spirit-Wrestlers' (Doukholor) Community of Transcaucasia. The word 'Spirit-II'restler' should be understood thus: that we see in the spirit and with our soul profess Goul (see, in the Gospel, the meeting of Christ with the Samaritan woman at the well).

"I implore thee, sister in Christ the Lord, Alexandra, pray thy husband Nicholas to spare the Sirit-llrestlers in the Caucasus from persecution. It is to thee that I address myself, because I think thy heart is more turned towards the Lord God. And there are at this monent more women and children suffering: lousbands and parents are confined in prisons, and families are dispersed in the native villages, where the authorities incite the population to behave coarsely with them. This falls especially heavy upon the Christian women. Lately they have been putting women and children into prisons.

"The fault on our part is that we, as far as it is possible to us, endeavour to become Christians. In regard to some of onr actions, their understandings may not be sufficiently enlightened.

"Thou are probably acquainted with the teaching of regetarianism; we are sharers in these humanitarian views. Lately we have ceased to use flech as food, and to drink wine, and have forsaken much of that which leads to a dissipated life, and darkens the light of the human soul. Refusing to kill animals, we in no case regard it as possible to deprive nen of life. If we were to kill an ordinary man, or even a robler, it would seem to us that we had decided to kill Christ.

"The state demands that our brethren should learn the use of the gun, in order to know well how to kill. The Christians do not agree to this: they are put into prisons, beaten and starved: the sisters and mothers are coarsely defiled as women, very often with railing exclamations: "Where is your God?' "Why does he not help you?' (1)ur God is in heaven and on earth and fulfills ail His will.)

"This is sad, especially because it is all taking place in a Christian country. Lut our commtinity in the Caucasus consists of about twenty thousand men. Is it possible that such a small number could injure the organism of the State, if soldiers were not recruited from among them? At the present moment ther are recruitel, but uselessly. Thirty men are in the Ekaterinograd penal battaliom. Where the authorities are only tormenting themselves by tormenting them.

"Man we regard as the temple of the living God, and we can in no 



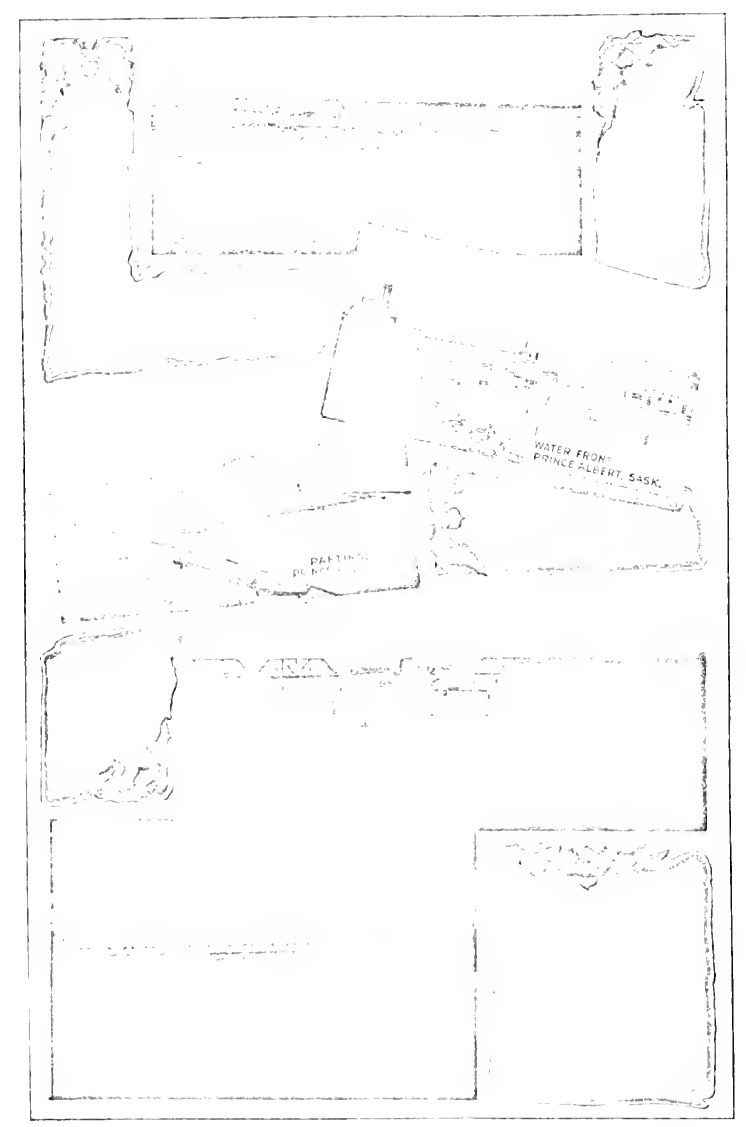



case prepare ourselves to kill lis, though for this we were to be threatened by death.

"The most convenient manner of dealing with us would be to establish us in one place where we might live and labor in peace. All State obligations in the form of taxes we wonld pay, only we cannot be soldiers.

"If the Government were to find it impossible to consent to this, then let it give us the right of emigration into one of the foreign countries. Wc would willingly go to England or (which is most convenient) to America, where we have a great number of brothers in the Lord Jesus Christ. family:

"From the fulness of my soul I pray the Lord for the welfare of thy

"The servant of Christ,

"(living in exile in the Government of Tobolsk)."

Peter.

Perhaps this petition may have had something to do with the ultimate grant of permission to the Doukhobors to leave the country, but until the very last their sufferings "for conscience sake" were extreme. So many of their men had been killed or banished that when these unfortunate people escaped from the land of their persecution, their women were in a majority of three to one as compared with the number of men. Indeed, the sufferings of the Spirit-IVrestlers had become so fearful that by common consent they concluded that it wotld be wrong to bring into the world more children to sufier such persectitions as they were enduring. This remarkable decision was given practical effect, a fact profoundly significant from the point of view of those desirous of judging the moral earnestness of this peculiar people.

The Doukhobors had that in their breast against which compulsion is of no avail. In 1895 a large number of the peasants gathered together all the weapons in their district and publicly burned them, thus signalizing in a dramatic manner their fixed determination never to give way before the forces of militarism.

Tolstoi now took up their cause and, with the active co-operation of numerous influential Quakers in Great Britain and America, funds were raised to assist a general enigration, leave for which was granted early in I898. Mr. Aylmer Maude, with Prince Hilkof and two Doukhobor families visited Canada to negotiate and Jiberal terms were offered by the Canadian Immigration Authorities. In I 899 seven thousand three hundred and sixty-three of the brethren came to Canada, where they were welcomed with remarkable cordiality by the Minister of the Interior. his numerous officials and the public generally. Some five thousand five hundred settled in the vicinity of Yorkton, ${ }^{1}$ and the remainder in the neighborhood of Rosthern,

1 These settlements were some thirty miles distint from Yorkton, but as that place was the nearest railway town its name (much to the disgust of the citizens of Yorkton) has been given by the public to the Doukhohor reserves. The reader will remenher, however, that Yorkton and the Yorkton Doukholor settlements are many miles apart. 

where some two hundred and seventy thousand four hundred and eighty acres was set apart as Doukhobor reserves. Very soon after their arrival, however, they commenced to protest with great carnestness against the Canadian Land Laws and certain other regulations, which conflicted with what they conceived to be their religions riglits and duties. Their views were set forth in the following petition, dated June 22, Igoo:

"Petition to the Canadian Government from the delegates of the Society of Universal Protherhood, near Yorkton, Assa.

"Pefore everything elsc, we must cxtend to you, from the communities which delegated us, their sincere and heartfelt thanks for opening the country which is governed by you to us, for your endeavours to help us to settle and for your interest in onr welfare. We feel and express to you our great gratitude. But now, after bcconing acquainted with the laws of your country, we are obliged to make another request, that you take into consideration our beliefs, which we consider to be the laws of God, and grant us the possibility to settle and live in your country without breaking those laws. You doubtless understand that we cannot break laws, as we believe them to embody the Truth of God, but we have found out that you have in force laws, the fulfillment of which will be a direct breaking of such Truth. Entumerating below what points in your laws do not correspond with our 11nderstanding of the Divine Truth, we ask you not to enforce against us such of your laws as contradict our belicfs, and thus give us the possibility of living in your country without breaking, openly or tacitly, directly or indirectly, our conception of the Truth.

"(I) The laws of your country require that every male emigrant, I 8 years of age, who wants to settle on vacant government land, has to record it in his name, and, after a certain term, such land hecomes his property. But we cannot accept such a law, cannot record homesteads in our individual names, cannot make them our private property, for we believe that in so doing we would break directly God's Truth. Who knows this Truth knows also that it opposes the acquisition of property. But if, through human weakness, a man may be forgiven for considering as his own anything which he has acquired by his labour, and which is necessary for his daily use, like clothing, food, or household goods and utensils, there is no excuse for a man who, knowing the law of God, still appropriates, as his own, something that is not the fruit of his labour, but was created by God for the use of everybody. Is not the division, the ownership and the recording of land the main cause of wars and strife among men, and is it not the cause of there being masters and serfs? The law of God commands men to live like brothers, without divisions, but in union for mutual help: but if a man cuts out and appropriates land for himself-land which he did not work to create-how is he going to divide with others the results of his own labour? And as every breaking of Divine Truth brings evil, so did evil creep among us when we thoughtlessly accepted land under your honestead laws. Already the division of land between our varions settlements has caused quarrels about that land among $u<$, quarrels unknown to us heretofore. And what will be the result if each one of us becomes the owner of a separate piece, and the land under our settlements becomes 

private property? It will prove a great temptation to the strong, and fatal to the weak. Taking all the alrove into consideration, we petition you to let us have the land for settlenent and agricnltural purposes, but upon the conditions given to your Indians-that is. the land is to be held by the community, and not by individual members. It matters not to us whether the land be considered our community property, or the property of your country; but we would like it to be considered as given to us for an indefinite period of time, and if you wish us to pay rent we are willing to do so, provided we shall be able.

"(2) You have also a law in your conntry that everybody who wants to contract marriage, in order to make it legal, shall obtain a license, and pay two dollars for the same; and that a divorce can be obtained only in the conrts; and if a person shonld rennary without a divorce so obtained he is liable to imprisonment for many years.

"We cannot accept such a law, for we believe that it also breaks the law of God. We cannot believe that a marriage can becone legal because it is recorded in a police register and a fee of two dollars paid for it: on the contrary, we believe that such recording and payment annuls marriage and breaks up its real legality. We believe that the real legalization of a marriage union is when it is brought alout freely as a result of a pure feeling of a mutual moral affection between man and woman. Only such a pure feeling of love, horn of the mutual recognition of moral traits of character, ereates a real legality of a marriage according to the law of God-not a record of the same in a police register and a money fee. Every marriage which has its source in this pure feeling of mutual love will be legal before God, althongh it were not registered and other people wonld not recognize its legality; and every narriage not the result of free will and pure love, but contracted turvillingly, or for lust, or 1noney, or any other consideration, will be always illegal before God, although it should be registered in all the police records and considered legal by everybody. Therefore, we believe that legalization of the marriage bond luclongs solely to God; and we cannot consent to transfer the legalization of our marriages from God to the police. As to divorce, we believe that every man who has divoreed his wife is an adulterer, and forces her to become an andultress; and that every remarriage, or marrying a divorced man or woman, is also adultery. Fut we helieve also that the law of God is the law of freedom. that an open sin is lighter than a sccret one, and that if a marriage union is contracted otherwise than through a pure fecling of love, such a union is illegal from its beginning, and constitutes the $\sin$ of adultery; and that therefore when persons living in such an illegal union cone to such a conclusion, and conceive the impossibility of making such a union legal, out of the two evils the lesser for them will be to divoree and to separate. And in such a case a divorce may become legal, if the heavenly Father will forgive the sin of the divorced parties, and so allow them to remarry with free consciences. As the forgiveness of God can be known only to two people concerned, no one, nor any human institution, can make a divorce legal or illegal, for they camot be competent to know whether God forgave the sin of divorce or not. That can be known only to the consciences of the divorced themselves.

In consideration of the above, we cannot recognize as correct, and 

cannot accept any human laws as to the marriage mion, being stre that all pertaining to it is in the province of Gorl's will and limman conscience.

(3) There is another law in your country, which requires that every inhabitant shall give notice to the police of every birth and death in his family.

We cannot accept that law, for we see no need for it in the order of things prescribed by God. Our hearenly Father knows, without a police register, whom He sends into the workl and whom He calls back. Only the will of God is important to humanity, for upon it depends our life and death, and not upon a police register. A man will live until he is called by his Creator, although he should not lie recorded in a police register, and can die immediately after laving been registered as living.

We do not refuse to answer, if called upon, about the number of births and deaths in our community. If anyone wants to know it, let lim ask, but we will not, by ourselves, report it to anyone.

Having explained what in the laws of your country is irreconcilable with what we consider the Divine Truth, and which we camnot break, we once more petition the govermment of Canada to grant us exceptions concerning the use of lands, legality of marriage unions and registration, in order that we may live in Canada without breaking the Divine Truth as we understand it."

The attitude of the Canadian Government was exceedingly liberal. The authorities believed that, with patience, they conld induce the peasants to aequiesce in Canadian institutions, and in the meantime the minimum compulsion was brought to bear upon them. Every possible latitude was allowed in connection with the land regulations. Indeed, the whole attitude of hostility, or distrust manifested by the Doukhohors was quite plainly the result of long and dreadful persecution. Their only relations with govermments and government officials had ever been one of passive resistance to laws and regulations doing viulence to their conscience. That the Canadian Govermment could really be their friends they could not comprehend. Is one of the wiser inembers of their Order said in extenuation of their conduct, "A hunted hare fears every stump." Even as regards Doukhobor aversion to our marriage laws, the authorities felt that no severity was called for as yet, as those familiar with the sect agreed that real immorality was all but unknown among them.

A much more perplexing problem arose, however, when in I9O2, a very large number of the Doukhobors in the colonics north of Jorkton became imbued with a notion that Jesus Christ was awaiting them somewhere and that they must go on a pilgrimage to meet him. After a march of thirty or forty miles to Yorkton, the authorities interfered to the extent of their detaining the women and children, one thousand and sixty in number. Some six hundred men and hoys, however, marched eastward as far as Minnedosa, Vanitoba, exposing themselves to the severities of a Saskatchewan Novem- 

ber, sleeping on the snow-covered prairies and dependent for their food upon the charity of their amazed fellow-citizens. With a faith or credulity astonishing in the twentieth century, they were in momentary expectation of meeting their re-incarnated Saviour, who would lead them on to evangelize the world. On November 8 th, the Canadian authorities took decisive action, and, though the party was already becoming disintegrated, it still numbered about four hundred and fifty. These were forcibly bundled into a special train and sent back to Yorkton and thence to their villages. A very large number of the Donkhobors had, of course, taken no part in the pilgrimage, and between them and their ultra-fanatical co-religionists serious dissentions arose.

All these troubles resulted, in part at least, from the lack of any recognised leadership among themselves. Partly, they were the result of the machinations of a few irresponsible busyljodies. These troublemakers were possessed of an elenentary education which, after their arrival in Canada, made them the spokesmen of their illiterate brethren and otherwise gave them a hitherto unknown importance. All this fostered foolish ambitions and in varions ways these dangerous individuals proceeded to show their influence. In December, 1902, however, Peter Verigin, after fifteen years" exile in Sileria without trial, was at last released, and joined lis people in Canada.

Verigin is admittedly a most perplexing character. In appearance he is tall and distinguished looking. His eyes are thoughtful and his manner is that of a brave and earnest man who has been tried by great suffering. As a theologian or philosopher he is impractical in the extreme, but as a business man he very soon demonstrated the possession of exceptional practical ability. He immediately set himself to the task of restoring harmony among the members of his disintegrated flock, and to guiding his people in such a direction as would lead to material prosperity.

Already a considerable number of the Doukhobors were showing a tendency to discard communism for individualism in the matter of real and personal property, and through Verigin's arrival checked this growth of individualism, in the Yorkton settlement especially, recent government reports indicate that by 1912 about thirty-five per centum of the members of the Brotherhood have broken away from communal conditions. It may be remarked in passing that their more orthodox brethren have not hesitated to punish this procedure by social and religious ostracism and the forfeiture of all share in the communal property.

Under Verigin's guidance and encouragement several grist mills and saw mills were set up, a considerable number of steam threshing ontfits were purchased, and several hundred additional horses were placed upon the farms. Owing to the communistic tenets of the sect, the property of the 

individual members of the community is practically all leld in Verigin's name.

While Verigin's influence is most extraordinary, it is exercised without ostentation. Indeed, taught caution by their experience in Russia, the Doukhobors maintain the utmost secrecy as to how the affairs of their community are managed. They are careful never to implicate their leader when announcing their decisions.

Even Verigin, however, has not been able to restrain some of his fanatical followers from extraordinary acts of folly which have brought the whole Protherhood into disrepute. A small number of the colonists decided among themselves that a restoration of the conditions existing in the Garden of Eden would require that the faithful should not only go abroad preachjng their gospel through the world, but should discard their clothingwhich was considered an ontward visible sign of man's fall.

The first of these extraordinary nudity pilgrimages occurred in 1903 . It was not quelled until twenty-six of the pilgrins had been taken into custody at Regina. Other such outbreaks of fanaticism occurred later, the last pilgrimage moving East in I9o7. Some of this party advanced as far as Fort William, where eighty of them narched nude through the streets on New Year's Day. In considering these outbursts of religions mania it is only fair to remember that the overwhelming majority of the Dotwhobors viewed them with the utmost disfavour, and while the handful of lunatics were cansing so much perplexity to the police, the remaining thousands of the Doukliobors were soberly and industriously labouring for the general good, and doing much valuable work in the development of Saskatcliewan.

Some of the members of the sect have always objected to the use of beasts of burden. On one occasion six of these fanatics decided to remove temptation from aniong their brethren by the destruction of machinery requiring horsepower. On Verigin's own instigation these deluded reformers were arrested and given two years in the Stony Mountain Penitentiary. This did not settle tlie matter, however. They argued that they were being sinfully detained in custody and that for them to do anything which would facilitate sucl detention would cast the moral responsibility upon themselves; consequently they decided to refrain from taking food in prison. So steadfastly did they stand by this amazing resolution that the authorities ultimately found it necessary to release them to prevent the whole party from dying of starvation. Indeed, they were already in such an emaciated condition at the time of their release that one of them died the following day. When people have the courage of their convictions developed to such an extent as this and yet recognize no authority except that of their own unenliglitened consciences, they certainly present a difficult problem to those entrusted with the oversight of public aftairs. 

In 1 gos it became evident that a very large number of the Doukhobor sect would never fulfi] the necessary homesteat duties, and that indeed the territory reserved for this purpose had been unnecessarily great. The situation was investigated by a Government Commission and one thousand seven hundred quarter sections were cht off from their reserves and thrown open for general homestead purposes. Two years later rather than cancel the remaining Doulhobor holdings, in their entirety, for failure to take the oath of citizenship and otherwise to fulfil the land regulations, the Government decided to solve the problem by allotting fifteen acres for each man, woman and child. The rest of what had been the Donkhobor Reserves was then thrown open to public settlement on ordinary terms.

Meantime the dissatisfaction of those Donkhobors who still clung uncompromisingly to their commmistic principles was increasing. They had been industrions and economical and were accumulating money very rapilly, but mere individual financial indejendence was not an end that to them seemed desirable.

Accordingly, on behalf of his brethren, Verigin purchased some ten thoutsand acres of fruit land at the junction of the Kootenay and Colnunbia Rivers in British Columbia and a very large number of the Donkhobors moved from Saskatchewan to settle on this tract. There they established a thriving settlement with a number of important and remuncrative industries. Even in British Columbia, however, they have not found themselves able to entirely ignore the anthority of provincial laws, and at the time of writing, Jannary, 1913, a general exodus is contemplated to Colorado.

A word must be said regarding their treatment of their women. The public are familiar with pictures showing Doukhobour women hitched to ploughs like oxen, and these portrayals of the manner of life have resulted in serious misconceptions. It has already been remarked that so many of the Doukhobor men had lost their liberty and even their lives in Russia for conscience sake, that their number in the Canadian Colonies were most disproportionately small. On their arrival in this country they were almost destitute of means, and as the quickest way to earn a little ready money, a very large proportion of the men temporarily left their colonies to work with railway construction gangs. In conseguence, if the early crops were to be planted at all it was manifest that the work must be done chiefly by the women. Moreover, they had not nearly a sufficient number of horses and oxen for their agricultural needs. The women, therefore, took counsel together and determined to periorm the task themselves. The reader will agree, therefore, that these scenes of women toiling in the fields like wen reflect not discredit on the man, but glory upon the women, whose undaunted courage enabled them to meet a distressing crisis.

It is, of course, not to be understood that Doukhobor women are unac- 

customed to manual labour in the fields. They, like most other European peasants, have never experienced and probably never desired any such definite division of labour between the sexes as is customary in Anglo-Saxon communities. Perhaps this has not been an ummixed disadvantage, if one may julge by the stalwart vigour characteristic of these peasant women.

The great majority of the Doukholors, including practically all their women, were illiterate when they came to Canada, and serious difficulties have been met in comnection with the establishment of schools among them. Suspicion and ignorance are congenial companions, and a totally unlettered community, the members of which believe themselves in exclusive possession of all knowledge of supreme importance regarding the duty and destiny of man, is not likely to assume with readiness the burden of maintaining public schools. Verigin, however, has expressed himself as favourable to obligatory elementary education.

The first schools in the Doukhobor communities were established and supported by the Society of Friends. Indeed, that Christian body has distinguished itself by the disinterested and seli-sacrificing efforts of its members to assist the Douklobors in every possible way. Iiss Nellie Baker, Mrs. Elizabeth Varney, Joseph S. Elkinton, and Joseph Elkinton. Jr., have been among those most active in guiding the spirit of Westlers along the pathway of Canadian citizcnship.

Many districts which were formerly settled almost exclusively by Doukhobors now contain numerous settlers of other sects and races. In these localities and among the non-communal Doukhobors generally, schools have been established as in ordinary foreign communitics. When the people are thonght to be ready, an official school organizer is sent among them by the Department of Education, and during its early years a new school district in such a community is managed by an official trustee appointed by the Government.

Even if the community. Doukhobors determine to withdraw from Canada it must not be forgotten that during their sojoum they have done much useful labour in the derelopment of the resources of Saskatchewan and other provinces, and in connection with the building of raihways. Real crime has been practically unknown among then. Indeed. not only are they free from the vices of indolence and intemperance. but they are also possessed in a marked degree of many substantial positive virtues. If they determine to remain in the land which has treated them with such patience and generosity, their sterling qualities will doubtless in course of time render them valuable citizens.

Though this chapter is devoted almost exclusively to the Doukhobor immigration, the reader must not forget that it accounts for but a small proportion of the sons of South Eastern Europe who are now dwelling in the 

Canadian West. Most ntmerous of all are the Ruthenians,-immigrants from the provinces of Galicia and Bukowina in Austria-Hungary. These people have done valuatle service in railway construction and are extremely industrious. In the citics thicir violent passions and inordinate love of strong drink have made then unpopular with many, but they have substantial virtues and are achieving rapid material betterment. The Ruthenians are cspecially marked by the desire to become real Canadian citizens; and now that elcincntary schools are doing efiective work among them the work of assimilation will proced much more rapidly than heretoforc. The chief Galician settlements in Saskatchewan lie north of the main line of the Canadian Northern and east of the Prince Albert branch. Scattered among them are many German-spcaking settlers and a few French. Galician settlement in the vicinity of Rosthern commenced about 1897 and many of the pioncers are now wcalthy.

The South Eastern European is so out of toucl with the ideas and ideals that constitute the characteristic and most valuable clements in Anglo-Saxon civilization that the problem of assimilation is a serious one, but it is one that British America must face with kindness and resolution. 



\section{CHAPTER XLVI}

\section{THE CATHOLIC CHURCH IN SASKATCHEWAN}

Importance of the Work of Religiols Pioneers-Tine First Missionary Chaplains to Exter the West-Citholics in tine Selikik Settlement-Vicar-General Provencher, isi8-Father Bel-

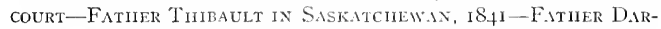
veau Martyred, I844-Sisters of Cin.sity Cone West, 184.4, and Oblate Fatilers, i845-Self-Sackificing Devotion of Fatilers Tacile and Faraud-Fatiler Taché Co-adjutor, I851, and Successor, i853, to Bisirop Provexciher-Early Indian Missions and Missionaries-Burnixg of St. Boniface, i860-F.ither Clut Coadjutor to Bishor Faraud--Iheroisa of Father Lacombe-Qu'Aipelle Mission Estabisised, y865-Bisilor Grandin's Seat Thansferred to St. Aleert, is67-Catholic Clekgx and the Troveles of i87o-Fathers Lestanc, Hugonjard and Saint GerMAin-Brother RejNard Assassinatid-Imaigration of Catholic Métis and Indians-Reverend Fatiler Maghan-Catholic Clergy and the Rerellion of '85-Creation of Diocese of Prince Aleert, i890-Deatil of Arcinishop Taché, i894-Recent Steady Growti-Sub-Dinision of Siskitcinewan for Ecclesiastical Purposes; Statistics.

In Saskatchewan, as in so many other new colonies, the pioneers of civilization have, to a very large extent, heen the missionaries of the Christian religion; and the story of subsequent progress is, likewise to a very large extent, the history of the Christian church. The writer, therefore, feels that no apology is called for in devoting considerable space to the record of the achievements of the Christian clurches, whatever be their denomination. The records teem with examples of self-sacrifice and heroism such as must command the reverence of all right-thinking people.

One phase of ecclesiastical and missionary history will, however, be deliberately avoided. Missionaries and churchmen are but human and in too many instances the representatives of different denominations have wasted their energy and spoiled their temper in strife and mutual recriminations. Nothing can be less edifying than the all too frequent professional 



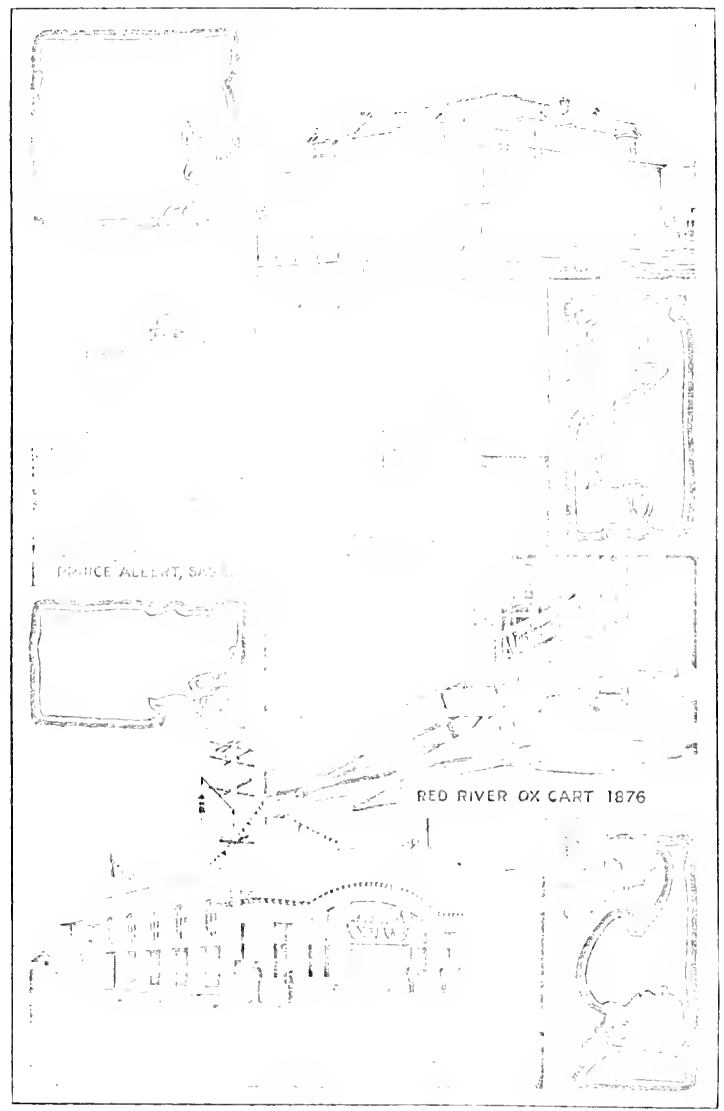



jealonsies among men honestly rlevoted to the service of the sanie Master and to the common uplift of the people, of whatever race or color.

The census of Igli showed the presence in Saskatchewan of about sixty Christian denominations. However, over sixty-eight per centum of the cntire population was included among the Presbyterians, Roman Catholics, Anglicans and Methodists, and the necessary limits of the space at our disposal will render it necessary to speali at length only of those four major bodies. Next to them in numbers come the Lutherans, $56,1+7$, the Greek Church, 24,795; the Memnonites, 14.400; and the Doukhobors, 8.470. The pagans were numbered at 2,129, and about 2,500 others disclaimed Cliristianity, or made no statement regarding their religion. The total population of the Province was stated to be 492,432 .

The present chapter will be devoted to a brief review of the history of the Catholic Church in the West, with special reference to the vast domain inclnded in the Province of Saskatchewan.

The first explorers of the prairies were chiefly lirench Catholics. When the famous Pierre Gaultier de Verennes, usually known as La Vérendrye, with his sons and his nephew, Christopher Dufrost de la Jemmeraye, undertook their epoch-marking western explorations, they, like most other French explorers, took with them as chaplains, missionaries of the Catholic faith. Father Charles Michel Mesaiger, S. J., accompanying La Verendrye, was the first priest to see the Lake of the Woorls (173I). In a subsequent expedition (1735), he was replaced by Father Jean Pierre Aulnean de la Tonche, $\mathrm{S}$. J. He was to have spent a short time among the Assiniboins and Crees and then to have carried the gospel to the Mandans. However, this unfortunate priest, returning with a group of Le lerendrye's men on a mission to Michillimackinac, June $8,173^{6}$, was with his companions, including La Vérendrye's son, massacred by the Sioux on an island some twenty miles south of Fort St. Charles. He was succeeded by Father C. G. Coqnart, but his sojourn in the llest was also very brief. In 1750 Father Jean Baptiste de la Marinie came to Fort La Reine, but when he likewise left for the East in the following year the western field was left without a Catholic missionary, and so remained for over sixty-five years. During this interval, however, a very large proportion of the traders in the IVest were Catholics.

When Lord Selkirk undertook the establishment of his colony, he ignored mere difference of creed in selecting his colonists and appointing his subordinates. Many of the colonists were Irish Catholies for whom Selkirk secured as chaplain the Reverend Charles Bourke. He also remained but a few months and it was not until 1818 that, through Bishop Plessis, Selkirk obtained the services of Reverend Joseph Norbert Provencher and Reverend Joseph Nicolas Severe Dumoulin, who were joyfully welcomed at the Red 

River Colony: Vicar-General I'rovencher thus becane the real founder of the church in the Middle West. In I8I9 the Vicar-General visited by dog train the trading posts on the Qu'Appelle River, some three Inndred miles from St. Boniface, and on the Souris River as well, baptizing forty children of Canadian Catholics. This lıcroic missionary habitually lived in extreme poverty. For months he had no bread and scarcely even flour enough for use in connection with the Sacrifice of the Mass. Much against his will, he was, in 1 Szo, made Bishop of Juliopulis and co-adjutor to the Bishop of Quebec for the North West. "I have not become a priest in order to amass money," he wrote to his superior. "If need be I shall go to devote my youth to the welfare of Red River, but as a simple priest; speak, I shall obey you. As for the episcopate, it is another thing; never could I persuade myself that I was born for such a high rank. Rome has spoken; I am full of respect for the chair of Peter; but its voice is merely an echo of your own words. The Holy Father docs not know me, and I an sure that if he did he would not admit me." Nevertheless, in spite of his own self-distrust, Provencher was consecrated by Bislıop Plessis on May 12, I822. At this time the Catholics of the Red River numbered approximately eight hundred. In I823 St. Boniface College was founded with two scholars,-a French Canadian and a Halfbreed. For many long years the Bishop devoted himself to manifold enterprises for the good of the Church and the people of the West. He had a district but little smaller than Europe, and much of the time he had but a single priest to assist him, so it is not remarkable that at first not much aggressive missionary work could be accomplished. A co-worker who achieved considerable success, showed great enterprise and industry and acquired the good-will of all classes of the people was the Reverend Georges Antoine Belcourt. Among other missions founded by him was one at the junction of the English and Winnipeg Rivers.

In $184 \mathrm{I}$ a French Halfbreed came to the Red River from Fort Edmonton to petition for a missionary. Accordingly, in the spring of the following year Reverend J. B. Thibault was sent out on a missionary journey of some twenty-two hundred miles across the prairies. On May 27 we find him at Fort Carlton. He returned to the Red River in October, IS 42 , having baptized a large number of children, adnitted four persons to the first commission and blessed twenty marriages. The founding of St. Amne's Mission dates from this year. The hardships and dangers experienced by Father Thibault and other missionaries in these early days were of the severest character. Indeed, in 1844 , the heroic priest, J. E. Darveau, met a martyr's death at the hands of Indian assassins at Duck Bay, on Lake Winnipegosis.

A religious order destined to perform invaluable services for Canada was founded in 1738 by Madame D'Youville. a sister of La Vérendrye's lientenant and kinsman, La Jemmeraye. This was the Order of the Sisters 

of Charity, popularly known as the Grey Nuns. Through the intercession of Pishop Provencher, four of these nuns, Sisters Valade, Lagrave, Contlée and Lafrance, came West in I84 4 . The same Bishop also secured for the West the services of the Oblates of Mary Inmaculate, an order which had been founded in France in 1816 by Mgr. de Mazenod, Bishop of Marseilles. The first Oblates reached Red kiver in $18_{45}$, one of them being Brother Alexandre Antonin Tache, then a mere boy. On sceing him, Provencher exclaimed, "I have asked for men and they send me a child!" For the next seventeen years the pricsts in the West were almost exclusively mombers of the Oblate Order. In I850 Bishop P'rovencher felt the necessity of a co-adjutor and the brilliant young Taché was chosen. At the time he was pursuing his missionary labors some fifteen hundred miles from St. lioniface. In the preceling year he and his associate, Father Farand, had heen given to understand that the lack of funds would necessitate the curtailment of their enterprises among the Indians. They thereupon presented to their superior the following letter:

"The news contained in your communication grieves us, but we are not discouraged by it. We know that you have at heart the good of our mission, and we cannot bear the thonght of abandoning our dear neophytes and our numerons catchumens. IVe hope that it will always be possible to get altar bread and wine for the Joly Sacrifice. Apart from this sonrce of consolation and strength, we ask of you only one thing: permission to go on with our nissions. The fisl of the lake will suffice for our subsistence and the spoils of the wild beasts for our clothing. For mercy's sake do not recall us."

Such a prayer could not be denied and the spirit which marked it reveals the character of the man chosen by Bishop Provencher as his assistant and successor. He reccived the news of his elevation to the episcopate in January, $18_{5} \mathrm{I}$, as Pishop of Arath, and was named Vicar of the Oblate Missions in North Western America. With him on his return to St. Boniface in 1852 were the Reverend Réné Grollier and the Reverend Albert Lacombe. Bishop Taché proceeded at once to Jle à la Crosse, and he was still in the interior when, on May 19, Bishop Provencher was scized with apoplexy. He died on June 7,1853 , and the Pishop of Arath became the Bishop of St. Boniface. ${ }^{1}$ Bishop Taché was at this time scarcely thirty years of age.

The Indian missions in his episcopal domains that at this time possessed resident priests were St. Anne, forty-five miles west of Edmonton; St. JeanBaptiste, at Ile à la Crosse, and La Nativité, on Lake Athabasca. Each of these stations had also a number of ouposts which the missionaries regularly visited. Among the missionary priests were Reverend M. M. Thibault,

${ }^{1}$ St. Boniface became an archepiscopal see on Septemher 22. 187t. 

La Flèchc; Lacombe, Faraud; Grollier, Tissot; Vègreville, Rèmas and Bourassa.

On the same night that he heard of Bishop Provencher's death, Tache set out for Lake. Athabasca on an important missionary and efiscopal tour. He was desirous of visiting and organizing all his mission posts hefore going back to St. Boniface. In interesting side light is cast upon his manner of life in a humorous description he has given of his episcopal palace at Ile à la Crosce: "It is twenty fect by twenty feet, and scren feet high, and smeared over with mud. This mud is not impermeable, so that rain, wind and other atmospheric elements have free access thereto. Two window sashes, comprising six panes, light the main aprartment; two pieces of parchment serve for the renainder of the lighting system. In this palace, where everything scems small, everything is, on the contrary, stamped with the character of greatness. For instance, my secretary is a Bishop, my chamberlain is a Pishop, at times even my cook is a Bishop. These illustrious employees all have numerous defects; nevertheless, their attachment to my person renders them dear to me. When they seem tired of their respective offices I give them all an outing and, joining myself to them, I strive to divert them from their cares." ?

On November third we find the Bishop in his Cathedral at St. Boniface.

In the face of great discouragement, useful and heroic work of many sorts was being performed by the missionaries. For example, Fathers Maisonneuve and Tissot, at Lac la Diche, cleared and cultivated considerable land, erected numerous buildings and in 1856 opened up a wagon road to give readier access to the south country. Father Morice tefls us that this road was the first work of its kind in the whole North and became an incentive to other parties to undertake similar conveniences of civilization. At Lake Athabasca, Fathers Grollier, Grandin and Faraud were devoting their evenings to books in the Indian tongue. In 1856 Dishop Tache nominated Father Grandin to the pust of co-adjutor, though circumstances delayed his appointment until December, 1857 . He himself did not learn of it until July, 1858 .

The extreme superstition and credulity of the Indians has always been a source of much difficuly to Christian missionaries. For example, about this time a young Indian at La Crosse was convinced by a dream that he was the Son of God. This ontburst of fanaticism resulted in many disorderly doings, but, through the influence of time and of Bishop Granclin. the false Messiah and his followers were ultimately restored to the fold of the Church.

Convents were already established at St. François-Xavier, St. Norbert

2 Vingt Années de .Missions, page 59 . 

and Ste. Anne, and in 18 ro one was founded at lle à la Crosse and another near St. Boniface at St. Vital.

On December 14,3860 , the Cathedral and cjiscopal palace at 5 t. Boniface with the lishop's invaluable library were totally destroyed by fire. Disaster followed wyon disaster. In is 8 I floods covered the ruins of the Cathedral, and indeed the whole settentent of St. boniface. The restoration of the Cathedral wats undertaken as stron as possible and on All Saints' Day, 1862, Bishop Taché was ahle to open, for use as a church, the stone vestry of the new edifice.

In the Far North. Bishp Faraut was granted a co-adjutor in the person of the Reverend Father Clut. The beginning of his episcopal duties was marked by a terrible struggle in which he and his fellow missionaries fought a deadly epidenic of scarlet fever which had broken out anong the Indians in the vicinity of Fort Simpson.

In 1856 Father Lacombe had entered the Oblate Order. Nine years later he was given the mission of following the nomadic tribes of the prairie and bearing the gospet to them. Many were his adventures annong these barbarians. In the terrible snullpox cpidemic of 1865 one thousand, two hundred Indians from anong only the Blackicet fell victims, and Father Lacombe performed prodigies in caring for the sick and in endeavoring to establish peace anong the warring trilies. In December, 1865 , the Blackfeet tribe with which he was living was attacked by the Crees. The bloody battle was brought to an end only when, after many hours, his hosts succeeded in making the Crees moderstand that Father Lacombe was of their number and had, indeed, heen wounded. Such men as these were worthy followers of the Apostle to the Nations, "in deaths oft, . . . in journeyings often, . . . in perils of robbers, . . . in perils by the heathen, - . in perils in the wilderness, . . . in weariness and painfulness, in watchings often, in hunger and thirst, in fastings often, in cold and nakedness, besides the care of all the churches." (II Cor. I I :23:28.)

In I $_{5}$ Fishop Taché sent Father Ritchot to establish what was thenceforth known as the Qu'Appelle Mission (now Lebret), and two years later Father Decorby took up his residence at that place. Shortly before this, Bishop Grandin had lecen made Vicar of the Saskatchewan Missions. When, in 1867 , this Bishop's residence and all the huildings connected with it at Ile à la Crosse werc destroyed by fire, Saint Allert became the seat of the new Vicar of Missions. Thus, by is 8 , the Catholic Church had established between Lake Superior and the Rocky MIountains four episcopal sces, the incumbents being Rishojs Taclé, Grandin. Farand and Clut. They were assisted by five secular priests, thirty-two Oblate missionaries and about twenty lay brothers, and the Grey Nuns were teaching, caring for orphans, the old and the infirm, in scren distinct establishments. 

The part played by the Catholic Clergy in connection with the Red River troubles of 1869 and 1870 was a very difficult one and has often been misunderstood and misrepresentcd. A considerable number of the priests were immigrants from France and the remainder were French Canadians. It is not surprising, therefore, that they deeply sympathized with the Métis in their resentment of the lighthanded mamer in which the Government of the New Dominion undertook to annex the Territories hitherts controlled by the Hudson's Bay Company. It will be remembered that the same resentment was felt by the English speaking settlers and their clergy, though they were naturally more ready than were their fellow-colonists of French origin to entrust the future of their colony to the good will of the English and Protestant Canadian Premier and his colleagues. The French clergy, like the writer of this book, did not look upon the establishment of a provisional government by Riel and his associates as in any proper sense an act of rebellion. In the unfortunate excesses of which young Riel was guilty (he was then but twenty-five), the Catholic clergy had no share, in spite of the insinuations and accusations that have been hurled against them by men who should have known better. Indeed, Father Lestanc was among those through whose intercession the death sentence was not executed upon Boulton, and the same clergyman did what he could to save Scott. Of the services rendered by Father Thibatult and other priests in the restoration of peace, we have already spoken in another chapter. It may be remarked that when Manitoba became one of the Provinces of Canada, the Catholic settlers were still in the majority.

In 1870 Reverend Father Lestanc was sent to Qu'Appelle and for four years he attended to the spiritual welfare of the nany IIalfbreets living on the prairies. In 1874 Reverend Lestanc went to St. Albert and was replaced at Qu'Appelle by Reverend Father Hugonnard, who had as companion (1878) Fr. Saint-Germain, whose principal work was the care of the Halfhreeds of Wood Mountain (now Willow-Buncl 1 ), and who said the first mass $\left(188_{3}\right)$ in the place where stands the city of Regina.

In 1875 Brother Alexis Reynard was assassinated by Indians. Three years later Father Fafard, who was likewise destined for a martyr's death, established a mission house and school at Fort Pitt. About this time, and sorely against the wishes of Bishop Taché, there was a considerable emigration of Catholic Métis from Manitoba into what is now Saskatcliewan. Moreover, several thousand Sioux had migrated into Canada and they. too, added to the task of the Church in the West. It is, of course, impossible to relate in detail how the spiritual needs of Indians and of Catholic immigrants were cared for. Mention must be made, howerer, of the coming of Father Lebret to Qu'Appelle in $388+$ and the establishment of the well-known Indian Industrial Sehool in that vicinity: Reverend Father 

Hugonnard being the first principal. This same year there came to Qu'Appelle Mission Father Maglian as first missionary among the Cree Indians. He was Superior of Qu'Appelle from I886 to I9oI and afterwards became Provincial of the Oblates.

In 1882 and 1883 Bishop Grandin visited Ottawa in the interests of those whose unsettled grievances were to culminate in the rebellion of 1885 . Prominent among the other clergy who also struggled, though in vain, to awake the authorities to justice and reason, was Father André. When the rising occurred Father Fafard and his brother Oblate, the Reverend R. P. Marchand, were, as we have seen, among the first victims. Father Paquette, of Batoche, communicated to the authoritics the dangerous proceedings of Riel, and after the Frog Lake Massacre he was obliged to flee to Ile à la Crosse. At Green Lake he was instrumental in saving from pillage by the Indians the local store. Fathers Vègreville, Moulin, Fourmont and Touze, with the nuns of St. Laurent, were kept by the rebels at Batoche practically as prisoners at large. In the subsequent fighting it will be remembered that Father Moulin was wounded by a chance shot from a gatling gun. Fathers Cochin and Legoff were for a long time prisoners among the Indians, as was also Father Scollen. Seven Catholic churches, with the missionary establishments connected with them were utterly destroyed. Nevertheless. the Catholic clergy were most active in their efforts to mitigate the punishment that was meted out to the rehels.

In 1885 the advancing age and increasing labors of Bishop Taché induced him to ask for an Oblate co-adjutor, but his request was not granted. Three years later, however, he was released from his charge as Vicar of Missions.

The Diocese of Prince Albert was separated from the Diocese of St. Albert in $\mathrm{I} 890$, and Bishop Pascal became the first vicar apostolic and soon after (1907) was appointed the first Pishop of the new diocese, situated between Manitoba and Alberta in the central northern portion of the Province of Saskatchewan.

Into the story of the school controversies, in which Archbishop Tache and his fellow prelates in Saskatchewan and elsewhere took so active a part for the next decade, I do not propose to enter. Doubtless the anxieties and disappointments which it entailed combined with disease and advancing years to ruin the venerable prelate's health. On June 22, I $\$ 94$, the first Archbishop of St. Boniface, and the most distinguished and influential of western prelates, died in his seventy-first year. In his "Making of the Canadian West," the Reverend R. J. MacBeth, M.A., Presbyterian minister, speaks of the late prelate in the following terms:

"He was a man of gentle. lovable disposition and had unbounded infuence over his own people. Essentially and by disposition a man of peace. he had great force of will and energy in following plans he considered 

in the interests of the work over which he presided. By the irony of fate he, the man of peace, lived through the stormy period of rebelitions and educational diseussions; but the old settlers who knew him best. I'rotestants as well as Catholic, always held him in high esteem for his unlolenished character and the simple saintliness of his personal life."

Archbishop Taché was sllececded by Father Lous Philippe Arlelard Langevin. O..1.1., who was appointed Archbishop of Saint boniface on January 8, I 8,5 , and consecrated the following . March.

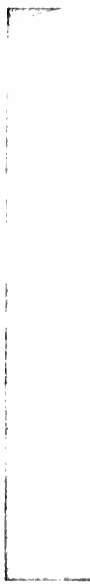

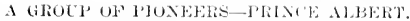

1-D. J. Hanafin; 2-II. Ross; 3-II. Woolman; +-T. J. Annew; J- Sherift Gralıam Neilson; (i-Mr. Sprout; 7-Freil Baker; Y-I. Jollowk; !-J. Sinelair; 10-Thos. Mekay; 11-T. Baker; 12-James Mokay; 13-T. Camplesl ; 1t-S. Donalilson; 15-Mr. Nortlgraves; $16-$ Indrew Agnew; $17-T$, J. Betts; $10-6$. F. Mills.

In the limits of the space at our disposal it is quite impossible to attempt a record of the steady and normal growth of the Catholic Church in Saskatchewan in recent years. Missionary enterprise among the ahorigines continues with mabated vigor, and though one by one the founders of the work have passed or are passing to their rest, many other devoted church- 

men are building upon the foundations laid by such men as Taché, Grandin, Faraud, Pascal, Lacombe and their heroic colleagtes of the early days.

The immense immigration of recent years has lirought many thousands of Catholics into Saskatchewan irom eastern Canada and from Euroue. Of thousands of these, German is the mother-tonguc, and, in consequence, a notable part in recent ecclesiastieal history has leen played hy clergymen of German or Atustrian lineage. This feature in connection with the development of the Catholic Churcl in the llest is giving rise to various important problems, to the solution of which the leaders of the church are now devoting their earnest attention.

Saskatchewan now includes the whole or part of four of the ecclesiastical provinces into which the vant Territories once administered wholly from Saint Boniface are now divided. The north western portion of the Irovince belongs to the vast Vicariate- Ipostolic of Athabasca which extends to the eastern boundary of British Colmubia. The remainder of the northern half of Saskatchewan is included in the Vicariate- Ipostolic of Keewatin. Central Saskatchewan lies in the Diocese of Prince Allert, and south of it is the Diocese of Regina. To the last named Jishopric the Right keverend Olivier-Elzear Matthicu was appointed on luly 2r, 10II, and consecrated on November 5 of the same year.

According to the Dominion census report pulblished in that year, the Catholics of the Province of Saskatchewan numbered go.092.. The spiritual oversiglit of this portion of our citizen body is entrusted to a clergy numbering about Ifo. Of these, many are jumarily concened in mission work proper. Of the clergy in the Southern See, 73 are members of the Order of Ohlates of Mary Immaculate, which has done such invaluable service for the church in Western Canada, and in the Diocese of Prince Albert the Oblates number 50. Among the other great religions orders laboring in the Province are members of Orders of the Redenmptorists. Benedictines. and Peris de la Salette. The nums in the Province number over Ifo, chiefly Sisters of Charity and members of the Order of Our Lady of the Mlissions.

${ }^{3}$ According to the Canada Foclesiastiguti ins and Personnel de la Congrogation des O. M. I., IgIr, the Catholic population of the Diocese of Regina and Prince Albert, respectively, numbered 46,000 and 52,500 . The other statistics in this paragraph are from the same source. 



\section{CHAPTER XLVII}

\section{THE METHODIST CHURCH IN SASKATCHEMAN}

Beginnings of Methodjsy in the West-Work of Rex. Jas. Elins-

Rev. Messrs. Rundee, Barneey, Brooking-Hurletrt, Silt and Steinifeur-The Flanous Missionary Party of i860: the Youngs, Campelels and McDotgills-Heroisur of Cimistian Indins in Smallpox Plague of isto-Ehects of building of tife C. P. R.Rev. Alex. Sutherlind-Rey. Messrs. Maclein, Liwson, Bridgenan, and Williams-Methodist Colonies-Fovendisg of Methodisi in Regini and Other Towns-Eifect of the Rebellion of 1885-Loyalt of Tribes Unuer Mfethodist C.areSursequent Develophent of Methodist Churchi-Regin. College.

Throughont Saskatchewan and Western Canada in general the representatives of Methodism liave ever been among the most valuable pioneers in all departments of progress. Apart from innumerable Nlethodist laymen who have wrought effectively in the public interest, there has been a noble army of self-sacrificing missionaries, whose heroic achievements justify the admiration and pride not only of the menbers of the church they represented. but of all public spirited Canadians.

In the year 18 to the Wesleyan Missionary Society of Fingland sent into the Hudson's Pay Company's territories a group of missionaries whose services in the cause of Christianity proved especially notable. The superintendent in charge of this little company was the Rev. James Evans, who had already been engaged for some time in the work of Christian missions among the Indian tribes of Upper Canada.

With his family, Mr. Evans travelled from the head of Lake Superior to Norway House by canoe. His library and other household effects it was necessary to ship to London from which point they crossed the ocean in a Hudson's Bay Company's vessel bound for York Factory; thence they were carried in open boats some five hundred miles farther. To go from Ontario to Rossrille Mission, Norway Honse, they had been transported about twelve thousand miles!

James Evans was the originator of the famous system of Cree syllabic 532 

characters which, with minor variations and improvements, has been adopted for use among the Indians of very many tribes widely distributed over America. This system of writing was based on a simple form of phonetic shorthand and is so simple that an Indian of fair intelligence can in a fortnight learn to read anything in his own tongue. Mr. Evans made his first type from lead procured from tea-chests, carving the letters with his own pocket knife! His ink was made from soot and the first paper used was simply birchbark. The inventor had even to make his own press, but no difficulties could discourage him, so success was ultimately achieved.

The Wesleyan Missionary Society heard of his invention and at once saw its profound importance. Types were accordingly cast in London, and, together with a good press and plenty of paper, were forwarded to the Rossville Mission. Later on the work was taken in charge by the British and Foreign Pible Socicty. Through the instrumentality of Mr. Evans' invention it became possible for missionaries to place in the hands of the nomadic tribes portions of the Christian Scriptures and copies of hymns and other religious literature. These the Jndians were able to read for themselves and to take with them when they wilhdrew far beyond the immediate reach of the missionaries' personal efforts.

The same indefatigable energy and originality of method which enabled James Evans to carry into successtul execution his project for placing Christian literature within the reach of the barbarous tribes of the West stood him in equally good stead in other respects. Few Canadian missionaries have accomplished a work so important and lasting and have left behind them such a tradition of unfailing helpfulness and heroism.

Intimately associated with Mr. Evans in his pioncer missionary enterprises were the Rev. Messrs. Rundle and Tarnley. Fourteen years after they and Evans had penetrated the Far West, the Indian Missions in the Territories were transferred from the English Wesleyan Church to the Wesleyan Church of Canada. In that year we note among their laborers the Rev. Robert Brooking, who, previous to coming to Canada, had served as a missionary in Ashantee, then stationed at Oxford House. His co-worker at Norway House was the Rev. Thos. Hurlburt, then a young man of twenty-fire. Both of these gentlemen labored among the Indians for very many years. At Lac la Pluie and Edmonton, respectively, Methodism was represented by native missionaries, Allen Salt and Henry Steinheur.

The last named missionary, when but a child, miserable, poverty-stricken and pagan, had been befriended by the Rev. WWm. Chase, of Rice Lake, Ontario. The lad developed a very decided musical talent and was associated with an Indian choir, which for a time travelled under the supervision of Mr. Chase. A gentleman by the name of Henry Steinheur was much attracted to Mr. Chase's protegé and, on condition that the lad would assume 

his benefactor's name, undertook the expense of seenring him a first-class education. The young Indian gladly accepted this condition and was educated at Victoria College, Cobourg.

For almost half a century this modest and talented missionary devoted himself to preaching the Gospel among his own people, spending the last years of his missionary career anong the Crees and Stoneys at White Fish Lake and elsewhere in Saskatchewan. At one of these stations, Mr. Stcinheur came upon a prayer-meeting, thongh the Indians lese had been without a missionary for some time. They were praying for "one like Rundle" to be sent to them. Mr. Steinheur had come to the encampment supposing it to be a pagan settlement, and one can imagine with what emotion he heard this appeal being addressed to Heaven. It need hardly be added that Mr. Steinheur answered the call.

Among the other notable missionaries in the Far North West one must mention Rev. Fgerton Ryerson Young, who, in 1860, left a flourishing congregation in IIanilton, Ontario, to go to Norway IIouse. He was accompanied by his heroic wife, to whose unfailing co-operation much of the success of his ministry was due. With him there came into the Wist the Rev. George Young, with his wife and son, bound for the Red River Settlement, there to establish Methodisn; the Rev. Peter Campbell, with his wife and family, on their way to a still more distant prairie mission, and a number of teachers and others. The party was under the guidance of the Rev. George MfCDongall, the veteran missionary of the Saskatchewan Valley: From St. Paul's the missionary caravan advanced by prairie schooner toward the scenes of their future activities. In a preceding chapter we have told of how the possession of a British flag protected this little party from any violence at the hands of the dreaded Sionx. At Fort Garry Mr. E. R. Young and his fanily separated from their companions to proceed to Norway House in a Hudion Bay open hoat. The story of the work of Mr. and Mrs. Young is told with effective simplicity in their book, entitled By Canoe and Dog-Train. The territory entrusted to $\mathrm{M} r$. Young was of great size, and his missionary journeys called for unfailing heroism.

In I870, it will be remembered, that the North West was visited by a terrible plagne of small-pox, and that in consequence, all communication between Manitoba and the infected regions was forbidden. This meant much real suffering and privation, especially anong isolated missionaries and other white men in the interior, and the Christian Indians of Mr. Young's mission heroically organized a brigade of boats to take supplies up the Saskatchewan for the relief of those in want. There were twenty boats in all, manned by a hundred and sixty volunteers. They realized to the full the danger of thenselves contracting the loathsome disease, of which the whole Indian population stood in unspeakable terror. Nevertheless, 

they rowed hundreds of miles up the Saskatchewan, passing, here and there, deserted camps and settlements that indicated all too clearly the terrible ravages of the disease. The heroic party successfully distributed their supplies without any direct intercourse with the people of the plains, and returnerl in safety to their homes, after a journey of two months and a half. The captain of the party, who, needless to say, was a Christian, had so spent himself to secure the rapid and safe return of his companions that his own health was ruined so that lie died shortly afterwards. The name of this humble imitator of the Good Samaritan was Samucl Papanckis; it should be remembered with honour by the people of Saskatchewan.

Five years after Mr. Young was stationed at Norway I Iowse, he received instructions from his ecclesiatical superiors to press further into the interior and establish a new mission among the Sanltean. Circumstances rendered it necessary for Mrs. Young and the children to set out in an open boat several weeks before Mr. Joung conld leave Norway Ilouse. It was July and the heat was terrific. Mrs. Yomng's little dangliter was overcome by the heat, and, far away from help or carthly consolation, the sorrowing mother was called upen to see her little one die. Truly, those who have borne the Gospel into the remoter regions of our comntry have paid the price at which the crown of heroism is purchased.

Nethodism, in what is now the Province of Saskatchewan, legan with the spectacle of such missionaries to the Indians crossing the plains from Fort Garry to Edmonton. The seer-like qualities of George MICDungall were sufficient to impress the distinguished members of the Sanford Fleming expedition, when that pioneer missionary accompanied their party in 1872. On that memorable journey, so faithfully recorded in Principal Grant's Occan to Occan, Mr. McDongall, with his knowledge of the fertility and vastness of the land, foresaw the great procession from realms beyond the sea, and prophesied the building of an empire in the West, where millions of prosperous and contented citizens wonld find a home.

In these early days the efforts of the missionaries were confined chielly to the evangelization of the aborigines, though regular services were held among the white people congregated at the IIndson's Bay Company's posts. and the forts of the Mounted Police. While crossing the plains, religions services were held at every convenient place where a small congregation conld be gathered, and at some of these points there grew up in later years, from these begimnings, large and important churches.

With the projection of the Canadian Pacific Railway, and the tours of exploration throngh the northern part of the Territories, a few settlers came from Ontario and located along the proposed ronte, chiefly in the Prince Albert and Battleford districts; and among these were some members of the denomination who did not wait for the pioneer missionaries to shepherd the 

flock, but hold services in the log shanties, thus maintaining the faitl of their fathers. During the summer of 1880 the Rev. Dr. Alexander Sutherland, General Missionary Secretary, made a tour of inspection of the Indian missions of the IVest,--travelling through the United States and up the Missouri River, then driving across the plains to Edmonton and beyond, boating down the Saskatchewan to Prince Albert, and travelling onwaris with a tean of ponies to IVinnipeg. Services were held at Battleford in the school house, and at Prince Albert a number of Methodists were found located,-one hundred or more. Nany of these were visited at their homes, and services were held on Sunday norning in a vacant store and in the evening in the Presbyterian Cluturcl. The people requested that a Methodist minister be sent them as there were sufficient to make a considerable congregation.

The building of the Canadian Pacific Railway across the plains in $188_{2}$ brought a new aspect of life and its conditions, as with the large companies of men in the construction camps, there was special need of religious oversight. Moreover, settlers began to come into the Territories in greater numbers and villages and towns sprang up at the railway centres as sources of supplies. The Rev. Thos. Lawson, Rev. Vellington Bridgeman and Rev. Clement Williams were stationed at Brandon, and the march of railway workers and settlers made a thrilling appeal to their mincls, so that they started on missionary tours covering vast distances, and going as far west as Moose Jaw. So wide were the distances covered and so pressing was the work that during the year the missionary trio laboured in nore than twenty-five preaching places.

The following year was a period of colonization, several colonies being established in the Territories as we have seen elsewhere. One of these was the Primitive Methorlist Colony at Plieasant Forks, north of Wolseley, under the leadership of the Rev. Wm. Bee, of Toronto, who induced a number of Primitive Methodists from Ontario and England to settle in the ristrict. Another was the Temperance Colony at Saskatoon, organized by John N. Lake, Esq., of Toronto, who had formerly been a Methodist minister, but had been compelled to retire on account of ill-health. Several missions were begun which subsequently developed into strong and wealthy congregations. When the first settlers arrived, and a few wooden shacks lad been erected in Moosomin, some enterprising laymen, including Messrs. J. R. Neff, Oliver Neff, E. WV. Early and others, met in one of the stores to consult about hold. ing services, with the result that a clurch was organized and a minister secured in the person of the Rev. Moses Dimmick. By the time of the union of the various Methodist bodies, $\mathbf{s} 88_{4}$, a regular service had been established. Three years later a comfortable parsonage was erected under the supervision 

of the Rev. T. B. Wilson; and in ISS9 a handsome and commodions church was btuilt during the pastorate of the Rer. T. IV. Davies.

In ISS $_{3}$, that year of beginnings, Broadview, as a railway divisional point, offered inducements for the estallishment of a mission, and the Rev. J. H. L. Joslyn was appointed, his field of operations taling him a short distance northward to the Cree Indian reserve, and in other directions as far as his time and strength permitted. There was no limit to possible expansion and personal enthusiasm sometimes carried the missionary far beyond the powers of endurance.

At Qu'Appelle, the Rev. Thos. Lawson, with a young man as assistant missionary, continted his extensive trips across the plains as he had done during the previots year from Brandon. The Qu'Appelle Valley beyond the lort was sufficiently attractive to become now the home of numerous settlers, and the building of the railroad made it possible for many more to come into the district. This enthusiastic and intrepid missionary laid the foundations of Methodism in the Qu' Ippelle district, and the territories covered by his extensive mission included centres that developed into strong and healthy congregations. It was a period of expansion, when settlers had to be sought ont, and it required men of vision and practical wisdom to seize the strategic points as missionary centres, to be held and manned by their successors. Qu'A ppelle was an important place as headquarters for an energetic missionary, and Thos. Lawson sallied forth as an explorer to establish outposts of Christianity and civilization, while he built up a solid cause in the town itself.

While the grading of the railway was under way, the Rev. IV. J. Hewitt came from Manitoba and after spending several months scouring the Ou'Appelle district, settled in Regina. The embryo city was a village of tents, but he began religious services there and travelled northward through the plains of the Wascann in search of souls. Failing health and the arduous nature of the work compelled him to retire at the close of the ecelesiastical year, and he was followed by the Rev. John Pooley. Fresh impetus was given to the cause of the denomination by the appointment from time to time of sclolarly and able ministers whose eloquent sermons and adaptability to ever-clanging conditions gave the church standing in the community, and made it a living force for good throughout the district. Rev. George Daniel charmed the people with his elounence, though he was hampered by a small and very umpretentious frame clurch; but through his efforts this was removed to Scarth Street, enlarged and repainted, and before he left at the end of a three-years pastorate, a commolious brick church was begun, and was completed during the term of his successor, the Rev. James M. Harrison. During this early period there were loyal laymen who shared the bur- 

dens, and maintained the prestige of the denomination in the capital, in the persons of Messrs. John Dobbin, J. WV. Smith, J. J. Young and George Brown, and much of the success of church enterprise is due to these faithful men.

Westward the Methodist pioneers followed the trail, and at Moose Jaw a nission was organized with the Rev. Coleman Bristol, MI. A., as minister. He remained one year, during which time he formed a congregation, and was succeeded by the Rev. Clement Williams, a man of scholarly attainments, and an able preacher, who built a frame church; but the people were so poor, and he had pushed the building enterprise so strennously, that an appeal had to be made to the missionary society to help the minister by a special grant.

The request of Prince Albert for a minister had not been forgotten. and the Rev. Caleb Parker, a gentleman of wide experience and an excellent preacher, became the first to minister to the spiritual needs of the people of the Methodist persuasion.

During the year 1884 , Regina mission was divided, and a young man sent to take charge of the Wascana mission, north of the town. which had been a part of the old mission. The Temperance Colony had assumed such proportions that, nnder its new nane of Saskatoon, it was formed into a mission, and the Rer. Willian Halstead, who bore the reputation of a pioneer in building clureches, undertook the task of erecting a church, but the work was so discouraging that he remained for a portion of the year only, and nothing was done toward reorganization for four years, when the Rev. Joln Peters was sent to take charge.

The year of the second Riel Rebellion, 1885 , witnessed sone changes in the life of the churches, as the people became insettled, and the presence of the soldiers served to lreak the orderly rontine of affairs. Prince Albert suffered especially, being the centre of the conflict, and the church was hardly able to hold its own: Regina was in conmotion as the seat of the Government of the Territories, and the denomination was represented by but a small congregation, and consequently the cause was retarded; and Moose Jaw declined so much that the church was closed for a year and a half. Despite these depresing circumstances, the work at Qu Appelle had made such progress. muder the efficient care of the Rev. Thos. Lawson, that the mission was divided, and the northern part formed into the Fort Qu'Appelle and Primitive Methodist Colony Mission, with the Rev. Oliver Darwin as missionary.

While the Haltbreeds and some of the Indians were in revolt, it is some satisfaction to know that none of the tribes under the care of the Methodist missionaries joined the rebels, and there is one notabie instance of the loyalty of Pelan, the Cree Indian chief, who shot the rumner bringing a mestage 

from the warlike tribes to his people to unite with them in the rebellion. Having killed the man who was tampering with the loyalty of his tribe, he gave hinself up to the General in command of the forces, and he was treated as a loyal subject who had acted in defense of the comtry.

The Buard of Exheation for the North West Territorics was organized in 1886 , and the establishment of public schools in the Province opened up a great field of operation for all religions bodies, as these buildings became centres of influence, and were used for holding religions services. The Methodist nissionaries utilized the new opportunity, and established congregations in larger numbers, and in nore central places, thus consolidating their work. In the following year, Moose Jaw, Saskatoon, and Prince Abert were without ministers, but new missions were formed at Crescent Lake and York Colony, and at Wolseley, where the Rev. IV. A. Cooke was stationed as the missionary.

The ticle turned in 188 7 with the appointment of the Rev. John H. Howard to Prince Albert, and Rer. IV. C. Bnint to Moose Jaw, and a year afterward Saskatoon had a minister, so that the period of racancies passed away. The work at these places, howcver, lad not been forgotten, as faithful laymen had maintaned the services by assembling the people and preaching. and the fact that they were withont ministers developed a spirit of loyalty and self-sacrifice, and when ministers were appointed the nimsions were found to have increased in numbers and financial strength.

The Methodist denomination having always a special interest in the native tribes of the Dominion, it was fitting that something should be done for the Sioux Indians, who were refugees in the comntry, having been implicated in the Minnesota Massacre, of whom there were scattered bands thronghout the Territories and in Manitoba. One of these bands roaned in the vicinity of Moose Jaw, but the greatest number, under Chicf White Cap, were located on a reserve near Saskatoon, known as Moose Moods Reserve. The Rev. Alfred Andrews, stationed at Qu'Appelle, interviewed the Indian Department on their behalf, and in Mlay, 1889 . he drove across the plains to Saskatoon, accompanied hy the Rev. W. C. Bunt, and Messrs. I Ingh McDougall. and Interpreter Taylor of the Indian Department, the object of the visit to White Cap's band being the establishment of a school and mission. The industrious habits of these red men, and the fact that they lad built sixteen $\log$ houscs, and were anxious to have a school, and assist in the building of it, greatly impressed the visitors. The Govermment treated the Indians with great liberality, a school being built. and the people being assisted in their farming operations. Mrr. and Mrs. Tucker were sent in charge, and under their guidance the native flances passed away, a new civilization was introduced by the influence of the day school for children, and a night school for adults. where they were taught to read in their own language, besides 



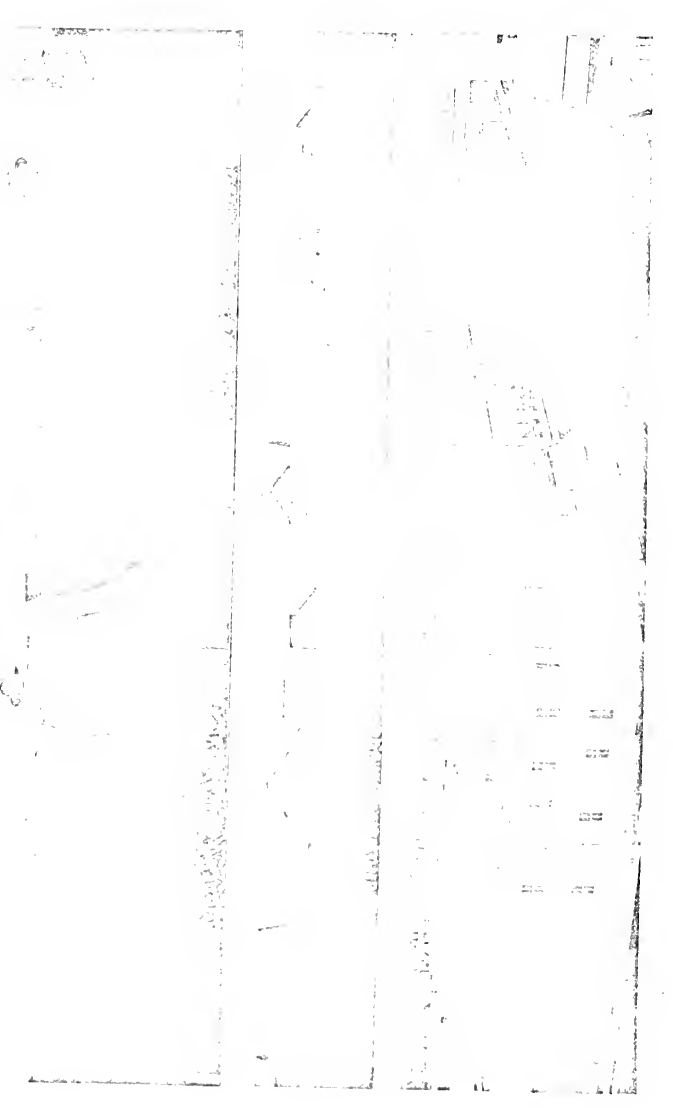



being given instruction in agriculture, and enjoying the inspiration of Christian religious services.

During the next decade, the progress of the denomination was slow but steady. The settlers were poor, farm help cotild not be obtained, and some became discouraged and left the province. It was a period of struggle, and the missionarics endured numerous hardships on account of small salaries and the high cost of living, but there were no desertions from the ranks, except throngh health giving way; and there were no complaints, as the men and women in the small parsonages and large fields were heroic at heart, and knew not that they were making any self-sacrifice. As an illustration of the extent of the average mission, the case of the Rev. Dr. John Naclean, of Winnipeg. may be taken. He was stationed at Moose Jaw from 1889 to 1892 , and during the first year, with the assistance of a colleague, he had preaching places outsicle the town, twelve miles north, twenty miles west, fourteen milcs east and south, and five miles south, inchuding eight appointments, preaching three times every Sunday and travelling from thirty to forty miles, with heavy pastoral work during the week. Fach of the pioneer missionaries had a like amount of work to do; still they were contented and happy, as they were laying foundations for the future, even thongh they were mnconscions of all that this meant. Despite the hard times. new missions were organized in 1890 , at Grenfell, and Pasqua and Caron, and in the years following there came expansion and consolidation by the formation of the denominational districts of Moosomin and Regina.

A new era dawned in 19o2, when the tide of immigration turned westward and the American invasion of peace took place. American capitalists bought large tracts of land for settlement, and during the first five months of the year, fiftcen thousand Americans came west, while Great Britain furnished for the whole Dominion abont six thousand immigrants, and the continent of Europe abont eight thousand. Homesteads were rapidly taken up, and the influx of settlers created such a dcmand for ministers that an appeal lad to be made to Great Britain to supply the need, and every year, until the date of writing this volme (ror3), the Rev. Dr. James Woodsworth, Senior Superintendent of Missions, made a trip to the Old Conntry and secured from forty to sixty young ministers to cope with the wave of immigration.

The building of new railroads brought new settlements, enterprising villages and towns, and the consequent rapid growth of the denomination. In order to keep up with the great procession of immigrants, the Senior Superintendent of Missions and Chairmen of Districts travelled continuously over the Province, founding new missions, and two Superintendents of Missions had to be appointed for the West. one of whom, the Rev. Oliver Darwin, still holds the office for the Province of Saskatchewan. Sunday Schools were established at every available point, and Epworth Leagues hecame an 

important factor in the spiritual, social, and literary life of the young people, and so rapil was the growth of these institutions that a Field Secretary for Manitoba and Saskatchewan had to be appointed in the person of the Rev. John A. Doyle.

During the past decade. Methodism in the Province has maintained its state of efficiency, and has grown in wealth and numerical strength. Small missions have developed into large and wealthy congregations, with com modious and expensive churches, especially at such centres as Regina, Moose Jaw and Saskatoon. The conference which formerly embraced a part of Western Ontario and the whole of the Provinces of Manitoba, Saskatchewan, Alberta, and the territory to the far north has been divided, and Saskatchewan has now a conference of its own. With the increase of puptlation, the denomination las kept pace, as in 19o there were 12,028 Methodists, and in I9II no less than 78,325 . In the year $19 \mathrm{I} 2$ there were seventy-live ordained ministers, and one hundred and twenty-five young men on missions or at college; seventeen new churches were built during the year, and wenty-two new parsonages, while the financial retums show that there was raised for missions, \$29,473; Woman's Missionary Society, $\$ 6,33^{6}$ : Connexional Funds, $\$ 55,864$; and the total raised for all purposes amounted to $\$ 424,499$.

The denomination has always been active in dealing with western problems, the first officers and nost of the members of the North Vest Prohibition Alliance, subsequently merged with the Dominion .Vlliance, being ministers and laymen belonging to the Methodict Church. In educational matters it has always maintained a keen interest. When the Board of Education for the Territories was organized, Lientenant-Governor Brown, then a young barrister in Regina, was a member of the Board of Examiners, and associated with him on that Board was the Rev. Dr. John Maclean, the first Public School Inspector of Southern . Iberta, and afterward a member of the Board of Education. With the call for higher education, there came the answer in the founding of the College at Regina in 19I0, with the Rev. Dr. W. W. Andrews as President, and the Rev. Hugl Dobson, B. A., as College Representative in the Field. Two years later, there was a college staft of twelve gentlemen and ladies engaged in three departments, namely, Academic, Commercial and Ausical. Dr. Andrews having resigned as President, the Rev. Robert Milliken, B. D., was appointed to succeed him by the Board of Governors, I9I3. The College owns a block in the city, and a site for new buildings, consisting of twenty-two acres on the north side of lake Wascana, opposite the Parliament Buildings, and has assets worth over half a million dollars. The outlook for a large and important institution is bright, in the number of students in attendance, the ability of the staff, the financial strength, and the loyalty of the denomination.

Whatever concerns the welfare of man was of interest to the ancient 

citizen of Rome, and that is the attitude assumert by Methodism on the public affairs of the Province. Nothing comen amiss to the true citizen, and no task is too heavy for the real patriot. In the centres of commerce in the towns and cities, from the earlicst days till the present time, there have been farmers, merchants and men of inclustry, whose souls were not so engrossed in their business concerns but that they were awake to the moral and social welfare of the community, and gave ireely of their time and wealth for the establishment of institutions, in which everybody ought to be interested. From the teaching profession graduated a large number of doctors, lawyers and politicians, whose denominational preferences have in nowise hampered them in their duties toward the public, but rather have given them a wider ontlook, controlled by a sense of justice and love of freedom. In the early days, journalism was indebted to Methodism for some of its leading editors, as in the case of the Hoose Jaw Timcs, the Regina Lcadcr, Qu'Apelle Progress, Moosomin Spectator, and Regina Standard. The great task of making citizens loyal, intelligent and progressive has been the supreme duty, and remains as an enduring responsibility.

Forty-four years lave passed since Rev. Dr. George Young reached Fort Garry and founderl the first Aletholist Church for the white settlers in the West, and from that date till the present the sons of Wesley have continned the work of pioneering, withont counting the cost, but glad of the honour of leading nen and women to the best there is in life, and moulding citizens for the nation yet to be. From that lone ontpost of empire there has sprung up a great host, all over the western land. In 1902, when there was only one conference west of the great lakes to British Columbia, there were fifteen districts, with 142 ordained ministers. 81 probationers for the ministry, and 49 missionary teachers, and in 1912 there were in Saskatchewan alone, fifteen distriets, with about 200 ministers, including probationers for the ministry.

The Jubilee of western Methodism is not far distant, and when that is celebrated, and the record of the years is made. it will be found that the glory of the denomination lies not in statistical returns and census reports. but in the fashioning of the age, the moulding of personal character, the giving of a new vision to men and women, and in real service to God and man. The Church that declares the power of an endless life, and is true to the cternal principles in man, and in revelation, will not labour in vain. 



\section{CHAPTER XLVIII}

\section{THE ENGLISH CHURCH IN SASKATCHEWAN.}

Foundation of Englisil Cirurcit in Western British North America -Rev. John West, i8zo-Other Phoneer Clergymen of the Red River Setrlexent-Bishop Mountain's Visit, i8 44 -Rev. J. Hunter and Others Penetrate the Interior-Rev. David ANDerson, First Bishop of Rupert's LANd, 1849 to i864-Bisiop Macilray-Creation of tine Dioceses of Saskatcheinan, Qu'Appelle, etc.-Work of Bishop Bompas in tile Far Nortil-Rev. Dr. Join Miclean, First Bisiop of Siskatchewan-Bishop Pinkilan-Bishop Newnilim-Emmanuel College-Missionary Enterprise in Diocese of Saskatchewan-Archideacon Llovi -Rer, Adeliert Anson, First Bisiop of Qu'Appelle, i88 4 Bishop Burn, is93-Bishop Grisdile, i8g6-Bishop Harning, igi2-St. Cinad's College-The Prarie Brotherhood-The Railway Mission.

On October 12, 1820, the Rev. John West. Hudson Bay Company's chaplain, arrived at Red River after a journey of five months, to lay the foundations of the Church of England in the far West. At that time there was no Protestant church or school hotse in the colony. With the Episcopalians coöperated the Presbyterian settlers, who were still without a clergyman of their own commmion, and very soon Mr. West was doing vigorons and effective work in a little log building that was fitted up for church purposes at St. John's. In the following year he visited Prandon and came westward on a missionary tour, spending the winter in the Qu'Appelle valley. In the summer months he proceeded to Norway House and York Factory. There he organized the first Bible Society of the Canadian West and through its instrumentality the Scriptures were, before long, available in six of the languages spoken in the great new land. Mr. West's term of service was, however, all too brief, but much useful work had been done before he returned to England in $\AA_{2} 3$.

He was succeded by the Rev. D. T. Jones, who undertook the interesting experiment of simplifying the liturgy and order of service of the church, with a view to rendering it nore acceptable to the Scottish adherents in the 

Selkirk Settlement. After fifteen years of faithful service, Mr. Jones returned to the motherland. For many years he had been assisted by the Rev. Willian Cochran, a useful, popular and generous clergyman, whom heavy labor seemed unable to weary. For a long time his regular Sabbath duties involved a drive of thirty or forty miles and three separate services. The Rev. W. Smithers and the Rer. Abraham Cowley came to his aid in I839 and I841, respectively. Mr. Cowley was probably the first Protestant clergyman to extend a mission beyond the Red River.

It is manifest that the spiritual supervision of north western British North America was a practical impossibility for prelates in Eastern Canada. In $18+4$ Bishop Nountain of Montreal indeed effected an episcopal tour into the West, but none other was afterwards attempted. This journey of the Bishop of Nontreal involved many weeks of hardship and exposure. as he travelled from place to place by canoe. At this time there were four churches in the colony and Pishop Mountain confirmed 846 persons.

This same year the Rev. J. Hunter, afterwards archdeacon, entered the country, ria York Factory, and commenced work among the settlers and Indians at The Pas. Through his efforts the Indians of that neighhorhood made rapid progress in civilization and by 1848.420 of them had been baptized, and nearly all professed Christianity. From The Pas as centre, the missions of the Church soon spread westward to I ac la Ronge, to which district, in 1845 , Mr. Hunter sent James Beardy as instructor in the Christian faith. Other pioneers of the church followed, and when, in 1847 , Mr. Hunter visited Lac la Ronge, he had the happy duty of baptizing forty-eight adults and fifty-nine children.

Invitations were soon coming for missionaries from many quarters, and the development of the Church in the West caused the Rev. David Anderson to be chosen first Bishop of Rupert's Land, in 18+9. The Bishopric was primarily endowed by a bequest of $E_{12} 2,000$, which had been left it by Mr. James Leith, a chief factor of the Iudson's Bay Company. Bishop Anderson established his headquarters at what had been called the Upper Church, in the Red River Colony. This he named the Cathedral of St. John's, and thirteen years later a new Episcopal Cathedral was dedicated by Bishop Anderson on the site of the old church. In 1850 the Bishop ordained the first native clergyman. This was the Rev. Henry Budd, who had commenced his life work ten years earlier as catechist at Cumberland House. and had been eminently successful.

By ${ }_{1} 8_{57}$ the Bishop numbered among his co-workers nineten ordained clergymen. Fifteen of these were maintained by the Church Missionary Society, two by The Society for the Propagation of the Gospel, one by The Missionary Society of the Colonial Church and one by the IIudson's Bay Company. Throughout its history the Canadian Church in the Viest has at 

all times received invaluable stupport from the motherland, especially through the Society for the Promoting of Christian Kmowledge, and the Society for the Propagation of the Gospel.

In 1864 Hishop Anderson retired. Prior to the arrival of his successor, Rev. Dr. Rohert Machray, in the following year, the Rev. T. T. Smith officiated in his place. The following tribute to Bishop Machray is quoted from the reminiscences of the Rer. R. J. Macheth, a prominent Presbyterian:

"The lators of Bishop, Nachray were unceasing, abundant and farreaching in their results on the history and life of the country. . . . Dr. Machray took an active part in the affairs of the country and was one of the factors in the peaceful solution of the Riel trouble in 1870 . He afterwards became. Archlishop of Rupert's Land and later l'rimate of all Canada. He took a leading part in the formation of the Lniversity of Manitoba, of which he was chancellor from its beginning until his death. In the course of his years of service the country opened up in all directions and the Church of England nolly diw her part in sending missionaries to all parts of the "New West and as far north as man conld live."

Bishop Nachrays diocese extended from Lake Superior to the Rocky Momtains, and from the forty-ninth parallel to the remotest North, including the valley of the Yukon. This stupendous territory was in 1872 reorganized by the formation of the diocese of Mooronee. At the same time Rupert's Land was established as an Ecclesiastical Province. The diocese of Saskatchewan was separated from that of Rupert's Land in 187.4 .

In $188_{3}$ and $188_{4}$ the dioceses of Qu Appelle and Mackenzie River, respectively, were organized; that of Calgary in 188 ; and that of keewatin in 1899. For the present sketch the records of the diocese of Qu'Apelle and the diocese of Saskatchewan are of most concern.

Special mention must be made, however, of IBishop Bompas of the diocese of Sellirk, in the Far North. "Ilis was a peripatetic episcopate," says the Rev. L. Norman Tucker, in his llistory of the English Church in the V'est" (page ${ }_{1} 3^{8}$ ). "He sojourned in many places, hut never resided in any one-Vermilion, Chipewayan, Simpson, Xoman, Wrigley, Pelly River, Rampart Honse, Sellirk, Carcross-moving continually from place to place. His love for the Indians was all absorling. To serve them and to save them. he not only lived with them, but he lived like them; and at the last he so felt the burden of the Indian work pressing on his soul that he was wont to consider himself the Pishop and the missionary of the Indians, almost to the exclusion of his own kith and kin. Tever was a mission more fully and more heartily embraced, and never was a work more conscientiously and more perseveringly done." The story of the life of Bishop Pompas is a stirring record of self-sacrifice for humanity's sake, of hardships sustained 

with the utmost good cheer, and of tireless devotion to the interest of the Church.

Very prominent among all those to whom the establishment of the Church of England in Western Canada is owing was the Reverend Dr. John Mclean, who became Irchdeacon of Assiniboia in 1866 . Eight years later he was consecrated the first Ijishop of Saskatchewan, in which office he died on Notember 7 , 1886 . On his first episcopal journey, Rimop McLean travelled two thousand miles with a temperature often falling forty degrees below zero. At Prince Albert the Bishop, built Emmanucl College, which. when opened in 1879. Was the first institution for higher education in the diocese. He was profomdly impressed with the necessity of a high standard of education in his clergy, and through his influence an Act was passed by the Dominion Government making provision for the establishnent of a University of Saskatchewan. The fullilment of this dream was frustrated by Doctor McLean's death.

When the diocese of Saskatchewan was created it contained about thirty thousand Indians and only a handful of white people. There were no endowments, no missionaries and no churches. Everything had to be hegun, so far as the Church of England was concerned.

Bishop McLean's first efforts were directed to securing the endownent of the episcopate. Very soon thereafter, however, his dearest charge was Emmanuel College, which he founded in 1879. This institution at I'rince Albert had its origin in the Sishop's need of a trained band of interpreters, schoolunasters, catechists and pastors, who, being themselves natives of the country, would be familiar with the language and modes of life of the people. Indeed Dishop McLean felt the need for native help to be so pressing that soon after his arrival in the diocese and even before the establishment of any regular and permanent diocesan institution he undertook personally to carry on the task of training future co-workers. While the chief work of Emmantel College was that of fitting native helpers for missionary activity among the Indians, a collegiate school was also conducted which, of conrse, did not confine itself to prospective missionaries.

When the Synod of Saskatchewan met, Oetober $11,188_{3}$, the Iishop announced that during the past year Assiniboia. which hitherto had been included in the Diocese of Saskatchewan, had been set apart as a new diocese. Other changes had also been made in the boundaries of his see, which still extended, however, from Lake Wimipeg to the mountains.

As the town of Prince Albert sprang ont to a distance of three miles from the main buildings of Enmanuel College, it became necessary to maintain lecture rooms in the settlement for collegiate work, which was greatly hampered by existing conditions. 

In 1885 the Rebellion prevented any meeting of the Synod of Saskatchewan. In the following year, however, it is interesting to note among the leading delegates were Star 13anket, John Smith and James smith, three Indian Chiefs who had been largely instrumental in restraining their people within the bonds of loyalty in the preceding troublous year. At this time there were twenty-two clergymen in the diocese, almost entirely supported by the Church Mlissionary Society and the Society for the Propagation of the Gospel. At Fort McLcod, Battleford, Calgary and Prince Albert the missions were self-supporting.

In 1889 Right Reverend Cyprian Pinkham, D. D., D. C. L., succeeded Bishop McLean, whose deatl occurred on November 7, 1886. In raising and completing the Episcopal Endowment Fund, in commencing the Clergy Endowment Fund, and in his persisting and self-denying labours for Emmanuel College the late Bishop had left an invaluable bequest to the people of the Ilest in general, and to his successor in particular. At the time of Bishop McLean's death he had secured endowments for the work of his bishopric to the amount of but little less than ninety thousand dollars.

Until his death Pishop Mclean had been himself warden and professor of divinity in Emmanuel College, and in his place Bishop Pinkham appointed Archdeacon J. A. Mackay. At one time there had been a large attendance of boys at the collegiate school affiliated with the eollege, but the growth of Prince Albert at a considerable distance from the college, and the excellence of its public schools had very seriously reduced the attendance.

In 1900 Archdeacon Mackay, who had been actively connected with the institution ever since 1887 , resigned the principalship. Upon the creation of the new Saskatchewan Lniversity, situated at Saskatoon, Emmanuel College was transferred to that city, the venerable Archrleacon Lloyd assumjing the principalship, which Archdeacon Nackay had vacated in igoo. As a theological college the institution has entered upon a period of renewed prosperity:

In the industrial school at Battleford, under Principal Reverend E. Matheson, from one hundred to one hundred and twenty Indian pupils have been enrolled annually for many years. In St. Barnelis Boarding School, Onion Lake, thirty-five or forty additional pupils were in 1897 in the care of the Reverend J. R. Matheson, the founder of the school. Mrs. Matheson, in order to increase ler nsefulness in her husband's mission and boarding school, at great inconvenience and self-sacrifice, took a full medical conrse in Toronto, receiving the degree of M. D.

Until 1903 Bishop Pinkliam had the oversight of both the diocese of Saskatchewan and that of Calgary. At that date Dr. Newnliam was transferred from Moonsonee to Saskatchewan, as Bishop, Dr. Pinkham retaining only the rapidly dereloping See of Calgary. 

An interesting feature in comnection with the work of the English Church in the diocese of Saskatchewan has been its system of missions. The settled portion of the diocese has been pareelled out into districts about thirty miles sepuare. It is the intention that such a territory should fully employ a thoroughly active worker while at the same time the poptuation that he must reach must not be so great as to prevent his liceping in close touch with all members of the Anglican communion, and maintaining some oversight over the spiritual affairs of the settlers in general. As such an unorganized district is transformed, under the administrations of the hard working missionary, it becomes first a mission, later a parish. and finally, when self-supporting, a rectory:

To man these fields the Church has relied not upon the stipends that could be offered, but upon the self-sacrifice and revotion uf those who felt the call to give their services as a labor of love. The money they actually receive is about half the salary of a country school teacher. Nevertheless, this appeal to moral heroism has proved more snccessful than any appeal to lower motives could have done. In 1907 Archeacon L.loydalready very widely known on account of his invaluable services in saving from utter wreck the "All Britsh" colony, named Lfoydminster in his honor-visited England with the call for workers. The olel conntry stpporters of the movement provided each catechist with a nominal stipend of $\$ 350.00$ in addition to $\$ 100$ for a "shack" and \$250 towards the butlding of a church. In Igro another such party numbering thirty came out as reinforcements and as this chapter goes to press still a third similar corps of missionary volunteers sails for Canarla to angment the forces of this diocese.

The difficulties and discouragements met by these catechists are many, and for their aid and encouragement they are grouped under the supervision of certain clcrgymen of experience and ability. These clergymen, whom we may call superintendents, each have under their care six or cight districts. and back and forth throngh them they drive continually, advising the catechists, administering the sacraments and otherwise supervising the work and interests of the Church. They are expected to make the circuit of their fields six or eight times a year. During part of the year the catechists are withdrawn to be instructed in theology and biblical knowledge at Emmantel College. At first this interval for special study and instruction was of only three months duration, the catechists coming in relays, and their companions in the field meanwhile rloing double duty. At present there is provision for seven months in the College and five months on the field. Almost all of these catechists, if successful in their examinations, reach ordination in about three years.

On Norember 7. 1807 , the Reverend John Sinclair, one of the native clergy of the Western Church, died at Cedar Hill. He was educated at St. 

Joln's College, Winnipeg, and Emmantel College, Prince Albert, and ordained by bishop McLeatu. Ife served as a missionary at Stanley and at Grand Rapids.

Bishop I'inkluam, speaking at Prince Allert on June 8, 1898 , spoke feelingly of the recent cleath of Chiei Alkkakoop (Star Blanket), who had been a delegate at the preceding Synod: "Who can forget that stately, gentle old IIan! He was a memler of the Synod from 1886 to his deatl. He was always present and he took a leep interest in all that was done. Those who heard him will never forget his address at the missionary meeting in connection with the synod a few years ago. He loved his God; he loved the Church of God. During the Rebellion he was conspicuous for lis loyalty, and afterwards when visiting Eastern Canda he was greatly honored by His Excellency, The Governor-General."

The Qu'Appelle diocese was co-terminous with the old district of Assiniboia, extending five hundred miles from east to west and two hundred and five miles from north to south. It had at first no church, no parsonage, no organized congregation, and but one clergyman, the Rev. J. P. Sargent, later Dean of Qu'Appelle. In the early days it was his duty to minister chiefly to the natives and settlers along the line of the Canadian l'acific Railway. For many years the Church Mlissimary Society hacl conducter Indian nissions at Fort Qu'Appelle, Touchwood Ilills and Fort Pclly, but there had been laid merely the first stones of the founlation of the great work yet to be accomplished.

In $188_{4}$ the Rev, the Hon. Arlelbert Anson, rector of Woolrich and Honorary Canon of Rochester. was consecrated first Bishoj, of Qu'Appelle. He at once sent forth the clarion call for missionary helpers. He promised then only the absolute necessaries of life and no stijend, relying upon Christian heroism and missionary enthusiasm to supply incentives for the work. Six volunteers responded and came to Mr. Sargent's relief, and, by 1887. thirteen clergymen, with fifty-four stations, were reaching more or less effectively twenty-four hundred members and adlherents of the Church of England. A theological college and hoys school were presently established at Qu'Appelle, and much work of genuine utility was being done, though, the progress of settlement and the general growth of the Church proved less rapid than had been anticipated. The work he had accomplished was much more enduring and far-reaching than Bislop Anson knew, but to him it seemed all too small and as a result of his profound depression he resigned the See, in 1892. During his term of office he had organized the diocese into parishes, created the Synod, raised \$50.000 for the entlowment of the See, and built twenty-four churches. It was only from the standpoint of Bishop Anson's own profound lumility and enthusiasm that such record could seem inadequate. 

The Right Rev. William John Burn from County of Durham, England, was chosen his successor. The Bishop was a keen worker and assiduous in visiting his diocese, even in the most remote posts. At this time a large influx of population was starting in the West, and in consequence Bishop Burn had much to do in the way of organizing and readjusting the different missions scatteren over lis wide see. Bishop Burn delighted in his spiritual work, and his experience and ability would have been of incalculable use, but he died suddenly of heart failure on Jume 16,1896 , shortly after presiding over his synod. Wherever he went he carried with him a cheerful and courteous bearing, which always won the hearts of men, and his faithful wife is still (1913) carrying on his work in England in the interests of $2 \mathrm{u}^{\prime} \mathrm{Appelle}$ Diocese.

Lpon the death of Bishop Burn, Dean Grisdale, of Winnipeg, was chosen successor, being the first Bishop of Qu'Appelle to be elevated to such dignity by the authoritics of the English Church in Canada. Ile was fortunate in having as coworkers a corps of faithful and industrious priests, among whom may be named. Archdeacon Dobie, Archdeacon T. W. Johnson, Canon Beale and the Rev. M. AcAdam Harding. Thanks to the stremons labours of these and other clergymen under Bishop Grisdale's leadership, his episcopate was prosperous in the extreme. 1iy 1906 the diocese contained sixty-seven churches and more than thirty-three hundred nembers of the Anglican communion, served by forty-eight ordained clergymen and twentyfour lay readers. By 1908 there were eighty-two churcles, thirty-nine rectories and vicarages and eight parish halls.

The first Synod of Qu'Appelle had been held in 1884 at the territorial capital. There were two churches in the diocese, that at liegina under the pastoral care of Rev. H. Havelock Smith, and that at Moose Jaw in charge of Dean Sargent. In 1912 there were one hundred and fifty churches and ninety-two clergy on the roll, under the able supervision of Bishop $M$. Mcidam Harding. who was concecrated as coadjutor to Bishop Grisdale, June 3 , I909, and succeeded him on the resignation of the latter, June 9, I9t 1 .

The year 1907 was maiked in the ecclesiastical history of Qu'Appelle diocese by the e-tablishment of St. Chad's Hostel at Regina. This college had its inception in Shropshire. England, when at a meeting held in Shrewsbury the Church people decided to assist the Church in the Diocese of Qu Appelle by supporting a Hostel which should have as its object the training of candidates for Holy Orders. The Rev. C. K. Littler, who had spent about twenty years in Manitoba, but who had been latterly residing in Shropshire, was appointed first Warden of the Hostel and began his work in May, 1907. On his retirement, owing to ill health, in 1909. Arehdeacon Dobic Was appointed Warclen, with the Rev. R. J. Morrice subwarden. Aready about fifteen of the ahmmi of St. Chad's are at work in 

the diocese, and the Bishop in his charge to the Symod, in January, 1913, spoke highly of their work and ministry. The College was affiliated with the University of Saskatchewan in 1912. New and commodions quarters are being erected in the capital city in 19I3. St. Chad's College is the first of a scheme of buildings which will eventually include the Lishop's Riesidence, Boys' School, Synod Office and a Cathedral Church.

In 1908 steps were taken to organize a Prairie Brotherhood, similar in tharacter to the Bush Drotherhood that has done such effective service in Australia. Iiehind this movement stood the Socicty for the Propagation of the Gospel. Its work was chiefly among the many thousands of new settlers that are establishing lomes in the sonthwestern quarter of the diocese. The organization disbanded, however, in Nay, 1913.

From the point of view of church history a quite exccptional interest attaches to the system of so-called Railway missions in the diocese of Qu'Appelle. To avoid a possible misunderstanding, it may be stated that these are quite distinct from those forms of missionary enterprise commonly associated with railway construction works. The scheme simply embodies a policy by which the railway lines are made the basis for dividing the country into missionary districts and establishing the Church in the new communities that spring up like mushrooms along the railway line. Acting upon the suggestion of Arclubishop Xatheson, the Arclibishops of Canterbury and York, in December, 1909, made an appeal for men and money to assist in Church extension work in North Western Canada. Fifty voluntecrs and an annual allowance of $£ 10,000$ for the North West was thus secured. Early in 1910 the Rev. W. G. Boyd assumed charge of this work at Edmonton, and a few months later the Rev. Douglas Ellison undertook like duties at Regina in the interest of the Qu'Appelle diocese. Rev. W. H. White, Vicar of Lanigan, rendered valuable assistance in the work of organization and the enterprise was in active operation by October, 1910 , with four ordained clergymen in the fields. To each of these was assigned a strip of railway abont one hundred miles in length, with the adjacent countryside. In 5913 this force had increased to twelve priests and six laymen. Within two years twenty-four churches had been established, $\$ 30,000$ had been raised from local sources and Church services were being conducted in sixty-seven places. Upon being assigned his strip of railway, the missionary makes it his business during the first year to find in what localities the Church of England population is strongest. There he leads the people in the building of a church by local funds, encouraging the pioneers by assuring them of free pastoral service for the period of twelve months. In the second year the new congregation assists in the maintenance of the missionary and in the third year every effort is made to render the clarge self-supporting. The headquarters of the mission is the Clergy House at Regina. In the autumn 

of 1912 Ilis Royal Ilighness the Duke of Connauglit laid the cornerstone of the present Clergy Honse. Here each of the missionaries has a room, and from Regina he works his territury by means of the railways. The advantages of such a plan in conncetion with districts in which the Church population is small and not yet particularly affluent, are obrious.

In 1912 Mr. Ellison devised a Hospital scheme to serve the needs of the smaller towns. The town itself erects the building and the mission maintains it and supplies the necessary staff of nurses. Davidson and Rosetown were the first places to take advantage of this offer, building hospitals capable of serving abont sixteen paticnts. Additional nurses not yet reruired for such institutions as these are, under direction of the mission, doing private prairie nursing in the meantime (1913).

Of the several great British Missionary Societies to which Saskatchewan owes a debt of gratitude, special mention must be made of the Society for the Propagation of Christian Knowledge. This venerable association celebrated its second centenary in 19or. It has done invaluable works in many parts of the world, the Church in the United States being practically founded by it. By the beginning of the present century it had expended nearly $\$ 1,900,000$ in Canada and Newfoundland.

In rgor the Anglican Church stood fourth, numerically, among the great religious bodies of the Province of Saskatchewan, 75.3.2 of our citizens registering themselves as members or adherents. 



\section{CHAPTER XLIX}

\section{THE PRESBYTERIAN CHURCII IN SASKATCHEWAN}

First Presbyterlins ix West for a Gener.titon Witholt a MinisterPreshyteriax Services L'vder L...y Leadershin, from $1813-$ Futile EFrorts to Secles: a Minister-Coming of Rev. Jonn

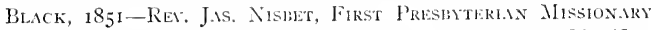

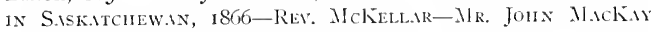
-First Presbytery, 1870-Rev: James Robertsun, the Gre.tT Pioneer Siperintexilent - Finincing Westers Missions -Rex. E. D. Mclaren, Generde Stiperintextext of MissionsDr. A. S. GR.INT-DR. C.IRMICHAEL'S GREAT WORK-I'RESWTERI.ANISM IN S.ISK.ITCHEW.IN IX 1913.

The cradle of Presbyterianism in Western Canada was the Parish of Kildonan in the Selkirk Settlement on the Red River. A very large proportion of the immigrants bronglit into the West by Lord Selkirk were I'reslyyterians from a parish named Killonan in the north of Scotland, and a minister of their faith, keverend Mr. Sage, from the same locality, was engaged by the great colonizer to come to Canada as their spiritual advisor. For some reason, however, Mr. Sage did not cone out, and for more than a generation the Iresbyterian settlers were without a minister of their own. It is a remarkable evidence of the religions tenacity of these hardy pioneers that during this long and disheartening interval they never lost their grip upon the teaching and customs in which they had been indoctrinated by their national church. Their clergy of an earlier date must indeed have performed their functions thoroughly. Neantime, before the Presbyterian settlers had an ordained minister of their own, they much appreciated the Christian courtesy of the Anglican clergymen, especially the Rev. D. T. Jones, with whose congregation the Scottish pioneers worshipped for many years.

Prominent among the settlers was Elder James Sutherland, in whom, though not an ordained minister, was vested special anthority to administer baptism, solemnize marriages and expound the Scriptures. To few men in Canada has the Presbyterian Church owed so much. Through the ministration of this devoted layman, the Presbyterian settlers maintained services among themselves from as carly as $s_{1} 3$. 

Selkirk had definitely promised to send a Presbyterian minister to the settlement, lut apparently owing to the stress of his legal difficulties he was unable to fulfil his pledge. After his death the settlers appealed to the authorities of the Hudson's Pay Company to carry out his promises, but without success. At last, in $184^{6}$, they laid their case before the authorities of the Church of Scotland, but the Red River was far away and few knew or cared seriously for the needs of the lonely pioneers. Three years elapsed before the petition was eren answered, and then no one was sent. The settlers, however, were steadfast in their determination, and in 1850 they took steps to obtain a grant of land for church. school honse and glebe purposes, in addition to $E_{15}$ o for the surrender of their claim on what was known as the $\mathrm{L}_{\mathrm{p}} \mathrm{per}$ Church. This establishment they held to be theirs by gift of Lord Selkirk, but for many years it had been in the hands of the English Church.

The Presbyterians then appealed to the Preslyyterian Church of Canada, and on September 19. 1851, the Reverend John Plack was welcomed by the congregation which had been waiting for so many weary years. On his arrival he found three hundred persons ready to take part in his first communion. Speaking of this remarkable man, the Reverend R. G. MacBeth has written as follows:

"John Black, afterwards Doctor Black, was a man of unusual power as a preacler and a theologian. Intense of nature and profound of conviction, his influence on the religious and educational life of the country was tremendous. His parish became the centre: and as new people began to come into the West, they came under the influence of that remarkable community. From that parish men and women scattered over the country, carrying their convictions with them and leavening the incoming settlers with their faith. In that parish plans were made for the planting of missions not only in the settlements near by, but as far northwest as the North Saskatchewan. In that parish Manitoba College was built, as the mission institution from which men have gone by scores out to the tields of the church, both at home and abroad."

Fifteen years after the formal establishment of the first Presbyterian congregation in Western Canada, the Kildonan settlers sent forth into the western wilderness a missionary party, outfitted largely by the congregation. to carry the Gospel and establish a Presbyterian Church in what is now the Province of Saskatchewan. The Reverend James Nisbet, who had been actively engaged in ministerial work in the settlement since 1862 , was at the head of the party. With him went Mr. John Mackay, a famous native buffalo hunter, his wife and Mr. Adam MacBeth, in addition to some assistants. The caravan moved with their ox carts across the plains for forty days, and ultimately established a mission at a point which Mr. Nisleet, in honour of the Prince Consort, named Prince Albert. This was the 

nucleus of the now flourishing city. Mr. Nisbet devoted eight years to unremitting and most successful labours, chiefly among the Crees, at the end of which time the health of both him and his wife had been shattered. He took her home to Kildonan, but the end was near. She died a short time afterwards in her father's house, and a few days later was followed to her rest by her devoted husband.

In the Presbyterian Church at I'rince Albert, however, there is a tablet to Nisbet's memory; but shared by Robertson and Carmichacl, the real monument to this heroic missionary and his wife is whatever F'resbyterianism stands for in the Province of Saskatchewan.

Mr. Nisbet was succeded at Prince Albert by the Reverend Mr. McKellar. Mr. Nisbet's devoted companion and assistant, Mr. John Mackay, had accompanied him chiefly to act as interpreter, and to supply the mission with food. In time, however, he was ordanind to the ministry himself and stationed on the Cree reserve of Mistawasis, near Prince Albert. He performed valuable services in connection with the negotiation of several of the treaties between the Canadian Govermment and the Indians, and in the troubles of 1885 he restrained the redmen of his distriet from joining the insurgents.

By 1870 there were five ordained Presbyterian ministers in the West, and the Presbytery of Manitoba was organized, with jurisdiction cxtending almost indefinitely through the vast interior. It is characteristic of Presbyterianism that even in those early days it was recognized that sound scholarship was an essential qualification for the most successful religious work among the pioneers and even among the native races; in consequence Manitoba College was organized under the acgis of the I'resbyterian Church. The Reverend George Bryce, for many years connected with Knox Church, Wimnipeg, was in 18,1 appointed the first professor.

Knox Church, Wimnipeg. becoming vacant, it was bold enough to invite the Reverend William Cochrane, convener of the Home Mission Committee, to himself assume charge of this field. This he was not able to do, but in his stead he sent the Reverend James Robertson, who for many years was to be the outstanding personality in western Presbyterianism. Wacketh s pen picture of this rugged prophet, statesman and organizer recalls to the mind's eye of many thousands yet living the impression produced by this great Presbyterian Bishop-for Episcopus he was in all reality: "That tall, spare, highland figure with the plain face and the eyes that could melt with sympathy or blaze with righteous indignation haunts us yet: the deep, intensely earnest voice still cries to us, and the strong grip of the sinewy hand still remains to us as assurance of a great gentineness of soul and purpose." ${ }_{1}$ The biography of Dr. Robertson as written by his staunch co-

${ }^{1}$ Our Task in Canada, page 34 . 

worker, the keverend (harles Gordon ("Ralph (Connor") is a book which no Presbyterian, indeed, no Canadian who respects religious heroism and national righteousness, can afford not to read.

Rev. Canon L. Norman Tucker, (ieneral Secretary of the Mlissionary Society of the Church of England in Canada, speaking at the Canadian Missionary. Congress held in Toronto in 1909, spoke as follows at a great meeting in Massey Hall: "Long before settlement began to pour into the West, there stood a man on the prairie, a prophet, a patriot, a great statesman, a missionary who foresaw the marvellous developments that were coming, who wisely prepared to meet them. Dr. Robertson stalied ont that great country, occupied its strategic points, early aroused his church to its needs and opportunities and dotted the whole land with Presbyterian Churches and manses, and thus enabled the I'resbyterian (hurch of Canada to work its noble and manly spirit into the very fibre of our national eye." This tribnte to Robertson brought the whole andience to its feet and precipitated an outlurst of umprecedented enthusiasm.

Six years after coming to knox College. Wimnipeg. Robertson was (1881) made Superintendent of Missions for Manitoba and the North West. "His parish," says Maclieth, "was from Lake Superior to the Jukon, but his sphere of operations was everywhere over the East and in the old land, where with resistles power he preached the flaming evangel of western opportunity. I met him in all sorts of places and situations during the great days of his superintendency-in buckbonds on the prairie, on trains in the mountains, and in wayside inns where he got his meals, and wrote his letters - sometimes all night long so that he could catch conveyance stage or train, or ride to some farther point in the morning. Nore than any man of his dat. he saw what the West was going to be, and the amazing development of these last few years would not have surprised hinn, for he saw it coming long ago. I have known personally most of the leading men of the West. splendid men, who developed the mnknown resources of the country. I have known the ministers of the Crown who have plamed important legislation, the men of husiness in the growing eities, the railroaders who have gridironed the lonely prairie, and who drove their iron horses over the mountains to drink on the Pacific shore, and I give them the tribute of great respect; but above them all as a real maker of the West 1 place the great superintendent who laboured to keep vivid in the new land the sense of God, who paid with his life the full price of his devotion to a noble cause." (Our Task in Canada, pages 3f-5.)

In IS 7 Robertson founded the first railroad missions in connection with the Presbyterian Church in the West. Four years later there were twentyone ordained miscionaries and fifteen catechists maintained by the Manitoba Presbytery. It was at this time that the new office of superintendent was 

created (largely through the intluence of the Reverend Dr. Black) and Robertson immediately gave up his pastoral charge in Wimipeg and entered upon his new work. His subsequent missionary journeys totalled a distance that would ten times girdle the earth.

In season and out of season, Doctor kobertson emphasized the necessity of giving visibility and prominence to the work of the Church, and of promptly occupying strategic points throughont the mighty region entrusted to his supervision. Ife accordingly established a special Church and llanse Fund and in the face of enormous difficulties he raised over sixty-three thousand dollars for this puryose within a few months. Through the instrumentality of this fund, four hundred and nineteen churches, ninety manses, and four school honses were erected in the North West before Robertson's death.

The year after the creation of the superintendency a I'resbyterian nission was established at Fort Quilppelle +1882 ) and very soon there were flourishing charges in almost all centres of settlement throughout Saskatchewan. In $18 S_{3}$ the Presbytery of Manitoba was divided into three, the Presbytery of Wimineg, kock Lake and Brandon, the latter including the North West Territories. Shortly afterward the first synod came into being. It had within its jurisdiction forty-seren missions with their associated stations. In I885 development justified further sublivision and the Presbytery of Regina was established, with thirty-four congregat jons and mission stations. It held its first meeting at Regina on July I5, 1885, when Robertson was elected moderator.

Thanks to the influence of such men as Dr. Robertson, Principal John M. Young of Nanitoba College, l'rofessors liryce, Hart, and Baird, Doctor John Camplell, of Victoria, B, C., and their mmerous devoted lieutenants, the eyes of the Presbyterian Church in Canada had now been serionsly turned towards the opportunity and privilege offered in western Canada, a fact evidenced by the mecting of the General Assembly at Wimipeg in I887. During the preceding five years mission stations had been created under Robertson's supervision at the rate of one per week, and the churches had increased in number from fifteen to nearly one hundred. The Assembly met in W'imnipeg again in 1897 , in Vancouver in 1903, and in Edmonton in 1912.

Outside support for Presbyterianism in the Territorics prior to 1894 rame almost exclusively from eastern Canada. In that year, through the instrumentality of the Reverend Charles IV. Gordon, greatly increased support began to come from the mother church in Scothand. Two years later Robertson himself visited the ofd land and sccured a considerable sum of money and undertaking to support forty missions. It is noteworthy, however, while in certain times of stress appeals have been made to the 

Presbyterian Church of Scotland, these have not been characteristic of Presbyterian methods in meeting the situation in the Canadian West; indeed, thonghtful critics within and without the Presbrterian communion have accounted for the remarkable success of Canadian Presbyterianism by citing the fact that it has been marked by a sturdy independence that has conduced to generous giving both in eastern Canada and in the pioneer districts themsclves. Thus in 1913 the Synod of Saskatchewan alone mudertook to contribute $\$ 80,000$ to mission work. For many years no financial aid has been either received or asked by the Canadian l'reshyterian Church from beyond the boundaries of Canada.

When the Yukon commenced to attract large immigration $(1807-8)$, Robertson sent into that remote territory a group of missionaries whose names will be forever fragrant. Anong these were Mr. R. .I. Dickey, a student from Manitoba College; A. S. Grant, who went by the White lass trail to Dawson along with the miners; the Pringle brothers. John and George; J. J. Wright, of White Horse, and J. A. Sinclair. To record the heroic service rendered by these men, and others who followed them or coöperated with them, would, however, take us too far afield.

In all this mighty enterprise Dr. Rolertson, through good report and bad report, had ever been in the forefront of the battle. The degree to which he threw himself into his work is evidenced by the fact that during a period of sixteen years he was home but once for Christmas, and on that occasion he was ill. To a man of his deep family affections such a life was one of continual sacrifice, but in it he was unfailingly supported by the sympathy and encouragement of his noble wife. The task which his genius had crẹted was, however, too great for any one man alone to perform, and doubtless hastened his death, which occurred in 1902 . He was succeeded by the Reverend Dr. E. D. McLaren, of Vancouver, who was given the title of Gencral Secretary of Xlissions, and with whom were associated as field superintendents the Rev. Dr. I. A. Carnichael, of Regina, and the Rev. Dr. J. C. Herdman, of Calgary. Doctor NcLaren himself retired eight years later to devote himself to educational work in Vancouver, and Dr. A. S. Grant, formerly of the Iukon, becane General Superintendent. With him were associated the Rev. J. H. Edmison as resident secretary at Toronto, and ten district superintendents, three of whom devote their whole time to the work in the Province.

The people of Saskatchewan are most concerned with the lahours of Dr. Carmichacl. While minister of Knox Church, Regina, he had the general supervision of a large section of the Province as convenor of the Home Mission Committee of Regina Presbytery. When an appointment had to be made after the death of Dr. Rohertson it was recognized that Carmiclael in a uinique degree was comversant with the situation and equal to the under- 

taking. Accordingly, he was appointed Superintendent of Missions for the Synod of Manitoba and Saskatchewan in the year 1002, and from that day forth he gave himself withont stint to the furtherance of the missionary cause. He travelled eastern Canada and in Britain in the endeavor to enlist the services of men for this work. Occasionally he had to make special appeal to his Church at large to meet the growing financial obligations. He organized lundreds of fields, visited missionaries in lonely places, and stirred up liss Church at large to nobler efforts. During his latter years he came into close tonch with what has conse to be known as the Independent Greek Church, an institution in the framing of whose constitution the aid of the Presbyterian Home Nission Committee at Wimipeg had been asked and granted. In this way Dr. Carmichel and his associates sought to provide for the religious nceds of Ruthenians, large numbers of whon he found destitute all over the prairic, and whose representatives appealed for guidance to Carmichael and the authorities of Manitoba Coliege.

Owing in a great degree to the lasting and growing success of the work inaugurated by Dr. Robertson. Dr. Carmichael within Saskatchewan alone had oversight over far more fields than Dr. Robertson had at the time of his death, in the undivided North West. Tireless in his work, he left it all too soon, and when he dicd, in $19 \mathrm{r} \mathrm{r}$, it was no small tribute to him that the Church for which he toiled was, as shown by the Dominion census, numerically the largest Christian denomination in Saskatchewan, and had contributed to the educational and political life of the Province even more generously than its membership would warrant.

Between 1904 and 1912 the gifts of the Presbyterian Church to Ilome Missions, chiefly for expenditure in the North West, have increased tenfold, largely through the influence of the Women's Home Mission Society, the Laymen's Missionary Movement, and the leadership of ecclesiastical statesmen like Dr. A. S. Grant. Schools and missions have been established among Indians of Saskatchewan at File Hills. Mistawasis, Prince Albert. Hurricane, Moose Nountain, Round Lake and elsewhere. Among the best known of the pioncer missionaries have been the Rev. Hugh McKay and Miss Baker, who have laboured heroically among the Sionx Indians of the Prince Albert district. Hospitals are supported by the Woman's Home Mission Society, which are devoted to the care of non-English-speaking people who otherwise would have no medical assistance. One of these institutions is situated at Wakaw, near Humboldt. 



\section{CHAPTER L \\ EDUCATION IN SASKATCHEIVAN}

Educational Beginnings in the Nortil West Under Ecclesilastical Auspices-Beginning of Goveryment Assist.nce, is;8-Oliver's Scilool Bill Intronuced, i883; P.issen 1884; in Operation, 1886-First Bolnd of Education-First Ixspectors-Reilgious Disputes and Amolition of Territori.ll Bo.mo of EducationTraining of Teichers-Doctor Goggin-Couxcil of Public Instruction Replaced by Departinext of Education, igoi-System of School Grants-Instficient Number of Tenchers-Creation of Higil Scirool Systen-Estimlisimatext of Provincial University-Supplementary Revenue Act-Provincial Educational Association-Departalental Cinangrs-Charicteristic Features of Saskitchimin Scimol. System-Educational Forces Apart from the School. System.

In the prescnt chapter it will be our purpose briefly to co-ordinate the various outstanding crents in connection with the cducational history of Saskatchewan, mcrely rccalling some of these in passing and trcating of others more fully than has proved convenicnt in the preceling pages of this work.

The first schools in the llest were established under the initiative of the early missionaries and other clergymen. The Reverend John West founded the Mission School at St. John for the children of Selkirk Settlers and employees of the Hudson's Bay Company soon after his arrivel in ISzo. In course of time the Scottish settlers cstablished another school to which the Reverend John Black gave such enthusiastic support that out of it may be said to have grown Manitoba College, which was founded in 1870 at Kildonan, but later removed to Winnipeg. Even before the arrival of the Reverend John West a Roman Catholic Mission School had been founded at Saint Boniface (1819). From these centres the institutions of elenentary education gradually spread over the Wcst with the slow advance of settlement. As early as 1850 the Methodist Church had mission schools in operation in the far North West and in I8 66 the Presbyterian Church organized such a school at Prince Albert under the charge of Mr. Adam MacBeth. 

Writing in 1873 Chief Factor Christie mentions visits he had paid to Anglican and Roman Catholic Mission Schools at Fort Simpson and at Providence and Isle a la Crosse, respectively. Four years later the University of Manitoba was founded by Lientenant-Governor Morris as the pioncer western institution of higher learning.

It will be remembered that some of the most interesting business that came before Mr. Laird's Conncil at its first session of 1877 arose ont of a petition for the granting of aid to a school at St. Laurcnt. The Council, however, regretfully confessed its inability to act in this matter, and referred the subject to Hon. David Mills, Minister of the Jnterior. In January of the following year that gentleman replied, agreeing that the North West Council had no authority to impose direct taxation. He suggested the inclusion of a school allowance in the estimates and recommended the early cstablishment of local school corporations with the right of self-taxation. Upon the first of these proposals action was taken in 1878 , when provision was made for a grant of two thousand dollars in aid of public schools for the fiscal year 1879-1880. Mr. Laird pointed out to the Ninister, however, that the wording of the North West Territories Act made no provision for the possibility of local taxation except in elcctoral districts having a thousand inhabitants, and as yet there were no stch districts. However, in the course of the ycar, as we have seen clscwhere, some provisional arrangements were made on the basis of which a few schools received the greatly needed financial assistance of the Government. The first definite action in this regard taken by the civil anthorities was embodied in a circular issucd by Mr. Laird in December of 1880 promising pecuniary aid to schools having a stated attendance. Interesting correspondence in this connection has already been quoted.

The next important step in advance was taken when, on September I3, $188_{3}$, Mr. Frank Oliver introduced a Bill for the organization of Public and Separate School Districts in the North West Territories. This measure was printed, distributed and reported by the Committec of the Whole Conncil and discussed at great length but did not reach its final stage in this sesion. In his speech from the throne in July, $188_{4}$, Lieutenant-Governor Dewdney referred to the wide-spread interest that had been taken in Mr. Oliver's Bill and to the increased information now available for the guidance of the Council. In due course M/r. Oliver's School Bill, amended with a view to rendering it more workable and to eliminating certain objectionable features. was finally passed on Angust 6, IS\&4, upon resolution of Messrs. Rouleau and Nlacleod. During the following legislative recess sixty-five applications were received for the erection of school districts. Thirty-eight new districts were duly proclamed before the Council met again, in addition to the twelve that had already becn receiving aid under the previous arrangenent, and the 

real establishment of the North West School System dates from I855,-or rather, from 11 arch, I886, for the neecsary expenditures were not provided for until that date.

The early minutes of the Ferritorial board of Education provide interesting realling, but our space will permit us to call only a few items. The first mecting was helel at Reginat on Masch II, I886. I'resent were: His Honor Lientenant-Governor Dewdney (Chairman), Father Laconbe, and Messrs. Secord and Marshallsay, together with Mr. James Brown, the secretary. For a long time Mr. Brown and a single assistant practically constituted the Education Department, and no other man has been more intimately associated with the efficient development of our school system than this talcuted and popular civil servant.

At the first mecting of the Board the following inspectors were appointed:

Mr. Thomas Grover, B.A., for the Protestant Sehools of western Assiniboia.

Mr. John Hewgill, for the Protestant Schools of Kastern Assiniboia.

Father Lebret, for the Roman Catholic Schools of Assiniboia. Kev. Mr. Mclean, for the Protestant Schools of the Calgary and Macleod Districts.

Mr. 1. W. Costello, for the Roman Catholic Schools of the Calgary and Macleod Districts.

Rev. Mr. A. B. Baird, M.A., B. D., for the I'rotestant Sehools of Edmonton District.

Father J. M. Lestanc, for the Roman Catholic Sehools of Edmonton District.

Mr. P. G. Larie, for the Protestant Schools of Battleford District.

Mr. E. E. Richard, for the Roman Catholic Schools of Battleford District.

Rev. Canon James Flett, B.D., for the Protestant Schools of I'rince Albert District.

Father Alexis Andre, for the Roman Catholic Schools of Prince Albert District.

The salaries payable to these gentlemen were fixed at sums varying from twenty-five dollars to five hundred dollars, in addition to travelling expenses. In view of more recent regulations, it may he of interest to note that on October 11, 1886, it was resolver that the expense allowance of each inspector should be five dollars per diem. Twenty dollars per sehool was made the basis of the regular salary.

The Rev. F. W. Pelley and The Rev. Father J. Hugonnard were eonstituted the first Board of Examiners for the Territories.

In accordance with the repuirements inposed by section fourteen of the North West Territories Act. delinite provision was male for state aid to 

Separate Schools, Protestant and Catholic. Among the teachers whose names are noted in the school records of these times are those of a number of gentlemen who have long been prominent in Saskatchewan affairs. Of these we may mention Mr. H. W. Newlands of Prince Albert, Mr. D. S. McCamel of Regina, and Mr. John Hewgill of Moosonin.

By. Oetober, 1886, the Territories had ninety schools and in I8S; the Lientenant-Governor reported one hundred and thirty-seven with a total enrollment of six hundred and ninety pupils. In this year some effort was made to extend Govermment assistance to High Schools, but the Privy Council vetoed this proposal in a dispatch dated November 29.

During the period of 1888 to 1891 the vexed question of the relations between the ecclesiastical and educational authorities was the subject of much controversy. The central Board of Education consisted of a Protestant and a Catholic department, each of which exercised a very free control of the schools belonging to citizens of its faith. This caused inevitable embarrassment, especially in districts where the poptulation was not homogeneons as regards religion, consequently the Board in IS92 was abolished and the educational affairs of the Territories were placed directly in the hands of the Lieutenant-Governor's Executive Council. In this capacity that body was known as the Council of I'tublic Instruction and with it sat two Protestant and two Catholic appointees, who, however, had no votes.

In its report for 1886 and 1887 the Board of Education had called atiention to the need of some central training school for the professional instruction of teacliers, but the demands on the public purse were many and several years elapsed before a Normal school was established. In March, i889, the Board passed a resolution requiring every union school-that is every graded school having classes above the ordinary pullic school grades-upon refuisition of the Territorial Board to maintain a Normal Department. Mr. A. H. Smith, B. A., of Moosomin delivered lectures to teachers in training under this arrangement in 1889 and 1800 . In September of the latter year the Territorial Board directed the establishment of Normal departments at Regina and Moosomin to be conducted by the Inspectors. No candidates presented themselves at Regina, however, but at Moosomin six teachers were trained by Inspector Hewgill. In the following year there were no Teacher Training Classes held in the Territories, but in 1892 and I 893 the work was continted at the previonsly mentioned centres by Inspectors John Hewgill and William Rothwell, B. A., of Regina. The Board also offered to concluct such a class in Alberta, but no students were forthcoming. In the three years preceding the establishment of Regina Normal School fifty-five students were trained by inspectors.

In 1893 Doctor Goggin, formerly Principa! of Manitoba Normal School. was appointed Superintendent of Education for the Territories, and Prin- 

cipal of the new Normal School at Regina. For the next decade Doctor Goggin was the guiding spirit in educational affairs. To the energy, tact, administrative capacity and broal knowledge of educational problems which he possessed, Saskatchewan of today is largely indebted for its advanced edncational system and for the absence of friction which to a large extent has marked its working. Those who are familiar with school administration need not be reminded that in actual practice peace and efficiency depend quite as largely upon the judicions framing and enforccment of Departmental regulations as upon the Ordinances passed by the Legislature. This work was so well performed by Doctor Goggin and his associates that until the time of his resignation in Igoz the Territorial School System experienced a quiet and unostentatiots development into the forefront of Canadian Edtcational Systems. During tinat time Regina Normal School trained an average of about ninety students per annum. More than twenty-five per cent. of these came from Ontario.

In rgor a beginning was marle in the manual training movement. Centres were established at Calgary and Regina with Mrr. L. H. Bennett as director, and summer courses in manual training were offered for teachers.

During the same year the Council of Public Instruction was replaced by a Department of Edtucation with the Hon. F. IV. G. Haultain as Commissioner. The School Ordinance which came into force the beginning of Iyor based the system of school grants upon (I) the assessable area of the school district; (2) the number of days the school was in operation; (3) the certificate of the teacher; $(4)$ the regularity of the pupils' attendance; and (5) the equipment and general efficiency of the school. This system has had a very valuable effect in improving the schools, as the various grants derivable from the Government rose or fell more or less in accordance with the interest shown by the local authorities.

With the first decade of the century the difficulty of supplying a sufficient number of adequately trained teachers commenced to become increasingly onerous. In 1903 one hundred and fifty students received Normal training in the Territories, lifty-five per cent. of these coming from the East; and two hundred and twelve other teachers were brought from outside points. Nevertheless, it proved necessary to increase to eighty-two the number of "permits" or provisional certificates granted. There were this year within what is now the Province of Saskatclewan alone four hundred and seventyseven school rooms and in 1904 and 1905 this number increased to six hundred and thirty-three and eight hundred and twenty-one. On September I there were eight hundred and ninety-six school districts. Sone of these of course had no schools as yet.

Shortly after the passing of the Saskatchewan Act D. P. McColl, B. A., who had succeeded Principal Goggin in the Normal School in I902, became 

Deputy Commissioner of Elucation and the oversight of Regina Normal School passed to MIr. T. E. Perrett, B. A.

In the following year Principal l'errett provicled that a short professional course for third class teachers should precede their adnission for training for the higher certificates. Every effort was made to encourage as many as possible to take advantage of this brief professional course and classes were organized from year to year at various centres under the immediate management of the Inspectoral staff. Nevertheless, the number of untrained teachers in the schools has steadlily increased. Inspector A. H. Ball in his report for 1906 comments on the fact that more than twenty per centum of the teachers in lis inspectorate were teaching on permits. In 1912, to meet the ever increasing denand a second Normal School for Saskatchewan was established at Saskatoon under Principal J. A. Snell. In spite of all measures that lave been taken, however, the proportion of non-certificated teachers has continuted to increase. In the first quarter of the year 1913 there were approximately three thousand sclools in the Province, and during the preceding twelve months the Department of Edtication found it necessary in some fourteen humdred eases to grant permission to trustees to employ teachers holding no certificates valid in this Province. Here lies one of the most important problems confronting the Educational authorities of Saskatchewan.

A number of very important statutes bearing upon education have been passed since the inatuguration of the l'rovince. Early in 1907 the Ilonorable James A. Calder, Commissioner of Education, and his deputy, Mr. McColl. held meetings through the Province to consider the creation of High Schools. The curriculum elraracteristic of such institutions had hitherto been incorporated with that of the Public Schools in the work outlined for what were called Standards VI, VII and V1lI.' The result of these conferences was the passing of the Secondary Education . Act at the next session of the Legislature. Before the end of the year six ligh school districts had been createdat Regina, Moosomin, Prince Albert, Moose Jaw, Weyburn and Qu Appelle.

A University Act was also passed in April, 1907. In 1883 at the instance of Bishop McLean the Dominion Parliament passed an Act providing for the creation of a University of Saskatchewan, but this measure proved a dead letter. In November of 1903 the North West Legislature also passed an Ordinance to incorporate and establish a [niversity, but the time was not yet ripe, and the proposal came to nothing. The Provincial Legislature was

1 This shrewd method of dealing with the question of sccondiry-education by leaving it to the rate-payers and ethers flirectly interested. to deternine how advanced a course was to be included in the curricutum of the local sclinol was recommencled in the Report of the Brard of Ethcation for 18 s and promptly incorporated in the School Ordinance. The first "Regulations with Request to Union Schools" wete adopted Warch 14, 1889. The first union schools tio he established were those of Regina, Moosomin, Moose Jaw, Calqary. Lacombe and Prince Albert. 

now, however, working under different conditions and a live Provincial University was soon in active operation at Saskatoon. Of the organization of this important institution under President Murray we lave spoken clsewhere.

Closely connected with the Secondary Education Act and the University Act was the Supplementary Rerente Act which was passed in the sane session. As we have already considered its provision when dealing with the political history of this period it need be but mentioned in passing.

The year 1907 was also notable for the promulgation of a ncw course of studies for the Public Schools. An eight grade systen was inaugurated in accordance with prevailing practice elsewhere.

In 1898 the sub-exaniners when assembled to read papers in connection with the departmental examinations organized the North West Teachers' Association. One of the most noteworthy enterprises undertaken by this body was the creation of a Teachers' Burcau which, in the course of time. became an independent institution, and which has been of great service in sccuring for the schools of the Province teachers from older settled communitics,--Ontario in particular. In 1908 the clief functions of the former association were taken over by a new organization, the Saskatcliewan Edncational Association, which has rapidly developed in nembership and influence so that its annual conventions are events of the first importance in the educational life of the Province. At the gathering in Easter, 1913, held at Regina, more than one thousand teachers and trustees were in attendance.

During the first six years of Saskatchewan history as a Province the minister responsible for educational aftairs was the Honorable J. A. Calder. In 1912, however, a re-adjustment of departmental folios occurred, under which the Premier hinself, Hon. Walter Scott, becane Minister of Education. Shortly previous to this (March 1, 1912) the former deputy, Mr. D. P. McColl, was appointed to the newly created office of Stperintendent of Education, which since the tine of Dr. Goggin had been discontinued. Mr. Augustus H. Ball, M. A., L.L. B., previously of the inspectoral staff and latterly of Regina Normal School, then becane Deputy Minister of Education. In 1912 Mr. T. E. Perrett, the veteran inspector and Normal School Principal, entered the scrvice of Regina School Board as City Superintendent, and in December he was succeeded in the Normal School by R. A. Wilson, M. A., Ph. D.

It may be well now to summarize briefly the outstanding features of the systcm of public education in the Province of Saskatchewan. Rural school districts are as a rule about five miles long and four miles wide. They are erected whenever within the area concerned there are twelve clildren between the ages of six and fourteen, and school grants continuc to be paid in undininished amount as long as there are half this number in actual average 

attendanee. Very generous Govermment grants are paid to all seliools and special provisions exist for the assistance of new or weak school districts. As a general rule the organization of school districts is left to local initiative, but when this is not sufficiently active, as sometimes in communities of nonEnglish spealing immigrants, this duty is performed by members of a special stafi of school organizers acting under the direetion of the eentral department of edueation.

In view of the liberal provision made for the sehools ont of the public funds, the department exercises through its inspectors a strict oversight upon the clementary and secondary schools. It preseribes the eurrieulum which is uniform throughout the Province, alike for urban and rural sehools, thus facilitating the transfer of children from one sehool to another as family circumstanees may require. The Department also prescribes a uniform system of text books and retains under its sole control the certificating of teachers.

The local management of the sehool, ineluding the employment and dismissal of teachers, is vested in Doards of Trustees eleeted by the local ratepayers. The system may thus be said to combine the maximum of super. vision by the central authorities with the compatible maximum of entrol by the local eitizens most concerned in rendering the school efficient.

In the eities public kindergartens exist and provision is made for special instruction in music, art, domestic seience and manual training. In most cities a speeial superintendent is employed by the Selhool Board to guide the general management of the sehool and keep the trustees in touch with the best modern methods.

The Public Sehools are free to all pupils residing in the district; on the contrary the High Schools are by statute free only to students from rural distriets. This eurious distinetion results from the fact that a small percentage of the funds derived from the stuplementary revenue tax on rural lands is applied for the support of High Selools and Collegiate Institutes. The latter are simply High Sehools reaching a eertain grade as regards equipment, efficiency and the qualifications of the teachers. In actual practice all High Schools and Collegiate Institutes are, as a rule, by law, free to all comers having the necessary qualifieations for adnission.

The course of study in the High Schools and Collegiate Institutes ordinarly eovers four years. Provision is made for the large number of students who simply desire an introduction to the elements of general culture, or preparation to commercial life. Other courses are offered for those desiring to enter the professions or to prepare for Universities and for those looking forward to service as teachers. Academic work is thuts practically exelurled from the Normal Schools of Saskatehewan, which devote themselves exclu- 

sively to educational history and training in the theory and practice of the teachers' art.

From the High School, students may pass directly into the Provincial University, entering either the classes of the first or of the second year, according to whether they have taken the junior or the senior matriculation examinations upon leaving the High School.

A word must be said regarding separate schools as they exist in Saskatchewan. These are few in number and differ in little but name from ordinary Public Schools. They are subject to the same general laws and regulations as regards curriculum, et cetera, and are supervised by the same inspectors as our Public Schools. Special religions training is by law confined to the last half hour of the school day.

The amazing growth of the school system of Saskatcliewan is strikingly reflected in the following statistical return. The total grants for education in the whole North West Territories was $\$ 25,000$ in 1886 . For the financial year 1913-1914 the estimates for Saskatchewan alone amonnt to $\$ 740,250$, exclusive of the funds derived from the Supplementary Revenue fund, which bring the total expenditure for education considerably over \$1, I00,000.

$V$ arious private and denominational schools exist especially to meet the needs of students who have lacked early advantages or who desire special training, particularly in music. Such institutions, however, receive no govermment aid.

Apart from the school system proper, important educational functions are performed by various societies. Prominent among these is the Regina Society for the Advancement of Art. Literature and Science, organized chiefly on the initiative of Magistrate Trant, who for a quarter of a century had been a leader in almost every movement of a literary or scientific cliaracter. As this organization is the pioneer in its field, it deserves some special mention. It was organized in the season of 1909 and 19 ro to constitute a bond of union among the studiously inclined, to facilitate systematic sttudy in any direction desired by a sufficient number of its members and to secure the advantage of hearing scholars and artists from other parts. Independent socicties of kindred aims may affiliate on terms approved by the Board of Directors. The anmul Art Exhibits held under the auspices of this socicty have been the most noteworthy events of this kind that have occurred in Saskatchewan. Courses are offered annually totalling between sixty and seventy lectures, covering work in Art and Architecture; Psychology and Child Study; Astronomy ; Literature; History and Economics and Music.

Another association the establishment of which likewise indicates the development of the Province along aesthetic lines is the Saskatchewan Musical Association which, chiefly through the initiative of Mr. F. W. Chisholm 

of Indian Ilead and Mr. F. Laubach of Regina, was organized in May, Igo8, with MIr. A. F. Angus of Regina as President and Mr. James Brown as Vice President. Under the auspices of this society the Saskatchewan Musical Festival has become an annual event to which the whole Province looks with interest. In rgog there were forty-four entries in connection with the various contests, and by 1912 entries had risen to one hundred and thirty-five. The musicians actually participating in the festival for this year numbererl about seven hundred and fifty. It would be hard to exaggerate the importance of the effect produced under the encouragement of this flourishing society.

Many other societies more or lese similar in aims have contributed to the higher education of Saskatchewan, but these two organizations, by virtue of the scope of the work undertaken, are specially significant and at the same time typical of the rest. 



\section{CHAPTER LI}

\section{THE ROYAL NORTI WEST MOUNTED POLICE}

Early Advocates of a Mounted Constanulary-Crestion or tile Force, 1873-Lieutenant-Colonel Jirench Aprointed CominissionerServices of NoN-COMmissioned OfFicers-Major Whlsil, with the Right Wing, Cones West atia Diwson Tran, iS73-Lert Wing, Under Comarissioner Frexch, Comes atia Fargo, 1874The Marcil Into the Wildersess, IS74-Colonel M.acleod Apponted Commissoner, 18;6-Demlings witu Rech.citrant

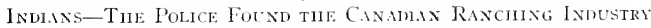
-A Fanous Police Ballib-Citrle Rusthing-Beididig of tilf: C. P. R-Colonet Irvine Apronted Commissioner, 1880 , and Heidovarters Trinsferken to Regina (I883)-The I'Ulice in

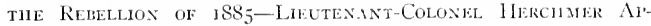
pointed Commissioner, 1886 ; Succeeded by Commissioner Perti, 1900-Manifold Duties of the Force-T.lles of Heroisn: Corporal D. B. Smith; Coxstaphe Conkum ; Constable Peiley; Corporal Fifed-Tine Chinges Kisg ifurder-Thie Return of Indax Reflges-Tine Trigedy or Almighty Volce-Arrest of Notable Desteradols: Comboy Jack; Idailo Kid; Bill MinekThe Policing of the Yukon-Tine R. N. M. M. P. ANd the South African War-Patrolling of tile Far Nortin: Insiector Pelletier's Expedition, igos; Inspector Fitzgerald's Disaster, i9io; Numerous Similak Patrols-Varyixg Strexgth of tue ForceRelations of Mounted Police to Provincinl Golernaexts.

Many years ago an old Indian chief, speaking at a council and addressing a representative of the Royal North II est Mounted Police, said: "Before you came, the Indian crept ahout. Now he is not afraid to walk erect." It is the prond boast of the force that since its celebrated march west in I 874 neither white man nor Indian has been afraid to watk erect, whether on the prairies, in the hinterland of the Hudson's Bay or in the far-away Yukon. It will be the purpose of the present chapter to sketch how the extraordinary sense of security enjoyed in the Great North West has been achieved. The topic is one familiar to all westerners, but one to which they 



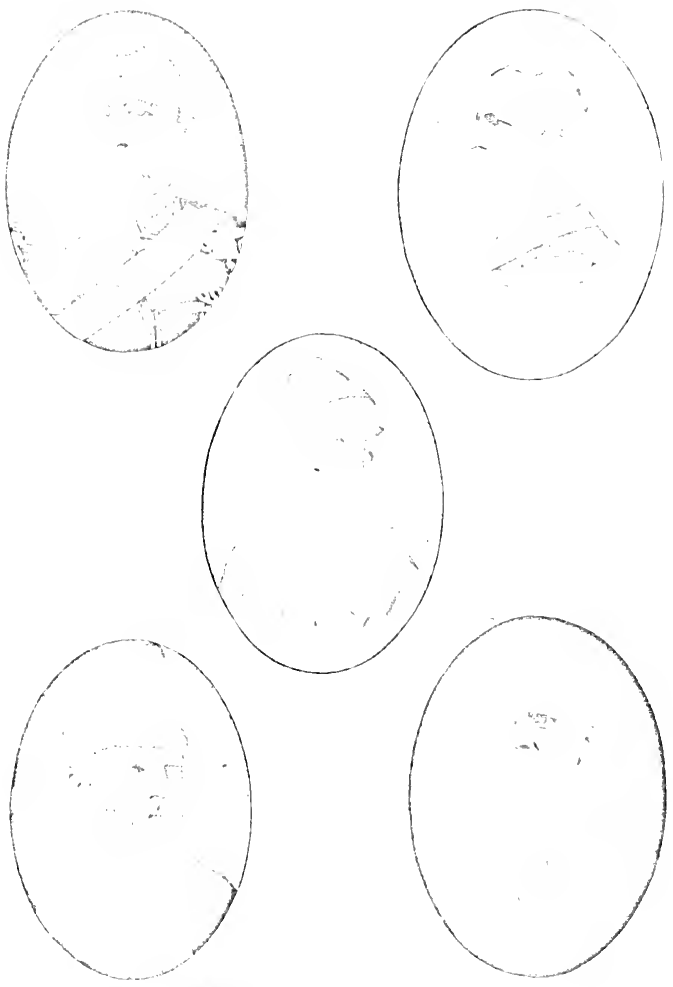

COMMISSIONERS OF R. N. W. M. P.

Major-Gen. Sir Geo. A. French, K. C., M. G., 1573-15io.

Lieut.-Col. Jaures F. Macleod, C. M. G.. 1 T6-1<so.

Lieut.-Col. A. (A. Irvine, 1su-1sut.

Lient.-Col. Lawrence W. IIerchmer, 1nti-1900.

Lieut.Col. A. Bowen Perry; C. M. G., 1900. 

ever revert with pride. In our days of crude commercialism it is refreshing to turn to an institution of our very own that combines the sanest acumen and business-like administration with the glamour and legitimate paternalism of the best things in the age of chivalry. Therefore, it is with no fear of failing to interest that the writer invites attention to the following recital of things new and old, bearing on the organization and achievements of the most famous mounted constabulary in the world.

The creation of such a force came under consideration immediately after the annexation of the IIudson's Bay Territories. Mr. Donald A. Smith had recommended it to the authorities in 1870 , as also did Captain Butler in 1871 . In 1872 Colonel Robert Ross, subsequently Adjutant-General, had been despatched by the Canadian Government to make a reconnaissance and to report upon plans for the preservation of peace and order, and had made a like recommendation. The estallishment of snch a body had been urged by Captain Louis de Plainval, the head of the Manitoba Provincial Police, and numcrous other prominent westerners. In the minutes of the North West Council for March 10, 1873 , occurs the following entry:

"That in the opinion of Council it is necessary that for the maintenance of peace and order in the North West Territories, a sufficient force of Military and Police, the latter under military discipline, and either wholly or in part mounted. should without delay be stationed in the Territories."

The need was certainly great, but it may be doubted whether it would have been met so promptly as it was had not the public conscience been shocked into activity by the hideous massacre of Canadian Indians at the hands of American whiskey traders and other desperadoes among the Cypress Hills. At least a few public men were wise enough to see that, in the default of firm and just precaution, the Canadian West was about to see duplicated the bloody drama familiar to all the western American states-outrages of lawless white men, massacres of settlers by the Indians, costly punitive expeditions and all the nameless horrors of a war of extermination. Accordingly, as we have seen in previous chapters, provision was made for a force of mounted police by an Act of the Dominion Parliament in the year 1873 . This measure was introduced by the Premicr, Sir John A. MacDonald, who always retained a special interest in the force. In September of 1873 the first steps were taken towards actual organization, the command being entrusted to Lieutenant-Colonel George A. French, who accepted the post in October and proceeded at once to Manitoba. This distinguished officer retained the commissionerslip only until July, 1876, when he returned to the Imperial Army. In the meantime, however, he had shared in the performance of a task entitling lim to the permanent gratitude of Canada.

The plans at first involved the present enrolment of a maximum of only 

three hundred men. Most of those accejted had had previous military experience, and sereral of the officers and non-commissioned officers had taken spccial training at the Loyal Nilitary College, Kingston, with a view to serving in the prospective force.

It is no reflection upon the officers of higher rank when one assigns to their non-commissioned coworkers it major part of the credit for the success of the force. "No matter what anybody else says or who may claim it, it was the non-commissioned officers that minte the Mounted Police," said Colonel Steele to the present writer. Is a matter of fact, no one secms inclined to dispute this verdict. The original non-commissioned officers in particular were an exceptional group of men, all thoronglily well fitted to excreise the duties of a rank much superior to that in which they were employed, and all absolutely devoted to the service and seeningly indifferent to promotion.

The regulations required that each recruit should be between seventeen and forty years of age and able to read, write and ride. Those accomplishments constitute "the three R's" of a policeman's education. The period of service was to be three years. A fine not exceding two lundred dollars might be inposed on any person refusing fool. shelter or transport to any member of the force when suitalle compensation was offered. The Conmissioner and each of his superintendents were er officio Justices of the Peace, and the force was to have jurisdiction througlutit Manitoba and the whole of the North West Territories.

Major Walsh, with the right wing, numbering one lundred and fifty, came west first, in 1873 , shortly before the coning of Commissioner French. Major IValsh followed almost the same line of march as that of the Wolseley expedition, which Colonel Stecle and some other mombers of the new force had accompanied. Though this second march, being over somewhat familiar ground, was relieved of some of the stupendons difficulties of the first, it was arduous enough, and the left wing followed a different route, a'ia American territory. The right wing spent the winter in Winnipeg in training before the left wing arrived in the West. Sixty raw bronchos supplied the recruits with material for practice in horsemanship. Najor WValsh and his fellow officers had been allowed practically no time for the proper selection of their men and it is not surprising that a number of the recruits had to be eliminated subseruently. From this and other causes the numerical strength of the first contingent was considerably impaired.

Commissioner French returned to Ontario in Fehruary, 1874 , to arrange for the recruiting of the force up to the limit of three hundred indicated in the Act under which it was organized. By April most of the new recruits were in training at Toronto. Pefore leaving for the West with the second contingent. June 6. 1874. Commissioner French gave the weak-kneerl two 

opportunities for withdrawal. No one was wanted who was not prepared for genuine hardships. After six days' railway journey the force reached Fargo, North Dakota, on June 12, 1874, and three days afterwards it began the famous march into its vast western domain. On June 17 th we find the colmmn one hundred and sixty miles northward, at Dufferin, Nanitoba (now known as Emerson), where it was joined by the Fort Garry contingent.

Many stories could be told of this famous initial expedition into the wilderness. The following is but an example. While the police were at Fort Dufferin, a terrific thunderstorm and gale swept over the encampment about ten o'clock at night. The wind tore away from a "prairie schooner" its canvas covering, carrying it into the air over the already terrified horses. They were seized with panic and some two hundred and fifty of them stampeded, charging over the heads of their sleeping masters, six of whom were injured. Fortunately, a few of the horses were gotten under control and upon one of these, followed at a considerable distance by some troopers, Colonel Walker pursued the panic-striken herd through the darkness and tempest. Most of the stampeded horses were recovered within thirty-five miles after a search of thirty hours; but many days were lost before the search for the other animals was given over. The actual loss was eventually reduced to one horse. The search involved terrific rides for the new police and proved the ability and endurance of the force. It also helped to elininate, before the real hegiming of the great march west, the remainintg "unfits." The column then proceeded westward in the second week in July.

It was a scene that appeals to the imagination. First, in conmand of Inspector Jarvis, came Division A, forty-one in number, mounted on splendid dark bays and followed by thirteen wagons. Division B, forty strong, came next, riding dark brown horses. Division C, forty-three in number, were on bright chestnuts and convoyed the guns and amnunition wagons. With Division D, numbering in all sixty-one, mounted on greys, rode the four staff officers. Division $\mathrm{E}$ consisted of forty-eight men on black horses, and the forty-three members of Division $F$ were mounted on light bays. Belind the main body came a long procession of ox carts, cattle, wagons and agricultural implements. The marching-ont state on Jnly 8, 1875, showed twenty-one officers, two hundred and ten horses, two field guns, two mortars, one hundred and forty-eight oxen, one hundred and fourteen ox carts, seventy-three double wagons, and ninety-three milch and beef cattle.

After a journey full of hardships the force reached the site of the present town of Lethbridge, Alberta. on September 11, 187, having ridden some 789 miles since leaving Dufferin. No human habitation save a few wigwams had been passed for over 760 miles. Assistant Commissioner Nacleod advanced to the Relly River in the vicinity of Fort Whoop Up. There he establisherl local headquarters in the mirlst of the Plackfoot conn- 

try, for the supervision of the Indians and the repression of the liquor traffic illicitly conducted by American desperadoes. He built Fort Nacleod on Old Man's River and from that centre so efficiently policed the wilderness that at the end of the year the whiskey trade had been all but completely stamped out, and the riots, robberies and assassinations of the recent past came to an end forever. Meantime, the commissioner himself had returned to Dufferin. It had been decided to transfer the headquarters to Fort Pelly, near Swan River, but the barracks there was not ready. Commissioner French administered the affairs of his office from liort Garry.

In summarizing the salient features of the famous marcl of 1874 , Commissioner French reported as follows:

"At this latter place (Emerson) the whole force was divided into six divisions or troops, and on July $\&$ started on an expedition which veteran soldiers might well have faltered at. Tied down by no stringent rules or articles of war, but only by the silken cord of civil contract, these men, by their conduct, gave little cause for complaint. Though naturally there were several officers and constables unaccustomed to command and having little experience or tact, yet such an event as striking a superior was munknown and disobedience to orders was very rare. Day after day on the march, night after night on picquet guard and working at high pressure during four months from daylight until dark,--and too frequently after darkwith little rest even on the day sacred to rest, the force ever pushed onward; delighted when a pure spring was met with, there was still no complaint when acrid water or the refuse of a mud-hole was the only liquid available. I have seen this whole force obliged to drink liquid which, when passed through a filter, was still the color of ink. The fact of horses and oxen falling and dying for want of food never disheartence or stopped them, but, pushing on on foot with dogged determination, they carried through the service required of them under difficulties which can only be appreciated by those who witnessed them. Where time was so valuable there could be no halting on account of the weather: the greatest heat of a Juiy sun or the cold of November in this northern latitude made no difference: ever onward had to be the watchword, and an almost uninterrupted march was maintained from the time the force left Dufferin with the themometer 95 to roo degrees in the shade till the balance of the force returned there in November, the thermometer marking 20 to 30 degrees below zero, having marched 1959 miles."

Gradually the little band of three hundred men were systematically organized into divisions and distributed far and wide over the Great New Land. At the close of $18 ; 7$ thirty-one members of the force were operating from bases in Manitoba (Swan River and Shoal Lake): seventy-nine were in what is now Saskatchewan (Qu'Appelle, Battleford. Wood Mountain, and Fort Walsh), and the remainder were assigned to what is now Alberta (Fort Macleod, Pinto Horse Butte, Milk River, Fort Calgary and Fort Saskatchewan). 



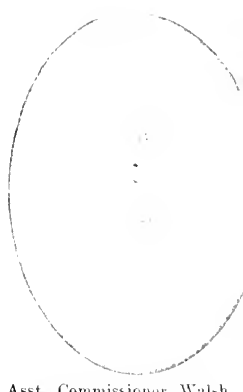

Asst. Commissioner Walsh, who commanted the first contingent of the $\mathrm{N}$. II. M. P, to arrive in the West, 1873 .

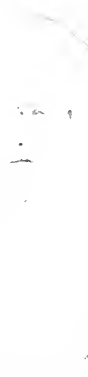

Lient.-Col. Fru] White, C. Lieut-Col. I:ts. Waller, a II. Ii., fomptroller of distinguished member of

Mounted Police, 1si:- Mounted Police in early 1913.

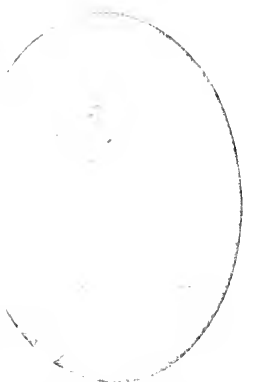
days.

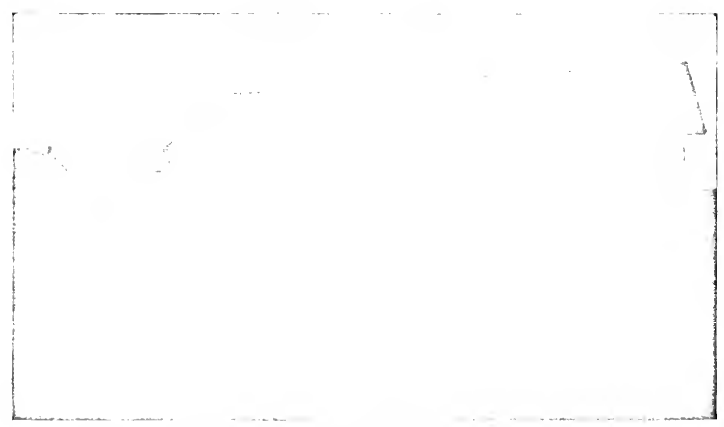

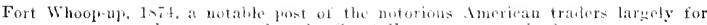
whose suppression the Great loree was organized. 

In 1876 Colonel J. F. Nacleod, C. II. G., succeeded Colonel French as Commissioner. Fort Nacleod became the headquarters of the force, but a few years later it was shifted one lundred and screnty miles castward, to Fort Walsh.

In $18 ; 6$ Colonel Walker was transferred to Battleford and organized police patrols at Ile à la Corne, Prince Albert, Fort Pitt, Duck Lake and Carletun. During this period the police performed valuable services in conncetion with the consummation of the Indian treaties, to which a previous chapter has been devoted.

When Treaty Number Six was signed at Fort Carleton, Chief Beardy, of Duck Lake, was recalcitrant. He sent word to the Lientenant-Governor that unless certain supplies that he lad desired were instantly sent to him he and his followers would loot the stores at Stobert and Eadon's Trading Post. The Licutenant-Governor entrusted to Colonel Walker the duty of preventing this outrage. Walker and three companions immediately rode to the trading post, where they were in waiting when Iieardy and his warriors in full war paint galloped up to the gate of the stockade, firing their guns and making the air ring with their war whoops. Beardy dismounted at the open gate, and, entering, found to his discomliture the four police officers ready to welcome him. After saluting lieardy, Colonel Walker commanderl his ment to load their weajons and stand in front of the store. He then addressed the astonished warrior to the following effect: "I have been informed that you have come here for the purpose of attacking the stores, and that you and some of your band have openly offered insult to both the Queen and the Governor. Now, the stores are in the building there, so all you have to do is to enter and take them. but I have given instructions to those three men who are on guard there to fill full of lead the first man who attempts to enter." This pointed oration had the desired effect and Beardy assured the Colonel that he and his men were the most loyal of Jndians and innocent of all desire to do mischief.

As we have seen in former chapters, the Indian situation in the seventies and early cighties was complicated by the presence in Canadian territory of many thousands of warlike American Sionx. A large number of these had settled in Manitoba near Portage la Prairic, after the Minnesota Massacre of 1862. Ten years later these unwelcome reiugees numbered approximately ten thousand, and after the Custer Massacre of 18 ; 6 their numbers were augmented by the ingress of Sitting Bull and his warriors.

Neantime, however, the Canadian North West lat been the scene of a bloodless revolution in which the Monnted Police had played an important part. The warring tribes had settled into permanent peace, and hostility to the whites had almost ceased to be dangerous. Indeed, the aborigines had now come to recognise in "the Riders of the Plains" their best friends and 

guardians. We have already commented 11pon the admiration for the police which took possession of Sitting Lull himself and upon the warm personal friendslip established between him and Major Walsh and other officers of the force. The details of the Sitting Bull episode have already been recounted elsewhere.

It was through the instrumentality of the Nomnted Police that the ranching industry was first established in the Candian West. Fresh horses were continually required for the force itself, as the work was very severe. For example, the police escort assigned to duty in connection with the tonr of the Marquis of Lorne travelled two thousand and seventy-two miles at an average rate of thirty-five miles a day. Upon the representations of Major Walsh a police farm was accordingly established near Fort Macleod.

In the Saskatchcian IIcrald of September 23. 1878, there appeared anonymonsly a stirring ballad which well depicts the work of the police in these early days, and, indeed, fairly represents their spirit and duties from that time to this:

"THE RIDERS OF THE I'LAINS

"We wake the prairie echoes with

The ever-welcome sound-

'Ring out the boots and saddles'-till

Its stirring notes resotnd.

Our horses toss their bridled heads, And chafe against the reins-

Ring out, ring out the marching call Of the Riders of the Plains.

"Full many a league o'er prairie wide Our pathless way must be:

And round it roam the fiercest tribes

Of Blackfoot and of Cree.

But danger from their savage hands

Our danntless hearts disdain-

The hearts of those that wear the helms

Of the Riders of the Plains.

"The thunderstorm sweeps o'er our way, But onward still we go;

We scale the weary mountain's range,

Descend the ralley low: 

We face the broad Saskatchewan, Made fierce with heavy rains-

With all its might it camot check The Riders of the Plains.

"We track the sprouting cactus land, When lost to white man's ken:

We startle there the creatures wild, And fight them in their den;

Where'er our leaders bid us move. The bugle sounds its strain;

In marching sections forward go The Riders of the Plains.

"For us no cheerful hostelries Their welcome gates unfold; No generous board or downy bed Await our troopers bold;

Beneath the starry canopy At eve, when daylight wanes,

There lie the hardy slumberersThe Riders of the Plains.

"We muster but three hundred In all this 'Great Lone Land'

Which stretches from Superior's waves To where the Rockies stand:

But not one heart doth falter. No coward voice complains-

Though all too few in numbers are The Riders of the Plains.

"In England's miglity empire

Each man must take his stand:

Some guard her honoured flag at sea,

Some bear it well by land;

Not ours to face her forcign foes-

Then what to us remains?

What duty does our country give

To the Riders of the Plains?

"Our mission is to plant the rule

Of British freedom here: 

Restrain the lawless savage

And protect the pioneer;

And 'tis a prond and daring trust

To hold these vast domains

With but three hindred mounted men-

The Riders of the Plains." ${ }^{1}$

The practical extinction of the buffalo herds in the later seventies and the early eighties reduced the Indians to the direst extremities and greatly increased the difficulties of the police in their efforts to restrain the wretched aborigines from depredations. The degree to which they were successful reflects great credit alike on the force itself and upon the care-burdened chieftains who coöperated in teaching their braves respect for the law. Horse stealing, of course, was very common, and anong the Indians themselves there were very few who viewed it as a crime.

This rendered exceedingly hazardous any attempt to arrest an Indian "rustler," but the police never flinched from their duty. If space would permit, many stirring anecdotes might be told in this connection. The following are typical:

A party of Sioux had all their horses stolen by some $\Lambda$ ssiniloins and Grosventres. The Sioux called upon Assistant Commissioner Irvine for succor. With six men he located the stolen horses in an encampment of three hundred and fifty lodges, which he entered with four companions and Sub-inspector Mlcillree. The balance of the story may be told in the words of Irvine's report:

"It was quite dark when I got into the camp. I went straight to the chief's lodge. It was surrounded with Indians. I told the chief I knew he had the stolen horses in the camp and had come to get them. He said he did not think his young men would give them up, and that the Americans were very strong, and would not allow any white man to harm them. I told him we could not allow anyone to steal horses on this side of the line, and that he should have to answer before I left his lodge. He then said, 'When you come in the morning, I will hand you over every one of them.' I went in the morning and they handed me over all they could find. It would lave been inpossible for me, witl only four men, to have made any arrests; besides it would have been difficult to find the guilty parties. However, I gave them a good lecture, and they promised to behave themselves in the future."

In May, 1877 , Major Walsh, with fifteen men, entered an encampment of two hundred excited warriors who had put the police at defiance, and arrested a number of turbulent braves on the instigation of other Indians

1 This poem was dater Cohurg, July, 1\&-8, and was simned "WV. S.' N. IV. M. P." A few verbal alterations have been made in the text. 

who had been molested. Indeed, such exhibitions of nerve and of the dominating powers of strong personalities were of everyday occurrence. Frequently Nacleod, Walsh, Irvine, Steele, or some other distinguished officer was the hero of the tale; as frequently it was a nameless private.

On the $4^{\text {th }}$ of $\mathrm{XJay}, 1882$, Inspector Macdonell, of Whod Mountain, was advised by Mr. LeGare, the well-known trader to whom frequent references have been made in preceding chapters, that on the evening of the $28 \mathrm{~h}$ of April a war party of thirty-two Crees took possession of his encampment. He had with him a Halfbreed and a Sioux Indian. During the night Mr. LeGare heard the Indians arranging to kill him and the Sionx; but in the morning it was decided to allow. Mr. LeGaré and his friends "to eat once more" before their execution. When LeGaré commenced preparations for leaving camp a terrific uproar occurred, some of the Crees crying for the scalps of the whole party, others wishing to kill only the Sioux. Two attempts at firing were made, but, fortunately, the guns missed fire both times. Finally, LeGare succeeded in buying the lives of his men at the cost of his ontfit. Macdonell determined to arrest the perpetrators of this outrage at any cost, and nitimately located some of them in a camp of about forty-five lodges. At first the presence of the criminals was denied, and there was every prospect of armed resistance to the police. Nevertheless, Macdonell, covering the ringleater with his revolver, so cowed the assemblage that they surrendered the miscreants. It became a tradition of the force that discrepancy of numbers was an irrelevant consideration when dealing with angry Indians. "Fortes fortuna juzat."

Another of the imnumerable examples of the extraordinary influence exercised by the police is recomted in the reports for $188_{3}$. An Indian called Crow Collar had destroyed some property, and when an officer was sent to arrest him the head chief, liull's Ilead, refused to give him up. Accordingly, Irvine ordered the arrest of liull's Head also. When he was scized he resisted violently and called on his braves to assist him. They were in a most excited state and Irvine saw the arrest conld not be made at that moment without blootshed. He accordingly retired for the night to the agent's house, but in the morning he returned to the lndians, and intimidated them into producing Crow Collar. Bull's IIead himself sent word that he would come the next day, and this he did, accompanied by most of his braves, and Irvine put the dismayed dignitary into a cell. There he kept him for a couple of days, when, after explaining to him in what a very wrong manner he and his tribe had behaved, the commissioner released him.

During the building of the Canadian Pacific Railway it was the duty of the Mounted Police to suppress the traffic in intoxicants among the enployees, kep a general oversight over the railway camp, and preserve order 

along the right-of-way. In a letter dated January $1,188_{3}$, Sir William Van Horne expressed his gratitude for the efficient manner in which these onerous duties were performed. "On no great work within my knowledge where so many men have been employed," said he, "has such perfect order prevailed."

When the great Imerican transcontinental roads were under construction they were continually impeded by the Indians. A few sporadic attempts in this direction wore made in Canada, but the energy and sang froid of the police prevented any serious trouble.

On one occasion Chief $\mathrm{Pi}$-a-pot and his band resorted to the stratagem of passive resistance, deliberately encamping on the right-of-way and refusing to move. A complaint was duly registered with the police authorities and a sergeant and a constable were sent to move the troublesome band. Accompanied by a jeering mob of the barbarians, they went dircetly to Pi-a-pots tent, conveyed the command for him to remove his encampment and informed him that if the order were not obeyed forthwith they twain would undertake the task at the end of fifteen minutes. The proposition was received with laugliter. The sergeant accordingly took out his watch and he and his companion stood at attention beside the tent door for a quarter of an hour, much to the entertamment of the Indians. When the time had expired the sergeant returned his watch to his pocket and. without further parley, the two constables cut the guy ropes of Pi-a-pot's tent, causing it to collapse on the heads of its surprised occupants. The whole encampment was instantly in an uproar and nothing lut the chieftain's vigorons personal efiorts saved the lives of the policemen. Pi-a-pot was no fool. He understood well enough that these two audacions Red Coats had hehind them the whole might of Canada and the King, and he promptly ordered his braves to strike camp and leave the railway line free of obstruction.

The third commissioner of the North West Mlounted Police was Colonel Irvine, who on November I, 18So, succeeded Colonel Macleod. It will be remembered that at this time the force was administered chiefly from Fort Macleod and Fort $1 \mathrm{Walsh}$, the latter having recently becu given special importance becanse situated in the midst of the region most directly affected by the recent Sionx incursion. In $I_{3} S_{3}$ the headquarters of the force was transferred from Fort Walsh to Regina, though the barracks at the new Territorial Capital was not completed until IS86. Commencing on May 23. I883, however, Irvine had demolished old Fort Valsh, which was off the line of the coming railway and otherwise ill-suited to remain the seat of police administration.

Of the part played by the police in rebellion days, sufficient las been said in previous pages. If the warnings of the commissioner and other prominent police officials and civilians had been heeded, there would have 

been no insurrection, and if, when the ill-starred outbreak occurred, the force had been suitably augmented and given the necessary frcedom of action, it seems unquestionable that it could have met successfully this great emergency as it has so many others, and that the rising would have cost Canada much less than it did, both in blood and treasure. As it was, it was the police more than anyone else who kept the disorders from spreading.

For several years after the rebellion it was necessary to issue relief every winter to large numbers of the Halfbreeds, who had been ruined in the rising. The oversight of this matter fell to the police. These were hard years, and poverty was widespread, but hard times did not bring its usual concommittant-an outbreak of lawlessness. In 1888 considerable treaty money was paid to the rebel Indian tribes, upon the recommendation of the Indian agents. In speaking of the numerous Indians in the Prince Albert district, the Superintendent was able for the third time to comment upon the excellent conduct of the Indian population. Not a single crime had been committed among them. Indeed, in his report for 1888 the commissioner comments on an almost entire absence of crime in the Territory during the preceding year. In all quarters of the Territories except the southwest the Indians were making rapid strides toward self-support. Some of their chiefs rendered very valuable assistance to the police in the enforcement of law and the capture of criminals.

Space will not permit more than a brief glance at the varied activities of the Mounted Police during the period of Licutenant-Colonel Herchmer's tentre of office as commissioner (IS86-1900). The following note from the report of Superintendent Perry ${ }^{2}$ for 1893 speaks for itself, however. What it implies must be left to the imagination of the intelligent reader. It is to be remembered that the Superintendent is speaking merely of the men of his own division:

"In Wood Nountain our men are found acting as cowboys, rounding up and driving back across the boundary vast herds of Ancrican ranch catte which again and again wandered norihward in search of better feed and more water. At Estevan and Gretna they are seen in charge of large herds of quarantined cattle; tending sick milch cows; and at the expiration of the term in quarantine driving them long distances by trail, loading them on trains, and convering them to their destination. In Manitoba they are engaged in cnforcing the customs laws, aiding the regular customs officials whose duties they at times perform, and executing the Crown Timber and Dominion Lands regulations, and in addition to this work of a special nattre they are carrying out their regular dnties of detecting crime, aiding the administration of justice, acting as prairie fire and game guard-

2 Superintendent Perry was promoted to the office of commissioner in 1900, assuming command on . Ingtst is, in succession to Lientenant-Colonel Ilerchmer, retired, and at the time of writing ( 1013$)$ is still at the head of the Force he has served so long and so efficicntly: 

ians, anl maintaining a patrol system which covers weekly some twelve hundred miles."

To the varied catalogue of dutics indicated above many others might be added. For cxample, in 1005 the police took the census of the old District of Assiniboia, Saslatchewan and Alherta. This ment a house-tohouse vicitation involving $65,8,3$ whites and $7,6,3,3$ Ialfhreels sparsely scattered over a stupendous area, and the magnitude of the task, assumed in addition to normal dutics, is rather appalling. Such vicitation, however, had

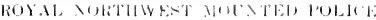

many advantages to the police in the exccution of their ordinary functions, by increasing their familiarity with the whole citizen looly. It all times the police patrols go and come, not as spies and ministers of outraged justice, but as the settlers' friends, and as such they are and always have been recognised-especially by the lomely homesteaders who often would be overtaken by actual destitution but for their aid and familiarity with pioneer conditions.

For instance, in his report for $100+$ the Commissioner specially com- 

ments upon the heroic work of Corporal D. B. Sinith, of Norway House, in connection with his public services during an epidemic of scarlet fever and diphtheria. Corporal Smith supplied the stricken people with food, disinfected their houses, helped nurse their sick and buried their dead. Indeed, one of the important duties of the Mounted Police is to care for the settlers in remote districts if for any reason they are overtaken by actual need that friendly hand can and may properly relieve. This happened to very many in 1907. The Commissioner reports that west of Saskatoon and south of Battleford, along the route of the Grand Trunk Pacific Railway and the Wetaskiwin branch of the Canadian Pacific Railway, relief was given to some one hundred and forty-five families, and patrols visited other settlers. The snow was very deep and there were no trails. A winter of great severity had set in much earlier than usual, and but for the vigilance of the police the sufferings of the pioneers would have been much more serious than they were.

The ever-present dread of the isolated settler on the plains is that of the prairie fire. Hundreds occur yearly; sometimes small, sometimes great; sometimes expending their fury in uninhabited expanses, sometimes bringing ruin and at times death to the pioneer: sometimes quickly extinguished, sometimes travelling far and fast and lingering long. The police, of course, are ever on the alert as fire guardians, and are continually saving valuable property and at times human life itself. Space will permit us to note but a single characteristic instance. On October 5, 1905, a constable by the nane of Conradi saw a trenendous prairic fire and learned that in the threatened country there was a settler with a wife and ten children, but he was warned by other settlers that it would be foollhardy to try to reach the doomed homestead. It was his to make the attempt, however, and fortunately he arrived at the settler's dwelling ahead of the conflagration, and helped plow a fire guard. Comradi then started a back fire with the assistance of the settler and his family. This did not prove successful. however, and the torrent of flame rolled on. The smoke and flames were so thick it was impossible to see more than a few yards. The constable ran through the fire and found the women and children in a slough. Two of them he carried away and the rest he led to what proved a place of safety, though they were nearly suffocated. Conradi was badly burned himself. and lost his own horse. The settler reported the affair to the authorities. stating that he and his family owed their lives to the constable.

Some of the reports of the activities of the force are most pathetic, especially those referring to the care of the all ton numerous unfortumates whom the solitude and hardships of the wilderness have bereft of reason. Almost all westerners will be familiar with the story of Constable Pedley's heroic conduct on behalf of such an unfortunate and of the fearful cost at 

which he did his duty. This officer was stationed at Fort Chipeweyan, and in that far-away region in 1904 a Presbyterian missionary went insane. Pedley took him in charge and on December 1 th set out with his demented prisoner for Fort Saskatchewan, five hundred miles away. The madman was refractory in the extreme. For a time he refused nourishment and had to be fed forcibly. Sometimes he had even to be carried. At all times he had to be watched and guarded with the utmost rigilance. Pedley reached his destination on January 7,1905 , and the unhappy missionary was turned over to the care of physicians, and in due time entirely recovered his reason. Meantime, his rescuer commenced his return trip to Fort Clipeweyan, but before reaching that post the hardships of the trip and his anxiety for the safety of his charge had produced their effect. At Lac La Biche he himself went violently insane. He was committed to Brandon Asylum. It is a relief to know that kindly care and skill at length restored him to such an extent as to enable his return to his duties. When his term of service expired he was reëngaged.

The official reports teem with such cases. One more I cannot refrain from recording in at least its bald outlines. Far away in the Haye River country a man went insane and Corporal Field sallied forth from Fort Chipeweyan to his rescue, subsequently reporting as follows under date of January 30, 1906:

"A few days before Christmas some of the Indians from the North were coming into Chipeweyan. A man named William Brown found ont where they were going and immediately followed them, carrying neither blankets nor provisions with hin.. . . I went out in search of him and found him wandering about on the lake. I saw at once that the man was insane, and unfit to be at large. I took him across and put him in the guard room. I thought possibly after a few days' rest with good food he would get around again. . . J January second he took a very had turn. becoming a raving maniac, refusing food or nourishment of any kind. I made preparations and started for Fort Saskatchewan as soon as possible with him, as I saw he required medical attendance. January i I I left Chipeweyan with lnwatic Frown and Special Constable Daniels, and the detachment $\log$ train. I also had to hire another man with his team of dogs to carry the provisions and dog food for the trip. . . . I arrived at Lac La Biche January 2.4. I left the train dogs here with the Indson's Bay Company to be fed until my return. I hired a tean and left the following day for Fort Saskatchewan, arriving on Jannary 29."

Commissioner Perry adds the information that the round trip was over a thousand miles.

The Clarles King murder occurred in September, 1904. In October of that year King rode through an Indian reservation in the vicinity of Lesser Slave Lake, northward bound. The Indians noticed that the white man's dog scemed unwilling to follow--a circumstance that was sufficient to 

rouse suspicion on the part of the observant natives. Chief Moostoos heard shortly after that when the traveller had been at Swan IJill the Indians there had seen a companion with him. Noreover, shooting had been heard, and King had been noticed to have built a camp-fire of most unusual proportions. Moostoos laid his information before the police and a careful investigation was initiated. In the ashes of the camp-fire were found htman remains. There was a marsh near by, and it was searched inch by inch by the Indians. In it were found a pair of shoes, a gold nugget and a portion of a needle, of which the other half had been found in the ashes of the fire. King was promptly placed under arrest, brought to Fort Saskatchewan, tried, found guilty and hanged. The moral effect of this remarkable incident and of the part played in it by the Indians was very important.

The lawless element were kept aware that no region of Canada's mighty domain was too remote to be reached by the red-coated guardians of Pax Britannica. In 190.4 Inspector Genereux, of Prince Albert, was notificd of a mysterious death in the remote North and promptly sct ont to investigate it. In due course he held a coroner's inquest in the wilderness and established that the death had been accidental. IJaving thus cleared up the mystery, he returned to Prince Albert on January 7,1905 , after an absence of one hundred and thirty-two days, during which he had travelled one thonsand seven bundred and fifty miles by dog train and canoe. Such exploits are almost numberless in the history of the force.

Superintendent Dean, in 1896 , reported the return to Canada of a large number of Indian refugees expelled from Ancrican territory, into which they had fled after the rebeltion of $I_{S} S_{5}$. They were rounded up by American cavalry and brought to the boundary. Much amazement was shown by the American military forces and much ammsement caused in the conntry when a couple of Mounted Policemen would replace fifty American cavalrymen at the boundary line to undertake the escort dutics across the prairie. Among the returning Indians wcre found some of the Frog Lake murderers, who were immediately arrested, but no one was molested for participation in the rebellion itself. The repatriated Indians caused no trouble at all. For example, Sergeant Caudle with two constables and a wagon escorted one hundred and twenty of the refugees, with three hundred and eight horses and twenty-five velicles, a distance of one hundred and fifty-one miles.

Of course, it would be folly to suppose that, in a force as large as the Royal North West Monnted Police, scattered over so vast an area, and necessarily subject to so little immediate supervision by their far-away superiors, mistakes, and episodes more discreditable than mistakes, have not sometimes occurred. The marvel is that they have been so few. An instance in which mismanagement was all too apparent is that of Almighty 

Voice. This was a well-known and popular young Indian athlete whose farm was in the Prince Albert country. In 1905 he was charged with a petty offence, and despite his protests and promises to come without resistance, the police officer insisted on handeuffing him. To be led into town a manacled captive broke the heart of poor Almighty Voice, and transformed a good Indian into a bad one. If this were the place, it might be shown that the young Indian had still juster and more serious grounds for swearing vengeance on the police. Presently he escaped from custody. He was pursued and tracked for several days by Sergeant Colebrook, who overtook him on the morning of the fourth day, and was promptly shot dead. Every effort was subsequently made to effect the murderer's recapture, but without success that season. In May of the following year a police patrol came upon Almighty Voice after a hunt of almost a twelvemonth. After seriously wounding a scout he took to cover in a bluff, where, with two companions, he was finally killed, but not until he had slain Civilian Grundy, Corporal Jlocken and Constable Kerr, and wounded Inspectors Altan and Raven seriously. In the final battle with Almighty Voice a ninepounder from Regina and a seven-pounder from Prince Albert were used.

Such occurrences as this have been exceedingly exceptional. Indeed, the success of the Mounted Police in dealing with desperadoes of all sorts is a matter of universal acknowledgment. A hundred good and entirely authentic stories could be told by way of illustration. For example, an interesting police report for 1006 relates to the arrest at North Portal of a notorions "bad man" known as Cowboy Jack. On the $\mathrm{s} 7 \mathrm{th}$ instant, states the report, Corporal Hogg was called to the hotel at North Portal to quell a disturbance. The hotel was full of cowhoys, who, under the leadership of Cowboy Jack, were proceeding to enact the customary melodrama of wild-west-shows. Hogg induced the ringleader to follow him into an adjoining room. When they had both entered, the officer locked the door and threw the key away. These details are omitted in the officer's report, however. Indeed, that document is delightfully laconic:

"On the 17 th inst., I, Corporal Hogg, was called to the hotel to quiet a disturbance. I found the room full of cowboys and one Nonaghan, or Cowboy Jack, was carrying a gum, and pointed it at me against sections I05 and Ioo of the Criminal Code. We struggled. Finally I got him handcuffed behind and put him inside. His head being in had shape, had to engage the services of a doctor, who dressed his wound and pronounced it nothing serious."

Whilst the doctor was in attendance Monaghan remarked that had IIogg not captured his gun, another death would have heen recorded in Canadian history. In official note also records that "during the arrest of Monaghan the following Goxermment property was damaged; door broken; screen 

smashed up; chair broken; field jacket belonging to Corporal Hogg spoiled by being covered with blood; and the wall plastered with blood." The Toronto Globc in commenting upon this report spolie as follows:

"It is too bad about the chair and the screen, and we trust that the Government will promptly see to their proper repair; and perhaps money for a new coat for Corporal Ilogg can be spared out of Mr. Fielding's big surplus of last year. It the Government should in addition see fit to carry out Commissioner Perry's recommendation of a grant of \$25 to Ilogg in recognition of his service, the country will not disapprove."

A somewhat similar arrest which was greatly appreciated by the citizens generally was effected by Constable Lett at Weyburn in Xay, I9o3. A desperado rejoicing in the title of "Idaho Kid" undertook to "shoot up the town." Among other pleasantries in which he indulged was that of compelling citizens to hold up their hats while he shot holes in them. At the same time he annonnced that there was nobody in Canada who could arrest him, and, indeed, offered to put ${ }_{11}$ ) a bet of $\$ 25$ to that effect. Constable Lett rode in from IJalbrite and promptly captured the bad man, took his revolver from him and then with the same weapon compelled him to hold up his hands while being handeuffed. The same officer has frequently distinguished himself ly his courageous defense of law and order. In 1907 an Ontario desperado broke jail and, when a subsequent attempt was made by county constables to arrest him, his immense strength bronght him off victor in an encotnter with three of them on the strects at Orangeville. Some time later another attempt was made to secure him, but the outlaw drew two revolvers and drove the constable away. The county council then placed a reward of a hundred dollars upon his head and he hastily removed to Saskatchewan, where he fell into the hands of Lett, now a sergeant. The desperado's domestic arsenal consisted of a brace of revolvers, a rifle and a shotgun, all loaded, which indicated that he had not anticipated being deprived of his liberty quite so suddenly and peaceably.

In 1906 Canada was startled by the news that the train robbing fraternity had perpetrated a "lold-mp"-the first event of its kind to occur in the Territories. This was a challenge to the Mounted Police, and they were not slow to act upon it. The reply of the violated Justice of Canada was given a few days later, when after an exciting chase and effective exchange of bullets, the notorions American train-robber, Bill Miner, was captured by the Nonnted Police and promptly consigned to the penitentiary. The easy trade of the train-robber will never gain a foothold on the Canadian prairies until the R. N. W. M. P. force is abolished!

In the middle nineties, as the gold fields of the Yukon commenced to attract miners and adventurers from all parts of the world, it became necessary to give special organization to the work of the police in that part of 

Canada. It was determined in 1895 that a party of twenty inclusive of officers should be dispatched to the lukon for duty there, and Inspector Constantine, an officer of great determination and ability who had been in that country the precerling year, was selected to command, the other officers being Inspector Strickland and Assistant Surgeon Mills. They left Seattle on June 5 and arrived at their destination on July 24 , where, at Fort Cndahy, after a journey of 4,800 miles, they constructed their barracks. This year about $\$ 300,000$ worth of gold was taken ont of the Canadian side. In his report for 18 go the commissioner remarks that "we still occupy the Yukon with twenty men, including officers, but communication has been so irregular this year that we know very little about them." In 1897 this number was considerably increased. The output of gowl this year was about $\$ 3,000,000$, that of $1897-8$ between six and seren millions, and the great and turbulent flood of mining immigration was rising fast. Indeed in 1897 it was seen necessary to relieve Commissioner Herchmer from the inmediate supervision of the work of the Mounted Police in this remote and difficult region and Major Walsh was accordingly made police administrator for the Yukon. For a few years (I8g8-rgoi) the normal strength of the Momnted Police detachment in the Yukon stood at 250 , and in Igor this number was raised to 3 oo. However, the detachment was gradually reduced as during the first decade of the century the extraordinary conditions of the preceding few years disappeared. In 1910 the force in the Yukon was fixed at fifty, the lowest strength since the great influx of gold seekers in 1897 . The relative security of life and property in the Canadian as compared with the American Yukon and with new and remote camps in other parts of the world has ever reflected the highest credit on the Mounter Police.

When the first Canadian Contingent sailed away to Africa to fight in support of Pritish interests and ideals, October, i 890 , numerons ex-members of the Mounted Police force volunteered. The recruiting of the second corps of Canadian Mounted Rifles was entrusted to the Mounted Police and many officers and men were given leave of absence to go to the front as members of this contingent. Besides these, more than thirty members and numerous ex-members engaged under Lientenant-Colonel Steele, of the Stratlicona Horse.

Nearly all of the officers and many of the men who were granted leave for the purpose of joining the Canadian Mounted Rifles of Strathcona Horse returned to the force during 1902 . One member of the force was awarded the Victoria Cross for conspicuous bravery at Wolvespruit on July 5, I900. This was Sergeant A. H. Richardson, a policeman of C Division, Battleford. Superintendent S. B. Steele, in command of the Strathcona Horse, was awarded a C. B. and was made a member of the Victorian Order. Inspectors R. Belcher and A. M. Jarvis were given C. M. G.'s and three other officers 

became Companions of the Distinguished Service Order. Distinguished Conduct medals were won by Scrgeant J. I Hynes, Sergeant-גIajor Richards and Constable A. S. Waite. The North West Monnted Police contributed to the South African War, all told, 245 members and ex-members, of whom four were killed in action and thrce died of disease while in Sonth Africa. The force also contributed thirty-four men to the new South African Constabulary, of which Superintendent Stecle, C. B., M. V. O., was appointed colonel.

In 1904, in recognition of the services of our Mounted Police in Western Canada and throughont the Empirc, the following was among the coronation honors announced on June 2t: "II Majesty the King has been graciously pleased to confer the title of Royal on the North West Monnted Police."

"Peace hath her victories no less than WVar," and every year of its existence the force is wiming them. From 1902 onwards onc of the most interesting portions of the amnual reports is that dcaling with the more and more systematic supervision of the shores of the Hudson's Bay and the Arctic Seas. It is the dity of these loncly patrols to supervise the Indians and Eskimos; to collect customs duties from foreign vessels doing business in the Bay; to maintain order among the somewhat turbulent whalers; to succor shipwrecked parties and relieve destitution in general; to convey mails; to conduct explorations; and to fulfill many other useful and heterogeneous duties. One R. N. II. M. P. post is 2,500 miles from headquarters!

A record was establishicd in varions regards by Inspector E. A. Pelletier's patrol in 1908. On Junc I he and his party left Fort Saskatchewan for Athabasca Landing, proceding thence to Fort Resolution on Great Slave Lake. Leaving that point on July $\mathrm{I}$. Inspector Pelleticr proceeded to Chesterfield Inlet, Hudson's Bay, reaching that point two months later. At this point they were met by a party in the coast boat McTaz'ish, which was chartered by Superintendent Moodic from the Hudson's Bay Company for the purpose of mecting Inspector Pelletier and his party. Unfortunatcly the McTavish was wrecked on the way to Churchill and the party was obliged to proceed to Fullerton, where there is a police post, and there await the freeze 11p. On the 20 th of November they started with dog trains overland for Fort Churchill, which they reached on the IIth of January. There they remained until the 7 th of February, and reached Gimli, a railway station on the west shore of Lake IVinnipeg, on the Sth of March. The total distance travelled by this patrol from rail to rail was 3.347 miles. Commissioner Perry comments in his report to the comptroller that of the many long and ardions patrols performed by the R. N. IV. M. P., this had becn the most extended and difficult.

The hardships of the work in the Far North was brought all too forcibly to the notice of the world when, two years later, a party of police died of 

starvation. Ever since the season of $1904-5$ a police patrol carrying mail has been sent from Dawson to Fort XIcI'herson and back, in the Yukon Territory. In rgro Inspector Fitzgerald, who had had many years' experience in the Far North and had thoroughly proven his fitness for such work, was given command of this patrol. He left Ilerschell Island at the end of November and arrived at Fort . MePherson on December 3, where he spent a fortnight in making preparations for the journcy to Dawson. On December 20 , 1910 , he left Fort XIc Pherson with thrce dog teams of five dogs each, accompanied by Constables Kinney, Taylor and Carter, the last named heing employed as guide. The party never returned. A relief expedition left Dawson on February 28 to search for the missing men. On March 21 the searchers came upon the camp where lay the bodies of Constables Kinney and Taylor, and on the following day the remains of Inspector Fitzgerali and Special Constable Carter were discoveres. Nothing in the anmals of arctic exploration exceeds in pathos the record of this ill-fated expedition as contained in Fitzgerald's diary. The disaster was cansed by the guile losing his way. Moreover, as the party wished to travel "light" the quantity of provicions proved inadequate. Fitzgerald's entry in lis diary for Jantary I2 is as follows: "37 below. Fine, with slight head wind. Sent Carter to look for portage, but he could not find it." Thus commenced the tragic search for a pathway of escape from the monntain wilderness in which the ill-fated patrol found itself. On the 1 th thizgerald says: "Carter is completely lost and does not know one river from another. We have now only ten bags of flour and eiglit pounds of bacon and some dried fish. My last hope is gone, and the only thing I can do is to return and kill some of the dogs to feed the others and myself, unless we can meet some Indians."

" $13^{\circ}$ below. Wednesday, Jan. 18. . . . Killed the first Jog to-night for dog feed. IIardly any of the dogs would eat him, and we had to give them a little dried fish. Onr food consisted of a small piece of dried bannock and dried fish.

" $28^{\circ}$ below. Thursday, Jan. 19. Very misty, with a slight southwest wind. . . We were at times ankle deep in water. Killed another dog to-night. 21 miles.

"21 ${ }^{\circ}$ below. Friday, Jan. 20. Very strong southwest gale all day. . Ate the last of the flour and bacon. All we have now is some dried fish and tea.

"Zero. Saturday, Jan. 21. Strong gale. . . Killed another dog to-night. 20 miles.

"50 $0^{\circ}$ below in a. m. Sunday, Jan. 22. $64^{\circ}$ in p. m. . . . Carter"s fingers badly frozen.

" $64^{\circ}$ below. Monday, Jan. 23. Nisty, with strong head winds.

" $56^{\circ}$ below. Tuesday, Jan. 24. Strong south wind with very heavy mist." Left camp at $7: 30$ and fomml the river open right across. Constable Taylor got in up to his waist and Carter up to his hips. We had to go into 



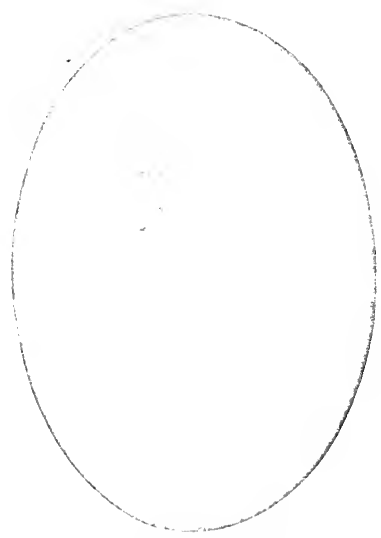

INSPECTOF FITZGERALD,

Who, with his entire detachment, died ou patrol duty in the Far North, 1911.

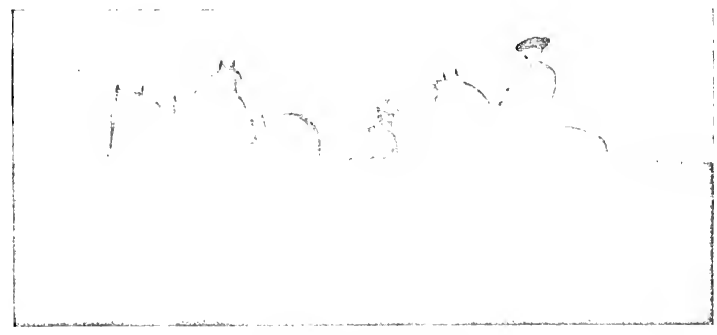

"NO COMPLAINTS."

Settler signing R. X. W. M. P. patrol book. From painting, property of Dominion (iovernment. 

camp at I a. 11. . . . Killed another dog and all hands made a good meal on dog meat.

"53" below. Wednesday, Jan. 25. . . . Killed another dog; our food is now dog meat and tea. Is miles.

" $21^{\circ}$ below. Thursday, Jan. 26. . . . Going very heavy in deep snow and all hands and dogs getting weak. 8 miles.

"I3" below. Jan. 27. Heavy snowstorn with heavy mists. Camped at Wauglis tent at $2 \mathrm{p} . \mathrm{m}$. Searclied tent and cache for food, but found none. Going very heavy. Killed another dog. We have now only nine dogs; the rest are gone for food. I m miles.

" $45^{\circ}$ below. Saturday, Jan. 28. Strong south wind with mist. Taylor sick hast night and all day. Going very heavy.

"20 below. Jan. 29. . . . Killed another dog to-night. Men and dogs very weak. Caclied one sled and wrapper and seven dog harnesses here. Io miles.

"5 $\mathrm{I}^{\circ}$ below. Monday, Jan. 30. . . . All hands feeling sick; suppose it to be from eating dog's liver.

" $45^{\circ}$ below. Tuesday, Jan. 3 I. $62^{\circ}$ below in p. m. . . . Skin peeling off our faces and parts of body and lips all swollen and split: I suppose this is caused by feeding on dog meat. Everybody fecling the cold very much for want of proper food. 17 miles.

" $51^{\circ}$ below in a. m. Wednesday, Feb. 1. . . Killed another dog to-night. This makes eight dogs we have killed, and we have caten most of them. We fed what dried fish we had to the dogs. I6 miles.

" $7^{\circ}$ above, in a. 12. Thursday, Feb. 2. 23 below in P. m. . . . Got astray in the mist.

" $26^{\circ}$ below. Friday, Feb. 3. . . . Killed another dog to-night. . Men and dogs very thin and weak and camnot travel far. IVe have travelled about 200 miles on dog meat and still lave about 100 miles to go: but I think we will make it all right.

" $52^{\circ}$ below. Saturday, Feb. 4. . . . Going very heavy and everybody suffered very much with cold.

" $48^{\circ}$ below. Saturday, Feb. 5. . . . Just after noon I broke through the ice and had to make a fire. Found one foot slightly frozen. Killed another dog to-night. Have only five dogs now, and can only go a few miles a day. . . . 8 miles."

Apparently at about this juncture Constables Taylor and Kinney were unable to proceed further. Accordingly a camp was made and Fitzgerald left with his companions what supplies he could, and with the unfortunate guide attempted to press forward in search of relief. As a matter of fact they were but thirty-odd miles from friends and safety, but the task was an impossible one.

In Inspector Fitzgerald's pocket was found the following pathetic document, written with a piece of cliarred wood:

"All money in despatch bag and bank. clothes, etc., I leave to my dearly beloved mother, Mrs. John Fitzgerald, of Halifax. God bless all. "F. J. Fitzger.lLd, R. N. W. M. P."

Such is the story of the saddest tragedy that has overtaken the North 

West Mounted Police Force in all its history. All Canada and especially all Westerners were plunged in mouning. $\dot{I}_{11}$ the following year a bronze tablet monnted upon a marble slab was unveiled by Lientenint-Governor brown in the chapel at the harracks of the Royal Forth West Mounted Police, Regina. Upon it are inseribed the following words:

"In memory of Inspector Francis Joseph Fitzgerald; Constable George Frances Kinney: Constable Richard O'llara Taylor: and Special Constable Sam Carter; who lost their lives in the thischarge of their duly on patrol from Fort McPherson to Dawson, February, 19r1. Erected by their comrades."

It is to be remembered that equally dangerous journeys are made by members of the police force every year. In the same report in which the commissioner tells the story of the Fitzgerald disaster may be found the record of the 700 miles and return journey made by Sergeant Hayter from Fullerton, along the west coast of Hudson's Bay, to Rankin Inlet, to mect Sergeant loorden coming from lort Churchill with mail and taking the census of the Eskimos. Sergeint Watker journeyed from lort Churchilt to York Factory and return; Sergeant Nicholls from Norway. IIouse to Fort Churchill and return; Sergeant Edgenton from Split Lake to Fort Churchill -three days withunt food; Sergeant Mhunlay from The Pas to Lac du Brochet and return-900 miles in $5 \mathrm{I}$ days; Sergeant . Facleod from Fort Vermillion across the terrible mountains to Great Slave Lake. All these heroic officers were performing definite police duties; carrying mails, supervising Indians and maintaining law, whether in the remotest districts of Canada. In the performance of stuch tasks tragedy is ever an immediate possibility, but service in these trying posts, far from being avoided, is ever an object of desire among the members of our famous force.

The strength of the force has varied greatly from time to time. It numbered $: 300 . . m e n$ in 1873 ; in 1882 , with the advent of the railway, the strength was increased to 500 , because of the new responsibilities thrown upon the police by the advance of settlement. In $188_{5}$ the membership was raised to 1,000 , at which it stayed for a decade, when it was gradually reduced to 750 . In $I S g S$ the gold discovery in the Yukon resulted in the increase of the force in that territory to 250 men. In 1902 fifty more men were drafted from the Territories to the Yukon. However, the authorized strength of the force was now made Soo. The population of the Territories had doubled and the strength of the force been cut in two in the preceding decade, though new conditions were continually increasing the work of the police and the responsibility necessarily placed upon its individual members. In 1912 there were five divisional posts and $8_{2}$ detachments in Alberta, with $252 \mathrm{men} ;+4$ divisional posts and 87 detachments in Saskatchewan, with 



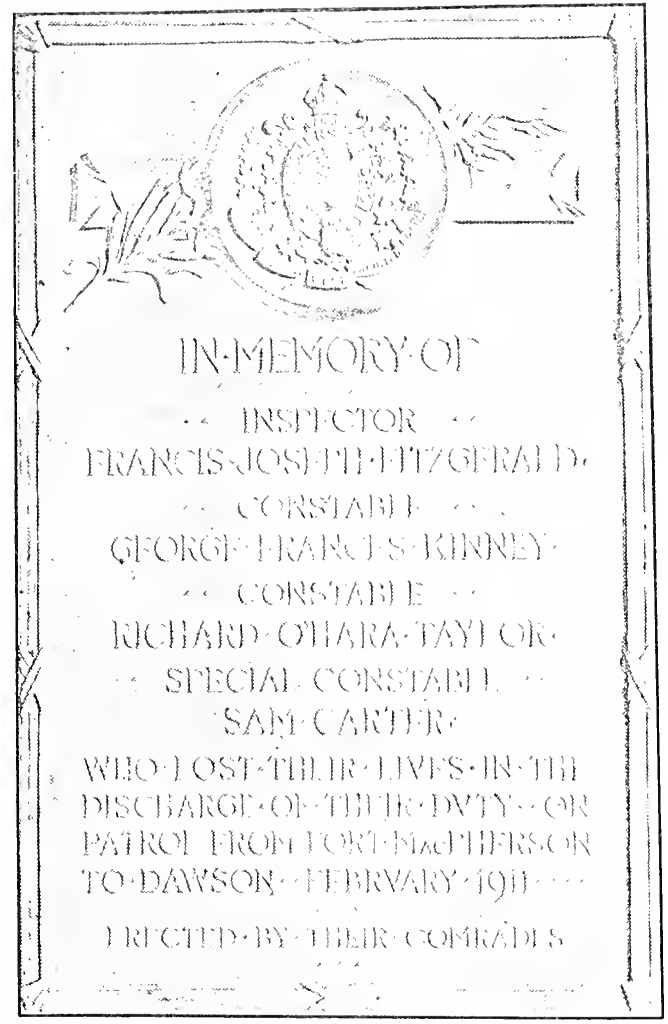

MEMORIAL TABLET, R. N. W. M. P. CIIAPEL. 

335 men; and 67 other menbers seattered through $\mathrm{New}$ Manitoba and the Far North.

In the spring of 190 the comptroller and the commissioner interviewed the governments of Alherta and Saskatchewan with the result that these provinces and the Federal Government entered into an agreement by which it was arranged that a strength of 500 men was to be retained in the two provinces for a term of five years. Each Provincial Government was to contribute $\$ 75,000$ towards the maintenance of the force. These terms were renewed in I9I. On May 15,1912 , a very latge portion of the Territories north of Manitoba was annexed to that province, but the services of the Mounted Police were retained by the Govermment of Manitoba on terms similar to those involved in the agreement with Saskatchewan and Alberta.

From time to time busybodies unacquainted with conditions in onr Great North West, and ignorant of the work of the Motnted Police and of the advantages in prestige and infuence which they enjoy, as compared with any other possible body that might take over their duties, have talked of withdrawing the force from the Saskatchewan and the other prairie provinces. Such proposals have always met with indignant remonstrance on the part of Westerners and all others who know the comtry. Long may the great force flourish and enjoy the affectionate admiration of the land it has served so well!

The space limits set for the present skctch have already been passed and the temptation to linger over our theme must be resisfed. Many interesting and important topics bearing upon our stuject have becn regretfully but rigorously excluded, with a view to necessary brevity. No attempt has becn made to formulate evidence indicative of the relative value of the services of different nembers of the force, and its successive eomptrollers at Ottawa have not even been named. Men whose services to their country have ontweighed those of numerons contemporancous cabinet ministers have been barely mentioned or passed over in silence. In short. I have not attempted a history; my aim has simply been to present a picture. I have not tricel to sketch the careers of its distinguished members; I have merely sought to indicate something of the work in which they and their humblest colleagues in the force have been engaged. Where individual officers and their exploits have been alluded to, they are to be taken as merely representative of the many similar devoted public servants and deeds of heroism that have made the R. N. W. M. P. the pride of Canada. 



\title{
CHAITER LII
}

\section{FRATERNAL SOCIETIES IN SASKATCIIEIVAN}

\begin{abstract}
Early Rise of Fraternal Socheties--Ancievt Free and Accepted Masons: Kinistino Lodee, 1879; Wascana Longe, i883; Grand Lodge of Saskatchew.in, igof-INinerexdent Order of OdDFelLows: Moose Jaw Lodge, i $88_{3}$; Sumegouent Rapid Developuent -Orange Association-Leiding Catholic Orders-Otiler FraTERNAL Societies.
\end{abstract}

The means of social intercourse are valued by no one more highly than by the man who for a period not too long has been deprived of them. It is not surprising then that tents had scarcely given way to "shacks" in our western settlements when iraternal societies of all sorts commenced to spring up in luxmiant growtl. Indeed, the development of these institutions faith fully reflects that of the I'rovince in the other nany' fields to which this book has been chiefly devoted. In obedience to the expressed wish of many promincnt citizens, therefore, this closing chapter is to be devoted to a brief record of a few outstanding facts bearing on the rise of some of the chief great fraternal orders.

The first such society to establish itself in the North West was the world-famons order of the Ancient Free and Accepted Masons. For a time the activities of the order were almost confined to Nanitoba, but as early as 1879 , on the 28 th of March, a group of Masons resident at or near Prince Albert Mission met in the old store of the Hudson's Bay Company to discuss the propriety of applying for a dispensation establishing a local lodge. A petition was in due course presented to the Grand Lodge of Canada and on May 2.2, 579 , the necessary dispensation was granted for the creation of Kinistino Lodge, Prince Albert. This lodge is therefore entitled to claim seniority in point of age over all others in what is now the Province of Saskatchewan.

The first officers of Kinistino Lodge were Brother C. F. Young, W. M.; Brother J. McKenzie, S. W., and Brother G. R. Duch. J. W., and the other bretluren signing the petition of application for the creation of the lodge were Brothers Charles Mair. John Frederick Kennedy, Joseph M. Coombes, A. E. Porter, Edward Stanley, Gcorge Tait and Joln L. Reid. It may be interesting to members of the craft to know that the first degrees con- 

ferred were at the initiation of Lrothers Thomas Mackay, Justice Duncan Wilson and Thomas E. laker. The total membership of the lodge at the end of its second year was twenty-eight.

A warrant of constitution was granted in July, ISSO, and some four months later Kinistino Lodge came under the jurisdiction of the Grand Lodge of Manitoba. It is to be remembered that this was before the era of railway communication in the Territories and that Prince Abert lies more than three times as far from $W$ imnipeg as does Lomdon from Paris!

In $188_{3}$ lodges were established at Jattleford and Lelmonton, and these, together with Kinistino Lodge, Prince Albert, constituted the first Masonic District of Saskatchewan, its first Distric Deputy Grand Masicr being Brother Charles F. Joung, of Prince Albert. The prime novers in Masonry at Battleford were Brothers Henry Sikes, S. B. Steele, 1)r. J. W: Kalph, Rev. J. F. Pritchard, II. J. Montgomery and J. M. MeGregor.

At this time Regina was but a cluster of camps and "shacks" upon the prairie, but early in January, $188_{3}$, steps were taken for the organization of a Masonic Lodge. A dispensation having leen duly obtained, the first meeting of Wascana Lodge, Regina, Was held on Marcli 6, when Right Vorshipful Prother James [Ienry lienson was appointed Master. The other first officers were Brothers .1. G. .1. Spragge and John .1. Kerr, Vardens; Brother T. C. Johnstunc, S. D. ; lirother J. W: Evett, I. D.; Brother W. I. Lindsay, Treasurer; Brother John Sccord, Secretary, and Brother Reverend A. Osborne, First Church of England clergynan in Regina, Chaplain. The first home of Wascana Lodge was in a building owned by the Presbyterian Church; hefore the end of the year it moved to guarters on Proad Strect. owned by Doctor Cotton; in March, IS85, the Lodge took a hall on Scarth Strect, the property of Mr. George Willis; in ISSO it was to be found in a building at the corner of Rose and Sunth Railway streets. This building was destroyed by fire in 1889 and for a short time the Masons were hospitably housed in the Ilall of the Canadian Order of Foresters. Meantime Brother Andrew Martin was erecting a new building on Scarth Street, the third floor of which was occupied by the Masonic Order from Iugust, I8go, until the present Masonic Temple at the corner of Eleventh Avenue and Cornwall Strect was erected in 1907. It is, of course, impossible to enter into a detailed history of the growth of the Order in any one city, but in view of the important rôle that Wascana Lodge has played in Masonry in this Province, memhers of the Order will be interested in recalling the names of those who have occupied the responsible post of Master in this Lodge.

${ }_{1} \&_{3}$-Prother I. H. Tenson.

ISS - lirother fohn A. Kerr.

1855 -Brother Percy R. Neale.

$1886-$ - -Brother James R. McGaul. 



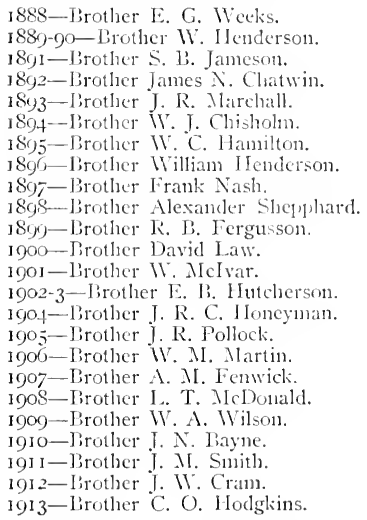

Upon the creation of Saskatclewan as an independent Province it became necessary to establish a separate I'rovincial Grand Lodge. The initiative was taken by Wascana Lodge on April 3. Iyo6, on the motion of W. Brother Alexander Shepphard, seconded by brother J. M. Snith. As, however, Kinistino Lodge, Prince Albert, was the oldest in the Province a dispatch was sent to it by the Wascana Lodge, asking Krinistino Lodge to call a convention to consider the matter, which course was duly followed. The convention met at Prince Albert, May 25, J906. A deputation was appointed to wait on the Grand Lodge of Nanitoba at its next meeting and lay before it a proposal to establish a Grand Lodge for Saskatchewan. Nuch other important business was also transacted, in the course of which it was agreed that the meeting for formal organization should be held at Regina. At this time there were twenty-nine Mlasonic Lodges in the Province of Saskatchewan, with a membership of approximately nine hundred. Twenty-five of the Lodges were dily represented by anthorized delegates at the Regina Convention, which met on August 8, 1906. M. W. Brothers, John MeKechnie and James A. Oris of the Grand Lodge of Manitoba installed the first officers of the Grand Lodge organized on this occasion. These were: M. IV. Grand Master H. II. Camplin; Deputy Grand Master C. O. Davidson; Senior Warden Jagger; Junior Warden Reverend W. B. Tate; Grand Treasurer Alexander Shepphard; Grand Secretary Doctor John MI. Shaw; 


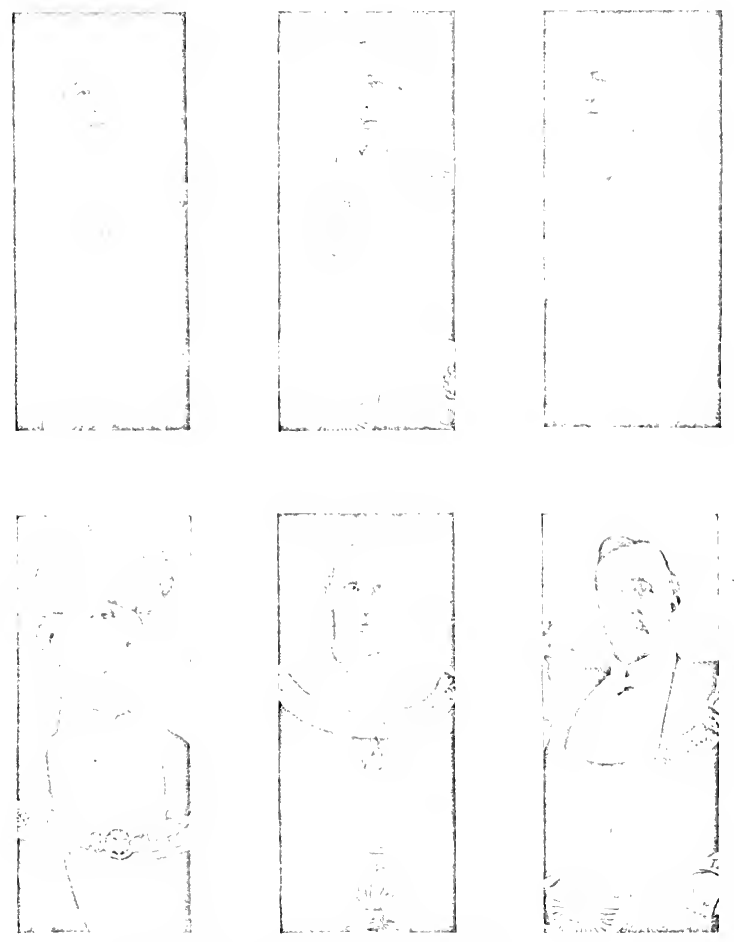

GRAND MASTERS FOK SASKATEIEWAN, A. F. \& A. M.

Wm. Hopkins, '1n-'11. H. II. Campkin, '06-'07. H. Gorrell, 2I. D., '11-'12.

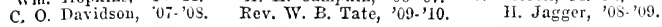



Grand Chaplain Reverend E. Natheson; Grand Registrar A. H. Smith; Grand Senior Deacon C. H. Griftin ; Grand Junior Deacon J. I. Ross; Grand Director of Cercmonies John Rutledge; Grand Organist R. B. Taylor; Grand Poursuivant IV. Barber; Grand Tyler William Barnwell.

From this time forward the Masonic Order in Saskatchewan has grown by leaps and bounds. By March $3^{\mathrm{I}}$, 1907, the membership had increased to fourteen hundred. A year later it had passed the two thousand mark, and by the end of 1912 the membership had reached the grand total of 5,190 .

The first annual Communication was held at Prince Albert in Igo7; the second was held at Regina, when R. W. Brother C. O. Davidson, of Prince Albert, was elected Grand Master; at Moose Jaw, in the following year, R. W. Brother II. Jagger was elected to succeed him, and in I9I0, at Saskatoon, R. IV. Brother IV. B. Tate was made Grand Naster for the year; in IgI I at Regina, Brother Hopkins was raised to this oflice, and Dr. A. S. Gorrel for 1912-13.

Noose Jaw, Regina, Saskatoon, Prince Albert, and Qu'Appelle all boast fine Nasonic Temples. There are twelve Chapters of the Royal Arch in the Province,-- Battleford, Moose Jaw, Sintaluta, Arcola, Estevan, Weyburn, Prince Albert, Regina and Saskatoon, Govan, Melville and Swift Current. There are Knight Templar Preceptories in the four cities (1912) and there is also a Temple of the Mystic Shrine at the capital.

At Moose Jaw in 1883 there was instituted the first lodge of the Independent Order of Oddfellows to be organized in the North West Territories. There were several lodges instituted each year thereafter, all being in affiliation with the Grand Lodge of Nanitoba. When the Territories were divided into provinces, the different lodges in Saskatchewan petitioned the Sovereign Grand Lodge for a clarter to establish a Grand Lodge in this Province. At that time there were thirty lodges working in what is now known as the Province of Saskatchewan, with a total membership of one thousand five hundred and sixty members. A charter was accordingly granted and the Grand Lodge of Saskatchewan, I. O. O. F. was organized at Regina on May 29, 1907. The laws of the Grand Lodge designate Regina as the headquarters of the institution.

The first Grand Master of the Grand Lodge of Saskatchewan was L. Rankin, Dominion Lands Agent, Regina (recently transferred to Winnipeg). The first Grand Secretary elected was F. I. Reynolds, of Regina, who has held the office continuously since the institution of the Grand Lodge. The Grand Masters serving since the first year of institution are as follows:

I908-J. Rutherford, Moose Jaw.

I909-J. A. M. Patrick, Yorkton.

I910-H. C. Pierce, M.L.A., Wadena.

1911-H. E. Armstrong, Regina.

1912-J. W. Cumningham, Wauchope. 

The growth throughout the Prutince since the Grand Lodge was organized has been very rapid, there having been up to the time of writing (I913) an average of thirteen Subordinate Lodges instituted each year with an average annual increase in membership of seven hundred. At the present tinc there are fifteen Relekati Lodges with a membership of one thonsand six hundred. The Subordinate Lodge membership of the I. O. O. F. now numbers six thousand two hundred, and one hundred and wo lodges have been established in the Province. The Encampment branch of the Order has four encampments and those interested are looking to the early establishment of a Grand Eneampment in this jurisdiction.

Among the men to whom the I. O. O. F. of Saskatchewan stands indebted is Mr. Joln Tucker, who since the early eiglties has resided in Moosomin. Ile instituted most of the lodges established before the creation of the Grand Lodge of Saskatchewan. At that time he was Grand Master of the Province of Nanitula which incluted the lodges organized in Sas- katchewan and Alberta as well. For some years he travelled both by rail and by tean to distant points to institute lodges, supported by a few menbers of the local lodges where he happened to be. Mr. Tucker is still very prominent in the official list of the organization, holding the offece of Grand Representative to the Sovereign Grand Lodge (I913).

The first Orange Lodge instituted in what is now the Province of Saskatchewan is Number I.493. The warrant appears to have been brought west by members of the Mounted Police, and organized at Wood Momntain about the time of the North West Rubellion in 1855. In 1893, Number I493 was re-organized at Naple Creek, where it is still located.

In the year I89I, there being fifteen I'rimary Lodges in the North West Territories, they were entitled to a Provincial Grand Lodge, which was accordingly instituted at Regina, by the late Stewart IIulvey, M.P.P., Past Grand Master of Manitoba, in the same year. A. G. Hamilton, Deputy Sheriff of Moosomin, Was elected first Grand Master; R. L. Alexander, Moose Jaw, Junior Deputy Grand Master, and W. J. Kernaghan, Prince Albert, Grand Secretary.

When the Provinces of Alberta and Saskatchewan were created, in 1905 , a separate Provincial Grand Lodge was formed for each province. Saskatchewan had then fifty-four lodges and a menbership of I,I6I. The membership remained practically stationary until 1909, in which year there was a net increase of 657 . In the three years prior to 1912 the net increase was 1,907 members, and the number of Primary Lodges had increased to I33 in the same period, a gain of ISo per centum. At the end of 1912, although full returns are not yet in, the membership stands at 4,350 , and the number of Primary Lodges at 164 . There are also twenty-two County Lodges in the Province at the present time, as against eleven in Igog. Dur- 

ing the last three years the number of Royal Llack preceptories had increased from seven to fourteen, and in 19I I, at Saskatoon, a Grand Black Chapter was formed having jurisdiction over all private preceptories within the Province.

Following are the names of Brethren who have held the office of Grand Master since the formation of the Provincial Grand Lodge in I891: A. G. Hamilton, Moosomin; B. Barber, Wolctey; J. II. Young, Moosomin; Dr. W. Henderson, OniAppelle; Thomas Iullock, Moosomin; John Wilson, Caron; E. J. Cudmere, Westriew; Simpson Shaw, Gainsboro; D. D. Ellis, M. D., Flening, and A. D. Ferguson, Wolseley.

The great Catholic orders in the Province are the C.AI.B.A. and the A.O.11. The Catholic Mutual Penefit Association has a membership of almost 25,000 in Canadit. Of its five hundred Canadjan branches, the first to be instituted in Saskatchewan was that at Prince Alhert. The Regina branch (Number 362 ) was organized in July, I902, with Mr. L. L. Kramer acting as District Deputy.

The Regina division of the Ancient Order of Hibernians was instituted ten years later, November 10, I9I2, by a degree team from W'imnipeg. accompanied by P. J. Henry, Esquire, Provinciat President for Manitolat. The frst Provincial President, Vice President, Secretary and Treasurer were, respectively, Messrs. Thomas M. Molloy, James Mrilliams. W. F. Mindiott, and John NoCarthy. The A.O.H. is an international organization, having divisions in practically all civilized countries. Its memberslip is made up entirely of Catholics of Irisl dencent. The motto of the Order is "Friendship, Unity and Christian Charity," and it is the aim of the Association to pronote these virtues by supporting a fund for the maintenance of aged, sick, blind and infirm members, and for the general improvement of the condition of the Irish people.

Necessary space Jimits compel us to pass over in silence the many other fraternal societies prominent in Saskatchewan. Their name is legion. The sociological significance of the popular demand, in all parts of our Province, for the social fellowship and ceremonious ritual that constitutes a common element in all such societies presents an interesting problem to the thoughtful mind. 
$F 235$
.102

$70 \leq 0 \quad 1$ 


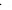








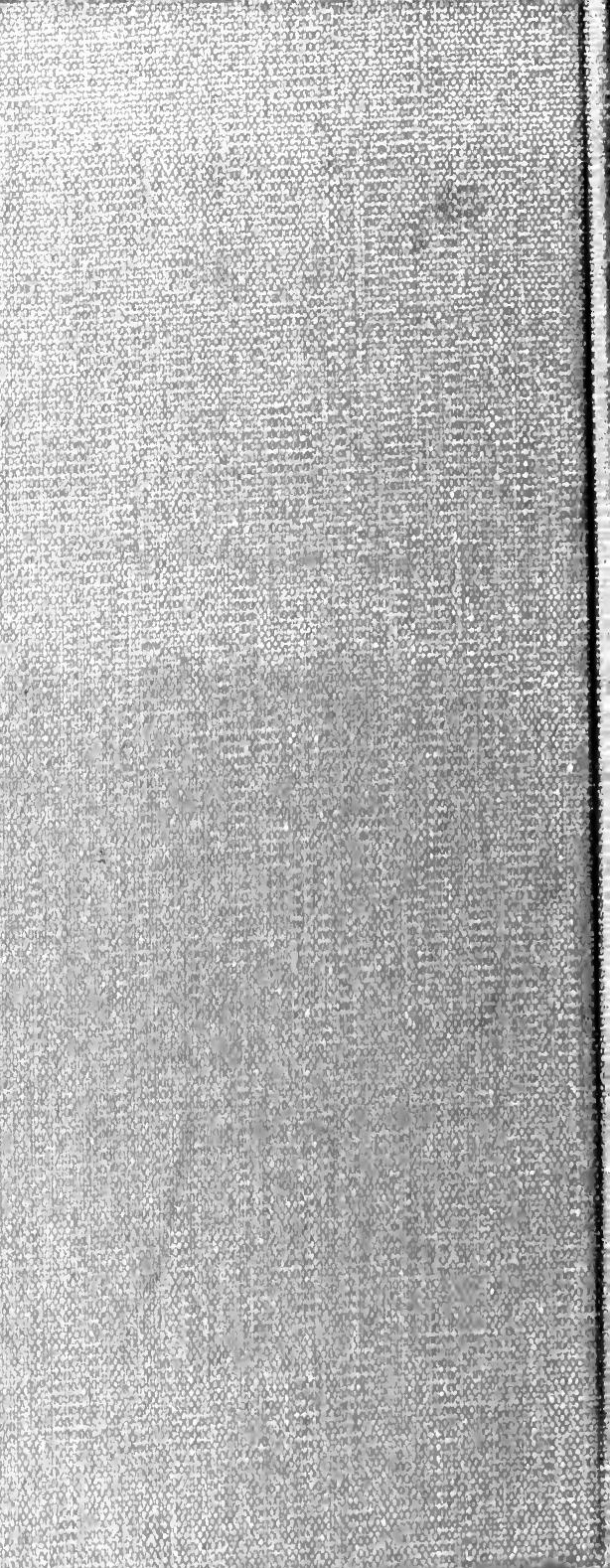

